UNIVERSIDADE DE SÃO PAULO

FACULDADE DE FILOSOFIA, LETRAS E CIÊNCIAS HUMANAS

DEPARTAMENTO DE ANTROPOLOGIA

PROGRAMA DE PÓS-GRADUAÇÃO EM ANTROPOLOGIA SOCIAL

\title{
VIDEOGAME É DROGA? CONTROVÉRSIAS EM TORNO DA DEPENDÊNCIA DE JOGOS ELETRÔNICOS
}

\section{Guilherme Pinho Meneses}

Dissertação apresentada ao Programa de Pós-Graduação em Antropologia Social da Universidade de São Paulo como requisito parcial para a obtenção do título de Mestre.

Orientação: Prof. Dr. Stelio A. Marras

(versão corrigida)

\section{São Paulo}


Meneses, Guilherme Pinho.

Videogame é droga? Controvérsias em torno da dependência de jogos eletrônicos. Guilherme Pinho Meneses, São Paulo, 2015, 324 p.

Orientador: Prof. Dr. Stelio Alessandro Marras

Dissertação (mestrado). Universidade de São Paulo. Faculdade de Filosofia, Letras e Ciências Humanas. Programa de Pós-Graduação de Antropologia Social.

Título em inglês: "Is videogame a drug? Controversies surrounding the electronic games addiction".

1. Videogame 2. Drogas 3. Dependência 4. Virtualidade 


\section{BANCA EXAMINADORA}

\section{PRESIDENTE DA BANCA}

\section{Prof. Dr. Stelio Alessandro Marras}

Professor Afiliado ao Instituto de Estudos Brasileiros (IEB) da Universidade de São Paulo (USP).

\section{TITULARES}

\section{Prof. Dr. Theophilos Rifiotis}

Professor Afiliado ao Departamento de Antropologia da Universidade Federal de Santa Catarina (UFSC).

\section{Prof. Dr. José Guilherme Cantor Magnani}

Professor Afiliado ao Departamento de Antropologia da Faculdade de Filosofia, Letras e Ciências Humanas (FFLCH) da Universidade de São Paulo (USP).

\section{SUPLENTES}

\section{Prof. Dr. Renato Sztutman}

Professor Afiliado ao Departamento de Antropologia da Faculdade de Filosofia, Letras e Ciências Humanas (FFLCH) da Universidade de São Paulo (USP).

\section{Prof. Dr. Gilson Schwartz}

Professor Afiliado ao Departamento de Radio e Televisão da Escola de Comunicação e Artes (ECA) da Universidade de São Paulo (USP).

\section{Prof. Dr. Marcelo Simão Mercante}

Professor Afiliado ao Programa de Pós-Graduação em Saúde Coletiva da Universidade do Vale do Rio dos Sinos (Unisinos) 
Aos erês, para que possam brincar em paz. 


\section{Agradecimentos}

Agradeço primeiramente a Deus, pela oportunidade de estar vivo e ter me permitido realizar este trabalho em paz, saúde e tranquilidade.

Em seguida, agradeço aos meus queridos pais, Agnelo e Maria Celeste Menses, a meu irmão Vinícius, à minha avó Zelita e à minha tia Maria, por todo o amor, carinho, suporte e, principalmente, por compreenderem a minha caminhada profissional.

Agradeço profundamente ao meu orientador e grande amigo Stelio Marras, que desde o primeiro momento me auxiliou de perto, com admirável atenção e cuidado, enfrentando comigo os percalços e desafios encontrados no desenvolvimento desta pesquisa. É impensável retribuir tudo o que recebi, restando apenas agradecê-lo de coração.

Agradeço encarecidamente ao professor Theophilos Rifiotis, cujas contribuições na qualificação e defesa foram fundamentais para o refinamento intelectual deste trabalho.

Ao professor José Guilherme Magnani, que sempre me abriu as portas e igualmente me auxiliou nesta trajetória acadêmica com sua sabedoria e amizade.

Agradeço também aos amigos do NAU, em especial Ana Fiori, Rodrigo Chiquetto, Yuri Tambucci e Lucas Lopes, que me acompanharam desde o processo seletivo até o dia da defesa desta dissertação. Agradeço especialmente a Vinícius Rossini, fiel companheiro do CyberNAU, por sua disposição em revisar partes deste texto.

À querida Júlia Yoshino, pela revisão cuidadosa de todo este trabalho.

Aos colegas do LAPOD, que leram com atenção minha qualificação e renderam-me boas sugestões, assim como aos amigos do CEstA, sempre dispostos a um bom diálogo.

Aos professores Gilson Schwartz, Luís Carlos Petry, Arlete Petry e Francisco Tupy demais pela iniciativa em abordar os videogames na academia paulistana.

A todos os interlocutores com que tive oportunidade de dialogar, especialmente Marcelo Mercante, Ivelise Fortim, Janos Geocze, Maria Paula Oliveira e Lucas Costa.

A todos os gamers e desenvolvedores que conheci durante esta pesquisa, especialmente Iuri Martins, Enric Llagostera, Emanuel Tavares, Johnny William e Olavo Silva, com quem pude compartilhar ideias e pensar coletivamente as questões aqui presentes. 
Aos meus velhos amigos de Santos: Rafael Lopes, Ricardo Prado, Lucas Baptista, Carla Sion e tantos outros com quem vivi anos e anos jogando videogames e os quais pude reencontrar ao longo deste estudo de outra forma. A eles também dedico este trabalho.

Aos caboclos Carlitos, Muri, Vini e Camila, pelo compartilhar do lar, pela força nas atividades de casa e pela paciência comigo nos últimos meses de escrita. À giriquinha Mew, que gosta de deitar no meu colo quando estou digitando e aos meus queridos giricos-mor, Billy e Risquinho, duplinha destruidora, mas de muita alegria.

Agradeço à Mônica Haibara, pelas aulas de Tai Chi Chuan e pela companhia, que tornaram mais leves as atividades de escrita. E à Elis Vasconcelos, que mesmo à distância sempre orou por mim e me acompanhou nessa trajetória.

Aos ladeiros Yanete, Chiqs, Bahia e André, por compreenderem meu estado "aperreado" no final da pesquisa e me darem a singela oportunidade de tocar suas belas canções dominicais.

A Alice Haibara, Carlos Nascimento (bis!), Talita Hayata, Nadja Marin, Alvaro Russo, Tadeu Kaxinawá, Isaka Kaxinawá, Txaná Ikakuru e a toda a linda equipe que se propôs a dar forma ao sonho de criar um jogo de videogame Huni Kuin.

Agradeço especialmente aos meus irmãos-amigos Marcelo, Dani, Marilis, Tina, Ana e Caio, e à querida Dona Chica, pelos ensinamentos de humildade, amor e caridade.

Ao nixi pae, dume e a todas as plantas sagradas, pelo cultivo da sabedoria e da calma e pelos valiosos ensinamentos que me levaram tratar esta pesquisa de forma mais saudável. Agradeço também aos alimentos que tive cada dia em minha mesa.

Enfim, aos videogames! Desde os consoles Atari, Mega Drive, SNES, Nintendo 64, Playstation, PC, Game Boy Advance, Dreamcast, Playstation 2, Xbox 360 e Playstation 4, aos meus jogos favoritos em diferentes épocas: Sonic the Hedgehog, B-Ball, Warcraft III, Counter-Strike, Mario Party, Pokémon, Rock Band, FIFA e Winning Eleven/PES.

Por fim, mas não menos importante, agradeço de bom grado à Fundação de Amparo à Pesquisa do Estado de São Paulo (FAPESP) por ter me concedido uma bolsa de estudos para realizar esta pesquisa. Sem isto, não haveria condições práticas para desenvolvê-la. 


\section{Resumo}

O objetivo geral deste trabalho é cartografar as práticas e experiências que ancoram os discursos dos diversos actantes em torno da questão da dependência de videogames. $\mathrm{O}$ intuito é simular, ainda que de forma provisória, um parlamento das coisas (LATOUR, 1994) acerca dos debates sobre o assunto. Por meio de uma investigação das práticas e discursos de atores humanos e não-humanos, desfazendo as fronteiras entre os chamados mundos reais e virtuais, pretende-se, então, descrever as suas relações em rede. Neste sentido, aqui há uma inversão em relação à maioria dos estudos sobre o tema: o vício não é entendido como uma explicação, mas exatamente o que precisa ser explicado.

Palavras-chave: videogames; dependência; drogas; controvérsia; teoria ator-rede. 


\begin{abstract}
The effort to be undertaken in this research will be mapping the practices of the various agents around the issue of video game addiction by investigating the manner in which the rhetoric of drug addiction works in the social regulation of the use of electronic games. In this sense, we'll map the varied semantics of notions, categories or concepts of dependence and addiction, such as enunciated and practiced by the various individuals involved in the controversy: the players themselves (in its multiple gaming environments such as home, school or work), parents or people close to these players, the games industry professionals, scientists from different fields (psychiatry, psychotherapy, education, game studies), politicians, laws and news. Through the analysis of practices and discourses of the actors, articulating the dimensions of the so-called "real" world and the "virtual" worlds, without, however, falling into an asymmetrical dichotomy between true and false, we intend to understand the meanings of their relationships with videogames.
\end{abstract}

Keywords: video game; addiction; virtuality; anthropology of science 


\section{Lista de figuras}

1.1 - Candy Crush Saga (2012)

1.2 - Distribuição normal

1.3 - Super Mario Bros. (1985)

1.4 - Intersecção entre as dependências de jogo patológico e de internet

1.5 - Modelo neuropsicológico de dependência de videogames

1.6 - Córtex frontal, núcleo accumbens, hipocampo, substância negra e corpo estriado

1.7- Teoria do fluxo

2.1 - Pirâmide de Maslow

2.2 - Castle Crashers (2010)

2.3 - World of Warcraft (2004)

2.4 - Ragnarök Online (2002)

2.5 - Barra de personagem de Ragnarök Online

2.6 - Ultima Online (1997)

2.7 - Pokémon (1996)

2.8 - Elder Scrolls V: Skyrim (2011)

3.1 - Civilization II (1996)

3.2 - FarmVille (2009)

3.3 - Devil May Cry (2013)

3.4 - Kinect (2010)

3.5 - FIFA 14 (2013)

3.6 - Auction House (World of Warcraft)

3.7 - The Last of Us (2013)

3.8 - With Your Destiny (2003)

3.9 - Skype (2003)

3.10 - MSN Messenger (1999)

3.11 - Call of Duty: Ghosts (2013)

4.1 - Priston Tale (2005) 
4.2 - Pinball Arcade

4.3 - CityVille (2010)

4.4 - Silver (1999)

4.5 - Dragon Age (2009)

4.6 - River Raid (1982)

4.7 - Estoura Balão (2013)

4.8 - Defense of the Ancients (2009)

4.9 - Doom (1993)

4.10 - Wolfenstein 3D (1992)

4.11 - Counter-Strike (2000)

4.12 - Metal Gear Solid (1998)

4.13 - Classificação dos gêneros de games (GRANIC et al, 2014).

4.14 - League of Legends (2009)

4.15 - Sonic: The Hedgehog 2 (1992)

4.16 - Tibia (1999)

4.17 - Bonsai Worlds (2003)

4.18 - Star Wars: TIE Fighter (1994)

4.19 - Pro Evolution Soccer 2014 (2013)

4.20 - Teoria do fluxo

4.21 - Flow (2006)

4.22 - Waze (2013)

4.23 - Bejeweled (2001)

4.24 - Colheita Feliz (2009)

4.25 - Turma do Chico Bento (2012)

4.26 - Unity3D (Game Engine)

4.27 - Cubisland (2013)

4.28 - Grand Theft Auto IV (2008) 


\section{Lista de tabelas}

1 - Questionário sobre o Comportamento de Dependência de Jogo

2 - Explicação da cadeia neuropsicológica da dependência de videogames

3 - Nível de dificuldade versus habilidade requerida para execução 


\section{Sumário}

Introdução à pesquisa 14

1 - A controvérsia 14

$\begin{array}{ll}1.1 \text { - O imobilismo e a guerra das ciências } & 14\end{array}$

1.2 - Videogames em perspectiva 18

2 - Questões e objetos da pesquisa 20

2.1 - Os enunciados da dependência $\quad 20$

2.2 - A incerteza sobre a determinação do vício 24

2.3 - As retóricas do vício 29

3 - Notas teórico-metodológicas 31

3.1 - Constituindo um parlamento das coisas 31

3.2 - Mapeando controvérsias 34

3.3 - Rumo a uma antropologia da cibernética 39

3.4 - Etnografias do virtual 41

4 - Procedimentos metodológicos 42

4.1 - A pesquisa de campo: técnicas e tecnologias 42

4.2 - A inserção do pesquisador na controvérsia 45

5 - Apresentação dos capítulos 46

Capítulo 1 - Por dentro da rede: o conhecimento médico 48

1.1 - Modos de classificação do jogador de videogames como dependente $\quad 48$

1.2 - Dependência: conceitos e classificações 57

1.2.1 - Drogas e dependência: um breve histórico 57

1.2.2 - Um corpo partido: a dependência física e psicológica 61

$\begin{array}{ll}\text { 1.2.3 - Componentes centrais da dependência } & 62\end{array}$

1.2.4 - Actantes institucionais 66

1.2.5 - Construindo dependências: formas de composição 71

1.3 - Apresentando teorias: a gramática das ciências 76

1.3.1 - Modelo cognitivo-comportamental 76

1.3.2 - Modelo neuropsicológico $\quad 81$

$\begin{array}{ll}1.3 .3 \text { - Teoria da compensação } & 92\end{array}$

1.3.4 - Fatores situacionais 97

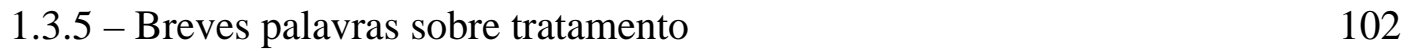


1.4 - Cosmopolíticas da dependência

1.5 - A gramática das dependências

Capítulo 2 - O sério e o lúdico: repensando as categorias lazer e trabalho a partir dos videogames

2.1 - Esquentando a controvérsia

2.2 - Entre usos legítimos e ilegítimos

2.3 - Videogames e seu aspecto lúdico

2.4 - Categorias em jogo

2.5 - Lazer e trabalho: desestabilizando conceitos

2.6 - Os gamers e suas classificações

2.6.1 - Os objetivos dos jogadores

2.6.2 - Os jogadores profissionais de videogame

2.6.3 - Concepções de tempo

2.7 - Por graus de comprometimento

Capítulo 3 - O real e o virtual: mundos distintos?

3.1 - Vida real

3.2 - O real em jogo

3.2.1 - Dependências do virtual

3.2.2 - O real, o atual e o virtual

3.2.3 - Mundos virtuais

3.3 - O virtual em controvérsia

3.3.1 - Sensibilidade

3.3.2 - Corporalidade

3.3.3 - Materialidade

3.3.4 - Comunicabilidade

3.3.5 - Sociabilidade

3.3.6 - Escapismo

3.4 - Recompondo mundos reais e virtuais 207

3.4.1 - Drogas e realidade 207

$\begin{array}{ll}3.4 .2 \text { - A realidade do virtual } & 210\end{array}$

Capítulo 4 - Por dentro do jogo: explorando o círculo mágico 214

4.1 - Concepções de vício 218

4.2 - Videogames e drogas: metáfora ou metonímia? 230 
4.3 - Gerenciamento de humor

4.4 - Ambientes de jogo

4.5 - Videogames, jogadores e familiares

4.6 - Os gêneros de games $\quad 257$

$4.7-$ MMORPGs 264

4.8 - A imersão nos games 270

$\begin{array}{ll}\text { 4.8.1 - A Teoria do Fluxo } & 275\end{array}$

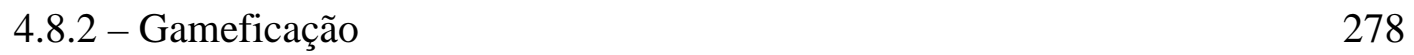

4.8.3 - Monetização 280

4.9 - Indie games, serious games, videogames e capitalismo 286

4.10 - Fim de jogo 291

Considerações finais 293

1 - Fechamentos provisórios 293

2 - Nova luz sobre a questão da dependência 298

3 - Breve reflexão sobre o culto moderno da Ciência Moderna 301

Referências $\quad 306$

$\begin{array}{ll}\text { Entrevistas } & 321\end{array}$

Lista de games $\quad 322$

Referências Online $\quad 324$ 


\section{Introdução à pesquisa}

\section{1 - A controvérsia}

\section{1 - O imobilismo e a guerra das ciências}

Grande parte da produção científica, mais marcadamente da área da ciência médica e de algumas vertentes de estudo da psicanálise, da psicologia e da pedagogia, tem trabalhado com as categorias dependência, adicção e vício para descrever a relação de usuários de videogame com seus jogos, na qual se sobressai uma associação semântica entre os efeitos dos videogames e das drogas de uso não-farmacológico. Frequentemente, os jogadores classificados como adictos são vistos por pesquisadores (YOUNG, 1998; SCARPATO, 2004; ABREU, 2008) como pessoas socialmente isoladas (THOMPSON, 2002), violentas e perigosas (BEAVIS, 1998); que estão aprendendo a expressar a sua reprimida raiva e agressividade por meio dos videogames, e são potencialmente capazes de engendrar novos episódios traumáticos, como o Massacre de Realengo ${ }^{1}$ ou de Columbine ${ }^{2}$ (KING; BORLAND, 2003).

Segundo as pesquisas acima citadas, o vício em videogames traria consequências prejudiciais para o indivíduo, como: uma piora no rendimento escolar e no trabalho, afastamento do convívio familiar e de outras formas de contato social, compulsão por jogar, insônia, falta de apetite, sedentarismo, tendinite, troca de prioridades da "vida real" para alcançar os objetivos dos jogos "virtuais", descaso com o bem-estar e o

\footnotetext{
${ }^{1}$ Em 24 de abril de 2011, a Rede Record (R7) exibiu uma reportagem de longa duração no programa Domingo Espetacular tentando associar a chacina ocorrida em uma escola do bairro do Rio de Janeiro ao uso de videogames violentos, no intuito de, possivelmente, encobrir motivos religiosos. A investida gerou uma grande revolta de gamers populares nas redes sociais da Internet, como Daniel Fraga, Monark e Guilherme Gamer, que publicaram vídeos em seus canais no YouTube, os quais juntos somaram mais de um milhão de visualizações, a fim de objetar tal direta associação. A seguir os endereços dos vídeos:
}

Domingo Espetacular: https://www.youtube.com/watch?v=LYza5hQDmOk\&feature=related

Daniel Fraga: https://www.youtube.com/watch?v=hYjk25TszmE\&feature=related

Monark: https://www.youtube.com/watch?v=2Pu4lLaugg8\&feature=related

Guilherme Gamer: https://www.youtube.com/watch?v=jWV1-dlP1lc\&feature=related

2 Antes, em 20 de abril de 1999, em Columbine (Colorado, EUA), dois jovens atiraram em colegas e professores da escola, matando 13 pessoas, para na sequência se suicidarem. Segundo o documentário Tiros em Columbine (2002), de Michael Moore, um dos motivos levantados na época pela mídia foi o uso de jogos de tiro como Doom e Wolfenstein $3 D$ pelos jovens que engendraram o massacre. Apesar de recuperarmos estes episódios logo aqui na introdução, o foco deste estudo será especificamente as controvérsias envolvendo a dependência em videogames e não as acusações de incitação à violência, ainda que em muitos casos estes dois grandes debates se encontrem. 
direito do próximo, aumento da agressividade (no caso dos jogos violentos), e até mesmo mortes em decorrência de prolongados períodos em frente à tela do jogo.

Apesar de esta ser a visão predominante, há outra corrente de estudos de caráter construtivista-relativista (ou sociologizante, diria Bruno Latour) verificada majoritariamente nos chamados game studies, a qual, em geral, considera a abordagem anterior falsa ou puramente retórica, e aponta o caráter historicamente construído dessas relações, destituindo-a de alguns de seus efeitos de realidade. Rob Cover (2006), por exemplo, em seu artigo "Game (Ad)Diction Discourse, Identity, Time and Play in the Production of the Gamer Addiction Myth", publicada no periódico Game Studies, apesar de manifestar interessantes inquietações, muitas das quais se encontram em consonância com as deste estudo, tece a aproximação dos games com as drogas como meras construções sociais (aqui, resumidamente, a dependência não seria nada mais que um conjunto de discursos, retóricas, imagens, metáforas e mitos sem sustentação empírica), deixando de levar em consideração dimensões cosmopolíticas importantes neste debate.

À primeira vista, podemos entender que essas duas grandes correntes conformam o que os filósofos Bruno Latour ${ }^{3}$ (1994) e Isabelle Stengers ${ }^{4}$ (2003) chamaram, cada um ao seu modo, de guerra das ciências. Por mais que haja um lado preponderante, o conhecimento científico, neste caso, não está estabilizado em torno de fortes associações que tornem impossível o questionamento de suas acepções, ou, conforme a terminologia latouriana, a abertura de suas caixas-pretas (LATOUR, 2000). Trata-se, pois, de uma controvérsia ${ }^{5}$ - ou seja, uma disputa científica entre aqueles que produzem

\footnotetext{
${ }^{3}$ Bruno Latour é um dos fundadores dos chamados Science, Technologies and Society Studies (STS). um dos principais desenvolvedores da Actor Network Theory (teoria ator-rede). Atualmente é diretor científico na Sciences-Po (França). Foi professor na École Supérieure de Mines de Paris (Mines ParisTech) e na Universidade da Califórnia. Tem atuação nas áreas de antropologia, sociologia e filosofia da ciência, apesar do próprio autor questionar tais divisões disciplinares ao longo de toda sua obra.

${ }^{4}$ Isabelle Stengers é uma filósofa belga e professora na Universidade de Bruxelas. Seus interesses incluem a filosofia da ciência e a história da ciência. Formada em química, ela é autora de livros em parceria com Ilya Prigogine que tratam de questões relativas à irreversibilidade e ao universo como um sistema aberto. Em algumas de suas obras (2003, 2007), traz um diálogo teórico próximo com Bruno Latour.

5 Este projeto foi inspirado pelo programa intitulado Mapping Controversies, criado por Bruno Latour e hoje coordenado internacionalmente por Tomasso Venturini, que agrega pesquisadores de diversas instituições (MIT, Sciences-Po, ENSMP, Oxford University, Manchester University, École Polytechnique Fédérale de Lausanne) e que, desde agosto de 2011, inclui a Universidade de São Paulo, por meio do curso Antropologia da Ciência e da Modernidade: Mapeamento de Controvérsias, a cargo do Prof. Dr. Stelio Marras e com a colaboração do Prof. Dr. Vincent Lépinay do Science-PO (ver websites sobre o mapeamento de controvérsias nas referências).
} 
epistemologias sobre o uso dos videogames no contexto atual. Assumimos, como Latour, que a Ciência fala de uma posição privilegiada, senão central, na sociedade moderna, e que esta, portanto, influencia de forma incisiva a opinião de jornalistas, governantes, profissionais da indústria de jogos, familiares e os próprios usuários de jogos eletrônicos.

Uma análise preliminar do material reunido acerca desta temática parece indicar uma polarização entre duas perspectivas de análise. O primeiro conjunto de estudos cria uma abordagem a partir da perspectiva da "coisa" - o objeto videogame causando um vício incontrolável ao homem, que perderia assim a sua racionalidade e capacidade de falar por si mesmo, ou seja, seu estatuto enquanto sujeito. Em contrapartida, o segundo grupo parte do "homem" para falar da coisa, ou seja, dos benefícios que o homem - sujeito por excelência, em pleno controle da relação - colheria a partir do uso dos jogos eletrônicos. Essa controvérsia, portanto, gira em torno do tema da captura da subjetividade humana, da relação homem-máquina: um tema clássico na história do pensamento ocidental.

Estaríamos de volta à antiga matriz ocidental/moderna: homem versus máquina? Esta problemática retorna não para reafirmar o que já foi explorado por outros autores, mas para dar um direcionamento teórico específico para esta pesquisa. A questão é: quem engloba quem? O homem domina a máquina, como parecem sugerir os pesquisadores que apontam para os benefícios cognitivos propiciados pelos videogames? Ou acontece o oposto, como defendem os especialistas que alertam para os perigos do vício?

A socióloga Sherry Turkle (1984) escreve que as tecnologias catalisam alterações não somente nas coisas que fazemos, mas também na maneira como pensamos as coisas. Ela argumenta que, com a popularização do uso dos computadores e da internet "as pessoas sentem a presença de algo novo e excitante. Mas receiam a máquina, que consideram poderosa e ameaçadora" (TURKLE, 1989, p. 14-15). Segundo Turkle, as máquinas e, principalmente, o computador:

Modifica a percepção que as pessoas têm de si mesmas, umas das outras, e da sua relação com o mundo. A nova máquina que está por trás do sinal digital luminoso, ao contrário do relógio, do telescópio ou do comboio, é uma máquina "pensante". Desafia, não apenas as nossas noções de tempo e distância, mas também as de mente. [...] Os computadores despertam sentimentos fortes, mesmo em quem não está em contato direto com eles (TURKLE, 1989, idem). 
Neste jogo de captura de subjetividades, a máquina se encontra numa posição de ambiguidade: de um lado aparece como uma virtude do desenvolvimento e de outro, como a causa de prejuízos sociais, cognitivos e psíquicos. Quem seria então o sujeito da relação? E o objeto? Buscando sair dessa dicotomia estagnadora, encontramos em Donna Haraway a perspectiva do ciborgue, que nos ajuda a refletir acerca desta questão:

O ciborgue nos força a pensar não em termos de "sujeitos", de mônadas, de átomos ou indivíduos, mas em termos de fluxos e intensidades, tal como sugerido, aliás, por uma "ontologia" deleuziana. O mundo não seria constituído, então, de unidades ("sujeitos"), de onde partiriam as ações sobre outras unidades, mas, inversamente, de correntes e circuitos que encontram aquelas unidades em sua passagem. Primários são os fluxos e as intensidades, relativamente aos quais os indivíduos e os sujeitos são secundários, subsidiários (HARAWAY; KUNZRU; TADEU, 2009, p.14).

Sem erigir barreiras intransponíveis entre o humano e o não-humano, a perspectiva do ciborgue, que mistura a mecanização e a eletrificação do humano com a humanização e a subjetivação da máquina, é especialmente útil aqui pois nos fornece um guia teórico frutífero para esta pesquisa: "afinal, são bits e bytes que circulam, indistintamente, entre corpos humanos e corpos elétricos, tornando-os igualmente indistintos: corpos humanoelétricos” (HARAWAY; KUNZRU; TADEU, 2009, pp.12-13).

No entanto, frisemos bem, não estamos nos referindo a qualquer homem e a qualquer máquina, mas a homens e máquinas específicos, situados em meio a outras associações $^{6}$. Assim, somente uma etnografia densa pode revelar as particularidades de cada um desses agentes. Afinal, o que é "homem" e "máquina" neste campo específico? E mais do que flagrar relações entre categorias, é preciso atentar à emergência delas próprias. O esforço empreendido aqui se deu no sentido de entender as categorias e ver a quê elas estão associadas. É a ideia do faz-fazer $^{7}$ de Bruno Latour: de que as associações, os engendramentos (ou agenciamentos) dão o sentido das coisas e pessoas em rede.

\footnotetext{
${ }^{6}$ Segundo Latour (2000), nunca somos postos diante da ciência, da tecnologia ou da sociedade, mas sim diante de uma gama de associações mais fracas e mais fortes; portanto, entender o que são fatos e máquinas é o mesmo que entender o que as pessoas são. Nas palavras de Latour (2004, p. 370), o conceito de associação "estende e modifica o sentido das palavras social e sociedade, que são sempre prisioneiras da divisão entre mundo dos objetos e o dos sujeitos; em vez da distinção entre os sujeitos e os objetos, falar-se-á de associações entre os humanos e não-humanos; o termo recupera, assim, ao mesmo tempo, as antigas ciências naturais e as antigas ciências sociais".

7 Ainda segundo Latour, não podemos afirmar que exista algo que seja por si só natural ou social. Humanos e não-humanos se associam, tais associações geram efeitos, e esses efeitos deslocam objetivos, redefinem posições e sentidos. O que importa não são as essências de entidades ou seres, mas os efeitos que esses "atores" fazem-fazer.
} 
Ao investigar as relações entre ciência, sociedade, tecnologia e as múltiplas associações aqui envolvidas e que se configuram de forma particular em cada situação, pretendemos, então, compreender as redes de associações em torno do uso de jogos eletrônicos, assim como a constituição de seus modos de regulação sociotécnica. Esta pesquisa, por fim, busca investigar quais concepções de humano e de desenvolvimento estão pressupostas em cada uma dessas visões da qual derivam imagens sobre a dependência e os dependentes.

\section{2 - Videogames em perspectiva}

É difícil entender a falta de trabalhos acadêmicos, em especial no Brasil, sobre o uso de videogames, tendo em vista sua ampla difusão mundial. Para dar uma dimensão do fenômeno: hoje, em 2014, a indústria de games é a mais lucrativa no ramo de entretenimento, com faturamento de US\$ 60,4 bilhões anuais ${ }^{8}$, superando o cinema e a música. No Brasil, segundo pesquisa do Ibope em 2012, 60 milhões de pessoas, ou seja, $33 \%$ da população, possui ao menos um videogame em casa ${ }^{9}$. Nos EUA, $99 \%$ dos garotos e 94\% das garotas entre 12 e 17 anos são adeptos dos videogames ${ }^{10}-\mathrm{e}$ confessamente preferem os jogos eletrônicos a filmes ou outras formas de diversão. Em 2008, a China atingiu a marca de 59 milhões de jogadores online ${ }^{11}$. Na Coréia do Sul, foram registrados de 300.000 a 500.000 casos de viciados em games ${ }^{12}$. E já existem clinicas de tratamento de dependência funcionando em diversos países, como Japão, China, Coreia, Holanda, Inglaterra, Estados Unidos e, mais recentemente, o Brasil - que curiosamente é o país em que as pessoas, entre as que têm acesso à Internet, passam o

\footnotetext{
${ }^{8}$ http://www.tecmundo.com.br/video-game/9708-o-tamanho-da-industria-dos-video-games-infografico.htm

${ }^{9}$ http://jogos.uol.com.br/ultimas-noticias/2012/03/31/segundo-ibope-mais-de-60-milhoes-de-brasileirospossuem-videogame-em-casa.htm

${ }^{10} \mathrm{http} / / / \mathrm{g} 1 . \mathrm{globo} . c o m / N o t i c i a s / G a m e s / 0$, MUL763009-9666,00 DOS+GAROTOS+NORTEAMERICANOS+SAO+ADEPTOS+DOS+GAMES.html

${ }^{11}$ http://g1.globo.com/Noticias/Tecnologia/0,,MUL268934-6174,00CHINA+TERA+MAIS+DE+MILHOES+DE+JOGADORES+ONLINE+EM.html

${ }^{12}$ http://g1.globo.com/Noticias/Mundo/0,,MUL57044-5602,00-

COREIA+TEM+MIL+VICIADOS+EM+GAMES.html
} 
maior tempo dedicado às atividades online: 45 horas mensais. Ainda segundo outra fonte $^{13}$, o brasileiro passa, em média, duas horas por dia jogando videogames.

Apesar de controversa, a associação do jogador de videogames com o vício circula em vários ramos de estudos psicológicos e pedagógicos e, com maior força e influência política, na imprensa e no discurso governamental. No entanto, alguns teóricos dos game studies (COVER, 2006) acostumaram-se com a ideia de que tal imagem é falsa, que a dependência de videogame não é real, ou pelo menos muito mais complexa do que sua representação na ciência médica. Observamos, contudo, que essas imagens são atuantes: informam a atitude de ministros do governo, políticos e legisladores perante os jogos, pesam nas classificações e decisões de censura, têm notáveis efeitos na indústria de games e no financiamento de seu desenvolvimento e influenciam o posicionamento dos próprios jogadores e seus familiares em relação aos jogos.

Devemos ter em mente que, se a imagem do vício permanece, é porque há uma base sociotécnica que a suporta. Não basta afirmar que o vício é socialmente construído. Isto é apenas um ponto de partida para esta investigação e não esgota de forma alguma o problema; pois, ao tratá-lo como algo falso, ilusório ou não existente, perdemos a sua dimensão de performatividade, isto é, os seus efeitos de realidade. É importante ressaltar que esta controvérsia está viva e posta em disputa: muitas pessoas vivenciamna cotidianamente, ora concordando com os especialistas, ora discordando, ou mesmo não os considerando. O que está em questão, pois, são as formas como são feitas e circuladas as diversas associações dos jogadores com o vício.

Acreditamos que, somente pelas razões já elencadas, a construção da ideia do vício em videogames seria digna de descrições e análises mais aprofundadas. Desse modo, ao invés de simplesmente ignorar ou denunciar tal imagem, um dos pontos centrais desta investigação encontra-se na desestabilização de uma série de conhecimentos acerca da dependência de videogames. Assim, a preocupação seguinte passa a ser: como abordar o uso dos jogos eletrônicos sem, no entanto, aderir prematuramente ao construtivismo ou ao naturalismo?

13 http://g1.globo.com/tecnologia/noticia/2012/06/brasileiro-passa-2-horas-por-dia-em-frente-umvideogame-diz-pesquisa.html 
A Antropologia da Ciência e da Tecnologia tem se mostrado proveitosa neste tipo de enfrentamento, já que possui a característica de estabelecer um diálogo interdisciplinar com as diversas ciências que emitem pareceres sobre o tema, e de envolver em sua argumentação, intrinsecamente, os pontos de vista de diversos "nativos" envolvidos, reconhecendo-lhes um estatuto ontológico não-reducionista. Além disso, somamos ao fato de que são praticamente inexistentes estudos antropológicos sobre a dependência de videogames, apesar da exaustiva exploração deste tema nas disciplinas psiquiátricas e psicológicas, sobretudo nos EUA e na China.

Deste modo, a composição de videogame, dependência e antropologia parece ser inédita no país, o que também pode revelar uma especificidade local da relação entre os atores envolvidos no problema, além de evitar generalizações apressadas que advêm da relação entre os jogos e uma estrutura cognitiva individual, suposta como universal. Não devemos, portanto, tratar a dependência de jogos digitais de forma isolada ou monocausal, mas em rede, situada em meio a outras associações e controvérsias.

Nesta pesquisa, trabalhamos por meio de algumas questões que se cruzam com argumentos em torno do jogo e do vício, tais como: lazer, infância e juventude, violência, drogas, corporalidade, virtualidade e a interatividade dos jogos. Por hipótese, estes são, em várias combinações, alguns dos campos em que o videogame é denunciado e que as associações do jogo com o vício são tecidas. Suspeitamos que estas questões estariam conectadas por preocupações que criam uma dicotomia entre o "real" e o "virtual" e uma apreensão contínua de atividades tidas como mero entretenimento e encaradas como perigosas, não apenas porque são vistas como novas, mas principalmente em virtude de suas associações com o lúdico e com o virtual, simultaneamente.

\section{2 - Questões e objetos da pesquisa}

\section{1 - Os enunciados da dependência}

\section{Jogar videogame teria efeito de cocaína}

SÃO PAULO - Terapeuta britânico afirma que jogar videogame por duas horas produz o mesmo 'barato' que inalar uma carreira de cocaína. Segundo Steve Pope, está havendo um grande aumento no número de jovens viciados em videogame - este, aliás, seria o vício que mais cresce naquele país. Uma das 
explicações apresentadas pelo terapeuta é a de que as pessoas cada vez mais usam os games para escapar do mundo real e acabam viciadas na adrenalina que a atividade libera. O comportamento que alguns jovens apresentam poderia então ser comparado ao uso da droga, como pular refeições, matar aula e até mesmo roubar dos pais para conseguir comprar mais jogos. Pope cita casos extremos de jovens que atende, como o de um garoto de 14 anos que jogou por 24 horas sem parar e apresentou sinais de desidratação. Quando os pais tentaram tirar o game dele, ele se tornou agressivo e ameaçou se jogar da janela. Pope diz que atende pelo menos duas crianças por semana que jogam excessivamente - e que mais de duas horas por dia no game produzem o "barato" equivalente a usar uma carreira de cocaína ${ }^{14}$.

Nas mídias jornalísticas, principalmente eletrônicas, não é raro encontrar notícias sobre a dita dependência de videogames. Nesta seção inicial, a partir de algumas dessas reportagens, serão apresentados alguns dos entendimentos científicos que compõem as controvérsias centrais deste trabalho. Os relatos foram recolhidos de fontes tanto nacionais quanto internacionais, sendo estas últimas, com folga, mais abundantes em campo. Basicamente, nestes enunciados públicos há um episódio que chama a atenção da mídia e um especialista é convidado a comentá-lo, a fim de explicar aos "leigos" o ocorrido e aconselhar os "responsáveis". A partir deste contexto geral, colocaremos em diálogo alguns desses depoimentos.

David Walsh ${ }^{15}$, presidente do Instituto Nacional de Mídia e Família dos Estados Unidos, argumenta numa reportagem da agência Reuters que, apesar de os videogames serem divertidos, algumas crianças estão tendo problemas. "Eu continuo a ouvir famílias preocupadas sobre os hábitos de jogo de suas crianças. Não somente precisamos nos concentrar em identificar o problema, como também precisamos encontrar maneiras de ajudar as famílias a evitar e tratar isso". Nesta mesma cobertura, o Dr. Douglas Gentile, professor assistente de psicologia da Universidade de Iowa, pondera que "apesar de a comunidade médica não reconhecer o vício em videogames como uma desordem mental", seu próximo estudo será um dos muitos que permitirá uma discussão sobre os efeitos positivos e negativos dos videogames.

Em reportagem à Folha de São Paulo, a psiquiatra Analice Gigliotti ${ }^{16}$, chefe do setor de dependências químicas da Santa Casa do Rio de Janeiro e médica do Espaço Cliff,

\footnotetext{
${ }^{14}$ INFO Online. Disponível em: http://info.abril.com.br/noticias/ciencia/jogar-videogame-teria-efeito-decocaina-28052010-10.shl (Acesso em: 08/09/2011)

${ }^{15} \mathrm{http}: / /$ br.reuters.com/article/internetNews/idBRSPE53J0CN20090420

${ }^{16} \mathrm{http} / / / \mathrm{www} 1$.folha.uol.com.br/ciencia/2012/09/1146914-viciados-em-jogos-preocupam-pais-epsicologos.shtml
} 
argumenta que "a internet é a dependência da vez, com um uso cada vez mais distribuído. Nela, os jogos on-line são os mais perversos”. Na mesma matéria, Daniel Spritzer, psiquiatra e coordenador do Grupo de Estudos de Adições Tecnológicas, em Porto Alegre, conta que "sempre se pensou que [o videogame] era um passatempo inofensivo". Mas, segundo ele, "começamos a ver uma situação curiosa nas famílias: o problema estava dentro do quarto dos adolescentes, enquanto os pais achavam que assim estavam seguros".

Cristiano Nabuco de Abreu, médico e pesquisador na área de dependência em internet no Instituto de Psiquiatria da USP, relata ainda nesta mesma notícia que "muitos dos pacientes contam que o mais legal é a interação com os colegas no jogo. Dizem se sentir mais valorizados, queridos e eficazes no jogo do que em casa ou na vida". Nabuco de Abreu ${ }^{17}$, em outra reportagem da Folha de São Paulo, conta que "no tratamento, buscamos fazer um paralelo com o paciente para mostrar o quanto a Internet não é uma opção, mas uma rota de escape de uma vida empobrecida”. Ainda segundo este pesquisador, todos os gêneros de games "promovem o aumento da autoestima. Para pessoas com depressão, fobia social ou problema psicológico pontual, a perspectiva de "controlar" um ambiente se torna uma porta de fuga de realidades mal vividas".

Ainda para Nabuco de Abreu, "os profundamente dependentes perdem a habilidade de manejar o tempo que passam na vida virtual". Segundo ele, "em 99\% dos dependentes, há depressão, fobia social ou transtorno bipolar. Geralmente, há questões muito mal trabalhadas, como problemas familiares". De acordo com Abreu, os seus pacientes descrevem uma qualidade de vida muito ruim e uma vida virtual muito boa, de forma que estes jogos "dão chances de o indivíduo realizar sonhos muito rapidamente, desejos e fantasias que não conseguiria de outra forma. E, de quebra, gera a expectativa de ser admirado", de forma que em determinado ponto o jogador "perde momentaneamente a habilidade de discernir o que é virtual do que é realidade". O médico chega à conclusão de que o indivíduo na internet "é o que não consegue ser de fato".

\footnotetext{
${ }^{17}$ http://www 1.folha.uol.com.br/equilibrioesaude/2010/04/719168-ate-os-joguinhos-mais-populares-dainternet-provocam-dependencia.shtml
} 
A psicóloga Eda Fagundes ${ }^{18}$, numa reportagem do jornal $O$ Globo, coloca que jogar videogame só se torna um problema quando este deixar de ser diversão, para tornar-se um vício: "Nós estamos falando aqui do limite. Quando um hobby ultrapassa o limite do saudável, do alegre, da diversão da família, ele começa a andar por caminhos exagerados, a incomodar". Para ela, nestes casos "a pessoa começa a tirar a atenção do filho, da esposa e até dos próprios amigos, dos familiares e de outros hobbys, de outros entretenimentos".

Para Luciana Ruffo ${ }^{19}$, psicóloga do Núcleo de Pesquisas da Psicologia em Informática (NPPI) da Pontifícia Universidade Católica de São Paulo (PUC-SP), "os jogos têm por característica o prazer da satisfação imediata. Quando se vence uma partida, a euforia da vitória e a ansiedade de conseguir viver aquela satisfação de novo tomam conta da pessoa e a levam a perseguir essa sensação de bem estar". Segundo ela, "no universo dos vícios, químicos ou não, quanto mais rápido atinjo o prazer e menor o seu tempo de duração, mais persigo continuamente aquela sensação". Para Ruffo, esse processo estaria relacionado com o sistema cerebral de recompensas para a sobrevivência da espécie: "Ele lhe dá o prazer a fim de repetir um comportamento. O problema é que deturparmos o caminho e então vamos atrás dessa sensação onde ela nem sempre deveria existir" (RUFFO, 2011a).

Por fim, Fábio Barbirato ${ }^{20}$, chefe do Setor Infantil da Psiquiatria da Santa Casa de Misericórdia, escreve para o portal G1, da Rede Globo, que "alguns jovens viciados em videogames chegam a roubar dinheiro dos pais para ir em uma lan house, igual ao que fazem alguns dependentes químicos para comprar drogas”. Segundo ele, a compulsão dos jovens por jogos eletrônicos "é muito parecida com a compulsão por drogas ou álcool, ou com a compulsão dos adultos por pôquer ou apostas no jóquei, ou dos idosos por bingo". Barbirato alerta para o tema do choque de gerações, que perpassa toda esta controvérsia: "É uma coisa muito nova e as famílias não conseguem perceber com facilidade. Falta um referencial. Como os pais vão dar limites e o exemplo aos filhos se eles não foram criados com computadores e videogames?” Ele coloca, então, a Ciência

\footnotetext{
${ }^{18}$ http://gshow.globo.com/programas/mais-voce/O-programa/noticia/2013/01/ha-um-vidogame-entre-nosjogo-e-o-culpado-por-12-dos-divorcios-na-inglaterra.html

${ }^{19} \mathrm{http}: / /$ www.pucsp.br/nppi/downloads/Porque_alguem_se_vicia_setembro_2011.pdf

${ }^{20} \mathrm{http} / / / \mathrm{g} 1 . \mathrm{globo} . \mathrm{com} /$ Noticias/Rio/0,,MUL1475029-5606,00DEPENDENCIA+DE+JOGOS+ELETRONICOS+TEM+SINTOMAS+IDENTICOS+AO+VICIO+EM+ DROGAS.html
} 
como mediadora fundamental na composição deste referencial. Para tanto, Barbirato recorre aos entendimentos mais conhecidos dos tratamentos de drogas químicas: "Em casos diagnosticados de compulsão, a criança diminui a tolerância em ficar distante dos jogos eletrônicos. Ela quer jogar cada vez mais".

A partir da leitura de uma grande quantidade de notícias sobre o tema, observamos que, nestes espaços midiáticos, a cobertura jornalística geralmente não expõe as metodologias e outras informações relevantes sobre as pesquisas (e este não parece ser uma característica exclusiva da área de adicção, mas algo mais geral sobre a forma de divulgação de pesquisas científicas). À primeira vista, pois, não haveria nestes lugares um espaço para reflexões mais aprofundadas sobre as noções enunciadas de vício ou de dependência como as que se buscará desenvolver neste trabalho.

No entanto, observamos que as notícias divulgadas na internet abrem um espaço para comentários do público, o que, inesperadamente, se revelou um espaço muito propício para a investigação. Ali os jogadores muitas vezes aprovam ou reprovam a opinião dos especialistas, alimentam interessantes discussões entre eles mesmos e entram em argumentações com pessoas que se preocupam com a situação de outros jogadores, conformando uma verdadeira arena de disputa de ideias, conceitos e valores - algo próximo daquilo o que Latour chamou de parlamento das coisas - o qual, em oposição ao velho parlamento dos homens, todos, homens e coisas, podem dar a sua contribuição ao debate, sem esperar que cientistas sejam seus únicos porta-vozes.

\section{2 - A incerteza sobre a determinação do vício}

A questão sobre a dependência ${ }^{21}$ de videogames é tomada como uma controvérsia em sentido estrito pois não há consenso em como diagnosticar, tratar e mesmo quanto à própria existência do dito vício. Muitos cientistas da área (GRIFFITHS, 2005; YOUNG, 1998) insistem que o vício em videogames (e em internet) existe em nível universal, e que é uma novidade da qual as pessoas ainda não foram conscientizadas. Como afirma a

\footnotetext{
${ }^{21}$ A confusão entre os termos dependência, vício e adicção se dá somente na tradução para o português. No inglês, língua na qual está escrita a maior parte do material de pesquisa que nos interessa sobre o assunto (apesar de também haver grande produção na China), adota-se geralmente o termo addiction. No Brasil, os autores da literatura especializada preferem evitar o termo vício (já que seria uma expressão amplamente apropriada para além dos "domínios" acadêmicos - como veremos adiante), preferindo, em geral, usar o termo dependência.
} 
psicóloga Kimberly Young ${ }^{22}$, pioneira na discussão de dependência em internet a partir do livro Caught in the Net (1998) e, atualmente, uma das profissionais mais conhecidas no campo, "a dependência de internet parece ser um problema crescente, que independe de cultura, etnia ou gênero" (YOUNG, 2011, p. 51).

Mark Griffths, professor e pesquisador da área de jogo patológico (gambling studies) na Nottingham Trent University (Inglaterra) e um dos mais influentes autores nas discussões de dependência de internet e videogame, em seu artigo escrito juntamente com Mark Davies, intitulado "Does video game addiction exist?" (2005), discute a existência desta chamada "nova desordem psíquica":

Além de notícias da imprensa, pesquisadores têm alegado há mais de vinte anos que patologias sociais estão começando a surgir entre os jogadores excessivos de videogame. Por exemplo, Soper e Miller (1983) alegaram que a "dependência de videogames" ('video game addiction') era como qualquer outra dependência comportamental e consistia em um envolvimento comportamental compulsivo, uma falta de interesse em outras atividades, associação principalmente com outros adictos e sintomas físicos e mentais ao tentar cessar o comportamento (por exemplo, as tremedeiras) (GRIFFITHS, DAVIES, 2005, p. 359, tradução nossa).

Griffiths e Davies argumentam que a dependência de videogames certamente existe, já que as respostas de alguns usuários aos questionários utilizados para diagnosticar a dependência de drogas químicas satisfariam os mesmos critérios gerais:

Por muitos anos, este autor tem definido operacionalmente comportamento adictício como qualquer comportamento que apresenta todos os principais componentes da adicção. É asserção deste autor que qualquer comportamento (por exemplo, jogar videogame) que cumpre estes seis critérios é, portanto, definido operacionalmente como uma adicção (GRIFFITHS;. DAVIES, 2005, p. 359, tradução nossa).

Os critérios a que Griffiths e Davies aqui se referem são aqueles contidos na teoria dos seis fatores centrais da dependência (saliência, mudança de humor, tolerância, sintomas de abstinência, conflitos e recaída/reinstalação), os quais serão descritos e investigados em detalhes no primeiro capítulo deste trabalho. É de interesse privilegiado desta investigação descrever como, e com base em quê, esses critérios e questionários são elaborados e aplicados e como, efetivamente, atuam na controvérsia.

\footnotetext{
${ }^{22}$ Kimberly Young é psicóloga e especialista em transtornos de dependência da Internet e comportamento online. É professora na St. Bonaventure University e diretora-fundadora do Center for Internet Addiction, em 1995. Foi professora de psicologia da Universidade de Pittsburgh em Bradford, com um PhD em Psicologia Clínica. Young é membro da Associação Americana de Psicologia, da Associação Psicológica Pensilvânia, e membro-fundadora da Sociedade Internacional de Saúde Mental online.
} 
No entanto, se tomarmos a citação de Griffiths como autoevidente, isto é, se a mantivermos trancada em sua caixa-preta ${ }^{23}$, imediatamente surge outra questão, que, segundo o próprio Griffiths, é mais interessante e mais importante que a primeira:

Sa dependência de videogames existe, de quê exatamente as pessoas são dependentes? De aspectos do seu estilo especifico? (por exemplo, de uma atividade anônima e desinibidora)? De tipos específicos de jogos (jogos agressivos, jogos de estratégia etc.)?" (GRIFFITHS, 2005, p. 360, tradução nossa).

Esta resposta não está dada a priori. Mark Griffiths mesmo comenta que esta controvérsia gerou muitos debates entre os pesquisadores e terapeutas que atuam neste campo. A princípio, pois, uma controvérsia quente neste debate parece ser, além da suposta "existência" do próprio vício, como, de fato, estes videogames viciam. Griffiths ainda pondera que existem diferenças significativas entre os tipos de jogos, bem como entre as formas de jogar, as quais buscaremos detalhar ao longo deste trabalho, em especial no quarto capítulo.

Há também a necessidade de uma taxonomia geral dos videogames, como pode acontecer de determinados tipos de jogos serem mais viciantes do que outros. Outro grande problema é que os videogames podem ser jogados de maneiras muito diferentes: em dispositivos portáteis, computadores pessoais, consoles, fliperamas e na Internet. Pode ser o caso de algumas mídias para videogames (como um fliperama ou a Internet) serem mais viciantes por conta de outros fatores em evidência nestes meios (por exemplo, a desinibição permitida pela Internet) (GRIFFITHS; DAVIES, 2005, p. 365, tradução nossa).

A seguir, encontramos depoimentos dos pesquisadores tchecos Lukas Blinka e David Smahel, da Faculdade de Estudos Sociais da Universidade de Masaryk, os quais demonstram uma especial apreensão no caso dos $\mathrm{MMORPGs}^{24}$ (jogos online de representação de papéis para multijogadores):

É praticamente certo, contudo, que a dependência de jogos online tem aumentado nos últimos anos. Acreditamos que a realidade virtual como uma forma de escape do mundo real será cada vez mais comum - e os MMORPGs

\footnotetext{
${ }^{23}$ Para Latour (1994), uma caixa-preta é qualquer actante tão firmemente estabelecido que podemos desconsiderar seu interior. As propriedades internas de uma caixa-preta não contam na medida em que estivermos preocupados somente com seu input e output. As caixas-pretas não são apenas aparatos, mas qualquer espécie de ator consolidado que se torna quase que inquestionável.

${ }^{24}$ Segundo Fortim (2013, p. 65), "os jogos conhecidos como MMOGs (Multi Massive Online Games) ou MMORPGs (Multi Massive Online Role Playing Games) são apontados como uma atividade de potencial adictício muito grande, desde a época dos antigos jogos de texto, conhecidos como MUDs (Multi User Domain). Atualmente, o jogo mais conhecido é o World of Warcraft (WoW), jogo com tema sobre o universo de J.R.R. Tolkien, que conta com 11,4 milhões de jogadores no mundo todo, segundo a Blizzard Entertainment" (BLIZZARD, 2012)".
} 
não serão exceção. Se a fronteira entre a realidade concreta e a realidade virtual continuar se tornando cada vez mais indistinta, seja pela melhora gráfica dos jogos, qualidade dos monitores, seja pelo desenvolvimento de novas ferramentas tecnológicas como monitores em óculos, luvas com sensores, e assim por diante, podemos esperar que esse fenômeno se torne ainda mais significativo e profundo. Será cada vez mais difícil para o jogador distinguir o mundo real do virtual, e sua imersão no jogo será ainda maior. A importância de se examinar os MMORPGs no contexto da dependência aumentará muito (BLINKA; SMAHEL, 2011, p. 115).

Até aqui, suspeitamos que o conhecimento científico que circula na área de tratamento de drogas nas disciplinas de Psiquiatria e em certas vertentes da Psicologia ligadas ao campo da saúde ${ }^{25}$ influencia o modo de conceber a relação dos jogadores com os videogames. Mas isto não é uma obviedade. Como se dá esta ligação? O que videogames e o crack teriam em comum - passando pelos vícios associados, como os jogos de azar, pornografia, internet - que justificaria a utilização dos mesmos métodos de diagnóstico e de tratamento? Na sequência, mostramos ainda outro trecho sobre o vício em MMORPGs, dos mesmos autores acima citados, que reforça o que se desconfiou inicialmente:

A dependência dos MMORPGs é específica devido à presença virtual do jogador em uma comunidade, e também devido ao relacionamento com o personagem virtual, mas aparentemente não é especial no que se refere aos princípios e procedimentos terapêuticos. A nossa recomendação aos terapeutas de possíveis dependentes dos MMORPGs é que usem os procedimentos comprovados que costumam usar para outros tipos de dependência ou problema e, possivelmente, combiná-los com as opções fornecidas pelo mundo virtual (BLINKA; SMAHEL, 2011, p. 114).

Quais seriam, então, estes conhecimentos científicos comprovados que tomariam o status de porta-vozes dos próprios jogadores? Só é possível vislumbrar alguma resposta a esta questão considerando as complexas articulações em rede (redes, estas, de saber e de poder) dos variados actantes. Uma vez entendidas as alianças e as caixas-pretas (LATOUR, 1994) que sustentam associações entre os actantes tornadas estáveis, será possível visualizar a influência-chave de alguns deles, como a Associação Americana de Psiquiatria $^{26}$ e seu documento principal, o Manual Diagnóstico e Estatístico de

\footnotetext{
${ }^{25}$ No âmbito de cada uma dessas disciplinas há uma grande multiplicidade de linhas de pensamento, assim como divergências entre argumentos, de modo que as suas fronteiras são borradas e não comportam certas generalizações.
}

26 A American Psychiatric Association (ou Associação Americana de Psiquiatria) é a principal organização profissional de psiquiatras e estudantes de Psiquiatria nos Estados Unidos e a mais influente no mundo. Seus cerca de 38 mil membros são, em sua maioria, estadunidenses, mas muitos vêm de outros lugares do mundo. A associação possui várias publicações e panfletos, dentre eles o Manual Diagnóstico 
Transtornos Mentais (DSM). Isso leva a resoluções como: "De todas as maneiras de avaliar a dependência de internet, os critérios baseados no DSM parecem ser a maneira mais aceita de definir o transtorno" (YOUNG; YUE; YING, 2011, p. 33). Segundo Marie Crowe:

O DSM-IV (APA, 1994) pretende ser "prático e útil para os médicos, procurando assegurar a brevidade dos conjuntos de critérios, clareza de linguagem e afirmações explícitas de construções incorporadas nos critérios de diagnóstico" (1994, xv). É basicamente um sistema classificatório que visa enxergar, isolar características, reconhecer aqueles que são idênticos e os que são diferentes, para então reagrupar e classificá-los em espécies ou famílias (Foucault, 1977). Como um sistema classificatório, sua finalidade pode ser entendida como a tradução de determinados comportamentos observados em sintomas. Estes sintomas são atribuídos com uma importância considerável anêmico, diagnóstico e prognóstico (Foucault, 1973) (CROWE, 2000, pp. 6970, tradução nossa).

Segundo Stuart Kirk (2005), autor crítico das desordens mentais psiquiátricas, se aprofundarmos na rede que constitui o DSM, veremos que o seu contexto político é um tópico controverso, incluindo seu uso por indústrias farmacêuticas e seguradoras. Um potencial conflito de interesses tem surgido porque aproximadamente $50 \%$ dos autores que previamente selecionaram e definiram as desordens psiquiátricas do DSM mantiveram ou mantêm relacionamentos com indústrias farmacêuticas. Alguns argumentam que a expansão dos transtornos no DSM foi influenciada por motivos de lucratividade e representa um aumento da medicalização dos seres humanos, enquanto outros argumentam que problemas de saúde mental são subestimados ou subtratados.

Apesar da prevalência de atores como o DSM, alguns dos cientistas e terapeutas trazidos para esse debate afirmam que as pesquisas sobre a dependência de videogames têm sido problemáticas. Segundo Kimberly Young (2011), muitos estudos carecem da solidez empírica do planejamento experimental, baseando-se apenas em dados de levantamento e informações de populações autosselecionadas. Para ela, algumas pesquisas também não usam de forma adequada os grupos de controle e, em alguns casos, tiram conclusões a partir de um número muito pequeno de estudos de caso e questionários. Mark Griffiths, no entanto, coloca que "mesmo a partir de pesquisas escassas, é evidente que os videogames parecem ser, pelo menos, potencialmente viciantes" (p. 365). É nesta toada que seguiremos a discussão daqui em diante.

e Estatístico de Desordens Mentais, ou DSM. Trata-se de uma publicação que descreve as condições psiquiátricas e é usado mundialmente como referência para diagnóstico de transtornos mentais. 


\section{3 - As retóricas do vício}

A transferência da concepção de vício para discursos que relacionam atividades que exijam repetição, ou que têm qualidades compulsivas, não está limitada aos games, mas tem sido aplicada aos jogos de azar (GRIFFITHS, 1998), à compulsão sexual (YOUNG, 1998) e à pornografia (PORNOGRAPHY \& SEXUAL VIOLENCE, 1983), entre outros "objetos". No entanto, as chamadas "novas tecnologias" parecem ser um alvo privilegiado; tanto a Internet quanto videogames e telefones celulares têm sido apontados como artefatos de qualidades inerentemente viciantes (YOUNG, 1998; QUIN, 2001).

Segundo a leitura crítica de Rob Cover (2006), o trabalho de Kimberly Young sobre o vício em internet serve como um significativo exemplo de como a retórica do vício é articulada para denunciar formações sociais que emergem por meio da mídia digital. Em seu texto, Young sugere que o uso frequente e "tomador de tempo" das mídias digitais não é diferente de "alcoolismo, dependência química, ou vícios como comer demais e jogos de azar" (YOUNG, 1998). Cover comenta que, ao invés de traçar um conjunto de paralelismos entre o digital como droga e as chamadas drogas químicas, Young trabalha por meio de uma noção de comportamento adicto que aproxima a clássica dependência de drogas a hábitos tais como o jogo compulsivo de apostas, comilança crônica, compulsão sexual e obsessão por assistir televisão. Para ela, "é o sentimento experienciado que é viciante, mais do que a mídia digital em si” (YOUNG, 1998, tradução nossa).

Para outros autores (BINAISA, 2002; FEDERWISCH, 1997; REID, 1998), a noção de dependência digital é fabricada por meio da articulação de uma semelhança entre as noções de ambos - os fármacos e os jogos eletrônicos - como escapistas, uma fuga do real. Exploraremos a fundo esta e outras noções de "realidade" no terceiro capítulo.

Sem purificar o que se entende por "físico" (ou "químico") do que é considerado "comportamental" (ou "virtual"), vemos que tanto a abordagem de Cover como a de Young são, cada uma a seu modo, complexas. Para a presente pesquisa, interessa clarear as diferenças em suas formas de composição. Uma indagação inicial, portanto, pode ser colocada do seguinte modo: por quê essa relação repetitiva específica é socialmente tida como negativa, ao passo que outras relações não são vistas como objeto de dependência, embora também possam desencadear doenças? 
Essa pergunta nos leva direto à questão central: $\mathrm{O}$ que seria mesmo o vício, ou a dependência de jogos eletrônicos? Essa é uma categoria-chave para a pesquisa. É justamente a noção de vício que é constatemente discutida, desestabilizada e colocada em risco na etnografia, já que não há consenso em torno de seu significado. É pouco afirmar que esta noção é socialmente construída, pois consideraríamos, assim, somente um dos dois lados da história (LATOUR, 1994).

Podemos trabalhar provisoriamente com a hipótese de que o vício é um fenômeno que compreende relações não-controladas, não-domesticadas, em que está em jogo a captura da subjetividade humana. O vício constantemente aparece ligado às ideias de embotamento, alienação e desumanização. Estaria o usuário de jogos eletrônicos se tornando um autômato, deixando de ser humano ou perdendo a essência de sua humanidade? Podemos suspeitar que, nesta tentativa moderna de purificar o humano (e o não-humano, separados de forma isolada nos pólos sociedade e natureza) de que fala Bruno Latour (1994), o videogame aparece como uma séria ameaça ao humanismo.

O antropólogo Eduardo Vargas (2006) alerta que indagar "por que as pessoas usam drogas?” ou “o que significa usar drogas?” não é colocar boas questões. Para Vargas, as respostas que os especialistas costumam dar a estes questionamentos apresentam uma invariável impressionante: o porquê ou o significado do uso de drogas são regularmente imputados a uma falta ou fraqueza, física e/ou moral, psíquica e/ou cultural, política e/ou social. Segundo Vargas, habituamo-nos a pensar que o consumo de drogas seria uma resposta a uma crise ou a uma carência qualquer: "consomem-se drogas porque falta saúde, afeto, cultura, religião, escola, informação, dinheiro, família, trabalho, razão, consciência, liberdade etc.” (p. 585-586). Sua proposta é que:

Em vez de indagar o porquê ou qual o significado do uso de drogas, cabe perguntar o que ocorre, ou que experiência os usuários atualizam mediante o consumo. [...] Minha hipótese de trabalho é que o que ocorre são eventos e que esses eventos implicam experimentações intensivas de autoabandono, ou o paradoxo de ações que deliberadamente visam "sair de si" (VARGAS, 2006, p. $583)$.

Suspeita-se que a denúncia dos jogos eletrônicos feita pela ciência médica de que estes jogos representariam uma forma inválida de engajamento textual erige-se a partir de diversas associações dos videogames com outros campos, como: drogas, violência, juventude, ludicidade, sensibilidade, comunicabilidade, materialidade, corporalidade e 
virtualidade. No entanto, é importante frisar que podemos verificar a validade destas suspeitas somente a partir de uma extensa etnografia realizada em campo. A partir do material coletado ao longo deste trabalho, propomos uma reflexão acerca de dois aspectos do videogame: o primeiro enquanto jogo, isto é, como algo associado ao campo do lúdico (o qual exploraremos no segundo capítulo), e o segundo enquanto algo pertencente ao campo do virtual (que veremos em detalhes no terceiro capítulo).

\section{3 - Notas teórico-metodológicas}

\section{1 - Constituindo um parlamento das coisas}

Antes de mergulhar na controvérsia propriamente dita, buscaremos apresentar um breve arcabouço teórico-metodológico associado a esta proposta de trabalho. Não será elaborado aqui propriamente um "referencial teórico", mas uma introdução a uma espécie de vocabulário mobilizado pelos autores referenciados, que, de alguma maneira, caminham em direção a uma antropologia pós-social, pós-humana e/ou simétrica. Devemos notar, como recomenda Latour (2006) em sua teoria-ator-rede (A-N-T), que ao longo da própria descrição os conceitos já aparecem conectados aos actantes, auxiliando o trabalho etnográfico. Portanto, não se está aqui meramente "aplicando" conceitos a uma realidade exterior que possa servir de exemplo empírico, mas os “experimentando" na prática, junto dos actantes.

Chamaremos aqui de cosmopolítica ${ }^{27}$ (STENGERS, 2007), a princípio, a proposta de agregar política $^{28}$ e cosmologia num mesmo plano de análise. Por um lado, isso busca levar em conta a alteridade cosmológica dos coletivos e, por outro, colocar tais cosmologias em relação, incluindo humanos e não-humanos no parlamento das

\footnotetext{
27 "Leva-se em conta aqui o sentido grego de arranjo, de harmonia, ao mesmo tempo que aquele, mais tradicional, de mundo. É então um sinônimo do bom mundo comum, o que Isabelle Stengers chama cosmopolítica (não no sentido multinacional, mas no sentido metafísico de política do cosmo)" (LATOUR, 2004, p. 374). Nota-se que há diferenças em torno deste conceito entre estes dois autores. Para Latour, cosmopolítica é "arranjo", composição, busca de "harmonia", ao passo que para Isabelle Stengers é resistência, portanto mais destinado a desmontar do que a montar.

28 "Entende-se, aqui, em três sentidos, que se distinguem por intermédio de perífrases: a) na sua acepção usual, designa a luta e os compromissos dos interesses e das paixões humanas diante das preocupações dos não-humanos; utiliza-se ainda a expressão políticas da Caverna; b) no sentido próprio, designa a composição progressiva do mundo comum e todas as competências exercidas pelo coletivo; c) no sentido restrito, chama-se política somente a um dos cinco alicerces necessários à Constituição, e que permite a representação fiel pela ativação, sempre a retomar, da relação um/todos” (LATOUR, 2004, p. 383).
} 
$\operatorname{coisas}^{29}$, sem tratar a política como uma esfera apartada da vida "social ${ }^{30 ",}$, ou como um fato "natural". Aqui, natureza e sociedade 31 não devem constituir, como para os Modernos, um par opositor ${ }^{32}$, mas dois lados de uma mesma moeda.

Como expressão a um só tempo de uma nova natureza da política e de uma nova política da natureza, o conceito/proposta de "cosmopolítica" ambiciona explorar relações simetricamente comparáveis entre coletivos muito distintos entre si, mas só aparentemente inconciliáveis no plano da análise. Dentre esses impasses privilegiaremos o que estamos chamando aqui de "contextos cosmopolitas", isto é, situações de sobreposição, convivência ou embate entre práticas e discursos [...]. Com isso, buscaremos fortalecer a aposta na comparabilidade de "modos de existência" ou "ontologias" (termos que, ao lado do dualismo "nós/eles", deverão ser problematizados) [...] algo que já tem sido experimentado pela assim chamada "Antropologia Simétrica" (cf. LATOUR, GOLDMAN \& VIVEIROS DE CASTRO apud SZTUTMAN; MARRAS, ementa do curso "Cosmopolíticas em comparação: diálogos entre a Antropologia da Ciência e da Modernidade e a Etnologia Indígena", 2013).

Para Márcia Moraes (2000), o objetivo do parlamento das coisas é tornar públicas as controvérsias sociotécnicas, conferindo representatividade a um maior número de agentes. Neste sentido, não se tomará de antemão a representação do tipo caixa-preta, mas serão seguidas etnograficamente as passagens do instável ao estável, das controvérsias a novos fechamentos.

A proposta da descrição etnográfica é seguir a rede sociotécnica de actantes (LATOUR, 2006), detalhando agenciamentos (DELEUZE, 1988) específicos entre humanos e nãohumanos, como os próprios videogames. Em direção à uma antropologia que se propõe simétrica, buscamos considerar os variados discursos que aparecem no campo num

\footnotetext{
${ }^{29}$ Segundo Márcia Moraes (2000), o parlamento das coisas celebra a não-modernidade das práticas científicas porque nele os cientistas não são os únicos representantes das coisas. É uma rede, um rizoma que funciona sem o julgamento de uma unidade transcendente, sem demarcações pré-estabelecidas, sem bordas.

${ }^{30}$ Segundo Latour, não podemos afirmar que exista algo que seja por si só social. Humanos e nãohumanos se associam e essas associações geram efeitos, e esses efeitos deslocam objetivos, redefinem posições e sentidos. Não importa as entidades, o que importa são os efeitos que esses "atores" fazem fazer. Neste sentido, estes atores não são apenas tomados como intermediários, que somente transportariam significados, desejos ou vontades (agências dadas de antemão pelos unificadores de natureza e sociedade), mas mediadores, cujas presenças modificam as redes de relações.

31 "Chama-se sociedade ou mundo social à metade da velha Constituição que deve unificar os sujeitos separados dos objetos, e sempre submissa à ameaça da unificação pela natureza; é um todo já constituído que explica as condutas humanas e permite, então, abreviar o papel político da composição; faz o mesmo papel paralisante que a natureza, e pelas mesmas razões. O adjetivo "social" (em inferno do social, ou representação social, ou construtivismo social) é, então, sempre pejorativo, pois designa o esforço sem esperança dos prisioneiros da Caverna para articular a realidade sem ter os meios" (idem, 2004, p. 385).

${ }^{32}$ A rigor, o melhor é livrar-se desse par, ou pelo menos não partir dele ou supô-lo agindo de antemão.
} 
mesmo plano, sejam estes provenientes dos aficionados por videogames, sejam estes dos psiquiatras. Assim, a partir dos princípios metodológicos da proposta de Latour (2007), buscamos entender de que modo os enunciados acerca da dependência de jogos eletrônicos são construídos, purificados e erigidos em caixas-pretas. Ao compreender este processo de transcendentalização, no qual a dimensão imanente, do construído (plano oficioso) se oculta e a "verdade" (num plano oficial) se mostra, foi possível apreender as controvérsias que desestabilizam as associações bem amarradas em torno do tema.

Concentramo-nos, por enquanto, nos enunciados e discursos sobre a dependência de jogos eletrônicos. O conceito de regimes de veridicção ${ }^{33}$, definido por Michel Foucault (2008) como um "conjunto de procedimentos regulados para a produção, a lei, a repartição, a circulação e o funcionamento dos enunciados" (FOUCAULT, 1988a, p.14), pode guardar semelhanças com a discussão da formação e manutenção das verdades (ou fechamento em caixas-pretas). O que interessa particularmente a Foucault $^{34}$ são "os efeitos de verdade no interior de discursos que não são nem verdadeiros e nem falsos" (1988a, p. 7). O seu interesse não é, portanto, pelo valor de verdade dos enunciados, mas pelo valor da verdade em termos políticos.

Em suma, neste estudo o esforço se deu no sentido de constituir um parlamento das coisas a fim de aproximar a teoria-ator-rede das informações de campo, mapeando a variada semântica de noções de dependência e de vício enunciadas e praticadas pelos variados sujeitos envolvidos na controvérsia: os próprios jogadores; pais, cônjuges e

33 São os tipos de discurso que uma sociedade acolhe e faz funcionar como verdadeiros. $O$ estabelecimento da verdade não consiste em buscar enunciados que descrevam com perfeição a realidade, mas, sim, produzir enunciados que atendam a rituais sociais de legitimação de um discurso. Por fim: “esse regime não é simplesmente ideológico ou superestrutural (FOUCAULT, 1988, p.14).

${ }^{34}$ Se há alguma aproximação possível entre a análise de discurso foucaultiana e a proposta de Latour, para quem os discursos não devem ser separados da prática (já que estes próprios seriam entendidos como práticas discursivas), necessitaríamos de mais investigação teórica. Sabe-se que Latour, em Jamais Fomos Modernos (1991), coloca-se contra o desconstrucionismo tão em voga na chamada onda pós-moderna, por autores como Francis Lyotard e Jacques Derrida; por sua vez apostando, com a companhia de Isabelle Stengers, no chamado composicionismo. Latour ressalta que o pesquisador não deve pretender descrever a realidade a partir de um nível de "análise" epistemologicamente distinto dos atores (tampouco "superior" ou "exterior"), como em certos trabalhos de análise de discurso, em que o analista termina por evidenciar apenas o seu caráter socialmente/culturalmente construído. Ao invés, deve fazê-lo junto dos actantes, num mesmo plano descritivo-epistemológico, e principalmente evidenciando suas próprias ações, relações e pontos de vista. Bruno Latour (2004) ainda elabora uma distinção entre matter of facts ${ }^{34}$ (coisas que são disputadas para construir fatos) e matter of concern (que envolvem os interesses), que poderá servir à presente discussão ao interrogar a aparente dicotomia construtivismo versus realismo, bem como à descrição dos dados etnográficos. 
demais pessoas próximas a estes jogadores; profissionais da indústria de games; cientistas de diversas áreas; teorias acadêmicas, notícias jornalísticas, vídeos circulados na internet e regulamentações legais. A descrição das práticas e dos discursos dos atores, por meio da articulação das dimensões do chamado mundo "real" e dos mundos "virtuais", tornou possível rastrear as associações com os videogames sem cair numa dicotomia assimétrica entre o verdadeiro e o falso.

\section{2 - Mapeando controvérsias}

Embora o termo controvérsia muitas vezes carregue o sentido de uma polêmica viva, ela foi empregada aqui em um sentido mais restrito, de um debate em torno de um fato que ainda não foi determinado. O principal objetivo desse tipo de análise é confrontar formas de conhecimento que ainda são instáveis para atingir a uma compreensão mais profunda das disputas na fabricação dos fatos. Segundo a documentação oficial do MACOSPOL (Mapping Controversies on Science for Politics):

A palavra "controvérsia" refere-se aqui a cada pedaço de ciência e tecnologia que ainda não está estabilizado ou fechado em "caixas-pretas"; isto não significa que haja uma disputa feroz ou que esta ainda não foi politizada; nós as utilizamos como um termo geral para descrever incerteza compartilhada" (VENTURINI, 2009, p. 6, tradução nossa).

Segundo o antropólogo André Lemos (2013, p. 110), as "cartografias de controvérsias" propostas por Tomasso Venturini e Bruno Latour, nada mais são do que formas de "desenhar" a distribuição das ações, seguir os actantes, visualizar os diagramas da mediação e agenciamentos e revelar cosmogramas. Para Lemos, "se a Teoria Ator-Rede é uma teoria, a Cartografia de Controvérsias é sua metodologia" (2010, p. 105). Neste sentido, o mapeamento de controvérsias é um conjunto de técnicas para explorar e visualizar polêmicas, questões emergentes em determinados agrupamentos, o movimento, a circulação da ação e a fluidez das mediações, revelando as diversas dimensões que compõem uma rede sociotécnica. Lemos lembra que "onde se vê estabilização, só há intermediários" (p. 105-106). Onde existe controvérsia, há diversos mediadores e actantes. "Consequentemente, a CC [Cartografia de Controvérsias] pode ser entendida como um método de pesquisa para revelar as mediações” (p. 105).

A ideia do princípio metodológico das controvérsias é a ideia política de simetrização. Neste caso, como a dependência tornou-se temática de especialistas, o intuito é 
expressar ou representar os debates de alguma forma que não-especialistas possam ter acesso e inclusive avaliar o que está sendo feito. A investigação buscará mapear quais são os argumentos, crenças e princípios envolvidos. Essa justificativa é, assim, uma prática aplicável e também teórica, já que a descrição de uma realidade está associada a uma narrativa teórica. Neste sentido, para Venturini, sua compreensão requer "abandonar uma das ideias mais veneráveis da cultura ocidental: a crença de que, por trás de todas as ideologias e controvérsias, deve existir alguma realidade objetiva independentemente do que os atores pensam ou dizem" (2009, p. 18, tradução nossa). Para este autor, a cartografia de controvérsias é um conjunto de pressupostos que balizam as observações e descrições de incertezas compartilhadas. Elas são situações nas quais os atores concordam na discordância.

Infelizmente (ou melhor, felizmente), não importa o quão confiante esses profetas possam parecer, nem todos finalmente concordam. Essa é uma das lições cruciais da cartografia de controvérsia (idem, p. 18, tradução nossa).

É neste movimento de acompanhar a transição de um estado de instabilidade em direção à estabilidade (e vice-versa), de abertura de caixas-pretas em direção a novos fechamentos, que se pode visualizar mais nitidamente, num plano da imanência, as associações entre os atores. Segundo Venturini (2009), este estado de magma - onde proliferam problemas, inovações e visões, onde está tudo em disputa - é um momento especial para cartografar ${ }^{35}$ controvérsias. A presente investigação, pois, incidirá nas situações em que as incertezas tornam-se mais complexas, e não menos, pelo conhecimento científico. E apesar de sempre buscar a complexidade, esta tampouco ambiciona ser uma etnografia da totalidade. Como se frisou anteriormente, a proposta é uma etnografia da própria controvérsia; mas como existem múltiplas delas em campo, serão perseguidos intencionalmente alguns dos rastros de seus atores-rede ${ }^{36}$.

Controvérsias são complexas porque são o cadinho onde a vida coletiva é derretida e forjada: elas são o social no estado magmático. Como a rocha em magma, o social nas controvérsias sociais é líquido e sólido ao mesmo tempo. Mas há mais sobre esta metáfora: magma em estados sólidos e líquidos existem uma transformação mútua incessante; enquanto, nas margens do fluxo, a lava

\footnotetext{
${ }^{35}$ Cartografar não significa cartografar entidades ou objetos, mas conexões, fluxos, pontos de inflexão, deslocamentos, controvérsias. A cartografia deve ter humanos e não-humanos, bem como conceitos, os quais não são exteriores ao sujeito.

${ }^{36} \mathrm{O}$ ator-rede não é um ator social, mas o efeito da rede. Isto é, surge a partir de uma conexão. Qualquer um dos elementos que ajude o fluxo (não somente valores, ou pessoas, ou entidades ou exclusivamente animais), que faça-fazer, que produza uma diferença na narração, é um ator-rede.
} 
resfria e cristaliza, algumas outras sólida tocada pelo fluxo de calor da gusa e torna-se parte do fluxo" (VENTURINI, 2010, p. 264, tradução nossa).

Isso vale tanto para a observação e descrição etnográfica quanto para a atuação no próprio debate, pois, uma vez que há uma maior abertura para mudanças nestes estados, há mais espaço para dialogar e interferir nas tentativas de composição destes mundos comuns $^{37}$. No entanto, antes de chegar a estes mundos comuns - e a chegada é sempre provisória, não um turno final, já que consensos são um caso de mediação, "assim como o repouso é um caso do movimento" (TARDE, 2007, p. 98) - , é necessário fazer um esforço de tradução entre estes mundos tidos, a priori, como incomunicáveis, reconhecendo novos canais de comunicação. Como estamos lidando com "mundos" ou "ontologias" muito distintas, o trabalho de tradução não é levado a cabo sem modificações que vislumbrem alcançar certo nível de comunicação com o diferente. Portanto, fica evidente nesta tradução a alteração de sentidos, interesses e posições dos agentes; o que, por outro lado, também possibilita novas criações e arranjos.

Seguindo as ideias de Latour, o antropólogo Tiago Coutinho (2011, p. 131) afirma que traduzir (ou transladar) significa deslocar objetivos, interesses, dispositivos, seres humanos. Implica desvio de rota, invenção de um elo que antes não existia e que de alguma maneira modifica os elementos imbricados. Para ele, as cadeias de tradução referem-se ao trabalho pelo qual os atores modificam, deslocam e transladam os seus vários e contraditórios interesses. Descrevendo diversas táticas de deslocamento de interesses e objetivos, Latour (2000, p. 6) esclarece que, além do significado linguístico de transposição de uma língua para outra, a noção de tradução tem aqui um significado de transposição de um lugar para outro. Assim, transladar interesses é, ao mesmo tempo, oferecer novas interpretações desses interesses e canalizar as pessoas para direções diferentes.

Neste mapeamento das controvérsias, buscamos seguir os quatro princípios metodológicos propostos por Latour em Ciência em Ação (2000): primeiro, escolher e

\footnotetext{
37 "Um mundo comum é possível, mas não como algo que venha a reconhecer, como se tivesse estado sempre aqui (e que não tinha até agora sido percebido). "Um mundo comum, se é que vai existir, é algo que teremos que construir juntos, com unhas e dentes" (LATOUR, 1994c, p. 455)" (VENTURINI, p. 1819, 2009, tradução nossa).
} 
evidenciar a porta de entrada na rede ${ }^{38}$. Em segundo lugar, identificar os porta-vozes ${ }^{39}$. Terceiro, desenhar os dispositivos de inscrição, ou seja, a forma como os actantes se inscrevem para formar a rede. Por fim, rastrear as associações ${ }^{40}$, isto é, mapear as ligações da rede evidenciando quem e em quê momento está falando e agindo.

De acordo com Tomasso Venturini (2009), o mapeamento de controvérsias tem uma metodologia precisa: utilizam-se cinco níveis de análise, ou "lentes" diferentes de observação, que propiciam uma multiplicação de perspectivas. Começa-se pela identificação das declarações concorrentes, dos argumentos em disputa, e segue-se para a discussão da literatura que os suporta. Da literatura, parte-se aos diversos atores envolvidos na questão. Estes atores estão ligados de alguma forma, aliados ou em conflito - eles constituem, portanto, redes complexas ${ }^{41}$. Das redes vamos à cosmologia e às suas diferentes versões. E, por fim, vemos como as diferentes cosmologias se confrontam em relações sociotécnicas de poder: a cosmopolitica. Devemos lembrar que estas cosmologias postas em diálogo não têm as fronteiras bem demarcadas, pois, na prática, aparecem como híbridas.

Segundo Venturini (2010), para que haja uma controvérsia ${ }^{42}$ é necessário o acordo de um grande número de actantes sobre a sua veracidade. E apesar de ter participação direta e agência nela própria, não é o analista que a "inventa" por si só. Venturini recomenda que se deve ouvir todos os actantes (lembrando que quem define a

\footnotetext{
${ }^{38}$ A escolha da entrada na rede, assim como a entrada em campo, define o conjunto de relações que o pesquisador estabelece e qual plano da vida social que será acompanhado. Deve-se explicitar e até rever qual é o ponto de entrada na rede. Sem isso, corre-se o risco de objetificar os saberes envolvidos.

39 Aqueles que falam em nome da rede, aqueles que sintetizam, aqueles que desviam. Não são os humanos que estão falando por eles. Ao identificar os porta-vozes, revelar-se-ão aqueles momentos que são mais sintéticos, actantes que permitem dar expressão à experiência que está sendo descrita.

${ }^{40}$ Rastrear como os sujeitos humanos estão cooperando, como a rede de cooperação às vezes é uma coisa e às vezes é outra dentro do mesmo circuito, mostrar como a rede de cooperação inclui outras entidades. Deve-se observar esses influxos e deslocamentos de fluxo (STRATHERN, 1996a).

${ }^{41}$ Segundo o antropólogo Jean Segata (2008b), as redes não devem ser compreendidas como essências, mas como eventos, pois são algo que não podem nem ser definido pelo que as sustentam, nem pelo o que elas produzem. Pode-se afirmar que as redes são compostas de atores, da mesma forma que os atores são compostos de redes - o que varia, portanto, são as lentes de observação.

${ }^{42}$ As controvérsias fabricam efeitos e têm produção de grupos e conceitos, aos quais se deve atentar. Mapear controvérsias, portanto, não é descrever um emaranhado de conceitos ou dar-lhes uma ordem, mas justamente trazer complexidades.
} 
controvérsia são os actantes $^{43}$ e não o analista), observar vários pontos de vista (a “objetividade" emerge daí) utilizando vários métodos de análise e de observação, e dar peso proporcional (poder diferenciado) aos actantes. Há ainda outras recomendações: não restringir a observação a uma simples teoria ou metodologia; observar a partir de tantos pontos de vista quanto possíveis, e ouvir as vozes dos atores mais do que as próprias presunções (VENTURINI, 2010, p. 260).

Latour (2000, p. 88-89) afirma que não se deve procurar as qualidades intrínsecas de qualquer afirmação, mas sim as transformações pelas quais esta passa em mãos alheias. Essa regra é consequência daquilo que ele designou no artigo "Society is technology made durable" como o primeiro principio: o destino de fatos e máquinas está nas mãos dos usuários posteriores. Para ele, devemos observar tudo o que está atado às afirmações: a) como são feitas as atribuições de causas e efeitos; b) que pontos estão interligados; c) que dimensões e que forças têm essas ligações; d) quais são os mais legítimos porta-vozes; e) como todos esses elementos são modificados durante a controvérsia (p. 315-316).

Michel Callon coloca que se deve reconhecer que nada pode ser descartado à negociação e que não existe um critério de verdade ou de eficácia que se impõe irrevogavelmente aos atores. Para ele, as necessidades são construídas, reforçadas e (mais ou menos) garantidas por relações de poder ${ }^{44}$ (CALLON, 1999, p. 155, tradução nossa). Ele aponta, abaixo, quatro características da cartografia de controvérsias:

1. A controvérsia é sobre um objeto técnico, mas não se reduz ao objeto pura e simplesmente técnico, já que esse não existe.

2. As soluções são sempre múltiplas e sem direção dada de antemão, já que envolvem a negociação entre diferentes actantes que são eles mesmos redes, eventos, híbridos.

3. Os grupos implicados têm interesses variados, cosmovisões que entram em conflito e que revelam forças e hierarquias diferenciadas.

4. As forças tendem a se equilibrar nas negociações ao longo da controvérsia, esfriando-a, criando pontualizações ou caixas-pretas (LEMOS, 2013, p. 108-109, apud CALLON, 1999).

\footnotetext{
43 Algumas entidades parecem ter capacidade para serem sujeitos da ação, outras não, embora tenham ação. $\mathrm{O}$ actante se torna uma entidade que efetivamente gera diferença naquela controvérsia.

${ }^{44}$ Neste ponto há algumas diferenças significativas entre os autores aqui citados. Latour (1991b), por exemplo, evita a utilização do termo relações de poder na sua proposta de descrição de controvérsias. Para ele, não devemos buscar explicar as coisas pelo poder, nem tomá-lo como algo pronto ou anterior. Latour prefere, no lugar, observar como se constroem as associações e os movimentos em direção a transcendências e imanências.
} 


\section{3 - Rumo a uma antropologia da cibernética}

Segundo Theophilos Rifiotis, professor do Departamento de Antropologia da Universidade Federal de Santa Catarina e coordenador do GrupCiber $^{45}$ na mesma instituição, “a pesquisa no campo da 'cibercultura' terá muito a ganhar levando em consideração a teoria ator-rede" (2012, p. 11). Não à toa, essa teoria-metodologia e a temática das tecnologias digitais possuem certas afinidades eletivas, como mostra o próprio livro de André Lemos, "A comunicação das coisas: teoria ator-rede e cibercultura" (2013). Acerca deste assunto, Rifiotis argumenta:

Podemos interrogar a própria prática etnográfica sobre os limites de produzir narrativas de agências humanas e não-humanas, sobre a prática de rastreamento de associações e como destacar agências, ou identificar coletivos híbridos, mapear fluxos da ação e seus deslocamentos e controvérsias (RIFIOTIS, 2012, p. 11).

A partir dos estudos do ciberespaço, Jean Segata (2008b), integrante do mesmo grupo de pesquisadores, aponta que se deve atentar, ao mesmo tempo, para a agência nãohumana (dos ditos “objetos"), assim como para a ação humana (ditos “sujeitos"), numa via de mão dupla. Com o objetivo de confiscar o privilégio da ação dos seres humanos do plano oficial, para Segata é necessário aplicar este esforço de reconsiderar a agência daquilo o que provém de outros seres até então relegados a um plano oficioso. Dessa forma podemos buscar uma simetria na prática entre o humano e o não-humano, eventualmente rompendo barreiras entre tais entes de ontologias de geometria variável (LATOUR, 1994, p. 87).

Para esclarecer o argumento, serão expostos alguns exemplos de enunciados. Assim, a afirmação de que "os videogames viciam as pessoas" pode ser entendida como um argumento materialista (num sentido oposto ao humanista ou sociologista), pois confere o privilégio da ação às coisas (no caso, aos videogames). Neste primeiro caso, não importam as pessoas, o jogo que é viciante. Por outro lado, a afirmação de que "as pessoas se viciam nos videogames" seria, por contraste, um argumento sociológico, pois a autoria da ação é oficialmente reconhecida como exclusiva do homem. Isto é, a pessoa é entendida como uma entidade autônoma, já que decidiria por si própria a hora que

\footnotetext{
${ }^{45}$ O Grupo de Estudos em Antropologia do Ciberespaço (GrupCiber), criado na UFSC em 1997, tem desenvolvido pesquisas voltadas para os fenômenos sociais engendrados no "ciberespaço" a partir da expansão das tecnologias da informação e da comunicação e das modalidades de "comunicação mediada por computador".
} 
quer jogar e parar de jogar. O videogame, deste modo, é visto como neutro ou intermediário e privado de ação.

A saída para este dilema não se dá por uma via essencialmente materialista (que confere prevalência à ação das coisas), nem sociológica (que olha privilegiadamente para as ações humanas). Segundo Segata (2008b), “a briga está entre objetos que acrescentam algo a sujeitos, e sujeitos que transformam objetos e vice-versa". Para ele, o duplo equívoco está, tanto do lado materialista, quanto do lado sociológico, em evocar as essências, tanto dos objetos, quanto dos sujeitos. De forma que, "quando as proposições são articuladas, elas se juntam numa proposição nova. Tornam-se 'alguém, alguma coisa mais' (LATOUR, 2001, p. 207), um composto coletivo de humano e nãohumano" (SEGATA, 2008b, p. 8).

Entre as disciplinas que estudam o ciberespaço, esta sugestão parece romper com as discussões analíticas que tratam apenas de vias de mão única, já que, em geral, os considerados sujeitos (dotados de agência) de tais relações são apenas os humanos, que "em grande parte de nossos discursos são aqueles que têm a possibilidade de se apropriar das tecnologias, que seriam, por óbvio, apenas objetos da ação humana" (SEGATA, 2008a, p. 10). O mesmo autor alerta que isso exige, pelo menos, que nos questionemos “quem, ou o que, também são sujeitos nessas relações".

Isso consiste em sugerir que não há como continuar pensando nas coisas em si mesmas, como meros objetos, ou que elas existem em si mesmas e que as conhecemos por que estamos distantes delas, no polo dos sujeitos. Se podemos conhecê-las e dizer algo sobre elas, é porque estamos mais próximos delas do que imaginamos, nos transformando, transformando-as. Afinal, estamos todos associados, entre sujeitos (SEGATA, 2008a, p. 11).

Nesta tentativa de recomposição de mundos "reais" e "virtuais", buscaremos, pois, repovoar o social com outros actantes além dos humanos, como os próprios games, consoles, fabricantes, equipamentos ${ }^{46}$, entre outras "coisas" que permitem nos colocar em relação aos humanos, como os usuários e desenvolvedores. Nesta discussão, o antropólogo francês Pierre-Lévy, em seu livro "Cibercultura", argumenta que:

O ciberespaço não compreende apenas materiais, informações e seres humanos, é também constituído e povoado por seres estranhos, meio textos, meio

\footnotetext{
${ }^{46}$ Deve-se lembrar que equipamento é uma coisa, sujeitos são outra. Ou seja, equipamentos podem vir a ser "sujeitos" (ou mediadores) na medida em que ganham agência significativa na rede; caso contrário, serão meros intermediários.
} 
máquinas, meio atores, meio cenários: os programas. Um programa, ou software, é uma lista bastante organizada de instruções codificadas, destinadas a fazer com que um ou mais processadores executem a tarefa. Através dos circuitos que comandam, os programas interpretam dados, agem sobre informações, transformam outros programas, fazem funcionar computadores e redes, acionam máquinas físicas, viajam, reproduzem-se, etc. (LÉVY, 2003, p. 41).

Assim podemos pensar que os videogames não seriam somente "apropriados" pelos humanos, como também agem sobre eles. As tecnologias, assim, também seriam sujeitos da ação. Assim, não somente o jogador jogaria o jogo, mas o jogo também joga o jogador. Seria, então, o jogador de fato autônomo na hora em que supostamente decidiria passar um tempo dedicado a atividade de jogo? Será que ele controla totalmente este seu uso dos videogames? Ou os games também disputam com o jogador este controle? Ao longo da descrição etnográfica pretendemos desenvolver estas e outras indagações.

\section{4 - Etnografias do virtual}

Pela própria característica do trabalho de campo, experimentaremos aqui, além da etnografia "convencional", a chamada etnografia virtual. Christine Hine $(2000, \text { p. } 7)^{47}$ coloca uma reflexão importante acerca da questão de onde localizar o trabalho de campo nesse tipo de etnografia: “"o campo’ é antes uma categoria epistemológica que ontológica: é um estado de espírito" (tradução nossa). A proposta de seu trabalho é estudar, por métodos etnográficos, a comunicação mediada por computador ${ }^{48}$ (CMC), passando por diversas reflexões sobre quais seriam eles, considerando o que se manteria e o que se modificaria em uma pesquisa no ambiente virtual em comparação aos métodos clássicos. Nesta releitura da oposição entre o "real" e o "virtual", Hine questiona a ideia de uma necessidade intrínseca de sempre estar fisicamente presente no local para que a observação participante ocorra (tal como supõe Malinowski [1922] em

\footnotetext{
${ }^{47}$ Cristine Hine é uma cientista inglesa que exerce atividades de ensino e pesquisa na Universidade de Surrey, Inglaterra. Adota uma abordagem fortemente interdisciplinar (vai da Biologia à Ciência da Informação e Comunicação), centrando-se em metodologias de pesquisa aplicadas a ambientes online.

48 Segundo Rifiotis (comunicação pessoal), o que Christine Hine estaria rastreando, mesmo quando coloca os equipamentos no meio, seria uma comunicação intermediada por computador, pois, no sentido estrito de produzir uma transformação ou de participar da produção da comunicação, os equipamentos estariam fora (2013).
} 
seu clássico roteiro de trabalho de campo). Knorr-Cetina ${ }^{49}$, a respeito dos estudos de ciência no laboratório, por sua vez pontua sua faceta de virtualidade: "o laboratório é um espaço virtual na maioria dos aspectos e na maioria dos aspectos co-extensivo com o experimento" (1992, p. 125, tradução nossa).

\section{4 - Procedimentos metodológicos}

\section{1 - A pesquisa de campo: técnicas e tecnologias}

Como não há uma demarcação espaço-temporal firmemente delimitada neste estudo, o ponto de unidade entre os diversos campos de coleta de dados é a própria controvérsia composta. Buscamos, assim, unir a proposta latouriana do mapeamento de controvérsias ao conceito de etnografia multissituada ${ }^{50}$ de George Marcus (1998). Segundo este último, o pesquisador deve seguir as cadeias, as trajetórias e os fios que compõem um fenômeno específico e de fazer conjunções ou justaposições de situações, estabelecendo uma associação entre elas (1998, p. 105).

A pesquisa de campo foi levada a cabo com uma imersão dupla no universo dos games e no universo das ciências psi, a fim de mapear os pontos gerais da controvérsia. Seguindo os atores-rede, buscou-se investigar a agência de jogadores, pais, cônjuges (ou outras pessoas que possam monitorar o seu uso), profissionais da indústria de games, desenvolvedores independentes, inovações, plataformas, artigos científicos, manuais de tratamento, teorias, questionários, pesquisadores, terapeutas, a mídia, leis e decisões do governo, consoles, e, por fim, os videogames propriamente ditos. Nesse sentido, buscou-se construir uma etnografia polifônica, tentando reconhecer a fala de diferentes atores a partir da "produção colaborativa do conhecimento etnográfico" (CLIFFORD, 1998, p. 54) e da citação extensa e regular de informantes.

\footnotetext{
49 Socióloga austríaca, conhecida por seus trabalhos em epistemologia e construtivismo social. É professora de Sociologia na Universität Konstanz e professora visitante na Universidade de Chicago.

${ }^{50} \mathrm{O}$ objeto da pesquisa não é, assim, necessariamente, restrito a determinado grupo situado no interior de um campo de observação. Muitas vezes, o objeto consiste em um determinado fenômeno social), e sua construção ocorre ao se fazerem determinados movimentos (por meio de passos já previamente planejados ou oportunistas), seguindo pessoas, histórias, objetos, ao longo de várias cadeias, superpondo situações e verificando os pontos nos quais as intersecções, ressonâncias e associações ocorrem" (MARCUS, 1995, p. 106).
} 
Não obstante estas duas referências, que abrem possibilidades para outra forma de produção etnográfica em uma antropologia contemporânea, este trabalho de campo pode não ser necessariamente lido como de cunho estritamente etnográfico, em sua acepção clássica (MALINOWSKI, 1922), isto é, no sentido de uma longa observação participante em que o pesquisador acompanha o dia-a-dia dos sujeitos estudados. O que empreendemos aqui foi basicamente uma triangulação entre os materiais reunidos na pesquisa: entrevistas, material publicado na internet (notícias, vídeos, fóruns e comentários) e referências acadêmicas (manuais de tratamento, artigos, livros, questionários) na área de adicção de drogas, videogames e internet.

A porta de entrada para esta investigação foram notícias e vídeos divulgados na internet, os quais contam com depoimentos de especialistas e comentários de usuários, e especialmente o livro Dependência de internet: Manual e guia de avaliação $e$ tratamento. A partir desta entrada, foi realizada uma revisão bibliográfica da produção científica sobre o tema do vício em internet e jogos eletrônicos produzida no país e sobretudo no exterior. Esta extensa pesquisa bibliográfica, virtude da natureza interdisciplinar da discussão, exigiu que o pesquisador adentrasse em campos que extrapolam as convencionais fronteiras disciplinares. A pesquisa da literatura especializada também foi encarada como parte do trabalho de campo, já que os próprios autores e suas obras são importantes actantes na controvérsia. Foram reunidos cerca de 50 documentos científicos, entre artigos, livros e teses. A partir da leitura e da sistematização desses trabalhos, foi possível esboçar um mapeamento da conexão entre os autores e suas respectivas perspectivas teóricas.

Também foi realizada uma documentação de notícias jornalísticas sobre o assunto, por sua vez reunidas em um website (http://gamedependencia.wordpress.com) para apresentação dos resultados da pesquisa, seguindo as recomendações do artigo "Building on faults: How to represent controversies with digital methods" (VENTURINI, 2010). Trata-se esta de uma proposta de nova forma de apresentação dos resultados da pesquisa, já que o tradicional método de exposição é limitado pela natureza linear e verbal do texto escrito.

Foram rastreadas mais de 140 notícias (e comentários dos usuários) em sites como Agência Universitária de Notícias, Coletivo Cult, Corpo Saun, Estado de São Paulo, 
FayerWayer Brasil, G1 (globo.com), Folha de São Paulo, GameAddict, GameStorming, Garotas Geeks, Geek, Hypescience, Mundo dos Hackers, O Globo, Outer Space, Página 22, Revista Galileu, RockPaperShotgun, Veja.com, TechTudo, Terra, Toda Teen, Via6, UOL. Ademais, dezenas de vídeos (em sites como YouTube) contendo reportagens do Canal Futura, Rede Bandeirantes, TV Globo, TV Ideologia, TV O Povo, TV Record, SBT, Via Legal; canais como Games For Change e TEDx; e nas redes sociais Facebook, Orkut e Twitter, além de produções independentes dos internautas.

As redes de interlocutores foram construídas a partir da incursão extensiva do pesquisador em diversos espaços, presenciais e virtuais. Entre eles, as próprias casas dos jogadores (assim como de seus pais e familiares), eventos científicos ${ }^{51}$, grupos do Facebook $^{52}$, fóruns de discussão, blogs, comentários de notícias, cursos de extensão ${ }^{53}$ e eventos de desenvolvimento de jogos ${ }^{54}$ e instituições ${ }^{55}$. A partir dos contatos iniciais seguimos as redes de atores que pareceram mais frutíferas.

Ao todo, foram feitas vinte extensas entrevistas (de 1h de duração, em média), por meio de um roteiro de perguntas semiaberto, com jogadores, familiares desses jogadores, desenvolvedores e cientistas, as quais foram transcritas e disponibilizadas integralmente no site da pesquisa. Os interlocutores foram elencados a partir da própria rede de relações do pesquisador, as quais se multiplicaram durante o período da investigação. Não foi usado qualquer critério exterior ou escala científica para definir se seriam dependentes ou não, e em diversos casos tivemos depoimentos de "ex-viciados", que contaram retrospectivamente os seus problemas passados com os games.

Para fins de organização e variação de perspectivas, as entrevistas foram divididas em quatro categorias: 1) jogadores; 2) pais/cônjuges; 3) desenvolvedores; 4)

\footnotetext{
${ }^{51}$ I Súmula de Pesquisa em Games; VIII Seminário Internacional Imagens da Cultura/Cultura das Imagens; III Seminário História de Roteiristas: Múltiplas Telas; I Festival Games Brasil, II e III Festival Games For Change América Latina, XI e XII Simpósio Brasileiro de Games e Entretenimento Digital SBGames; defesa do doutorado de Ivelise Fortim),

52 Dependência de Internet; IDGA São Paulo; Curso Unity Puc 2013; Unity 3D Brasil; Indie Game Developers; Boteco Gamer e SPjam.

${ }^{53}$ Desenvolvimento de Games com Unity 3D, na PUC-SP.

${ }^{54}$ São Paulo Indie Developers (SPIN) e a II e III Maratona Paulista de Desenvolvedores de Games ( SPJam).

${ }^{55}$ Núcleo de Estudos em Psicologia da Informática (NPPI) da Pontifícia Universidade Católica de São Paulo (PUC-SP) e o coletivo Games For Change.
} 
terapeutas/cientistas. Em muitos casos, no entanto, esta divisória não é clara. Por exemplo, quase todos os desenvolvedores também são jogadores, assim como alguns cientistas e familiares.

\title{
4.2 - A inserção do pesquisador na controvérsia
}

\begin{abstract}
Não há definições para aprender; não há premissas para honrar; nenhuma hipótese para demonstrar; nenhum procedimento a seguir; nenhuma correlação para estabelecer. [...] Os pesquisadores não podem fingir serem imparciais apenas porque obedecem alguma diretriz teórica ou metodológica. De acordo com a cartografia de controvérsias, perspectivas de investigação nunca são imparciais (VENTURINI, 2010, p. 259-260, tradução nossa).
\end{abstract}

O interesse nesta pesquisa surgiu quando se tomou contato com as abordagens de alguns profissionais da saúde que propunham um tratamento médico para o problema da dependência.. Os mesmos, no entanto, à primeira vista não mostravam ter a mesma familiaridade dos usuários com o objeto específico (videogames) com o qual estavam trabalhando. Por meio de discussões antropológicas contemporâneas, vimos uma oportunidade de colaborar na construção de um diálogo entre estes mundos apartados: as ciências e os games. Frise-se bem: o autor não tem qualquer ligação institucional ou pessoal relacionada à abordagem clínica. Seu interesse na discussão é, sobretudo, acadêmico.

No entanto, podemos dizer que há componentes políticos e mesmo emocionais (e todos estes adjetivos) no seu envolvimento com os games, já que sua história na área de jogos coincide com a história de sua vida: praticamente desde o seu nascimento tem o hábito de criar jogos e brincadeiras e, claro, jogar videogames - embora nem de perto com a mesma intensidade que alguns jogadores que foram abordados na pesquisa. É um desenvolvedor independente há mais de 10 anos: criou cerca de 20 jogos, entre jogos de cartas, tabuleiros e de computador, a maioria publicada não oficialmente e sem qualquer interesse financeiro. Hoje coordena um projeto de criação de um game, Huni Kuin: Yube Baitana (os caminhos da jiboia), com os índios Kaxinawá do Acre.

O pesquisador passou por um forte processo de mudança ao longo da pesquisa. Inicialmente demasiado avesso às iniciativas clínicas, o problema da chamada dependência afetou o seu modo de conceber a questão ao atentar para casos delicados, tomar contato com experiências de outros pesquisadores e reconhecer que a questão da dependência é por demais complexa: há casos em que este uso intenso vem 
acompanhado de uma série de sofrimentos. Este processo auxiliou no refinamento da investigação e, em verdade, reforçou a necessidade inicial de construir uma abordagem complexa e interdisciplinar entre estes mundos distintos, buscando entender de perto o que se passa nos games. Esta afetação está incorporada neste presente texto, e de certo modo, valida este trabalho enquanto experiência etnográfica. Por fim, reconhece-se que ainda é incipiente sua intervenção neste campo de estudos de escala ampla e global.

\section{5 - Apresentação dos capítulos}

Nesta seção apresentaremos o caminho a ser percorrido por esta dissertação. A proposta do primeiro capítulo, Por dentro da rede: o conhecimento médico, consiste em mapear parcialmente os distintos modos de classificação, métodos de diagnóstico e tratamento relacionados à dependência de videogames. Nos apoiando na teoria-ator-rede de Bruno Latour, buscamos constituir um parlamento das coisas inicial. O propósito foi descrever a variada semântica de noções de dependência, adicção e vício enunciadas e praticadas pelos diferentes sujeitos envolvidos na controvérsia, principalmente entre cientistas (de diversas áreas, como psiquiatria e psicoterapia) e teorias acadêmicas. Passamos por uma discussão acerca das principais correntes teóricas que abordam o assunto, tais como o modelo cognitivo-comportamental, o modelo neuropsicológico, a teoria da compensação, numa tentativa de desestabilizar os seus pressupostos e ressaltar os elementos colocados em controvérsia. Ao costurar este cruzamento de perspectivas a partir das práticas, discursos e classificações dos sujeitos, tentamos multiplicar as possibilidades de traçar os rastros destas conexões entre homens e videogames.

No segundo capítulo, O sério e o lúdico: repensando as categorias lazer e trabalho a partir dos videogames, investigamos as associações entre jogo, lazer e trabalho. Para tanto, foi colocada em discussão a articulação entre estes três conceitos para, a partir das problemáticas levantadas pelos jogadores na etnografia, rever as possibilidades de experimentação destes enquanto categorias analíticas nesta e em futuras pesquisas. No fim, propomos um modelo para investigar o engajamento humano em atividades cotidianas, baseado em graus de comprometimento, a despeito de serem classificadas como lazer ou trabalho, prazerosas ou maçantes, de "tempo livre" ou "tempo ocupado".

No terceiro capítulo, O real e o virtual: mundos distintos?, abordamos o aspecto virtual (ou da comunicação mediada por computador) da dependência de jogos eletrônicos. 
Exploramos os pontos de contato e afastamento entre as dependências de internet e de videogame. Em seguida, destrinchamos controvérsias específicas sobre corporalidade, sensitividade, imaterialidade, comunicabilidade e anonimidade presentes nos enunciados acerca da dependência. Seriam os "mundos virtuais" realidades apartadas do que se entende por "vida real"? A partir da etnografia, descrevemos os sentidos do que se entende por realidade através de diversas perspectivas presentes na controvérsia. Propomos, junto com demais autores, redefinir o conceito de virtual para lidar com a emergência de realidades mediadas por computador.

No capítulo derradeiro, Por dentro do jogo: explorando o círculo mágico, descrevemos de forma mais detalhada a experiência do jogador, ressaltando a importância de conhecer sua realidade, para então compreender mais a fundo suas relações com os videogames. Foram mapeadas disputas envolvendo os conceitos nativos de vício, as diferenças entre os gêneros de videogames, os ambientes de jogo (casa, lan-house etc.) e as relações com familiares, cônjuges e demais pessoas afetadas pelo uso dos jogos. Adentramos também os "mundos" dos MMORPGs, apontados pelos próprios jogadores como o tipo de jogo com mais frequência de casos de dependência. Por fim, trouxemos à tona os conhecimentos dos desenvolvedores de jogos sobre os mecanismos de recompensa, além da Teoria do Fluxo. Fechando o capítulo, há uma reflexão acerca da monetização nos games, da gameficação e da proposta dos jogos independentes.

Na conclusão, refinamos a reflexão sobre as aproximações entre videogames e drogas, apresentando novas propostas que possibilitam uma imbricação entre conhecimentos científicos e as realidades dos jogos digitais. A partir das implicações do trabalho de campo, descrevemos algumas taxonomias modernas e constatamos uma infertilidade nas compreensões teóricas da dependência de cunho generalista. Na sequência, propomos e encorajamos, enfim, abordagens alternativas, tanto acerca das questões das drogas como dos videogames. Neste sentido, reafirmamos uma abordagem que ressalta as entre-capturas (STENGERS, 2003) ou as possessões recíprocas (TARDE, 1910) entre os agentes, rumando a um espiritualismo generalizado, em que todos os seres homens, coisas, ideias e máquinas - agem e são agidos sobre e por cada um. 


\section{Capítulo 1 - Por dentro da rede: o conhecimento médico}

Impõe-se a necessidade de falar da medicina com sendo um discurso. E, primeiramente, para extrair o fato de que se participa do discurso médico mesmo que não se possua seu saber e sua prática (CLAVREUL, 1983, p. 48).

Resumo: A proposta deste capítulo de abertura consiste em um mapeamento inicial dos distintos modos de classificação, métodos de diagnóstico e tratamento acerca da dependência de videogames. Apoiando-se na teoria do ator-rede de Bruno Latour, buscou-se constituir um parlamento das coisas a fim de descrever a variada semântica de noções de dependência e de vício enunciadas e praticadas pelos variados sujeitos envolvidos na controvérsia. A isto somam-se a apresentação e discussão de modelos explicativos, questionários, teorias acadêmicas e os depoimentos de cientistas e terapeutas. Junto destes diversos sujeitos, buscamos investigar a maneira pela qual os múltiplos saberes científicos sobre a dependência de drogas associam-se a outros elementos, como as dependências comportamentais, dentre as quais nos interessa, em especial, a dependência de jogos de azar e as chamadas dependências tecnológicas. Passaremos por uma discussão entre as principais correntes teóricas que abordam o assunto, tal como o modelo cognitivo-comportamental, o modelo neuropsicológico, a teoria da compensação e os fatores situacionais, numa tentativa de desestabilizar alguns de seus pressupostos e ressaltar elementos colocados em controvérsia pelos demais actantes. Ao costurar este cruzamento de perspectivas a partir das práticas, discursos e classificações dos sujeitos, buscaremos multiplicar as possibilidades de rastrear estas conexões dos homens com os videogames.

Palavras-chave: dependência; videogame; drogas; virtualidade.

\section{1 - Modos de classificação do jogador de videogames como dependente}

Neste capítulo iremos nos debruçar sobre algumas formas científicas de entendimento da dependência de videogames. A maioria das teorias aqui tratadas é oriunda das áreas da Psiquiatria (especialidade da Medicina) e da Psicologia, ambas bastante múltiplas, em especial esta última, que contempla diversas linhas de trabalho - como a psicologia comportamental, a psicanálise, a neuropsicologia, entre outras. Nosso esforço aqui será entender algumas das principais controvérsias científicas, primeiro entre elas próprias, e depois em relação às visões dos jogadores. Para tanto, pedimos paciência ao leitor para, inicialmente, exibir as teorias na forma que são apresentadas pelos terapeutas que as adotam. A seguir, iremos colocá-las em relação a partir dos questionamentos suscitados 
pelo cruzamento das perspectivas dos pesquisadores e pela experiência etnográfica com os jogadores (esta última descrita, sobretudo, no capítulo final desta dissertação).

A primeira questão aqui é: quem determina se o jogador é viciado (ou não) nos jogos eletrônicos? A sua própria enunciação? Um teste científico? A fala daqueles que convivem com o mesmo, como pais, cônjuges e familiares? Vê-se que, em muitos casos, os terapeutas tratam de jogadores que supostamente não identificariam a sua própria doença e teimariam em não querer largar o jogo. Ao mesmo tempo, há especialistas que afirmam que muitos daqueles que se dizem viciados, na verdade, não apresentam sintomas de dependência; enquanto outros jogadores que não se acusariam viciados, apresentariam tais sintomas. É nesta encruzilhada entre médicos, pacientes, aparelhos, modelos, teses, questionários e jogadores que debateremos estes modos de classificação. Abaixo segue uma reflexão da etnógrafa Annemarie Mol:

O que se tornou contestável não são apenas as representações da realidade, sob a forma de informação que circula sob a forma de palavras e imagens; mas também a própria modelação material da realidade no diagnóstico, nas intervenções e práticas de investigação. Por isso, se é importante ter em conta as formas como os pacientes se representam (como clientes ou como cidadãos), é pelo menos importante também perguntar como são eles representados nas práticas de conhecimento (MOL, 2007, p. 19).

A psicóloga Ivelise Fortim (2013), professora da Pontifícia Universidade Católica de São Paulo (PUC-SP), membro do Núcleo de Pesquisas da Psicologia em Internet (NPPI) na mesma universidade, e importante interlocutora nesta pesquisa, argumenta que apesar de existir uma série de controvérsias neste tema, é consenso entre diversos pesquisadores que o excesso de uso de videogames é prejudicial e que este pode trazer muitas consequências negativas aos usuários, tais como: problemas físicos (fadiga, dor física, redução do tempo de sono, pular refeições); problemas na vida pessoal (conflitos com a família e/ou amigos, baixa interação social) e problemas acadêmicos e profissionais (falta às aulas ou ao trabalho, desempenho ruim) (GRIFFITHS, 2008; HSU; WEN; WU, 2009; HUSSAIN; GRIFFITHS, 2009b; LIU; PENG, 2009; PETERS; MALESKY, 2008; SMAHEL; BLINKA; LEDABYL, 2008 apud FORTIM, 2013). Segundo estes pesquisadores, as consequências negativas podem ser diversas, tais como sentimentos de isolamento, depressão e baixa autoestima (SCHMIT; CHAUCHARD; CHABROL et al., 2011 apud FORTIM, 2013). 
Como veremos mais adiante, nem tudo o que Fortim apresenta como consenso é realmente inquestionável ao longo das diversas redes que compõem esta controvérsia: as caixas-pretas aos poucos vão sendo abertas. Contudo, podemos inicialmente colocar que há casos em que constatamos certo consenso na avaliação se uma pessoa nutre uma relação problemática com os videogames. Por exemplo: ela mesma acredita que está viciada e quer parar de jogar, as pessoas com quem convive partilham da mesma opinião, e os especialistas, por meio de suas metodologias científicas, confirmam que a pessoa vive uma relação negativa de dependência com os jogos eletrônicos. Já em outros casos, há jogadores que não se intitulam viciados, ninguém ao seu redor reclama de seu modo de utilização dos jogos eletrônicos e os cientistas não avaliam a relação como adictícia. Contudo, não são esses os casos que nos interessam, mas justamente aqueles em que, ao contrário, há controvérsia. Neles que verificamos a disputa de argumentos e a construção das associações - em suma, a formação da própria ideia do que é um viciado em videogames.

O principal objetivo aqui, enfim, é descrever as diversas metodologias, classificações e modos científicos de categorização da dependência, inclusive como estas se apoiam e se afastam entre si. Não nos interessa simplesmente mapear a disputa pelas determinações, nem somente apresentar os critérios geralmente usados para classificar a dependência, mas entender, sobretudo, o que a classificação científica de um usuário como dependente faz-fazer (LATOUR, 2000). Nesse sentido, as classificações são entendidas também como actantes (idem), pois participam e modificam as redes de relações. Devese ter em mente que este tipo de categorização pode ser mobilizado como instrumento político por diferentes actantes para os fins mais variados possíveis. Um caso apresentado pela pesquisadora acima referida nos ajuda a pôr o problema:

Tem um caso de um autor que chama Elias Aboujaoude ${ }^{56}$, que foi citado num processo, porque ele acredita em dependência de internet. Aí teve um cara que ficava vendo pornografia no trabalho e foi demitido. O cara entrou com um processo falando que dependência de internet era um diagnóstico novo e que se era um diagnóstico então a empresa tinha que cobrir e pagar o tratamento dele, igual pagava de álcool, igual pagava de drogas. E botou a empresa no pau (FORTIM, 2013, comunicação pessoal).

\footnotetext{
${ }^{56}$ Elias Aboujaoude é um psiquiatra situado na Universidade de Stanford (EUA), especialista no chamado transtorno obsessivo compulsivo e nas ditas dependências comportamentais, como o uso problemático de Internet.
} 
Nesta descrição, Fortim aponta que há interesses e negociações por toda parte. Ela abre as portas para o ponto central de nossa discussão: as controvérsias nas formas científicas de classificação da dependência.

Então, vai botar a empresa no pau? Porque aí tem um lobby dos planos de saúde: "Isso não é um diagnóstico, a gente não tem que pagar isso!"; "Você é um pervertido que ficou vendo pornografia no emprego, não é um dependente!". Agora, onde está a linha fina do quê que a gente chama na psicologia o que é normal e o que é patológico? Lembrando que a gente fala normal e patológico porque está dentro da curva normal. Só que a curva normal é dada pela época. Têm doenças que aparecem mais numa época, aparecem mais em outra. (idem)

Fortim ainda apresenta uma questão crucial no contexto norte-americano: a agência de duas grandes indústrias com interesses opostos: a indústria farmacêutica e a de planos de saúde. Por um lado, a indústria farmacêutica age a favor da criação e a ampliação de novos diagnósticos psiquiátricos, pois isto aumenta suas vendas de remédios. Por outro, a indústria de planos de saúde se coloca contra, porque a institucionalização desta "nova dependência" aumenta seus custos com o pagamento de médicos e indenizações. Neste embate, há algumas dimensões cosmopolíticas que podem visíveis mesmo em porções da rede que chegam até o Brasil.

Nos Estados Unidos tem dois lobbies fortes, um é indústria farmacêutica e outro é plano de saúde. A indústria farmacêutica tem um lobby forte pra criar novos diagnósticos. Porque quanto mais diagnóstico novo você tem, mais remédio você tem pra dar pras pessoas. Então, nos Estados Unidos tem um lobby forte de indústria farmacêutica acerca dos diagnósticos e esse é um dos debates da história da ritalina do TDAH. Quer dizer, você cria um diagnóstico pra dar ritalina. Eu não acho que é assim. Eu acredito em TDAH e em dependência de internet, só que eu acho que tem um exagero com $n$ lobbies de indústrias. Só que nos Estados Unidos também tem um lobby forte contra os diagnósticos, que são os lobbies dos planos de saúde. Porque uma vez que dependência de videogame seja catalogado como uma patologia, os planos de saúde americanos têm que cobrir. E eles não querem cobrir. (idem)

Em ambos os casos, há uma série de actantes que povoam aqui o chamado social. Todos estes estão contemplados no seio de nossa discussão cosmopolítica: médicos, métodos estatísticos, interesses, indústrias, teorias, autores, substâncias, processos jurídicos, doenças, videogames, jogadores, entre outros seres, situados num mesmo plano de relação. Fortim opina, por fim, que o papel dos pesquisadores (e, de forma mais abrangente, da Ciência) seria clarificar as distinções de "normal" e "patológico". Nos resta entender de que forma isto é feito. Com isso, partiremos para uma imersão nas 
próprias teorias e entendimentos médicos e psicológicos e faremos uma espécie de revisão científica sobre o assunto.

Como adiantado na introdução, a porta de entrada para este âmbito da discussão médico-acadêmica da controvérsia foi o livro "Dependência de Internet: Manual e Guia de Avaliação e Tratamento", única publicação em português sobre o assunto. Uma boa parte das teorias analisadas neste capítulo foram extraídas deste material, mas somaramse a ela diversas outras fontes, entre artigos e livros acadêmicos de diversos autores. Neste sentido, a leitura e a articulação de seus enunciados junto aos cientistas e jogadores também se constitui como parte do trabalho de campo. No entanto, de antemão esta primeira fonte nos trás uma limitação: a psicóloga americana Kimberly Young, principal autora do livro, assim como os autores colaboradores, encaram a dependência de videogames como um subcaso específico da dependência de internet, sendo esta considerada mais abrangente. Este modo de classificação se apresenta, na atualidade, como um dos mais destacados e influentes no tratamento do problema na medicina. Entretanto, esta não é a única forma possível. Neste sentido, pretendemos apresentar como se constroem sobreposições e articulações entre diferentes teorias de dependência de drogas químicas, jogos de azar, internet e videogames.

A disputa entre as definições do próprio jogador e as definições por meio de outros agentes (ex: testes científicos) estaria posta a partir de um suposto desconhecimento do jogador sobre a sua situação real. A pergunta que os cientistas anteriormente referidos externam é: em que extensão alguém que se classifica como dependente realmente apresenta um comportamento de dependência? $\mathrm{O}$ que significa, afinal, este comportamento de dependência? Para alguns, a princípio isso não poderia ser definido pelo usuário ele próprio (pois este não teria real consciência de seu estado), mas por conceitos e métodos científicos em tese "neutros" e "exteriores", isto é, esse entendimento pertenceria assim ao campo das Ciências Naturais, articulado em rede com seus pesquisadores e aliados (LATOUR, 2000). Ou pelo contrário, para outros, o suposto comportamento de dependência somente poderia ser definido pelo próprio usuário de forma autônoma, apreendido deste modo como único legítimo detentor (e representante) do conhecimento de seu corpo e de seu estado de saúde, ignorando argumentos, por exemplo, como o dos mecanismos de recompensa e da possível perda de consciência do jogador. Na sequência, colocamos algumas questões neste sentido. 
Rob Cover (2006) comenta que, segundo uma pesquisa de Kimberly Young, 5 a 10\% dos utilizadores da internet seriam classificados como dependentes. Neste estudo, com base em estimativas de diferenciação de usos de álcool, jogos de azar e drogas, Young conclui que cinco milhões de usuários de internet seriam dependentes. Cover escreve que, Young articula uma narrativa particular de dependência online unicamente a partir das respostas dos usuários, Para ele, no entanto, tal pesquisa tem pouca legitimidade em termos metodológicos, já que confia inteiramente nestas respostas. Além disso, para Cover, o dado de que $97 \%$ de seus entrevistados "gastaram mais tempo na internet do que eles gostariam" acrescenta pouco sobre o efetivo uso dessas mídias digitais.

Em outro estudo quantitativo (SMAHEL; BLINKA; LEDABYL, 2007), encontramos uma concordância entre a autodefinição como dependente e o que estes autores denominam como comportamento de dependência, em aproximadamente $21 \%$ dos jogadores. Essa é, segundo Smahel, Blinka e Ledabyl, a proporção de jogadores que apresentam sintomas de dependência e se consideram dependentes. Cerca de um quarto dos jogadores afirma ser dependente, mas não apresentaria sintomas de dependência. Isso ocorre, segundo os mesmos pesquisadores, provavelmente devido ao uso popular exagerado da palavra dependência - ou seja, ao "cair" no senso comum, um termo tido como próprio não estaria mais sobre seu total controle, tendo que disputá-lo com os demais atores em campo, extrapolando as fronteiras das ciências.

Bkinka e Smahel, pesquisadores da Faculdade de Estudos Sociais da Universidade de Masaryk (República Tcheca), contam que muitos jogadores baseiam seu julgamento sobre ser ou não ser dependente unicamente na quantidade de tempo dedicada aos jogos. De seu ponto de vista terapêutico, $6 \%$ dos jogadores não se considerariam dependentes, mas apresentariam sintomas de dependência. Segundo eles, esse grupo não reconheceria seu comportamento dependente e isso deveria ser trabalhado terapeuticamente. Os $49 \%$ restantes dos jogadores não se consideram dependentes e não apresentariam sintomas de dependência. Ainda em outro estudo (BLINKA; SMAHEL, 2011, p. 113), um total de $27 \%$ dos jogadores de MMORPG apresentaria todos os seis fatores de dependência (descritos mais adiante), uma parcela relativamente elevada, considerando-se dados como, por exemplo, o jogo World of Warcraft ser jogado por mais de 11 milhões de pessoas no mundo todo. 
Blinka e Smahel argumentam que, uma vez que os jogadores passam muito tempo no jogo, é comum que estes se auto classifiquem como dependentes usando somente esse critério. Outra investigação (YEE, 2006) aponta que cerca da metade dos jogadores acredita ser dependente do jogo. Para explicar os resultados, a pesquisadora afirma que isso seria apenas uma tendência atual causada pelo emprego excessivo da palavra dependência, pois uma grande parcela desses jogadores não apresentaria "de fato" sintomas de dependência do jogo. Por fim, outro estudo (SMAHEL, 2008; SMAHEL et al., 2008), por meio de sua metodologia estatística, concluiu que aproximadamente um quarto dos jogadores de MMORPG apresenta sintomas de dependência.

Ivelise Fortim, em comunicação pessoal, comenta que a definição de dependência escolhida pelos pesquisadores é uma das principais questões que perpassam as pesquisas nesta área:

Uma das controvérsias é: Qual que é a definição de dependência? [...] Eu fiquei jogando várias horas no Candy Crush Saga... Tem dependência de Candy Crush Saga? Tem. Me falaram que tem um advogado que gastou 300 mil dólares no Candy Crush Saga. Mas o resto da população continua vivendo e continua jogando. A questão que eu vejo é: qual é a definição que você dá pra dependência? (comunicação pessoal)

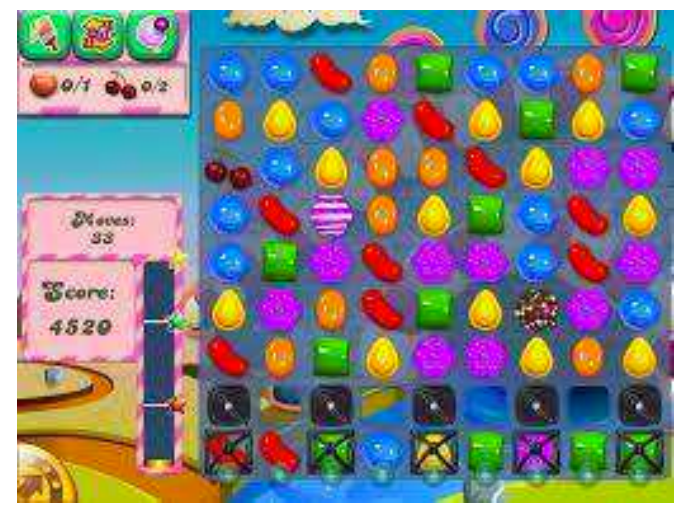

Figura 1.1 - Candy Crush Saga (2012)

Fortim comenta que a severidade estatística adotada pelo pesquisador na definição de dependência é central para o resultado posterior da investigação. Ou seja, a quantidade de desvios-padrão $(\sigma)$ em relação à média $(\mu)$ na curva normal $^{57}$ formada pelos dados da pesquisa vai determinar em grande parte a quantidade de pessoas que serão classificadas como "normais" ou "patológicas".

\footnotetext{
${ }^{57}$ Nesta figura, o desvio padrão é igual a 1. Desta forma, os pontos localizados entre o intervalo -1 e 1 serão considerados normais, e os menores de -1 e maiores de 1 serão considerados outliers (ou patológicos). A quantidade de desvios-padrão (neste caso, 1), e não o valor deste (que neste caso também é igual a 1), é a severidade da escala adotada pelo pesquisador.
} 


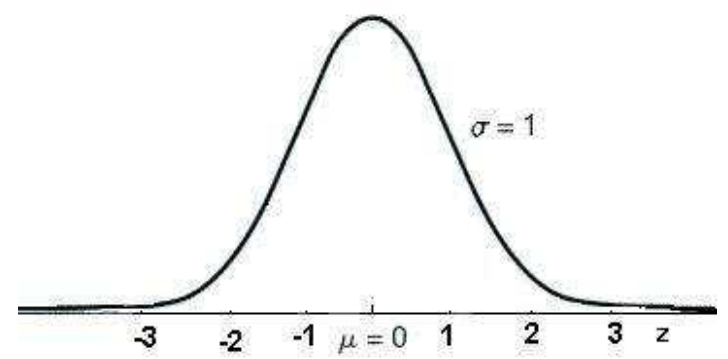

Figura 1.2 - Distribuição normal

Se a tua definição é muito severa, você tem uma parte enorme da população. Se a tua definição é menos severa, você tem uma parte menor. Quando eu vi estudo de prevalência, que é incidência na população, tem de $2 \%$ até $30 \%$. Qual que é a diferença? É a escala que você deu. Se você for olhar uma das escalas de dependência de internet, a que mais usa hoje, uma das perguntas é: "Você tem amigos online?" Isso é crivo de dependência? Isso é super usado. Uma é: "Você acessa os seus e-mails de manhã?" Claro, senão eu estou demitida! Uma parcela enorme da população tem que acordar de manhã e acessar os e-mails pra trabalhar. Isso não é critério de dependência. Então, um dos problemas de estatística, das controvérsias, são as escalas. Eu lembro que eu levantei as escalas e tem escala surreal! (comunicação pessoal)

Para a mesma autora, "dependência existe, mas é uma parcela muito pequena da população, pensando no ponto de vista psiquiátrico ou psicológico". Esta é a mesma opinião da maioria dos pesquisadores desta área, como Mark Griffiths e Kimberly Young, que comentam que só uma minoria dos jogadores seria de fato dependente.

Tendo operacionalmente definido adicção, é convicção deste autor de que a adicção de videogame de fato existe, mas esta afeta somente uma minoria muito pequena de jogadores. Parece haver muitas pessoas que usam videogames excessivamente, mas que não são classificadas como adictas quando mensuradas por esses (ou quaisquer outros) critérios (GRIFFITHS; DAVIES, 2005 , p. 360, tradução nossa).

Fortim, no entanto, considera que hoje há um exagero de diagnósticos. Segundo ela, para auferi-los, há de se considerar consequências graves e não confundi-la com o chamado "espírito do tempo".

Pra você dar diagnóstico de dependência, você tem que ter consequências muito graves. Tipo, o cara perdeu o ano na faculdade. $\mathrm{O}$ cara deixou o filho morrer. $\mathrm{O}$ cara ficou dois dias sem tomar banho. A mãe foi lá e desconectou o computador, o cara foi agressivo, bateu na mãe. A dependência é caracterizada por consequências graves. Eu não acredito nessas histórias, assim: "a família não sabe pôr limite na pessoa e a criança é dependente". (comunicação pessoal)

Ao adentrar no reino das controvérsias, veremos que o que se considera "grave" pode bater de frente com um argumento relativista. Como postulam as teorias 
antropológicas na linha da hermenêutica (GEERTZ, 1973), a propensa "gravidade" de determinados assuntos também depende da carga simbólica ${ }^{58}$ conferida pelos atores. Se tomarmos exemplo a idade ideal para começar a manusear aparelhos digitais, veremos que tal "ideal" se transforma conforme as relações se dão, incluindo o tempo e o espaço em que estas situam-se. Não obstante, na prática científica, os pesquisadores em geral posicionam a variedade de casos distintos dentro de uma régua normal, onde os casos "graves" seriam aqueles pontos que saem fora da curva (outliers).

Reforçamos que não está sendo negada a gravidade do problema da dependência, nem suas possíveis consequências nefastas (como a geração de doenças e sofrimentos e o surgimento de conflitos), tanto para o usuário, quanto para outros envolvidos. A questão da dependência é por demais séria e delicada, e apresenta uma série de riscos. No entanto, verificamos divergências em suas definições, formas de diagnóstico e métodos de tratamento, que compõem suas imagens controversas nas ciências e para além destas.

Diante destes questionamentos, em quem confiar? Nas teorias e nos cientistas, que mais distanciada e sistematicamente aplicam métodos científicos para tentar acessar de forma privilegiada a suposta realidade dos fatos? Ou nos usuários, os quais estão mais próximos da experiência de jogo e seriam, em tese, os maiores conhecedores da atividade propriamente dita? $\mathrm{Ou}$, ainda, nas teorias e métodos qualitativos que, de perto e de dentro (MAGNANI, 2002), incluem a perspectiva dos usuários em suas próprias constatações empíricas? Por fim, por que não nos usuários, que, segundo alguns terapeutas, de tão envolvidos com o jogo, perderiam a autonomia para diagnosticar seu próprio vício e mentiriam para as pesquisas?

Não há uma saída única, até porque estes grupos são heterogêneos e, empiricamente, sequer existem de fato (WAGNER, 1974) sem a intervenção do próprio pesquisador. A intenção aqui é multiplicar e interligar as perspectivas que aparecem em campo. Neste ponto, nos interessa conhecer mais sobre os conceitos de dependência e verificar de quê sua noção depende. Para isto, apresentaremos uma breve revisão bibliográfica do conceito, para a partir daí entrar nas discussões mais recentes sobre a dependência especificamente de videogames e de internet.

\footnotetext{
${ }^{58}$ Importância simbólica e não simbólica, mas não menos relativa.
} 


\section{2 - Dependência: conceitos e classificações}

\subsection{1 - Drogas e dependência: um breve histórico}

A seguinte seção é baseada na revisão bibliográfica escrita e sistematizada por Marcelo Mercante (2013), em artigo publicado na revista Saúde e Transformação Social. Compondo os argumentos para os fins desta investigação, no início da discussão sobre dependência, primeiramente nos deparamos com o problema do alcoolismo, para somente então adentrarmos no mérito das chamadas "drogas" químicas. Nesta seção ainda não entraremos no assunto das dependências comportamentais ou das dependências tecnológicas e digitais, já que no período retratado nesta reconstituição histórica ainda não se pensava em internet, jogo patológico e videogames como nos dias de hoje. Mercante começa recuperando a obra de Berridge (1994), que indica que:

\footnotetext{
a noção de adição e dependência foram "descobertas" no século XIX, ainda que as ideias de "embriaguez crônica" e "habituação às drogas" já fossem conhecidas desde o século anterior. Segundo esta autora, no século XVIII não era feita ainda uma diferenciação entre o desejo e a vontade de consumir uma substância psicoativa. Esta distinção, segundo a autora, é central para a elaboração de um conceito de adição: "considerava-se que o beber fosse alguma coisa sobre a qual o indivíduo tivesse o controle final" (p. 16), ainda que, por volta da metade do século XVIII já houvesse "uma tendência para ver os bebedores como indivíduos que haviam perdido a capacidade de beber moderadamente" (p. 16 apud MERCANTE, 2013, p. 126).
}

Berridge diz que o crédito da "descoberta" da adição, no caso do álcool, deve-se à Thomas Trotter, em 1804, que dizia que a adição era uma doença da mente, tendo que ser tratada por médicos. Em 1791, Benjamim Rush já dizia que a embriaguez crônica era tanto uma doença quanto um transtorno da vontade. Em 1891, Carl von BruhlCramer afirmou que a embriaguez resultava de "uma doença do sistema nervoso, que produzia um desejo irresistível pelo álcool" (p. 17), e chamou tal doença de “dipsomania”. Em relação às drogas, Edward Levinstein (1878) considerava que o "morfinismo" era uma doença similar à dipsomania. Berridge coloca então que, ainda que os conceitos não fossem realmente novos, no século XIX havia uma "determinada conjunção de forças políticas, culturais e sociais que deu hegemonia a esses conceitos" (p. 17), aliada a uma reivindicação por parte da classe médica de um reconhecimento de sua autoridade científica.

George Harley, em 1884, coloca que a embriaguez era hereditária, assim como a 
loucura, passando então a ser vista como uma "questão da própria predisposição hereditária e da constituição do indivíduo" (p. 18). Em 1935, E. W. Adams enumera os cinco pontos principais que permitiriam reconhecer a adição denominada por ele de "verdadeira":

O primeiro é o domínio do uso da droga, o segundo, o motivo que leva o adito a refugiar-se da realidade, ou o impulso eufórico; o terceiro, a emergência de uma necessidade imperiosa ou desejo irresistível; o quarto, o estabelecimento da tolerância e o quinto, a ocorrência da síndrome de abstinência (ADAMS, 1935, p. 23 apud MERCANTE, 2013, p. 127).

Berridge também indica que em 1964 a expressão "dependência de drogas" passa a ser adotada, sendo definida como "um estado resultante da administração repetida de uma droga, de modo contínuo ou periódico... ela pode ser química e, algumas vezes, física, sendo a base bioquímica a verdadeira força propulsora" (p. 24).

Em 1977, a Organização Mundial da Saúde (OMS), segundo a mesma autora, passa a utilizar a ideia de "síndrome de dependência do álcool" e de "deficiências relacionadas ao álcool" (p. 24). Berridge coloca que tais definições da OMS tinham motivos políticos, visando manter o poder da classe médica sobre o assunto. Em resposta surgiu a ideia dos "problemas relacionados ao álcool" (p. 25). Assim, tenta-se minar o tratamento hospitalar desta condição, fazendo com que os médicos passassem a "ocupar uma posição menos central, dando lugar a uma abordagem local, apoiada na comunidade, que utiliza os mais variados recursos. Essa mudança está ligada ao desejo de se encontrar alternativas de baixo custo para o tratamento médico hospitalar; o 'problema' implica uma solução rápida, ao passo que a 'doença' pode ser uma condição permanente" (p. 25 apud MERCANTE, 2013, p. 127).

Bruce Alexander (2008), após reconstituir uma etimologia do conceito de adicção, argumenta que este é muito complexo e propõe, então, uma divisão em quatro tipos (p. 29): 1) envolvimento sobrepujante (“overwhelming”) com drogas ou álcool que é prejudicial para a pessoa adicta, para a sociedade ou ambos; 2) inclui o primeiro tipo e o envolvimento não-sobrepujante com drogas ou álcool que são problemáticos para a pessoa, a sociedade ou ambos; 3) envolvimento sobrepujante com qualquer elemento (incluindo, mas não limitado a, drogas e álcool) que é prejudicial para a pessoa adicta, para a sociedade, ou ambos; 4) envolvimento sobrepujante com qualquer elemento que não é prejudicial para a pessoa adicta, para a sociedade, ou ambos.

Segundo Mercante, Babor (1994) faz uma relação de diferentes modelos de estudo da dependência, que resultam, por sua vez, em distintas práticas de tratamento. O modelo médico trabalha com a noção de que a dependência tem uma origem física, sendo uma 
"doença" que necessita de tratamento médico apropriado para que seja controlada (JELLINEK, 1960). Em 1966, a American Medical Association passa a considerar o alcoolismo como uma doença, e em 1988, a adição em drogas. Para Babor, tratar a dependência química como uma doença visava, primeiro, chamar a atenção da classe médica para este problema e, segundo, influenciar os planos de saúde a incluir este tipo de tratamento nos seus programas de atendimento.

Madsen (1973 apud HEATH, 1987) via o alcoolismo como uma doença biopsicossocial. Por outro lado, os modelos psiquiátricos e psicológicos trabalham com a ideia de dependência como uma doença mental, ou ainda como o sintoma de algum conflito psicológico anterior. Há também psicólogos que veem a dependência como um "transtorno do comportamento" (p. 42) e enfocam o ambiente que iniciaria e manteria a dependência, evitando as chamadas causas "físicas".

Há ainda o que Babor chama de "definições científicas", que visam uma abordagem mais "operacional, a fim de facilitar a pesquisa experimental e o discurso acadêmico" (p. 47). Dentro das definições científicas Babor destaca as com origem na psicologia cognitivo-comportamental e na farmacologia comportamental. Tais abordagens surgem como alternativa aos modelos médicos, evitando traçar pressupostos baseados nas bases biológicas ou psicológicas da dependência. Busca-se aqui focar a atenção no comportamento observável do dependente: "o modo como esse comportamento é aprendido e modificado por condições antecedentes e consequências de reforço e à aplicação das teorias de condicionamento psicológico à investigação e ao tratamento dos transtornos de uso de substâncias" (p. 47 apud MERCANTE, 2013, p. 128).

De acordo com a abordagem experiencial/ambiental de Stanton Peele ${ }^{59}$, apresentada em Love and Addiction (1975), os vícios seriam padrões negativos de comportamento que resultam de um excesso de apego das pessoas às experiências geradas a partir de uma série de envolvimentos. Segundo este autor, a maioria das pessoas experimenta algum grau de dependência, pelo menos, por períodos de tempo durante suas vidas. Peele não vê os vícios como problemas médicos, mas como "problemas da vida", que a maioria das pessoas supera. Para ele, a incapacidade de fazer isso é a exceção e não a regra.

Rachel Lart (1998) observa que por vezes a dependência é apresentada como uma experiência de desordem moral, uma falha física, uma falha social, ou como uma doença infecciosa que deve ser contida ou monitorada por medo de espalhar o vício de

${ }^{59}$ Stanton Peele é psicólogo, advogado, psicoterapeuta e autor de livros e artigos sobre alcoolismo, dependência e tratamento de dependência. 
um corpo para outro. Segundo Mercante, "as definições do que é a dependência ditam as práticas adotadas para tratar este problema" (2013, p. 129). Ele comenta, em comunicação pessoal, que não tem uma ideia fechada do que é dependência, já que este seria um problema multicausal e não haveria um tipo de pessoa específica que desenvolva dependência. Segundo Mercante, enfim, há duas linhas principais que trabalham com o problema, uma centrada no indivíduo e outra centrada no social:

\begin{abstract}
Você vai ter uma linha que trabalha a dependência como uma doença da pessoa, como uma doença centrada no indivíduo; e você vai ter uma linha de trabalho que está tentando começar a ver a dependência como o resultado de algo que não está naquele indivíduo. Que está no jeito da sociedade se mexer. A maior prova disso é: tem sociedades tradicionais que sempre usaram um monte de substâncias e nunca tiveram problema com dependência até o ponto que elas tinham o modo de vida tradicional deles. Na hora que você coloca o branco lá e você perturbou aquilo e teve a obrigatoriedade de um rearranjo do estilo de vida daquelas pessoas e dentro de um modelo novo que não atende as necessidades como atendiam o antigo, você começa a ter dependência, abuso de uso de substância. Então, o problema não está centralizado exatamente no indivíduo, apesar de aparecer no indivíduo, porque a coisa vem de um âmbito maior. A sociedade está funcionando, aquele agrupamento está funcionando de uma maneira que não é legal. Então, um dos resultados disso é a pessoa desenvolver dependência. Tanto que você tem dependência em $\mathrm{n}$ coisas. Você tem dependência em drogas, em álcool, em jogo, em sexo, internet e por aí vai. Enquanto não tem uma maneira específica de olhar pra situação, você continua sem ter uma definição exata do quê que é dependência. Enquanto você não tem uma definição exata do que é dependência, você não tem uma definição exata do quê que é recuperação, do quê que é tratamento e do quê que é cura. (comunicação pessoal)
\end{abstract}

Em seu argumento, Mercante parece defender a segunda opção (a origem da dependência na sociedade). No entanto, do nosso ponto de vista estas alternativas infernais não se reconectam inteiramente em sua análise. Apesar de não questionar da mesma forma que Bruno Latour a dicotomia indivíduo versus sociedade, Mercante nos ajuda a reconstituir este histórico e lembrar que "uma vez problematizado o próprio conceito de dependência, passamos a ter mais de um modelo "correto" de tratamento" (2013, p. 129).

As perguntas que colocamos aqui, inspirados pelas reflexões de Mercante, são: Quais são as regras para que um jogador de videogame seja classificado como viciado? E dependente? Quem julga e delimita tais regras, os médicos psiquiatras, os psicólogos, os jogadores ou seus pais/cônjuges? Por outro lado, se os jogadores não possuírem escalas próprias para rotular alguém como viciado ou dependente (o que pode não proceder) 
caberá a outros agentes esta classificação? Se sim, como isto se dá? Seguindo a proposição cosmopolítica, o quê mais está em jogo?

\subsection{2 - Um corpo partido: a dependência física e psicológica}

Nesta seção buscaremos conectar algumas das noções de dependência elencadas anteriormente àquelas comuns nas atuais práticas dos diagnósticos e tratamentos em dependência de videogames. Almejamos aqui, principalmente, apresentar os conceitos de dependência com os quais as redes de cientistas, clínicas e terapeutas desta área estão se movimentando. Para isto, mais conexões terão de ser estabelecidas, incluindo o trânsito pelas dependências comportamentais e tecnológicas. Afinal, por que os problemas com certos usos de internet e de jogos de azar seriam de natureza semelhantes?

Olhando mais de perto as práticas das ciências, vemos que, nos discursos médicos em torno das drogas químicas, a dependência é muitas vezes definida como uma mudança de comportamento processual relacionada a uma experiência repetitiva nas disciplinas sócio psicológicas, ou uma adaptação neural a estímulos (tais como substâncias químicas psicoativas), entre os entendimentos orientados pela bioquímica. De qualquer forma, vemos que um conceito de dependência geralmente envolve uma noção de mudança de comportamento e um desejo de experiência ou de repetição.

As dependências são definidas como uma compulsão habitual a realizar certas atividades ou utilizar alguma substância, apesar das consequências devastadoras sobre o bem-estar físico, social, espiritual, mental e financeiro do indivíduo. Em vez de lidar com os obstáculos da vida, administrar o estresse do cotidiano e/ou enfrentar traumas passados ou presentes, o dependente responde de forma desadaptativa, recorrendo a um mecanismo de pseudomanejo (YOUNG; YUE; YING, 2011, p. 22, grifo nosso).

Para além da simples substância, esta noção de dependência parece depender de um abalo no trabalho, na economia ou no bem-estar para constituir-se. Aparentemente, isto se aplicaria tanto nos casos de álcool, drogas, internet ou videogames. Segundo Young, Yue e Ying, a dependência apresenta tipicamente características psicológicas e físicas. Para estas autoras, a dependência física ocorreria quando o corpo da pessoa se torna dependente de uma substância e experimenta sintomas de abstinência quando o consumo é descontinuado, como nos casos das drogas ou álcool. Nesta perspectiva, embora a substância adictícia inicialmente induza ao prazer, seu consumo continuado 
seria mais instigado pela necessidade de eliminar a ansiedade provocada por sua ausência, o que levaria a pessoa a um comportamento compulsivo.

Estas autoras escrevem que a dependência psicológica, por sua vez, se tornaria visível quando a pessoa experiencia sintomas de abstinência como depressão, fissura, insônia e irritabilidade. Tanto a dependência comportamental quanto a dependência de substâncias geralmente originam a dependência psicológica. Scott Caplan (2002), professor do departamento de comunicação da Universidade de Delaware (EUA) e pesquisador da linha cognitivo-comportamental de dependências, considerou as dependências tecnológicas (referindo-se à própria internet e aos videogames) como um subgrupo das dependências comportamentais, já que apresentariam todos os seus ditos componentes centrais, os quais descreveremos na sequência.

\subsection{3 - Componentes centrais da dependência}

O modelo dos seis fatores centrais da dependência é um dos mais aplicados na área das drogas, bem como de jogos eletrônicos. Uma de suas formas de aplicação pode ser vista no questionário que se segue. Seus componentes são baseados nos critérios gerais de dependência do DSM-IV (GRIFFITHS, 2000a, 2000c; WIDYANTO; GRIFFITHS, 2007). Segundo Mark Griffiths, os usuários de videogame podem ser considerados dependentes se satisfizerem todos os seguintes critérios ou apresentarem escores elevados (não sabemos, porém, quantos "pontos" precisamente) em todas as dimensões. Segundo David Smahel et al. (2008), estes critérios seriam ao mesmo tempo sintomas da dependência virtual e poderiam ser utilizados para determinar os efeitos concretos sobre os jogadores de MMORPG (p. 104). Abaixo seguem os critérios:

I. Saliência: quando a atividade passa a ser a coisa mais importante na vida da pessoa, podendo ser dividida em cognitiva (quando a pessoa pensa frequentemente sobre a atividade) e comportamental (por exemplo, quando ela negligenciaria necessidades básicas como sono, alimentação ou higiene para realizar a atividade).

II. Mudança de humor: experiências subjetivas influenciadas pela atividade executada.

III. Tolerância: o processo de precisar de doses continuamente maiores da atividade para obter as sensações iniciais. $\mathrm{O}$ jogador, portanto, precisa jogar sempre mais e mais.

IV. Sintomas de abstinência: sentimentos e sensações negativas acompanhando o término da atividade ou a impossibilidade de realizar a atividade requerida.

V. Conflito: conflito interpessoal (normalmente com as pessoas do entorno mais próximo, família, parceiros) ou intrapessoal provocado pela atividade executada. É frequentemente 
acompanhado por uma deterioração dos resultados acadêmicos ou profissionais, abandono de antigos passatempos, e assim por diante.

VI. Recaída e reinstalação: a tendência a retornar ao comportamento de dependência mesmo após períodos de relativo controle (SMAHEL; BLINKA, 2011, pp. 104-105).

\begin{tabular}{|c|c|}
\hline Fatores & Perguntas \\
\hline Saliência & $\begin{array}{l}\text { Você já negligenciou suas necessidades (como comer ou dormir) para ficar } \\
\text { conectado à internet jogando? } \\
\text { Você às vezes imagina que está no jogo quando não está? }\end{array}$ \\
\hline $\begin{array}{l}\text { Modificação } \\
\text { do humor }\end{array}$ & $\begin{array}{l}\text { Você já se sentiu irrequieto ou irritado quando não pode estar no jogo? } \\
\text { Você se sente mais feliz e mais contente quando finalmente consegue jogar? }\end{array}$ \\
\hline Tolerância & $\begin{array}{l}\text { Você sente que está passando cada vez mais tempo no jogo online? } \\
\text { Você se pega jogando sem estar realmente interessado? }\end{array}$ \\
\hline Conflitos & $\begin{array}{l}\text { Você às vezes briga com as pessoas mais próximas (família, amigos, } \\
\text { parceira/o) por causa do tempo que passa jogando? } \\
\text { Sua família, amigos, trabalho e/ou passatempos sofrem por causa do tempo } \\
\text { que você passa jogando na internet? }\end{array}$ \\
\hline $\begin{array}{l}\text { Restrições de } \\
\text { tempo }\end{array}$ & $\begin{array}{l}\text { Você já fracassou ao tentar limitar o tempo que passa jogando? } \\
\text { Acontece de você ficar no jogo mais tempo do que planejara originalmente? }\end{array}$ \\
\hline
\end{tabular}

Dentro desta perspectiva, os dependentes de videogame apresentam saliência da atividade, experienciando frequentemente fissura (desejo incontrolável de usar) e preocupação com o videogame quando desconectados. Os autores também sugerem que jogar videogames seria uma maneira de escapar de sentimentos perturbadores, em que os jogadores desenvolveriam uma tolerância ao videogame para chegar à satisfação, sofrendo abstinência quando reduzido o uso, tendo mais conflitos com as pessoas por causa da atividade e voltando a recair: ou seja, todos os sinais clássicos de dependência. Este modelo tem sido replicado no caso de comportamentos compulsivos de sexo, consumo de alimentos e jogos de azar, e, segundos os autores, aparentemente seria útil para examinar o uso patológico de videogames (PEELE, 1985; VAILLANT, 1995).

A princípio, esses mesmos componentes poderiam ser apontados em atividades como o trabalho e o estudo, mas estas, em geral, não são vistas como potencialmente viciantes apesar do surgimento de notícias na mídia e de estudos acadêmicos sobre os casos crescentes de viciados em trabalho (workaholics) (WILLIAMS, 2012; 2009; ROBINSON, 2001) - ou pelo menos não no mesmo grau que são acusados os jogos eletrônicos. Por quê, afinal, a dependência ou doença aparece dessa forma em relação ao videogame? 
A partir da leitura de seu discurso oficial, vemos que este modelo aborda a utilização da internet e dos videogames a partir de uma analogia ao uso de drogas. Ao transportar critérios previamente estabelecidos para outra rede de relações (a virtual) e vislumbrar que estas mesmas métricas podem ser aplicadas sem grandes modificações, este discurso diminui a questão e limita-se a entender o uso dos games a partir de uma gramática científica da dependência que, apesar de reconhecer similitudes, não leva em conta as efetivas diferenças entre os videogames e as chamadas "drogas químicas".

Há também críticas internas em relação aos próprios critérios da dependência, seja a sua uniformidade ou sua limitação. Charlton e Danforth (2007), por exemplo, consideram que talvez seja inapropriado usar alguns critérios prévios para dependência quando se pesquisam as chamadas "dependências tecnológicas". Os autores diferenciam os critérios essenciais dos critérios periféricos para o diagnóstico. Os autores fazem esta distinção, pois acreditam que itens como saliência, tolerância e euforia são critérios importantes, mas não cruciais. Segundo eles, também há uma importante distinção entre os jogadores de MMOGs com alto envolvimento daqueles considerados dependentes. $\mathrm{O}$ psicólogo clínico Janos Geocze (em comunicação pessoal) também questiona o fator da tolerância nos games:

A tolerância pra mim entra no fisiológico. E não no psicológico. É fisiológico! Por exemplo: o cara toma um tanto de álcool. Depois de um tempo um tanto de álcool não vai fazer o mesmo efeito. No jogo não. No jogo, esse tanto de álcool pode estar representado por uma fase dois, três, quatro, cinco? Talvez o cara [cientista] vá dizer isso. Que a fase um já é tão simples que ele tolera. Igual ao álcool, se ele bebe duas doses ele tolera, não acontece nada. Porque no Mario ele já sabe tranquilamente chegar na fase dois. Não sei se eles vão comparar dessa forma.

No entanto, essa comparação não parece se sustentar se multiplicarmos os exemplos de campo. Janos Geocze postula a existência de outro critério não mencionado anteriormente: o fator do segredo, do desconhecido. Possivelmente este item sequer foi cogitado porque aparentemente não seria relevante no caso das drogas e por se tratar de um aspecto mais próprio aos jogos. Ele argumenta que:

Agora tem outra palavra, que eu não sei se está nos seis: sedução. O jogo seduz. Ele tem que seduzir, senão perde a graça. Um dos maiores poderes de sedução é você lançar um desafio. E o jogo faz isso. Muito, muito! No jogo você acaba recriando isso. Eu já vi que tem games que um cara lá resolve o game. Aí o cara escreve em uma revista quais são os passos... Não tem coisa mais sedutora do que você ter o segredo. É um poder enorme. As pessoas fazem qualquer coisa 
pra descobrir o segredo [...] Você quer prender a atenção de um cara, diz pra ele: eu tenho algo pra te oferecer que ainda não foi explicado. E o jogo tem isso. Os que sabem o segredo e os que não sabem o segredo. Quem não sabe o segredo é um babaca. Conforme o cara vai sabendo do segredo... "E aí, pra quem que eu conto o segredo?" Geralmente pra pessoa, em princípio, que é merecedora de saber esse segredo. Aí vem outro poder. Então, geralmente, troca-se uma coisa por outra. Eu tenho o poder de saber isso. Você tem alguma coisa que me interessa. Troca de figurinhas. Eu vou revelar esse segredo pra você. Eu estou te revelando algo enorme dentro da sua vida. O jogo tem isso. Então, sedução.

Outro modelo bastante aplicado nos casos de dependência é o chamado Ciclo PararComeçar de Recaída. Este também é um esquema oriundo do tratamento de dependência de drogas químicas. Aqui tampouco é feita qualquer alteração significativa para sua aplicação a este novo caso, bastando alterar o substantivo "droga", "internet" ou "computador" por "videogame" em qualquer ocorrência, como fizemos abaixo. O componente da abstinência mantém-se como eixo central da explicação, sendo um dos quatro estágios distintos (mas interdependentes) previstos no modelo:

Estágio 1: racionalização. O dependente racionaliza que o videogame é uma compensação, um prazer, depois de um dia de trabalho longo e difícil, e geralmente diz coisas como: "Eu trabalho duro; mereço isso"; "Só um pouquinho não faz mal"; "Eu sou capaz de controlar o meu uso do videogame"; "O videogame me relaxa" ou "Com todo estresse que tenho sofrido, eu mereço isso". Ele justifica a necessidade de jogar com amigos, e finalmente acaba descobrindo que não é capaz de controlar o comportamento tão facilmente.

Estágio 2: arrependimento. Depois da experiência com o videogame, o dependente vivencia um período de profundo arrependimento. Desligando o videogame, percebe que o trabalho está se acumulando e sente culpa pelo comportamento, e faz declarações como "Eu sei que isso prejudica o meu trabalho"; "Não acredito que desperdicei todo esse tempo" ou "Sou mesmo uma pessoa horrível, olha só o que eu fiz".

Estágio 3: abstinência. O dependente vê o comportamento como uma falta total de força de vontade, um fracasso pessoal e promete jamais fazer isso de novo. Segue-se então um período de abstinência. Durante esse tempo, ele adota padrões saudáveis de comportamento, trabalha diligentemente, retoma o interesse por antigos passatempos, passa mais tempo com a família, se exercita, descansa o suficiente.

Estágio 4: recaída. O dependente anseia voltar a se conectar ou se sente tentado a voltar ao videogame em momentos estressantes ou emocionalmente difíceis. Ele se lembra dos efeitos apaziguadores de estar conectado e do relaxamento e prazer a esses comportamentos associados. Lembra como era bom estar jogando e esquece como era ruim depois. O período de racionalização recomeça, e a disponibilidade do videogame facilmente dá início mais uma vez ao ciclo (adaptado de YOUNG, 2011, p. 65-66).

Já McIlwraith (1990) propôs alternativas teóricas oriundas da dependência de televisão na literatura popular e psicológica, que parecem bons modelos para testar os limites da dependência em videogames. Substituindo "televisão" por "videogame" no modelo de 
McIlwraith, como Griffiths e Davies propuseram, teríamos quatro possíveis entendimentos, a seguir:

1. A dependência em videogames acontece em função de seus efeitos sobre a imaginação e a fantasia. Ou seja, pessoas que jogam videogames em excesso têm imaginações pobres.

2. A dependência em videogames acontece em função dos efeitos que produz no nível de excitação. Ou seja, pessoas que jogam videogames em excesso querem fazê-lo por sua excitação ou efeitos tranquilizantes.

3. A dependência em videogames é uma manifestação de uma personalidade dependente ou adictícia. Ou seja, pessoas que jogam videogames em excesso devem fazê-lo devido à sua personalidade interior - em oposição a uma origem externa do vício.

4. A dependência em videogames é um padrão distinto de usos e gratificações associados ao meio do videogame, ou seja, pessoas que jogam videogames em excesso apreciam o ato físico de jogar apenas quando estão entediados (GRIFFITHS; DAVIES, 2005, p. 362-263, tradução nossa).

Como se vê desde o início desta seção, nestas formas de organização, os saberes científicos inicialmente vêm de uma compreensão sobre a dependência de drogas, caminham para uma intersecção com vício em internet (com algumas mediações) e entram, por fim, na seara dos videogames, sendo este considerado um subcaso específico do uso de internet. Esta é uma das formas de composição. Há diversas outras, as quais exploraremos na seção seguinte. Por enquanto, devemos observar que estes modelos não pairam solitários no mundo, mas têm uma rede que os fabrica, os movimenta e faz uso dos mesmos. Traremos a seguir alguns actantes institucionais importantes nestas controvérsias que estão ligados a modelos teóricos.

\subsection{4 - Actantes institucionais}

De acordo com a Associação Americana de Psiquiatria (2013), o Manual Diagnóstico e Estatístico de Transtornos Mentais (Diagnostic and Statistical Manual of Mental Disorders, DSM) é um guia para profissionais da área da saúde mental que lista diferentes categorias de transtornos mentais e critérios para diagnosticá-los. É usado ao redor do mundo por clínicos e pesquisadores, bem como por companhias de seguro, pela indústria farmacêutica e por parlamentos políticos. Existem quatro revisões posteriores do DSM desde sua primeira publicação, em 1952, sendo que a última, o DSM-5, foi publicada em 2013. Apesar de existirem outros guias, como o ICD, o DSM continua sendo a maior referência na atualidade em pesquisa em saúde mental. 
Segundo o Manual Diagnóstico e Estatístico de Transtornos Mentais (AMERICAN PSYCHIATRIC ASSOCIATION, 2013), o diagnóstico do uso patológico de computadores é conceitualmente entendido como um transtorno do espectro compulsivo-impulsivo, que envolve o uso conectado e/ou desconectado do computador e consiste em pelo menos três subtipos, entre os quais jogar excessivamente é um deles, ao lado de "preocupações sexuais" e "envio de mensagens de e-mail/texto". Segundo este documento, todas as três variantes compartilham os quatro componentes a seguir para definir os componentes do que chamam comportamento compulsivo:

1. Uso excessivo, frequentemente associado à perda da percepção da passagem do tempo ou negligência de impulsos básicos;

2. Abstinência, incluindo sentimentos de raiva, tensão e/ou depressão quando o computador está inacessível;

3. Tolerância, incluindo a necessidade de um computador melhor, com mais recursos, mais softwares ou mais horas de uso;

4. Repercussões negativas, incluindo brigas, mentiras, desempenho insatisfatório, isolamento social e fadiga (BEARD; WOLF, 2001; BLOCK, 2008 apud YOUNG; ABREU, 2011, p. 39).

Em maio de 2013, a American Psychiatric Association (APA) incluiu o diagnóstico de uso patológico do computador na última revisão do $\mathrm{DSM}^{60}$, o DSM-5. Neste documento, a APA propôs a elaboração de critérios para definir a adicção em videogames, mas concluiu que não havia provas suficientes para incluí-la como um transtorno mental oficial. No entanto, a Associação incluiu critérios ${ }^{61}$ para avaliar o

\footnotetext{
${ }^{60}$ Segundo Mercante (2013), o DSM-IV (pp. 176-177) apresenta a seguinte tabela para o diagnóstico da dependência de substâncias: um padrão mal-adaptativo de uso de substância, levando a prejuízo ou sofrimento clinicamente significativo, manifestado por três (ou mais) dos seguintes critérios, ocorrendo a qualquer momento no mesmo período de 12 meses: (1) tolerância, definida por qualquer um dos seguintes aspectos: (a) uma necessidade de quantidades progressivamente maiores da substância para adquirir a intoxicação ou efeito desejado; (b) acentuada redução do efeito com o uso continuado da mesma quantidade de substância; (2) abstinência, manifestada por qualquer dos seguintes aspectos: (a) síndrome de abstinência característica para a substância; (b) a mesma substância (ou uma substância estreitamente relacionada) é consumida para aliviar ou evitar sintomas de abstinência; (3) a substância é frequentemente consumida em maiores quantidades ou por um período mais longo do que o pretendido; (4) existe um desejo persistente ou esforços malsucedidos no sentido de reduzir ou controlar o uso da substância; (5) muito tempo é gasto em atividades necessárias para a obtenção da substância, na utilização da substância ou na recuperação de seus efeitos; (6) importantes atividades sociais, ocupacionais ou recreativas são abandonadas ou reduzidas em virtude do uso da substância; (7) o uso da substância continua, apesar da consciência de ter um problema físico ou psicológico persistente ou recorrente que tende a ser causado ou exacerbado pela substância.

${ }^{61}$ A APA desenvolveu nove critérios para caracterizá-lo, aplicáveis por meio das seguintes perguntas para o usuário: 1. Preocupação. "Você fica muito tempo pensando em jogos mesmo quando você não está jogando, ou fica planejando quando você vai jogar novamente?" 2. Retirada. "Você se sente inquieto,
} 
“Transtorno de Jogos na Internet” (Internet Gaming) na Seção III do documento, intitulada "Condições para Estudo Posterior". Na ocasião da publicação do quinto volume, foi emitido o seguinte comunicado oficial:

Na quinta edição do Manual Diagnóstico e Estatístico de Transtornos Mentais (DSM-5), o Transtorno de Jogos Online foi aprovado na Seção III, com uma condição que garante mais pesquisas e experiências clínicas antes que este possa ser incluso no livro principal como um transtorno oficial (APA, 2013, tradução nossa).

Enquanto o chamado "Transtorno de Jogos Online" é proposto como um distúrbio, ainda é discutido entre os profissionais da área até que ponto esta "doença" seria causada pela atividade de jogo em si ou em que medida esta seria um efeito de outras desordens. Ivelise Fortim conta que houve uma larga discussão em torno do excesso de patologias presentes nas últimas revisões do DSM, as quais impactaram na decisão acerca da não-inclusão das dependências de internet e videogames na última versão do documento:

Tem uma discussão grande sobre o excesso de patologias do DSM-V, em que a dependência de internet está inclusa. Porque aí de repente você tem sujeitos que estão usando, que estão dentro do espírito do tempo e que não é um transtorno psiquiátrico. E você está tentando patologizar uma coisa que é moderna e que vai ser o padrão. Essa é uma discussão. Por enquanto está se plantando estudos para que essas definições sejam mais claras. Mas tem muita pesquisa que eu acho que o pressuposto já está errado (comunicação pessoal).

Segundo a reflexão de Marie Crowe, o discurso do DSM-IV (APA, 1994 apud CROWE, 2000. p. 76) fornece uma imagem do que os indivíduos poderiam se tornar e propõe ajudar a realinhar o que eles são com o que querem ser - ou o quê o discurso psiquiátrico decreta que os indivíduos deveriam se esforçar para ser. Para Crowe, esta

irritado, mal-humorado, zangado, ansioso ou triste quando tenta diminuir ou parar de jogar, ou quando você não pode jogar?" 3. Tolerância. "Você sente necessidade de jogar cada vez mais tempo, jogar jogos mais emocionantes, ou usar equipamentos mais potentes para sentir a mesma emoção que você contumava sentir?" 4. Reduzir/Parar. "Você sente que você deveria jogar menos, mas é incapaz de diminuir a quantidade de tempo que você passa jogando?" 5. Desistir de outras atividades. "Você perde interesse ou participa menos de outras atividades recreativas (passatempos, encontros com amigos) por causa dos jogos?" 6. Continuar apesar dos problemas. "Você continua jogando mesmo sabendo das consequências negativas, como não dormir o suficiente, chegar atrasado à escola/ao trabalho, gastar muito dinheiro, discutir com outras pessoas, ou negligenciar deveres importantes?" 7. Enganar/encobrir. "Você mente para familiares, amigos ou outras pessoas sobre o quanto você joga, ou tenta esconder de familiares ou amigos sobre o quanto você joga?" 8. Fuga/escape de humores negativos. "Você joga para fugir ou esquecer de problemas pessoais, ou para aliviar sentimentos desconfortáveis como culpa, ansiedade, desamparo, ou depressão?" 9. Risco de perder relações ou oportunidades. "Você arrisca ou perde relacionamentos significativos, ou oportunidades de emprego, educação ou de carreira por causa de jogos?" (APA, 2013 apud PETRY et al, 2014 p. 11). 
imagem de normalidade depende da modificação dos desejos pessoais com objetivos socialmente ou institucionalmente valorizados. Assim, o DSM pode ser considerado um texto central para garantir que os indivíduos atendam requisitos sociais para uma subjetividade aceitável. Quando os indivíduos não conseguem atender estes requisitos, para a autora eles se tornam parte do atendimento psiquiátrico crescente em todos os aspectos da vida cotidiana.

Além do $\mathrm{DSM}^{62}$, outro actante institucional importante nesta controvérsia é a Organização Mundial da Saúde (OMS), que possui definições e classificações de dependência amplamente utilizadas. Baseando-se no relatório de 2004 do ICD-10 ${ }^{63}$, (p. 14), a OMS descreve seis critérios próprios ${ }^{64}$ para caracterizar a dependência de substâncias, a partir do que entende como consequências deletérias sofridas pelo usuário.

Assim como no caso das classificações do DSM, aparentemente não há um motivo explícito para eleger três (e não quatro, cinco ou seis) critérios como suficientes para se chegar à satisfação das exigências do modelo de classificação da dependência. Os critérios parecem, assim, intercambiáveis: não há nenhum que seja imprescindível e tampouco há diferença entre eles em grau de importância, o que parece enfraquecer a capacidade explicativa do modelo. Aparentemente, o motivo da escolha deste número (três) parece ser a manutenção de uma faixa numérica de dependentes dentro da porção estatística fixada como meta (por exemplo: $5 \%$ da população).

${ }^{62}$ O DSM certamente é um dos porta-vozes mais relevantes desta controvérsia, porque muitos outros actantes do campo (conselhos de medicina, as falas dos sujeitos etc.) utilizam-no como referência.

63 A Classificação Estatística Internacional de Doenças e Problemas Relacionados com a Saúde, frequentemente designada pela sigla CID ou ICD (do inglês International Statistical Classification of Diseases and Related Health Problems) fornece códigos de classificação de doenças e de uma grande variedade de sinais, sintomas, aspectos anormais, queixas, circunstâncias sociais e causas externas para ferimentos ou doenças. A CID é revista periodicamente e encontra-se, à data, na sua décima edição. A CID-10 foi desenvolvida em 1992 para registrar as estatísticas de mortalidade.

${ }^{64} \mathrm{O}$ sujeito deve ter apresentado ao menos três dos seguintes sintomas durante o ano anterior ao exame: 1) um forte desejo ou compulsão para utilizar a substância; 2) dificuldades em controlar a ingestão em termos de início, término ou nível de uso; 3) um estado de crise de privação quando o uso da substância foi interrompido, ou o uso da mesma substância (ou alguma outra relacionada) com a intenção de aliviar ou evitar a crise de privação; 4) evidência de tolerância, tais como aumento das doses da substância psicoativa para se ter os mesmos efeitos originalmente produzidos por doses menores; 5) negligência progressiva de prazeres alternativos ou interesses devido ao uso de substâncias psicoativas, aumento do tempo necessário para obter ou utilizar a substância ou se recuperar de seus efeitos; e 6) insistência do uso da substância em despeito de evidências claras de consequências deletérias, como danos ao fígado por excesso de bebida, humor depressivo em consequência de uso abusivo de dada substância, dano cognitivo por uso de substância. Esforços devem ser feitos para determinar se o usuário estava consciente da relação entre uso e consequências deletérias (WORLD HEALTH ORGANIZATION, 2004, p. 14). 
Segundo Mercante (2013), em 2004, a OMS modificou sua definição: a dependência deixaria de ser causada pela "administração repetida" de uma substância, estando a partir de agora relacionada à "necessidade do uso", sendo em seguida estabilizada da seguinte forma: "a dependência de substâncias é uma desordem de funções cerebrais alteradas provocadas pela necessidade do uso de substâncias psicoativas". Mercante se pergunta: afinal, o que estaria por trás de tal necessidade? A OMS, assim, fecha seu entendimento de que a dependência é uma doença mental:

Com os recentes avanços na neurociência é claro que a dependência de uma substância é uma desordem do cérebro tanto quanto qualquer outra doença (illness) neurológica ou psiquiátrica. Novas tecnologias forneceram meios para visualizar e medir modificações no cérebro a partir do nível molecular e celular até modificações em processo cognitivos complexos que ocorrem após um curto e um longo tempo de uso de uma substância (2004, p. 18).

Apesar dos videogames não serem considerados pela OMS substâncias psicoativas (há também controvérsias acerca dessa afirmação) e de a própria instituição não incluir neste relatório os jogos eletrônicos entre os seus exemplos de dependência, ela propõe critérios gerais de "dependência a substâncias". A OMS constata, por fim, que:

Como não há uma visão universalmente válida ou verídica sobre o que é dependência, não há nenhuma fórmula universalmente válida ou verídica para avaliar suas definições. O que existe, em vez disso, são perspectivas culturais específicas associadas a teorias sociais de dependência, cada uma das quais predizendo diferentes tipos de significado. A controvérsia importante torna-se, então, descobrir que grau de controle um grupo cultural obtém sobre o que define como dependência. Não se pode, porém, questionar se as definições estão certas ou erradas [...]. Porém, pode-se debater a sua utilidade e a que funções as definições servem (idem, p. 52).

O interesse aqui nesta seção não é somente listar classificações, mas resgatá-las para o debate junto com outros actantes e seguir os rastros de suas ações e efeitos. Deste modo, investigamos que está sendo dito, quais são os argumentos utilizados, em que momento aparecem e a quais outros tipos de doenças este actante aparece associado. Vemos, assim, que em todos os modelos e teorias até aqui apresentadas, tomam-se as substâncias e não as relações como preeminentes. Nestes esquemas teóricos, a dependência é introjetada em um sujeito individual. E, contudo, a própria definição de vício - medido a partir de sua produção de consequências "negativas" ou "deletérias" para a vida - depende de sair do indivíduo (sede das substâncias) e ir para o mundo (sede das relações). Este mundo, porém, não é somente o local das relações "sociais", mas de relações de qualquer espécie. Portanto, a solução não é simplesmente sair do 
indivíduo e ir para a sociedade (ou seja, atentar para as supostas causas "sociais"), mas interrogar esta própria dicotomia, olhando para o ser-no-ambiente (INGOLD, 2000).

\subsection{5 - Construindo dependências: formas de composição}

Como adiantado na seção anterior, vislumbramos quatro grandes possibilidades de considerar a dependência de games em relação a outras dependências: 1) como um subgrupo da dependência de internet, 2) como um tipo específico de jogo patológico, 3) como uma dependência tecnológica, e por fim, 4) como uma nova dependência, que reúne diversos aspectos das anteriores.

No primeiro caso, não se considera a especificidade da atividade do jogo, mas somente o uso do objeto técnico: em geral, o computador (ou o console). Assim, o videogame é posto em paralelo a outros supostos vícios, como sexo virtual, compulsão por comunicação online, utilização de redes sociais, entre outras atividades. Aqui não importa qual a atividade desempenhada no computador, mas sim o seu efetivo uso, a sua dimensão (oculta) de "virtualidade", o efeito "fisioquímico" propiciado pelo contato próximo a um objeto eletroeletrônico/magnético, entre outros enunciados. Griffiths escreve sobre estes casos:

Há relatos de estudos de casos de indivíduos que parecem ser adictos à internet em si (por exemplo, Young, 1998; Griffiths, 1996a, 1998, 2000b). Estas são geralmente pessoas que usam salas de chat ou jogam jogos fantasiosos de interpretação de papéis (RPGs) - atividades com as quais não iriam se envolver exceto se na própria Internet. Estes indivíduos, em alguma medida, estão envolvidos em realidades virtuais baseadas em textos e assumem outras personas e identidades sociais como uma forma de sentirem-se bem consigo mesmos. Em outros casos, a internet pode proporcionar uma realidade alternativa para o usuário e permiti-lo sentimentos de imersão e anonimato que podem levar a estados alterados de consciência. Estes, em si, podem ser altamente gratificantes (psicologica e/ou fisiologicamente). Obviamente, estas especulações podem fornecer insights sobre a natureza potencialmente adictícia dos jogos de computador para aqueles que jogam neste meio (GRIFFITHS; DAVIES, 2005, p 360, tradução e grifo nosso).

Para Kimberly Young (1999), dependência de internet é um termo amplo, que abrange uma grande variedade de comportamentos e problemas de controle do impulso. Em sua visão, haveria um vício geral em internet, mas que seria divisível em diversos subtipos. Para ela, este se trata de um transtorno específico e a ser catalogado nos manuais 
nosográficos como uma nova patologia. Young inseriu ${ }^{65}$ a compulsão a jogos eletrônicos num dos cinco subtipos específicos do que chamou de "Compulsões do computador":

1) Adicção a cibersexo: uso compulsivo de sites adultos para sexo cibernético e pornografia.

2) Adicção a ciber-relacionamentos: o excesso de envolvimento em relacionamentos online.

3) Compulsões da rede: jogos de azar online obsessivo, compras online, ou de ações na bolsa (day-trading).

4) Excesso de informação: navegar na web ou através de pesquisas de banco de dados compulsivamente.

5) Adicção a jogos de computador: jogo obsessivo de jogos de computador (por exemplo, o Doom, Myst, Paciência, etc.) (YOUNG, 1999, tradução nossa).

Baseado na teoria-ator-rede, entendemos que os diferentes actantes em relação provocam interações específicas, e, portanto, o mero transporte de uma teoria (no caso, de dependência de internet) para outro "contexto"66 (dos videogames) sem as devidas mediações, pode acabar operando uma demasiada simplificação do problema, diferente do trabalho que se está propondo, de investigar a complexidade da controvérsia.

No segundo caso, o videogame é considerado um subcaso da dependência de jogos de azar. É preciso lembrar que esta foi a primeira dependência cientificamente oficializada após a dependência de drogas "químicas" e chamada, assim, uma dependência comportamental. Aqui se enfatiza o caráter lúdico da relação com os jogos, como a compulsão por ganhar, vencer desafios, obter recompensas e alcançar o êxtase. O jogo de azar tradicional, no entanto, envolve a utilização de moeda em espécie (dinheiro), que funciona como elemento de mediação nas apostas. Exceto em exemplos específicos, como online poker, que une os dois aspectos na discussão sobre o vício em videogame, nos jogos eletrônicos não está presente o componente eminentemente financeiro das apostas: são outras moedas que estão em jogo.

Outros insights sobre a natureza potencialmente viciante dos videogames vêm de pesquisas sobre máquinas caça-níqueis. Ambas as máquinas de videogames e máquinas caça-níqueis caem sob o rótulo genérico de "máquinas de divertimento" (Griffiths, 1991a). A principal diferença entre as máquinas de videogame e máquinas caça-níqueis são que os videogames são jogados para

\footnotetext{
${ }^{65}$ Em suas obras mais recentes, a autora acredita que a melhor classificação seria de Transtorno do Controle do Impulso (apud FORTIM, 2013).

${ }^{66}$ Entendido aqui como uma rede de relações, e não como um plano de fundo, fora das relações.
} 
acumular tantos pontos quanto possível, enquanto que máquinas caça-níqueis são jogadas (apostas) para acumular dinheiro (GRIFFITHS; DAVIES, 2005, p. 360, tradução nossa).

Apesar da distinção de Griffiths e Davies, vimos, no entanto, que em muitos jogos não se joga para se acumular pontos. Em Journey, por exemplo, não há qualquer tipo de pontuação. Em jogos de futebol, como Winning Eleven, marcar um gol não é exatamente o mesmo que "acumular pontos". E mesmo quando há pontos, como em Super Mario Bros., eles podem não ser relevantes: o mais importante é passar de fase e chegar ao final do jogo. Griffiths e Davies continuam comparando o videogame com o fliperama:

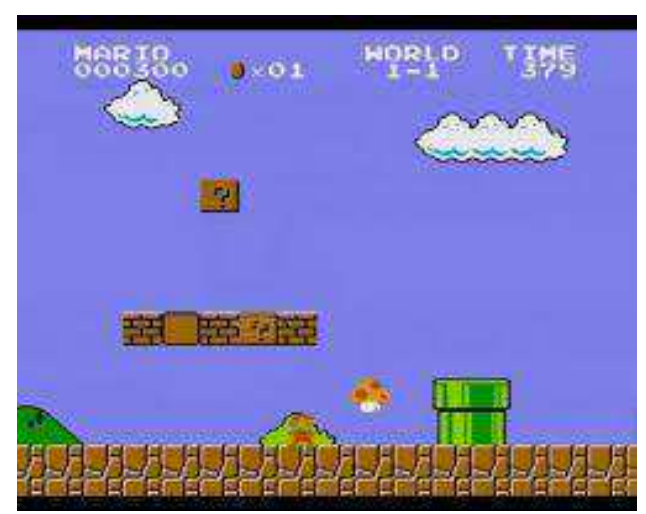

Figura 1.3 - Super Mario Bros. (1985)

'Griffiths (1991a) sugeriu que um videogame pode ser considerado uma forma não-financeira dos jogos de azar. Ambos os tipos de máquina (no caso de máquinas de fliperama) exigem a inserção de uma moeda para jogar, ainda que o tempo de jogo em uma máquina caça-níqueis seja geralmente bem menor do que em uma máquina de videogame. Isto porque em videogames o resultado é quase que exclusivamente dado pela habilidade do jogador, ao passo que nas máquinas caça-níqueis, o resultado é um produto do acaso. No entanto, a filosofia geral de jogo de ambos os jogadores de máquinas caça-níqueis e de videogames é ficar na máquina o maior tempo possível, utilizando a menor quantidade de dinheiro (Griffiths, 1990a, 1990b). Griffiths argumentou que jogadores regulares de máquinas de caça-níqueis jogam mais com dinheiro do que por dinheiro, e que ganhá-lo é somente um meio para um fim (ou seja, continuar na máquina pelo maior tempo possível) (GRIFFITHS; DAVIES, 2005, p. 360, tradução e grifo nosso).

A associação dos videogames com as habilidades competitivas em oposição à sorte dos caça-níqueis, apesar de proceder até certo ponto, não pode ser generalizada. Como Roger Caillois postula em Os Jogos e os homens (1959), quase todos os jogos contam em alguma medida com o elemento "sorte" (alea). Há, pois, um continuum, e não uma divisão estanque, entre os jogos com mais espaço para a aleatoriedade (como o caçaníqueis, jogo de dados e roleta, os quais também têm seus saberes e habilidades 
psicotécnicas exigidos na formação de um bom jogador, principalmente se pensarmos numa sequência de partidas) e jogos que tendem menos para a aleatoriedade e mais para o lado da habilidade (aspecto agôn) e, como o xadrez.

Mas Griffiths deixa uma pista em sua última frase: jogar o jogo pode se tornar um fim em si mesmo. Johann Huizinga já fazia esta mesma observação em 1938, quando afirmou que o jogo "se insinua como atividade temporária, que tem uma finalidade autônoma e se realiza tendo em vista uma satisfação que consiste nessa própria realização" (HUIZINGA, 1938, p. 12). Ao longo da descrição, veremos que este assunto é de suma importância para a discussão sobre as definições de vício e para o reconhecimento da existência de passagens entre usos benéficos e prejudiciais.

A seguir, Mark Griffiths e outros autores (BROWN \& ROBERTSON, 1992; GRIFFITHS, 1991a, 1993, 1997a; FISHER, 1994; GUPTA \& DEREVENSKY, 1997; FISHER; GRIFFITHS, 1995 apud GRIFFITHS; DAVIES, 2005) comparam os fliperamas (arcade games) às máquinas caça-níqueis, apontando sete aspectos que ambos compartilhariam, incluindo o potencial para dependência. Esta conceituação opera na lógica de reforço do comportamento correto, como descreveremos mais adiante numa seção acerca do modelo neuropsicológico.

1) A exigência de resposta a estímulos que são previsíveis e regidos pelo ciclo do software.

2) A exigência de concentração total e coordenação de olhos e mãos.

3) Duração do jogo negociável, em certa medida, pela habilidade do jogador (mais marcada nos videogames).

4) A prestação de recompensas visuais e auditivas para jogadas vencedoras (por exemplo, luzes piscando, jingles eletrônicos).

5) A oferta de uma recompensa incremental para uma jogada vencedora (pontos ou dinheiro) que reforça o comportamento "correto".

6) Placar digitalmente exibido do "comportamento correto" (na forma de pontos ou dinheiro acumulado).

7) A oportunidade para chamar a atenção do grupo de pares e aprovação através da competição (GRIFFITHS; DAVIES, 2005, p. 361, tradução nossa).

Já no terceiro grande caso, o vício em videogame é considerado uma dependência diferente da dependência de internet e de jogos de azar. Comumente é agrupado em uma categoria chamada dependências tecnológicas (CAPLAN, 2002), a qual inclui o vício em televisão, celulares, tablets e outros gadgets. Aqui, por um lado, considera-se o 
aspecto virtual do uso dos videogames (além de outras características do que se considera "tecnológico" no senso comum), mas por outro, não é considerado seu aspecto lúdico, presente, por exemplo, nos jogos de azar. Segundo Griffths e Davies:

Mais recentemente, alguns vícios (incluindo a dependência de máquinas caçaníqueis e de internet) têm sido chamados de "dependências tecnológicas" e operacionalmente definidos como dependências (comportamentais) nãoquímicas, que envolvem uma interação homem-máquina excessiva. Elas podem ser passivas (por exemplo, televisão) ou ativas (jogos de computador) e geralmente contêm características induzidas e reforçadas que podem contribuir para o avanço de tendências viciantes. As dependências tecnológicas podem, assim, ser vistas como um subconjunto das dependências comportamentais (MARKS, 1990 apud GRIFFITHS, 2005) e apresentam os componentes centrais da dependência descritos primeiramente por Brown (1993) e modificado por Griffiths, tais como saliência, alteração de humor, tolerância, abstinência, conflito e a recaída (GRIFFITHS; DAVIES, 2005, p. 359, tradução nossa).

Fortim (2013, p. 64-65), por sua vez, afirma que como os videogames mudaram desde a classificação de Young, ela preferiu agrupar na categoria "jogos eletrônicos" todos aqueles que exigem como mediação a internet, o que inclui o jogo patológico, classificado por Young em outro item. Fortim acrescenta (em comunicação pessoal) que a pessoa não é dependente do computador, da internet ou da luz elétrica, mas é de sexo, MMO ou de comunicação: "Você é dependente do ambiente funcionando. Mas da luz em si, você não é dependente. Você é dependente da lâmpada, de outras coisas que você usa”. Ou seja, aqui a psicóloga retira a ênfase da tecnologia (do objeto), e foca na atividade específica desenvolvida pela pessoa. A partir da citação de um texto da psicóloga Nicolaci da Costa, ela argumenta:

Não me venha com esse papo de que somos muito dependentes de tecnologia. Água sai da parede, por acaso? Água não sai da parede. Você é dependente da tecnologia do cano. Luz elétrica é luz solar? Não é luz solar. Você é dependente da tecnologia da eletricidade. Você é dependente de tecnologia, ponto. Desde que a gente fez a pedra lascada pra matar o bicho você é dependente de tecnologia; que é uma dependências das tecnologias mais gerais. Então, você é dependente de computador e internet? Sim, todos nós dependemos. Tenho certeza que todo sistema que é informatizado, o banco é informatizado, o Governo é informatizado. Você é dependente de tecnologia. Dificilmente você consegue ir tirar lá no banco o dinheiro sem passar nada no computador.

Diante destas distintas abordagens, propomos, enfim, encontrar um ponto comum entre elas: tomar o videogame como um objeto único e distinto dos demais, que une aspectos tanto do lúdico, como do virtual (como no diagrama abaixo, que sugere posicionar a dependência de videogames numa intersecção entre as dependências de internet e jogos 
de azar). Para tanto, abordaremos minuciosamente, na forma de dois capítulos distintos, as relações dos videogames em ambas as esferas lúdica e virtual.

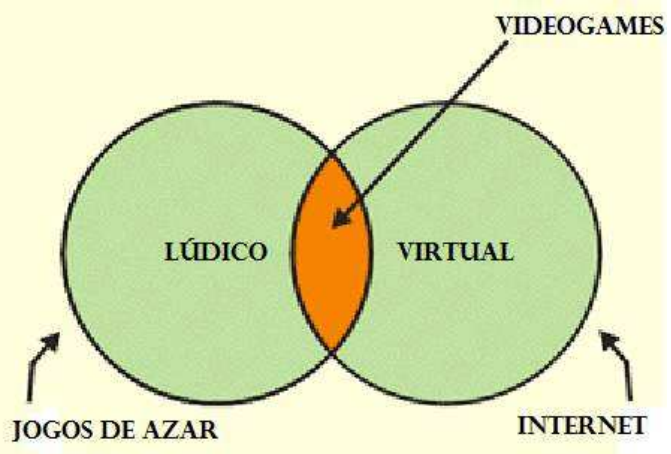

Figura 1.4 - Intersecção entre as dependências de jogo patológico e de internet (do autor)

A seguir apresentaremos alguns dos modelos teóricos mais utilizados por um grupo específico de terapeutas psiquiátricos e psicólogos, que trabalham com noções de dependência aplicadas aos casos da internet e dos videogames: o modelo cognitivo comportamental, o modelo neuropsicológico, a teoria da compensação e os fatores situacionais, presentes no livro Dependência de Internet: Manual e Guia de Avaliação e Tratamento (2013), organizado por Young e Nabuco de Abreu.

\section{3 - Apresentando teorias: a gramática das ciências}

\subsection{1 - Modelo cognitivo-comportamental}

Richard Davis (2001), psicólogo organizacional e consultor na empresa canadense $R H R$ International, introduziu a teoria cognitivo-comportamental do uso patológico de internet (UPI) para explicar a etiologia, o desenvolvimento e as consequências associadas a esse tipo de uso. Davis caracteriza o UPI como algo que vai além de uma dependência comportamental: este seria um padrão distinto de cognições e comportamentos relacionados à internet que resultam em consequências negativas para a vida. Ele propõe duas formas distintas de UPI: específica e generalizada. Segundo Davis, o UPI específico envolve o uso exagerado ou abuso de funções de conteúdo específico de internet (por exemplo, jogos de azar). Além disso, o autor argumenta que os transtornos comportamentais ligados a estímulos específicos provavelmente se manifestam de alguma maneira alternativa se o indivíduo não tiver a possibilidade de acessar a internet. 
O UPI generalizado é conceitualizado como um uso exagerado multidimensional da própria internet, que resulta em consequências pessoais e profissionais negativas. Seus sintomas incluiriam cognições e comportamentos desadaptativos relacionados ao uso de internet que não estariam ligados a nenhum conteúdo específico. Davis defende que isso ocorre quando a pessoa passa a ter problemas devido a um contexto exclusivo de comunicação virtual. Em seu entendimento, a pessoa seria levada à experiência de estar conectada por si e em si mesma, e demonstraria preferência por comunicações interpessoais virtuais, em vez daquelas estabelecidas face a face.

Nesta mesma linha de trabalho, outros pesquisadores (GREENFIELD, 2001; ORZACK, 1999) afirmam que o uso moderado e controlado de internet seria a forma mais adequada de tratar o suposto transtorno. Segundo Young (2007), a terapia cognitivocomportamental é o método preferido de tratamento e visa um maior controle dos pensamentos (esta teoria se baseia na premissa de que os pensamentos determinam os sentimentos). O objetivo principal deste tratamento é que a pessoa se abstenha das aplicações consideradas problemáticas, ao mesmo tempo mantenha um chamado uso controlado do computador por razões classificadas como legítimas. Em relação aos comportamentos não relacionados ao computador, o paciente seria auxiliado a fazer mudanças entendidas como positivas e permanentes em seu estilo de vida, excluindo a internet. Atividades fora da internet e que não envolvem o computador são estimuladas pelos terapeutas, como "reuniões sociais" e atividades com a família.

Da perspectiva cognitiva, a pessoa que pensaria de modo adictício se sentiria apreensiva, sem aparentemente nenhum motivo lógico, ao antecipar desastres (HALL; PARSONS, 2001). Embora os dependentes não sejam as únicas pessoas que se preocupam e antecipam acontecimentos negativos, eles tenderiam a fazê-lo mais frequentemente que outras pessoas. Young sugeriu que esse tipo de pensamento catastrófico poderia contribuir para o uso compulsivo de internet, ao fornecer um mecanismo de escape psicológico para evitar problemas reais ou percebidos.

Estudos subsequentes hipotetizaram que outras cognições mal adaptativas, como a supergeneralização e a catastrofização, além de crenças centrais negativas, também contribuem para o uso compulsivo de internet (CAPLAN, 2002; CAPLAN; HIGH, 2007; DAVIS, 2001). Nestas pesquisas, admite-se que as pessoas que sofrem de 
pensamento negativo geralmente teriam baixa autoestima e apresentariam atitudes pessimistas. Na tentativa de superar essa inadequação, elas poderiam ser atraídas para o potencial interativo anônimo da internet. Assim, o modelo cognitivo ajudaria a explicar por que os usuários de internet criariam um hábito de uso compulsivo e como os pensamentos negativos sobre si mesmo manteriam padrões de comportamento compulsivo.

\section{Discutindo o modelo cognitivo-comportamental}

Para distinguir quais seriam os usos recomendáveis e os usos problemáticos (estes, os únicos passíveis de serem classificados como potencialmente adictícios), este modelo, ao mesmo tempo que relega a segundo plano a influência do social $^{67}$ em sua teorização da dependência, baseia-se numa oposição estanque entre razões legítimas e ilegítimas de usos do computador. Neste entendimento, apreendemos que as atividades classificadas como legítimas seriam somente as que estariam relacionadas à família, ao trabalho e ao estudo, e as ilegítimas aquelas ligadas ao lazer e entretenimento. Como veremos no capítulo seguinte, os games, neste caso, não possuiriam um espaço legítimo, pois não teriam, em tese, finalidades produtivas, mas somente recreativas.

Como veremos em detalhe no próximo capítulo, dedicado especificamente às controvérsias envolvendo lazer e trabalho, tais conceitos são fruto das associações entre os actantes pelas quais as próprias pesquisas são compostas. Se ampliarmos a rede, reconheceremos não somente a legitimidade dos usos laborais dos computadores, mas a importância dos jogos para crianças (na pedagogia) e dos jogos simuladores em treinamento de guerra, além dos diversos benefícios (cognitivos, motivacionais, "sociais") desenvolvidos pelo uso dos videogames (GRANIC et al., 2014) ou, ainda, de propostas inovadoras de ONGs como Jogos para Educação, Games for Change e Games for Health. Com isso, podemos testar a seguinte hipótese: o jogo se transforma em vício quando se torna um fim em si mesmo (esta é uma característica central da

\footnotetext{
67 "Chama-se sociedade ou mundo social à metade da velha Constituição que deve unificar os sujeitos separados dos objetos, e sempre submissa à ameaça da unificação pela natureza; é um todo já constituído que explica as condutas humanas e permite, então, abreviar o papel político da composição; faz o mesmo papel paralisante que a natureza, e pelas mesmas razões. O adjetivo "social" é, então, sempre pejorativo (LATOUR, 2004, p. 385).
} 
própria definição de jogo para Huizinga ${ }^{68}$ ) e não quando é mero meio para outras atividades consideradas úteis ou produtivas.

Como uma forma de determinar o dito comportamento patológico, na teoria cognitivocomportamental também se aponta para o que os autores chamaram de consequências negativas para o indivíduo. No entanto, vemos que o que é classificado como negativo passa por uma classificação dos próprios terapeutas. Isto pode vir a ser problemático, pois eventualmente desconsidera o entendimento da própria pessoa que está sendo diagnosticada. Esta determinação heterônoma aplicada via questionários e outros métodos científicos parece carregar consigo diversas associações do que é positivo e negativo, ocultando muitas de suas relações em nome de uma neutralidade, a ponto de expulsar do parlamento das coisas outras explicações dos atores ${ }^{69}$.

O tratamento cognitivo-comportamental visa, sobretudo, mudar o pensamento das pessoas para que estas não pensem negativamente e, assim, se livrem de uma forma compulsiva de utilização dos videogames. Aqui se concebe, portanto, o pessimismo como o principal fator adictício. Isto também é controverso: uma pessoa pode estar com baixas expectativas sobre a sua relação com as coisas e pessoas no futuro, mas isto não significa necessariamente que ela deixe de se envolver com as mesmas. Pessimismo não é o mesmo que negar o convívio ou deixar de participar das relações, e por isso mesmo o uso de videogames não seria simplesmente uma fuga do que se entende por real. Esta visão catastrofista ou premonitória é no mínimo estranha, já que de algum modo uma suposta habilidade de prever acontecimentos negativos seria alçada a um componente causador do vício. Assim, o que neste modelo é considerado real e falso (ou fantasioso) tem a ver propriamente com o que se entende por real $^{70}$. Dissecaremos este assunto a fundo no terceiro capítulo.

\footnotetext{
${ }^{68}$ Huizinga não postula que o jogo seria inútil, pelo contrario, ele "torna-se uma necessidade tanto para o indivíduo, como função vital, quanto para a sociedade, devido ao sentido que encerra, à sua significação, a seu valor expressivo, a suas associações espirituais e sociais, em resumo, como função cultural". Ele questiona: "Mas o fato de ser necessário, de ser culturalmente útil e, até, de se tornar cultura diminuirá em alguma coisa o caráter desinteressado do jogo? Não, porque a finalidade a que obedece é exterior aos interesses materiais imediatos e à satisfação individual das necessidades biológicas” (1938, p. 12).

${ }^{69}$ Até aqui, pode parecer que se está questionando solitariamente tais modelos. No entanto, ao longo da dissertação, outros agentes (como os próprios jogadores) comporão este debate. Aqui apenas estamos levantando, de forma inicial, pontos em controvérsia.

${ }^{70}$ Segundo Latour (1991), real seria um maior volume de relações bem alinhadas, enquanto que o irreal seria menos volume de relações e não alinhadas.
} 
É aparentemente compreensível que se relacione uma maior utilização dos jogos com a baixa autoestima em ambientes fora do jogo, apesar dos problemas de medição que isto possa acarretar. Mas podemos também entender que uma pessoa possa alcançar uma melhora desta autoestima via jogos e que ela mesma desempenhe habilidades sociais melhores dentro do jogo em comparação com outras atividades "fora da tela", o que lhe geraria aumento de status, reconhecimento e realização nos primeiros ambientes. No entanto, percebemos que essas imagens médico-científicas da doença/dependência dependem da oposição indivíduo/sociedade, que é caracteristicamente Ocidental (LATOUR, 1994). A própria noção de autoestima também é centrada numa noção Moderna de indivíduo ${ }^{71}$, pois posiciona a origem do bem-estar (ou do mal-estar) numa unidade individual. Esta noção de indivíduo pressupõe uma entidade desrelacionada, enquanto a ideia de pessoa, em termos antropológicos mais contemporâneos, é de um ente relacionado, que participa de uma ampla rede de causalidades e efeitos.

Esta visão do escape muitas vezes não considera que as pessoas possam se envolver mais com os videogames porque, entre suas possibilidades de atividades, a escola e o trabalho parecem pouco interessantes se comparadas aos jogos ou estas não apresentam componentes motivacionais bem desenvolvidos que atraiam a sua atenção, sendo encaradas como maçantes, entediantes e repetitivas. Em contrapartida, vimos que muitos interlocutores relatam experiências mais estimulantes com os videogames, com os quais têm a possibilidade de vencer desafios e desenvolver aprendizados de uma forma mais engajada, mais imersa - exatamente o que aparece como sinal de dependência para os teóricos acima referidos. Em suma, um dos principais problemas da análise cognitiva-comportamental (e de muitas outras semelhantes neste campo) é que esta continua operando a partir de um rompimento dicotômico entre online e off-line, como se ambos fossem dois mundos incomunicáveis, enquanto que hoje, com a expansão acentuada do uso da internet e dos videogames, estas formas de interação quase sempre estão interconectadas.

\footnotetext{
${ }^{71}$ Segundo Louis Dumont (1985), pessoas são definidas como eminentemente relacionais e socialmente determinadas, enquanto que o modelo do "indivíduo" seria aspirado nas noções modernas de liberdade, igualdade, autonomia, autodeterminação e singularidade.
} 


\subsection{2 - Modelo neuropsicológico}

A seguir trataremos do modelo neuropsicológico de dependência de videogames. Apesar de existir uma lógica simples de encadeamento neste modelo, há uma série de conhecimentos médicos complexos, em especial sobre a anatomia do sistema nervoso, que dificulta o entendimento dos leigos. Diante destas limitações, buscaremos compreendê-lo mais a fundo.

Pesquisadores há muito tempo associam a dependência a mudanças em neurotransmissores no cérebro, e alguns deles argumentam que toda dependência pode ser desencadeada por mudanças semelhantes no cérebro. Especialistas chineses têm a cada ano realizado mais pesquisas sobre dependência de internet. No relatório de 2005 , a China Youth Association for Network Development apresentou um padrão para avaliar a dependência de internet incluindo um pré-requisito e três condições (CYAND, 2005). O pré-requisito é que a dependência de internet deveria prejudicar gravemente o funcionamento social e a comunicação interpessoal. Assim, um indivíduo seria classificado como dependente ao satisfazer qualquer uma das três seguintes condições:

1. Sentir que é mais fácil se autorrealizar virtualmente que na vida real;

2. Experienciar disforia ou depressão sempre que o acesso à internet for interrompido ou deixar de funcionar;

3. Finalmente, tentar esconder dos membros da família o tempo real de uso (YOUNG; ABREU, 2011, p. 25).

Ying, um dos cientistas dessa associação, propõe um modelo neuropsicológico de encadeamento para explicar o comportamento virtual dependente (TAO, YING, YUE; HAO, 2007). Ao examinar o que é entendido por impulso primitivo associado à dependência, este modelo parte de uma descrição sobre o que constitui o comportamento cerebral e cria uma associação direta com a dependência química. Nesta perspectiva, a ativação farmacológica dos sistemas de recompensa do cérebro seria a grande responsável pela produção das potentes propriedades adictícias das drogas. A personalidade, o social e a genética entrariam como fatores secundários, já que apenas explicariam o envolvimento inicial e a velocidade do desenvolvimento da dependência. Contudo, não são considerados fatores determinantes: este seria unicamente o efeito da droga sobre o sistema nervoso central. Ainda segundo este modelo, no caso de certas substâncias que geralmente não são consideradas adictícias, 


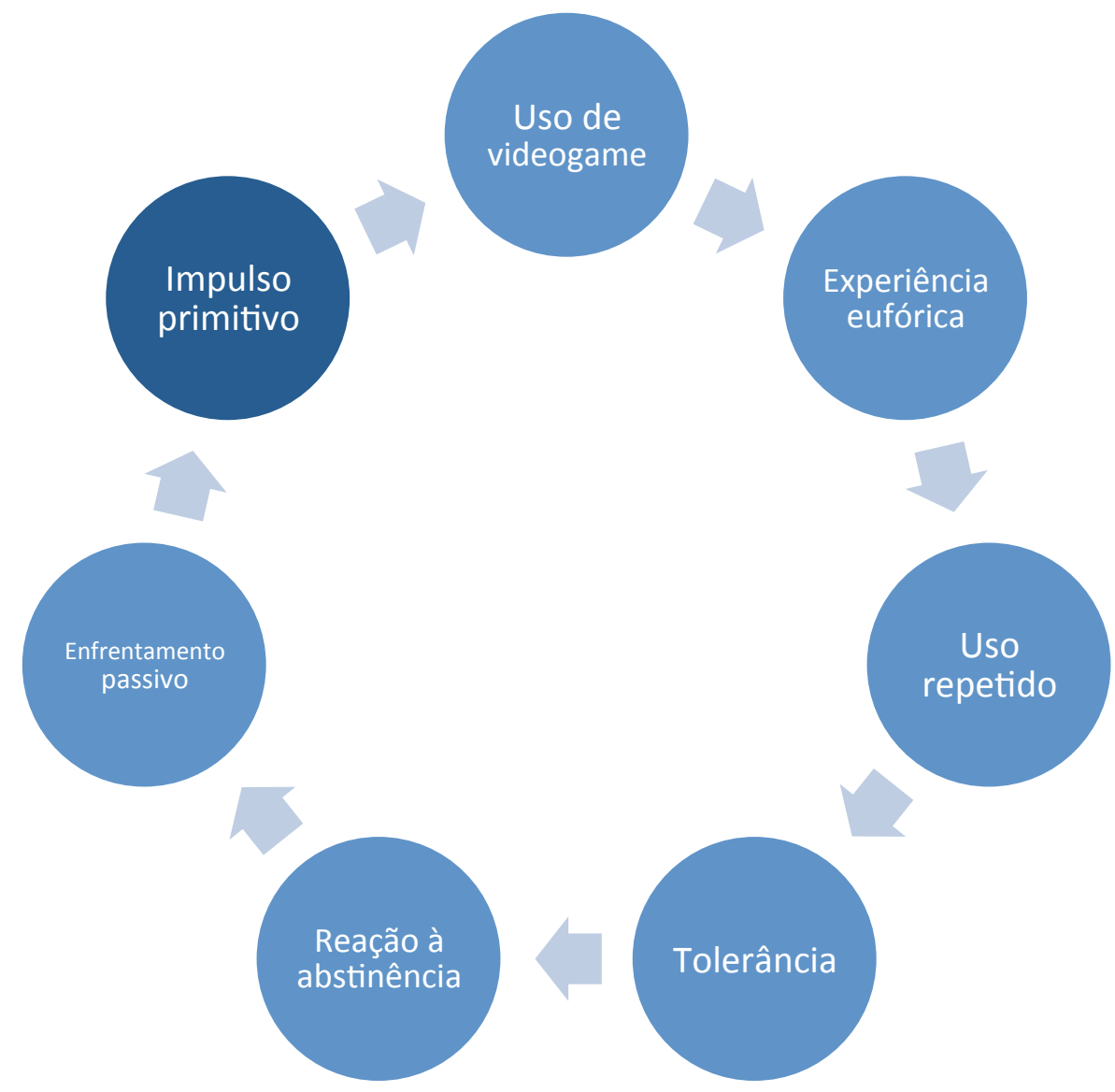

Figura 1.5 - Modelo neuropsicológico de encadeamento da dependência de videogames (adaptado de YOUNG; ABREU, 2011, p. 26)

Nesta teoria, a dopamina ${ }^{72}$ (um dos neurotransmissores encontrados no sistema nervoso central) tem uma função importante na regulação do humor e do afeto, por conta de seu papel nos processos de motivação e recompensa ${ }^{73}$.

\footnotetext{
72 A dopamina (DA) é um neurotransmissor monoaminérgico, da família das catecolaminas, produzido pela descarbonização dedihidroxifenilalanina (DOPA). Ela é produzida especialmente pela substância nigra e na área tegmental ventral (ATV). Está envolvida no controle de movimentos, aprendizado, humor, emoções, cognição, sono e memória. É precursora natural da adrenalina e da noradrenalina, outras catecolaminas com função estimulante do sistema nervoso central. A desregulação da dopamina está relacionada a transtornos neuropsiquiátricos como Mal de Parkinson, no qual ocorre escassez na via dopaminérgica nigro-estriatal, e na Esquizofrenia, na qual ocorre excesso de dopamina na via dopaminérgica no mesolímbico e escassez na via mesocortical.

${ }^{73} \mathrm{Na}$ via de recompensa, dopamina é fabricada na área tegmental ventral e é liberada no núcleo accumbens, seguindo para o córtex pré-frontal. Na via responsável por movimentação, a dopamina é produzida na substância nigra e liberada no corpo estriado. A substância negra (ou substância nigra) é uma porção heterogênea do mesencéfalo, responsável pela produção de dopamina no cérebro. Possui papel importante na recompensa e vício.
} 


\begin{tabular}{|l|l|}
\hline \multicolumn{1}{|l|}{$\begin{array}{l}\text { Tabela 2 - Explicação da cadeia neuropsicológica da dependência de videogames } \\
\text { (adaptado de YOUNG; YUE; YING; 2011, p. 27). }\end{array}$} \\
\hline Conceito principal & Explicação específica \\
\hline Impulso primitivo & $\begin{array}{l}\text { O instinto do indivíduo de buscar o prazer e evitar a dor, que é } \\
\text { representativo de vários motivos e impulsos para usar o videogame. }\end{array}$ \\
\hline Experiência eufórica & $\begin{array}{l}\text { As atividades virtuais estimulam o sistema nervoso central do } \\
\text { indivíduo, que se sente feliz e satisfeito. O sentimento impulsionará } \\
\text { a pessoa a usar continuamente o videogame e prolongar a euforia. } \\
\text { Depois de estabelecida a dependência, a experiência eufórica logo } \\
\text { se transforma em hábito e em estado de entorpecimento. }\end{array}$ \\
\hline Tolerância & $\begin{array}{l}\text { Devido ao uso repetido de videogame, o limiar sensorial do } \\
\text { indivíduo diminui; a fim de atingir a mesma experiência de } \\
\text { felicidade, o usuário precisa aumentar o tempo e o apego ao } \\
\text { videogame. A tolerância de nível elevado é o trampolim para a } \\
\text { dependência de videogame e o resultado do esforço da experiência } \\
\text { eufórica referente ao videogame. }\end{array}$ \\
\hline Reação de abstinência & $\begin{array}{l}\text { As síndromes física e psicológica acontecem quando o indivíduo } \\
\text { interrompe ou diminui o uso de videogames, e incluem } \\
\text { principalmente disforia, insônia, instabilidade emocional, } \\
\text { irritabilidade, e assim por diante. }\end{array}$ \\
\hline Enfrentamento passivo & $\begin{array}{l}\text { Quando o indivíduo se confronta com frustrações ou sofre efeitos } \\
\text { prejudiciais do mundo exterior, surgem comportamentos passivos } \\
\text { de acomodação ao ambiente; comportamentos que incluem } \\
\text { imputação adversa de eventos, falsificação de cognições, supressão, } \\
\text { escape e agressão. }\end{array}$ \\
\hline Efeito avalanche & $\begin{array}{l}\text { O efeito avalanche inclui experiências passivas, que consistem em } \\
\text { reação de tolerância e abstinência, e impulso combinado } \\
\text { consistindo em estilos de enfrentamento passivos com base no } \\
\text { impulso primitivo do indivíduo. }\end{array}$ \\
\hline
\end{tabular}

Segundo Di Chiara (2000), algumas drogas adictícias produzem seus potentes efeitos sobre o comportamento ao aumentar a atividade de dopamina mesolímbica. "A ligação neuroquímica com dependências comportamentais, como o jogo patológico ou a comida, ainda precisaria ser confirmada" (YOUNG; YUE; YING; 2011, pp. 27-28), mas alguns estudos sugerem que os processos neuroquímicos desempenham um papel central em todas as dependências, quer de substâncias, quer de comportamento (DI CHIARA, 2000). Dentre os diversos sistemas de dopamina no cérebro, o sistema mesolímbico de dopamina ${ }^{74}$ aparentaria ser o mais importante nos processos motivacionais. De acordo com Mark Griffiths (2010) "todas as dependências (sejam

\footnotetext{
${ }^{74}$ A via mesolímbica é uma das vias dopaminérgicas do cérebro. A via inicia-se na área tegmental ventral do mesencéfalo e forma conexão com o sistema límbico através do núcleo accumbens, a amígdala cerebelosa e o hipocampo, e também com o córtex pré-frontal medial. É sabido estar envolvida na modulação das respostas comportamentais aos estímulos que ativam as sensações de recompensa através do neurotransmissor dopamina.
} 
químicas ou comportamentais) são essencialmente sobre constantes reforços e recompensas e reforços.

O proposto modelo de circuito cerebral de recompensas na dependência envolve o aumento de dopamina quando certas áreas do cérebro ${ }^{75}$ são estimuladas. Sua estimulação excessiva resultaria na dessensibilização dos receptores, gerando maior necessidade de dopamina para o usuário obter o mesmo efeito (esse mecanismo teria um papel importante nos vícios em jogo, adicção sexual, alcoolismo e drogadicção). Para operá-lo, o cérebro possuiria trajetórias especializadas, que mediariam a recompensa e a motivação. Segundo Di Chiara (2000), a estimulação elétrica direta do feixe medial do

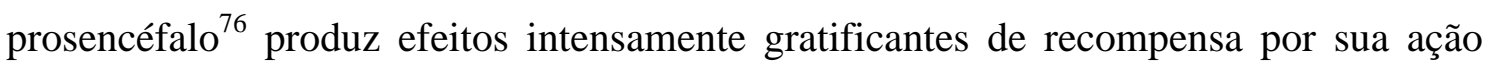
farmacológica, respectivamente, sobre o núcleo accumbens ${ }^{77} \mathrm{e}$ a área tegmental ventral $^{78}$. A ação ventral tegmental dos opiáceos provavelmente envolveria um sistema endógeno de peptídeos opioides, mas "a localização anatômica desse sistema ainda não foi identificada" (YOUNG; ABREU, 2011, p. 28). Recompensas ditas "naturais" (como comida e sexo) e outras substâncias (como cafeína, álcool e nicotina) também ativariam este mesmo sistema cerebral de recompensas.

No relatório de 2004, a OMS detalha que o desenvolvimento da dependência seria um processo de aprendizado movido por recompensas ou reforços após os circuitos motivacionais do cérebro serem ativados, aumentando a possibilidade de repetição deste comportamento. O relatório menciona que tais circuitos são normalmente ativados por comida, água, perigo e acasalamento. Isso faz com que o cérebro seja "enganado pelas substâncias e respondendo como se tais substâncias e seus estímulos associados fossem biologicamente necessários" (p. 22). Com a continuidade do uso, esta associação se

\footnotetext{
${ }^{75} \mathrm{O}$ cérebro consiste de córtex cerebral, substância branca subjacente e glândulas da base.

${ }^{76}$ Prosencéfalo (ou encéfalo frontal), na anatomia dos vertebrados, é a parte mais rostral e frontral do cérebro. O prosencéfalo, o mesencéfalo e o rombencéfalo são as três partes principais do cérebro no começo do desenvolvimento do sistema nervoso central. Ele controla a temperatura corporal, as funções reprodutivas, a alimentação, o sono e todas as emoções.

${ }^{77}$ Núcleo accumbens é uma estrutura cerebral ligada à sensação do prazer. É pertencente ao sistema mesolímbico dopaminérgico e localiza-se próximo ao hipocampo.

${ }^{78}$ Área tegmental ventral é um grupo de neurônios localizados em uma região do tronco cerebral. Uma parte dele secreta dopamina. A descarga espontânea ou a estimulação elétrica dos neurônios da região dopaminérgica na via mesolímbica produz sensações de prazer, algumas delas similares ao orgasmo. Indivíduos que apresentam, por defeito genético, redução no número de receptores das células neurais dessa área, tornam-se incapazes de se sentirem recompensados pelas satisfações comuns da vida e buscam alternativas "prazerosas" atípicas e nocivas como, por exemplo, alcoolismo, cocainomania, compulsividade por alimentos doces e pelo jogo desenfreado.
} 
torna mais forte, criando uma "sensibilização por incentivo". O cérebro passa então a reconhecer vários "gatilhos" para a vontade do uso de uma substância, gatilhos estes feitos por associação do uso com locais, pessoas, objetos etc. Isso leva as pessoas às recaídas, mesmo depois de um longo período de abstinência. O próximo passo para a investigação científica seria a busca de genes específicos relacionados a uma vulnerabilidade maior de grupos específicos de sujeitos.

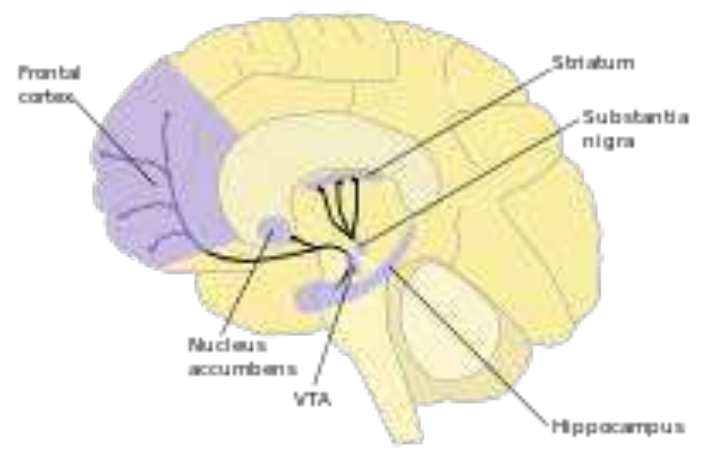

Figura 1.6 - Córtex frontal ${ }^{79}$, núcleo accumbens, hipocampo ${ }^{80}$, substância nigra e corpo estriado (Fonte: http://pt.wikipedia.org/wiki/Dopamina).

Pesquisas farmacológicas buscaram construir o argumento científico do impacto positivo do tratamento medicamentoso nesse dito transtorno em testes de laboratório, como, por exemplo, o uso do remédio antidepressivo escitalopram (DELL'OSSO, 2008). Para tanto, os pesquisadores utilizaram uma série de técnicas, como a seleção prévia de candidatos classificados como dependentes por suas métricas, separação do grupo que "respondeu" daquele que não reagiu ao medicamento, uso de grupo de controle e de placebo controlado, entre outras.

\footnotetext{
${ }^{79} \mathrm{O}$ córtex pré-frontal (PFC) é a parte anterior do lobo frontal do cérebro, localizado anteriormente ao córtex motor primário e ao córtex pré-motor. Esta região cerebral está relacionada ao planejamento de comportamentos e pensamentos complexos, expressão da personalidade, tomadas de decisões e modulação de comportamento social. A atividade básica dessa região é resultado de pensamentos e ações em acordo com metas internas. A função psicológica mais importante relacionada com o córtex préfrontal é a função executiva. Esta função se relaciona a habilidades para diferenciar pensamentos conflitantes, determinar o bom ou ruim, melhor e pior, igual e diferente, consequências futuras de atividades correntes, trabalho em relação a uma meta definida, previsão de fatos, expectativas baseadas em ações, e controle social. Muitos autores indicam uma ligação entre a personalidade de uma pessoa e o funcionamento do córtex pré-frontal.

${ }^{80}$ Hipocampo é uma estrutura localizada nos lobos temporais do cérebro humano, considerada a principal sede da memória e importante componente do sistema límbico. Está relacionado à navegação espacial.
} 


\section{Problematizando o modelo neuropsicológico}

A teoria neuropsicológica trata o videogame como um estimulante que ativa ou desativa outras substâncias e que, consequentemente, fabrica um efeito sobre o corpo, de forma análoga às narrativas sobre drogas. Esta teoria trata, pois, da interação de um só vetor de uma substância (neste caso, o videogame) sobre um corpo (humano). A princípio, vemos que o modelo neuropsicológico desconsidera o social (no sentido moderno) como mediador, ao invés, o toma como mero intermediário, ou, como dizem, fator secundário. Uma vez que o caminho para a cura tampouco estaria relacionado ao "social", a proposta de tratamento passaria então pela medicalização, ou seja, pela ingestão de outras substâncias farmacológicas que alterariam a dinâmica dos atores (vide as pesquisas acima citadas). Neste esquema teórico, todos os outros actantes desconsiderados (o próprio social) se reuniriam então num plano oficioso, ao contrário da dopamina, do sistema nervoso, das recompensas - estes sim entendidos como agentes naturais, objetivos, dos fatos científicos, que ocupam o plano oficial.

Esta abordagem tem um caráter universalista, isto é, pretensamente se adequaria a qualquer caso, independendo de cultura, idade, sexo, ou qualquer outro "fator sociocultural". Termos como "indivíduo", "felicidade”, "autorrealização", "mundo exterior", "ambiente”, "sistema nervoso central", "síndromes física” e "psicológica" carregam pressupostos universalistas tanto da unidade de análise (indivíduo), quanto do corpo, entendido como "natural", e, portanto, em certa medida igual de uma pessoa para outra; assim como algumas oposições, como "vida real" e "virtual", que aparecem como autoevidentes e dispensam explicação por parte dos teóricos. Frente a isso, nossa proposta irá em direção oposta. A ideia é retirar esses termos de suas caixas-pretas e, na medida do possível, abrir seus campos semânticos. A intenção aqui não se trata de simplesmente negar o sistema nervoso para reafirmar um sistema social ou psíquico, mas sim entender a rede de causações recíprocas entre esses "domínios" só aparentemente (ou politicamente) autônomos.

Podemos considerar que o argumento central desta teoria mobiliza uma série de seres difíceis de visualizar por um não-expert. Actantes como a dopamina, o sistema mesolímbico, o sistema de afetos, as trajetórias especializadas do cérebro e suas as recompensas entram como actantes importantes, que movimentam tantos outros a partir de associações estáveis que as sustentam. A não ser com o exame minucioso da 
complexidade de sua linguagem, técnicas e conhecimentos, tais associações permanecem amarradas a agentes invisíveis e fechadas em caixas-pretas de difícil abertura.

Acerca dos sistemas de recompensa, a psicóloga Ivelise Fortim explica a diferença entre o que chama de modelo neurobiológico (ou neurológico-cerebral) e um modelo comportamental, que estaria mais próximo da corrente behaviorista da psicologia.

Pensando em game, em internet, tudo tem a ver com sistema de recompensa. A mecânica da dependência está baseada no sistema de recompensa. Tem um modelo biológico de liberação. Então, quando você faz um comportamento X, libera dopamina no cérebro e tem uma sensação de prazer. $\mathrm{E}$ o cérebro vai aprendendo que cada vez que você faz aquilo libera aquela sensação de dopamina. O problema é que tanto na dependência comportamental quanto na dependência de droga, no começo você faz pra se sentir bem, depois você faz pra não se sentir mal. Aí você não faz mais porque é legal, você faz pra você não ficar ruim, porque eles vão chamar lá de abstinência. Você faz pra não entrar em abstinência. Então tem um modelo que é um modelo neurológicocerebral. (comunicação pessoal)

Fortim retoma uma experiência de trabalho, a qual evidencia algumas de suas ligações institucionais. Contrária a um modelo biologicamente determinista, ela, como psicóloga social, ressalta as chamadas causas socioculturais (ou comportamentais):

Eu trabalhei no PROAD. Lá a gente não acredita que o modelo biológico é determinante. Mas tem muita gente que sim. Se você acreditar que o modelo biológico é determinante, não tem recuperação. Isso não é verdade. Tem gente que se recupera. Então, tem esse modelo biológico e tem um modelo que é um modelo comportamental de ser recompensado, que é um modelo que, por exemplo, o pessoal de behaviorismo vai trabalhar bastante. As pessoas fazem coisas com que elas são mais reforçadas, quanto mais reforça um comportamento maior a probabilidade de acontecer. (comunicação pessoal)

A oposição básica que rege a controvérsia aqui enunciada é: o vício é uma característica herdada (natureza) ou um comportamento aprendido (sociedade)? É evidente que esta pergunta ainda opera no modelo "guerra das ciências", purificando em polos opostos as causas da dependência. Hoje, o modelo proposto pela corrente behaviorista de comportamento de seres humanos e animais (WATSON; 1913, SKINNER, 1953) possui uma série de críticas e controvérsias dentro da própria psicologia e para além dela (CHOMSKY, 1971). No entanto, ainda é muito aplicado por profissionais da área. É nesta linha de pensamento que o psicólogo clínico Janos Geocze comenta sobre os sistemas de recompensa do cérebro. 
O cérebro é um sistema que pode ser muito bem utilizado e ele gosta de certas repetições. Então, coisas repetitivas, ao invés de cansar (que muita gente acredita que a pessoa vai se extenuar com isso), nos jogos eles são muito sedutores. Esse Candy Crush, por exemplo, que está agora tanto em moda, é altamente viciante [...], alcançar etapas, estágios, é um desafio. (comunicação pessoal)

Para Geocze, a teoria behaviorista da dependência é uma lógica universal e aplicável a uma grande diversidade de casos. Para ele, até mesmo os animais podem se viciar:

Como é que eu posso sentir falta de algo que não é essencial pra mim? Pensa nos animais, e vê lá se você consegue viciar. Você consegue, desde que você mexa no centro de prazer dele. O bicho deixa de ser bicho. Melhor jeito de você ver isso: circo. Os animais são condicionados, se fizerem determinadas coisas eles vão receber uma gratificação. Seja mel pro urso ou seja choque ou nãochoque. Isso é, se você não fizer o que eu quero, você vai sentir um desprazer muito grande. Então com medo do desprazer... Punição! Com medo do desprazer você acaba tendo o prazer de não ter o desprazer. O urso naturalmente não vai levar choque. Alguém criou mecanismos pra que através do choque dominasse o urso e o urso fizesse o que ele quiser. Então, ele está viciado em não levar choque. Mas na natureza ele não levaria choque. Você criou essa condição. O jogo cria ou não cria essa condição? (comunicação pessoal)

Nesta fala, é visível que Geocze manipula uma certa imagem de "natureza" como algo pronto e exterior, enquanto que entende a "sociedade" como um produto exclusivo da ação do homem. Ou seja, nesta visão que chamamos de Moderna, o homem "usa" a natureza a seu bem entender. Ainda sim, esta lógica parece ser eficiente, seja entre os médicos, seja entre os jogadores. Portanto, não é questão de simplesmente desqualificála, mas levá-la a sério, compreendendo-a juntamente com outros dados de campo que nos ajudam a compor coletivos mais complexos acerca do assunto:

No fundo, o que eu estou mexendo é com prazer e desprazer. [...] São as famosas endorfinas ${ }^{81}$. O antidepressivo entra exatamente aí. Nós estamos falando de atenção. Você vai ou não me dar atenção? Eu posso obter a tua atenção pelo desprazer? Porra, se posso. As pessoas necessitam de atenção. E no jogo o cara acha que obtém atenção. É por essa atenção que ele está lá. O pior, ele consegue atenção com "ç" e consegue com "s", que é tensão muscular, por causa do jogo. E fica totalmente adrenalizado. (comunicação pessoal)

\footnotetext{
${ }^{81}$ A endorfina é um neuro-hormônio produzido pelo próprio organismo na glândula hipófise. Sua denominação se origina das palavras endo (interno) e morfina (analgésico). A endorfina é produzida em resposta à atividade física e durante o orgasmo, visando relaxar e dar prazer, despertando uma sensação de euforia e bem-estar. A endorfina é um neurotransmissor, assim como a noradrenalina, a acetilcolina e a dopamina, e é uma substância química utilizada pelos neurônios na comunicação do sistema nervoso. É uma hormona que, transportada pelo sangue, faz comunicação com outras células. A dificuldade na coleta desse hormônio na região de sua produção explica muito das controvérsias a seu respeito. (Fonte: http://www.assessocor.com.br/noticias.aspx?_idNot=230).
} 
Geocze ainda atenta para o componente "desafio" nesta lógica de recompensa e punição. Para ele, há um “tesão" e uma "graça” em arriscar nos videogames comparável ao sexo e aos jogos de cassino. Aliás, para Roger Caillois (1957) seria este exatamente um dos quatro aspectos centrais dos jogos, o qual chamou de Ilinx.

Janos Geocze comenta que o vício deve estar estreitamente ligado com o nível do desafio proposto pela atividade e pela chance do jogador atendê-la com sucesso. Ele pergunta: "Por que o jogo de xadrez contra o computador não vicia? Porque você não ganha. Você só perde. Aí você tem que baixar o nível do negócio e fica ridículo pra você ganhar" (GEOCZE, 2014). Isto é, se o jogo for fácil demais, perde a graça. Se for difícil demais, idem. Há de se ter, por menor que seja, alguma chance do jogador ganhar e perder. Ele continua: "Pra que o cara tente, você tem que premiar. Você não pode só não premiar. E o jogo tem isso. Ele tem subprêmios dentro do prêmio". Segundo Caillois (1957), quanto mais imprevisível (aspecto alea) o resultado, mais emocionante se torna o jogo. É exatamente esta incerteza que gera a sensação de desafio, a qual contribui para incentivar o jogador a jogar mais.

Em todo caso, o tema dos sistemas de motivação e recompensa que aparece no argumento dos teóricos que mobilizam este modelo neuropsicológico parece ter rendimento para a continuidade desta pesquisa, pois oferece um bom canal de diálogo com os game designers (profissionais que criam os videogames). Estes também trabalham com o mesmo termo sistemas de recompensas, mas aparentemente com um objetivo contrário ao dos agentes de saúde: investigar como se pode fabricar jogos que mantenham a atenção e a motivação dos jogadores de modo que não parem de jogar ${ }^{82}$.

Para isso, os game designers criam sistemas de cumprimento de metas e calculam meticulosamente o balanceamento de uma série de variáveis, tais como: a relação de risco-recompensa que um jogador vivencia em uma situação de jogo; a curva de aprendizagem do jogo (o aumento de dificuldade do nível de jogo em relação ao aumento da habilidade do jogador, decorrente de seu ganho de experiência); o posicionamento de certos momentos de clímax no roteiro etc. Estas recompensas podem

\footnotetext{
${ }^{82}$ Isto é valido em uma certa porção da rede mais ligada às grandes produtoras, mas há outras estratégias de mercado para a venda e distribuição de jogos. Há certos desenvolvedores, por exemplo do movimento indie, para os quais o objetivo principal não é vender ou prender a atenção do jogador em seu game, mas desfrutar a experiência de um jogo autoral ou artístico.
} 
se apresentar de diversas formas, como a descoberta de novos espaços e/ou de novas fases, evolução de avatares, ganho de novas habilidades ou equipamentos, pontuação extra, aumento de status entre os jogadores e até mesmo a inserção de animações, sons ou imagens como estímulo pelas vitórias e conquistas.

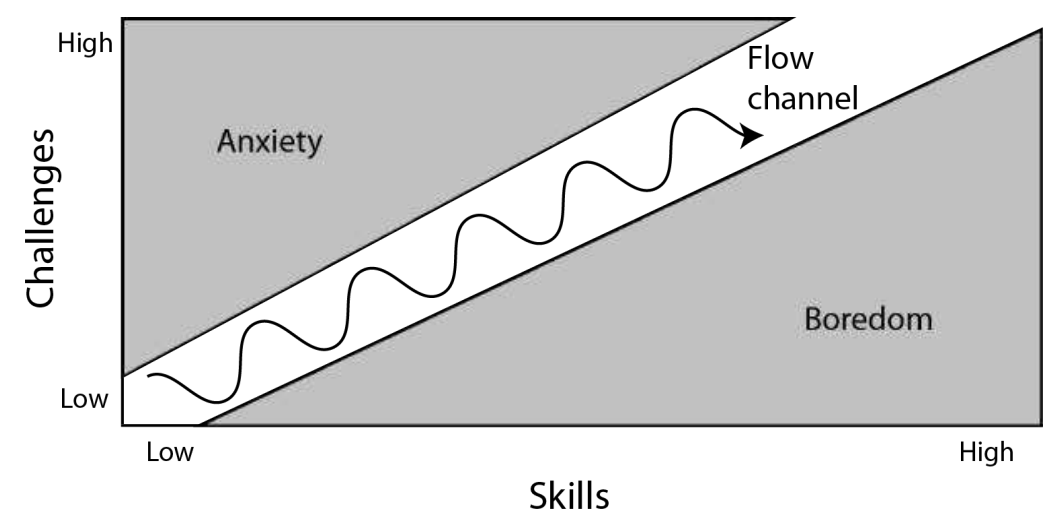

Figura 1.7 - Teoria do fluxo

Uma teoria atualmente bastante citada por acadêmicos, assim como por game designers, é a chamada teoria do fluxo (flow theory), do psicólogo húngaro Mihaly Csikszentmihalyi. Basicamente, esta teoria postula a existência de um estado de "fluxo" (flow), que seria um estado de prazer atingido quando as habilidades e desafios estivessem harmonizados. Este equilíbrio é atingido quando o nível de desafio de uma atividade não é muito maior do que as habilidades requeridas para executá-la (pensando nos jogos, neste caso sempre perderíamos, gerando frustração ou ansiedade). Por outro lado, as habilidades também não poderiam ser muito maiores do que os desafios (aqui, sempre ganharíamos), gerando tédio. A teoria do fluxo trata justamente desta linha tênue, onde as habilidades seriam suficientes para cumprir os desafios e estes, por sua vez, estivessem na dose certa para gerar motivação e a sensação de conquista.

Segundo esta perspectiva, a chave que explica o que os leigos denominam de "vício" pode estar claramente relacionada a estados de fluxo que proporcionam aos jogadores níveis elevados de engajamento, motivação e imersão nestas atividades. Mas este é um assunto que trataremos no quarto capítulo, a partir de uma etnografia específica com os desenvolvedores de jogos. No momento, podemos indicar que tanto os neuropsicólogos como os desenvolvedores de jogos parecem afirmar coisas semelhantes quanto ao sistema de recompensas. No entanto, o que um considera como negativo, o outro vê como positivo. 


\section{Característica neurobiológica versus comportamento social}

Neste trecho exploraremos brevemente uma controvérsia presente no campo de disputa entre abordagens "naturalistas" e "culturalistas". Segundo Ivelise Fortim, há pesquisadores que acreditam na existência de uma personalidade adictiva, a qual seria uma configuração neurobiológica herdada, mas que, para ela, não seria infundado:

Se você for estudar família de alcóolatra, família de dependente, sempre tem outro dependente na família. Sempre. Então, por exemplo, se for pegar o cara alcoólatra, o pai era alcoólatra; se não era o pai, era o tio; se não era o tio era tal... Vai ter dependente na família. (comunicação pessoal)

De acordo com esse modelo, a pessoa já possuiria uma personalidade adictícia de antemão, que somente estaria a espera de um estímulo para se manifestar: "Você nasceu com uma configuração que a hora que te derem um estímulo, você vai ser adicto".

No entanto, Fortim comenta que ainda não há consenso se o quê os cientistas chamam de personalidade adictiva é uma característica herdada neurobiologicamente ou se este comportamento é aprendido por meio de uma configuração familiar. Segundo ela, há estudos de terapia de família que mostram como uma pessoa mantém os comportamentos na família por meio de uma dinâmica familiar. Ou ainda, se na verdade esta personalidade ou comportamento adicto têm as duas coisas.

A seguir, Fortim conta que a personalidade adictiva, em uma das explicações majoritárias, seria uma característica geneticamente herdada, enquanto que na outra, seria um comportamento aprendido, ligado à questão das dependências familiares. Ao explicar a dinâmica das dependências familiares e das co-dependências, a psicóloga argumenta que existem certos tipos de pessoa mais propícios a desenvolverem "dependência", desde drogas aos videogames. E que estas pessoas trocam mais facilmente uma dependência pela outra. Formada no interior das ciências humanas (é graduada em Psicologia na PUC-SP e mestra em Ciências Sociais na mesma instituição), Fortim toma uma posição bem clara, defendendo a segunda opção: de que estes são comportamento socialmente aprendidos.

Não é hereditário. Se o seu pai é alcoólatra, não é obrigado você ser alcoólatra. Bom, eu sou psicóloga. Então, eu entendo que a dinâmica familiar é fundamental. Assim, você pode nascer com uma semente, mas se não te derem terreno fértil, você não planta. Pensando pelo ponto de vista da Psicologia, uma das questões é: uma família que tem um dependente, provavelmente toda a 
família tem uma dinâmica de dependente. Vamos supor, você tem um cara que é alcoólatra, esse cara tem uma filha, e tem uma dinâmica psicológica de alcoólatra na família. A probabilidade dessa filha casar com um marido alcoólatra e repetir esse padrão familiar é muito alta. Às vezes o quê acontece: Ela não casa com um cara alcoólatra, mas o cara é dependente de outra coisa... O cara é drogado, casa com um outro padrão de dependência. Por exemplo, o cara é viciado em jogo, o filho desse casal é alcoólatra igual ao avô. Isso é super comum. Outra coisa que é comum é trocar uma dependência pela outra. Se você olhar a constituição familiar de dependente, tem dependente na família toda. Pode ser um pouco longe, por exemplo: Você não é, mas o tio é. Mas do ponto de vista da Psicologia, um dos problemas é que, por exemplo, essa moça aprendeu um papel de co-dependente com esse alcoólatra, ela repete esse papel com o filho, com o marido. Então, estimula a dinâmica do outro ser dependente, mas é porque ela está nesse papel. (comunicação pessoal)

Aqui temos recolocada a clássica divisão moderna entre natureza e sociedade (ou cultura). A explicação neurobiológica, do comportamento herdado, operaria exclusivamente no polo "natural". Com Fortim, entramos para dentro da explicação sócio-psicológica, que opera no polo da cultura. Aparentemente aqui estaria instalada uma nova versão da velha guerra das ciências. Mas, como sair dela? Ou, pelo menos, como não ficar paralisado? Entendemos que seria reconhecendo as passagens (oficiais e oficiosas) entre estes sistemas purificadores, tal como a terceira via por ela mencionada, que reunia aspectos de ambos os sistemas explicativos. No entanto, vimos que todas as três hipóteses pelo menos concordam em um aspecto: que de fato existe uma personalidade adictiva; isto é, que o comportamento de dependência, seja herdado ou aprendido, está localizado na personalidade do sujeito, no seu “eu” interior.

\subsection{3 - Teoria da compensação}

A teoria da compensação trabalha basicamente com a ideia do uso de videogames como um meio de compensar ou lidar com déficits de autoestima, identidade e relacionamentos. Em suas pesquisas, Caplan e High (2007) argumentam que foram encontrados níveis mais elevados de solidão entre os considerados usuários patológicos.

De acordo com esta teoria, os considerados dependentes de videogame em geral têm dificuldade em construir relacionamentos íntimos com outras pessoas e, portanto, se esconderiam na anonimidade do ciberespaço a fim de se conectar com pessoas de uma maneira não ameaçadora. Virtualmente, assim, o indivíduo poderia criar uma rede social de novos relacionamentos. Com visitas rotineiras a um determinado grupo, ele estabeleceria um alto grau de familiaridade com outros membros do grupo, criando um sentimento de comunidade. Dessa forma, o usuário se adaptaria às normas correntes do 
grupo. Como os autores colocam: "o grupo existe supostamente em um tempo e espaço paralelos, e se mantém vivo somente porque os usuários se conectam uns com os outros pelo computador" (p. 29).

Uma vez estabelecido o senso de pertencimento a um determinado grupo, os dependentes de internet dependem do intercâmbio pela conversação para obter companhia, conselhos, entendimentos e, inclusive, romance. A capacidade de criar uma comunidade virtual deixa para trás o mundo físico, e pessoas conhecidas, fixas e visuais deixam de existir, e os usuários anônimos criam um encontro de mentes que vivem em uma sociedade baseada puramente em textos. Pelo intercâmbio de mensagem pela internet, os usuários compensam o que lhes falta na vida real (CAPLAN; HIGH, 2007 apud YOUNG, 2011, p. 29).

Segundo esta linha, em algumas circunstâncias da vida consideradas limitadoras do acesso aos outros, seria mais provável que o indivíduo utilizasse os videogames como um meio alternativo para estabelecer alicerces sociais que faltariam em seu, assim chamado, ambiente imediato. Em outros casos, quem se sentisse socialmente pouco hábil ou tivesse dificuldade em estabelecer relacionamentos (entendidos como) sadios na (suposta) vida real descobriria que consegue se expressar mais livremente e encontraria nos jogos o companheirismo e a aceitação ausentes em sua vida.

Há estudos (KRANT, 1997) que apontam uma correlação entre o isolamento social, a depressão e o uso de jogos eletrônicos. Outros, que investigam impactos psicológicos, associam o jogo à diminuição da comunicação familiar e à redução do círculo social local; a um aumento na solidão e depressão - mesmo no uso considerado modesto, pronunciados no caso dos jovens. Há pesquisadores (YOUNG; ROGERS, 1997) que afirmam ter descoberto que quanto mais os usuários forem dependentes, mais eles usarão os games como fuga.

Quando mais estressados pelo trabalho ou deprimidos, os dependentes tendiam mais a acessar a internet e relatavam graus mais elevados de solidão, humor deprimido e compulsividade quando comparado aos outros grupos. A depressão foi ligada ao uso excessivo de internet de modo geral. Não foi demonstrado se a depressão causa dependência ou se ser dependente causa depressão, mas os estudos demonstraram que as duas síndromes estavam fortemente correlacionadas, reforçando-se mutuamente (YOUNG; ABREU, 2011, p. 30).

Esta teoria recomenda que os terapeutas atentem para como os usuários podem compensar o que falta em sua "vida real" com o uso dos videogames, destacando que podem se tornar extremamente reforçadores na superação da baixa autoestima, falta de habilidade social, solidão e depressão. Ao mesmo tempo, quem sofresse desses 
problemas poderia estar mais passível de desenvolver tal transtorno. Enfim, esta teoria recomenda que os terapeutas examinem outros fatores considerados comórbidos, com os quais o cliente estaria lidando (somente aqui entraria o "social"). Ao final, sugere perguntas, como: O cliente está usando o videogame para satisfazer necessidades sociais? Estabelece relacionamentos virtuais para fazer amigos devido à fobia social? Ele usa o jogo online para se sentir poderoso quando sofre de baixa-estima? Ele usa o jogo para lidar com uma depressão clínica?

\section{Questionamentos sobre a teoria da compensação}

Num primeiro olhar, pode parecer que, ao contrário do modelo neuropsicológico, a teoria da compensação levaria em consideração o dito "social". Isto acontece em certo grau, mas de uma forma bem específica - para não dizer, moderna. A visão de que as pessoas recorrem à internet por estarem sozinhas, ou por terem baixa autoestima, deriva de uma concepção de solidão que somente leva em consideração as relações entre seres humanos. O social, pois, aqui é entendido como o mundo exclusivo dos humanos. Os outros seres, como os animais, plantas, espíritos e objetos pertencentes ao reino da tecnologia (LATOUR, 1991), tais quais os videogames, estariam fora do dominio da sociedade e, assim, fora das relações entendidas como verdadeiras. No entanto, vemos que a única ausência aqui seria a de relações entre humanos em ambiente offline.

Operando na visão da falta - de autoestima, relacionamentos, de identidade e, em último caso, até mesmo de realidade - esta teoria perde de vista outras coisas que estão acontecendo com os jogadores, como a qualidade das conexões que estabelecem nestes ambientes. Para o psicólogo Lucas Costa, nos games, os jogadores não estão a sós, mas justamente o contrário: eles estão buscando se conectar aos próprios videogames (e seus personagens, desafios, histórias e conhecimentos) e a muitos outros actantes a eles enredados (como amigos que jogam o mesmo jogo, desenvolvedores, revistas, fóruns etc.). Para Costa, a solidão é exatamente o contrário do que os jogadores buscam.

A solidão vai ser um sofrimento. Porque o ser humano tem o instinto gregário. O que o ser humano mais quer é se sentir parte de algo. A primazia do corpo humano nunca é buscar a solidão, é buscar o sentido gregário. Os exemplos que a gente tem de solidão extrema, como os caras que vão fazer meditação e ficam sozinhos durante anos, na verdade eles não estão ficando sozinhos, eles estão tentando ficar perto de Deus. Buscando se tornar mais próximo do nirvana pros hindus. [...] Por mais que não precise de contato com ser humano nenhum, o ideal ainda é se unir a algo maior. Esse ideal é o que permeia tudo. É por isso 
que eu também concordo que a internet multiplica esse poder por mil. Porque a capacidade gregária dela é real, mesmo que numa ficção, num mundo virtual. Então, você está criando um núcleo de convívio. (comunicação pessoal)

Em nossa pesquisa de campo, vimos que o ciberespaço, anunciado como o local da anonimidade e preservador de uma certa identidade "real" do "eu", ao contrário do que postulam estes teóricos, pode se tornar um local público à medida que o usuário mantém relacionamentos profundos nos jogos e cria uma reputação online. Isto para não repetir o argumento já citado de que esses mundos - online e offline - estão intrinsecamente conectados e de que as pessoas conhecidas em ambientes offline em muitos casos são as mesmas daquelas com quem as pessoas mantêm contato via online. Desse modo, a ideia postulada nesta teoria de que relacionamentos íntimos verdadeiros seriam impossíveis de existir na internet (ou de que os laços seriam mais fracos) não leva em conta a sobreposição destes "dois mundos" tomados como separados.

Ivelise Fortim menciona o trabalho The Multiplicities of Internet Addiction: The Misrecognition of Leisure and Learning (2009), da autora Nicola Johnson, para rebater argumentos de Kimberly Young (1998) e Sherry Turkle (1987; 1999), postulando que muitos critérios antigos de dependência não têm mais sentido nos dias de hoje.

Perde o sentido, porque a fronteira entre o real e o virtual fica muito borrada. Alguns critérios de dependência de internet não tem nada a ver. Por exemplo, o critério é de uma época em que os amigos virtuais eram só virtuais. Não é de uma época em que todo mundo que você tem no Facebook você conhece ou conheceu. São pessoas reais, do seu convívio, que estão no seu Facebook, não são pessoas estranhas, que era a ideia que a Sherry Turkle tinha. Um dos problemas dos critérios, e que a Johnson vai pegar bastante no pé da Kimberly Young, é que você está usando critérios de uma internet antiga pra dar diagnóstico de uma internet nova. Isso a Johnson vai pegar pesado, com razão. Ela vai falar assim: "Você fez um critério nos anos 90, a internet mudou e você continua aplicando e validando o mesmo questionário como se a internet não tivesse mudado". Que é a tal da história: "Você acessa os seus e-mails todos os dias?" Isso tinha sentido na década de 90 numa época que você não tinha email. Hoje não tem o menor sentido. Mas continua no critério. Tem muito critério de diagnóstico que ainda está lá. (comunicação pessoal)

A ideia de que estes grupos existiriam apenas virtualmente e de que se manteriam vivos apenas por meio da intermediação do computador, parte da velha aproximação dicotômica entre real e virtual, mesmo considerando que a agência do objeto sociotécnico "computador" aqui seja fundamental para a construção e transformação destas relações. Ou seja, este é mediador e mero não intermediário. É possível afirmar 
que estes grupos existam em um tempo e espaço diferentes das convenções ditas como normais, e pode ser exatamente por conta disso que apareçam como tão ameaçadores ${ }^{83}$.

O mais curioso é que esta teoria parece trabalhar com uma contradição inerente ao seu próprio argumento: ao mesmo tempo em que afirma que os videogames contribuem para formar vínculos íntimos e superar a solidão (entre humanos), diz, ao contrário, que estas relações são falsas e que as pessoas que fazem uso dos games são mais solitárias e depressivas. A vida vivida no virtual é novamente entendida como não-real, já que esta não estaria dentro do que estes cientistas chamam de ambiente imediato. Constrói-se, então, uma referência circular: os mais dependentes são, aqui, os que mais fogem da vida "real"; ao passo que as pessoas que passam mais tempo no virtual, logo no "nãoreal", são classificados como dependentes.

Isto não invalida seu argumento central, de que as pessoas efetivamente substituem atividades offline por atividades online. Pensando numa economia do tempo, é claro que se as pessoas se dedicam a certas atividades, não se dedicarão a outras no mesmo grau. Um ponto controverso é que quando se constroem ligações invalidando as primeiras (supostamente falsas) e em favor das últimas - consideradas as únicas reais perde-se tanto a simetria na descrição e na análise, quanto a própria conexão com os dados empíricos, os quais evidenciam uma relação contínua entre estes ambientes online e offline. Segundo Moraes (1998), “o que está em jogo é a afirmação do real como experimentação e fabricação, de forma que a dicotomia moderna longe de ser raivosamente negada, passa a ser, ela própria, um efeito desta atividade fabricadora que constitui o real".

Portanto, não se trata apenas de uma simples contradição. A ideia aqui novamente não é desqualificar uma teoria para qualificar outra, argumentando que uma (a teoria-atorrede) compreende efetivamente os jogadores, e que outras estão impedida de explicá-los ou estudá-los. Por mais que tenha aspectos contraditórios ou incoerentes, esta última teoria pode ser muito mais "efetiva" entre médicos e mesmo entre usuários. Deve haver, assim, operadores que permitam passar da imagem positiva para a imagem negativa dos jogos - um limiar, uma tênue região de passagens de uma a outra imagem.

\footnotetext{
${ }^{83}$ Também poderíamos pensar, em hipótese, que há aqui poderia haver uma certa "dependência das trocas": as múltiplas trocas realizadas se reforçariam a tal ponto que não permitiria mais o indivíduo sair dessa rede de prestações múltiplas.
} 
Em vista disso, podemos então investigar mais a fundo quais seriam as réguas que medem o que é solidão, compulsividade e adequação ao uso, rastrear a que estão ligadas, de onde surgiram, entre outros aspectos. Já encontramos uma multiplicidade de concepções tanto nos relatos científicos (já múltiplos em si mesmos), quanto na prática dos demais atores envolvidos - como os jogadores, os quais estão o tempo todo se servindo desses relatos e misturando-os com outras concepções e experiências próprias (lembrando sempre que a distinção entre ciência e não-ciência não é dada de uma vez por todas, mas é negociada constantemente na rede).

\subsection{4 - Fatores situacionais}

Segundo outra linha de pesquisadores (YOUNG, 2007; TAO, 2005; TAO et al. 2007; LIN; YAN, 2001; LIN, 2002 apud YOUNG; ABREU, 2011), os chamados fatores situacionais desempenham certo papel no desenvolvimento da dependência de videogame. Neste entendimento, os indivíduos que se sentem oprimidos enfrentam problemas pessoais ou passam por mudanças de vida (por exemplo, um divórcio recente, recolocação profissional ou morte de alguém querido) e poderiam se absorver num mundo de fantasia e fascínio (YOUNG, 2007). Para eles, o videogame pode se tornar uma fuga psicológica, que distrai o usuário de um problema ou de uma situação difícil da chamada vida real. Assim, como um modo de lidar com um novo ambiente, o usuário pode assim recorrer ao videogame para preencher o vazio dos momentos solitários. O usuário também poderia ter uma história de dependência de álcool ou drogas, e considerar o videogame uma alternativa fisicamente segura para sua tendência adictícia. Este usuário pode acreditar que ser dependente de videogame seria medicamente mais seguro do que ser dependente de drogas ou álcool, "sem perceber que continua se comportando compulsivamente para evitar as dificuldades subjacentes à dependência" (YOUNG; ABREU, 2011, p. 31, grifo meu).

Ainda nesta forma de entendimento, os usuários que sofrem de múltiplas adicções seriam os que correm maior risco de dependência de videogame. Assim, pessoas com personalidade adictiva tenderiam a usar abusivamente álcool, cigarros, drogas, comida ou sexo como uma maneira de lidar com problemas.

Observamos que o estresse situacional, seja ele divórcio, luto, perda recente do emprego ou luta pelo sucesso acadêmico, pode levar a pessoa a usar a internet com maior intensidade. Nem todos os indivíduos que usam a internet como uma 
fuga momentânea ou um meio de controlar o estresse situacional se tornam dependentes. Seu comportamento pode ser temporário e desaparecer com o tempo. Mas há casos em que o comportamento passa a ser persistente e constante, e as atividades virtuais se tornam exageradas. O comportamento, progressivamente, passa a girar em torno do uso de internet. A pessoa adapta seu comportamento e se concentra em aplicações que inicialmente eram necessárias para o trabalho, como um BlackBerry, ou recreativas, como uma sala de bate-papo ou jogo. Na medida em que o comportamento se intensifica e o uso de internet se torna crônico e arraigado, transforma-se numa obsessão compulsiva. Nesse estágio a pessoa se torna incapaz de manejar sua vida, e o comportamento compulsivo passa a prejudicar os relacionamentos e/ou a atividade profissional (idem, p. 32).

Segundo o psicólogo Stanton Peele (1985), a pessoa estaria vulnerável à dependência quando se sente insatisfeita com sua vida, não tem relacionamentos pressupostos como íntimos ou sólidos com os outros, não tem autoconfiança nem interesses envolventes ou não tem mais esperança (p. 42). De maneira semelhante, os indivíduos que estariam insatisfeitos ou sofrendo em alguma área específica ou em várias áreas da vida apresentam maior probabilidade de se tornarem dependentes de internet por não conhecerem outra maneira de lidar com isso (YOUNG, 1998). Por exemplo, em vez de fazer escolhas positivas, que trariam benefícios, os alcoolistas costumam beber, o que, segundo estes autores, amorteceria a dor, evitaria o problema e manteria o status quo.

Todavia, quando ficam sóbrios, estas pessoas perceberiam que suas dificuldades não mudaram. Nada seria alterado pela bebida, mas pareceria mais fácil beber do que lidar com os problemas de frente. De forma semelhante, o usuário dependente acessaria a internet para "amortecer a dor, evitar o problema real e manter as coisas como estão. Mas quando se desconectam eles perceberiam que nada mudou" (YOUNG, 2011, p. 32) Essa substituição de necessidades não atendidas em geral permitiria ao dependente escapar temporariamente do problema - mas não seria assim que os problemas seriam resolvidos. Neste sentido, seria importante que o terapeuta avaliasse a situação do paciente para determinar (pp. 32-33) se ele não estaria usando o videogame como um cobertor de segurança, para evitar uma situação de infelicidade.

\section{Fatores situacionais?}

Um dos aspectos que pudemos apreender deste apanhado intitulado "fatores situacionais" é que aqui se enfatizam os períodos de maiores mudanças pelas 
quais as pessoas $^{84}$ enfrentam. Nestas situações, a pessoa experimentaria um enfraquecimento de algumas de suas relações e recorreria ao jogo para se reconectar a experiências significativas. No entanto, assim como nos outros modelos, esta experiência também é encarada como falsa: desconsidera a sua capacidade de auxiliar na resolução de problemas e no aprendizado que esta possa trazer.

Room (1985) chama a atenção para um detalhe interessante sobre a questão dos "fatores socioculturais". Segundo ele, em geral a "natureza da adicção" é tratada como "dada", ou seja, "existindo fora da visão do sociocultural" (p. 133), ainda que tenha a prevalência afetada por estes fatores. Room foca sua atenção na forma como a doença em si mesma é uma construção histórica, social e cultural: tanto a ideia de adicção e de "perda de controle" seriam construções nos Estados Unidos e Inglaterra. Sua conclusão, por fim, é que "embebedar-se habitualmente não se torna alcoolismo sem um padrão específico de crenças culturais gerais e normas" (p. 137).

Contudo, colocar apenas que a dependência é "culturalmente construída" não revela a forma como tal construção se dá e acaba por fechar a explicação numa das duas esferas da modernidade - agora, na sociedade. Ademais, mesmo quando se considera a cultura ou a sociedade como "construções", não se leva em conta a dificuldade em desfazê-la, como se esta, por ter sido feita arbitrariamente por humanos, fosse facilmente desfeita. Ora, nem o pressuposto da separação prévia entre cultura e natureza, e nem o pressuposto da construção mole e arbitrária (política, ideológica etc.) de padrões ditos culturais, se mostram etnográfica e teoricamente verossímeis. Precisamente, os estudos levados a cabo nesta dissertação desautorizam a validade de ambos os pressupostos.

Assim, fica difícil entender o que estes cientistas entendem por fatores situacionais. Parece que tudo o que os modelos universais não conseguem explicar são enxotados para este "resto". A “cultura" e a "educação", por exemplo, aparecem constamentemente como fatores situacionais daquilo que as explicações universais não dão conta de abarcar. Estes "fatores" são colocados, portanto, como externalidades;

\footnotetext{
${ }^{84}$ Aqui, pessoa é entendida diferente de indivíduo. Segundo o clássico (e moderno, no sentido latouriano) antropólogo britânico Radcliffe-Brown, o "todo ser humano vivendo em sociedade tem dois aspectos: ele é indivíduo, mas também pessoa. Como indivíduo, ele é um organismo biológico, um conjunto muito vasto de moléculas organizadas em uma estrutura complexa em que se manifestam, enquanto ele persiste, ações e reações fisiológicas e psicológicas, processos e mudanças. [...] O ser humano como pessoa é um complexo de relações sociais" (RADCLIFFE-BROWN, 1973).
} 
mas, se nos aproximarmos em detalhe das situações práticas, observaremos que podem fazer toda a diferença.

Os economistas usam a expressão externalidades para designar o que não pode ser levado em conta, mas que desempenha um papel importante (negativo ou positivo) nos cálculos; dá-se lhe aqui um sentido mais geral e mais político para substituir a noção usual de natureza exterior ao mundo social; isso não é um dado, mas o resultado de um procedimento explícito de colocar no exterior o que a pessoa decidiu não levar em conta ou o que põe em perigo o coletivo" (LATOUR, 2004, p. 337).

Pode-se dizer, então, que esta necessidade de criar um modelo único, simples e até mesmo teleológico para prever os acontecimentos acaba por deixar de fora uma série de potenciais agências, fechando as portas, no plano oficial (sobre a decisiva diferença entre oficial e oficioso, no pensamento e na prática dos modernos, cf. LATOUR, 1994), para o imprevisível - sendo que este está sempre presente, principalmente em se tratando de jogos, nos quais a imprevisibilidade é elemento central (CALLOIS, 1957). Os resíduos, assim, como não se encaixam nem em um modelo, nem em outro, aparecem como híbridos. Para Moraes ${ }^{85}$ (1998), “a emergência de tais híbridos, ao contrário de ser uma exceção, um resíduo, é tudo o que há. Todo embate da modernidade consiste em tentar fazer com que os híbridos sejam reduzidos a uma das duas zonas ontológicas que lhes são constitutivas”.

No entanto, a primeira solução que comumente se dá à questão do que é social remete pensar em uma espécie de contexto - "contexto social", ou "dimensão social", ou "ordem social", ou "prática social", ou "estrutura social" - onde domínios da realidade, como a economia, a biologia, a geografia, o direito, a psicologia, ou a comunicação, para citar alguns, estão em parte situados. Neste caso, o social aparece de maneira negativa, como aquela instância que faz perder a pureza de algum desses domínios, cuja totalidade deve prever aquelas nuvens dos "aspectos sociais", ou dos "fatores sociais", que geralmente são tomados como fator de desordem - aquilo que não se pode ter o controle do rigor científico, justamente por não se saber ao certo as consequências daquelas dimensões "obscuras" e "mutantes" (SEGATA, 2008a, p. 8).

O ensaísta Phillipe Pignarre (1999) conta que a estes "resíduos" os cientistas naturais costumam denominar efeito placebo. Este é o efeito o qual não se consegue explicar pela pura agência da substância (ou do videogame) sobre o corpo do paciente (ou do jogador), que é visto como um receptáculo neutro e sem ação. A tentativa de isolar o

\footnotetext{
${ }^{85}$ Márcia Moraes é Professora Adjunta do Departamento de Psicologia da Universidade Federal Fluminense. Desenvolve investigação ligada à epistemologia da Psicologia, História e Filosofia da Psicologia, teoria ator-rede e os estudos de ciência, tecnologia e sociedade (CTS) nas suas interfaces com a psicologia.
} 
efeito da molécula, assim como o de um game específico, gera, por efeito sistemático, híbridos-resíduos, os quais fogem às classificações nosológicas previstas nos modelos.

Eis o verdadeiro dilema da medicina ocidental moderna. Criou-se uma maquinaria que impede a explicação de tudo que se agrupou sob a expressão mutilante de "efeito placebo": seja remetendo-o à relação médico-doente e fazendo desaparecer sua especificidade de ser produzido pelo objeto medicamento e de não ser dissociável dele, seja remetendo-o a um resto que acompanharia a molécula, único verdadeiro objeto conhecível substancialmente quando toma a forma de um arrombador biológico (PIGNARRE, 1999, p. 47).

Para o antropólogo Stelio Marras ${ }^{86}$, a separação naturalista entre uma substância (agente) sobre um corpo (paciente), por consequência leva a compreensão de que as influências subjetivistas da psique, do sujeito e da cultura apareçam como falhas racionais. Estas serão insistentemente combatidas por testes contra-placebo, que buscarão eliminar tais efeitos ou, senão, incorporados, a posteriori, em seus modelos.

É o caso do chamado "efeito placebo" ou "sugestão". Efeito subjetivista porque arbitrário, seja em função da psique do sujeito que idiossincraticamente o manifesta, seja em função da cultura, também sempre particular, que circunscreve os modos de sensibilidade e visão de mundo desses seus sujeitos. Efeito cujo fundamento, de princípio simbólico, mostra-se avesso ao previsível, resistente ao controle científico; pois controle, cujo fundamento, por sua vez, é biológico ou material - como o aplicado nas experiências de ação e reação com ratos de cobaia. Ora, e por ser razão pouco domesticável, compreendemos porque receba, nessa cognição naturalista, o qualificativo de "má razão" conforme o próprio jargão nativo. Indesejável efeito, enfim, que sempre e necessariamente se manifesta à experiência (à montante ou à jusante), tal um resíduo irredutível. Resíduo que, contudo, é já o bastante para erguer todo o aparato dos laboratórios farmacológicos, definir sua função e seu destino aliás, laboratórios não por acaso denominados "contra-placebo". E destino esse, sob todo esforço, voltado a eliminar essa tal "má razão" que insiste em se instalar na molécula medicamentosa no ato mesmo de sua criação, à montante no laboratório, tanto quanto no ato de sua ingestão, a jusante no mercado. Mas criação, finalmente, que só resiste se vencer (ou melhor, responder com índices pelo menos satisfatórios ou estáveis) o teste contra a má razão, contra a sugestão, contra-placebo (MARRAS, 2002, p. 2).

Decerto, algo mais ocorre nas relações entre o medicamento e o paciente, assim como entre o videogame e o jogador, do que supõem algumas destas teorias "realistas". Para captar estes efeitos, buscaremos observar a agência de um actante sobre os demais, e vice-versa, sem prender-se num reduto exclusivamente naturalista ou culturalista. Devemos observar, sobretudo, a emergência de fenômenos a partir das associações entre

\footnotetext{
${ }^{86}$ Stelio Marras é professor do Instituto de Estudos Brasileiros da Universidade de São Paulo, especialista na área de Antropologia da Ciência e da Modernidade.
} 
actantes heterogêneos. Vemos, finalmente, que a barreira entre a vida "real" e a vida "virtual" acaba sendo o ponto de contato que perpassa todas as teorias e modelos que aqui apresentamos, sendo, portanto, um grande ponto em embate desta controvérsia: Haveria uma só realidade, aquela ligada à matéria, à família, ao trabalho, desconectada do que se entende no senso comum por "tecnologia"; ou, pelo contrário, existiriam realidades múltiplas?

\title{
1.3.5 - Breves palavras sobre tratamento
}

Até aqui praticamente não falamos sobre tratamento, pois este tema abre para um campo muito extenso de discussão, o qual não teremos fôlego para enfrentar neste trabalho. Neste trecho apenas traremos breves palavras de terapeutas que convivem com o problema da dependência, para ajudar-nos a compor as próprias controvérsias.

A princípio, em tratamento de dependência não há nada óbvio nem pronto de antemão. Primeiro, vimos que cada tipo de tratamento parte de uma concepção específica de dependência. Ou seja, o conceito de dependência também cria as alternativas de tratamento. Para Ivelise Fortim, o tratamento depende da linha de trabalho. Segundo a psicóloga, este tem início assim que a pessoa admite que tem um problema e procura por ajuda. Em seu trabalho no Programa de Orientação e Atendimento a Dependentes (PROAD), na UNIFESP, ela observou que:

\begin{abstract}
A primeira coisa em tratamento de qualquer dependência, primeiro é você ter consciência de que você tem um problema e do tamanho do seu problema. Só que o problema é que a grande maioria dos dependentes nega que tem um problema: "São os outros é que estão errados". Muitos dependentes não vão pra tratamento porque passam a vida toda negando que têm um problema. Está cheio de alcoólatra assim. Já fez transplante de fígado de tanto que bebeu e diz que não tem um problema. Depois disso, aí faz várias coisas, mas uma delas, geralmente, pensando nessa ideia de dinâmica psicológica, é tentar entender porque você está fugindo. Qual é o problema de verdade está fazendo você fugir desse problema?
\end{abstract}

Adiante, o antropólogo Marcelo Mercante expõe um pouco de sua experiência no tratamento de drogas "químicas". Para ele, a experiência com tratamentos de drogadictos é decepcionante, tanto em relação ao próprio trabalho com os dependentes, quanto em relação à recuperação dos dependentes, e ainda para o pesquisador, em relação a elaborar intelectualmente soluções para o problema: 
Como eu já ouvi de várias pessoas nesses lugares todos que eu passei: é a clínica da decepção. Porque você trata, acompanha, o cara se levanta, vai, passa dois, três anos, o cara de boa, tranquilo, com a vida legal, equilibrada, de repente isso dá uma pira no sujeito, o cara chuta o pau da barraca, volta a usar tudo. Descaceta, passa uma semana fora de casa, quando vão achar o cara, o cara está sem roupa, porque ele já fumou até a roupa... Aí já desanda emprego, família, tudo vai pro saco de novo. E aí volta do zero. Aí começa o trabalho todo de novo pra poder trazer o sujeito novamente. O cara não se recupera nunca. (comunicação pessoal)

Apesar de não se tratar da dependência de videogames da mesma forma com que se trata de drogas psicoativas, podemos pensar em alguns paralelos. Por exemplo, seria a abstinência total um indicativo de cura? Antes disso: o quê, afinal, seria cura? Certos terapeutas, como Jacques Mabit (apud MERCANTE, 2013, comunicação pessoal), propõem: "um indivíduo totalmente livre" - o que não parece ser nem teoricamente nem praticamente realista. Alguns terapeutas cognitivos-comportamentais (GREENFIELD, 2001; ORZACK, 1999; YOUNG, 2007) sugerem a abstinência de usos problemáticos do computador e da internet (aqui se incluem os videogames e as pornografias virtuais), enquanto defendem um uso legítimo dos mesmos para fins de estudo e trabalho.

No caso de drogas, além de métodos considerados mais agressivos, como a internação compulsória em hospitais mentais e asilos psiquiátricos, tratamento em clínicas de reabilitação e da introdução forçosa do uso de remédios antidepressivos, há o modelo de redução de danos, as terapias de substituição e as psicoterapias - estas últimas, oriundas de diversas linhagens. No entanto, apesar de existirem iniciativas experimentais de algumas dessas alternativas para o problema dos videogames - há clínicas dedicadas a este problema no exterior, principalmente na China, Coréia do Sul e Japão, e em menor quantidade, nos EUA e em alguns países europeus -, nenhuma delas parece ser amplamente utilizada ${ }^{87}$. Como veremos na sequência da descrição, muitos jogadores relatam que param de usar o videogame (ou diminuíram o uso) por mudanças "naturais" de fases na vida, como o surgimento de outros interesses e compromissos, entre outras motivações, e não pela agência de um tratamento médico específico.

Para Mercante, a maioria destes tratamentos é centrado no indivíduo. No entanto, isso restringiria muito o entendimento e a eficácia do tratamento de dependência, pois, para

\footnotetext{
${ }^{87}$ Tampouco comentaremos acerca da eficácia (ou ineficácia) destes tipos de tratamento, pois não há dados de campo suficientes e nem consenso sobre o quê exatamente seria esta eficácia, e quais os parâmetros indicados para medi-la.
} 
ele, o problema real paira para muito além deste. Em sua perspectiva, o indivíduo seria somente um local de manifestação de uma produção social sistemática de dependências. Sua alternativa, sociológica, termina num paradoxo sem fácil solução. Mercante elabora uma metáfora a partir da imagem de uma fogueira para ilustrar seu ponto:

Porque é isso, você apagou o fogo aqui, o fogo pegou em outro lugar, você foi cuidar de outro lugar, esqueceu desse aqui. Mas esse aqui a brasa estava lá no fundo, porque a brasa está conectada com essa fogueira que está no centro aqui. E a fogueira não apaga. Então, e aí? É um paradoxo. É um dilema. Como é que você sai de dentro disso? Eu não tenho resposta. E ninguém tem. [...] Porque quando você sai dessa perspectiva individual e você cai numa perspectiva maior, o quê que acontece? Como é que eu trato isso? Se o problema não é no indivíduo, o problema é na sociedade, como que é eu trato a sociedade? Tem que mudar o estilo de todo o funcionamento da sociedade. Isso é impossível. Ou pelo menos é extremamente difícil. "Ah não, mas trabalhar com indivíduo é mais fácil". Então fica um ciclo. Porque se você foca o problema no todo, você não consegue tratar o todo. Então, você foca o problema no indivíduo, você até trata o indivíduo, mas aí você continua tendo o input, você continua tendo cada vez mais pessoas com problema de dependência. Você trata aquela pessoa específica ali que está com problema naquele momento, mas você não corta a causa. Então, você resolve essa, aparece mais dez aqui. Aí você resolve essas dez, aparece mais cem atrás. E por aí vai. É como um campo pegando fogo. Você vai trabalhando na beirada e não trata da fogueira que está lá no meio. E talvez isso seja uma das causas por que a eficácia do tratamento de dependência seja tão baixa. (comunicação pessoal)

A constatação da baixa eficácia destes tratamentos, o reconhecimento da influência de uma dimensão coletiva e a quebra da imagem de indivíduo como uma unidade autônoma e independente certamente abalam as formas mais convencionais de tratar o problema. No entanto, voltando-se a este mesmo depoimento a partir de uma perspectiva latouriana, vê-se que o argumento restaura uma guerra das ciências, na medida em que opera reiteradamente dentro de um registro moderno, que opõe o indivíduo à sociedade. Haveria aí uma espécie de "sociologização" ${ }^{, 88}$, no sentido de que retira do indivíduo e desloca para a sociedade a origem da dependência. Não seria possivelmente por isso que apareça como insolucionável? Nossa proposta é recusar esta dicotomia, reconhecendo, como Gabriel Tarde, o infinitesimal no todo, e o todo na partícula infinitesimal ${ }^{89}$.

\footnotetext{
${ }^{88}$ Latour coloca que "o único meio de escapar às armadilhas simétricas da naturalização e da sociologização consiste em conceder à linguagem sua autonomia” (1994, p. 64). Este autor cunha o conceito de coletivo, a fim de superar as barreiras entre indivíduo e sociedade.

${ }^{89}$ Para Tarde, as mônadas não são, como para Leibniz, as substâncias simples que entram nos compostos: "esses elementos últimos aos quais toda ciência chega - o indivíduo social, a célula viva, o átomo
} 
Isso quer dizer que nem a sociedade constitui uma ordem mais alta e complexa que a dos indivíduos, nem os indivíduos são o fundamento das sociedades: indivíduos e sociedades, como células e átomos, são todos compostos e, como tais, imediatamente relacionais (VARGAS, 2004, p. 175).

Segundo Vargas (2004), isso supõe "que toda coisa seja uma sociedade" (TARDE, 1910, p. 49) ou que social seja um termo aplicável a qualquer modalidade de associação (LATOUR, 2001). Para Tarde, a sociedade seria então a "possessão recíproca, sob formas extremamente variadas, de todos por cada um" (p. 85). A ideia, por fim, é multiplicar as agências e perspectivas, rompendo as linhas que convencionalmente circunscrevem os domínios ontológicos modernos. A fogueira, mencionada no comentário anterior como uma imagem metafórica do problema da dependência, assim pode ser tomada como uma rede complexa de causalidades sociotécnicas.

\section{4 - Cosmopolíticas da dependência}

Ao termo "cosmopolítica" corresponde aquilo que não é nem uma atividade, nem uma negociação, nem uma prática, mas o modo pelo qual se atualiza a copresença problemática de práticas: a experiência, sempre ao presente, daquele em que atravessa o sonho do outro. Entrecaptura não simétrica que não garante nada, não autoriza a nada e não pode ser estabilizada por nenhuma restrição, mas por onde aquele que atravessa e aquele que é atravessado se submetem um ao outro ao exame que constitui a efração desse terceiro termo "assustador", não apropriável por nenhuma medida: "Nós não estamos sozinhos no mundo" (STENGERS, 2003, p. 355 apud FLEURY, 2013, p. 17-18).

Nesta seção, nos deteremos em examinar algumas das discussões que evidenciam dimensões de discordância em aspectos oficiais e não-oficiais. Além da teoria-ator-rede, que se serve de várias tentativas de explicação (as controvérsias) para entender como algo não se dissolve em algum consenso, nossa outra inspiração será a ideia de política do cosmos, de Isabelle Stengers (2003). Segundo Donna Haraway (2011), a proposta cosmopolítica de Stengers é de que as decisões devam acontecer de alguma forma na presença daqueles que sofrerão suas consequências ${ }^{90}$, já que ninguém sabe como fazer isso antes de se juntar em composição (STENGERS, 2007). Auxiliando-nos na compreensão das ideias dessa autora, Márcia Moraes comenta:

químico - somente são últimos ao olhar de sua ciência particular", afirma Tarde (p. 23), "eles mesmos são compostos", compostos até o infinitesimal (VARGAS, 2004, p. 174).

90 Para Haraway, tornar concreto esse "de alguma forma" é o trabalho de praticar combinações engenhosas. Chegar "na presença de” requer trabalho, invenção especulativa e riscos ontológicos. 
Stengers não fala da ciência em nome de qualquer princípio a priori, o que está em jogo é analisar como uma prática produz uma certa racionalidade. Stengers pretende estabelecer uma leitura política das práticas científicas, e isso significa dizer que a distinção entre ciência e não ciência não é tomada como ponto de partida. A autora pretende criar um espaço problemático onde a construção da diferença entre ciência e não ciência pode ser seguida, acompanhada no âmbito mesmo da prática. Não há de saída uma concepção prévia acerca do que é uma ciência; o ponto de partida é sempre simétrico, isto é, coloca num mesmo plano ciência e não-ciência, sendo o problema então mostrar como se constrói tal distinção (MORAES, 1998, p. 49-56).

Para retomar o argumento proposto neste capítulo, consideraremos uma resolução da American Academy of Pediatrics ${ }^{91}$, que regulamenta que duas horas de atividades frente à tela, incluindo televisão, computador, videogame, celular, tablets etc., como o máximo tolerável diariamente, depois disso já seria considerado uso excessivo. O publicitário Chuck, 26 anos, se revolta contra tal determinação:

Como assim duas horas por dia? Então, se você trabalhar na Microsoft mais de duas horas por dia, eu sou viciado em trabalho? Não tem isso. Você tem que ver o que o cara faz. Tem que ver o jeito que o cara joga, ver como ele joga, ver tudo, ver se atrapalha. Tem gente que realmente tem problema, não sai da frente do computador, fica lá o dia inteiro comendo aqueles sanduíches rápidos só pra não sair da frente do computador. Aí, ok. Mas um moleque normal, que joga três horas por dia com a galera, eu não vejo problema nisso.

Ivelise Fortim, que continua sendo nossa principal informante até aqui, afirma que a rotulação de determinados usos de videogames enquanto patologias lembra a discussão entre os próprios cientistas em torno do Transtorno de Déficit de Atenção e Hiperatividade (TDAH).

Tem um excesso de diagnóstico de TDAH que não existe. A escola é que não motiva. Não é que a criança é uma débil que não tem atenção. Você está em outro espírito do tempo, as crianças são super estimuladas, mexem com computador, fazem $n$ coisas, e aí você obriga a fazer um negócio que não tem mais sentido. Não quer dizer que as crianças não tenham que se concentrar durante algum tempo. Tem um excesso de diagnóstico de TDAH. As crianças não têm TDAH. É a forma como que você educa as crianças. Não é um problema da Psiquiatria. (comunicação pessoal)

O ponto ressaltado por Fortim é que estas formas de classificação de patologias, compiladas, por exemplo, na Classificação Internacional de Doenças (CID) da OMS, e no DSM, da APA, transformam-se com o tempo:

\footnotetext{
91 Houve uma forte discussão em torno da inclusão das dependências digitais (internet, celular, videogame) no novo documento da associação, o DSM-5 (Manual Diagnóstico e Estatístico de Transtornos Mentais). A proposta foi, inclusive, rejeitada na primeira tentativa e inclusa como anexo, solicitando mais pesquisas e experiências clínicas sobre o tema.
} 
A homossexualidade estava na CID na década de 60. A homossexualidade saiu da CID na década de 60. Porque pra Ciência da época ainda era considerado perversão sexual. Só se considerou orientação sexual depois. Então, os diagnósticos também mudam, de acordo com norma. Isso tem que ter um contexto também. No DSM-V eles não deixaram colocar dependência de internet. (comunicação pessoal)

Diante da emergência de novos casos ditos problemáticos, da propagação de novas tecnologias digitais, da aparição de iniciativas de tratamento e da predominância das intervenções domésticas, qual seria, afinal, o papel da ciência neste meio? Para Fortim, neste exato momento os cientistas ainda estão buscando estudar mais a questão. $\mathrm{Na}$ sequência, ela traz a sua visão (que classifica como otimista) acerca deste assunto:

Hoje, por enquanto, a Ciência tem um papel exploratório de tentar entender melhor o que está acontecendo. Por vários motivos. Primeiro, fazer uma diferença do que é espírito do tempo e do que é dependência. Porque às vezes tem uma mistura aí. Trinta, quarenta anos atrás, não tinha internet. Eu lembro que em um dos primeiros critérios, duas horas de internet você era dependente. E tem uma dificuldade grande, que é não patologizar quem está no espírito do tempo. Isso é complicado. Porque a ciência já fez isso $n$ vezes. (comunicação pessoal)

Vemos que a psicóloga apresenta novamente a categoria "espírito do tempo", que é colocada em oposição a uma determinada classificação da dependência como patologia. Ela propõe que sejam empreendidas mais pesquisas para entender a "linha fina" de onde que "isso está dentro do espírito do tempo em que as diversões são eletrônicas" e onde que "você se divertir de forma eletrônica é você ser dependente porque você não quer se divertir de outro jeito". Para Fortim, saber distinguir estas duas explicações implica na escolha dos critérios que serão aplicados nas pesquisas e nos seus resultados futuros.

O que seria, afinal, esse chamado "espírito do tempo"? Aparentemente, espírito do tempo é uma noção ligada à ideia de "contexto ${ }^{92, " ~ B r u n o ~ L a t o u r ~(1991) ~ r e c u s a ~ e s s a ~}$ ideia como um painel explicativo que esteja "fora" do plano das relações. Sua proposta é arregimentar as relações todas no mesmo plano ontológico: as redes. O modo de distinção de Fortim entre os diagnósticos "verdadeiros" e o "espírito do tempo" parece

\footnotetext{
92 "Simétrico à ilusão de uma trajetória que cruza um contexto é que um contexto é atravessado por inovações. Precisamos descartar esse fantasma sociológico se quisermos compreender como as tecelagens de humanos e não-humanos são feitas. [...] O que observamos é um grupo de geometria variável entrar em relação com um objeto de geometria variável. Ambos se transformam. Observamos um processo de tradução - não de recepção, rejeição, resistência ou aceitação. [...] Ao contrário das afirmações daqueles que querem manter constante ou o estado da tecnologia, ou da sociedade, é possível considerar o caminho de uma inovação em que todos os atores coevoluem. A unidade de uma inovação não é dada por algo que permanece constante ao longo do tempo, mas pela tradução em movimento do que chamamos, com Serres (1987), um quase-objeto" (LATOUR, 1991, p. 116-117, tradução nossa).
} 
uma tentativa de purificação, em que se toma o diagnóstico como natural e o "espírito do tempo" como o social, a qual novamente fracassa enquanto sua aspiração moderna, já que não terá sua linha clarificada (ou purificada), uma vez que fabrica sistematicamente elementos híbridos. Ela mesmo dá evidências desse conhecimento, quando lembra que os diagnóstico psiquiátricos também entram no "espírito do tempo".

Ivelise Fortim ainda questiona o quanto certas pesquisas quantitativas baseadas em escalas e questionários realmente contribuem para o entendimento científico do fenômeno da dependência. Para ela, nestas pesquisas há uma separação do diagnóstico do chamado "contexto". Aparentemente, a maior preocupação dos pesquisadores é "rodar" os dados da pesquisa a fim de encontrar correlações entre variáveis, seguindo a mesma cartilha funcionalista do século passado (método ainda majoritário nos estudos atuais neste campo). Segundo Fortim, muitos questionários são elaborados para aplicação em massa e perdem o cuidado de uma análise qualificada.

Se for pegar uma pesquisa dessa, "Tá, e aí, qual é o crivo"? Aí você fala: “20\% tem uso patológico". Não sei se eles têm. Tem o quê o questionário deu. Tem o crivo que você deu. [...] Tem uma tendência de algumas áreas da Psiquiatria de ver só o diagnóstico e não ver o contexto, que é um dos problemas das pesquisas. Se você for pegar um monte de pesquisa de dependência de internet e de videogame, tem uma quantidade enorme de pesquisa assim: O cara vai lá numa escola, passa um monte de questionário pros fulanos, joga tudo no computador e correlaciona as estatísticas. Só que aí você vê lá, todos os relatos são de auto-referência. Você não foi ver se o cara está deprimido ou não, o cara que acha que está ou não está. Segundo, ninguém te pergunta o que você acha, você vai lá e só preenche com um X. (comunicação pessoal)

Fortim lembra o caso da China, que, segundo ela, é o país com o maior número de pesquisas sobre este tema (maior até que os Estados Unidos), que usa os critérios mais severos e que também consequentemente acaba classificando como dependentes um maior número de pessoas. Haveria interesses políticos nestas classificações? Concordando com essa suspeita, ela advoga contra tais influências misturadoras, afirmando que a Ciência deveria ser livre de interesses e usos políticos - uma imagem, assim, neutra e naturalista do fazer científico.

Pensando principalmente na história da China, você dá margem pra uso político do diagnóstico. Eu entendo que na China eles têm um uso político do diagnóstico de dependência de internet, porque na China a internet é controlada. Então, eles têm um patrulhamento muito grande de hacker. Se você começa a ficar dependente de internet, na China você pode ser internado, você fica em clínica de desintoxicação e toma choque... Não é pra usar [o videogame]. A China é quem tem os índices mais altos de dependência de internet no mundo. 
Agora, você vai olhar o crivo, o crivo deles é severo. Não é que os chineses são mais viciados, é que o crivo é severo. E você tem um controle. Então, é papel da Ciência tomar cuidado pra que não tenha uso político de diagnóstico. Porque no caso da internet e dos games, é um jeito de você cercear a informação. (comunicação pessoal)

Podemos argumentar que Fortim defende uma separação entre ciência e política, como se uma não estivesse contaminada pela outra. Ou seja, como se a ciência fosse somente "natural", e a política, apenas "social". Latour, demonstrou em Jamais Fomos Modernos, junto com a obra de Shapin e Schaffer (1985), Leviathan and the Air Pump: Hobbes, Boyle and the Experimental Life, como estas esferas se coproduzem e são compostas por elementos híbridos. Neste sentido, Moraes comenta:

Há uma dimensão política inerente, constitutiva à atividade científica. Política no sentido de referir a ciência à rede de sua prática, de forma que é dessa prática, com tudo que ela comporta de inventivo e contingente, que se constrói tanto o objeto a ser conhecido pela ciência quanto o seu modo de inteligibilidade (MORAES, 1998).

Para Mercante, estes mesmos questionários servem "politicamente" para muitas coisas. No entanto, na perspectiva de tratamento e da cura, estes não seriam elementos decisivos: o usuário é que deve buscar ajuda.

Nessa ciência que é montada em cima de estatística e número, questionário serve pra bastante coisa. Mas no empírico lá, no dia-a-dia, o que determina mesmo é isso: é o sujeito virar e dizer assim: "eu estou com um problema na minha vida e preciso resolver". Ele efetivamente ir bater numa casa de recuperação, pedir ajuda. E o parâmetro principal é o cara estar (ou na iminência de estar) com a vida destruída. E ele se tocar que a coisa está muito forte e que está tudo indo por água abaixo. Emprego, família, relacionamento, amigos... Está tudo indo pro espaço. (comunicação pessoal)

Para Geocze, a interpretação puramente estatística de assuntos relacionados à Psicologia tem sérias limitações analíticas. Ele rebate com um argumento notadamente humanista:

Conheça todas as técnicas, domine todas as teorias, mas quando estiver na frente de uma alma humana seja apenas outra alma humana. Então, eu acho que a Estatística é algo que não deveria ser usado na Psicologia. Porque a Estatística não consegue mensurar coisas [...] Isso é pra rotular, pra aprisionar e pra colocar o ser humano num lugar que não é do ser humano. É da Matemática. Agora você quer resumir tudo à Matemática? Tem filósofos que querem. (comunicação pessoal)

Ivelise Fortim, enfim, indica o sofrimento (não só individual, mas coletivo) como uma possibilidade de critério geral para indicar a dependência. Esta ideia aparece conectada a uma perda de controle da pessoa sobre o "objeto" de vício: 
Tem sofrimento em qualquer dependência nesse crivo. Porque o problema pra pessoa é a sensação de que você perdeu o controle de si mesmo. Eles falam muito assim: "Eu tô passando e parece que o computador me puxa". "Eu tô andando na rua e o computador me chama". O pessoal de drogas no PROAD falava assim: "Entrei no carro pra ir pra escola e aí quando eu me dei conta eu já estava na boca. No fumo". O sofrimento é uma sensação de que você perdeu o autocontrole, de que você sabe que não é pra fazer aquilo mas você vai lá e faz. E aí você resiste, resiste, resiste e você não consegue não fazer aquilo, mesmo sabendo que é prejudicial. Na minha tese, tinha uma [moça] que arrumou um namorado lá no videogame, mas ela tinha um namorado fora. Ela falava: "Eu sei que não é pra acordar às $9 \mathrm{~h}$ da manhã mas quando eu vi eu já levantei, eu fiz uma coisa quase que involuntariamente, eu perdi o controle sobre mim mesma". Você sabe que não é pra fazer, vai lá e continua fazendo. E aí depois se sente culpado. "Pô, eu sabia que eu não devia ter feito aquilo.", "Eu sabia que eu não devia ter jogado." "Eu sabia que eu não devia ter entrado na internet.", "Eu sabia que eu não devia ter feito aquilo, mas eu fui lá e fiz", "Eu não consigo controlar esse comportamento". (comunicação pessoal)

Mas se, de acordo com Latour (2002, p. 88), tudo o que o homem faz o ultrapassa ${ }^{93}$ e está além de seu controle em qualquer tipo de relação, por que esta especificamente seria classificada como doentia? Não estaria neste caso posta uma nova tentativa do homem moderno de controlar a natureza e os demais seres com quem convive, mas que, ao mesmo tempo, desconsidera? Os terapeutas dos jogos, neste sentido, tentariam reestabelecer a imagem do homem senhor de si, do usuário que, assim que curado mediante tratamento médico-científico, passaria então a controlar seu uso de forma plena.

A hipótese é muito mais simples, e os modernos, na verdade, nunca a abandonaram. Aquele que age não tem o domínio daquilo que faz; outros, que o superam, passam à ação. Nada que autorize, contudo, a afogar o sujeito no mar do desespero. Não existe em lugar algum um ácido capaz de dissolver o sujeito. Este último ganha autonomia, ao conceder a autonomia que não possui aos seres que advêm graças a ele. Ele aprende a mediação. Ele provém dos fe(i)tiches. Ele morreria sem eles. Se a expressão parece difícil, que ela seja comparada à

\footnotetext{
${ }^{93}$ Latour explica a ideia de superação a partir de seu exemplo das marionetes: "Sim, os modernos têm que prestar um culto explícito aos fe(i)tiches, às mediações, aos passes, já que nunca tiveram o domínio do que fazem, e é bom que seja assim. A imagem da marionete vem bem a propósito, contanto que se indague um pouco o marionetista. Ele lhe dirá, como todo mundo, como todo criador e manipulador, que suas marionetes lhe ditam seu comportamento, que elas o fazem agir, que elas se exprimem através dele, que ele não saberia manipulá-las, nem automatizá-las. Entretanto, ele as mantém, as domina e as controla. Ele irá confessar, naturalmente, que é ligeiramente superado por aquilo que controla. Suponhamos, agora, que um marionetista de segunda categoria venha manipular nosso artista. Não faltarão candidatos: o texto, a língua, o espírito do tempo, o habitus, a sociedade, os paradigmas, as epistemes, os estilos, qualquer agente fará o trabalho para controlar nosso marionetista como este controla suas marionetes. Mas, justamente esses agentes, tão poderosos quanto vocês os fizerem, serão superados pelo marionetista, como este é superado por suas marionetes. Vocês jamais farão melhor do que isso; vocês jamais o terão tão sob controle. Ao invés de uma cadeia causal que transmitiria uma força, que atualizaria um potencial, que realizaria uma possibilidade, vocês obterão apenas sucessões de ligeiras superações. Sim, acontecimentos, outro nome do fe(i)tiche e do culto que lhe foi prestado" (idem, p. 102-103).
} 
aparelhagem inverossímil, como todos seus maquinismos, engrenagens, contradições, feedbacks, reparos, epiciclos, dialéticas e contorções destes marionetes-marionetistas, enredados em seus fios, às vezes visíveis e invisíveis, mergulhando na crença, a má consciência, a má fé, a virtualidade e o illusio... Ao querer fazer mais simples que os fe(i)tiches, os modernos fizeram mais complicado. Ao querer fazer mais luminoso, fizeram mais obscuro. Quem quer fazer o anjo, faz o homem (idem, p. 102).

\section{5 - A gramática das dependências}

Buscou-se neste capítulo propor uma discussão sobre a dependência de videogames a partir de algumas teorias e pesquisas científicas, oriundas em sua maior parte de vertentes diversas da Psiquiatria e da Psicologia, que buscam encontrar critérios precisos para defini-la. Juntamente com tais estudos, interviu-se a partir de uma orientação teórico-metodológica específica, proveniente da Antropologia da Ciência e da Tecnologia e dos Science Studies. É dessa relação pós-disciplinar, portanto, que nasce esta reflexão. A investigação até aqui ainda é incipiente, pois carece dos dados etnográficos que diversos outros actantes trarão para esta controvérsia ao longo da dissertação, mas, ainda sim, o material construído em campo até aqui nos permite tecer algumas considerações parciais.

Vê-se que as imagens da dependência dependem de uma série de noções e conceitos como "real", "virtual", “indivíduo", "sociedade", "trabalho, "lazer", "substância", "felicidade", "autorrealização", "comportamento cerebral", "funcionamento social", "fuga psicológica", "consequências positivas" e "negativas - que seriam, a princípio, aparentemente estáveis quando apresentados na forma de questionários ou manuais de diagnóstico e de tratamento. No entanto, destrinchando as controvérsias suscitadas em torno destes mesmos termos, vemos que estes não estão blindados de questionamentos ou fechados para entendimentos alternativos. De certa forma, estamos aqui nos contrapondo a uma noção transcendental de vício e dependência. Ao chamar a atenção para a especificidade, buscamos trazer o problema para a imanência dos processos para forçar a reabertura, então, das caixas-pretas do vício e da dependência.

Na esteira desta crítica, Heather Holliday (2000) postula que, comumente, os conceitos mencionados no parágrafo anterior são usados na retórica do vício digital para produzir a figura (ou personagem) do jogador hardcore como um dependente. Segundo Holliday, muitas vezes a dependência é vista, simultaneamente, como distúrbio psicológico e 
como produto daquilo que é tido como viciante (neste caso, mídia digital), sendo entendida como decorrência não das relações, mas da "substância".

O conceito de retórica não está sendo aqui tratado como um falso discurso, mas como uma prática discursiva que carrega diversas associações e que ativa uma série de códigos, conformando um conjunto de significados que se relacionam entre si e que pode abarcar novos elementos. Segundo Latour "a força da retórica está em fazer o discordante sentir-se sozinho" (2000, p. 76). Para este autor, "sem o recrutamento de numerosos aliados, sem a tática sutil que permite ajustar simetricamente os recursos humanos e não humanos, a retórica da ciência torna-se impotente" (idem, p. 236). Isto implica que, para Latour, a retórica tampouco é oposta à ciência (pp. 55-57).

Jacques Derrida se refere a uma noção de "dicção" da "adicção" como um conjunto de características significantes que são aplicadas aos usuários de drogas dentro de um particular conjunto ideológico e político de valências (DERRIDA, 1995). Para Derrida, é importante notar que a aplicação da metáfora da dependência restringe e fabrica certos comportamentos, e estabelece o "mundo digital" como uma substância não-natural, irreal e perigosa, e representa o usuário por meio de imagens dos viciados em drogas.

Segundo Cover (2006), dentro desta dicção da adicção, em geral cria-se uma dependência do "eu", ou do corpo, ou da personalidade, ou de alguma faceta da individualidade (ou seja, o indivíduo é entendido como uma unidade com contornos precisos), a alguma coisa. Enquanto as drogas são vistas como um complemento físico (um comprimido, um pó, um líquido) que é ingerido, (que penetra no corpo através da pele ou de alguma outra maneira), é o que a droga representa (o seu "efeito") que é considerado virtual, irreal, sem realidade ou fora da razão. O vício é geralmente concebido em termos de uma dependência do não-real, ou de algo que é visto como menos real em relação ao que é classificado como natural, justo, apropriado e benéfico. A fim de não realimentar esta guerra de valores, interesses e crenças, preferimos trabalhar com a realidade do real, que pressupõe como real tudo o que age, em detrimento de uma realidade da ilusão.

A partir da descrição dos dados de campo, postulamos que o problema original (causa, etiologia) da dependência não esteja na substância, mas sim nas relações. Ou seja, há uma preeminência das relações. Sendo assim, as etiologias das relações devem ser 
outras que as normalmente aplicadas. Vemos que as ligações entre diferentes dependências (tais como as comportamentais, tecnológicas, de internet, de jogo patológico) não são autoevidentes, mas requerem um árduo trabalho de mediação. Analisando por outros critérios, como os dos usuários, a dependência de videogames pode, por fim, não ser compatível com uma série de outras dependências.

Neste ponto, podemos pensar no conceito de "entre-capturas" do modelo de feitiçaria de Isabelle Stengers (2005). Nesta perspectiva, as relações entre usuários e seus "objetos" de vício (sem replicar aqui a divisão moderna entre sujeito/homem versus objeto/coisa) emergem como capturas muito distintas, para receberem o mesmo título de dependência. Apesar da etiologia da dependência soar universal, este revela-se, ao invés, como um saber local e imanente. O caráter universalista, maleável e transcultural das concepções mais convencionais de dependência começa assim a ser manchado.

Claro, muitos vão reconhecer que as disciplinas contemporâneas, tais como a Psicologia, a Psicanálise ou mesmo "teorias" mais ou menos afetadas pela Neurofisiologia, que pretendem definir "mente", são claramente incapazes de explicar a eficácia do que chamamos de "feitiçaria". Mas um bom senso crítico, no entanto, irá insistir em marcar uma diferença do tipo: "tudo a mesma coisa"! Não se pode realmente colocar os inconscientes, neurônios e feitiços no mesmo plano! (STENGERS, 2005, p. 39, tradução nossa).

Podemos pensar, enfim, na existência de uma gramática estruturante das dependências que se multiplica e se retroalimenta. Propomos, pois, que em todos os casos apresentados esteja operando uma gramática estruturante das dependências. A partir de sua própria régua e de seus mecanismos de referência circular - a classificação do dependente cria o próprio comportamento dependente e vice-versa -, esta gramática pode abarcar em sua estrutura lógica, em tese, tudo o que é considerado negativo por aqueles que se colocam nesta posição acusatória.

Vimos que o discurso médico sobre a adicção em videogames opera esta mesma gramática para as demais dependências. Na maioria dos casos, basta trocar o substantivo "droga" por "videogame" para que se tenha um modelo prontamente adaptado a um novo “objeto". Esta gramática abrange tanto o nível dos discursos como o das práticas, afinal, ambos são praticados. A gramática das dependências aparece, então, como uma estrutura de elementos estáveis, mas totalmente adaptável a novos "casos" - que, por isso mesmo, acaba por criar e multiplicar dependências. 


\title{
Capítulo 2 - O sério e o lúdico: repensando as categorias lazer e trabalho a partir dos videogames
}

\begin{abstract}
Pai: ... A questão é que o objetivo dessas conversas é descobrir as "regras". É como a vida - um jogo cujo propósito é descobrir as regras, que estão sempre mudando e são impossíveis de descobrir.
\end{abstract}

Filha: Mas eu não chamo isso de jogo, papai.

(BATESON, 1972 apud SALEN; ZIMMERMAN, 2012, p. 168)

Resumo: A proposta deste capítulo é investigar as associações entre jogo, lazer e trabalho, discutindo a articulação entre estes três conceitos para, a partir das problemáticas levantadas na etnografia de jogadores e videogames, rever as possibilidades de experimentação dos conceitos "lazer" e "trabalho" nesta e em futuras pesquisas. No fim, propomos um modelo para investigar o engajamento humano em suas atividades cotidianas baseado em graus de comprometimento, a despeito de serem classificadas como lazer ou trabalho, prazerosas ou maçantes, de "tempo livre" ou "tempo ocupado".

Palavras-chave: jogo; lazer; trabalho; videogames; dependência.

\section{1 - Esquentando a controvérsia}

O psicólogo Cristiano Nabuco de $\mathrm{Abreu}^{94}$, chefe do Programa de Dependência de Internet do Ambulatório Integrado dos Transtornos do Impulso (AMITI), em entrevista publicada na internet pela TV "O que eu tenho?", com o tema intitulado "Uso Abusivo de Videogames", expõe o seguinte depoimento:

Provavelmente você já deve ter observado na sua vida, ou na vida de um colega, de um irmão, de um primo... aquele menino ou aquela menina, ou muitas vezes até aquele adulto, que começa a utilizar o videogame em suas horas de lazer. Bom, até aí nada demais. Acontece que, à medida em que essas pessoas passam a usar o videogame, muitas vezes elas acabariam perdendo a noção de um uso adequado. O quê que é isso? Muitas pessoas começariam a usar tanto videogame, mas tanto, tanto, tanto, que elas perderiam, provavelmente, a capacidade de controlar esse uso e elas se tornariam dependentes de videogame. Bom, você deve pensar: "Dependência de

\footnotetext{
${ }^{94}$ Cristiano Nabuco de Abreu é psicólogo clínico e especialista em Terapia Cognitiva e dependência de internet. Foi coordenador da Equipe de Psicologia do PRO-AMBULIM/IPq/HC/FMUSP e presidente da Federação Brasileira de Terapias Cognitivas. Atualmente coordena PRO-AMITI do Instituto de Psiquiatria do HC/FMUSP. A unidade oferece sessões de terapia e aconselhamento a adultos, adolescentes e familiares desde 2005 .
} 
videogame... Será que isso existe?" Existe e está sendo muito pesquisado, e já é um problema muito sério. Então, o que ocorre na maior parte das vezes: À medida em que essas pessoas começam a usar o videogame de uma maneira excessiva, seja o adolescente ou o adulto, eles começariam a deixar de fazer coisas do mundo real, deixar de se dedicar ao trabalho, deixar de se dedicar à escola, para ficar jogando. Ou seja, o tempo no mundo virtual começaria a competir com as atividades do mundo real. Chegaria um determinado momento em que esse rapaz ou esse adulto ficaria praticamente aprisionado. E aí teríamos então instalado um verdadeiro transtorno psicológico. A grande ideia qual é? Fique atento. Se você tem alguma pessoa que está próxima à você, que começa a preferir jogar do que encontrar com um amigo, um outro colega seu que você percebe que, nos horários de almoço do trabalho, ele está jogando ao invés de ir almoçar com a turma, fique atento, porque provavelmente alguma coisa não vai bem. Essas pessoas de uma maneira geral perderiam a capacidade de identificar que isso teria se tornado um problema. Então, vale a dica aí: Fique atento, porque você enquanto conhecido, colega, amigo ou pai, pode estar prestando uma grande ajuda se levar essa pessoa, sugerir alguma forma de orientação profissional $^{95}$.

Em resposta a este vídeo postado no YouTube em 2009 (com 6.925 visualizações até a última revisão desta pesquisa), diversas pessoas manifestaram-se postando declarações no espaço reservado aos comentários - a maioria delas contrária ao psicólogo. Numa rápida compilação, foram registrados diversos depoimentos contra a fala do psicólogo (muitos deles com termos de baixo calão, os quais não reproduziremos aqui) e somente seis de acordo. Exporemos alguns desses comentários, começando pelo usuário Wodston Eduardo:

Olha, eu sou muito viciado em games, eu jogo em casa, eu jogo no meu portátil no almoço da empresa, mas mesmo assim eu não estou aprisionado no vídeo game como o vídeo diz. Tenho uma vida normal, vou ao cinema, namoro, estudo, trabalho e faço atividades físicas, poucos os dias em que eu não jogo nem sequer 2 horas ou mais, a não ser em semanas de prova ou seminários da faculdade. Ser um "gamer" pode ser considerado um novo estilo de vida e, diferente do que muitos pensam, não mais solitário ou isolador, pois hoje em dia, com a internet conectando jogadores do mundo inteiro. A ideia de jogo solitário ficou no passado. O videogame é um entretenimento comum como filmes, seriados, novela, futebol etc., a única atenção que se deve tomar em relação aos games é respeitar a classificação indicativa (censura por idades) de cada jogo, isso sim é muito importante.

O usuário Masahito Junior Iwasaki, por sua vez, questiona o argumento de Nabuco de

Abreu, que coloca o jogo como prejudicial nas horas de descanso do trabalho.

Eu jogava no horário de descanso do trabalho ao invés de ficar junto com meus coleguinhas falsos de trabalho, que só queriam puxar o tapete dos outros, muitas vezes preferia ficar jogando do que sair de casa com meus amigos para

\footnotetext{
${ }^{95} \mathrm{https}: / / \mathrm{www}$. youtube.com/watch?v=Ful0zdCSARA\&feature=related
} 
ir em lugares que pouco me agradavam. Nem por isso fui viciado. Tanto que eu troquei os jogos pela minha namorada.

Shelby GT pondera as palavras do psicólogo, reconhecendo que os jogos atrapalham sim o seu trabalho. Seu pedido, no fim, é por ajuda:

Eu estou viciado em games desde o ano passado, vocês criticam o cara, mas o que ele disse é real, estou viciado em jogos multiplayer online como $C S$ e Battlefield 3. Isso atrapalha meu trabalho já que sou empresário; tive muitas perdas nos negócios por culpa dos games. Games são muito bons, mas não consigo parar, perco horas do dia jogando e não consigo me concentrar no trabalho. Eu gostaria de encontrar uma saída para poder parar de jogar.

Em comunicação pessoal, Allprot comenta que, além da questão de encontrar a "boa medida", há uma questão etária importante neste debate:

O que ele fala é real, mas só em casos extremos. Ele está exagerando demais. $\mathrm{Na}$ verdade, esse tipo de discurso é só pra deixar os pais da geração passada paranoicos. Ele por sinal também é velho e provavelmente não cresceu jogando videogame.

Há uma série de controvérsias que podemos descrever a partir destes relatos ${ }^{96}$. No entanto, neste capítulo iremos nos restringir a descrever mais a fundo os debates em torno do tema do lazer, trabalho, jogo, tempo livre e tempo ocupado, conforme suscitado pelo próprio trabalho etnográfico.

\section{2 - Entre usos legítimos e ilegítimos}

Alguns terapeutas que postulam a ideia de uma dependência em jogos eletrônicos (GRIFFITHS, 2008, YOUNG; DONG，YING，2011; YOUNG，2011; BLINKA; SMAHEL, 2011) trabalham com a hipótese de que existem dois tipos de uso dos computadores: os legítimos e os ilegítimos. Os usos legítimos seriam aqueles

\footnotetext{
${ }^{96} \mathrm{Na}$ mesma lista de discussão, o usuário hsc411 escreve: "no videogame, todos têm os mesmos direitos, no videogame, se você morre, é só clicar em restart checkpoint, no videogame, você não sente dores, no videogame, não existe namorada falando merda enchendo o saco, no videogame, não existe drogas, no videogame, você não fica entediado, no videogame, você não tem filhos, no videogame, se você é preso você aparece na frente da delegacia na hora, conclusão: jogamos videogames porque sabemos que a vida virtual tem o que queremos e a vida real não tem". Vemos que aqui, apesar de defender os games, o usuário erige uma barreira tal como o psicólogo, apartando a "vida real" da "vida virtual". No entanto, aqui o "virtual" não é negativado.

Islei Mir, no mesmo espaço de comentários, conta que uma partida de Battlegrounds [áreas para confronto jogador vs. jogador] no MMORPG World of Warcraft, pode ter salvo a sua vida. Ele narra: "Legal sábado passado meu primo me chamo pra ir pra uma festa, eu recusei fiquei em casa jogando WoW... Resultado: morri umas 50 vezes durante uns BG's. Resultado da festa: 5 mortes, 2 baleados levados pro hospital, +3 presos, 2 brigas, e bastante cachaça...", o que vai contra o argumento da irrealidade dos games.
} 
relacionados ao trabalho e ao estudo; enquanto os ilegítimos seriam aqueles destinados a outros fins, como os recreativos ou hedonistas (nos quais se encaixariam a pornografia virtual e os games), ou mesmo para fins próprios, os quais, em certa medida, deveriam ser evitados sob o perigo de se criar uma relação de dependência. A partir dessa distinção surgem algumas recomendações de tratamento, tais como:

Depois de estabelecida uma linha de base inicial de comparação, a terapia comportamental é empregada para a pessoa reaprender a usar a internet para atingir resultados específicos, tais como o uso moderado e, mais especificamente, a abstenção de aplicações virtuais problemáticas e uso controlado, por razões legítimas. Por exemplo, um advogado dependente de pornografia virtual precisaria reaprender a se abster de sites exclusivos para adultos e a usar controladamente o computador para fazer pesquisas legais e trocar e-mails com os clientes (YOUNG; DUE; YING, 2011, p. 24).

Os videogames, lúdicos por excelência, uma vez enquadrados nesta classificação, não teriam outra saída senão a restrição de seu uso. Para sustentar este argumento, os teóricos da dependência fazem uso da ideia de que há um mundo virtual, existente na tela de jogo ${ }^{97}$, mas que é falso. E que, ao mesmo tempo, há um mundo real, existente fora da tela e das redes da internet, portanto offline, o qual seria o único verdadeiro.

Partindo desta argumentação, é de se esperar que a proposta de cura ou de tratamento seja retirar a pessoa desse mundo falso, onde ela mantém uma série de relações (inclusive com não-humanos) também ditas falsas, para reinseri-las no mundo presencial verdadeiro, onde fará parte de uma série de relações com seres humanos: sobretudo na família, na escola e no trabalho - estas sim consideradas legítimas.

Em comunicação pessoal, Ivelise Fortim critica esta abordagem apoiando-se no livro de Nicola Johnson "The Multiplicities of Internet Addiction: The Misrecognition of Leisure and Learning", em que esta autora ataca o trabalho de Kimberly Young:

Quem é você pra dizer como as pessoas tem que usar o computador? Por quê que computador é só pra você trabalhar e não é pra você brincar? As pessoas usam o computador do jeito que querem. Não é? Você fez pra ser usado daquela forma. Mas não pode dar qualquer outro uso pra aquilo. Aí ela [Johnson] vai criticar bastante a Kimberly Young, falando assim: "Por que você não pode passar o seu tempo de lazer no mundo digital?" Ué, tem gente que passa lazer de $n$ formas, por quê que o lazer digital é patológico? Você pode ter um lazer virtual, você pode passar suas horas de lazer no computador. Como

\footnotetext{
${ }^{97}$ Seja tela do computador, da televisão onde se liga o console para jogar, do dispositivo móvel (celulares, tablets, portáteis) ou ainda quaisquer outros tipos de tela. Pensar em máquinas de pinball ou em jogos de realidade aumentada, por exemplo, já começa a desafiar tais concepções.
} 
uma livre escolha e como uma atividade que é uma atividade humana que você escolheu. Você pode passar o dia inteiro vendo futebol, por quê que você não pode passar o dia inteiro jogando videogame? As pessoas passam o dia inteiro vendo televisão. E isso não é [condenado]. Você tem uma atividade ilegítima, televisão? Isso não existe.

Sherry Turkle (1997), em Life on the Screen, expõe uma diferença entre usos criativos e usos repetitivos. Turkle entende que o número de horas dedicado a uma atividade não define o tipo de uso. Para ela, o uso criativo é quando a pessoa consegue integrar aquele uso em outras esferas de sua vida e o uso repetitivo é quando a pessoa entra e faz sempre a mesma coisa e começa a cindir as duas vidas, a virtual e a real. Fortim explica: "Você vai lá, faz sempre a mesma coisa e você só se sente frustrado porque você não consegue integrar essas coisas. Mas não é uso legítimo e uso ilegítimo, que é a ideia da Kimberly Young” (FORTIM, 2013).

Suspeitamos que neste modelo esteja implícito uma determinada visão de mundo e do que é o humano. Na perspectiva do tratamento cognitivo-comportamental, o verdadeiro humano parece ser aquele que se relaciona com a sua família, e que, sobretudo, trabalha, ou se prepara para o trabalho na escola ou na universidade, que vence desafios reais (e não virtuais) no mundo adulto do trabalho, que ganha dinheiro real (e não "pontos"), que progride como um profissional real etc. Em hipótese, os videogames aparecem aqui como perigosos porque ameaçam comprometer uma suposta humanidade plena: a do homem moderno, senhor do mundo, das coisas, dos objetos, da tecnologia.

O interesse deste capítulo, enfim, é verificar o quanto o conjunto de associações que configuram uma concepção moderna de trabalho - em oposição a uma determinada noção de lazer - cria suas as próprias noções de jogador, vício, dependência e doença, ao mesmo tempo que reforça uma ideia (também moderna) de produtividade e utilidade. Lembramos que, no nível prático, de doença e cura, estas definições serão a base dos critérios para classificar as pessoas como doentes ou sadias.

Esta não é uma simples questão, nem para os teóricos e muito menos para os práticosterapeutas e para os usuários adictos, pois há diversos tipos de lazer, e eles não são tomados do mesmo modo. Embora partilhem características comuns da esfera lúdica, todos eles se situam em diferentes redes de associações (LATOUR, 2006). Mas de algum modo, o jogo, numa concepção mais ampla, é entendido como lazer e inserido na 
categoria "tempo livre" (entendido como lazer não-produtivo), em oposição à categoria "tempo do trabalho" no pensamento moderno ordinário.

Isto não significa que os videogames não sejam vistos também como positivos. Há um conjunto de trabalhos científicos (COYNE, 2011; OLSON, 2011) que aborda a relação do jogador com o videogame de uma perspectiva benéfica, apontando para o desenvolvimento cognitivo e para o bem-estar psicológico capacitados pelos jogos, tais como: o alívio do estresse e da agressividade, maior resistência à distração, o aumento na capacidade de resolver problemas e fazer estimativas, reconhecimento de padrões, mapeamento do ambiente, gerenciamento de recursos, raciocínio rápido, memória, coordenação visual-motora e percepção de contrastes visuais. Nos jogos multiplayer, destaca-se também a promoção de habilidades sociais, como cooperação, trabalho em equipe e desenvolvimento de estratégias.

Há uma exaustão de argumentos educativos, pedagógicos e psicológicos que também ressaltam diversos benefícios dos jogos. No artigo "The Benefits of Playing Video Games" (GRANIC; LOBEL; ENGELS, 2014), publicado na American Psychologist, da APA (a mesma proponente do DSM), os autores agrupam os benefícios dos videogames em quatro domínios principais: cognitivos (ex: alocação de atenção, habilidades espaciais, resolução de problemas, criatividade), motivacionais (resiliência diante do erro, engajamento, inteligência, cultivo de um estilo persistente e motivacional), emocionais (gerenciamento de humor) e sociais (comportamento pró-social).

Num extremo dessa vertente otimista, Jane McGonigal, autora do livro "Reality is Broken (2012), defende uma hipótese relativamente ousada (e controversa): a de que os games atraem cada vez mais pessoas porque fazem um trabalho melhor do que a realidade no atendimento dos verdadeiros desejos da humanidade. A autora defende que, muito mais do que formas de entretenimento, os videogames são capazes de desencadear transformações "sociais" significativas e, no futuro, contribuirão para a solução de vários problemas globais.

Segundo Granic et al. (2014) apesar da presença deste conjunto de trabalhos, a vasta maioria das pesquisas psicológicas sobre os efeitos dos jogos, no entanto, ainda tem sido focada em seus impactos negativos, como o dano potencial relacionado a agressão, 
o vício e a depressão (ANDERSON et al., 2010; FERGUSON, 2013; LEMOLA et al., 2011).

Se a imprensa popular simplifica os efeitos dos videogames, isto não é menos verdadeiro para a maioria das pesquisas psicológicas. Ao dicotomizar videogames em "bons" ou "maus", "violentos" ou "pró-sociais", os psicólogos estão em grande parte (com exceção de psicólogos de mídia) negligenciando o complexo playground dos videogames contemporâneos e a variada paisagem de interações virtuais que encontramos nesses jogos. [...] Assim, a questão para a pesquisa psicológica em videogames não é quais jogos são "bons" ou "maus"; para nós, em vez disso, parece importante começar a reconhecer a sua crescente complexidade e interatividade e, a partir daí, desenvolver modelos igualmente complexos para explicar como os games influenciam o jogador em domínios cognitivos, sociais e emocionais relevantes (GRANIC et al., 2014, p. 74, tradução nossa).

Lembramos que, como começamos a ver no capítulo anterior, tais terapeutas respondem por Ciência, e as Ciências têm grande força para legitimar os fenômenos do mundo moderno (LATOUR, 1994), de modo que as formas de classificação de dependência emergidas neste âmbito (e ancorada em outras concepções, como lazer, trabalho, jogo, real, virtual) ganham agência nesta rede.

\section{3 - Videogames e seu aspecto lúdico}

Trataremos primeiro, pois, de recuperar algumas reflexões já realizadas sobre estes conceitos-chave. O primeiro a ser debatido aqui será o de jogo. Mais especificamente, buscaremos entender como o jogo se associa ao lazer e, por contraste, ao não-trabalho. Há dois autores clássicos no estudo deste tema: Johann Huizinga, com seu livro de 1938, Homo Ludens, e posteriormente Roger Caillois, em 1957, com Os jogos e os homens. Estes dois trabalhos ainda são as grandes referências nas pesquisas contemporâneas (em áreas como: ciências humanas, game design e game studies). Seja para concordar ou discordar destes autores, notamos que as atuais pesquisas estão em constante diálogo com estes trabalhos clássicos.

De saída, quando pensamos em jogos (na cultura ocidental contemporânea), poderíamos classificá-los como pertencentes ao domínio do tempo livre, do não-trabalho. A clássica definição de Huizinga demarca uma característica específica do jogo em contraponto à racionalidade instrumental. Para ele o jogo é:

Uma atividade livre, ficando conscientemente tomada como "não séria" e exterior à vida habitual, mas ao mesmo tempo capaz de absorver o jogador de 
maneira intensa e total. É uma atividade desligada de todo e qualquer interesse material, com a qual não se pode obter qualquer lucro. Ela é praticada dentro de seus próprios limites de tempo e espaço de acordo com regras fixas e de uma maneira ordenada. Promove a formação de agrupamentos sociais, que tendem a se cercar de sigilo e sublinhar a sua diferença em relação ao mundo comum, por disfarce ou outros meios (HUIZINGA, 1938, p. 16).

A definição que Huizinga apresenta de jogo $^{98}$ possui certas noções básicas: é uma atividade que, diferente do trabalho, é livre, e que não faz parte da vida "cotidiana", "comum", "corrente", ou "real". Para ele, estas são duas de suas características fundamentais.

Chegamos, assim, à primeira das características fundamentais do jogo: o fato de ser livre, de ser ele próprio liberdade. Uma segunda característica, intimamente ligada à primeira, é que o jogo não é vida "corrente" nem vida "real". Pelo contrário, trata-se de uma evasão da vida "real" para uma esfera temporária de atividade com orientação própria (idem, p. 11).

Ainda segundo Huizinga, o “jogo distingue-se da vida 'comum' tanto pelo lugar quanto pela duração que ocupa. É esta a terceira de suas características" (p. 12). Portanto, segundo seu entendimento, além de serem "livres", os jogos não se constituem como parte da vida ordinária, mas têm outra orientação de tempo e espaço. Essa orientação própria é geralmente entendida pelos terapeutas como aquilo que habilita o videogame a atuar como uma forma de escape da vida real para um mundo ilusório. Também é isso que dá origem ao que os teóricos dos games (LIN; SUN, 2007; SALEN; ZIMMERMANN, 2004) chamam de círculo mágico, isto é, as regras próprias que separam o jogo do não-jogo e da vida comum.

Todo jogo tem suas regras. São estas que determinam aquilo que "vale" dentro do mundo temporário por ele circunscrito. As regras de todos os jogos são absolutas e não permitem discussão. [...] E não há dúvida de que a desobediência às regras implica a derrocada do mundo do jogo. $\mathrm{O}$ jogo acaba: $\mathrm{O}$ apito do árbitro quebra o feitiço e a vida "real" recomeça. O jogador que desrespeita ou ignora as regras é um "desmancha-prazeres". Este, porém, difere do jogador desonesto, do batoteiro, já que o último finge jogar seriamente o jogo e aparenta reconhecer o círculo mágico (HUIZINGA, 1938, p. 14)

Para Huizinga, há no jogo uma íntima relação entre regras, liberdade e seu desfrute. Acreditamos que, ao desdobrarmos o que nessa literatura se entende por "real" e "livre",

\footnotetext{
${ }^{98} \mathrm{Na}$ época em que Huizinga e Caillois escreveram ainda não existiam os jogos de videogames. Os exemplos de Huizinga são brincadeiras entre cachorros (p. 3), futebol (p. 5), jogos infantis, xadrez, futebol (p. 8), jogos solitários de destreza e ação (quebra-cabeças, charadas, jogos de armar, paciências, tiro ao alvo) (p. 14), bola de gude e bridge (p. 15), amarelinha (p. 23), jogos de força e destreza, jogos de sorte, de adivinhação, exibições de todo o gênero (p. 33), entre outros.
} 
poderemos analisar o que também se entende por "habitual", "sério", "necessidade", "lúdico", "interesse", "material”, “cotidiano", entre outras categorias. Segundo Huizinga, pois, o jogo consiste na necessidade de encontrar, de inventar imediatamente uma resposta que seja livre dentro dos limites das regras ${ }^{99}$. Para o filósofo, essa liberdade de ação, essa margem concedida à sua ação, é essencial ao jogo e explica, em parte, o prazer que ele suscita (pp. 27-28). Ele comenta que os jogos não "servem" para atingir outros objetivos planejados; têm, ao contrário, um fim em si mesmo.

No que diz respeito às características formais do jogo, todos os observadores dão grande ênfase ao fato de ser ele desinteressado. Visto que não pertence à vida "comum", ele se situa fora do mecanismo de satisfação imediata das necessidades e dos desejos e, pelo contrário, interrompe este mecanismo. Ele se insinua como atividade temporária, que tem uma finalidade autônoma e se realiza tendo em vista uma satisfação que consiste nessa própria realização. É pelo menos assim que, em primeira instância, ele se nos apresenta: como um intervalo em nossa vida quotidiana (idem, p. 12).

Como não faz parte da vida ordinária, para este autor o jogo faria parte do campo do extraordinário ou mesmo do supérfluo. Para Huizinga, o jogo não é, por assim dizer, tão necessário como o trabalho e outras atividades tidas como de necessidade básica: alimentação, sono, sexo, excreção, abrigo etc. Deve, também, ser praticado num tempo específico - nas horas de ócio, ou, no chamado tempo livre - e, portanto, não deve "invadir" as horas de trabalho sério.

Seja como for, para o indivíduo adulto e responsável o jogo é uma função que facilmente poderia ser dispensada, é algo supérfluo. Só se torna uma necessidade urgente na medida em que o prazer por ele provocado o transforma numa necessidade. É possível, em qualquer momento, adiar ou suspender o jogo ${ }^{100}$. Jamais é imposto pela necessidade física ou pelo dever moral, e nunca constitui uma tarefa, sendo sempre praticado nas "horas de ócio". Liga-se a noções de obrigações e dever apenas quando constitui uma função cultural reconhecida, como no culto e no ritual (idem, p. 11).

Ao retomar o tema da necessidade, Huizinga abre um diálogo com a longa história dessa ideia no Ocidente. Por exemplo, o clássico antropólogo polonês Bronislaw Malinowski opera uma divisão modernista entre necessidades biológicas (naturalmente dadas, "físicas") e soluções culturais (socialmente construídas), as quais seriam

\footnotetext{
${ }^{99}$ Há muitos jogos que não envolvem regras. Desse modo, não existem regras, pelo menos em termos fixos e rígidos, para brincar às bonecas, aos soldados, aos policiais e aos ladrões. Em geral aos jogos que supõem uma livre improvisação e cujo principal atrativo advém do gozo de desempenharmos um papel (idem, p. 28).

${ }^{100}$ Empiricamente, observa-se que nem sempre se pode suspender o jogo a qualquer momento.
} 
organizadas para atender a estas necessidades. Segundo Eunice Durham (1986), ao elaborar a teoria das necessidades básicas e universais, das quais derivam necessidades atendidas por respostas culturais diversas, Malinowski ${ }^{101}$ faz surgir de um determinismo biológico um determinismo cultural intimamente ligado e dependente da necessidade biológica.

Camargo (2003) nos lembra de que esta mesma divisão entre necessidades básicas e supérfluas aparece na teoria de hierarquia de necessidades de Abraham Maslow, que, com sua conhecida Pirâmide de Maslow $^{102}$, postula a ideia de que as necessidades fisiológicas e as de segurança seriam mais fundamentais que as necessidades sociais. Camargo alerta que, portanto, essa divisão não deve ser tomada como autoevidente ${ }^{103}$ sob o perigo de desqualificar de antemão as atividades de lazer.

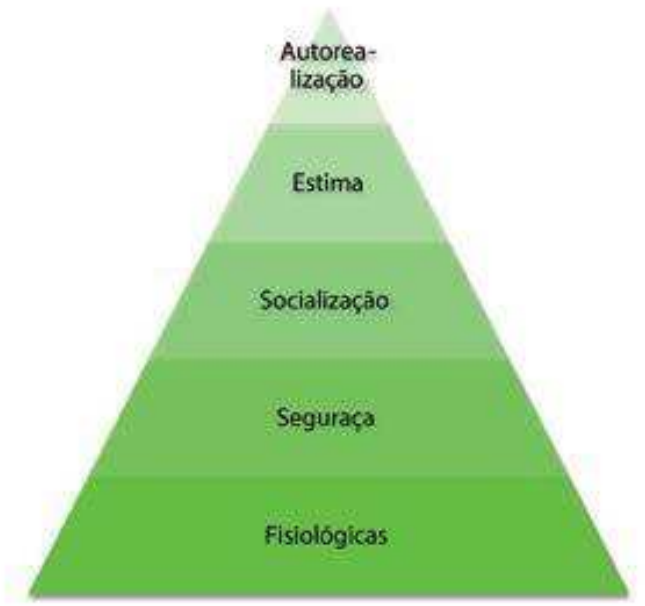

Figura 2.1 - Pirâmide das necessidades de Maslow; as necessidades humanas partem da base e, conforme vão sendo realizadas, as necessidades superiores passam a ser prioridade.

As pessoas têm outras preocupações mais importantes do que o lazer, dizia-se então. A favor desse argumento, havia uma teoria e uma pesquisa recente. A

\footnotetext{
${ }^{101}$ Ao formular a teoria das necessidades, Malinowski propõe dois axiomas que permitem alcançar uma definição mais precisa do conceito de função. Primeiro, toda cultura deve satisfazer o sistema de necessidades biológicas. Segundo, "toda valorização cultural que implica o uso de artefatos e de simbolismo constituiria uma valorização instrumental da anatomia humana, referindo-se, direta ou indiretamente, à satisfação de uma necessidade corporal” (DURHAM, 1986, p. 185).

102 A pirâmide de Maslow é empregada em sistemas de TQC (Total Quality Control, ou Controle de Qualidade Total). É usada dentro das empresas, em especial pelo setor de Recursos Humanos, que procuram seguir a ordem da mesma para o desenvolvimento e o bem estar dos funcionários, principalmente pela sua fácil comunicação e implementação em uma estrutura organizacional.

103 O economista e filósofo chileno Manfred Max Neef tem argumentado que as necessidades humanas fundamentais são não-hierárquicas e são ontologicamente universais e invariáveis em sua natureza - parte da condição de ser humano. A pobreza, argumenta, é consequência de uma destas necessidades ter sido frustrada, negada ou não plenamente realizada.
} 
teoria era a das necessidades básicas de Maslow. [...] Curiosamente, os que recorriam a essa teoria sempre concluíam que o lazer não fazia parte das necessidades básicas e sim das supérfluas (CAMARGO, 2003).

Complementando a definição do filósofo Huizinga, trazemos também para o debate a conceituação do sociólogo Roger Caillois (1957). O trabalho deste autor complementa a clássica conceituação de jogo de Huizinga com a proposta das características da interação lúdica, a seguir:

Livre: A interação lúdica não é obrigatória; se fosse, perderia de uma vez só sua qualidade atrativa e alegre como diversão.

Separada: Circunscrita dentro dos limites de espaço e tempo, definida e fixada antecipadamente.

Incerta: $\mathrm{O}$ curso do qual não pode ser determinado, nem o resultado obtido previamente e alguma margem para as inovações deixadas para a iniciativa do jogador.

Improdutiva: Não cria bens, riqueza, nem elementos novos de qualquer espécie; e, com exceção da troca de bens entre os jogadores, termina em uma situação idêntica à que prevalecia no início do jogo.

Regida por regras: Sob convenções que suspendem as leis ordinárias e, no momento, estabelecem uma nova legislação, que conta sozinha.

Faz-de-conta: Acompanhado por uma consciência especial de uma segunda realidade ou fantasia livre, como em oposição à vida real (CAILLOIS, 1957 apud SALEN; ZIMMERMAN, 2012, p. 91-92).

Embora Huizinga e Caillois difiram em diversos pontos e tenham focos diferentes em suas análises, o conceito básico de jogo ${ }^{104}$, para os fins que aqui nos interessam, é bastante semelhante:

A palavra "jogo" evoca por igual as ideias de facilidade, risco ou habilidade. Acima de tudo, contribui infalivelmente para uma atmosfera de descontração ou de diversão. Acalma e diverte. Evoca uma atividade sem escolhas, mas também sem consequências na vida real. Opõe-se ao caráter sério desta última e, por isso, vê-se qualificada de frívola. Por outro lado, opõe-se ao trabalho, tal como o tempo perdido se opõe ao tempo bem empregado. Com efeito, o jogo não produz nada - nem bens, nem obras. É essencialmente estéril. A cada novo lance, e mesmo que estivessem a jogar toda a sua vida, os jogadores voltam a estar a zero e nas mesmas condições de início. Os jogos a dinheiro, apostas ou

\footnotetext{
${ }^{104}$ Caillois classifica os jogos em quatro aspectos: agôn, alea, mimicry e ilinx. Em agôn, ressalta-se o caráter competitivo. Seus exemplos são o xadrez, damas, bilhar, pólo, tênis, futebol, boxe, esgrima e críquete. Em alea, jogos em que predomina a aleatoriedade, e que a decisão não depende do jogador; ele cita o jogo de dados, roleta, cara ou coroa, bacará, loteria etc. No aspecto mimicry, ou seja, do "como se", Caillois lembra dos brinquedos de miniatura, cavalinhos de madeira e da representação teatral. Ilinx , onde se ressalta o aspecto de risco e da vertigem, o autor menciona os dervixes dançarinos, voladores mexicanos, carrossel, tobogã, baloiço, jogo do pião, milho de ouro, escorrega e rolar na ladeira. Caillois comenta que em jogos como bridge, pôquer, corrida de cavalos, desafios de futebol ou de pelota basca, há uma maior mistura entre estes aspectos.
} 
loterias, não são exceção. Não criam riqueza, movimentam-na (CAILLOIS, 1967, p. 9).

Tanto para Huizinga como para Caillois, ao contrário do trabalho, o jogo não produz nada $^{105}$. Não se constitui propriamente numa tarefa (diferentemente da conceituação de Tim Ingold, que exporemos mais adiante). Como não é visto como produtivo, é associado à perda de tempo ou ao tempo mal utilizado. Enfim, aqui o jogo opõe-se à seriedade representada pelo trabalho. No entanto, como o próprio Huizinga afirma, isto não significa que o jogo não seja sério.

[...] o jogo é diametralmente oposto à seriedade. À primeira vista, esta oposição parece tão irredutível a outras categorias como o próprio conceito de jogo. Todavia, caso o examinemos mais de perto, verificamos que o contraste entre jogo e seriedade não é decisivo nem imutável. É lícito dizer que o jogo é a nãoseriedade, mas esta afirmação, além do fato de nada nos dizer quanto às características positivas do jogo, é extremamente fácil de refutar. Caso pretendamos passar de o "jogo é a não-seridade" para "o jogo não é sério", imediatamente o contraste tornar-se-á impossível, pois certas formas de jogo podem ser extraordinariamente sérias. Além disso, é facílimo designar várias outras categorias fundamentais que também são abrangidas pela categoria da "não-seriedade" e não apresentam qualquer relação com o jogo (HUIZINGA, 1938, p. 8).

Mesmo se o jogo não é trabalho (ou não é sério), como não dizer que não há seriedade em sua prática? É preciso que as suas regras se apliquem dentro de seu tempo e espaço específicos. Pensemos no que acontece quando alguém quebra uma destas regras: por exemplo, um jogador de futebol (de linha) segura a bola com as mãos; ou, no videogame, um jogador utiliza trapaças (denominadas cheats) para avançar as fases do jogo, ou para tornar seu personagem mais forte que o dos demais jogadores - tudo isto quebra a "fantasia" do jogo.

Esta consciência do fato de "só fazer de conta" no jogo não impede de modo algum que ele se processe com a maior seriedade, com um enlevo e um entusiasmo que chegam ao arrebatamento e, pelo menos temporariamente, tiram todo o significado da palavra "só" da frase acima. Todo jogo é capaz, a qualquer momento, de absorver inteiramente o jogador. Nunca há um contraste bem nítido entre ele e a seriedade, sendo a inferioridade do jogo sempre reduzida pela superioridade de sua seriedade. Ele se torna seriedade e a seriedade, jogo (HUIZINGA, 1938, p. 11).

Essa absorção aqui mencionada parece ser semelhante à qual o antropólogo Clifford

\footnotetext{
${ }^{105}$ Certamente há pressupostos que informam esta noção de produtividade, os quais tentaremos desdobrar durante a descrição. McGonigal (2012), por exemplo, cita numerosos exemplos de produtividade nos jogos em sua obra, inclusive afirmando a sua não-oposição à "vida comum”.
} 
Geertz descreve em Um jogo absorvente: notas sobre a briga de galos balinesa (1973). Tanto absorção, imersão e engajamento são atributos que interessam aos jogos, aos jogadores, aos desenvolvedores e, se invertermos o sentido, aos teóricos da dependência. Pois, afinal, no que consiste um bom jogo? Como veremos melhor no último capítulo, é aquele com o qual o jogador se engaja profundamente. Podemos pensar que uma semântica possível de seriedade, então, seja engajamento. $\mathrm{O}$ engajamento abarca tanto as dimensões de criação e de invenção, como o feedback (retorno e reajuste). Aliás, esta parece uma saída para as alternativas infernais (PIGNARRRE; STENGERS, 2005, p. 40) que permeiam este diálogo, como sujeito versus objeto, e liberdade versus necessidade. Ainda, esta ideia vai de encontro com a noção de comprometimento, a qual exploraremos ao final do capítulo.

Podemos nos perguntar, afinal, o que torna a vida ordinária não-livre? Se o trabalho é visto como atividade obrigatória (ou pertencente a um tempo ocupado), estaria a vida ordinária relacionada ao trabalho e, por consequência, à não-liberdade? $\mathrm{O}$ próprio Huizinga já dá pistas para responder esta questão. Para ele, o jogo é colocado em oposição à seriedade no sentido mais estrito de trabalho.

O valor conceitual de uma palavra é sempre condicionado pela palavra que designa seu oposto. Para nós, a antítese do jogo é a seriedade, e também num sentido muito especial, o de trabalho, ao passo que à seriedade podem também opor-se a piada e a brincadeira. Deixando de lado o problema linguístico, e analisando mais atentamente a antítese jogo-seriedade, verificamos que os dois termos não possuem valor idêntico: jogo é positivo, seriedade é negativo. $\mathrm{O}$ significado de "seriedade" é definido de maneira exaustiva pela negação de "jogo" - seriedade significando ausência de jogo ou brincadeira e nada mais (HUIZINGA, 1938, p. 51).

No entanto, Huizinga comenta que não há fronteiras bem demarcadas entre o jogo e a seriedade. Para exemplificar isto, ele compara os jogos com os investimentos na bolsa de valores, que evidenciam dinâmicas semelhantes entre si:

A indeterminação das fronteiras entre o jogo e a seriedade tem um exemplo perfeito na expressão "jogar na Bolsa”. O jogador de roleta não terá dúvida alguma em reconhecer que está jogando, mas já o mesmo não sucederá com o corretor de valores. Este último sustentará que a compra e venda ao sabor das altas e baixas da Bolsa fazem parte das coisas sérias da vida, ou pelo menos, da vida dos negócios, e constitui uma função econômica da sociedade. Em ambos os casos, o fator operante é a esperança do lucro. Mas, enquanto no primeiro caso o caráter puramente fortuito da coisa é geralmente reconhecido (não obstante todos os "sistemas"); no segundo, o jogador ilude-se a si mesmo com a 
ideia de que é capaz de prever a tendência futura do mercado. Seja como for, é ínfima a diferença de mentalidade em ambos os casos (idem, p. 60).

Hector Rodriguez, artista digital e teórico dos Game Studies, em um artigo que comenta Homo Ludens, afirma que as definições de Huizinga de seriedade e de jogo não são muito precisas. Para Rodriguez, apesar de estas serem aplicáveis em muitos casos, em outros, no entanto, a fronteira entre ambos os conceitos não é exatamente clara.

Homo Ludens não expressa, entretanto, a tese de que jogar ${ }^{106}$ é, em todos os aspectos, isolada de preocupações sérias. A fronteira entre o lúdico e o sério é certamente real e amplamente aplicada, mas não bem definida em todos os lugares, e sempre sujeitas à revisão. Em alguns casos, a fronteira não pode ser marcada de forma alguma. Além disso, questões éticas sobre civilidade e justiça são muitas vezes intimamente ligadas com o ato de jogar. Huizinga afirma, por exemplo, que muitas formas de cultura séria se originaram a partir de ações lúdicas. O lúdico está na origem da arte, religião, política, filosofia e da lei. É enganoso ver essas instituições em termos meramente funcionais, como veículos para a transmissão de valores sociais ou de reprodução da coesão social. A ação social é, em parte, motivada por um desejo de experiências intensas de risco, incerteza, superação de si mesmo, desafio etc. Estas regiões da vida social atravessam a distinção entre o lúdico e o sério (RODRIGUEZ, 2006, tradução nossa).

Apesar de Huizinga trabalhar com dicotomias não muito bem definidas, como seriedade e não-seriedade, necessidades básicas e supérfluas, vida real e vida extraordinária, jogo e não-jogo; que até certo ponto são problemáticas, a sua noção de jogo não permite classificá-lo como uma atividade ilegítima, tal como os psiquiatras e psicólogos (YOUNG, DUE; YING, 2011; ABREU, 2013), que condenam o uso excessivo dos videogames.

O jogo não é compreendido pela antítese entre sabedoria e loucura, ou pelas que opõem a verdade e a falsidade, ou o bem e o mal. Embora seja uma atividade não material ${ }^{107}$, não desempenha uma função moral, sendo impossível aplicarlhe as noções de vício e virtude (HUIZINGA, 1938, p. 9).

\footnotetext{
${ }^{106}$ O termo em inglês "play”, pode ter o sentido de jogar ou brincar, dependendo da situação.

107 Apesar de Huizinga classificar o jogo como uma atividade não material, pela teoria-ator-rede não encontramos uma a oposição clara entre material e imaterial, pois, por esta perspectiva, os actantes (que não têm uma essência fixa) ligam-se em cadeias a redes de actantes tanto materiais, quanto imateriais.
} 


\section{4 - Categorias em jogo}

Entre os autores da área da ludologia (ou Game Studies, como o campo também é chamado), Brian Sutton-Smith ${ }^{108}$, em The Study of Games, escreve que "cada pessoa define jogos a sua própria maneira - os antropólogos e especialistas em folclore, em termos de origens históricas; os militares, empresários e educadores, em termos de usos; os sociólogos, em termos de funções psicológicas e sociais. Em tudo isso há provas contundentes de que o significado dos jogos é, em parte, uma função das ideias daqueles que pensam a respeito deles" (SALEN; ZIMMERMAN, 2012, p. 19). Já Clark $\mathrm{Abt}^{109}$ propõe outra definição, mais estruturada:

Um jogo é uma atividade entre dois ou mais tomadores de decisão independentes buscando alcançar seus objetivos em um contexto limitador [...] um jogo é um contexto com regras entre os adversários tentando conquistar objetivos (ABT, 1970 apud SALEN; ZIMMERMAN, 2012, p. 90).

Este mesmo autor comenta que um dos problemas dessa definição é que nem todos os jogos são disputas entre adversários. Em alguns games, como os do gênero beat'em up (por exemplo, o jogo Castle Crashers), jogos cooperativos contra a "máquina", os jogadores cooperam para atingir um objetivo comum, contra uma força obstrutiva ou situação natural que não é realmente um jogador, uma vez que não têm objetivos (ABT, 1970).

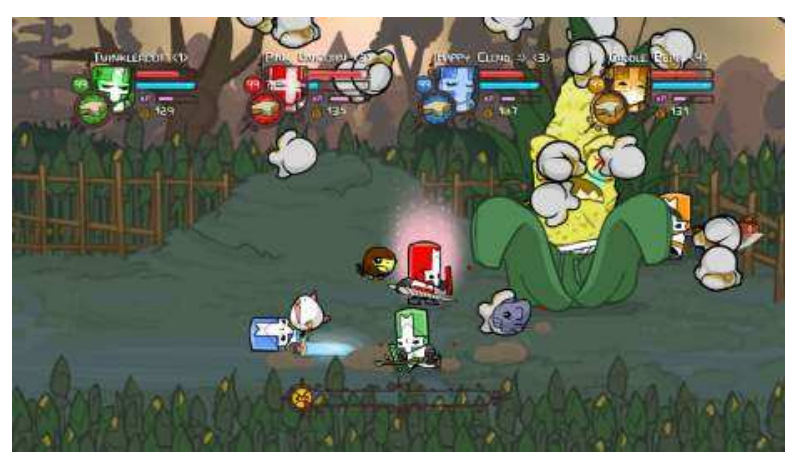

Figura 2.2 - Castle Crashers (2010)

\footnotetext{
${ }^{108}$ Sutton-Smith é um teórico dos jogos que propõe uma abordagem interdisciplinar, que mistura antropologia, psicologia, educação e folclore. Sua obra The Ambiguity of Play (1997) é muito reconhecida nos estudos do gênero. Em sua carreira, lecionou nas universidades de Columbia e da Pensilvânia e foi presidente da The Anthropological Association for the Study of Play e da American Psychological Association, divisão de Psicologia e Artes. Hoje é professor aposentado.

${ }^{109}$ Clark Abt é professor da Brandeis University (EUA). Em sua carreira, desenvolveu os ofícios de engenheiro, educador, ambientalista, empreendedor e cientista social. É criador do termo "Serious Games", em seu livro homônimo, de 1968.
} 
Avedon e Sutton-Smith (1971) formulam que "jogos são um exercício de sistemas de controle voluntário, em que há uma competição entre forças, limitadas por regras para produzir um desequilíbrio". Já Greg Costikyan ${ }^{110}$ (1994) coloca que "um jogo é uma forma de arte na qual os participantes, denominados jogadores, tomam decisões a fim de gerenciar os recursos por meio das fichas do jogo em busca de um objetivo". Por sua vez, Bernard Suits teoriza que:

Interagir em um jogo é engajar-se em uma atividade direcionada para produzir um determinado estado de coisas, usando apenas meios permitidos pelas regras, em que as regras proíbem meios mais eficientes em favor dos menos eficientes, e em que tais regras são aceitas apenas porque possibilitam essa atividade (SUITS, 1990, p. 34).

Todas estas definições apontam para alguns elementos em comum, mas também guardam algumas divergência, as quais, por ora, não vamos entrar em detalhes. Encontramos, pois, em Eric Zimmerman ${ }^{111}$ e Katie Salen (2012) uma conceituação de jogos que sintetiza alguns destes elementos. Para estes autores, "jogo é um sistema no qual os jogadores se envolvem em um conflito artificial ${ }^{112}$, definido por regras, que resulta em um resultado quantificável”.

Apesar de esses autores esforçarem-se para encontrar a mais apta conceituação, a ideia geral ou abstrata de jogo, no entanto, deve ser questionada. Pois, apesar de buscarem semelhanças entre os muitos tipos de jogos, estes autores podem estar unificando rápido demais essa multiplicidade. A categoria "jogo" abrange um conjunto muito vasto e diferenciado de jogos. Há jogos esportivos, de cartas, de tabuleiro, de videogame, fliperamas, advergames (jogos para publicidade), jogos para dispositivos móveis, consoles, jogos de realidade-virtual, jogos profissionais, jogos amadores e muitos outros. Qual seria, afinal, a legitimidade dessa ampla categoria para representá-los em sua inteireza? Defendemos que a categoria deve se manter atada ao nível da experiência. Assim, uma hipótese possível é tomar "jogo" como um mediador sóciotécnico.

\footnotetext{
${ }^{110}$ Greg Costikyan, também conhecido como Designer X, é um game designer e escritor de ficção científica. Em sua carreira criou jogos de diversos tipos, entre jogos de tabuleiro, RPGs, jogos de cartas, de computador, online e para dispositivos móveis. É cofundador da empresa Manifesto Games.

${ }^{111}$ Eric Zimmermann é um reconhecido game designer e cofundador da Gamelab, uma empresa de desenvolvimento de games situada em Manhattan. Leciona no Game Center da New York University.

${ }^{112}$ Para evitar maiores complicações, o termo "artificial" será aqui entendido no sentido de que o jogo ocorre dentro do chamado "círculo mágico", isto é, dentro de um espaço e de um regime de tempo distintos da "vida ordinária", como Huizinga (1938) postula. No entanto, a concepção de jogo como nãoreal possui sérias objeções, as quais veremos na rede cartografada neste trabalho.
} 
Edward Castronova, um autor bastante citado em estudos relacionados aos MMORPGs ${ }^{113}$ (jogos de interpretação de personagens online em massa para múltiplos jogadores), argumenta em The Right to Play (2004) que todos os seres humanos têm uma necessidade fundamental de jogar. Para ele, o desejo de jogar é "enterrado profundamente em nossa psique, bem abaixo do pensamento racional e, de alguma maneira, um pouco acima da vontade de comer e fazer sexo", e se a necessidade for insatisfeita, coisas terríveis acontecem (pp. 202-203, tradução nossa). Neste artigo, Castronova defende uma legislação específica para proteger o círculo mágico do jogo das regras "do mundo lá fora", desconsiderando seus efeitos em outros agentes e a sua interpenetração prática no "não-jogo" ou "não-virtual". Para definir o que qualifica como jogo, ele se refere a Huizinga:

Para Huizinga, nada pode ser um jogo se envolver uma consequência moral [...] se alguma consequência realmente importa no final, o jogo acaba. De fato, o único ato de consequência moral que pode acontecer dentro de um jogo é o ato de acabar com o jogo, negando seu caráter de faz de conta [as-if], estragando a fantasia (CASTRONOVA, 2004, pp. 188-189, tradução nossa).

Algumas noções de Castronova, como de "seres humanos" e "necessidade fundamental" aparecem aqui como termos genéricos. Devemos, pois, interrogá-los, desdobrando os seus sentidos. Antes mesmo de entrar na etnografia com os jogadores, vemos que o próprio Huizinga descreve as brincadeiras dos animais como jogos, mostrando a nãoexclusividade humana nos atos de jogar. "Necessidade fundamental" também é outro conceito controverso. Vimos que o jogo, por exemplo, não está incluso nas camadas mais básicas da pirâmide das necessidades de Maslow, tampouco aparece citada (tal como a satisfação de sono, fome e sede) nos questionários mais comuns aplicados nos diagnósticos de dependência de videogames, internet ou drogas.

Seguindo a discussão em torno do suposto círculo mágico fabricado pelos jogos (espaço e tempo próprios do jogo, separados daqueles da vida social ordinária), o qual se referem Huizinga (1938) e Caillois (1957), o pesquisador Greg Lastowka postula uma distinção clara entre os MMORPGs e o mundo exterior: "Enquanto os MMORPGs têm

\footnotetext{
113 "Um MMORPG (Multi Massive Online Role Playing Game) geralmente apresenta um lugar bem semelhante ao mundo real, mas com componentes mágicos e fantásticos. Os jogadores podem se envolver em uma variedade de interações com outros jogadores através de batalhas, comércio, vendas de itens valiosos, namoros e sexo virtual, aventuras feitas pelos programadores (FORTIM, 2004a). O objetivo principal no início é melhorar o personagem, adquirindo armas e equipamentos. Com a interação social, os jogadores adquirem outros objetivos como participar de clãs, guildas, campeonatos, coleções de itens, aventuras em grandes grupos, missões, etc.” (FORTIM, 2013, p. 65).
} 
algumas coisas em comum com weblogs e redes sociais, eles também são muito diferentes de outras formas de atividade online, uma vez que MMORPGs são jogos" (LASTOWKA, 2007, p. 3, tradução nossa). Seria exatamente este círculo mágico que poderia fazer com que o jogador ficasse completamente imerso no mundo do jogo, onde supostamente nada que ocorre fora de seus limites alcança importância para fazê-lo parar de jogar.

Esta visão do círculo mágico dos jogos tornou-se bastante influente nos estudos contemporâneos. Muitos pesquisadores de games (COPIER, 2005) já entraram nesta discussão para argumentar a favor ou contra esta visão. De acordo com as autoras chinesas Holin $\operatorname{Lin}^{114}$ e Chuen-Tsai Sun ${ }^{115}$ (2007), a visão do círculo mágico implica tratar o jogo como "um mundo independente do mundo cotidiano real". A melhor experiência de jogo seria alcançada quando o jogo fosse "isolado ou oposto às características utilitárias do mundo físico" (LIN; SUN, 2007, p. 336, tradução nossa). A partir desta visão do círculo mágico, Huizinga também supõe que na vida ordinária haja apenas uma orientação de tempo e espaço, o que não é empiricamente verificável. Malaby, por exemplo, sugere que esta definição isolacionista dos jogos é "o maior obstáculo para a compreensão do que é poderoso sobre eles” (2007, p. 96, tradução nossa).

Quase todos os partidários de Huizinga (especialmente Salen e Zimmermann) concordam que a manutenção do círculo mágico pressupõe uma conformidade a dois conceitos. Em primeiro lugar, o círculo mágico cria um mundo independente do mundo cotidiano real. Em segundo lugar, ele preserva a ordem dos mundos de jogo através do uso de regras (LIN; SUN, 2007, p. 366, tradução nossa)

A partir das definições acima, podemos afirmar que o aspecto lúdico pode estar relacionado com a esfera do lazer, que, por sua vez se encontraria em posição imediatamente oposta ao cálculo utilitarista e à ética moderna do trabalho, como entendidas por Max Weber (1904-05). Associado ao campo do lazer, do tempo livre e da não-seriedade e, ao mesmo tempo, afastado do campo do trabalho, da vida ordinária e da lógica utilitária, o videogame possivelmente se ligaria com as drogas, já que ambas pertenceriam ao campo do lazer e seriam avessas à lógica de produção de mercadorias:

\footnotetext{
${ }^{114}$ Professora do Departamento de Sociologia da Universidade Nacional de Taiwan.

${ }^{115}$ Professor do Departamento de Ciência da Computação da Universidade Nacional Chiao Tung.
} 
aparentemente não haveria nada sendo produzido em nenhum dos casos, apenas coisas consumidas num tempo devotado ao puro ócio. Seriam os games, assim, considerados uma forma de lazer não-produtiva?

Testaremos a seguinte hipótese: o trabalho, o estudo e as atividades físicas tendem a ser resistentes às tentativas de classificação como potenciais geradoras de vícios, dependências ou doenças porque são atividades largamente prestigiadas e valorizadas. De certa maneira, o usuário se alimenta desse rebatimento coletivo positivo. Então, temos que a noção de dependência (individual) está sujeita ao nível coletivo das relações. Entretanto, esses pressupostos da dependência não aparecem no discurso e na prática de muitos médicos, e devem, pois, ser investigados mais a fundo na sequência da descrição, retirando-os de seus estabelecidos redutos.

\section{5 - Lazer e trabalho: desestabilizando conceitos}

Classificar os jogos eletrônicos como atividade de lazer, não-produtiva e, sobretudo, não pertencente ao mundo real, é uma maneira simplista de desqualificá-la, já que este seria somente para um de seus múltiplos aspectos. Iremos, a partir de agora, problematizar tais aproximações dicotômicas entre lazer e trabalho, jogo e não-jogo, à luz de algumas teorias contemporâneas e junto com a intervenção de jogadores ditos viciados, com o intuito de demonstrar que os videogames têm efeitos de realidade.

O próximo movimento é, agora, levar a discussão dos jogos para um debate mais amplo em torno do lazer. O sociólogo francês Joffre Dumazedier (1976), autor pioneiro nos estudos de lazer e referência clássica neste assunto, caracterizou-o como:

um conjunto de ocupações às quais o indivíduo pode entregar-se de livre vontade, seja para repousar, seja para divertir-se, recrear-se e entreter-se ou ainda, para desenvolver sua informação ou formação desinteressada, sua participação social voluntária ou sua livre capacidade criadora após livrar-se ou desembaraçar-se das obrigações profissionais, familiares e sociais (p. 94).

Segundo Dumazedier, o lazer completo possui caráter liberatório, de livre escolha; caráter desinteressado, sem fim lucrativo; caráter hedonístico, de satisfação; caráter pessoal, onde as expectativas superam as necessidades. Dumazedier classifica, então, o lazer em quatro tipos, conforme o tempo disponível: lazer do fim do dia, do final de semana, do final do ano e do fim da vida. 
Vemos que o conceito de lazer de Dumazedier é construído em torno das noções de liberdade (em contraste com a obrigação), autonomia, voluntariedade, desinteresse. Podemos, contudo, suspeitar dessas noções. Algumas de suas características são parecidas com o conceito de jogo de Huizinga. Até mesmo sua tipologia dos quatro tipos de lazer está fortemente baseada num modelo específico de trabalho, daquele organizado em jornadas. Já Nelson Marcellino (1990), pesquisador destacado nos estudos do lazer no Brasil, prefere a noção de tempo disponível ao invés de tempo livre.

o lazer é por mim entendido como a cultura - compreendida no seu sentido mais amplo - vivenciada (praticada ou fruída) no tempo disponível. É fundamental, como traço definidor, o caráter "desinteressado" dessa vivência. Não se busca, pelo menos basicamente, outra recompensa além da satisfação provocada pela situação. A disponibilidade de tempo significa possibilidade de opção pela atividade prática ou contemplativa (p. 31).

Em sua obra, no entanto, não parece haver diferenças significativas entre estes termos, que muitas vezes são tomados como sinônimos. Para Marcellino, pois, o tempo disponível seria o tempo de não-trabalho. Sua característica "desinteressada" aproximao da noção de jogo de Huizinga, isto é, nenhuma das duas são entendidas como meios para outras finalidades, mas um fim em si mesmo ${ }^{116}$.

O pesquisador brasileiro Renato Requixa (1980) também oferece contribuições para a teoria do lazer. Para ele, lazer é "uma ocupação não obrigatória, de livre escolha do indivíduo que a vive e cujos valores propiciam condições de recuperação psicossomática e de desenvolvimento pessoal e social” (p. 35). Tal como os autores anteriores, Requixa parte de uma noção individualista e autonomista de indivíduo. Sua noção de "recuperação" refere-se a um descanso do trabalho, de modo que aqui o lazer ainda é entendido em oposição ao primeiro.

Em nosso caso, a questão parece ser encontrar a divisória entre uma medida moderada e excessiva que define o videogame entre "lazer" e "vício". A liberdade, pois, aparece como um problema do humanismo para os modernos. Afinal, que noção de liberdade está orientando estas definições? Podemos resgatar as noções de liberdade positiva e liberdade negativa do filósofo político Isaiah Berlin para pensar esta questão. Este, que

\footnotetext{
${ }^{116}$ Esta afirmação não passa sem controvérsias. Se intercambiarmos as perspectivas, poderemos observar a presença de uma série de interesses, tanto no caso do jogo, como no caso do lazer (por exemplo, o interesse financeiro das produtoras de jogos, o interesse em relaxar, socializar e/ou vencer dos jogadores, entre muitos outros, nos quais, entretanto, não nos aprofundaremos).
} 
é considerado um dos principais pensadores liberais do século $\mathrm{XX}$, no texto Dois Conceitos de Liberdade (1958), definiu liberdade negativa como a ausência de impedimentos, obstáculos, barreiras ou restrições à ação do indivíduo. Para Berlin, a liberdade negativa é a habilidade de tomar atitudes que um homem pode tomar sem a interferência de outros. Se alguém intencionalmente o forçar a agir de certa maneira ou o impedir de fazer algo, ele reduziria sua liberdade negativa.

Em contrapartida, o conceito de liberdade positiva envolve ação e a presença de condições para que os indivíduos ajam de modo a atingir seus objetivos. Não é liberdade de alguma coisa, mas liberdade para fazer certas coisas, como controlar a própria vida e libertar-se da escravidão espiritual (se alguém induz uma pessoa a fazer coisas que o primeiro pensa serem boas pra ela, isto é uma destruição da sua liberdade individual). A liberdade positiva permite que uma pessoa alcance suas metas e faça suas próprias escolhas. Diferentemente da liberdade negativa, pode-se reduzir a liberdade positiva por conta própria e com suas habilidades.

Observarmos que a noção que prevalece aqui neste debate é de uma liberdade no sentido negativo (BERLIN, 1958), isto é, da ausência de impeditivos a um indivíduo considerado autônomo. Retomemos, pois, a questão do lazer. Entendemos, como o sociólogo Norbert Elias (1985), que o lazer é um conceito histórico de classificação de atividades humanas, existente propriamente nas sociedades modernas, e não de forma universal, apesar das atividades em si (por exemplo, os jogos) existirem de forma comparável.

Poucas sociedades humanas existem, se é que existe alguma, que não possuam equivalente às nossas atividades de lazer, que não tenham danças, confrontos simulados, exibições acrobáticas ou musicais, cerimônias de invocação de espíritos - em resumo, sem instituições sociais que proporcionam, por assim dizer, a renovação emocional por meio do equilíbrio entre os esforços e as pressões da vida ordinária, com suas lutas a sério, os riscos e seus constrangimentos (ELIAS, 1985, p. 74).

A ideia de lazer, tal como se conhece no ocidente (ou na modernidade), só pode ser pensada por oposição a uma determinada ideia de trabalho. É construída, portanto, em relação a um conceito de trabalho específico, no sentido moderno, sendo geralmente este assalariado, realizado fora do ambiente doméstico, dotado de uma jornada contabilizada em horas e, o mais importante, organizado em um tempo próprio. Pode-se dizer, então, que na modernidade as tarefas e os tempos são separados de modo radical - 
uma atividade ou é rigorosamente trabalho ou é puro lazer, ou é para ser realizada no tempo ocupado ou no tempo livre. Além disso, há outra oposição de fundo neste pensamento: da mesma forma que o trabalho é associado à razão, o lazer é ligado à emoção - vide, por exemplo, a renovação emocional citada por Elias no trecho acima. Seguindo a discussão, José Acácio Ferreira, autor do livro Lazer Operário, retoma o sociólogo Gilberto Freyre para discorrer acerca do lazer e do chamado tempo livre:

Freyre afirmou que à medida que a máquina substituía o homem, a organização do lazer tornava-se mais importante que a organização do trabalho. [...] Temia não conseguir a compreensão de que, se o tempo livre era um problema sério para os países desenvolvidos, para as nações que desejam progredir, a concretização das potencialidades contidas nessas horas de folga era um imperativo. A palavra do ilustre sociólogo pernambucano vinha de certa forma em meu auxílio. [...] Acontece, porém, que nos países padrões do sistema cultural em que nos inserimos, "tempo é dinheiro" e amar a vida no que ela tem de belo e desinteressado, uma deformação ou um vício (FERREIRA, 1959 apud GOMES, 2004, p. 2-3).

A temática do lazer parece ser uma grande controvérsia entre "nós, modernos". Suas noções variam desde aquelas ligadas a certas correntes marxistas que afirmam que "o lazer seria uma alienação, uma ilusão de autossatisfação das necessidades do indivíduo, porquanto estas necessidades são criadas, manipuladas pela forças econômicas da produção e do consumo de massa, conforme o interesse de seus donos" (MARCUSE, 1971, p. 50), até aquelas amparadas em constatações empíricas sobre o papel fundamental do lazer para a reprodução ainda mais rentável do trabalho e do capitalismo (como por exemplo, o regime de trabalho na Microsoft ou na Google).

Sendo assim, qual seria exatamente o ponto de choque das "sociedades" modernas com o lazer? Colocando de outra forma: o que o lazer e o videogame, mais especificamente, ofenderiam? Pode-se pensar que a organização do trabalho e lazer nas sociedades modernas, que seguiriam uma determinada lógica de divisão de tempos, seria de alguma forma ameaçada pelos jogos, os quais operariam em regimes de tempo e espaço diferenciados. Uma vez que os jogos não obedecem à máxima de que "tempo é dinheiro" e que, eventualmente, "invadem" o tempo do trabalho, extrapolando o tempo de lazer que fora alocado para contê-lo; não se estaria ameaçando o próprio cerne do pensamento ou da cosmologia moderna?

O problema passaria a ser, então, não o lazer em si mesmo, mas a prática de atividades destinadas a serem executadas no tempo livre dentro do tempo de trabalho. Estaria aí 
posto o perigo do excesso de lazer; ou o problema de tornar essas fronteiras mais turvas, borradas, de difícil supervisão. Afinal, pensam os modernos, como distinguir quem está trabalhando e quem está desfrutando do tempo de lazer? Será que alguns estão levando vantagens às custas de outros? Como então proceder sem que os videogames sejam classificados arbitrariamente como "irreais" ou de fora do "mundo real"?

Buscando sair das visões catastrofistas e das meramente exaltadoras dos jogos, devemos flexibilizar algumas destas divisões modernas (LATOUR, 1996), que nos impedem de tratar a questão de forma mais cuidadosa. A sugestão aqui é diluir as categorias de lazer, trabalho e jogo a partir de outros pontos de vista teóricos. Como argumenta a socióloga T. L. Taylor" ${ }^{117}$ (2006, p. 153): "Imaginar que podemos segregar essas coisas - jogo e não-jogo, [...] virtual e real - não é só não entender a nossa relação com a tecnologia, mas também a nossa relação com a cultura".

Um conceito que não parte de uma associação rígida entre trabalho e seriedade; nem lazer e não-seriedade; é o do sociólogo americano Robert Stebbins (1982). Ele forjou o conceito de serious leisure (lazer sério). Segundo o autor, este é uma perseguição sistemática de uma atividade amadora ou voluntária que os participantes acham tão substanciais e interessantes que, no caso típico, se lançam em uma carreira para adquirir e expressar suas habilidades especiais, conhecimentos e experiências.

No entanto, apesar de avançar na discussão, Stebbins ainda continua operando num vocabulário que mantém os conceitos de lazer e trabalho como categorias analíticas, o que ainda não atinge nosso objetivo derradeiro. A seguir, nos aprofundaremos no trabalho do antropólogo britânico Tim Ingold (2000), o qual adota uma perspectiva chamada dwelling, que, em oposição à commodity perspective, rompe com as dicotomias modernas de tempo (tempo livre e tempo do relógio), de atividade (lazer e trabalho), produção (arte e tecnologia/produção em massa) e troca (sistema da dádiva e do mercado); para trabalhar com uma orientação às tarefas (task-orientation) e habilidades (skills).

Em Work, Time and Industry (2000), Ingold, na tentativa de problematizar tais dicotomias, retoma o local e o tempo de sua formação: o cenário das fábricas tayloristas

\footnotetext{
117 T. L. Taylor é professora de mídias comparativas no Massachusetts Institute of Technology (MIT), especialista nos campos nos estudos de internet e games.
} 
e fordistas, nas quais os capitalistas, na tentativa de maximizar a mão de obra, organizaram o tempo em unidades mensuráveis e impuseram um tempo regrado para o trabalho. Segundo Ingold, com esta organização produtiva, a rotina das pessoas foi regulada de forma abstrata em unidades como "horas" e "minutos", e, partir daí, gerada uma divisão entre o tempo que estas pessoas devem utilizar para trabalhar (ou seja, o trabalho entendido não como uma atividade, mas como um tempo) e o tempo que descansariam, o lazer.

Ingold faz menção ao clássico Os Nuer, no qual E. E. Evans-Pritchard (1978) descreve uma sociedade tradicional em que a rotina é organizada de acordo com as tarefas a serem realizadas, o que, em decorrência, transforma-se na base da mensuração do tempo. Ingold argumenta que o mesmo acontece na chamada sociedade ocidental contemporânea: quando se organiza o dia, estão se organizando as tarefas que serão postas em prática durante este dia; e muitas vezes, quando queremos mensurar o tempo, utilizamos como referência estas mesmas tarefas. Desse modo, divide-se a experiência temporal não necessariamente em termos abstratos, mas por meio de tarefas.

O autor desconstrói estas divisões, afirmando que, de modo análogo às sociedades ditas "tradicionais", nas sociedades modernas não se depende necessariamente de "horas" e "minutos". Além disso, Ingold postula que esta forma de organizar o tempo não seria exclusiva do momento do lazer, mas se estenderia por todas as dimensões da vida dos agentes. Rodrigo Chiquetto ${ }^{118}$ (2012) comenta que, por esta perspectiva do ser-noambiente (dwelling), todos os atores são agentes no meio que habitam, reconstruindo ativamente este meio durante sua existência. Assim, tanto o meio da casa quanto o meio do trabalho oferecem diferentes possibilidades para a construção de relações com o outro, para a criação e utilização das habilidades que são incorporadas durante a vida e por meio das quais se compreende o ambiente em que se vive.

Uma vez que, para Ingold, a fronteira entre trabalho e lazer não é tão rígida, do mesmo modo, a relação entre tempo de trabalho e tempo livre também parece ser mais complexa do que indica a purificação promovida pelos modernos (LATOUR, 1996). Não é todo o tempo de trabalho que é ocupado e dedicado às atividades produtivas - e estas não são necessariamente repetitivas, maçantes e entediantes, mas, ao contrário,

${ }^{118}$ Rodrigo Chiquetto é Mestre em Antropologia pela FFLCH/USP e membro do Laboratório do Núcleo de Antropologia Urbana (LabNAU) da Universidade de São Paulo. 
podem conter componentes lúdicos e criativos (vide novamente os regimes de trabalho na Microsoft). Assim como outros teóricos contemporâneos, tais como os sociólogos Ricardo Antunes (1995) e Richard Sennett (1999), apontaram para fenômenos também contemporâneos do trabalho, como o regime de trabalho flexível e o trabalho doméstico, os quais não mais nos permitem compreender a realidade atual por meio dessas redutoras dicotomias. Assim como todo o tempo de lazer não é exatamente livre ou destinado ao puro descanso, desfrute ou prazer. Estamos diante, pois, de um embaralhamento de noções e categorias.

O que fazer com estas classificações? Negá-las? Hector Rodriguez (2006) recomenda que não por completo, pois em muitos casos elas ainda seriam úteis enquanto boas aproximações, ainda que não funcionem como categorias absolutas:

Huizinga ressalta que o conceito de jogo, por vezes, não pode ser circunscrito dentro de precisos limites conceituais. Homo Ludens raramente avança com definições rígidas. A tentativa de Huizinga de "definir" jogo em termos do círculo mágico, por exemplo, não deve ser entendida como um conjunto de condições necessárias e suficientes, mas como uma aproximação preliminar a certas regiões de vida que resistem a uma categorização exata. Como um bom historiador, Huizinga não se furta da ambiguidade. Seu estudo completo pode ser visto como um esforço para falar o mais precisamente possível de categorias e distinções que não podem ser claramente demarcadas. As definições são úteis na medida em que sugerem tópicos comuns que perpassam manifestações heterogêneas, mas elas não são destinadas a funcionar como categorias absolutas. Assim, jogar é tanto sério como não sério. A dificuldade está em prestar atenção a importantes diferenças conceituais, mantendo nossas categorias descritivas suficientemente flexíveis para acomodar a ambiguidade e a imprecisão (RODRIGUEZ, 2006, tradução nossa).

Sendo assim, resta-nos mapear ainda mais esta controvérsia e trazer à tona a multiplicidade da explicação dos agentes que a tornam complexa, para tentar compreender o que eles mesmos entendem por lazer e trabalho, tempo livre e tempo ocupado, jogo e seriedade, e quais são, afinal, as relações de tudo isso com a dependência de videogames.

\section{6 - Os gamers e suas classificações}

Segundo alguns autores (YEE, 2006; GRIMES, 2006, pp. 982-985 apud LEHDONVIRTA, 2010), a jogabilidade de um MMORPG (Massive Multiplayer Online Role Playing Game) pode vir a assemelhar-se a um trabalho: é laboriosa, entediante e, 
ocasionalmente, lucrativa. Os próprios jogadores de videogame constantemente relatam casos em que jogam por intermináveis horas mesmo sem ter prazer na maior parte do tempo de jogo; e em muitos casos fazem movimentos tão mecânicos e repetitivos que lembram o trabalho nas fábricas fordistas. Para subir um nível num MMORPG, por exemplo, um jogador deve basicamente matar monstros por centenas ou milhares de vezes seguidas apertando apenas um botão, quando muito acionando alguns botões especiais. O jogo pode se tornar chato, maçante, desinteressante, mas o jogador continua jogando. Como entender tal situação?

A partir da etnografia, buscaremos não exatamente explicações, mas descrições mais minuciosas dos actantes humanos e não-humanos, por meio de uma entrada mais profunda nestes mundos dos videogames. Esta experimentação intenta abrir espaço para o imprevisível e permitir a dissolução da dicotomia sujeito-objeto - já que não é o analista, como sujeito, que aplica, sem transformações, uma técnica (objeto), mas ambos que se engajam. Serão perseguidas, portanto, as perspectivas dos próprios jogadores, bem como sobre estes jogadores (em relação uns aos outros), a fím de multiplicarmos as perspectivas. Para descrever algumas destas experiências faremos uso de notícias, fóruns e listas de discussão na internet ${ }^{119}$ e mais abaixo, de entrevistas (os depoimentos foram transcritos tais quais encontrados nos sites e fóruns).

Um trecho da famosa e divertida entrevista com o Anônimo da TP (na verdade, não se trata de um anônimo, mas sim do nome pelo qual é conhecido na internet), personagemsímbolo dos jogadores brasileiros chamados "viciados" entre os próprios jogadores, nos ajuda a pôr a questão.

Ae, ramela. Caralho, mano. Tá foda de ficar aqui no PC, na real. [- Por quê?] Ah, mano, tô jogando faz mó cara aqui, eu não saio aqui, mano. Tá fedendo pra caralho, mó cheirão de presunto, tá ligado? Nego tá chiando pra mim tomar banho, mas não dá, mano. Se eu sair aqui, como que eu vou upar nessa porra? Anônimo da TP

\footnotetext{
${ }^{119}$ Notícias, fóruns e listas de discussões citados:

http://omelete.uol.com.br/games/confira-um-documentario-sobre-jogadores-profissionais-de-videogame/ http://us.battle.net/wow/pt/forum/topic/6079712970?page $=10$

http://www.gamevicio.com/i/noticias/31/31734-jogadores-amadores-superam-profissionais-emcampeonato-de-games/

http://www.techtudo.com.br/jogos/noticia/2011/11/entrevistamos-daigo-umehara-o-pele-dosvideogames.html

http://sites.levelupgames.com.br/Forum/ragnarok/forums/t/463547.aspx
} 
Em muitos dos jogos denominados MMORPGs ${ }^{120}$, "upar ${ }^{121}$ ", isto é, adquirir pontos de experiência que deixarão o seu avatar (personagem dentro do jogo) mais forte, torna-se o principal o objetivo do jogador no game e/ou na sua rede de sociabilidade virtual. Em muitos casos, ter um personagem forte significa adquirir o respeito dos demais, ganhar status, obter companhia, favores, além de dar acesso a novas áreas e possibilidades do jogo. O usuário Sengoku, do jogo Ragnarök Online, dá outro exemplo dessa caracterização em uma postagem no fórum oficial do servidor brasileiro:

Eu upei a vida inteira praticamente de $m o b^{122}$, e ter que matar de 1 em 1 monstro com Golpe Fulminante é frustrante. Ah, claro, eu preciso de uns 4 golpes e os monstros morrem, o risco de eu morrer é ínfimo e upo mais rápido do que antes, mas está tedioso. Bom, a única coisa que penso é ficar treinando, treinando, treinando... Eu sei que para o personagem ficar "do jeito que eu quero" vai demorar muito (lá pelo nível 145, acredito eu). Até fiquei animado com algumas habilidades novas e a nova configuração de mapas, mas está repetitivo - Sengoku.

Perseguindo este objetivo, o jogador terá de enfrentar missões e se aventurar por florestas e cavernas (dependendo do tema do jogo), matando monstros, conseguindo ítens especiais e, eventualmente, confrontando outros jogadores. No entanto, muitos jogadores tentarão fazer estas mesmas coisas ao mesmo tempo - tudo se converte, pois, numa disputa agonística que pode levá-los a exaustão. Evoluir um personagem leva tempo. Subir um nível pode significar muitas horas de jogo, matando os mesmos monstros exatamente da mesma maneira. Obter dinheiro no jogo também costuma ser uma tarefa dura, e exige que o jogador consiga itens demandados pelos demais e que este faça boas trocas. Conseguir um item raro, inclusive, pode ser tão difícil a ponto de, às vezes, demandar mais de um ano de procura em vão. Por conta disso, muitos relatam que estão trabalhando nos seus (ou com os seus) personagens. Por que não levá-los a sério? Também não trabalhamos offline, pelo menos por um lado, para conseguir, além do ganho material, os mesmos status, respeito e companhia?

\footnotetext{
${ }^{120} \mathrm{O}$ jogo ao qual o Anônimo da TP aqui se refere, Cabal Online, opera nesta lógica, mas muitos outros também o fazem de forma quase idêntica - World of Warcraft, Ragnarök Online, Ultima Online, Everquest, Grand Chase, Priston Tale, Tibia, EVE Online, Guild Wars, Perfect World, entre outros. Tais jogos são ditos pelos próprios jogadores como os mais "viciantes", e atraem a atenção de especialistas das ciências médicas que tratam da dependência, como Blinka e Smahel (2005).

${ }^{121}$ Upar é um neologismo que se originou do termo em inglês "up" (aumentar). Aqui nos games (em especial RPGs e MMORPGs) é uma lógica de ganho de pontos de experiência e a aprimoramento dos atributos de habilidade do personagem.

${ }^{122}$ Mob: monstros que os jogadores devem matar no jogo para ganhar experiência, coletar itens, etc. No mundo de Ragnarök, monstros são criaturas que habitam diversos mapas do jogo - com exceção das cidades - e que garantem Experiência e Drops para o jogador que os derrotou.
} 
Para lidar com estes dados de campo temos de desmontar aqui a separação entre o material e o imaterial (ou simbólico). Há tempos, a economia, o marketing, a sociologia e a antropologia reconheceram o valor do trabalho intangível ou simbólico. Recusamos, assim, a falsa oposição material versus imaterial. Como mostra Latour (1991), nada do que é material se sustenta sem o imaterial, e vice-versa. É só seguirmos as redes que observaremos como ambos estão conectados.

Nós nunca nos deparamos propriamente com objetos ou com relações sociais, nós somos confrontados com correntes de associações de humanos $(\mathrm{H})$ e nãohumanos $(\mathrm{NH})$. Ninguém sequer viu uma relação social por si só, nem uma relação técnica. Em vez disso, estamos sempre confrontados por correntes que se parecem com esta: H-NH-H-NH-NH-NH-H-H-H-H-NH (onde H representa um actante humano e $\mathrm{NH}$, um não-humano). Naturalmente, numa montagem $\mathrm{H}$ $\mathrm{H}-\mathrm{H}$ aparentam relações sociais, enquanto uma porção NH-NH-NH parece um mecanismo ou uma máquina. Mas a questão é que eles são sempre integrados em cadeias mais longas (LATOUR, 1991, p. 110, tradução nossa).

Muitos jogadores produzem itens, casas e muitas coisas inimagináveis nos jogos online; e mesmo no mundo offline, os jogadores vendem seus personagens, são contratados como jogadores profissionais e são patrocinados por empresas para jogar. Apesar de disso, seria o jogo apenas lazer? Pura liberdade? Este tipo de trabalho seria de todo falso? Responder afirmativamente a estas questões seria descartar tudo aquilo que os gamers praticam e nos contam acerca de suas experiências - embora não se trate, do mesmo modo, de respostas únicas, mas, ao contrário, extremamente controversas.

\subsection{1 - Os objetivos dos jogadores}

Em muitos jogos, emerge uma tipologia que varia desde um tipo de jogador "curtidor", que supostamente utiliza o jogo como seu lazer - seu objetivo é divertir-se, desfrutar, socializar com outras pessoas, sem se importar muito em cumprir as metas do jogo, em se tornar mais poderoso ou utilizar as melhores estratégias para vencer os desafios - até o jogador "apelão" (ou hardcore), que faria o oposto, não importando nada senão ser o melhor. Este tipo conta que "trabalha duro" para "upar", ser forte e rico. Sua diversão pode vir exatamente disso. Condenando esse tipo de jogador, Abadi, um paladino em World of Warcraft, fala:

Alguém aí já parou para ler a história do WoW? Já parou para ler algumas quests ${ }^{123}$ ? Sem querer ser muito roleplay ${ }^{124}$, mas as quests são muito massa,

${ }^{123}$ Quests: missões dentro do jogo, que o jogador pode cumprir em troca de uma recompensa. Por exemplo: ir até um lugar específico para matar um monstro e pegar o item deixado por ele. 
véio! É divertido pensar que seu personagem irá evoluir ajudando e rodando o continente inteiro fazendo trabalhos. Que entediante ficar numa cidade voando e voando esperando aparecer um $\operatorname{tank}^{125}$ para fazer aquela dungeon ${ }^{126}$ pela décima vez! Talvez esse seja o motivo de muitos players abandonarem o jogo. [...] Pra mim, para um verdadeiro jogador de WoW upar é de menos! Parem de se preocupar com seus chars que irão ficar [nível] 85! Aproveitem o momento e conheçam os lugares desse jogo, que por sinal tem $30 \mathrm{~GB}$ ! Vivenciem e chorem para o massacre do campo taurajo! - Abadi

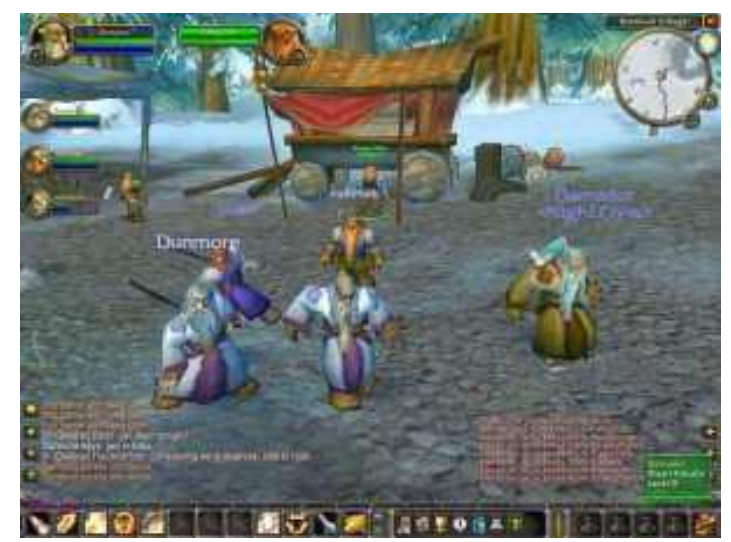

Figura 2.3 - World of Warcraft (2004)

A seguir recuperamos uma discussão mais larga, porém muito interessante, sobre os objetivos do jogo Ragnarök Online, promovida por seus membros no fórum oficial do bRO (Brasil Ragnarök Online), que seguem a mesma linha: "Upar”, se divertir, ganhar respeito, explorar diferentes ambientes... O que, afinal, buscamos no jogo? O usuário Festa Brasileira coloca a diversão como a maior motivação, em contraste com a ânsia de muitos jogadores em subir níveis.

Meu objetivo em qualquer jogo é a diversão. Acho que o Ragnarök toma uma trilha meio errada ao estimular o up intenso e demorado (antes que me critiquem, é demorado pegar 150, tanto quanto era pegar 99 trans). O level lin $^{127}$ deveria ser um dos meios do jogo, e não um fim. Upar pode até ser divertido sob certas condições, mas ficar no point \& click pra upar - seja matando tartarugas ou magmarings - não me empolga nada. Me senti cansado só de pensar em ter que upar mais um monte de level de novo, e sinceramente, talvez eu nunca pegue 150. O que eu esperava para o jogo é que investissem numa diversão de verdade pra quem já tem level máximo, e não que tudo ficasse

\footnotetext{
${ }^{124}$ Roleplay: interpretação de papéis/personagens. Geralmente é usado para distinguir uma forma de jogar mais "teatral" num sentido oposto a "matar, pilhar e destruir", ou evoluir freneticamente.

${ }^{125}$ Tank: estratégia de batalha em equipe, a qual consiste em colocar um personagem mais forte no combate corpo a corpo na frente (como cavaleiros e cruzados) para resistirem aos danos causados pelo inimigo - e os demais atrás (como arqueiros, magos e sacerdotes).

${ }^{126}$ Dungeon: caverna (ou outros ambientes fechados), onde os jogadores entram para matar monstros, cumprir missões e buscar de tesouros. São, em geral, áreas "selvagens”, desconhecidas e perigosas.

${ }^{127}$ Level: Os pontos fortes de cada personagem e habilidades são medidos por dois tipos de níveis: o nível de base e seu nível de classe. É possível mudar de nível ao adquirir a experiência necessária para completar os $100 \%$. Quanto maior o nível, mais experiência será preciso para atingir o próximo.
} 
naquela "agora que eu peguei level máximo, vou criar outro char, porque o que importa nesse jogo é upar" - Festa Brasileira.

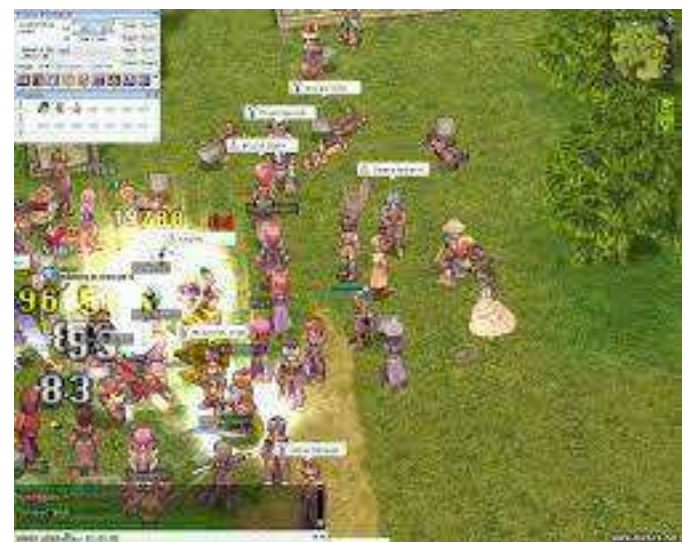

Figura 2.4 - Ragnarök Online (2002)

Jogadores como Sakura estabelecem metas claras. Ela conta que seu objetivo principal é "reestruturar-se" para atingir o nível máximo (na época, o nível 99).

Objetivos... É uma pergunta bem interessante de se fazer, bem o objetivo real do jogo no caso, seria chegar ao nível máximo do jogo, como todos os outros, mas tem pessoas como eu que fazem metas, eu já tive muita esperança, por exemplo, de me tornar Suma-Sacerdotisa, aquilo pra mim era tudo, mas com o passar do tempo aquilo parecia que se distanciava cada vez mais de mim a cada \% que eu conseguia, por incrível que pareça, eu tinha perdido as esperanças, até largar de uma vez eu larguei, mas como eu disse o que não me falta são pessoas me apoiando pra seguir em frente. Bom, meu objetivo agora seria me reestruturar para poder atingir o 99, mas isso também vai ser um grande desafio. Mas eu prometi a mim mesma que não iria desistir não importa o quão difícil fosse. Até por que vou ter que conciliar um TERCEIRO ANO DO ENSINO MÉDIO com o Ragnarök, ou seja, mais tempo fazendo temas, trabalhos e coisa e tal e menos tempo no bRO, mas o que não me falta é organização. Enfim, objetivos não me faltam, é só passar essa tempestade e eu vou arrumar essa Sacerdotisa maltratada que eu tô jogando - Sakura.

Para $T s u$, por sua vez, "upar" é uma atividade cansativa, porém exigente para o jogador que deseja ficar mais forte. Interessa-lhe também jogar junto com os amigos.

Bom, sempre quis me divertir, pena que poucos pensem assim, up hard cansa mesmo, mas não vou parar agora que resetei $^{128}$ pela primeira vez. Vou ficar forte e jogar junto com meus amigos. - Tsu

Já o objetivo de Waltz é jogar enquanto seus amigos jogarem:

\footnotetext{
${ }^{128}$ Reset: Quando um personagem chega ao nível 99 e decide "resetar", o jogo recomeça. Isto é, este personagem volta o nível 1, à profissão de aprendiz, mas com pontos extras e com a possibilidade de evoluir para as transclasses. Em outro sentido "resetar" pode ser somente em relação aos atributos (como força, destreza, inteligência, vitalidade, agilidade, sorte ) e habilidades, com a finalidade de reordená-los.
} 
Meu único objetivo no bRO é jogar enquanto meus amigos jogarem, que é o que me diverte atualmente no jogo. Não é mais tão interessante jogar sozinho, embora com o renewal ${ }^{129}$ isso esteja até legal. - Waltz

Para Yuukorin, o mais importante é fazer coisas em grupo e rir bastante. Além disso, interessa-lhe vencer as missões e obter itens especiais.

Pra mim, enquanto for divertido irá durar. Claro, vou ter que fazer uma pausa (vestibular e pans), mas enquanto for agradável eu vou jogar. A verdade é que o up pra mim não importa muito. O que eu gosto é fazer coisas em grupo e rir bastante. A maior parte dos meus contatos já virou $3-\mathrm{x}^{130}$, mas eu acho que ficar upando que nem louco é bobeira. E fora que quero fazer as quests do éden pra pegar aquele $h a t^{131}$ ! - Yuukorin.

NickStarMaster, por sua vez, tem o objetivo de evoluir e alcançar o nível 99 (nível máximo, na época). Ele fala sobre a caraterística dura e repetitiva desta tarefa:

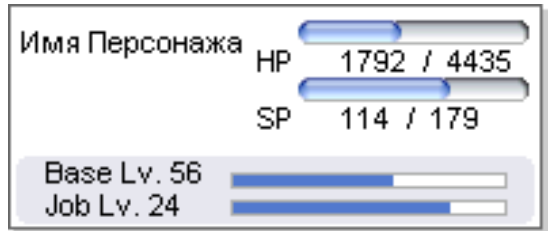

Figura 2.5 - Barra de personagem de Ragnarök Online

Meu objetivo neste momento é upar e alcançar 99. Também acho frustrante um jogo visado no "entretenimento" e "diversão sem limites no Thor e Odin ${ }^{132}$ ", você ficar horas e horas rodando um mapa, vendo os mesmos monstros, matando com mesmas skills ${ }^{133}$, usando mesmos itens, passando a mão na barrinha de experiência ${ }^{134}$, raramente usando chat. Isso chega a ser deprimente, mas enfim quase todos os MMORPGs você tem que ficar no mesmo mapa ou área upando desse modo. - NickStarMaster

${ }^{129}$ Renewal: A "Renovação" é um episódio especial de Ragnarök Online, em que a mecânica do jogo foi alterada em diversos fatores - fórmulas de habilidades, interface, tabelas de experiência etc. Tais mudanças foram necessárias para aprimorar a jogabilidade dos novos usuários do jogo. Além disso, com a chegada das Terceiras Classes, o nível limite precisou ser ampliado para 150 e os atributos, reformulados para não ocorrer um desequilíbrio com a implantação das novas habilidades.

${ }^{130}$ Transclass: Após alcançar o Nível de Base 99 como segunda classe, um personagem pode escolher renascer e recomeçar o processo novamente, sendo recompensado com mais poderes. "Renascer" significa voltar a ser nível 1 de base e classe como Aprendiz Transcendental. Após tornar-se Classe 1-1 e atingir os níveis de classe 40 ou 50, o jogador poderá mudar para uma Classe Transcendental, com as mesmas habilidades da classe 2 anterior, mas com outras novidades.

${ }^{131}$ Hat: em português, chapéu; item especial que o personagem pode usar para ganhar bônus de atributos.

${ }^{132}$ Thor e Odin são alguns nomes de servidores oficiais de Ragnarök Online no Brasil. Cada servidor roda um "mundo de jogo" próprio.

133 Skills: habilidades especiais dos personagens, distintas para cada classe. Por exemplo: Golpe Fulminante (para os espadachins) e Raio de Gelo (para os magos). Em Ragnarök existem quatro tipos de habilidades: passiva, ativa, ofensiva e suporte.

${ }^{134}$ Experiência é um valor numérico variável, que determina a mudança de nível de um personagem. Em Ragnarök Online há dois tipos de experiências diferentes: para o Nível de Base e o Nível de Classe. Um personagem ganha pontos de experiência ao completar quests ou derrotar monstros. 
Para Leinad, o jogo aparece como uma válvula de escape para um cotidiano agitado:

Existem tipos de diversão: existem pessoas que se unem para evoluírem seus chars ${ }^{135}$ e poder alcançar novos poderes e vê-los crescer, principalmente se divertindo no processo. Outros fazem exatamente a mesma coisa para poder avacalhar a diversão dos outros, que por sinal expressam claramente o dito popular "espírito de porco". Deixando isso de lado, cada um tem um tempo próprio a que se dedique ao Ragnarök. Muitos estão na fase do pré-iminente vestibular, outros trabalham, têm faculdade, assim dificultando algumas possibilidades de diversão. O que define o jogo e seu objetivo pessoal é somente você! Atualmente ele é minha válvula de escape do cotidiano agitado, aonde encontro alguns amigos e juntos nos divertimos um bocado. - Leinad

Para Sengoku, o que interessa é poder customizar o personagem e experimentar com seus amigos as diferentes possibilidades e recursos do jogo.

Meu objetivo mesmo é moldar o personagem do jeito que quero pra experimentar as features ${ }^{136}$ do jogo com os amigos. Tem sempre algo bacana pra fazer em conjunto, sejam quests extensas, subir Torre de Thanatos ou a Sem Fim, as Instâncias, os $M V P s^{137}$, talvez uma $W O E^{138}$, ajudar outros. Cada dia que passa eu acredito mais que meu objetivo não vai ser definido só por mim, mas a única certeza que eu tenho é de continuar treinando. - Sengoku

Para Festa Brasileira, a dinâmica do jogo transforma-se radicalmente quando se atinge o nível máximo, onde os objetivos passam então a ser outros que simplesmente o aumento de níveis de personagem e a melhoria de suas habilidades.

Depois que eu comecei a jogar WoW eu mudei totalmente as minhas concepções de o que é se divertir num RPG. Eu já não me divertia faz tempo no RO e não sabia o que estava faltando. O jogo SÓ COMEÇA depois que você chega ao level máximo. Infelizmente, a grande maioria dos RPGs anda copiando o WoW em tudo (como esse sistema de party finder aí), menos no que realmente importa - Festa Brasileira.

\footnotetext{
${ }^{135}$ Char: abreviação de character, isto é, o personagem de jogo. Também conhecido como avatar.

${ }^{136}$ Features: possibilidades de jogo.

${ }^{137}$ MVP: é a abreviação para Most Valuable Player, que significa "Jogador de Maior Valor". É uma definição que não se limita apenas à Ragnarök Online. A dificuldade de um MVP está pelo seu HP, dano e experiência altíssimos. Eles são do tipo Chefe, ou seja, possuem certas prioridades que um monstro comum não possui.

${ }^{138}$ War of Emperium (WOE): A Guerra do Emperium é um evento com 2 horas de duração em mapas com o PvP (player versus player) ativado. O Emperium é uma pedra dourada que representa o "coração" da fortaleza da guilda dominante. Para se conquistar um ou mais dos 26 castelos, deve-se chegar à sala do Emperium e destruí-lo. Uma vez destruído, todas as pessoas que não são do clã vitorioso e suas alianças são movidas para o ponto de retorno, para que a guilda que se apossou do castelo possa armar sua defesa.
} 
O objetivo de Delatroixx é relatar os bugs para a Level Up Games (empresa de jogos), para que esta possa consertar os erros de programação, já que o servidor seria "resetado" (reiniciado, apagando os personagens) após este período de testes.

Hoje a tarde aqui na empresa, fiquei jogando e anotando alguns defeitos, então resolvi criar um grupo para ver como o jogo se comporta em tais situações, foi quando me deparei que muitos players aqui não estão nem aí para os bugs ${ }^{139} \mathrm{e}$ problemas do jogo, tentei umas 17 vezes criar um grupo e sempre me davam uma resposta do tipo "Aff, vai encher outro, eu quero upar", eu fico me perguntando o que passa na cabeça desses carinhas, acham que o char que eles estão upando vai continuar no servidor depois do closed $_{\text {beta }}{ }^{140}$ ? Então peço uma coisa para esses players, não se esqueçam: o objetivo principal aqui é relatar os bugs para a LUG, pois quando o closed acabar, seu char vai junto, e para quem se acha o melhor do melhor do mundo em matar low level, pare de perturbar quem está preocupado com os defeitos do jogo, e pare de abusar dos bugs, isso não te faz ser top rank, apenas deixa claro o nível da sua noobisse ${ }^{141}$, sem mais.

Para SouL, seu objetivo é cumprir as suas promessas no servidor:

Acho que o objetivo no jogo, pra todo mundo, é virar classe $3^{\text {rd }}$ nível $150^{142}$. Lembro até hoje quando eu era 2-1, fiz quests repetíveis até o nível 85 e aí fui upar. Eu não tinha a MÍNIMA noção de $u p$, não sabia nada sobre Ragnarök e só consegui upar pro 86 depois de 10 dias. Eu achava que quando eu pegasse $99 \mathrm{eu}$ ia dar uma volta olímpica por São Paulo, ia comemorar um título, fazer tudo que eu tinha direito. Mas com o passar do tempo, não só eu, mas todo mundo descobre que é uma coisa muito normal, nada muito maravilhoso. Quando eu cheguei lá, só dei um sorrisinho e avisei pro clã ${ }^{143}$ que tinha pego 99. Depois disso veio o trans, pegar 99 de transclasse foi MUITO mais fácil, eu já tinha mais noção do jogo, já sabia onde eu iria upar e peguei 99 muito mais rápido. Hoje com as classes 3, eu acho que meu objetivo é esse, alcançar o nível 150, cumprir minhas promessas no servidor e aí eu penso se eu continuo com outros personagens ou se eu paro de jogar. Depois que tudo que todos passamos, sabemos como lidar com as dificuldades no jogo, cada vez mais novidades seriam mais objetivos a serem alcançados, e por aí vai. Novidades no jogo seriam a essência para os velhos players, e eu acho que merecíamos isso. SouL

\footnotetext{
${ }^{139}$ Bugs: defeitos de programação do jogo.

140 Closed beta: é um período que antecede o lançamento oficial do jogo, quando somente algumas pessoas são convidadas a jogar. Neste período são feitos testes, contando com a presença dos jogadores, para eliminar os bugs e realizar as últimas alterações antes do lançamento. Depois deste período, há um "reset", e todos recomeçam do zero, além de se abrirem as portas para os demais jogadores. Neste tipo de jogo há constantes atualizações de software.

${ }^{141}$ Noobisse: acusação pejorativa de "novato".

${ }^{142}$ Terceira classe nível 150 é o nível mais alto que um jogador pode chegar no Ragnarök (na época).

${ }^{143}$ Clã: grupo de jogadores que se reúne para jogar. O clã conta com algumas possibilidades dentro do jogo, como o compartilhamento de ganho de pontos de experiência, a conquista de castelos, etc. Todos os membros de um clã podem acessar uma janela que mostrará quem está online, seus níveis e classes. Além disso, todos podem usar um canal de chat especial para conversas exclusiva do clã, além de uma mensagem de aviso que só poderá ser visto pelos membros.
} 
Notamos que há vários sentidos de "diversão" nesta rede. A partir disso, podemos, então, tentar desdobrar etnograficamente a sua semântica. Pelos comentários dos usuários, o videogame parece estar mais relacionado à fruição do que à distração, tal como Caillois postula em relação aos jogos: "Fruição, sim, pois hesitamos em apelidar de distração uma exaltação que mais se assemelha ao espasmo do que ao divertimento" (1957, p. 47). Assim, as concepções de diversão e de fruição devem estar estreitamente relacionadas com a questão do prazer.

Até aqui não desenvolvemos as controvérsias em torno das noções de prazer nas atividades de jogo. Não à toa, pois parece difícil mensurar as atividades por meio das técnicas geralmente utilizadas em pesquisas na área de Ciências Sociais, e pelo prazer gerado por sua execução, o qual varia de acordo com cada configuração particular de actantes. Além disso, exigiria uma incursão ainda mais profunda nos quadros, teorias e métodos da Psicologia, o que extrapola as limitações deste trabalho. De todo modo, parece evidente que o prazer experienciado por certas atividades tem estreita relação com sua dimensão coletiva.

Não podemos, pois, omitir-nos em colocar questionamentos suscitados pelos dados de campo. Afinal, o prazer do jogador deriva da representação de personagens e do convívio coletivo (como sugerem os adeptos do roleplay), ou do cumprimento das metas atingidas por meio da prática do jogo, tal como o subir um nível (como sugerem os adeptos do lema "matar-pilhar-destruir")? Apesar desta distinção provisória entre "curtidores" e "apelões", vemos que ambos, em certo aspecto, buscam o mesmo: formar e integrar grupos, se relacionar pela mediação dos jogos. Ou seja, existe aqui uma motivação coletiva para se associar. Esta é uma imagem inteiramente contrária àquela do indivíduo antissocial, que deseja se isolar e que recusa o convívio com outras pessoas para ficar "trancado no quarto jogando".

Enfim, fica evidente por estes comentários que os jogos não têm um único uso, nem uma única finalidade. Eles podem ser apropriados de diversas maneiras pelos jogadores. Diante dessa diversidade de relatos e posições, o teórico Hector Rodriguez abre novas portas para abarcarmos a multiplicidade das experiências com os jogos.

Uma vez que os jogos nos abrem para a experiência do risco, confiança, dependência, vulnerabilidade, fatalismo, vício, incerteza e violência, jogar pode, assim, nos possibilitar novas formas de subjetividade e interação, que surgem a 
partir de modificações experimentais na vida cotidiana (RODRIGUEZ, 2006, tradução nossa).

Há formas que parecem se aproximar ao que os modernos chamam de trabalho, e outras que se aproximam do que chamam de lazer, mas sustentamos que ainda assim não é proveitoso continuar operando análises antropológicas que partem destas categorias. Veremos, no próximo caso, outra disputa que colocará estas classificações definitivamente em cheque.

\subsection{2 - Os jogadores profissionais de videogame}

Os jogadores profissionais ${ }^{144}$ existem em diversos países. No entanto, eles são vistos de formas muito distintas ao redor do mundo. Comenta-se que nos países do leste asiático, como Japão, Coreia do Sul e China, tais jogadores são pessoas muito prestigiadas em seus locais de origem, seja em meios on ou offline. Como um breve exemplo, a final do mundial do game League of Legends, em 2014, na Coreia do Sul, reuniu 40 mil pessoas num estádio utilizado na Copa do Mundo de $2002^{145}$.

Em outros países, principalmente no Ocidente, e em especial no Brasil (onde está concentrada a presente análise), os jogadores profissionais invariavelmente são acusados de não trabalhar "de verdade", viverem na "moleza", sofrerem de "falta do que fazer" e "não terem vida". Para ilustrar esse debate, exibimos alguns comentários de notícias e listas de discussões online (Omelete/UOL e GameVício):

- É realmente, lá eles não tem muito o que fazer da vida... são meio alienados, com certeza - diz Diego.

- Falta do que fazer. - diz Rafael.

- Meio que sem-vida. - diz Vinícius.

- Ficar só jogando não dá, tem que praticar esporte, estudar. - diz Madnessrsd.

- Na boa, jogar videogame e ganhar pra isso é um sonho, mas puta trampo de vagabundo, hein. - escreve KillerST.

- Bando de playboy patrocinado pelos pais, enquanto eu to ralando por aqui no meu curso de programação de jogos, para poder no futuro quem saber poder fazer o mesmo... - escreve Matador-CD.

\footnotetext{
${ }^{144} \mathrm{O}$ assunto dos jogadores profissionais de videogame está bem documentado na etnografia intitulada Unidos pelo Controle de Daniel Costa Valentim (2012), que trata dos jogadores profissionais de futebol digital, especialmente na seção "A gente era tudo menino". Passaremos apenas brevemente por algumas discussões acerca do tema.

${ }^{145}$ http://jogos.uol.com.br/videos/assistir.htm?video=bastidores-do-mundial-de-league-of-legends04024C1B3962D0915326
} 
- Faz um mês que eu vendi minha lan-house, e assim como todo "lan gamer" eu era eu viciado em World of Warcraft, Warcraft e Starcraft, fora os famosos jogos de FPS [First-Person Shooter], tipo Counter-Strike e Modern Warfare 2. Jogava sempre desde manhã até a noite. Agora, depois da venda tenho que levantar cedo pra trampar em uma empresa no setor administrativo. Levantar cedo e trampar de verdade é muito mais difícil, mas tenho que concordar que não fazer nada e só jogar é realmente enfiar a vida no cu. Acordem nerds, vamos trabalhar de verdade e parar de ficar fazendo da vida um eterno joguinho, porque na vida real, joguinho não te ajuda em nada! - diz Felipe.

Em contrapartida, outros jogadores elaboram respostas afirmando que jogar videogames profissionalmente é uma atividade justa e um trabalho propriamente dito - inclusive, para alguns, o trabalho dos sonhos. Há aqui uma espécie de guerra de conceitos, categorias, noções e identidades:

- Como "falta do que fazer" se eles estão FAZENDO alguma coisa? Você acha que um cara que joga 10 horas por dia não considera isso um trabalho? Se ele for patrocinado e pago, porque não fazer? - retruca Vismael.

- Sem vida? Sem vida é quem acorda cedo, passa o dia trampando e só volta pra casa à noite. Queria eu ter uma vida de jogador assim - Dario.

Para alguns usuários de videogame, ainda que poucos, a soma de dinheiro e prestígio mostra-se muito atraente na prática desta atividade.

- Isso é a vida que eu pedi a Deus. Ganhar a vida jogando e ainda ser homenageado por isso. Mano, quem não quer isso? - Lucas.

- Quem fala que os caras são vagabundos morrem de inveja e queria estar no lugar deles, porra pra estar lá é um dom mano, os caras jogam pra caralho, queria eu, ganhar dinheiro, viajar vários países só jogando videogame. Ia ser massa! - Nieow.

Outros comentários ressaltam a aproximação entre o treinamento de esportes de alta performance e os videogames, que exigem treino e preparação:

- Gamer profissional já é realidade há anos. Se um cara precisa passar 10, 15 horas por dia treinando é porque a profissão exige isso. Ele é patrocinado como qualquer outro atleta e respeitado por milhares de fãs. A cultura na Coréia do Sul é outra - Luiz Gustavo.

- Vida de gamer não é mole não, encarem a realidade - gdc23.

- O lance é que ninguém faz o comentário "sem-vida" para o cara que passa 15 horas por dia treinando dentro de um ginásio. Eu não entendo como pessoas que jogam videogame ainda têm preconceitos bobos contra videogames. Starcraft é gigante na Coreia do Sul, lá esses caras fazem dinheiros e ficam famosos. Um campeonato atrai multidões. Recentemente teve até um escândalo que virou caso de polícia, pois descobriram jogadores que estavam perdendo 
propositalmente por causa de acordos feitos com apostadores. Ou seja, eles treinam o dia inteiro porque ganham dinheiro com isso - Fernando.

- Sugiro que vocês procurem a namorada do Grubby, jogadora de Starcraft, grande rival do Moon. Orientais em geral são tímidos e reservados, não significa que são nerds. Campeonatos da Ásia são extremamente badalados, diferente do Brasil. Esses putos têm fãs (incluindo mulheres). Certamente eles se dão bem melhores que a maioria dos brazucas baladeiros - Juan.

Condenando ou louvando, os jogadores de videogame mostram uma mudança no envolvimento com os jogos a partir de sua profissionalização: jogar deixaria de ser lazer - desfrute, brincadeira - para ser trabalho - duro, repetido e sério.

- Ah, na boa, acho que jogar desse jeito perde toda a graça. É como assistir um filme em fast forward - Marc.

- Eu sempre sonhei em ser um gamer profissional, mas não sabia que teria que desistir da vida. Eu provavelmente irei continuar um amador mesmo - Thomas.

Daigo Umehara, considerado o melhor jogador do mundo em jogos de luta no ano de 2011, quando questionado sobre a situação no Brasil, onde os chamados esportes eletrônicos não são encarados com seriedade, respondeu:

Vivemos a mesma situação por muito tempo no Japão. Lutamos contra a noção de que "um videogame é apenas um jogo, nada sério". As pessoas nunca encararam isto com seriedade. Então eu entendo a dificuldade pela qual o brasileiro está passando. Mas a situação no Japão mudou vagarosamente ao longo dos anos. Eu verdadeiramente acredito que isto pode mudar no Brasil também $^{146}$.

Segundo Umehara, o principal obstáculo dos jogadores profissionais é que esta mudança de envolvimento ainda não seria reconhecida por outros atores, e, portanto, desvalorizada sob o argumento de que a pessoa não trabalharia de verdade e ganharia a vida na moleza, gerando falta de apoio, patrocínio e de reconhecimento de seus talentos.

\subsection{3 - Concepções de tempo}

Nesta seção reunimos alguns trechos de entrevistas em que jogadores falam sobre concepções de tempo envolvendo os videogames. Como os jogadores organizam as suas atividades diárias e como os videogames entram (ou não) nessa divisão de tempo? Qual seu grau de comprometimento com tais atividades? O quê consideram útil e produtivo? Quais concepções de lazer e trabalho, tempo livre e tempo ocupado estão manipulando?

\footnotetext{
${ }^{146} \mathrm{http}: / / \mathrm{www}$. techtudo.com.br/jogos/noticia/2011/11/entrevistamos-daigo-umehara-o-pele-dosvideogames.html
} 
O jogador Orochi fala sobre o seu envolvimento com Ragnarök Online. Ele conta que o lazer invadiu o seu tempo de estudo e "atrapalhou" sua produtividade. Mas, em certo momento, quando passou a trabalhar para a própria empresa que gerencia o jogo no Brasil, tudo transformou-se, pois o jogo passou a ser trabalho. Segundo Orochi, a questão da dependência, assim, tem a ver com a mecânica específica dos games online:

Eu gostava muito de jogar. Sempre que dava, eu estava jogando um pouquinho. Joguei também o Ragnarök, inclusive depois de um tempo acabei indo trabalhar na Level Up, porque eu era envolvido bastante com esse jogo. Level Up é a empresa que tem o servidor brasileiro de Ragnarök. E muitas vezes eu gastava horas por dia jogando. Mas, teoricamente, era algo que você deveria fazer no seu lazer, então às vezes era o momento de lazer você jogar, às vezes você gastava o seu momento que deveria ser pra estudo jogando, e nessa parte eu realmente concordo que o jogo acaba sendo um vício e acaba atrapalhando muito da sua produtividade. Porque é uma coisa que prende muito a gente e principalmente jogos online, como Ragnarök, tem muita gente que está jogando ali praticamente 24 horas por dia, então se você joga um pouquinho você não acompanha a galera. Você fica pra trás no jogo. Você está sempre preocupado em ficar ali jogando. - Orochi

Qual seria o conceito de produtividade que Orochi mobiliza aqui? Afinal, está se falando da produção de quê, especificamente? Neste sentido, Orochi levanta uma suspeita sobre certa valorização cultural diferenciada entre as atividades. É importante também notar neste depoimento a presença de actantes aparentemente invisíveis ou imateriais, como valores, símbolos e ideias.

Numa questão cultural, o videogame é tido como um passatempo, ele não é algo produtivo. Um livro, por mais que às vezes seja tão inútil, ou mais do que um jogo, de uma forma cultural é considerado mais "cult". Mas aí eu não acredito que isso seja por definição. Isso é mais uma projeção que as pessoas fazem. Elas acreditam que quem toca algum instrumento ou que quem pinta um quadro tem mais valor do que quem joga um jogo. Eu particularmente não acredito nisso. [...] Os jogos muitas vezes são muito mal vistos pelos nossos pais como uma coisa em que você está ali perdendo muito tempo, ou em vez de você estar produzindo algo ou fazendo algo útil pra sua vida, você está simplesmente jogando, se divertindo, jogando tempo fora. Mas tem muito jogo que acaba trabalhando muita coisa. Trabalhando raciocínio, trabalhando coordenação, tem jogo que trás muita informação histórica, geográfica etc. Acaba trazendo várias coisas pra gente. - Orochi

Ainda sobre o uso que se faz dos diferentes tempos, seguiremos com a discussão da noção de tempo livre. Para Hyou, jogador e estudante de Ciências Sociais, o tempo livre "é o tempo liberado da imposição de você estar num lugar. Na escola ou com a família, você sente que é um horário reservado pra estar se ocupando de obrigações”. Para ele, desde a infância até seus 15, 16 anos, o videogame era a principal atividade no uso deste 
tempo livre. Ele comenta que esporte e "saídas" não contavam como parte dessa categoria. Nas palavras de Hyou, o seu tempo livre era "um tempo que eu não estava cumprindo funções formais". Esta ideia, vale lembrar, em muito se assemelha à noção de liberdade negativa, tal como conceituada por Isaiah Berlin.

Marxistpokemon, desenvolvedor de jogos e professor universitário, ressalta um aspecto da liberdade positiva de Berlin. Para ele, o tempo livre de uma pessoa é um tempo criativo: "O adulto é tão imerso no cotidiano corrido que ele não consegue se dar ao tempo de aprofundar essas criações". Marxistpokemon comenta sobre as opções de atividades na infância e na adolescência e a mudança nas brincadeiras de rua:

"O quê que tem que fazer quando você é uma criança ou um adolescente?". Bem entre aspas, porque varia muito da experiência de criança e adolescente de cada um. Mas, por exemplo, uma cidade como São Paulo: "Meu, o que que você vai fazer? Você não pode sair na rua... Se você sai na rua, você não tem espaço público, você não tem outras crianças brincando na rua - em alguns lugares você tem, depende do bairro que você mora, da família que você tem, mas as pessoas que tinham esse acesso a computador, classe média, classe média-alta, classe alta, entre aspas, isso não existia. O que vai fazer? Ver TV? Jogar? Entre ver TV e jogar eu vou jogar! É muito mais legal. Vou ler. Era o que eu fazia também. E isso que eu não morava numa cidade tão grande, Campinas, que é grandinha, mas nessa época eu brinquei muito na rua em Campinas, mas conforme fui ficando mais velho foi piorando, ficou mais difícil de brincar na rua. - Marxistpokemon

Peter_pano, 27 anos, desenvolvedor de softwares, explica rapidamente a sua rotina e em que momento, dentro dela, reserva um tempo para jogar videogame. Ele conta que diminuía suas horas de sono para poder jogar, mas que isso não o atrapalhava - algo de que sua namorada logo na sequência da entrevista discorda:

Uma coisa que acontece até hoje mas eu meio que incorporei à minha rotina já, é por exemplo, eu chego do trabalho, eu começo a jogar videogame. Às vezes eu chego tarde do trabalho e eu começo a jogar videogame 11 horas da noite, eu continuo jogando videogame praticamente até duas horas da manhã ou uma e meia da manhã sem problema nenhum. E aí eu vou dormir pra acordar cedo e ir pro trabalho. Antes, quando eu acordava quatro horas da manhã pra ir trabalhar, eu ia dormir tranquilamente duas horas, uma hora da manhã porque eu estava jogando videogame. - Peter_pano

Tosas, 17 anos, estudante de ensino médio, comenta acerca da relação entre o seu uso de videogames e o ritmo das atividades escolares. Ele conta que, por exemplo, quando é época de férias, ele invade a madrugada jogando videogame: "Puta merda! Agora nas 
férias, velho, tô madrugando!". No entanto, quando é época de provas, ele diminui o ritmo e se volta mais aos estudos.

É, eu faço a lição, é, normal. Mas quando tem coisa assim, chegar semana de prova, coisa assim, eu começo a dividir, velho, eu começo a parar um pouco, joga menos... Começa a olhar mais o livro... - Tosas

Eskilu, 26 anos, conta que passava muitas horas jogando jogos na época da escola. Buscando reduzir as horas de jogo, ele trocou um jogo de MMORPG, Ultima Online, por um jogo de tiro, Counter-Strike, algo que, no final das contas, não adiantou muito.

O que eu mais joguei foi Ultima Online, foram uns 3 anos. Sexta, sétima e oitava série. Aí então eu tinha uns 12, 13 e 14 anos. Aí era imersão realmente. Pelo menos umas 8 horas, 6 horas diárias. Daí não tinha o que fazer, não saía de fim de semana... Em fim de semana devia passar de 10 horas diárias. Foi uma época bem tensa. Foi uma época até que depois eu parei pra perceber que o bagulho consumia muito tempo e daí eu parei de jogar. Daí eu comecei a jogar CS porque era uma coisa mais esporádica, mas aí na real eu percebi que no fundo eu gostava muito de videogame, porque daí eu comecei a jogar $C S$ por ser uma coisa esporádica, mas acabava fazendo corujão da Monkey [lan-house] Então passava, tipo, 12 horas jogando $C S$ de vez em quando... - Eskilu

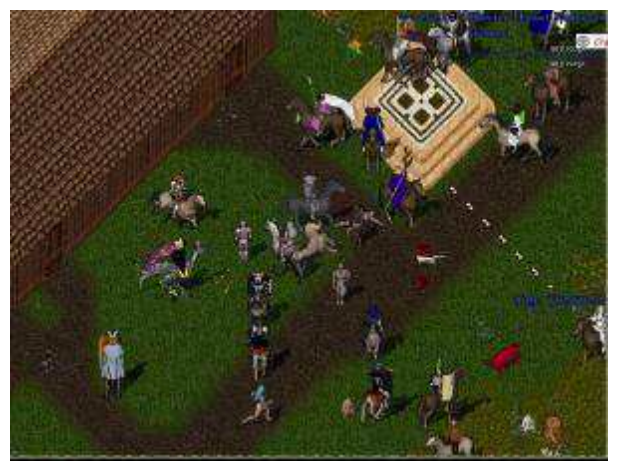

Figura 2.6 - Ultima Online (1997)

Hyou explica como era a divisão de seu tempo na época de sua infância e adolescência.

Ele conta também como o videogame passou de principal atividade de seu "tempo livre" para apenas uma entre muitas outras. Vemos que este uso não era totalmente livre, como ele mesmo explica:

Os pais também limitavam isso. Até o próprio tempo senso de ter que parar de jogar pra fazer outra coisa, também existe. Mas mesmo assim o videogame era a principal atividade dentro de casa e também nos finais de semana, na casa dos amigos. Foi o que ligava as pessoas comigo. Era o videogame. As conversas sobre videogame e jogos. E quando eu comecei a tocar música e a me interessar pela leitura eu comecei a dividir esse tempo com outras atividades do meu tempo livre. Que foi também uma coisa que veio a partir da obrigação de estar estudando pra passar no vestibular. Que, enfim, eu não queria naquela época, mas eu tinha que fazer por obrigação. Mas eu desenvolvi outras atividades 
dentro do lar, dentro de casa, que eu ocupava o meu tempo. Que a partir desse momento eu achei mais produtivo. Mais produtivo tocando, escrevendo, lendo, do que jogando videogame. - Hyou

O tema da produtividade volta mais uma vez à tona. À luz do depoimento de Hyou, podemos nos questionar: estaria a produtividade relacionada à questão etária, ou seja, com a entrada no chamado mundo adulto? Ou, ainda, a uma integração dessa atividade com outras esferas da vida, como comenta Sherry Turkle (1999)? Seguindo essa linha, uma atividade seria considerada produtiva quando gerasse benefícios ou implicações para além da própria atividade; no caso, para além do jogo. Isto retoma a hipótese de que o problema dos games acusado por certos terapeutas e psiquiatras seria estes se tornarem um fim em si mesmo (característica a qual, por outro lado, se constitui como fundamental na definição de jogo de Huizinga).

Esta acusação, portanto, classificaria os videogames como meramente improdutivos. Isso, no entanto, atropela as falas dos jogadores que demonstram os efeitos dos jogos em suas vidas (sejam estes positivos ou negativos) e mesmo as fronteiras borradas entre o jogo e o não-jogo. Então, se seriam improdutivos porque não se integram com outras esferas da vida, poderíamos supor que o videogame se encerra em si mesmo? Isto, no entanto, não aparece na maioria de nossos relatos, que apontam, ao contrário, para benefícios extensivos aos jogos, como conta Eskilu.

Eu não consigo descrever o tanto de conhecimento que eu consegui adquirir, desde algumas palavras em japonês [...] por causa de Pokémon. Eu consegui aprender mitologia grega por causa de Age of Mythology. E os caras realmente fizeram um jogo cujo conteúdo é pesquisado, é bem-feito. [Este jogo] tem mais conteúdo do que vários filmes que eu já vi sobre mitologia. E eu já vi me ajudar na vida prática. Com conhecimentos que eram pra ser totalmente "julgados" pelos outros fúteis, já me foram úteis. - Eskilu

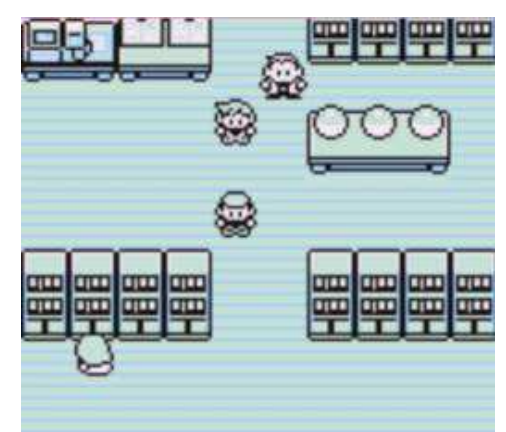

Figura 2.7 - Pokémon (199X)

Vemos que no jogo há uma série de implicações na vida de quem joga e de quem não joga. A proposição de que o jogo é improdutivo, portanto, somente procede se forem 
adotadas definições naturalistas de "produtividade" e "necessidade", ligada aos seus supostos atributos "biológicos". Aliás, como Huizinga escreve, o jogo é necessário e até culturalmente útil: "Em sua qualidade de atividade sagrada, o jogo naturalmente contribui para a prosperidade do grupo social, mas de outro modo e através de meios totalmente diferentes da aquisição de elementos de subsistência" (1938, p. 12).

Na contramão de concepções como "tempo livre" e "tempo ocupado", os próximos trechos trazem depoimentos em que os jogadores abordam as suas relações de comprometimento com o jogos. Peter_pano conta como era o seu envolvimento com o jogo Call of Duty - um jogo de tiro em primeira pessoa (FPS, abreviação de First Person Shooter) - em comparação com um esporte. Ele aponta o foco em um só jogo como a característica mais marcante deste período descrito:

Quando eu comecei a jogar Call of Duty, que é um FPS, comecei a sentir que eu estava jogando bem e tudo mais... Eu fui chamado pra participar de um clã, que é basicamente um grupo de pessoas que se unem e jogam de maneira organizada. Nessa época, a gente tratava o jogo não simplesmente como um jogo, mas como um esporte, como se eu fosse um jogador de futebol. A gente treinava todo dia, tinha horário marcado pra treinar, tinha períodos que a gente treinava. E era basicamente todo dia às 6,7 horas da noite, e a gente jogava duas, três horas seguidas pra treinar pra tentar participar de competições. Foi uma fase que durou por volta de sete meses e foi a época que eu joguei mais um jogo repetidamente, repetitivamente. Mas não que tenha alterado o tempo que eu gastava em jogos, porque era mais ou menos sempre isso. Simplesmente foi uma época que eu peguei todo o tempo que eu tinha em jogos e foquei em um. Desde antes eu já jogava praticamente de duas a três horas por dia, exceto final de semana. Então, não é questão do jogo em si, o jogo, o mundo do videogame. Foi uma questão de foco e não de alteração na minha rotina. - Peter_pano

Peter_pano encara os jogos de uma forma muito séria: para ele "videogame não era brincadeira". O sério aqui tem a ver com treino, repetição, preparação, alta performance, cobrança, compromisso - diferente do desinteresse, autonomia e liberdade, explícitos nas concepções de Huizinga e Dumazedier de jogo e lazer.

A questão de você chegar e assumir aquilo como uma responsabilidade e não mais como uma brincadeira. Aquilo deixava de ser uma brincadeira, passava a ser algo muito importante, algo sério, onde você tinha que realmente se empenhar, melhorar, treinar todo dia. Se você deixasse de treinar todo dia, primeiro que você acabava se sentindo mal porque ia perdendo um pouquinho daquelas habilidades e segundo que existia uma cobrança num nível quase como se fosse um trabalho. Compromisso que você assumiu e você tem que cumprir, porque você além de você se cobrar, o que mais gera cobrança é o fato de você ter sido selecionado pra fazer parte de uma coisa elitizada. Além de jogar o jogo, você faz parte de um grupo de elite dentro daquele jogo, numa competição de elite. Isso faz com que realmente tenha uma cobrança interna e 
externa, porque se você simplesmente abandonar e deixar de lado, você além de deixar de fazer parte dessa elite, provavelmente você vai desfalcar o seu time que depende de você em algum aspecto, se você foi selecionado você tem alguma coisa diferencial que soma àquela equipe. É praticamente como se fosse um esporte mesmo, futebol, basquete... - Peter_pano

Orochi comenta sobre o comprometimento nos videogames citando dois casos: no primeiro, há um vínculo com um trabalho profissional, mais próximo das concepções modernas de trabalho; no segundo, concepções que não envolvem o aspecto financeiro, mas o gosto pessoal, sem deixar de manter com os games uma relação de sério compromisso. Já para Eskilu, o grau de comprometimento depende também do jogo, pois cada jogo apresenta possibilidades diferentes de engajamento e exige determinados tipos de dedicação (apesar das diferenças de relação entre pessoa e jogo).

Depende muito do jogo, mas sempre tem um comprometimento, porque vai precisar de tempo. E tempo é o negócio mais difícil da gente arrumar hoje em dia. Você vai ter que sacrificar uma hora que você ia estar fazendo outra coisa pra fazer isso. - Eskilu

Tosas complementa que há um comprometimento no sentido de se esforçar para realizar as aspirações mentais:

No Skyrim, você quer ser aquele personagem, virar aquela pessoa. Tipo, você está usando o chaos, quer ser um mago, você vai fazer as quests relacionadas a mago ou algo que te dê uma recompensa relacionada à tua classe, que tu queira fazer na tua mente. Então é meio que um comprometimento mesmo. - Tosas

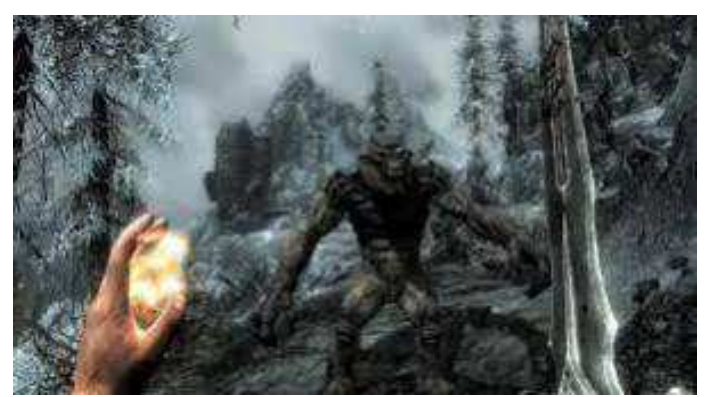

Figura 2.8 - Elder Scrolls V: Skyrim (2011)

A partir dos depoimentos, podemos formular que o comprometimento é uma categoria pertinente na qualificação dos atores acerca de seu envolvimento com os videogames. Verificamos também nessas falas um questionamento de um utilitarismo puro e de afirmações de que os jogadores escolheram jogar "livremente". Enfim, poderíamos multiplicar os exemplos, mas para os objetivos da discussão proposta neste capítulo há material suficiente para impactar a reflexão teórica e encaminhar algumas conclusões. 


\section{7 - Por graus de comprometimento}

Começamos neste capítulo discutindo os conceitos de jogo, lazer e trabalho, a fim de entender por que, afinal, os jogos são considerados por certos terapeutas e teóricos uma atividade ilegítima e passível de geração de comportamento dependente, enquanto o estudo e o trabalho as únicas atividades legítimas, e não pensadas, em geral, como viciantes. No entanto, isto não significa que não haja controvérsias acerca dessas definições. Basta ampliarmos a rede para ver que há aqueles que reconhecem e outros que não reconhecem alguma produtividade nos jogos.

Vimos que, numa perspectiva moderna (LATOUR, 1994), o lazer é entendido em imediata oposição ao trabalho (MARCELINO, 1990; DUMAZEDIER, 1976; HUIZINGA, 1938). Assim, o trabalho é visto como uma atividade produtiva, maçante, repetitiva, obrigatória e recompensadora - oposto ao lazer (e por consequência ao jogo, inclusive o videogame), que seria, em tese, improdutivo, prazeroso, criativo, livre e desinteressado. Já se adotarmos uma perspectiva sociológica contemporânea, trabalho também pode ser entendido como uma atividade criativa, prazerosa, de horário flexível, não-repetitiva e não necessariamente produtiva - como descrevem autores que acompanham recentes mudanças na sociedade do trabalho, por exemplo, o regime de acumulação flexível (SENNETT, 1999). Por outro lado, jogar videogame, como demonstraram jogadores amadores ou profissionais, pode se tornar do mesmo modo uma atividade repetitiva, maçante, comprometida e produtiva - com vistas a fins como a subsistência material - tal qual inerente a uma concepção moderna de trabalho.

O ponto, afinal, é que, ao praticar uma antropologia da ciência e da modernidade, não se deve tratar as noções de jogo, lazer e trabalho como categorias que pairam num nível epistemológico distinto das chamadas categorias nativas, pois são tarefas enunciadas pelos agentes e inseridas em um sistema de classificação propriamente moderno e conferidas de uma carga simbólica invocada por tais categorias. O presente trabalho pode ser entendido como um esforço para simetrizar estas formas de classificação.

Ao invés de separar as categorias nativas e analíticas, parece mais interessante reconhecer o analítico ou explicativo nas reflexões dos nativos, como sugere Eduardo Viveiros de Castro (2002). Para o antropólogo americanista, "é preciso saber transformar as concepções em conceitos, extraí-los delas e devolvê-los a elas”. Um 
conceito é, assim, uma relação complexa entre concepções, um agenciamento de intuições pré-conceituais. Viveiros de Castro entende que, no caso da Antropologia, as concepções em relação incluem "antes de mais nada, as do antropólogo e as do nativo". Sua hipótese é de que "os conceitos nativos são os conceitos do antropólogo" (p. 128).

Até aqui permanecem em aberto muitas questões ${ }^{147}$. Mas, certamente, podemos afirmar que a oposição estanque entre lazer e trabalho foi colocada em risco na etnografia. À parte da sua representação numa face oficial, vemos que, para um jogador esta atividade pode adquirir um sentido muito próximo ao que se entende por trabalho nas sociedades modernas, ao mesmo tempo em que pode ser classificado como lazer por alguém que esteja observando o jogo de fora.

Em sintonia com as ideias de Chiquetto (2012), sugerimos, por fim, adotar o conceito de graus de comprometimento para medir o engajamento das pessoas em suas tarefas cotidianas (na perspectiva de Ingold), além de elencar as suas prioridades. Para ele, "deve-se ampliar a categoria de lazer, desvinculando-a da categoria de tempo livre, para que se possa compreender de que modo diferentes coletivos humanos investem seu tempo em diferentes atividades" (2013, p. 9). Não se trata de um engajamento individual da pessoa com a tarefa, mas de um comprometimento em rede, que considera a agência de todos sobre esse um e desse um sobre todos os demais.

É importante ressaltar que todas, absolutamente todas, as tarefas são sociais em relação com humanos ou não-humanos (apud LATOUR, 2005) - e nenhuma ação é inteiramente desprovida de compromisso (em nota: mesmo essa mensuração entre mais e menos compromisso deve ser também problematizada, mas como se trata de um discurso amplo e através do qual os agentes organizam suas ações, torna-se fundamental para a análise da organização das tarefas no tempo e no espaço) (CHIQUETTO, 2012, p. 21-22).

As perguntas mais frutíferas aqui seriam: que associações estariam levando uma pessoa a fazer tal coisa? A que isso está se ligando: pessoas, coisas, ideias, recursos materiais e tudo mais? Nossa proposta, mais do que descobrir uma causa, é desvendar essa rede de agenciamentos. Investigando o conjunto de atividades das pessoas e elencando as suas prioridades, poderemos chegar a uma compreensão mais fiel de seu cotidiano, mais do que se mantivermos como instrumento de análise a dicotomia trabalho versus lazer e tudo aquilo de problemático que esta oposição carrega consigo.

${ }^{147}$ Embora muitas delas não sejam exclusivas aos jogos, pois podem ser colocadas para as atividades legitimadas do trabalho, os games podem trazê-la à baila de um modo privilegiado 


\section{Capítulo 3 - O real e o virtual: mundos distintos?}

Resumo: Neste capítulo pretendemos abordar as controvérsias envolvendo o aspecto virtual (ou da comunicação mediada por computador) da dependência de jogos eletrônicos. Iniciamos com uma breve retomada teórica dos principais pontos em discussão. Em seguida, exploraremos os pontos de contato e afastamento entre as dependências de internet e de videogame, para destrinchar controvérsias específicas sobre sensibilidade, corporalidade, materialidade, comunicabilidade, sociabilidade e escapismo presentes nos enunciados acerca da dependência. Os "mundos virtuais" seriam realidades apartadas do que se entende por "vida real"? A partir da etnografia desenvolvida em campo, buscaremos descrever o sentido do que se entende por realidade e virtualidade em diversas perspectivas: a dos próprios gamers, de seus parentes, desenvolvedores de jogos e cientistas. Por fim, resgataremos o conceito de equivocação não-controlada para lidar com possíveis equívocos de comunicação emergidos entre as diferentes perspectivas.

Palavras-chave: virtual; videogame; realidade virtual; dependência.

\section{1 - Vida real}

Em diagnósticos psiquiátricos de tratamento de dependência de videogames, assim como na fala dos jogadores, inclusive dentro dos próprios games, é comum ouvir a expressão "na vida real", ou em inglês, "In Real Life" (IRL $\left.{ }^{148}\right)$, para distinguir a experiência de fora da tela de jogo daquela própria do game. Apesar de existirem diversas ressalvas a esta oposição (que serão descritas ao longo do capítulo), verifica-se que muitos jogadores ainda adotam a expressão "na vida real" para distinguir e referirse aos acontecimentos fora de jogo daqueles da própria experiência com os videogames.

Nas controvérsias sobre a dependência de jogos eletrônicos, este é um ponto-chave: se admitirmos que o jogo de videogame está associado ao não-real ou ilusório, o tratamento, então, deveria buscar retirar o jogador deste falso mundo e realocá-lo no "mundo verdadeiro" - o das relações sociais (lêe-se aqui: relações presenciais entre humanos). A questão que logo emerge é: $\mathrm{O}$ que acontece na tela seria de fato uma experiência fora da vida real? A experiência do jogo eletrônico é, afinal, considerada totalmente real, possui algum grau de realidade ou é meramente ilusória?

\footnotetext{
${ }^{148}$ Este termo é geralmente utilizado na internet para se referir a algo do "mundo real" e não no "mundo da internet". Também pode ser usado para diferenciar um ator/atriz do personagem que ele/a interpreta. O documentário IRL - In Real Life (2012), de Anthony Rosner, conta a história de um avatar do game World of Warcraft e de um jovem viciado neste jogo - curiosamente, o próprio diretor do filme. Disponível em: http://vimeo.com/35199868
} 
Como vimos no capítulo anterior, para o filósofo Johann Huizinga (1938), o jogo não se limita à vida mundana ou cotidiana, mas cabe a uma dimensão extraordinária. No seu entedimento, “o jogo não é vida 'corrente', nem vida 'real'. Pelo contrário, trata-se de uma evasão da vida "real" para uma esfera temporária de atividade com orientação própria (p. 11). Este espaço e tempo próprios do jogo são chamados por Huizinga (e por alguns de seus comentadores) de círculo mágico (vide capítulo 2). Se equiparássemos o que este autor chama de vida cotidiana ao que discutimos aqui por vida real, poderíamos cair no engano de acusá-lo de não considerar o jogo parte da vida das pessoas. Entretanto, o argumento central de Huizinga em Homo Ludens é que jogo é um elemento constituinte da cultura e forma estruturante da vida social, de modo que este não é tratado como ilusão ou irrealidade, mas o contrário.

O sociólogo finlandês Vili Lehdonvirta (2010) coloca que a dualidade "real-virtual" em alguns estudos de jogos de MMORPGs (também apresentados no capítulo 2) pode ser vista como uma herança de duas tradições anteriores: a dos jogos e da internet. Nessa última, o uso de termos constrastantes como "IRL" (In Real Life) e "ciberespaço" ilustra o pensamento de que a comunicação mediada pela rede é uma atividade que acontece num espaço distinto e separado dos assuntos do "meatspace" (espaço de carne e osso). Uma expressão muito clara e influente deste pensamento é A Declaração de Independência do Ciberespaço, de John Perry Barlow ${ }^{149}$ (1996). A essência deste manifesto é que um mundo novo e muito diferente do antigo está surgindo na internet.

\begin{abstract}
Mundos virtuais são agora uma realidade. Os mundos virtuais permitem a todos criar um personagem digital para representar a si próprios e interagir em tempo real com outros indivíduos, paisagens, empresas administradas virtualmente e instituições virtuais - todos também criados por computador. De maneira fascinante, ambas as ordens endógenas, econômica e social, estão emergindo a partir desses mundos virtuais. Candidatos políticos estão fazendo campanha em mundos virtuais, enquanto algumas vendas de bens virtuais estão produzindo demanda no mundo real para itens equivalentes (BARLOW, 2007, anúncio de conferência, tradução nossa).
\end{abstract}

$\mathrm{Na}$ declaração de Barlow, o ciberespaço, local onde os games seriam jogados, aparece como um domínio independente: isto é, um mundo à parte. Outros autores, como Vili Lehdonvirta, apontam a fragilidade desta separação e questionam o quão enganosa se torna a repartição teórica e discursiva entre mundos reais e virtuais.

149 John Perry Barlow é um dos três fundadores da Electronic Frontier Foundation (San Francisco, Califórnia, EUA), uma organização sem fins lucrativos cujo objetivo declarado é proteger os direitos de liberdade de expressão na era digital. 
Nossa hipótese preliminar é a de que estamos diante de uma dupla encruzilhada: o virtual do game não seria considerado real (por seu aspecto computacional, ligado à artificialidade das máquinas e dissociado dos humanos), assim como o jogo (por seu aspecto lúdico, apartado da esfera da seriedade e do trabalho, como vimos no capítulo anterior). Fruto de tais associações, a experiência do game estaria, desse modo, afastada da chamada "vida real". A própria palavra videogame seria, assim, uma combinação destes dois aspectos supostamente "irreais": o virtual e o lúdico.

Defrontamo-nos, assim, com uma possível afirmação (elencada a partir da leitura do material de pesquisa) que norteia a discussão deste capítulo: Videogames causam dependência porque criam uma realidade virtual que leva os jogadores para fora de suas vidas reais. Diante desta afirmação, buscaremos abrir as caixas-pretas que as sustentam. Para isso, a descrição etnográfica deverá descrever e evidenciar, afinal, que noções de real, virtual e de dependência estão circulando nesta rede. Quais são elas? Onde estão ancoradas? Quais seus pontos de desencontro?

Quando, a partir da etnografia, o que acontece no jogo não for considerado real ou não fizer parte da vida real de determinados atores, buscaremos entender o que estes, afinal, consideram "vida real". Para tanto, investigaremos as bases nas quais estão amparadas tais clivagens e onde se encontram os videogames no meio disso. Quando jogar videogame, por outro lado, for encarado por certos actantes como uma experiência concernente à "vida real", nos interessará mapear o que mais acontece nestes jogos (suas atividades e objetivos de jogo, como matar monstros, passar de fases, evoluir o personagem etc.), observar as conexões estabelecidas pelas pessoas com os demais aspectos da vida e entender as diferenças criadas por meio destas práticas.

Neste sentido, nos interessa investigar as passagens, como, por exemplo, quais são os efeitos de uma experiência in-game para a vida de uma pessoa fora do jogo e vice-versa. Buscaremos, em suma, mapear o que se entende por "real" e "virtual" ao longo desta rede. Afinal, estaríamos aqui nos referindo a reais diferentes ou a uma só realidade vista de várias formas? Em outras palavras, estaríamos diante de múltiplas realidades ou de uma só realidade enxergada a partir de diferentes pontos de vista? Não devemos esquecer, em meio a isso, que há um papel cosmopolítico (LATOUR, 1999; STENGERS, 2003) presente nestas classificações e que é possível rastrear os efeitos de 
tais agenciamentos. Estaríamos, pois, diante de uma disputa pelo real? Será sobre estas e outras questões que nos debruçaremos neste capítulo.

\section{2 - O real em jogo}

\subsection{1 - Dependências do virtual}

Como enfocamos o caráter lúdico dos games no capítulo anterior, nos concentraremos agora em seu caráter virtual. Pois, além de serem jogos (num sentido mais amplo, associado ao lúdico), os videogames possuem certas características específicas: diferente dos jogos esportivos ou jogos de cartas, eles são mediados por dispositivos eletrônicos - em geral, por meio de um computador, console, tablet ou celular - e acontecem num espaço chamado virtual ou cibernético ${ }^{150}$.

Isso aproxima os videogames da internet, de telefones celulares e da temática mais geral do vício digital. Ao contrário de autores como a psicóloga Kimberly Young (1998), que tratam praticamente da mesma forma os usos de internet e de videogames, e apontam a interatividade e a imersão de ambos como os fatores causadores da dependência, há outro ramo do discurso médico (GRIFFITHS, 2005; LEMOS; SANTANA, 2011) que procura discernir um do outro e acusar exclusivamente os games de um potencial viciante.

Em resposta a Young, Griffiths (1999, 2000a) argumentou que muitos desses usuários excessivos não são "dependentes de internet", mas que estes usam a internet excessivamente somente como um meio para alimentar outras dependências. Simplificando, um dependente de jogos de azar ou um dependente de jogos de computador que se engaja em um comportamento online não é dependente de internet. A internet é apenas o lugar onde eles se engajam em seu comportamento (GRIFFITHS; DAVIES, 2005, p. 360, tradução nossa).

Por outro lado, o videogame e a internet compartilham uma série de características por participarem do "mundo digital": são eventualmente classificados como atividades virtuais, em que a corporalidade do ser humano estaria comprometida por supostamente não operar com toda a potencialidade de seu aparato sensitivo. Nesta perspectiva, eles proporcionariam experiências incompletas, menos humanas, ou até mesmo falsas.

\footnotetext{
${ }^{150}$ Isso de forma alguma está desconsiderando os aparatos materiais que são necessários não só para o jogo acontecer (como a tela, os controles, o hardware, o console, o sinal de conexão com a Internet, o corpo dos jogadores), como são também fundamentais mediadores nesta rede, pois agem e provocam alterações na forma com que o jogo é jogado.
} 
Suspeitamos, mais uma vez, que a combinação desses diversos elementos conformariam associações negativas em torno dos videogames.

Por exemplo, Lister et al. (2003) indicam uma dicotomia entre formas de comunicação mediadas por computador (CMC) e videogames, apoiada respectivamente em várias das seguintes oposições binárias: conteúdo criativo versus entretenimento estúpido; usuários adultos versus consumidores jovens; identidade fluida versus hipermasculinidade; socialidade versus espaço mercantilizado; ferramenta versus brinquedo. Mais importante: onde a internet é vista como imersiva e produtora de interatividade, os games são vistos como viciantes (LISTER et al., 2003).

Cover (2006) promove uma leitura crítica do trabalho fundador de Young (1998) Caught in the Net, no qual esta última considera o espaço de comunicação digital, textualidade digital e engajamento interativo como um mundo de faz-de-conta ${ }^{151}$, que tem consequências perigosas para a identidade e para o comportamento pessoal.

Ao impor uma distinção rigorosa e mais simplificada entre o comportamento da "vida real" e o comportamento "virtual", ela valida um falso conceito de realidade sobre a digitalidade. Sua preocupação é que, passando o tempo online, as inibições seriam quebradas e as pessoas passariam a digitar "palavras que nem sonhariam em dizer em sua vida real" (YOUNG, 1998 apud COVER, 2006, tradução nossa).

Young (1998) teme que os usuários intensivos (hard users) de internet negligenciem a sua vida real: "outros membros da família e amigos de viciados em internet lamentam a perda total, pelo viciado, de interesse em passatempos outrora preciosos, como ver filmes, ir a festas, visitar amigos, conversar durante a refeição" (1998, p. 7, tradução nossa). Este ponto ecoa o lamento do filósofo francês Paul Virilio de que:

quando as coisas distantes são trazidas para a proximidade imediata, aqueles que são proporcionalmente próximos - como amigos, parentes, vizinhos transformam o que é próximo - a família, trabalho ou bairro - em estrangeiros, quando não em espaço hostil (VIRILIO, 1993, pp. 10-11, tradução nossa).

Young associa o "tempo engajado em comunicação digital e entretenimento" ao "tempo expirado" (isto é, tempo "gasto em vão"), o que acaba por enfatizar o caráter físico e local como o real, enquanto trata o espaço imaginário do digital como virtual e falso, isto é, como o ambiente de uma forma mais baixa de comunicação e experiência, que é

${ }^{151}$ É neste sentido que Richard Bartle define virtual como: "aquilo que não é, tendo a forma ou o efeito de que é" (2003, p. 01). 
considerada viciante por si só. Para a psicóloga, o tempo dispendido online é o principal critério para indicar a dependência: "Na minha pesquisa, 97\% de todos os entrevistados relataram que gastaram mais tempo online do que pretendiam" (YOUNG, 1998, p. 36, tradução nossa).

Ainda segundo Cover (2006), outro problema conceitual no trabalho de Young está na maneira como determinados arranjos sociais são representados não apenas como normativos, mas também como desejáveis. Em favor de sua concepção de "vida real" sobre o enganoso "virtual", ela privilegia as relações físicas e geograficamente locais sobre a comunicação, o entretenimento e a procura de informação em formato digital, além de celebrar a família suburbana e conservadora (lembremos também que ela escreve dos Estados Unidos) como uma unidade social hermeticamente selada de amizades, relações e práticas comunicativas que ocorrem por meios digitais e através de longas distâncias.

Os jogadores de $\mathrm{MUD}^{152}$ (DAVIS, 2001), por exemplo, são vistos por Young como pessoas que ignoram suas famílias reais, que "estão na sala ao lado" (1998, p. 89), e esta lamenta o fato de que já não mais "conhecemos os nomes das pessoas ao nosso lado", e que as famílias "quase nunca comem juntas" (1998, p. 113-114): o slogan de uma articulação conservadora e normativa da vida doméstica. A solução que Young oferece para a dependência digital é baseada em uma combinação de vigilância e alarmismo, apelando para um nível de vigilância dos outros e de nós mesmos, que lembra o panóptico descrito por Foucault (1995).

Um viciado em Internet pode ser seu melhor amigo, seu próprio filho, seu pai, seu parceiro ou seu empregado. Um viciado em Internet pode ser o presidente do banco local ou seu custodiante, o diretor de uma escola pública ou um estudante regular. Ou você! (YOUNG, 1998, p. 30, tradução nossa)

Para Cover (2006), as formas discursivas e estratégias de articulação do conceito de dependência digital trabalham por meio de um conjunto conservador de ideias sobre o comportamento humano, normatividade e mudança. Tais formas e estratégias não são diferentes do discurso que alimenta um pânico moral alarmista sobre o uso de jogos eletrônicos, que são vistos como algo anormal, produtor de violência e jogados por “pessoas impróprias". Estaríamos, assim, propondo reconhecer que essas acusações

\footnotetext{
${ }^{152}$ Abreviação para Multi-User Dungeon, jogo eletrônico para multijogadores em formato de texto.
} 
pressupõem uma dificuldade intrínseca com a diferença, como é próprio do pensamento conservador. E a internet e os jogos eletrônicos aparecem como sede privilegiada das diferenças.

Em suma, junto com esta crítica de Cover, vimos que o conceito de "virtual" nas teorias predominantes sobre dependência digital nas áreas médica e psicológica (considerando evidentemente que isto não é consenso nem mesmo dentro dessas disciplinas) aparece posto em paradoxo com uma visão própria do que se considera "real". A seguir proporemos uma revisão destes termos a partir de outra chave teórica, alinhada aos trabalhos mais recentes de Antropologia da Ciência e da Técnica.

\subsection{2 - O real, o atual e o virtual}

De fato, sempre se admitiu que a "realidade" não é inteiramente imutável. É este o ponto de partida da tecnologia - e, sem dúvida, da política. Ambas as esferas se assentavam no pressuposto de que o mundo podia ser dominado, modificado, controlado. Adotando as convenções da tecnologia e da política, a questão de como modelar a realidade era, portanto, uma questão em aberto: algures no futuro, as coisas poderiam passar-se de outra forma. Mas, ao mesmo tempo, partia-se do princípio de que as peças constituintes da realidade eram permanentes: poderiam ser descobertas através de investigação científica adequada (MOL, 2007, pp. 2-3).

Para enfrentar a dualidade entre real e virtual presente nos trabalhos anteriormente mencionados, um caminho interessante é voltarmos aos clássicos para estudar a genealogia dos termos. Segundo o cientista social Rodrigo Fonseca (2006, p. 2), o esquema do virtual aristotélico começa por distinguir, na gestação contínua da realidade do universo, uma relação dialógica entre o "real" e o "possível”. Sob a rubrica da tensão dialética, Aristóteles instituiu uma equivalência entre atual (ato) = real; e virtual (força) $=$ irreal ou ilusório. Todo e qualquer movimento do mundo trata-se, deste modo, de um jogo agonístico, por meio do qual surge um par de conceitos opostos que ele chama de "dynamis / energeia".

Fonseca (idem) ainda comenta que Aristóteles recorria então à noção de virtual para justificar a ontológica oposição entre "possibilidade" e "existência". A lógica do sistema aristotélico obedecia ao princípio da identidade, da recognição e da nãocontradição no pensamento, cuja premissa dispunha que não seria possível existir, ao mesmo tempo, "A" e "não-A". Isso quer dizer que, entre várias possibilidades, apenas 
uma era realizada em cada momento, sendo que o virtual serviria apenas para hierarquizar, com a sua força germinal, as possibilidades realizáveis.

A fim de trabalhar com uma concepção não-hierárquica da relação entre o "real" e o "virtual", diferente de Aristóteles, podemos recorrer aos conceitos do velho sociólogo Gabriel Tarde (1910). Para este autor, o real não é hierarquicamente superior aos possíveis (virtuais), pois estes são condição de possibilidade daquele. Em Tarde, os possíveis não são menos reais (senão o contrário, mais reais) que o próprio real: este é apenas um aborto, um sacrifício, um "dispêndio dos possíveis".

O filósofo contemporâneo Pierre Lévy (1996), estudioso das tecnologias digitais, em sua obra $O$ que é o virtual? retoma as noções de outro filósofo, Gilles Deleuze, para cunhar outro entendimento das noções de real e virtual. Para Lévy, começamos por desfazer esta falsa oposição:

Consideremos, para começar, a oposição fácil e enganosa entre real e virtual. No uso corrente, a palavra virtual é empregada com frequência para significar pura e simplesmente ausência de existência, a "realidade" supondo uma efetuação material, uma presença tangível. O real seria da ordem do "tenho", enquanto que o virtual seria da ordem do "terás", ou da ilusão, o que permite geralmente uma ironia fácil para evocar as diversas formas de virtualização (LÉVY, 1996, p. 15).

Em Diferença e repetição (1988), o próprio Deleuze distingue o conceito de possibilidade e o conceito de virtualidade. Para ele, o possível se realizará sem que nada mude, em sua determinação nem em sua natureza, sendo assim um "real" fantasmático (possível). O possível é exatamente como o "real", só lhe faltando a existência. A realização de um possível é a produção inovadora de uma ideia ou de uma forma. Sendo assim, a diferença entre possível e real é puramente lógica. Lévy complementa:

O virtual não se opõe ao real, mas sim ao atual. Contrariamente ao possível, estático e já constituído, o virtual é como o complexo problemático, o nó de tendências ou de forças que acompanha uma situação, um acontecimento, um objeto ou uma entidade qualquer, e que chama um processo de resolução: a atualização. Esse complexo problemático pertence à entidade considerada e constitui inclusive uma de suas dimensões maiores. O problema da semente, por exemplo, é fazer brotar uma árvore (LÉVY, 1996, p. 16).

Eladio Craia (2009), em comentário à obra de Deleuze, postula que a diferença pode pertencer ao devir sem se manter amarrada à fundamentação da passagem do que não é para o que é, porque o virtual, isto é, a natureza da própria diferença, já é absolutamente 
real. Para este filósofo, trata-se do devir ontológico postulado entre formas da realidade, já que o atual não é mais que uma expressão do virtual como dimensão real.

\begin{abstract}
Deixando momentaneamente de lado a abrangência que o conceito de virtual tem em nossos dias, o ponto de partida deleuziano para discutir a noção de virtual e atual é aquele traçado pelos conceitos aristotélicos de "potência e ato", e pelas noções medievais de "possível real". Para Deleuze, potência-ato e possível-real, são noções que interrogam questões ontológicas, não físicas, gnosiológicas, éticas ou dinâmicas. O que se encontra em relevo nestas reflexões é o "problema do devir", isto é, da mudança ontológica, não do movimento ou dos deslocamentos fáticos dos entes. Para expor esta análise nos centraremos no problema medieval do possível-real e sua vinculação com a questão do virtual (CRAIA, 2009, p. 112).
\end{abstract}

Fonseca (2006, pp. 6-7) comenta que levar em conta a realidade do virtual em nossas vidas é assumir o paradoxo, a composição de virtualidades não-humanas e de devires moduláveis, como uma imagem-ritmo, como produtores de um imanente ethos intensivo, singular, múltiplo e criativo.

Bruno Latour (1991), em seu artigo Technology is society made durable, afirma que tudo possui o grau de realismo delineado por suas redes. Se o real é o que pode ser acompanhado nas redes, e se a existência em rede só pode ser descrita pelo o que se nela faz (existir = agir), então a diferença entre real e não-real pode ser medida pela ação em rede: o faz-fazer. Segundo Latour, então, apenas podemos reconhecer variações de realização e irrealização. Para ele, o real não é diferente do possível, do irrealista, do realizável, do desejável, do utópico, do absurdo, do razoável, do custoso. É dissolvendo a diferença entre o que muda e o ambiente no qual uma inovação muda, que simetrizamos o realizável e o irrealizável. A descrição, pois, deve empregar as mesmas ferramentas para tratar cada situação sem julgar quão uma associação é “intrinsecamente" realista ou irrealista.

Esta "nova" ontologia dos termos atual, real e virtual, proposta por este grupo de autores, nos permite quebrar a concepção antagônica entre os termos inicialmente abordados neste capítulo. Com isto, entramos em outro registro, que buscará, a partir de um foco sobre as ações e seus efeitos, evitar as clássicas cisões modernas em sua face exclusivamente oficial e purificadora (LATOUR, 1994) e abrir mais espaço para lidar com a heterogeneidade dos agenciamentos presentes nas controvérsias.

Buscando agora transitar dessa discussão filosófica para a temática do ciberespaço e da 
virtualidade, tomaremos o argumento da antropóloga lusitana Adelina Pereira da Silva.

A virtualidade, via de regra, é associada a uma "não-realidade", concepção que não é das mais adequadas para se pensar o Ciberespaço. Vários pensadores argumentam que o virtual não se opõe ao real, mas sim que o complementa e transforma, ao subverter as limitações espaço-temporais que este apresenta. Desta forma, o virtual não é o oposto do real, mas sim uma esfera singular da própria realidade, onde as categorias de espaço e tempo estão submetidas a um regime diferenciado. Esta forma de conceber o virtual (o "real virtual") é fundamental para se tratar de uma das dicotomias problemáticas dentro do campo da Cibercultura - a oposição entre o on-line e o off-line (SILVA, 2007, p. 3).

Seguindo este pensamento, Sherry Turkle (1999), socióloga contemporânea e professora do MIT, acredita que se comete um erro grave ao falar-se em vida real e em vida virtual, como se uma fosse real e a outra não. Turkle sustenta que enquanto os especialistas continuam a falar do real e do virtual, as pessoas comuns constroem uma vida na qual as fronteiras são cada vez mais permeáveis.

Se assiste, atualmente, mais entre os especialistas do que entre os usuários (seria melhor chamá-los de cidadãos) à defesa da fronteira entre o virtual e o real, ao esforço para situar certos tipos de experiência numa ou noutra dimensão. Enquanto isso os cidadãos das comunidades virtuais recusam essa fronteira e exprimem claramente o desejo humano de ter acesso aos dois aspectos ao mesmo tempo (TURKLE, 1999, p. 119).

Para ela, à medida que as pessoas passam mais tempo em lugares virtuais, acontece uma pressão, uma espécie de expressão do desejo humano de tornar mais permeáveis as fronteiras entre o real e o virtual. Assim, enquanto a maioria dos estudiosos parece querer separar o virtual do real (V-R), ela não faz essa distinção. Para evitar o emprego da palavra "real", Turkle prefere, ao invés, referir-se ao virtual e ao resto da vida (R-V),

Penso que, cada vez mais, há menos necessidade de usar uma oposição tão categórica. No futuro, as fronteiras permeáveis serão as mais interessantes para estudar e compreender. As pessoas sempre terão necessidade da "imediaticidade" do contato humano, sempre terão vontade de discutir em torno de uma xícara de chá, de ver onde o outro mora, fisicamente, com o corpo (TURKLE, 1999, p. 118).

O sociólogo Manuel Castells (1999), a partir de uma base teórica ligada à sociologia urbana marxista (distinta dos atores até então citados), que busca compreender grandes processos de transformação de uma forma mais generalista, argumenta que, no que chama de paradigma informacional, surgiu uma nova cultura a partir da superação dos lugares e da invalidação do tempo pelo espaço de fluxos e pelo tempo intemporal: a 
cultura da virtualidade real. Para Castells, virtualidade real é um sistema em que a realidade em si (no seu entender, a existência material/simbólica das pessoas) está imersa por completo em um ambiente de imagens virtuais, no mundo do faz-de-conta, em que os símbolos não são apenas metáforas, mas abarcam a experiência real.

Neste sentido, nós vivemos efetivamente no tipo de cultura que [...] chamei de cultura da virtualidade real. É virtual porque ela é construída principalmente por meio de processos de comunicação virtuais de base eletrônica. É real (e não imaginária) porque é a nossa realidade fundamental, a base material com que vivemos nossa existência, construímos nossos sistemas de representação, fazemos o nosso trabalho, nos relacionamos com os outros, obtemos informações, formamos a nossa opinião, atuamos na política e alimentamos nossos sonhos. Esta virtualidade é a nossa realidade. Isto é o que caracteriza a era da informação: é principalmente através da virtualidade que processamos nossa criação de significado (CASTELLS, 2001, p. 230).

Apesar de reconhecer a realidade da virtualidade em termos de efeitos, notamos em seu argumento uma prevalência da base material (a estrutura, nos termos marxistas) sobre a chamada cultura da virtualidade real e seu mundo de faz-de-conta (a superestrutura). Isso fica claro quando afirma que é "a base material que explica por que a virtualidade real é capaz de dominar a imaginação e os sistemas de representação das pessoas e o modo de vida delas no espaço de fluxos e no tempo intemporal" (CASTELLS, 1999). Bruno Latour (1991), por exemplo, não somente questiona esta relação de dominação como rechaça tal separação, propondo reposicionar o mundo das coisas (a tal base material) e dos humanos (e suas culturas) em bases simétricas.

Ao olhar para as controvérsias, o "real" não aparece como unívoco nem como dado de antemão. Não é autônomo por si só, nem vem desacompanhado, pois, se seguirmos as redes, veremos que há outras associações que o sustentam. Como Latour (1999), podemos mapear como essas associações se estabilizam e realizam um movimento rumo à transcendência, para se fecharem temporariamente em caixas-pretas. E viceversa, isto é, quando as associações se encontram em fase de instabilidade e suas caixaspretas são abertas, evidenciando o dissenso e questionando as suas verdades, num trânsito que evidencia a imanência das práticas e a tecedura de alianças ou cortes de rede (STRATHERN, 1996a).

O interesse nesta descrição é, pois, evidenciar formas de apreensão e construção do real. 
A isto Foucault (1984) chama de formas de veridicção ou jogos de verdade ${ }^{153}$. Nesta investigação, especificamente, nos interessa descrever o que os diferentes actantes tomam por real e virtual, seja em relação de dicotomia, englobamento, complementariedade ou de outras formas. Tendo em vista as abordagens acima recuperadas, adentraremos, pois, estes tais ambientes "virtuais" para seguir na descrição etnográfica.

\subsection{3 - Mundos virtuais}

Não subestimem os mundos virtuais e não os demonizem. Os mundos virtuais, primeiro lugar e antes de mais nada, são simplesmente um outro lugar para as pessoas se realizarem, para o melhor ou para o pior (BLINKA; SMAHEL, 2011, p. 115).

Nesta seção exploraremos os chamados mundos virtuais. Prontamente, aqui nos deparamos com algumas questões: Adentrar um ambiente virtual seria ingressar num mundo diferente deste "real" ou "presencial"? Seriam estes ambientes mundos distintos e apartados de nossas realidades?

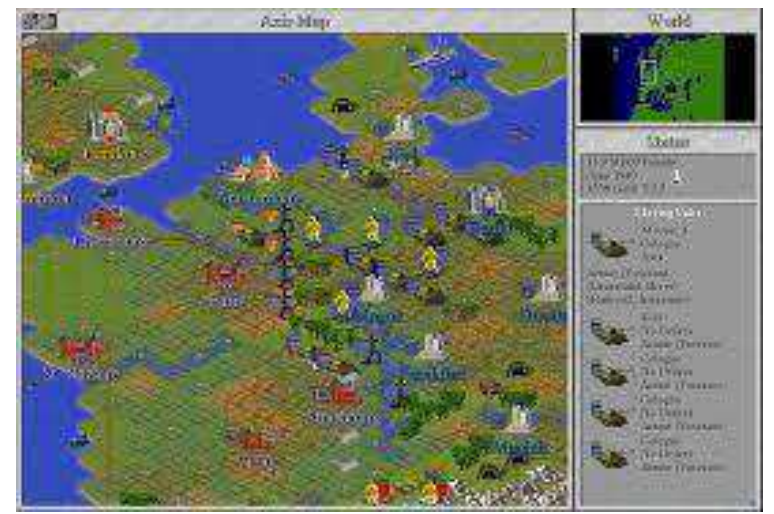

Figura 3.1 - Civilization II (1996)

Segundo Vili Lehdonvirta (2010), sociólogo e pesquisador de economias virtuais na Oxford University, na linguagem dos jogos de computador, os desenvolvedores e os jogadores têm utilizado o termo "mundo" quando discutem jogos como Civilization ${ }^{154}$, apesar deste uso ser mais um rótulo do que uma conceituação da realidade.

\footnotetext{
${ }^{153}$ Foucault define a palavra "jogo" como o conjunto de regras de produção da verdade; não se trata de um jogo no sentido de imitar, disputar ou fazer rir; é um conjunto de procedimentos que conduzem a um determinado resultado. Em função de seus princípios e de suas regras de ação, este pode ser considerado válido ou não, vencedor ou não (FOUCAULT, 1984, p. 112).

154 Civilization II é um jogo de estratégia por turnos em que cada jogador deve desenvolver uma civilização da pré-história até a idade contemporânea, administrando os aspectos domésticos de sua civilização, desenvolvendo tecnologias, e. quando necessário, guerreando com seus vizinhos.
} 
A referida dicotomia conceitual pode também ser encontrada nos RPGs de mesa (jogo de interpretação de papéis, não eletrônico), em que os jogadores usam os termos "on" e "off" para traçar uma linha entre o fluxo imaginativo do jogo (roleplay) e aquilo que não constitui parte dele ${ }^{155}$. Nos circuitos acadêmicos inspirados pelos trabalhos de Huizinga, esta fronteira é conhecida como círculo mágico.

Quando um lutador de sumô entra no "círculo mágico" do dohyō ou o pugilista profissional entra no espaço e no tempo do ringue, as regras relativas aos comportamentos sociais desejáveis e proibidos são, de repente, mudados radicalmente. Os ataques físicos, violentos e poderosos, contra outra pessoa, que normalmente são proibidos por leis e normas sociais, tornam-se o modo de conduta obrigatório (LATOWSKA, 2007, p. 8, tradução nossa).

Edward Castronova ${ }^{156}$ argumenta que os mundos virtuais são ótimos lugares para satisfazer necessidades de uma forma segura: "são mundos muito parecidos com o nosso mundo, e os seres humanos estão começando a passar muitas horas dentro deles jogando videogames" (CASTRONOVA, 2004, p. 189, tradução nossa). Para este autor, o único problema seria mundo real ser "vazado" para dentro destes mundos. Isso faria com que, segundo ele, o ato de jogar se tornasse significativo no "mundo real", estragando o jogo e privando os seres humanos de seu "direito fundamental" de jogar.

Lehdonvirta comenta que, desta forma, este autor acaba tratando os mundos virtuais como espécies de duplos computadorizados das sociedades terrenas. Ele alerta que os publicitários e a mídia convencional gostam desta forma de visualização dos MMORPGs, já que evocam imagens poderosas de mundos paralelos, provenientes da ficção científica e tornados realidade. Para os pesquisadores que se dedicam a este tema, no entanto, esta pode se tornar uma fantasia traiçoeira:

O problema com essas agendas e com vários outros estudos relacionados a MMO é que eles estão baseados em uma perspectiva que opera com a dicotomia "real-virtual" nos MMOs [...]. Nesta perspectiva, MMOs são tomados como mundos separados, localizados fora "do mundo real", de muitas maneiras espelhando-o como um duplo sintético, mas que existem independentemente dele como um planeta distante (LEHDONVIRTA, 2010).

\footnotetext{
${ }^{155}$ Num sentido interpretativo, pois ações como lançar dados e consultar regras, por exemplo, fazem parte do jogo, ao mesmo tempo que são considerados off-game. Aqui, portanto, temos dois sentidos diferentes: ações on e off do jogo; e o que é parte do jogo e o que não é.

${ }^{156}$ Professor de telecomunicações na Universidade de Indiana, EUA.
} 
Segundo Rob Cover (2006), os mundos digitais são vistos como um paradoxo que os tornam estranhos à representação do "real": eles são, ao mesmo tempo, ordenados e caóticos. Na retórica da dependência digital (DAVIS, 2001; GRIFFITHS, 1998; YOUNG; ABREU, 2011), os games são entendidos como caóticos, não-estruturados em torno de um tempo, nem centralizados; um domínio no qual categorias são misturadas, cruzadas, hibridizadas e turvas (GAILLOT, 1998). Por outro lado, as formas digitais são vistas como inteiramente estruturadas - um mundo fechado -, tanto que a estrutura do espaço da narrativa em um jogo interativo, não importa o quão complexo, é considerada simples (NEWMAN, 2002), com regras são impossíveis de se desafiar (HUMPHREYS, 2003). Ou, ainda, essas formas digitais são entendidas na chave da falta de prazer da “vida real”, do jogo físico e da comunicação face a face (CAPLAN; HIGH, 2007).

Lehdonvirta (2010) observa que o conceito de mundo virtual reúne, na mesma categoria, um servidor de MMORPG e um conjunto de diferentes grupos e instituições sociais. Com isso, espera-se que suas fronteiras coincidam e encaixem tão perfeitamente que sejam incluídas em uma mesma entidade sócio-técnica, uma sociedade e seu ambiente; em outras palavras, em um "mundo". No entanto, esses limites não necessariamente estão alinhados. Lehdonvirta relata que os agrupamentos sociais de um MMORPG frequentemente ultrapassam as fronteiras do servidor para outros servidores, fóruns, plataformas e espaços físicos.

O mesmo autor, em sua pesquisa, aponta que qualquer estudo que opte por tratar um MMORPG como um mundo, um mundo virtual, apartado do "mundo real", deve levar em conta as seguintes ressalvas: 1) o espaço que o mundo virtual ocupa não se distingue claramente; 2) a população do mundo virtual é ambígua; 3) as identidades dos seus habitantes não podem ser equiparadas a avatares; 4) os relacionamentos sociais não são limitados pelas suas fronteiras; 5) as normas e instituições externas regulam os comportamentos internos; 6) sua economia é influenciada por mudanças na economia real; e 7) sua legislação e política são moldadas por processos externos.

Segundo este mesmo autor, para encontrar um conceito que dê conta dessa relação entre o suposto mundo "real" e o "virtual" de forma mais consistente, pode-se recorrer ao conceito de mundos sociais do sociólogo Anselm Strauss. Este autor os define como "universos de discurso" (STRAUSS, 1978, p. 121), cujas fronteiras não são definidas 
"nem pelo território, nem pela adesão formal dos membros, mas pelos limites de uma comunicação efetiva" (p. 199). Na perspectiva dos mundos sociais, a realidade social como um todo é vista como uma composição de vários mundos sociais de tamanhos variáveis, que se sobrepõem, se intercruzam e se segmentam em submundos. Segundo Strauss (p. 123), as fronteiras dos mundos sociais ${ }^{157}$ e a autenticidade de suas atividades estão sob constante debate e negociação.

A perspectiva de mundo social destaca o fato de que, enquanto tais noções como bens, instituições, normas e políticas podem ser identificadas nos MMOs, elas não devem ser consideradas "versões virtuais" ou "simulações" de fenômenos do "mundo real". Em primeiro lugar, elas não são duplos, mas entidades específicas, sui generis. Em segundo lugar, fenômenos paralelos existem em vários mundos sociais, mediados por computador e de outras maneiras (LEHDONVIRTA, 2010).

Segundo Lehdonvirta, o mundo social de um servidor de MMO está emaranhado e atravessado por outros mundos sociais, e seus limites nunca são definitivos. O mundo experimental e outros mundos não são simplesmente separados de uma maneira que justifique considerar o servidor de MMORPG uma sociedade humana independente. Lehdonvirta conclui que, até agora, a estratégia típica para lidar com essa dificuldade tem sido tratar as ressalvas listadas acima como "ligações" ou "interações"158 entre o mundo real e o mundo virtual. Esta estratégia busca resolver os referidos problemas, mas ainda se mantém presa ao modelo dicotômico que distingue o real do virtual. Poucas exceções não invalidam um modelo, mas elas estão começando a se acumular de tal forma que se torna difícil para um investigador manter controle sobre as mesmas. É como se o modelo dicotômico não se encaixasse muito bem na realidade empírica.

Apesar das diferenças de abordagem, não seria esta justamente a essência do argumento de Latour (1991a) em Jamais Fomos Modernos? Neste livro, Latour se refere à moderna proliferação dos híbridos como um resultado da prática de purificação. Quanto mais estes híbridos são suprimidos, mais secretamente se reproduzem. Sua visibilidade atual

\footnotetext{
${ }^{157}$ Manuel Castells (2001) também manipula um conceito similar quando coloca que: "o mundo social da Internet é tão diverso e contraditório quanto a própria sociedade" (p. 48). No entanto, ele opera a velha divisória entre "a sociedade" e o "mundo social da internet", separando as relações dos humanos entre si (sociedade) das coisas (tecnologia) no mundo; o que aqui, junto com Latour (1991a), buscamos reconectar.

${ }^{158}$ Para Stelio Marras (em comunicação pessoal) estaria seria uma interação no sentido fraco, isto é, sem a efetiva afetação recíproca ou transformação das partes envolvidas por conta da relação, que se seriam próprias do sentido forte. Veremos mais a frente essa distinção numa discussão com o interacionista Erving Goffman (1959).
} 
é somente o resultado deste processo, que culminou no atulhamento desta máquina purificadora.

Diferente de Lehdonvirta, Latour não enfoca os limites da comunicação como o principal parâmetro para traçar as redes, nem os toma como universos de discursos separados da prática, e, principalmente, não os considera apenas mundos sociais (em que não se considera a presença e a agência de não-humanos). No entanto, no ponto específico acima levantado, isto é, a incapacidade dos modelos científicos modernistas de lidar com a excessiva emergência de agentes híbridos, parece que as teses de Latour e Lehdonvirta se convergem fatidicamente. Ambos estão lidando com a dificuldade em operar por meio de dois polos separados que incessantemente produzem exceções (os tais híbridos), já que os seres com os quais estão lidando não pertencem inteiramente nem a um, nem a outro polo ontológico.

\section{Equivocações não-controladas}

Como indicado no início do capítulo, observamos que os próprios jogadores também se apropriam do conceito de "virtual" para se referirem às suas experiências com os videogames. Seja com significados semelhantes ou distintos daqueles praticados pelos autores aqui citados, em geral, os jogadores sabem muito bem a quê estão se referindo. Seria esta discussão um mero problema de linguagem ou de desentendimentos acerca do uso de terminologias científicas? Para enfrentarmos esta questão, é interessante retomar o conceito de equivocação controlada, proposto pelo etnólogo americanista Eduardo Viveiros de Castro (2004).

De acordo com este autor, a ideia de mal-entendido é concebida no específico sentido de equivocidade encontrado na cosmologia perspectivista ameríndia, em que um equívoco não é um erro, engano ou trapaça, mas a possibilidade de estabelecer uma relação de exterioridade com o que é diferente no momento em que se difere (VIVEIROS DE CASTRO, 2004, p. 19). O perspectivismo ameríndio, pois, se apresenta como uma teoria do equívoco, ou seja, um modo de comunicação entre posições perspectivistas diferentes por excelência.

De modo sucinto, esta equivocação não é entendida como um erro, mas uma possibilidade de comunicar-se com o diferente. Para o antropólogo Tiago Coutinho 
(2011, p. 254), a noção de tradução acionada por Viveiros de Castro torna-se uma operação de diferenciação: uma produção de diferença que conecta dois discursos no exato ponto onde ambos não afirmam a mesma coisa, ao mesmo tempo em que apontam para exterioridades discordantes através dos sinônimos-equívocos entre eles.

Enquanto o erro ou um engano só pode ser determinado no interior de um único código cultural, o equívoco revela o intervalo entre diferentes codificações que exploram os pontos de aparente continuidade. Na comunicação por equívocos, o que funda a relação de significados entre dois discursos distintos são seus referentes em comum que produzem visões paralelas do mesmo objeto (COUTINHO, 2011, p. 253)

No caso da dependência de videogames, será que realmente ocorre uma equivocação não-controlada entre as diferentes perspectivas em jogo? É o que veremos adiante com a ajuda dos relatos de campo. O nosso trabalho daqui em diante consistirá num esforço de controlar essa equivocação, forçando a abertura das principais caixas-pretas nesta controvérsia, marcando as diferenças entre os discursos e evidenciando as condições em que tais termos ganham sentido. Para isto, buscaremos aproximar os termos pela diferença e com isso operar traduções. A descrição etnográfica, portanto, nos auxiliará a mostrar os diferentes sentidos e equivocações presentes nos discursos. A pergunta que norteia esta discussão é, afinal: Que noções de real e de virtual estão circulando neste rede?

\section{3 - O virtual em controvérsia}

Passaremos agora para a apresentação de trechos de entrevistas ${ }^{159}$ com gamers e cientistas que propõem reflexões sobre este tema. $\mathrm{O}$ que pensam os jogadores de sua experiência de jogo? Esta é real? Irreal? Nem uma coisa nem outra? Em campo, há uma grande variedade de posições. Portanto, deixemos os próprios jogadores apontá-las.

\footnotetext{
159 A seleção dos entrevistados foi feita a partir da rede construída ao longo da pesquisa pelo próprio pesquisador. Não foi utilizado nenhum crivo de "vício" ou "dependência" para habilitar o entrevistado a participar da pesquisa. As entrevistas foram realizadas a partir de um roteiro semiaberto, com perguntas semelhantes para os diferentes entrevistados, na medida do possível. Não se utilizou nenhum dos chamados marcadores sociais de diferença (idade, geração, gênero, escolaridade, classe etc.), comuns em estudos de Ciências Sociais. Não buscamos aqui, portanto, uma "amostra significativa" que representasse de forma estatisticamente consistente toda a população de gamers, pois isto seria inviável, mas pretendemos somente mapear uma diversidade dos principais argumentos e discursos acerca da questão debatida neste capítulo. As entrevistas na íntegra encontram-se transcritas e compiladas no seguinte endereço eletrônico: http://gamedependencia.wordpress.com/
} 
Masamune, programador de games como Calango e co-organizador do encontro SPIN (São Paulo Indie Developers), pensa o game como um simulacro da "vida real".

Eu considero jogo um modelo arcaico e simplificado da vida real. Não é que ele deixa de ser um jogo, mas a pessoa que não consegue entender o jogo. Pra você conseguir muitas vezes engajar a pessoa, aquela pessoa tem que ter uma certa ligação emocional com aquilo. Por exemplo, em FarmVille as pessoas têm uma ligação com o fato de "eu sempre quis ter a minha própria horta", por exemplo, "sempre quis poder ter as minhas vaquinhas, meu lugar". Mas ela nunca pode realizar aquilo nesse mundo, nessa realidade, nesse plano. E ela meio que externa essa vontade em um jogo.

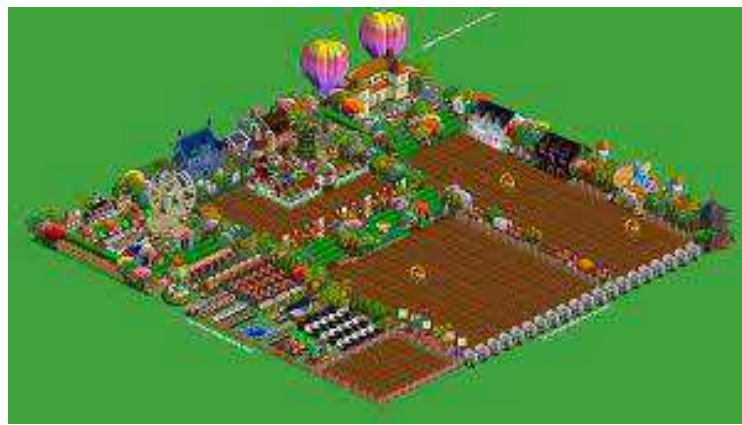

Figura 3.2 - FarmVille (2009)

Eu, por exemplo, sempre quis ser um ninja. Então, jogos de ninja ou jogos muito loucos como Ninja Gaiden, Devil May Cry, eu sempre gostei muito porque eu posso fazer o caralho, fazer altos combos e o caramba, isso me engaja. Porque eu sempre quis ser assim, e ali naquele momento eu posso, eu sou aquilo. Eu sou aquela letra B que eu ganho a cada fase que passa. Eu tenho duas espadas que eu faço o caramba. Eu sei que aquilo está ali, está relegado àquele plano. - Masamune

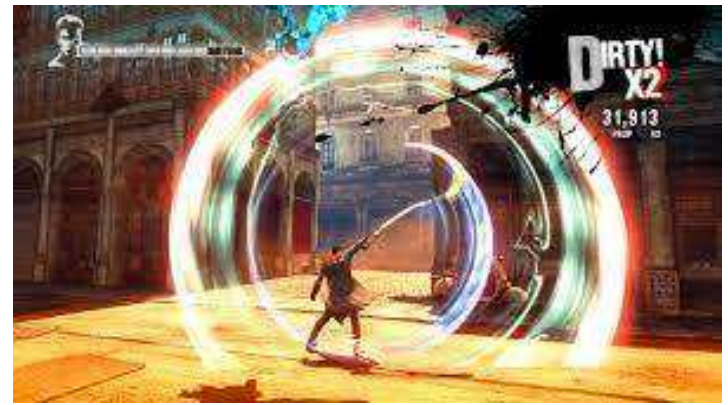

Figura 3.3 - Devil May Cry (2013)

Masamune, quando evidencia as suas transformações no jogo, nos abre espaço para pensar os jogos de videogame como experiências de devir, metamorfose, diferenciação, alteridade, saída de si e alteração de consciência (em sentido restrito). Esta fala também vai ao encontro do que argumentam alguns psiquiatras (ABREU et al., 2008): os games não são a vida real, eles a simulam. Para Masamune, as pessoas saciam desejos "reais" por meio dos jogos. O jogo é entendido, assim, como simulação do real e uma via para a satisfação de desejos. 
Já Sepio, professor de ensino médio, coloca que quando se joga videogame é possível suprimir, por meio do jogo, necessidades do "mundo real".

Você sente um alívio, você consegue expressar aquilo que você tem, às vezes você acumula a vontade de fazer aquilo, que é a vontade, não necessariamente de apertar um botão e ver o boneco pulando, mas vontade de vivenciar aquela sensação. E que, como sensação, não quer dizer que ela é mais verdadeira ou menos verdadeira. Mas que é diferente do mundo real, no sentido de que talvez eu não consiga suprir a minha vontade fazendo outras coisas. - Sepio

Esta fala de Sepio mostra efeitos do virtual sobre o real, ou seja, não se vai ao virtual (quando "realmente" se vai) sem que isso produza consequências para o "real". Esse trânsito modifica, portanto, o próprio real. Essa interação forte (no sentido proposto por Stelio Marras) entre real e virtual põe em causa a origem da "vontade" e o rumo de sua satisfação. Nestes dois primeiros depoimentos, portanto, vemos que a dimensão privilegiada de real é a dos desejos dos jogadores, que encontram nos jogos um ambiente que forneceria condições para que possam satisfazê-los. Aqui os desejos são reais, ou seja, partem da vida real dos jogadores.

Neste sentido, é preciso refinar o que se entende por simulação do real. A partir de um referencial de Antropologia da Performance, podemos descrever os jogos em um modo subjuntivo de experiência no "como se". De acordo com Richard Schechner (2011), o "como se" abre o campo das potencialidades, nos movendo da dinâmica entre o real e o possível para aquela entre o virtual e o atual, pois permite manipular as circunscrições do real. O antropólogo Bernardo Lewgoy (2009), da Universidade Federal do Rio Grande do Sul (UFRGS), argumenta:

O mundo virtual nasce percebido pelas ciências humanas como um simulacro (no sentido de Baudrillard, 1981 e Gilles Deleuze, 2007) dotado de realidade, copiando a forma do real para existir, tornando-se após uma metáfora para, posteriormente se reontologizar como um conjunto de convenções pétreas naturalizadas e convertidas em nova paisagem mundana [...]. O mundo virtual da internet não parece ser nem menos-real nem mais-real, mas antes hiper-real num sentido de um simulacro ou quase-objeto em constante e irregular processo de autonomização, que ganha um estatuto próprio cujo contexto de existência incorpora a ambiguidade como dimensão constitutiva e positiva de seu ser e devir (LEWGOY, 2009, p. 193).

Johnny William, 25 anos, desenvolvedor de games como Cubisland e Pullator, nega enfaticamente as acusações de irrealidade dos games, comparando estes a outras experiências artísticas. Para William, saímos sim do "mundo real" por meio dessas 
experiências. E de certa forma, estas não somente seriam bem-vindas, como até mesmo necessárias:

O jogo é arte. É que nem o teatro. Quando você vai assistir um teatro, o bom do teatro é justamente você sair, entre aspas, do mundo real e se envolver na peça. Videogame é a mesma coisa, videogame é arte. Então, o objetivo é realmente te tirar do mundo real. Pô, lógico, quando você desliga o jogo, você volta pro mundo real, mas é que nem um filme, que nem o cinema, que nem um seriado, que nem um livro, você sai mesmo do mundo e você é envolvido por aquilo lá. E isso é bom, é arte. - William

O real aqui pode ser entendido como o "ordinário" em oposição ao "extraordinário" possibilitado pelas experiências lúdicas e artísticas. Já Hyou, 23 anos, estudante de Ciências Sociais, coloca a sua experiência com videogames como uma realidade em outra dimensão, mas que também permite criações a partir dela própria.

É um mundo real porque é um mundo criado, e um mundo concebido. E você pode criar a partir dele também. É uma realidade, só que ela é em outra dimensão. Ela é uma dimensão interativa, como a gente está vivendo num contato físico, mas é um contato virtual. Isso não constitui como falso, ou fora da realidade, é como se fosse um plano de interação, assim como a gente tem vários planos de interação durante a vida. - Hyou

Aqui o real já não é o desejo, mas o mundo realizado do jogo. Nota-se que o mesmo entrevistado opera de formas distintas estes mesmos termos, quando afirma que: "muitas vezes a vida do videogame é muito mais interessante que a vida real, onde as pessoas estão entediadas da escola, dos problemas dos pais, e não tem muito o que fazer e vai jogar videogame" (grifo nosso). Não devemos, pois, congelar ou resumir a posição de uma actante somente a partir de trechos de suas falas, mas verificar que estas são transitórias, múltiplas e situacionais. Pode-se, no entanto, captar os diferentes sentidos enunciados por elas e rastrear as caixas-pretas que as amparam.

Tosas, jovem de 17 anos, estudante recém-ingresso no curso de Engenharia da Computação e gamer hardcore (segundo ele mesmo), aponta para uma questão largamente debatida nos círculos de jogadores: os conteúdos dos games influenciam as pessoas? Se sim, isto já seria um motivo para considerar que eles têm certos efeitos reais, ou, no mínimo, que afetam o dito mundo real?

[O game] transmite algo pra pessoa? Transmite. É que nem assistir anime. Tem vezes que você vai assistir alguma coisa e acaba esperando muito daquilo e tu ver que aquilo é triste, isso vai te afetar de alguma forma. É que nem o jogo, tu está no enredo, se tu está aproveitando... Se alguma hora algo acontecer, isso 
pode acabar te afetando, tu ficar triste porque o personagem morreu, ou não foi aquilo que tu queria, tu fica nervoso... - Tosas

Esta é justamente a preocupação de Hideko, professora de artes marciais e mãe de Iago, de 7 anos, estudante do Ensino Fundamental. Para ela, "não importa se é real ou irreal. O que importa são os conceitos que vão entrando nas mentes das pessoas". Hideko também ressalta uma maior fragilidade das crianças em lidar com os conteúdos dos jogos. Nesta perspectiva, assim, "real" é a agência dos conteúdos e conceitos.

A psicóloga Ivelise Fortim aponta que, no grupo de estudos que integra (Núcleo de Pesquisa em Psicologia da Informática), o virtual é tratado como meio (e não como mentiroso). Na linha de Psicologia que segue, trabalha-se a ideia de virtual como aquilo que é mediado pelo computador: "Então, se você brigou no computador, é tão real quanto se você tivesse brigado com uma pessoa fora, porque aquilo te afetou". O real, nesta abordagem, é entendido como realidade psíquica.

O antropólogo Marcelo Mercante (em comunicação pessoal) coloca que, quando algo gera uma influência na vida das pessoas, não estamos lidando com uma coisa totalmente fantasiosa. Ele afirma que, quando começamos a trabalhar com a imaginação, mente, quando não há algo que podemos tocar ou "que desmancha no ar", há de se encontrar novos caminhos para a abordagem. Para Mercante, portanto, não podemos separar as experiências em reais ou virtuais. Contudo, ele tem dúvidas se nos jogos de videogame estamos diante de algo totalmente real. Seja como for, o que aqui aparece como real são as influências e experiências.

O conjunto dos relatos até aqui vão indicando uma conclusão importante: eles não autorizam a definição de uma vez por todas de um caráter contínuo ou descontínuo entre real e virtual. São os efeitos que modificam o curso da ação dos atores. Trata-se então de mapear, a cada vez, essa continuidade e descontinuidade, ambas como estratégicas e visando determinados efeitos.

Apreendemos ainda destes relatos que, por mais que as pessoas estejam usando as mesmas palavras, as próprias noções variam significativamente. É justamente aqui onde entra a ideia dos enganos de comunicação, ou, mais precisamente, das equivocações não-controladas, que retomaremos no final do capítulo. Por enquanto, a nossa hipótese é de que as noções de real e virtual circuladas nesta rede são sustentadas por outras 
noções, as quais analisaremos daqui em diante. Descreveremos, pois, uma série de controvérsias acerca do virtual em seis subtemas elencados a partir dos dados de campo: sensibilidade, corporalidade, materialidade, comunicabilidade, sociabilidade e o escapismo presente nos discursos da dependência de videogames.

\subsection{1 - Sensibilidade}

A primeira grande discussão em torno da realidade dos games aparece no tema das sensações. Seriam reais as sensações que temos nos jogos? Se sim, em decorrência, isto bastaria para nos levar a crer que as experiências com os videogames são da mesma forma reais? Novamente, os próprios jogadores nos auxiliam a conduzir a discussão. Ricardinson, 25 anos, desenvolvedor de aplicativos e de outros softwares na empresa Martin.labs, propõe a seguinte a reflexão:

O mundo virtual é real. O mundo virtual é tão real quanto o mundo que a gente vive. Eu não tenho a menor dúvida disso porque as minhas sensações são reais. A sensação de liderança, a sensação de batalha, a adrenalina... Se as sensações são reais, por quê que não é real? É real, é totalmente real! Se as sensações são reais, se as coisas são reais... Eu sou o cara que acredito que a gente vive atualmente numa simulação, eu tenho essa teoria que a gente vive na Matrix e tudo mais. E isso aqui é real. Então, eu não vejo motivos pra não crer que um jogo que seja extremamente imersivo não seja real. Ele passa a sensação de ser real, então por quê que ele não é real? Se você discutir assim: "Ah, não, mas realidade-realidade?" Bom, realidade-realidade só existe essa. Mas que é real entre aspas, outro tipo de real, é. Porque as sensações são reais. Então é real. E o jogo é diferente de filme, que você age passivamente, você sente aquelas sensações reais, no jogo você age de forma ativa e tem as sensações. Então, você está atuando, você não está só recebendo coisas. Você está agindo e você está sofrendo com as consequências dos seus atos da mesma maneira que você sofre na vida real. Então é real. - Ricardinson

Mencionando uma série de efeitos práticos (e reais) do virtual sobre a sua "vida real", Ricardinson postula a coexistência de dois "reais", que são iguais e diferentes entre si.

Seriam dois significados linguísticos diferentes abarcados na mesma palavra? Pretendemos dar conta desse questionamento na sequência dos relatos. Peter_pano, por exemplo, propõe a seguinte reflexão a partir de sua experiência:

Eu encaro que a partir do momento que você está jogando videogame, aquilo é real. Porque não importa se você está vendo através de uma TV ou de um óculos de realidade aumentada. Aquilo é real, porque o sentimento que você tem é real. O sentimento de frustração, apesar de ser algo que não está acontecendo de fato (são só processamento de dados), a reação que você tem, o estímulo que você tem, é real. Nada daquilo é falso. Se você tem um apego, por exemplo, ao personagem que você está jogando, você vai ficar triste se ele morrer. Se você tem raiva do inimigo, você vai ficar feliz ao vencer ele e você 
vai ficar feliz ao superar um obstáculo. Da mesma maneira que é na vida real. Se você simplesmente jogar futebol e fizer um gol, você vai ficar feliz. Aquilo deixou de ser real só porque não é uma partida oficial? Não. É um jogo de futebol. Não importa o nível que ele está. É claro, não dá pra falar, "Ah, jogar videogame é estar numa guerra? Não, não é estar numa guerra, mas, talvez, em alguns momentos ele consiga te proporcionar os sentimentos ou algo próximo ao real, que é o que se fala do estresse e tudo mais, porque você tem isso quando você joga videogame. Você tem estresse, você tem euforias, você tem tudo isso. E você tem isso na vida também. E como o sentimento está lá, ele é real. E pelo menos pra mim, quando eu jogo alguma coisa, eu sinto que eu consigo me isolar do mundo. Consigo simplesmente jogar e estar dentro de uma bolha onde eu estou focado naquilo. Eu particularmente não consigo jogar um jogo deitado na cama, de uma posição extremamente confortável. Eu preciso estar muito focado no que eu estou fazendo, porque eu levo muito a sério a questão de jogar videogame. Então, eu encaro como sendo real pra mim. Ele sempre foi muito real pra mim. Inclusive, um ponto interessante: Ah, é real? Não é real? Não sei, mas a Carla [sua noiva] uma vez assistiu uma cena de um jogo comigo onde tinha um personagem morrendo, e ela chorou. É real aquele sentimento? Não é real? O sentimento ela teve, ela ficou triste. Era real? Aquela pessoa realmente morreu? O sentimento estava lá. A questão é essa. Peter_pano

Sepio, professor de Ensino Médio, conta que nos jogos de MMORPG há um dispêndio grande de tempo na construção e evolução do personagem, de modo que o empenho dedicado a essa relação acaba produzindo sensações de prazer no jogador em momentos de conquistas ou, ao contrário, medo de perda do que já foi alcançado, em caso de derrotas.

Pode ser verdadeiro o fato de ser um heroico desbravado lá assim... Seu inimigo é muito forte, você vai lá e enfrenta. Você tem essa sensação de coragem, sensação de medo, ainda mais o RPG, que você tem um dispêndio de tempo na constituição uma pessoa, você não vai querer simplesmente perder o seu char [personagem], morrer, então você tem um dispêndio de tempo, e você tem um empenho de tal modo que você realmente produz uma sensação de prazer em conseguir aumentar aquilo que você tem ou de medo de perder, uma sensação realmente íntima com aquilo que torna, próximo da realidade, realidade como cognição ou como interação do seu corpo físico, mas de sentimentos, de sensação. - Sepio

Não é preciso reafirmar que, nesses três depoimentos, o real são as sensações. Vimos por estes comentários que a sensibilidade, além de abrir um novo ramo de controvérsias, é um ponto fundamental para os jogadores qualificarem as suas experiências de jogo em termos de realismo. 


\subsection{2 - Corporalidade}

Nesta seção buscaremos recuperar as controvérsias envolvendo a corporalidade nos games, passando por debates acerca das técnicas, tecnologias, alívio de tensões e pela diferenciação entre jogos eletrônicos e jogos esportivos. Alguns questionamentos que norteiam este debate são: Videogames são esportes? Todos os esportes são jogos? Há games que podem ser considerados esportes ou atividades físicas? Como o corpo e os órgãos do sentido estão envolvidos nas experiências específicas com os games?

Os primeiros estudos sobre corpo e corporalidade em Antropologia nos levam de volta ao texto de Marcel Mauss, As técnicas do corpo (1934), que até hoje é uma das grandes referências na área:

O corpo é o primeiro instrumento e o mais natural instrumento do homem. O mais exatamente, sem falar de instrumento, o primeiro e mais natural objeto técnico, e ao mesmo tempo o meio técnico do homem é seu corpo (MAUSS, 1974, p. 217).

Pesquisadores do GrupCiber (Grupo de Pesquisa em Ciberantropologia), de Santa Catarina, recuperam tais reflexões de Mauss a fim de reconectar alguns estudos atuais sobre técnica e tecnologia (dentre os quais Latour também é incluído) a uma referência clássica na disciplina antropológica; a qual além de oferecer uma base sólida para a discussão, não reestabelece algumas das rupturas modernistas em seu método etnográfico.

O objetivo de Mauss era lançar luz sobre um domínio até então oculto pela noção tradicional de tecnologia: em geral, diz ele, considera-se equivocadamente que existe tecnologia quando um instrumento é envolvido no ato de manipulação. A esta 'technique à instrument', Mauss opõe um conjunto de 'techniques $d u$ corps', às quais confere mesmo um papel preliminar: o corpo é o primeiro instrumento a dominar, aquele que intermedeia a relação com todos os demais (REDE, 2003, p. 283).

A herança maussiana reúne num mesmo esforço etnográfico os estudos de corpo com a dimensão da técnica ${ }^{160}$. Mauss, portanto, também aparece como uma das primeiras referências na discussão sobre técnica e tecnologia em Antropologia Social. Se

\footnotetext{
${ }^{160}$ Para Mauss, técnicas são séries de atos que têm natureza não apenas física, mas também social: atos elaborados, coordenados, classificados e entendidos como eficazes, transmitidos por educação e de modo variável em cada sociedade. São "atos tradicionais, agrupados com vista a um efeito mecânico, físico ou químico, atos conhecidos como tais. [...] O conjunto de técnicas forma indústrias e ofícios. O conjunto de técnicas, indústrias e ofícios forma o sistema técnico de uma sociedade" (1926, p. 33).
} 
aplicarmos aqui sua classificação (que distingue utensílio, ferramenta e máquina) proposta no Manuel d'ethnographie (1926), podemos inferir que o videogame seria considerado por ele uma máquina. A atividade de jogar videogame, portanto, seria uma tecnologia ${ }^{161}$ que envolve tanto o corpo do jogador (desde as técnicas de movimento feitas geralmente com as mãos, até as ondas elétricas emitidas por seu cérebro), mais o console, os controles, a tela, a energia elétrica e tudo a eles conectado.

Mauss nos permite, assim, trabalhar com uma visão alargada do que se entende no senso comum por tecnologia, para além da concepção comum de "aparelhos eletrônicos", "novas invenções" ou "hi-tech". Assim compreenderemos que não só computadores, celulares e videogames, mas também o nosso corpo e nossos olhos são tecnologias de apreensão e intervenção no mundo. "Evitar a tecnologia", como proposto pelo Sabbath Manifesto ${ }^{162}$, portanto, parece ser um lema que reduz o problema.

Assim, com quais estímulos sensoriais os games operariam? Se nos detivermos à clássica definição (que nos remete a Aristóteles, segundo Kaufmann, 1899) de que o corpo humano possui cinco sentidos, os games, enquanto materiais audiovisuais, trabalhariam predominantemente com a visão e a audição. No entanto, não podemos tomar esta afirmação como autoevidente. Hoje é consenso na comunidade científica de que estes não são os únicos sentidos do corpo humano, mas somente os mais conhecidos. Entre os próprios cientistas (CERRETANI, 2010) não há acordo quanto ao número exato de sentidos, pois isso depende de sua própria definição ${ }^{163}$. Diante dessas

\footnotetext{
${ }^{161}$ Mauss compreende tecnologia como o estudo das técnicas, um processo que envolve dois aspectos fundamentais: a dimensão do ferramental e a forma de utilizá-los (1928). Segundo o autor (1926), é importante atentar tanto para o estudo dos instrumentos, em sua composição e lógica mecânica interna, quanto para seu uso de acordo com os objetivos e o meio social em que são utilizados. As técnicas são específicas para cada equipamento, de modo que as ferramentas e sua manipulação variam infinitamente. Em outros estudos de hoje, como os do próprio Latour (1991), já se questiona essa vinculação direta da técnica à dominação. Ele observa que "ferramentas nunca são meras ferramentas prontas para serem aplicadas: elas sempre modificam os objetivos que você tinha em mente. Isto é o que "ator' significa" (LATOUR, 2006, p. 340).

162 Sabbath Manifesto é um projeto ligado às tradições judaicas e que propõe a uma "desaceleração da vida". Seus dez princípios são: 1) Evite tecnologia. 2) Conecte-se com quem ama; 3) Nutra sua saúde; 4) Saia de casa; 5) Evite o comércio; 6) Acenda velas; 7) Beba vinho; 8) Coma pão; 9) Busque silêncio, 10) Dê de volta.

163 Uma definição é que “os sentidos são os meios através dos quais os seres vivos percebem e reconhecem outros organismos e as características do meio ambiente em que se encontram, isto é, são as traduções do mundo físico para a mente". Outra definição bastante aceita é a de que "um sentido é um sistema que consiste em um grupo de um tipo de células sensoriais que responde a um fenômeno físico específico, e que corresponde a um determinado grupo de regiões do cérebro onde os sinais são recebidos e interpretados". (Fonte: http://pt.wikipedia.org/wiki/Sistema_sensorial).
} 
controvérsias, podemos aqui atentar para como os jogadores constroem diferentes relações de input e output sensoriais em seus discursos.

Por exemplo, os videogames que acionam a vibração nos controles (tecnologia adotada a partir do lançamento do Rumble Pak, em 1997, no Nintendo 64, e comum nos controles dos consoles posteriores) são apenas uma das formas de experimentar o tato nos games. O jogador YuriBT, em conversa informal, argumenta que jogar um jogo original de SNES (Super Nintendo) com o controle original é uma experiência muito diferente de jogar o mesmo jogo num emulador de PC, em que o controle se dá pelo teclado, e há facilidades como poder salvar o jogo a qualquer momento ou acelerar o tempo dele.

O psicólogo clínico Lucas Costa, por exemplo, coloca a internet como uma camada intermediária entre o "real" e o "virtual", marcando uma diferença entre os games jogados online e offline. Ele aponta também para uma limitação dos sentidos envolvidos nesta interação tecnológica. Isso faria do exercício de jogar uma experiência incompleta ou menos humana?

A internet é o que cria uma subcamada entre a realidade e o virtual. Porque você estar falando com pessoas que você conhece na internet não é bem virtual, porque senão a gente teria que considerar o telefone uma experiência virtual. E não é bem isso. Então, no final das contas a internet permite esse estágio intermediário. Não é um contato humano total, você não tem acesso à expressão facial. Se você tiver uma câmera você até tem, mas você não tem acesso ao calor, você não tem acesso ao tato, você não tem acesso ao olfato... Você perde três sentidos dentro daquilo, mas você ainda tem um nível de experiência real. Então você tem dois sentidos que estão funcionando. Você tem a audição, fala, a possibilidade da linguagem, que é o que transforma a gente em ser humano funcionando... Então você tem meia experiência sensorial e a gente está rumando pra cada vez mais experiência sensorial através da máquina. - Costa

Costa aponta, por um lado, para um meio sensorial limitado que possibilita o que ele chama de experiências semi-virtuais ${ }^{164}$; e por outro, um conteúdo realista da experiência e a possibilidade de junção em tempo real de corpos distanciados no espaço.

Eu estou comparando com uma experiência total humana, entre você estar num local com outro ser humano, olhando, tocando, podendo ver, podendo ter um contato pleno, o máximo que a gente conhece de contato humano. Você podendo usar todos os seus sentidos pra experienciar aquele evento, aquela

\footnotetext{
${ }^{164}$ Neste argumento está implícito um pressuposto de que o humano se realiza como tipicamente humano apenas junto a seus semelhantes. Isto é, são pressupostos do "ser" e não do "devir" com sujeitos heterogêneos.
} 
experiência. É isso que torna o negócio confuso. Porque você tem gente que você conhece, com quem você convive, são seres humanos e você está trocando ideias, trocando experiências por mais que elas sejam semi-virtuais, ou seja, em corpos virtuais, as mentes e o tipo de ideia que está sendo trocada vão ser reais, na minha opinião. É isso que permite a diferença da coisa. Você entra com uma possibilidade de junção em tempo real de dois corpos que estão distanciados no espaço.

Orochi constroi sua interpretação a partir de uma separação entre três planos: físico, mental e virtual. Para ele, estes dois últimos às vezes se confundem na prática dos videogames por deixarem de lado uma suposta dimensão do físico. Em seu discurso, o virtual, portanto, aparece conectado ao mental e distinto do físico.

O jogo trabalha num plano virtual, mas ao mesmo tempo você está trabalhando mais com o seu plano mental do que com seu plano físico. Você muitas vezes vai ficar sentado horas e horas, e você só mexe o dedo. Você não está trabalhando de forma física, você está trabalhando só a sua cognição, só de forma mental com o jogo. Então, de certa forma, é um outro plano. Muitas vezes a pessoa joga, joga, joga até uma hora que ela começa a se sentir mal e fala assim: "eu estou morrendo de fome", "nossa, eu estou muito cansado", e o cara nem tinha se tocado disso antes. Tem até casos extremos que a gente já viu que acontece na televisão de a pessoa ter problemas sérios e até morrer de não sair da frente do computador. Mas isso, claro, é um caso extremo. - Orochi

Entendemos que essa separação entre físico e mental não pode ser dada a priori, assim como o corpo ou a corporalidade não podem ser compreendidos apenas como plano ou dimensão física. Observamos que diferentes jogos exigem diferentes movimentos no corpo humano, sejam eles coordenados pelas mãos e por controles convencionais (de botões), até por meio de controles que possibilitam outras experiências de movimento. Exemplos deles são: Wii Remote, da Nintendo; Kinect, da Microsoft e PS Move, da Sony, compatíveis com jogos que envolvem a movimentação de outras partes do corpo; e também controles que são imitações de instrumentos musicais, para games como Guitar Hero e Rock Band.

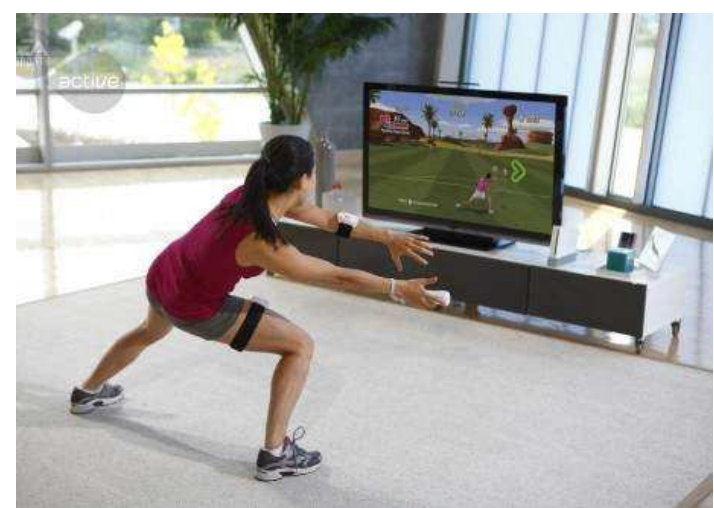

Figura 3.4 - Exemplo de game jogado com o Kinect (2010) 
Um dos pontos por quais o jogo eletrônico se afasta do esporte é o primeiro não ser entendido para alguns como uma atividade corporal, mas, que, pelo contrário, causa prejuízos à saúde devido ao sedentarismo gerado por seu uso contínuo. Afinal, que noção de corporalidade está sendo acionada em cada caso? Trata-se de uma controvérsia dentre alguns trabalhos recentes de Antropologia, como se verá a seguir.

David Le Breton (1999), em Adeus ao corpo, aponta para o perigo das supostas relações não mediadas pelo corpo ao refletir a respeito do ciberespaço como lugar de seu desaparecimento. Para Le Breton, a virtualidade seria, por excelência, um espaço onde o corpo (fisiológico) fica pendente, provisoriamente esquecido enquanto matéria. Este seria o território das imagens e dos signos, onde coexistem em virtualidade inúmeros corpos em potencial. O corpo físico seria então desnecessário, e mesmo indesejável, em um mundo onde se pode potencialmente vestir qualquer máscara, ter qualquer forma e tornar-se qualquer personagem imaginável.

Se seguirmos o pensamento de Le Breton, parece-nos que quanto mais o videogame é associado com o corpo e à esportividade, mais ele se associa ao real. A despeito de nossa discussão sobre o lúdico (explorada no capítulo anterior), os esportes são considerados atividades reais, já que, supostamente, o corpo humano inteiro se faria presente. Por outro lado, sem o corpo, a impressão é de que há uma tendência para o virtual, para o etéreo, ou seja, para experiências puramente mentais ou imaginárias, sem concretude. Neste sentido, o psicólogo Janos Geocze coloca:

Pelo menos, objetivamente, quando você vai jogar um futebol, você está correndo, você está xingando o juiz, você levou um pontapé... Aí você pega esse mesmo jogo, põe num computador e o cara fica lá com o FIFA. Monta o jogo dele... Ele está correndo? Ele está xingando o juiz? Está. [...] Mas ele não tem nenhuma atividade física condizente com aquilo que ele está fazendo lá no campo. (comunicação pessoal)

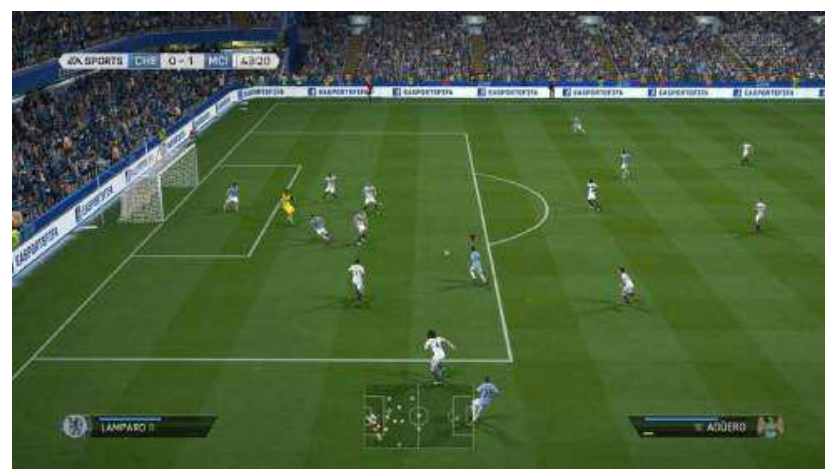

Figura 3.5 - FIFA 14 (2013) 
$\mathrm{Na}$ visão de outros autores, no entanto, a não-presença do corpo para o outro não significa necessariamente a sua ausência. Pierre Lévy argumenta que "a virtualização do corpo não é, portanto, uma desencarnação, mas uma reinvenção, uma reencarnação, uma multiplicação, uma vetorização, uma heterogênese do humano" (1996, p. 33). Para ele, "os sistemas de realidade virtual nos permitem experimentar uma integração dinâmica de diferentes modalidades perceptivas" (idem, p. 28).

Tim Ingold (2000), por sua vez, aponta para uma integração dos sentidos envolvidos em todas as atividades que desempenhamos - diríamos aqui, como jogar videogame. Para Ingold, o corpo não é uma coleção de órgãos adjacentes, mas um sistema sinérgico, cujas funções todas são exercidas e conectadas na percepção do ambiente. As formas de percepção e interação com o ambiente nos games vão muito além do meio audiovisual, posto que a jogabilidade, a interface e os comandos criam diferentes "órgãos do sentido" pelos quais os jogadores recebem informações do ambiente e a ele reagem.

Segundo alguns médicos, como o Dr. Mario Guarnieri, do Hospital Israelita Albert Einstein, na maioria dos videogames os jogadores movimentam os dedos (eventualmente causando tendinite ${ }^{165}$ ) e fazem um exercício considerado mental ${ }^{166}$ (não físico). Há acusações que colocam os games como causadores de prejuízos à saúde em virtude do sedentarismo ${ }^{167}$ motivado por sua prática, que por vezes leva os jogadores a passar um longo período sentado à frente da tela de jogo. Esta é uma preocupação totalmente relevante e nos interessa saber as implicações dos específicos usos de jogos eletrônicos para a saúde dos jogadores, o que exige outros estudos com este enfoque.

No entanto, não temos como reafirmar este argumento, pois não se observa uma divisão demarcada de onde termina a mente e começa o corpo, e vice-versa. Assim como não há nada estritamente físico, corporal ou mental. Tampouco podemos tomar o videogame como o único responsável pelo estado de saúde de uma pessoa, já que esta, além de jogar, realiza outras atividades em seu cotidiano. A forma como tudo isto está articulado em cada situação é que pode fornecer respostas mais consistentes a estas questões.

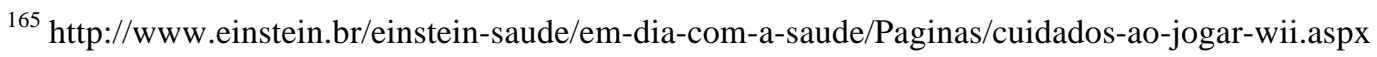

${ }^{166}$ Isto depende se se trabalha com a ideia de que mente também é corpo, ou faz parte do corpo, como Ingold (2000); ou, como é comum no pensamento moderno, se se separa mente do corpo físico, isto é, se a mente não é entendida como corpo, não faz parte do corpo ou não é considerada matéria.

167 Aliás, muitas formas de estudo e trabalho também tendem ao sedentarismo. Por que, então, o sedentarismo é logo acusado nos videogames, mas não no trabalho e, sobretudo, na educação formal?
} 
Janos Geocze coloca que a condição encarnada dos seres humanos os obriga saber operar estas "máquinas". Para ele, existe uma única realidade palpável e concreta: a do corpo. Assim, a realidade do ser humano encarnado seria vivida por meio dele. Sem esse instrumento, não haveria vida possível. Para Geocze, portanto, temos que cuidar bem do corpo e não deixar de prestar atenção às suas necessidades.

\begin{abstract}
Não tem o que discutir. Nós temos pinto, cu, boca, olho, inclusive tem gente que está perdendo vista por causa que não cuida da vista e não pisca o suficiente enquanto olha o jogo. A gente sabe disso e manda piscar. Vai ter sérios problemas porque o cara esquece que ele é um ser humano. É igual o carro. Você não vai botar gasolina e você quer andar com o carro? Ele vai pifar. E o ser humano pifa [...], quer dizer, se eu começo a valorizar mais os milhões que eu ganho e esqueço que eu preciso comer, eu estou desviando da realidade, das minhas necessidades básicas. Eu preciso tomar água, eu preciso comer. E eu estou deixando de comer, tomar água [...] e não vou no banheiro, não me mexo, não faço nada, eu esqueço que eu tenho um corpo. - Geocze
\end{abstract}

Aqui vale resgatar a discussão sobre as hierarquias de necessidades de Maslow (apresentada no capítulo anterior), de que somente podemos satisfazer necessidades sociais ou de autorealização depois de satisfeitas as necessidades fisiológicas e de segurança. Até que ponto esta afirmação é generalizável ${ }^{168}$ ou aplicável a outros "vícios", como do trabalho e do estudo? E até que ponto esse vício se torna problemático para a saúde? Como Orochi aponta em seu depoimento, há um problema maior quando "a pessoa não consegue se desligar" e "acorda pra fazer isso... Está almoçando, aí vai no banheiro com o celular pra dar aquela jogadinha rápida”.

Como dissemos no início, suspeitamos que uma determinada concepção de corporalidade nos games seja informada por uma noção de virtualidade que a iguala ao irreal, ao não-corpóreo e/ou ao imaterial (como veremos na próxima seção), que pode torná-lo suscetível à gramática do vício em drogas.

\title{
3.3.3 - Materialidade
}

Mais uma controvérsia da discussão "real-virtual" na experiência com os jogos eletrônicos se apresenta com a questão da materialidade (ou sua aparente ausência). A hipótese do jogo não ser todo feito de matéria palpável faria a experiência se aproximar

\footnotetext{
168 Apesar da pirâmide de Maslow mostrar que para atingir o topo é necessário passar pelas partes inferiores, o economista Manfred Max Neef (1989) aponta que há pessoas que chegam a autorealizar-se sem passar por todas as etapas da pirâmide. Para ele é possível, por exemplo, uma pessoa estar autorealizada, e não conseguir, contudo, uma total satisfação de suas necessidade fisiológicas.
} 
de uma irrealidade? Seriam os games experiências de fora deste mundo terreno ou desconectados de um substrato material? Afinal, qual a materialidade dos games?

Os videogames, como já antecipado, envolvem tanto (supostas) materialidades, como o console, a tela, os controles, jogadores, desenvolvedores, chips, dinheiro; quanto aparentes imaterialidades, como ideias, sensações, conhecimentos e imagens digitais. No entanto, segundo Latour (1991), não existe nada que seja puramente material ou imaterial $^{169}$, pois tudo está ligado a amplas redes de humanos e não-humanos. Mais importante, ambas estão desligadas apenas analiticamente e não funcionam separadas uma da outra. Para Tim Ingold (2007), materialidade é um termo muito vago, confuso e ambíguo, que paradoxalmente parece ter nos movido para mais longe da realidade - isto é, de um ambiente povoado por coisas, animais etc. -, tornando-se o solitário domínio da subjetividade humana.

Donna Haraway (1985) argumenta que a fronteira entre o físico e o não físico é muito imprecisa para nós, ocidentais. Numa entrevista, ela coloca que as fronteiras separando físico e não físico sempre dizem respeito a um modo específico de criação de mundos (worlding). Além disso, acredita que o virtual talvez seja, atualmente, um dos aparatos em que mais pesadamente se investe no planeta. Ela conclui: "não importa qual seja o assunto, mas se você pensa que virtualismo é imaterial, não sei em que planeta você vive!" (HARAWAY; GANE, 2006).

Há um ponto simples aqui de que o virtual não é imaterial. Quem pensa que é está maluco! [...] Mas a palavra convida a ser pensada como imaterial, o que é um movimento ideológico. Se alguma vez precisamos de análise ideológica, é para entender de que modo o virtual entendido como imaterial é um desses erros que os teóricos críticos nos ensinaram a perceber. Acreditar que de alguma forma há este devir descosturado, livre de fricções é um erro ideológico que devíamos ficar espantados de ainda cometer (HARAWAY; GANE, 2006).

Outra questão dentro do tema da materialidade são as próprias relações econômicas que envolvem os games. Para além do que já discutimos no capítulo anterior sobre os jogadores profissionais de videogame, uma das principais preocupações com o vício

\footnotetext{
${ }^{169}$ Manuel Castells, no entanto, opera essas mesmas dicotomias quando afirma, por exemplo, que a arte "é cada vez mais uma expressão híbrida de materiais físicos e virtuais, pode se tornar uma ponte cultural fundamental entre a rede e o eu (CASTELLS, 2001, p. 232)”. Castells aqui acaba igualando o virtual ao imaterial quando opõe o virtual ao material físico.
} 
seria afugentar as pessoas do trabalho ou do estudo. Masamune comenta sobre algumas destas experiências, já dando mostras de passagens entre o considerado virtual e real.

A não ser em casos muito específicos, por exemplo o Warcraft, existe uma forma de você ter uma vida ali dentro de forma que essa vida sustente você, você pode obter itens e ir vendendo, tem a Auction House lá pra você vender item. Se você quiser viver daquilo, você vive. Então, de certa forma esse é o tipo de jogo que permite que as suas realizações virtuais saiam do virtual pra vir pro real. Pro real de uma forma que: "Eu tenho dinheiro pra ter a minha própria casa com o dinheiro do Warcraft, porque eu sou muito bom no Warcraft". Ou então, por exemplo, o pessoal que gosta de jogar muito Street Fighter e eventualmente vai pra aqueles campeonatos de luta, o EVO [Evolution Championship Series]. Pô, os caras vão lá disputam, ganham e ganham uma bolada, uma grana boa. E ganham prestígio também! - Masamune

Quando então os jogos geram renda ao jogador (finalidade importante do trabalho), eles parecem se esquivar de várias acusações. Orochi também questiona a própria Psicologia (inclui-se aqui tanto o fazer científico, quanto a prática clínica) e atividades como a leitura, que também trabalharia com o "imaterial" - o que não torna os games uma forma exclusiva de passagem entre materialidades distintas.

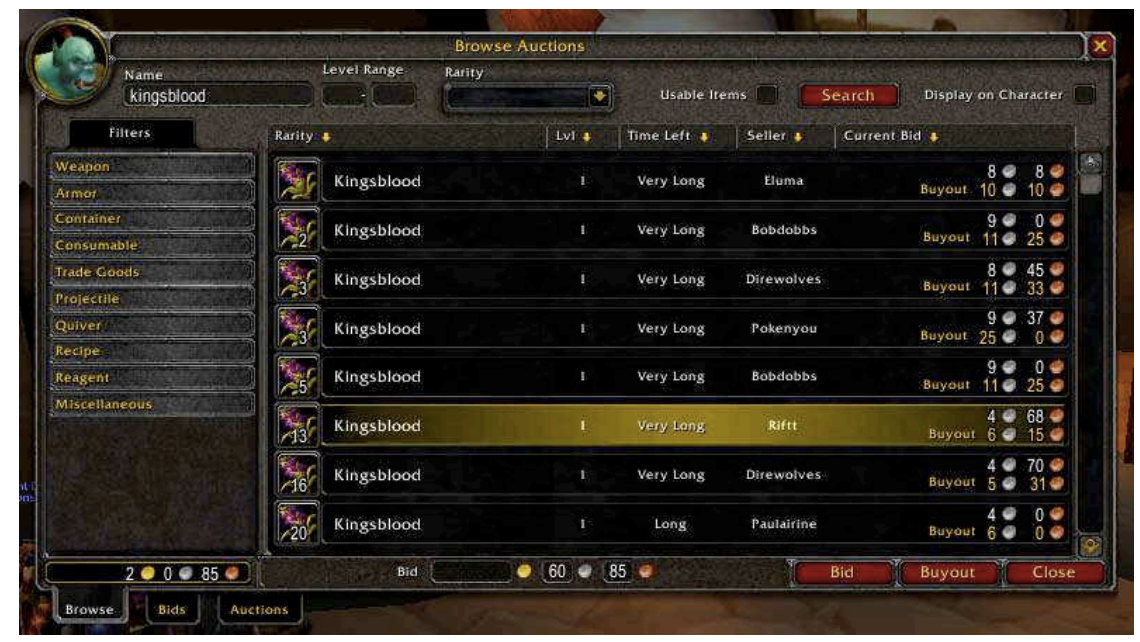

Figura 4.5 - Auction House (casa de leilão) do game World of Warcraft

Se o videogame trabalha num plano que não existe, a psicologia também, porque ela está falando de algo que a gente não consegue ver, a gente não consegue tocar, não é físico. É um plano das suas ideias, você pode sentar e ficar pensando sem mexer o seu corpo e você vai chegar em cognições ou, que seja, reflexões... É difícil você falar que isso não é real. Assim como o jogo. Como a imaginação ou como a pessoa que vai escrever um livro vai ter que passar por um processo muito grande nesse plano imaterial, antes de essa ideia ser um monte de letra num papel. - Orochi

Estamos aqui buscando junto com os jogadores, enfim, revelar associações frequentemente invisíveis nas acusações de dependência causada pelos jogos. Com estas 
passagens, portanto, podemos pensar que a experiência do jogo, na retórica da dependência, apareça como irreal ou virtual, não por causa de algo que nos leva para fora do mundo físico e do comportamento normal, nem porque se baseie em tecnologias relativamente novas; mas talvez porque, de acordo com este entendimento, esses “mundos” narrativos, comunicativos e articuláveis não possuem substância física.

As preocupações sobre a dependência digital continuam a invocar uma separação entre o real e o virtual por meio da "divisória" representada pela tela do computador (ou do console de videogame) e pelos dispositivos de interface ${ }^{170}$. Neste sentido, a antropóloga Maria Elisa Máximo (2010, p. 37) argumenta que, num sentido geral, a digitalização, a mediação da tela do computador e dos vários níveis de interface técnica e, principalmente, a não-presença física dos atores envolvidos, acabam facilitando a compreensão dessa produtividade como fruto de um processo de desrealização.

\subsection{4 - Comunicabilidade}

Nesta seção exploraremos algumas questões envolvendo a comunicabilidade dos meios virtuais. Suscitamos aqui algumas perguntas: Seria a comunicação nos games menos verdadeira ou plena do que a comunicação face-a-face? As tecnologias digitais trabalham todos os nossos sentidos ou somente alguns deles? Qual a validade de separar estas experiências em reais ou virtuais?

Sherry Turkle (1999) afirma que há uma integração entre as diferentes formas de encontros virtuais e presenciais, de modo que ambos se complementam. Para ela, existe a necessidade de uma relação presencial para estabelecer relações com informações sobre o corpo das pessoas em comunicação. Mas, segundo Turkle, também há uma forma de intimidade particular construída pela comunicação online.

[...] as pessoas terão vontade também - agora que tomaram gosto - de encontrar-se no virtual, assim como sempre haverá desejo de velocidade, de extensão planetária e até mesmo da forma particular de intimidade constituída pela comunicação on-line (TURKLE, 1999, pp. 118-119).

Seguiremos nosso argumento na companhia de alguns "nativos". Orochi afirma que há de fato diferenças entre as formas de comunicação mediadas por tecnologia digitais e as

\footnotetext{
${ }^{170}$ Nesse sentido, tanto Tim Ingold (2000) quanto Gilles Deleuze (1980) vão questionar a fronteira do corpo e a noção de interface como o que liga dois entes diferentes. Deleuze, em Mil Platôs, dialoga com a noção do teatro da crueldade de Artaud (1993), do "corpo sem órgãos".
} 
interações presenciais face-a-face, mas que elas não chegam a demarcar uma como real e a outra não. Para ele, na comunicação virtual:

Você não tem um contato. A sua comunicação pode ser, por exemplo, no telefone, ela vai ser basicamente através do som. Se você vai conversar por email, vai ser através de leitura, quando você conversa face-a-face, você tem toda a sua questão da gesticulação, a forma como você olha, toda a sua expressão, isso realmente tem uma diferença. Por exemplo, no jogo se você está sentado olhando pra tela e jogando ou se você está sentado na frente do seu amigo e vocês estão inventando um jogo ali, vou citar, por exemplo, o RPG. Tem uma diferença sim, mas acho que não dá pra dizer que um é real e o outro não. É meio difícil chegar nesse ponto. - Orochi

Para Hyou, a comunicação virtual é sublimada de vários bloqueios e de dificuldades da comunicação face-a-face. Para ele, no ambiente virtual você cria ou inventa uma imagem de si, podendo expressar seus desejos mais profundos, suas alucinações e criatividades. Ele argumenta que o ciberespaço:

É um espaço liberado, um espaço criativo, onde o desejo humano se realiza ali, tirando algumas amarras. Lógico que tem implicação isso, de a pessoa acreditar que a imagem que a pessoa está transmitindo é de fato "real". Ela é real porque ela é fruto de um desejo, mas ela não está necessariamente acoplada à vida daquela pessoa. Ela existe em outro plano, fora do jogo, do chat, do plano da Internet. - Hyou

Peter_pano conta algumas experiências com os jogos Journey e The Last of Us, que ele classifica como jogos emocionais. Segundo ele, Journey "é um jogo que você basicamente joga com o personagem, você não consegue falar, você não tem voz, você não se comunica, você joga com outro player que você não sabe quem é”. Segundo Peter_pano, é um jogo que dura praticamente duas horas por partida e que ele próprio consegue jogar até os dias de hoje: "Eu volto nele pra jogar, pra rever essa experiência, pra ter isso de novo".

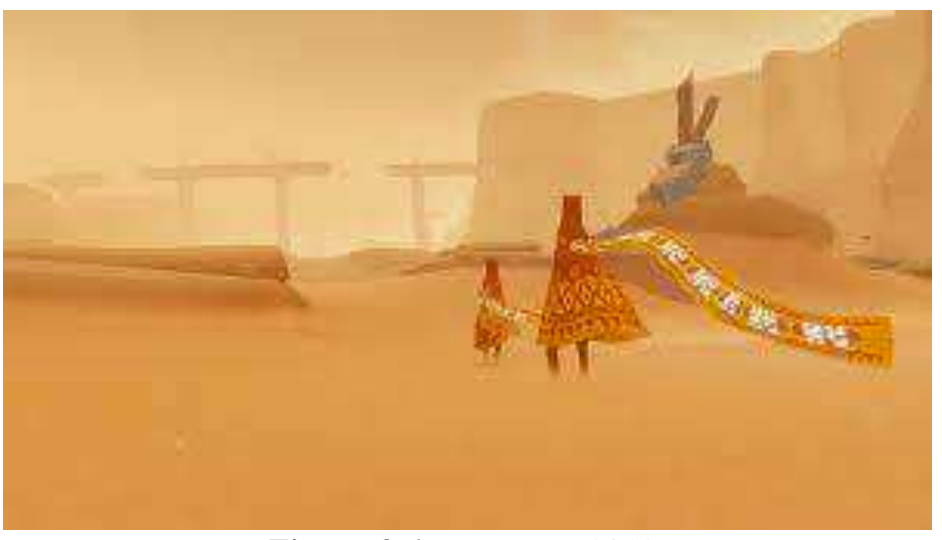

Figura 3.6 - Journey (2012) 
No The Last of Us também foi isso, eu fechei o jogo, acabei fechando o jogo acho que umas cinco vezes, e ele tem sempre o mesmo final, nada é diferente, simplesmente o jogo é sensacional. Então, esses jogos acabam, não diria a questão do vício, mas até as vezes a gente consegue encontrar alguma coisa que sente falta no cotidiano, na emoção mesmo, naquilo que ele tenta transmitir. No The Last of Us é a questão do carinho ao próximo, ter alguém pra se cuidar, no Journey é a questão da comunicação minimalista com uma pessoa que você não conhece e você criar de certa maneira um amor durante aquele período daquele jogo por essa pessoa. A busca por esse sentimento acaba tornando a coisa "viciante". Que é a questão de você querer aquilo de novo. - Peter_pano

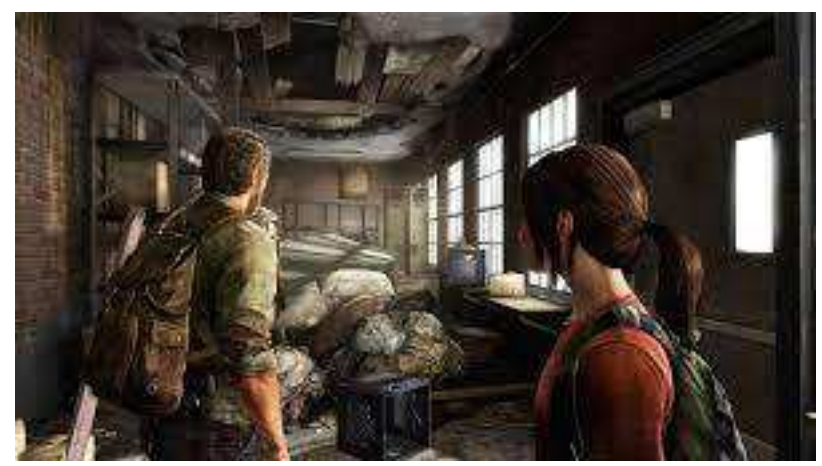

Figura 3.7 - The Last of Us (2013)

Por sua vez, Allprot, desenvolvedor de games, coloca a questão do compartilhamento da experiência com pessoas próximas como um fator que fortalece o engajamento na experiência de jogo, que foi o que vivenciou na época em que jogava o MMORPG With Your Destiny.

$\mathrm{Eu}$ comecei jogando esse jogo porque um amigo me chamou pra jogar. No começo do jogo era muito difícil jogar sozinho e ele me acompanhou, a gente jogou junto o começo. Se você não tem alguém com quem se comunicar sobre o que você está fazendo, eu acho que não é tão divertido assim. Você está fazendo aquilo, mas você não está compartilhando com ninguém. Não tem muito sentido. Tem sentido pra você, mas não está explorando totalmente esse sentimento que você pode ter. - Allprot

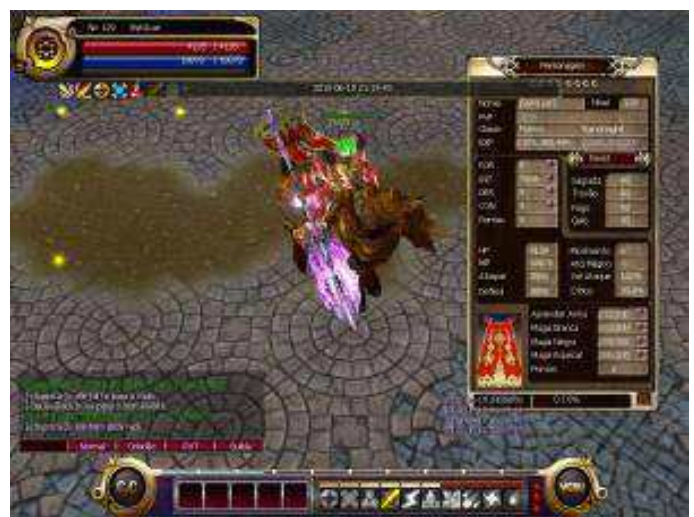

Figura 3.8 - With Your Destiny (2003) 
Hyou coloca o videogame como um mediador fundamental de diversas associações que ligam humanos entre si (acrescentaríamos, ainda, os não-humanos ${ }^{171}$ ). O videogame é um nó importante desta rede. Portanto, a ação deste quase-objeto faz muita diferença; pois sem ele, estas pessoas não se ligariam. Estes dois últimos exemplos não se limitam ao tema da comunicação, mas também avançam na questão da sociabilidade, a qual nos aprofundaremos na seção seguinte.

[O videogame é] um mediador e um motor da coisa, porque a partir do momento em que todos pararam de jogar, todos pararam de se comunicar. E ele se sustentava pelo jogo. Não é só pela mecânica também (o sistema do jogo), é a relação que a gente cria dentro do jogo. - Hyou

Alertamos, enfim, que a noção de presencial não deve ser tomada como dada. Na ideia de comunicação face-a-face, não agiria um pressuposto de que ela seria também mediada? Observamos que nela há linguagem, padrões de expressão, gestos, vestuário etc. Assim, não basta estar em presença para eliminar as mediações. Há aqui um humanismo purificador modernista operando como pressuposto. Cegos e surdos-mudos, por exemplo, seriam menos humanos porque privados de alguns sentidos? Parece novamente que os modernos temem que as máquinas ameaçem a sua humanidade. Mas, e se jamais fomos modernos (LATOUR, 1994)? Ou, ainda, e se jamais fomos humanos (VANDENBERGHE, 2010; HARAWAY; GANE, 2006)?

\subsection{5 - Sociabilidade}

Nesta seção examinaremos a questão da sociabilidade e dos relacionamentos nos games, posteriormente abrindo espaço para uma discussão sobre as chamadas comunidades virtuais. A partir da leitura dos manuais de diagnóstico e tratamento de dependência de internet (YOUNG; ABREU, 2011), uma das questões que logo emerge é: Os relacionamentos nos games seriam menos intensos que os da "vida real" (de fora do jogo)? Sherry Turkle nos ajuda a pôr a questão:

\footnotetext{
Nas minhas pesquisas, acho que as pessoas descrevem as relações on-line com grande intensidade, grande força, grande importância. Mas quando se olha com atenção as conexões, não se vê nem onde nem como ocorrem tantas coisas ali. Esse fenômeno está ligado à noção de transferência em psicanálise. Projeta-se sentido, dá-se profundidade e consistência a uma relação, mas não pelo que é dito. Creio que a noção daquilo que trazemos para as relações e das maneiras pelas quais as construímos, a partir dos nossos desejos, torna-se mais real para as pessoas graças às experiências on-line (TURKLE, 1999, p. 122).
}

\footnotetext{
${ }^{171}$ Não-humanos medeiam relações entre humanos, como sempre foi.
} 
A própria Turkle (1999) coloca que a relação online tem um caráter um tanto fantasioso. Para ela, com frequência, as pessoas vivem uma relação online como algo irresistível, mas quando olhamos a essência e a substância literal, encontramos algo completamente superficial: "Graças a isso, as pessoas compreendem a que ponto uma relação depende do imaginário e percebem a própria contribuição, bem como a parte de fantasia existente em torno de uma relação" (idem).

No entanto, não podem as próprias relações offline também ser superficiais? No clássico As grandes cidades e a vida do espírito, o sociólogo Georg Simmel (1903) argumenta que a intensificação da vida nervosa ocasionada pelo aumento de velocidade da vida e da quantidade de estímulos sensoriais na cidade grande, em comparação com a vida no campo, leva o cidadão a buscar preservar sua vida subjetiva, envolvendo menos suas emoções do que seu intelecto, pois este seria, entre nossas disposições psicológicas, a mais superficial, a menos sensível, e, portanto, a mais resistente e adequada ao intenso fluxo da metrópole.

Apesar de não compartilharmos com Simmel suas concepções de indivíduo, de sujeito, e mesmo de sociabilidade ${ }^{172}$ (preferimos, por exemplo, a noção de socialidade $^{173}$, como proposta por Marilyn Strathern) precisamos sempre atentar para a questão do urbano em geral presente, e às vezes esquecida, nas comunicações mediadas por computador. Afinal, para se conectar na web, em geral, a pessoa deve se encontrar em um local com condições materiais que permitam esta conectividade, que envolvem desde energia elétrica, os próprios computadores e seus periféricos, sinal de internet e/ou telefone, até acesso à internet banda larga etc.

Seria o virtual, então, uma exacerbação deste fenômeno urbano? Segundo Máximo (2010), sim. O ciberespaço, concebido como algo que extrapola a mera construção técnica - uma experiência imaginativa e social (REID, 1991, 1994, apud MÁXIMO, 2010) e um campo de emergência de diferentes formas de relações sociais, papéis e

\footnotetext{
172 Segundo Georg Simmel (1903), sociabilidade é uma forma de associação entre pessoas que se autonomizou de qualquer conteúdo, isto é, deixou de ter um fim exterior a ela e passou a ser valorizada em si mesma, como uma forma lúdica de sociação (como denomina o autor). Em outras palavras, a sociabilidade é uma forma de associação em que as pessoas se reúnem porque querem estar juntas e ter um momento sociável, sem quaisquer objetivos para além disso.

${ }^{173} \mathrm{Na}$ perspectiva da socialidade, as relações sociais são intrínsecas à existência humana, não se podendo, portanto, conceber pessoas como entidades circunscritas (STRATHERN, 1988; 1996b).
} 
definições do self (RHEINGOLD, 1993) -, se apresenta como um catalisador do fenômeno urbano, complexificando-o e the fornecendo outras possibilidades para a diversificação social e fragmentação individual (p. 34). Aqui não estamos adotando esses conceitos, os quais são ainda baseados numa separação estanque entre sociedade e indivíduo, mas os conectando ao debate levantado pelos atores.

Quais seriam, pois, as diferenças e similitudes que emergem dessas relações entre pessoas, jogos eletrônicos, computadores e demais dispositivos? Passemos, pois, a mais depoimentos dos jogadores. Em entrevista, Chuck comenta sobre a qualidade de suas amizades nos games com conexão online, como Ragnarök Online. Para ele, além de reais, as amizades virtuais podem substituir outras amizades.

Se você faz uma amizade lá dentro do jogo, se você gostar do cara, facilmente pode se tornar uma amizade que você vai ficar sempre conversando com o cara. O Mimeu [amigo dele] é o perfeito exemplo disso. Nunca vi esse cara ao vivo, eu continuo conversando com ele. Então acho que isso acaba se juntando, e se você joga muito, acaba virando seus amigos. E é muito substituível, porque a galera é mó legal! Às vezes você entra no jogo nem pra jogar, você entra no jogo pra sentar e ficar conversando com o pessoal lá dentro. - Chuck

Sepio comenta sobre relacionamentos íntimos nos MMORPGs, os quais se desenvolvem por meio de uma linguagem própria aos games.

Se você tem um namoro virtual dentro do MMORPG, às vezes não é porque você quer ter (e nem porque você acha que é) um namoro de verdade, mas só o fato de você experimentar uma sensação de namoro dentro do conjunto simbólico do próprio MMORPG, tipo: "Nossa, que prova de amor, você me deu uma armadura +5 de habilidade!". Talvez seja uma experimentação da própria relação de amor que você tem no mundo de fora e gere, de modos diferentes, uma própria constituição dialética de você mesmo. - Sepio

Hуои coloca que "a relação que a gente cria com as pessoas enquanto joga, tanto no jogo online e offline, não termina no jogo em si [...], mas ela se expande pra tudo". Para ele, esta relação envolve tudo que cabe à interação entre os jogadores: "Era muito além do só o progresso dentro do jogo".

Chuck compara a experiência de sociabilidade dos games a outras experiências online, como MSN Messenger e Skype. Quais seriam as diferenças que emergem destas relações? Seriam reais da mesma forma?

Uma pessoa que liga o $M S N$ pra ficar conversando com os amigos pela internet não é diferente de uma pessoa que liga o Ragnarök pra sentar na cidade e conversar com os amigos no Ragnarök. É a mesma coisa, a diferença é que o 
cara está dentro de um jogo e o cara do $M S N$ acha que ele não está. "Ai, não sou nerd, não jogo jogos". Mas ele está fazendo a mesma coisa, ele está entrando no $M S N$ pra sentar e conversar com os amigos, no Ragnarök você entrava pra sentar, é tudo a mesma coisa. Esse negócio de amizade virtual e amizade real, pra mim é a mesma merda. Se você conhece um cara e você gosta do cara, você vai continuar a ser amigo do cara sempre, não tem essa porra de "os jogos vão te deixar influenciado e você fica louco". Não. Isso é coisa que a pessoa inventa pra se achar melhor que o outro. MSN, o maior jogo virtual da história. Agora é Skype. Tudo a mesma coisa, igual pra mim.
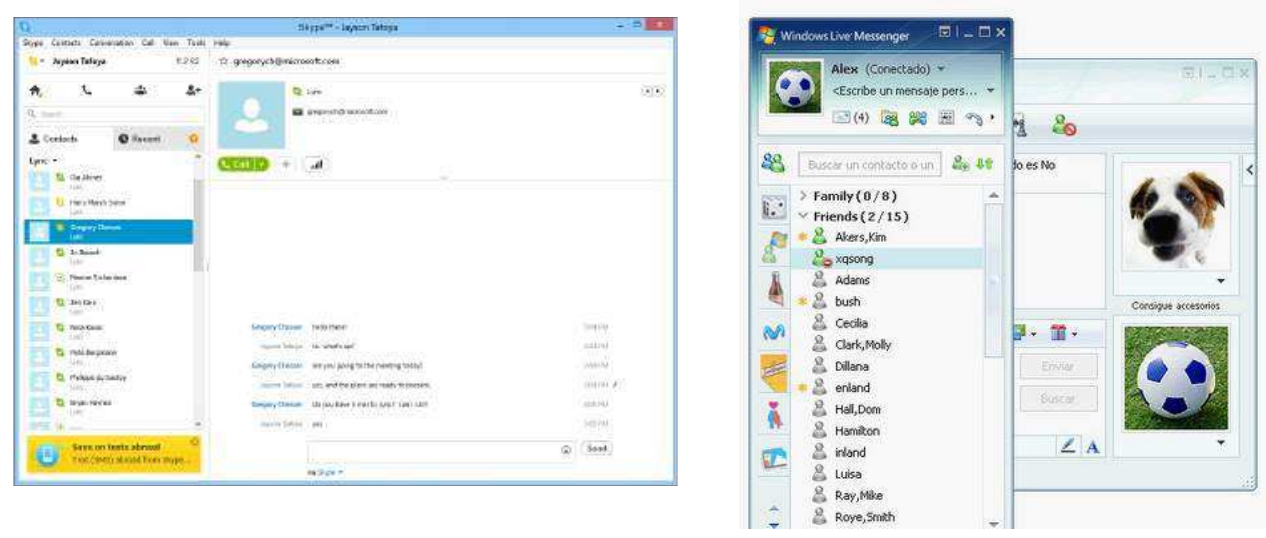

Figuras 3.9 e 3.10 - Skype (2003) e MSN Messenger (1999)

A fala de Chuck é reforçada por Hyou, que também questiona o quanto as redes sociais, os e-mails e os próprios meios de informações são atividades que compartilham a mesma natureza "virtual" dos jogos eletrônicos.

Por que a gente não poderia usar o mesmo argumento pra esse tipo de coisa para além dos jogos? Alguém já se pôs essa questão? As interações virtuais são de fato um outro plano de realidade ou uma ficção, uma mentira, uma fuga de realidade? Porque as próprias pessoas que falam isso usam redes sociais. Hyou

Vemos que muitos diagnósticos de dependência de games e de internet centram-se apenas na tecnologia utilizada pelo usuário (como o computador e o videogame) e não discriminam o tipo de atividade desenvolvida de fato nesta interação - como comunicação, sexo, navegação difusa, jogos, relacionamento amoroso, filmes/música, obsessão amorosa, personagens, trabalho, coleção etc., em ordem de recorrência, segundo os dados da tese de Ivelise Fortim (2013). Neste caso, observa-se o surgimento de termos como "dependência em comunicação", "dependência em sexo virtual", "dependência em jogos online", entre outras.

\section{Uma ou duas coisas sobre elas, as comunidades virtuais}

Ainda sobre a questão da sociabilidade, vemos que em muitos casos se formam 
coletivos transitórios em torno dos games, isto é, agrupamentos de jogadores, desenvolvedores, plataformas, sites, blogs, fóruns, outros games e demais actantes. Alguns autores, como Howard Rheingold, denominaram estes agrupamentos de comunidades virtuais. As chamadas comunidades virtuais entram na questão da dependência de videogames porque, em tese, seriam o local onde as pessoas passariam a viver relações "falsas", em detrimento daquelas consideradas "verdadeiras". Quais seriam as controvérsias envolvendo este conceito? Rheingold argumenta:

Talvez o ciberespaço seja um dos lugares públicos informais onde possamos reconstruir os aspectos comunitários perdidos quando a mercearia da esquina se transforma em hipermercado. Ou talvez o ciberespaço seja precisamente o lugar errado onde procurar o renascimento da comunicação, oferecendo, não um instrumento para o convívio, mas um simulacro sem vida das emoções reais e do verdadeiro compromisso perante os outros. Seja qual for o caso, precisamos descobri-lo o mais rapidamente possível (RHEINGOLD, 1996, p. 43).

Kimberly Young (1998, p. 30) argumenta que recorrer às comunidades virtuais é uma forma de as pessoas contornarem deficiências pessoais na "vida real". Segundo ela, a formação dessas arenas virtuais cria uma dinâmica de grupo de apoio social que atende a uma necessidade profunda e compelidora em pessoas cuja vida real é empobrecida e carente de intimidade. Ela afirma que, em outros casos, quem se sente socialmente pouco hábil ou tem dificuldade em criar relacionamentos sadios na vida real descobre que consegue se expressar mais livremente no âmbito virtual e encontra o companheirismo e a aceitação ausentes em sua vida.

Seguidor de sua linha de trabalho, o psiquiatra Cristiano Nabuco de Abreu, Coordenador do Grupo de Dependência Tecnológica do Programa de Transtornos do Controle dos Impulsos do Hospital das Clínicas, em coluna publicada em seu blog, se mantém na visão dos games a partir da falta, compensação e frustração.

Pensemos agora naqueles jovens que não se sentem socialmente aceitos por se sentirem muito tímidos. Através dos jogos interativos, eles podem se tornar mais habilidosos (e interessantes) do que são na vida real, assegurando assim uma valorização que não possuem ainda, obtendo finalmente o tão sonhado reconhecimento social. [...] Obviamente que ninguém e, neste momento, um enorme grupo de pessoas literalmente troca as experiências da vida cotidiana pelas da vida cibernética, ficando assim aprisionados nos ambientes virtuais de sucesso e de reconhecimento, enquanto simultaneamente perpetuam suas inabilidades com o mundo real (NABUCO DE ABREU, 2013). 
Caplan e High (2007), teóricos que trabalham com a teoria da compensação (vide capítulo 1), colocam que a capacidade de criar uma comunidade virtual deixa para trás o mundo físico; assim, pessoas conhecidas, fixas e visuais deixariam de existir, e os usuários anônimos criariam, então, um encontro de mentes que vivem em uma sociedade baseada puramente em textos. Dessa forma, "pelo intercâmbio de mensagem pela Internet, os usuários compensam o que lhes falta na vida real" (CAPLAN; HIGH, 2007 apud YOUNG, 2011, p. 29).

Manuel Castells (2001) coloca que empiricamente não existe algo como uma cultura comunitária unificada da internet. Para ele, a maioria dos observadores, de Howard Rheingold a Steve Jones, enfatiza a extrema diversidade das comunidades virtuais. No entanto, apesar de aproximá-los, Castells ainda trabalha com a oposição "mundo social da internet" versus "a própria sociedade", o que vai de encontro às proposições de, por exemplo, Bruno Latour (1994), Gabriel Tarde (1910) e Marilyn Strathern ${ }^{174}$. Castells afirma que os usuários tendem a adaptar novas tecnologias para satisfazer seus interesses e desejos: "Assim, para deleite dos teóricos pós-modernos, os MUDs são o domínio privilegiado para a representação de papéis e as identidades falsas (p. 70)”.

Os autores citados nesta breve seção apresentam um conceito de comunidade virtual que vai num sentido oposto ao que defendem alguns críticos. Para Lehdonvirta (2010), acadêmicos e publicitários frequentemente se referem à base de usuários de um MMO como "uma comunidade", lembrando a noção de Rheingold (2000) de uma comunidade virtual. Para ele, este é um termo mal-ajustado.

A comunidade virtual de Rheingold, bem como a noção clássica de comunidade na Sociologia ${ }^{175}$, são caracterizadas pela familiaridade, unidade e, até mesmo, pela intimidade entre seus membros. Um grupo de um milhão ou mais de indivíduos que, por diversas razões, comprou o mesmo jogo ou criou uma conta no mesmo site, claramente não compartilha essas características. Um servidor

\footnotetext{
${ }^{174}$ Strathern argumenta que sociedade corresponde a uma abstração reificada, concebida como a soma de interações individuais ou como uma entidade que regula a conduta dos indivíduos. E assim como a sociedade constrói a ordem de relações entre seus membros, a individualidade destes é tomada como logicamente anterior. Indivíduos aparecem, então, como o fenômeno primário da vida e as relações, como secundárias (STRATHERN, 1996b).

175 Ferdinand Tönnies, sociólogo alemão, cunhou uma distinção clássica entre dois tipos básicos de organização social: a comunidade e a sociedade. Para ele, as relações de comunidade, típicas de grupos de caçadores-coletores e hordas, baseiam-se na coesão nascida do parentesco, das práticas herdadas dos antepassados e dos fortes sentimentos religiosos que unem o grupo. Já as relações de sociedade seriam típicas de grupos que vivem vida urbana desenvolvida, organizam-se em Estados e possuem uma complexa divisão do trabalho. Esta visão possui uma série de críticas na Antropologia, como por exemplo na discussão etnológica contemporânea (ver STRATHERN, 1988; 1996b; WAGNER, 1974).
} 
de MMO pode atuar como uma arena onde comunidades se reúnem, mas algum outro conceito deve ser utilizado para se referir à base maior de usuários (LEHDONVIRTA, 2010, tradução nossa).

Segundo Lehdonvirta (2010), desde os primeiros estudos sobre comunidades mediadas por computador (RHEINGOLD, 1993; TURKLE, 1995), vem sido amplamente aceito que as amizades mediadas por redes de computadores possam ser tão profundas e significativas como aquelas sustentadas face-a-face. É igualmente reconhecido que uma distinção entre "amigos do mundo real" e "amigos do mundo virtual" é complicada, uma vez que as relações transitam entre ambientes online e offline.

Theophilos Rifiotis (2010) nos alerta que sob a alcunha de comunidades virtuais se encontra uma variedade grande de coletivos. Para ele, essa denominação é utilizada correntemente para, ao mesmo tempo, descrever e qualificar um conjunto amplo e diversificado de interações sociais que tem lugar no ciberespaço (RIFIOTIS, p. 76). Dessa forma, devemos atentar aos diferentes usos desse conceito.

É a multiplicação desses quase objetos que está em questão na modernidade e a não separação radical natureza-cultura, técnica e sociedade. Seguindo a análise de Latour e procurando dela tirar as consequências pertinentes ao nosso diálogo, diria que a noção de "comunidade", como é aplicada para os grupos sociais que se formam no ciberespaço, para além de um caráter nostálgico, tem sido empregada com um certo virtuosismo ("vitalista"), que prescinde de uma consideração falha no seu ponto de partida, ou seja, que a modernidade realizou aquilo que ela afirma, apesar das constantes e longamente enumeradas e discutidas provas em contrário apresentadas por Latour (RIFIOTIS, 2010, pp. 78-79).

Este autor expande a sua crítica ao conceito de comunidades virtuais para outros agrupamentos com o mesmo adjetivo. Rifiotis propõe, enfim, que consideremos "comunidade virtual" uma categoria êmica e, portanto, ela mesma objeto de análise.

Ao empregar o adjetivo "virtual" associado a noções tais como "novas formas de sociabilidade" e a onipresente "sociabilidade", que precisam igualmente ser problematizadas, estamos fazendo uma operação que não é apenas descritiva, mas qualificadora e carregada desses pressupostos (idem, p. 79).

Adelina Pereira da Silva (2007), por sua vez, coloca que o termo comunidade virtual sugere uma comunidade que aparentemente só existe no ciberespaço. De qualquer modo, isso implica uma nova forma de ligação que passa a existir no meio de, ou entre, comunidades no espaço sócio-geográfico real, ligando e estendendo-as. 
Para Turkle (1999), a comunidade não pode existir no transitório, é necessária uma permanência. Ela não chega a chamar tais lugares não transitórios na internet de comunidades, pois considera esta uma questão em aberto, mas se interessa por seus efeitos identitários e ressalta a criação de histórias pessoais nesses lugares. Turkle demarca novamente a questão da comunidade como a ausência de transitoriedade.

Sustento que uma das chaves do comunitário é a ausência de transitório, a permanência. Assim, pode-se partilhar uma história, uma memória. Com a continuidade vem a possibilidade de construir normas sociais, rituais, sentido. Aprende-se, aos poucos, na medida em que se estabelece uma cultura on-line, com experiências comuns, a confiar uns nos outros. Mas, uma vez mais, quero destacar que as melhores possibilidades para o desenvolvimento das comunidades encontram-se nos lugares em que se cruzam as experiências virtuais e o resto da vida (TURKLE, 1999, p. 120).

Com esta discussão, vemos que não se deve adotar sem atenção termos como comunidade virtual, pois de outra modo corremos o risco de pré-qualificar estas relações sem o devido conhecimento do que acontece efetivamente entre tais pessoas, jogos e coisas. As variações de sociabilidade nos games, portanto, aparecem de várias formas específicas. Unificar rapidamente suas características é, pois, perder de vista a sua multiplicidade.

\subsection{6 - Escapismo}

Nesta seção abordaremos o tema do escapismo dos jogos, tão recorrente nos diagnósticos e teorias de dependência. Será que, como escreve em seu artigo a psicóloga Luciana Ruffo (NPPI), nos refugiamos de nossos problemas ao adentrarmos os games?

Se me sinto como um Zé Ninguém no mundo real, mas no virtual sou o todo poderoso, por que voltar para o real? Se no real tenho uma família problemática, poucos amigos, por que sair do virtual onde encontro pessoas que cuidam de mim e me tratam como irmãos? Aliás, é comum os graus de parentescos fazerem parte das regras de funcionamento em alguns desses jogos. Quando não há um grau de parentesco, ainda assim existem os grupos, que se ajudam, como na vida real (RUFFO, 2011b)

Será que jogamos para escapar da dura realidade, como esta e outros psicólogos alertam, ou, pelo contrário, "descarregamos" o estresse e as más energias nestes jogos, nos renovando para enfrentar novos desafios da vida cotidiana? Será que podemos qualificar em definitivo essas experiências com videogames ou, em nome do realismo, só podemos fazê-lo a cada vez? Seja como for, somente podemos falar em escape se confiarmos que de fato estamos diante de dois mundos distintos, com fronteiras bem 
estabelecidas: um real, do qual a pessoa almeja "fugir", e o outro virtual, no qual a pessoa busca "refugiar-se". Vamos seguir com o que os jogadores comentam.

Ricardinson relata uma intensa experiência com um MMORPG em determinada fase de sua vida. Este é um exemplo de descida etnográfica que nos leva a considerações sempre particulares e repele as generalistas ${ }^{176}$.

Eu não jogo mais atualmente, mas eu jogava Ultima Online. E aí a minha vida era no Ultima Online, a minha vida não era a minha vida real. A minha vida do Ultima Online era muito mais legal, porque eu era rico, eu tinha dinheiro, eu era respeitado, eu era forte... Esse era o jogo que eu jogava o dia inteiro, eu não parava de jogar e eu não fazia nada além de jogar. A minha vida era muito mais dentro do jogo do que fora dele. Então, não fazia sentido eu viver a vida real. Ricardinson

Em outras partes de sua entrevista, Ricardinson conta que a sua relação com o jogo somente pode ser desvendada a partir da compreensão de outros aspectos de sua vida que o levaram a se dedicar mais ao jogo do que a outras atividades e companhias.

Chuck comenta que, dependendo do caso, a pessoa pode fugir de problemas em casa, com a família, assim como, por outro lado, simplesmente gostar do jogo e querer jogar mais para se divertir. No entanto, ele mesmo alterna para uma compreensão generalista, quando afirma que o viciado seria "aquele que não aguenta conviver numa maneira social, pois quer voltar pro virtual e para encontrar seus amigos desconhecidos". Retornando para a perspectiva de "a cada caso", Chuck alerta que temos de atentar para os diferentes graus de envolvimento e analisar cada situação em particular.

Se o cara tem um problema na família e vai pro mundo virtual pra fugir disso, ele não consegue fugir completamente. Você não escapa completamente, na realidade, você vai estar num quarto a 100 metros do problema. E tem gente que foge do problema e arranja mais problema lá. Aí fica pior ainda. Mas eu acho que muita gente que fala que é viciado não é simplesmente, é uma pessoa que gosta de jogar. Eu era completamente viciado em Ragnarök. Não vejo nenhum problema nisso. O que eu viciei em Ragnarök me ajudou muito, conheço gente até hoje que jogava, mó de boa. Não tem problema nenhum. Chuck

Peter_pano, por sua vez, comenta seu uso intenso do videogame como um escape durante um período de turbulência em sua vida. Nesta época, ele focou sua atenção em um só jogo, mas, após essa fase, se abriu para outras experiências.

\footnotetext{
${ }^{176}$ Para Stelio Marras (em comunicação pessoal), as compreensões generalistas são, em geral, esposadas com os propósitos estatais e um modo estatal de pensar e agir, donde a estatística tem papel fundamental.
} 
Essa época foi uma das épocas que eu estava bem estressado. Então eu acho que acabou que eu foquei muito no Call of Duty e usando ele de válvula de escape. Tanto que no primeiro momento que eu consegui ficar calmo, que foi quando eu pedi demissão e voltei pra morar em Santos, eu praticamente parei de jogar Call of Duty. Passei a jogar outros jogos de novo. Então eu estava suprindo uma necessidade minha naquele momento. Depois eu não tinha mais aquela necessidade. - Peter_pano

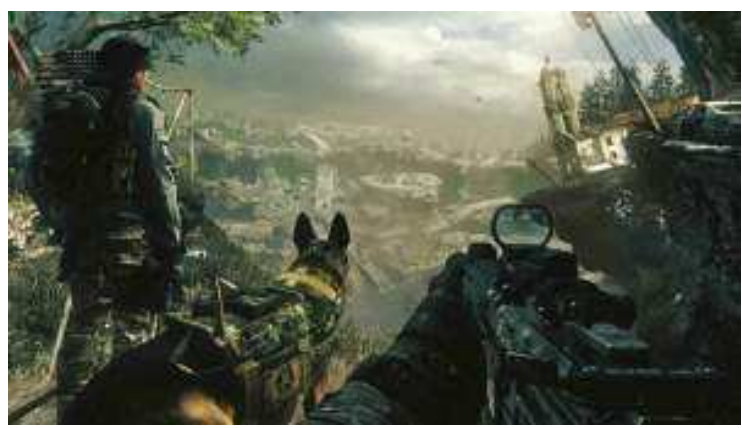

Figura 3.11 - Call of Duty: Ghosts (2013)

Hyou comenta que, às vezes, o videogame funciona como uma válvula de escape: "Quando a gente está muito atarefado, a gente dá aquela respiração, joga uma partida e volta" (ver seção: Gerenciamento de estresse, no capítulo quatro). A questão é: mesmo que o game seja escapismo, ele não é o único recurso para isso. Pode-se, por exemplo, escapar trabalhando, estudando, ou, ainda, pelo uso das chamadas "drogas", pelo sexo ou, ainda, por outras formas de "lazer". Em sendo assim, temos de redimensionar o escape de modo a não mais tratá-lo exclusivamente como algo negativo.

A psicóloga Ivelise Fortim argumenta que acontece uma cisão de personalidade nos casos mais fortes de escapismo, em especial nos MMORPGs jogados no computador, em que a pessoa manteria uma personalidade dentro do game (ou da internet) e outra fora (na "vida real").

Você tem que ver do que o cara está fugindo. Isso é uma das coisas. Outra coisa que tem que pensar é que tem graus de dependência. Têm dependências mais leves e têm dependências mais severas. Principalmente internet e videogame têm um fenômeno de dividir a personalidade em dois. Por exemplo: "Ninguém me aceita fora da internet, ninguém me aceita fora do MMO, mas no MMO eu posso ser uma outra pessoa. Eu posso ser diferente. Então, se eu tenho autoestima baixa, ninguém gosta de mim, mas aqui as pessoas gostam de mim". E é por isso que vicia. "Porque aqui é o único lugar onde as pessoas me amam, aqui é o único lugar onde eu participo". MMO é assim, console é uma outra discussão. E eu vi pouco trabalho de dependência de videogame falando de console. Mas é assim: "Aí eu sou amado, aí eu sou importante, aí começa a entrar assim só no videogame, eu só existo no videogame. Eu não existo fora”. (comunicação pessoal) 
Sherry Turkle (1999), no entanto, discorda dessa interpretação de distúrbios de personalidade online. Em sua opinião, não se trata de dupla personalidade, mas sim de cada um mostrar diferentes aspectos de si mesmo. Para ela, as pessoas dos MUDs não sofrem de dupla personalidade. Quem sofre disso enfrenta o problema de ter partes de $s i$ mesmo cortadas, cindidas, com a eliminação de certos aspectos. Para Turkle, o sintoma da doença é a falta de comunicação entre os componentes do ser. Ela diz que não houve, ao menos na tradição americana, respeito suficiente pelos estados não patológicos de multiplicidade, pois a linguagem da saúde mental centra-se na integração, no alcance de um estado ${ }^{177}$ de "unidade". Fica evidente na fala anterior, então, um compromisso com uma imagem estabilizada do ser. A seara da Antropologia contemporânea, por exemplo, já nos permite desvencilhar-se dessa imagem pela ideia de devir (BIEHL, 2008). E nem mesmo a Psicologia é una em relação ao ser (vide GUATARI, 1992).

Um dos assuntos mais recorrentes na discussão sobre o escapismo dos games é o avatar, isto é, o personagem que o jogador controla no jogo. Em muitos jogos, principalmente nos MMORPGs, há um grande esforço por parte do jogador em construir, customizar e evoluir o seu avatar. A partir disso, uma das controvérsias é: o avatar seria a própria encarnação do jogador no game, ou uma entidade independente, que em nada se assemelharia à pessoa que o controla?

Orochi fala que a pessoa não é um, nem o outro - isto é, ela não é inteiramente ela mesma nem o personagem. O avatar seria uma parte de sua personalidade (conceito que se mantém aqui como caixa-preta).

\begin{abstract}
Porque uma pessoa que no jogo é um guerreiro super valoroso e honrado e ela se identifica com isso, e na vida normal dela ela não parece esse guerreiro, talvez fisicamente o cara é magrelo, medroso e tudo mais, mas no jogo ela não é, não dá pra dizer que ele é um ou é outro, porque se ele se identifica com esse personagem criado no jogo, aquilo de alguma forma faz parte da personalidade dele. Mas que também não é toda a personalidade dele. Talvez seja a forma mais confortável pra ele se expressar. Ele preferiria ser só aquela parte da personalidade dele e não o resto. Mas ele tem aquela parte e tem as outras que às vezes ele quer negar quando ele vai pra esse jogo mesmo se ele se sente mais ele mesmo, se identifica mais com o personagem do jogo do que com ele na vida natural. Ele é um pouco dos dois. - Orochi
\end{abstract}

\footnotetext{
177 Segundo Marras (comunicação pessoal), o acento em uma só personalidade pode estar relacionado com um compromisso com o Estado, que reduz todas as diferenças à expressão da chamada cidadania. Portanto, esta parece uma forma de captura estatal.
} 
Questionariam os psicólogos (RUFFO, 2011b): Será que nos tornamos quem sempre gostaríamos de ser nesses jogos, superando limites de nosso corpo físico, ou nos enganamos fingindo ser personagens os quais não somos em nossas vidas ordinárias? Seria o avatar, afinal, uma construção da corporalidade virtual ou uma negação do corpo "real"? O psicólogo Lucas Costa explica que, por meio do avatar, uma pessoa pode alcançar coisas que uma caraterística física ou comportamental sua não lhe permite. Com estas mediações, o jogador pode aliviar tensões de um modo diferente, ativando um mecanismo psicológico de sublimação ${ }^{178}$ em que os jogos atuariam.

Você é um cara fraco, mas seu avatar é mega forte. Ou você é muito bonzinho, você faz um cara mega mal. No seu avatar você expressa um outro lado. Isso pode ter um nível saudável, que eu vejo assim, um mecanismo de sublimação, o menino tem muita raiva por coisas que acontecem na casa dele, ele vai lá, atira em todo mundo, isso rebaixa o nível de raiva dele. Aí funciona de uma certa forma. Ou a parada não funcionar, daí só se tornar compulsivo. - Costa

Janos Geocze, discordando do raciocínio anterior, argumenta que a pessoa não permanece "ela mesma" (já que esta entidade sequer existiria de fato) ou se torna completamente "o personagem" (que tampouco existe por si só), uma vez que estas identidades não são únicas nem bem demarcadas, mas sim, compostas.

De imediato eu te responderia: é eu também. Óbvio que alguma coisa daquele personagem capta você. Um cara mais franzino, por incrível que pareça, não vai escolher o antagônico a ele. Ele pega lá um franzino com muito poder. Pega o mágico, pega alguém que vai batalhar contra o brutamonte lá. - Geocze

Vemos, então, que há mais transformações e passagens do que conversões. Marcelo Mercante aponta para o quanto a pessoa consegue carregar as imagens de jogo para o seu cotidiano de forma que lhe ajude em suas atividades diárias. Para ele, "muitos ficam somente na máquina" e não conseguem trazer isso para o seu dia-a-dia.

E quem consegue trazer isso pra fora? Aí pra você começar a dizer que tem uma dimensão virtual, que é aquela imagem que você tem agência, começa a poder escapulir de dentro da tela e está atuando na vida do cara de verdade. E não só um momento que o cara está ali projetando. "Ah, porque quando eu estou no jogo eu sou esse guerreiro, eu sou esse avatar, que eu queria muito ser na minha vida e não consigo ser. Então aqui eu consigo realizar isso. Então é

\footnotetext{
${ }^{178} \mathrm{Na}$ literatura psicanalítica, a sublimação é frequentemente entendida como um mecanismo ou um modo de defesa contra as pulsões. Ela é o processo através do qual a libido se afasta do objeto sexual para outra espécie de satisfação (FRANCO, 1995). A sublimação de uma pulsão implica que esta possa se satisfazer com os objetos de substituição e também que uma satisfação imaginária ou simbólica possa se equiparar a uma satisfação real. O resultado da sublimação é o desvio da energia libidinal de suas metas originais, para ser investida em realizações culturais, ou em realizações individuais úteis ao grupo social. (BRABANT, 1973).
} 
por isso que eu não quero sair daqui”. Beleza. Mas quando você não está na frente da tela, o quanto do jogo você carrega pro teu dia-a-dia? Ou o quanto do jogo continua atuando no dia-a-dia? - Mercante

Masamune admite que muitas empresas de jogos exploram ${ }^{179}$ as fraquezas dos jogadores, buscando implementar mecanismos para obter mais vendas (nos deteremos sobre a questão da monetização dos games no capítulo seguinte).

Tem muito jogo que trabalha essa questão da pessoa não ter uma certa realização no mundo real. No mundo real aquela pessoa é tipo um merda. Uma pessoa que se morrer amanhã ninguém se importa... No mundo virtual ela é aquela pessoa que no Warcraft tem um personagem do level 100, com uma espada do caralho, umas quatro ou cinco casas diferentes... No mundo virtual ela é outra pessoa. Ela é alguém realizada, uma pessoa realizada. Muitas vezes ela consegue obter essa realização a partir da compra de DLC, ou seja, [ $a$ empresa de jogos] se aproveita daquela fraqueza da pessoa, daquela falta de uma espécie de realização pessoal, para que a partir de uma realização virtual ela gaste mais dinheiro, em troca. - Masamune

Podemos recuperar o argumento do sociólogo Erving Goffman em A representação do "eu" na vida cotidiana (1959) para questionar a dicotomia entre "verdadeiro eu" e "falso eu" presente em alguns enunciados. Goffman aponta que, da mesma forma que não temos uma única identidade (acrescentamos aqui, tampouco múltiplas identidades já prontas, mas sempre emergentes, contingentes), também não existe um "eu" verdadeiro, pois representamos diferentes personagens em diferentes situações. A própria noção de "eu" é criada a cada relação ${ }^{180}$.

Erving Goffman, no entanto, se refere ao "real" como a relação face a face, o que aqui também está sendo colocado em questão. Sua noção de interação também é distinta daquela trabalhada por Latour, Tarde e outros autores afins, que preferem a relação no sentido forte, isto é, da possessão recíproca, que afeta e transforma os termos em relação. Apesar dessas diferenças de abordagem, podemos entender o avatar como uma forma de representar o "eu" no ambiente de jogo. Isto, entretanto, não significa que ele é de fato a pessoa que controla o personagem, tampouco que é falso.

Dessa forma, vimos que há interesses diversos circulando em torno da captura de subjetividade do jogador. Com essas discussões em torno da sensibilidade,

\footnotetext{
${ }^{179}$ Não desconhecemos essa exploração e sua eficácia, mas tampouco desconhecemos que a intenção das empresas nem sempre se realiza e muito menos da forma como elas imaginam.

${ }^{180} \mathrm{Em}$ meu relatório de iniciação científica abordei esta questão de forma mais aprofundada, a partir das discussões em torno do conceito de identidade (MENESES, 2009).
} 
corporalidade, materialidade, comunicabilidade, sociabilidade e escapismo, passamos, enfim, por algumas das principais controvérsias em relação ao tema da virtualidade, a qual associa o videogame à dependência de drogas. A discussão tecida junto aos actantes agora nos leva para uma reflexão sobre esse capítulo.

\section{4 - Recompondo mundos reais e virtuais}

O procedimento nesse capítulo, como indicado, foi apontar pressupostos dos enunciados que põem como incomensuráveis o virtual e o real. Vimos que tais pressupostos têm a ver com um foco sobre as essências e identidades. Alternativamente, propomos nos debruçar sobre as ações, diferenças e passagens. Assim, buscamos mostrar os compromissos metafísicos (como, por exemplo, os ligados ao conservadorismo do típico americano médio) de certa oposição intransitiva entre virtual e real - e, em seu lugar, repomos essa oposição, abrindo-a - tornando-a, portanto, transitiva.

\subsection{1 - Drogas e realidade}

Nossa hipótese inicial era, pois, de que uma determinada concepção de virtualidade utilizada para compreender os videogames poderia torná-los suscetíveis à retórica do vício em drogas. As controvérsias sobre este tema apontam para lugares distintos: uma apreensão, no caso daqueles que postulam uma separação radical entre o virtual e o real, e uma celebração, no caso dos apologistas do digital, entre eles muitos jogadores de videogame. Apesar disso, sejam entusiastas ou luditas ${ }^{181}$, ambos veem o escape virtual dos videogames, da internet e de outras tecnologias relacionadas a uma realidade virtual como o reino de uma nova ordem mundial, pós-humana, pós-cultural. Como a escritora Elizabeth Grosz (2001) argumenta:

Considerando que muitos veem na RV (Realidade Virtual) a capacidade de aspirar um status de Deus, para criar, controlar, viver dentro de mundos, ter um poder de simulação que supera ou ultrapassa a desordem incontrolável do real; outros (às vezes até os mesmos autores) injuriam e temem a RV por sua transformação das relações de sociabilidade, comunidade, fisicalidade e corporalidade, localização e sua colocação, a sexualidade, a intimidade pessoal e o espaço de trabalho compartilhado - a perda de imediatismo, de presença física [...] Apologistas desavergonhados das cyber-tecnologias e luditas nostálgicos que anseiam pelos dias passados, respectivamente, veem a RV

\footnotetext{
${ }^{181}$ O ludismo foi um movimento no século XIX de trabalhadores fabris contra as máquinas da indústria, por temer que elas tornariam os trabalhadores obsoletos. É um termo hoje apropriado como revolta contra certas tecnologias, mas tem uma filiação histórica política importante, que constrói imaginários poderosos sobre as relações com agentes não-humanos.
} 
como uma poderosa força de libertação e uma forma de controle fascista cada vez mais invasiva (GROSZ, 2001, p. 77, tradução nossa).

Um ponto importante é que aqueles que celebram ou denunciam novas formas de mídia a partir de um conceito binário de real/virtual, veem um potencial de transformação para o real e para o "eu real" (outro conceito também controverso) no encontro com o virtual; de forma que os usos repetitivos, frequentes, apaixonados e até mesmo obsessivos das mídias digitais - entendidos como a falta de prazer da "vida real", do jogo físico e da comunicação face a face - geram uma ansiedade que iguala o virtual com a droga, com a fantasia da pornografia, e com outros "não-reais" relacionados à dependência.

Nesse sentido, jogar poderia ser entendido como viciante não porque os jogos são usados compulsivamente, mas porque, de acordo com Cover (2006), ao representar seu universo conceitual como "irreal", eles se ligam às drogas, e, assim, se tornam sujeitos ao discurso do vício em drogas. Como coloca o filósofo Jacques Derrida, rejeita-se o viciado em drogas porque:

Ele se isola do mundo, no exílio da realidade, longe da realidade objetiva e da vida real da cidade e da comunidade; [...] drogas, diz-se, fazem o sujeito perder qualquer senso da verdadeira realidade. No fim das contas, é sempre, penso eu, nos termos da presente acusação que a interdição é declarada. Não nos opomos ao usuário de drogas pelo prazer em si, mas pelo prazer tomado em uma experiência sem verdade (DERRIDA, 1995, pp. 235-236, tradução nossa).

Argumenta-se que a ligação entre a dependência de drogas e a dependência de games seja mais do que uma comparação metafórica, já que é enraizada em uma percepção do que constitui o "real". No entanto, uma simples substituição na citação acima do significante "drogas" por "jogo" indica a maneira como a noção de viciado digital é construída dentro dessa gramática das dependências. Por não estar, supostamente, dentro do conhecimento da realidade objetiva, o entretenimento interativo seria um prazer experienciado "sem verdade". Ou seja, quando o usuário retorna a este prazer ou experimenta o mesmo jogo diversas vezes, por exemplo, sentindo a tensão gerada pelo cumprimento das metas dos jogos, a retórica da dependência entra em cena e uma lógica de que seria possível referir-se ao usuário hardcore como um viciado seria estabelecida.

A seguir, vamos explorar algumas consequências do que vimos até aqui, colocando alguns questionamentos finais. Como suspeitamos no início, será que temos realmente 
um caso de equivocação controlada no caso da dependência de videogames? Tiago Coutinho comenta que a noção de mal-entendido proposta por La Cecla, Losonczy e Mesturini implica que compartilhar uma determinada linguagem que explora sinônimos de códigos culturais distintos não exclui a possibilidade de as pessoas acreditarem que elas estão se entendendo, quando na verdade estão falando de coisas bastante diferentes.

O modelo de comunicação baseado em mal-entendidos cria espaços que conferem uma maior liberdade interpretativa ao receptor, ao mesmo tempo que chama a atenção, através da informação transportada pelo próprio símbolo, para a importância de ferramentas metalinguísticas como gestos, posturas ou qualquer outro símbolo pertencente à comunicação não-verbal neste campo dialógico. Isto faz com que, nestas interações, a mensagem seja alterada inicialmente, no momento de sua transmissão e posteriormente, ao longo de sua propagação. A mensagem transmitida sofre ainda mais uma alteração quando a interpretação do receptor contrasta com o código cultural do transmissor (COUTINHO, 2011, p. 252).

Aparentemente, sim, podemos pensar na hipótese da equivocação controlada. Como exemplificado desde o início do capítulo, os jogadores, de fato, utilizam os termos "real" e "virtual" para se referirem a situações específicas, muitas vezes querendo dizer simplesmente "fora do jogo" e "dentro do jogo", respectivamente. Existe uma série de questões práticas da esfera da comunicação que podem facilitar o entendimento e a troca de informações em situações específicas. No entanto, não podemos reduzir essa longa discussão apenas ao entendimento de um equívoco de comunicação, pois observamos que essas mesmas classificações têm múltiplas agências e acarretam sérias implicações. Ou seja, estas não são simplesmente classificações discursivas, mas, sobretudo, cosmopolíticas ${ }^{182}$ (STENGERS, 2003).

Essas expressões linguísticas, como "vida real" e "mundos virtuais", por ventura são tomadas por atores, sejam jogadores, empresários ou terapeutas, de uma forma que as imputam de uma significação que reafirma a realidade do real e a irrealidade do virtual. Ou seja, por meio desses entendimentos, acabam-se criando associações entre o "real" e o "virtual" que dão origem a novas realidades. Como podemos ver durante descrição do trabalho de campo, invariavelmente esses termos são manuseados e transformados por

\footnotetext{
182 Stengers (2007) insiste que não podemos denunciar o mundo em nome de um mundo ideal. Haraway (2011) comenta que, para Stengers, o cosmos é o desconhecido possível construído por entidades múltiplas e diversas: "Cheio da promessa de articulações que seres diversos podem eventualmente fazer, o cosmos é o oposto de um lugar de paz transcendente" (p. 46). Para isso, ela invocou "o idiota" descrito por Deleuze, aquele que sabia como desacelerar as coisas, a fim de parar a corrida ao consenso ou a um novo dogmatismo ou à denúncia, para dar possibilidade a um mundo comum.
} 
especialistas e não-especialistas com diversas finalidades, com implicações tanto materiais quanto imateriais, que variam desde financiamentos de pesquisa, laboratórios e centros de tratamento, consultas médicas e psicológicas, venda e produção de games, assim como na circulação de ideias, valores e legislações em torno dos games. Em suma, devemos sempre ter em mente que as palavras e as coisas criam realidades.

\subsection{2 - A realidade do virtual}

Como os sociólogos há tempos descobriram, ideias ou crenças podem gerar sérias consequências no mundo real. Uma explicação importante para isso foi dada por W. I. Thomas (1922) que, de forma sucinta, declarou: "Se os homens definem situações como reais, elas se tornam reais em suas consequências" (TELLES, 2004, p.17).

Tomaremos o real, enfim, como um efeito (LATOUR, 1991; TARDE, 1910), concentrando-nos não nas supostas essências, mas sim nas ações. Assim, tudo o que gera efeitos na rede aqui será considerado real, pois de outra forma desconsideraríamos arbitrariamente tais agências em nosso mapeamento. Turkle (1999, p. 122) coloca que "até agora, creio que se julgou agradável comparar a experiência online com o que se conhece do real, mas tais analogias não levam muito longe e já é tempo de superá-las". A corruptela "virtual", neste caso, pode ser entendida como "mediado por computador", e não que eles seriam irreais ou derivados. Para Lehdonvirta (2010), na maioria dos casos, o prefixo não é sequer necessário. É nesse sentido que a antropóloga Maria Elisa Máximo reforça este argumento:

Dessa forma, afastamo-nos da tendência de situar a produtividade social do ciberespaço numa dimensão não real, paralela ou oposta à "vida real"; uma tendência que se mantém pelo uso corrente da palavra "virtual" como adjetivo do que se produz nesse universo: realidades, comunidades e outras entidades ou acontecimentos que nele possam se organizar [...] No entanto, a definição do "virtual" como sinônimo de "não real" pode e deve ser problematizada (MÁXIMO, 2010, p. 37).

Buscamos aqui fazer um esforço de recomposição dos mundos reais e virtuais, que também apresenta uma proposta para futuros estudos. Para Lehdonvirta (2010), o ponto mais óbvio é que um videogame (ex: um servidor de MMO) não enclausura uma "sociedade" ou um "mundo" separado da Terra. Ele elabora um projeto de mudança nos modelos de estudos de MMORPGs, que aqui reafirmamos e complementamos.

O primeiro passo para um melhor modelo é desacoplar a plataforma tecnológica dos grupos de usuários e instituições. Devemos fazer as fronteiras de uma 
sociedade inteira mediada por computador coincidir com os limites de um servidor de EverQuest, como sugerido por Castronova (2006a)? Ou devemos olhar também para, por exemplo, servidores de guildas e fóruns de discussão como modos paralelos do mesmo mundo social? (LEHDONVIRTA, 2010)

Para Lehdonvirta, o segundo passo para esse novo modelo é conceitualmente reinserir os MMORPGs no resto da sociedade da qual ele foi separado quando a retórica o transformou em um mundo próprio. O ponto, afinal, não é desistir completamente de estabelecer limites ou deixar a pesquisa perder seu foco, mas evitar traçar fronteiras artificiais baseadas em distinções puramente tecnológicas. Em palavras próprias, a proposta seria reinserir os games nos coletivos sociais (humanos) e tecnológicos (nãohumanos) abertos para transformações e possessões recíprocas (TARDE, 1910).

De acordo com o antropólogo e professor do Museu Nacional (UFRJ) Márcio Goldman (em comunicação oral), não há ponto de vista que permita julgar qual realidade é mais real que as outras. Segundo ele, todas as realidades são igualmente reais. O perspectivismo proposto por Viveiros de Castro (2004), pelo próprio Goldman e outros atores, postula basicamente a inexistência de uma transcendência, a inexistência de um ponto de vista externo, total ou geometral. Se não há ponto de vista extrínseco, portanto, há de se descrever o mundo dos outros como ontologicamente verdadeiro. Os pressupostos do humanismo modernista nas terapêuticas médico-científicas sobre a dependência solapam essas considerações; contudo, suas práticas (sobretudo de tratamento) estão contaminadas de participações não-modernas.

Inversamente, se há problemas com o conceito de "mundo virtual", também há problemas com a maneira pela qual o "mundo real" é implicitamente conceituado em muitos estudos sobre os games: como uma realidade uniforme e monolítica, onde as pessoas levam uma "vida real" racional, com sua "identidade real" unitária (LEHDONVIRTA, 2010). Questionamos simetricamente: afinal, que noção de realidade construímos quando adotamos a virtualidade como sua oposição?

Elizabeth Grosz aponta que aquilo que o mundo digital faz de melhor é "revelar que o mundo em que vivemos, o mundo real, sempre foi um espaço de virtualidade" (GROSZ, 2001, p. 78). Pensar sobre a dependência do videogame somente torna-se produtivo para a reflexão sobre as relações entre sociabilidade e novas mídias por meio da recomposição dessa dualidade estéril entre o real e o virtual. Como esses mesmos 
autores têm apontado, apesar de às vezes serem representados como puros, autossuficientes e independentes, o "real" e o "virtual" nascem simultaneamente.

T. L. Taylor conclui que "imaginar que podemos segregar essas coisas - jogo e nãojogo, [...] virtual e real - não é só não entender a nossa relação com a tecnologia, mas também a nossa relação com a cultura" (TAYLOR, 2006, p. 153). Ela observa que "da mesma maneira que agora vemos a relação entre a vida online e offline como não delimitada, em muitos aspectos, uma dicotomia jogo/não-jogo não se sustenta" (p. 19).

Por fim, buscamos descrever neste capítulo algumas das controvérsias envolvendo o aspecto virtual da dependência de jogos eletrônicos. A partir de um mapeamento parcial de uma variada semântica de noções de real, virtual e vício, apoiada por noções (também controversas) de sensibilidade, corporalidade, materialidade, comunicabilidade, sociabilidade e escapismo no caso dos videogames, pudemos multiplicar algumas perspectivas e notar certas regularidades e irregularidades.

Entretanto, de forma alguma isso esgota a questão, já que as possíveis redes em torno desse objeto de pesquisa são por demais extensas e dispersas, de modo que seria impraticável não cortá-la em certo ponto. Além disso, a rede descrita neste trabalho foi construída a partir do próprio pesquisador, ou seja, tem declaradamente a sua agência, seleção e organização. Isso, no entanto, não enfraquece a análise, mas a situa em torno da objetividade alcançada pela reunião das diversas subjetividades aqui presentes.

Congregando as conclusões do capítulo anterior com este próprio, entendemos que, se na perspectiva de certos terapeutas (YOUNG, 1998; ABREU, 2013, RUFFO, 2011b, CAPLAN; HIGH, 2007), jogar videogames não é considerada uma atividade do mundo "real", tal como o trabalho e o estudo (offline), em outra os videogames são também atividades que compõem o mundo "real" - como demonstram uma série de pesquisas acerca de seus efeitos, sejam eles positivos (como a educação e o desenvolvimento cognitivo) ou negativos (como a suposta dependência ou violência).

Por outro lado, vemos que, se na categoria "virtual" estão inseridas (pelos mesmos cientistas) atividades como navegar na internet, jogar videogames e ver pornografia digital, ampliando a nossa rede, elas seriam consideradas "reais" (vide, por exemplo, as pesquisas que postulam a "produtividade" dos jogos, seus benefícios cognitivos e 
educacionais, a profissionalização dos jogadores e a influência dos games na "sociedade"). Enquanto que, se invertermos os sentidos das palavras (retornando à perspectiva das acusações iniciais), o trabalho e o estudo também podem se tornar, na prática, atividades "virtuais", ou seja, quando o ofício exige a mediação de um computador, de uma tela, de um sinal de internet ou demais tecnologias digitais.

A proposta, enfim, é que não se considere exclusivamente a concepção moderna da separação estanque entre o real e virtual para debater a controvérsia sobre o uso dos jogos eletrônicos, mas que se congregue as diversas perspectivas dos actantes envolvidos na questão, como a dos próprios jogadores e desenvolvedores, para multiplicar as formas de entendimento da questão. Essas perspectivas, além de trazerem conhecimentos fundamentais para o debate, abarcarão consigo outros não-humanos, como os próprios videogames, outorgando mais objetividade ao parlamento das coisas. É preciso também adentrar os ambientes dos jogos chamados "mundos virtuais", e ver o que eles têm a nos mostrar. Somente assim, os invisíveis se tornarão visíveis, para que possamos contemplar uma rede mais complexa de agências e causalidades.

\begin{abstract}
Apenas escolho com cuidado os termos, para que eles possam passar de um lado a outro da antiga "grande divisão", varrendo um tipo de fenômeno que nem a psicologia - sem objeto - nem a epistemologia - sem sujeito - parecem-me capazes de abrigar. Interessam-me somente as questões que essa reformulação permite colocar, agora que dispomos de uma base comparativa mais simétrica e mais vasta: já que eles não têm mais psicologia que os outros [...] Quais são os invisíveis indispensáveis à construção provisória e frágil de seus invólucros e de seus quase-sujeitos? Como fazem para afastar os pavores e para transferi-los para outro lugar? Por meio de quais dispositivos? Quem são seus curandeiros? Quem são seus etnopsiquiatras? (LATOUR, 2002, p. 100).
\end{abstract}

Não se trata, portanto, de escolher a "correta" relação entre virtual e real, como pretenderia uma teoria geral que se apresente para explicar todo e qualquer fenômeno aí relacionado, ou mesmo de eliminar essa oposição, mas sim de descrever etnograficamente as práticas, isto é, os efeitos de uma e de outra concepção.

No capítulo derradeiro adentraremos mais a fundo o universo dos games: $\mathrm{O}$ que, de fato, acontece nestes jogos? Quais são esses jogos? De quê tipos? Há jogos que "viciam" mais do que outros? Com quem esses jogadores jogam? O que se pensa na família desses jogadores? Existem conflitos? Passaremos brevemente por essas questões acerca de violência e gerenciamento de humor e buscaremos entender como os desenvolvedores buscam criar um maior envolvimento, entre outros temas. 


\title{
Capítulo 4 - Por dentro do jogo: explorando o círculo mágico
}

\begin{abstract}
Os videogames são uma janela para um novo tipo de intimidade com máquinas, que caracteriza a cultura de computador nascente. O relacionamento especial que os jogadores estabelecem com os videogames tem elementos comuns a interações com outros tipos de computador. O poder dominador dos videogames, o seu fascínio quase hipnótico, é o poder dominador do computador. As experiências de jogadores de videogames ajudam-nos a compreender esse poder dominador e algo mais (TURKLE, 1989, pp. 58-59).
\end{abstract}

Resumo: No capítulo derradeiro, descreveremos de forma mais detalhada as experiências dos jogadores, buscando compreender os significados de suas relações com os videogames. A partir de entrevistas colhidas em campo, buscaremos descrever aquilo que é mobilizado pelos games, extraindo regularidades e diferenças entre os diversos casos. Examinaremos algumas das classificações dos próprios jogadores sobre as noções de dependência (ou vício), gerenciamento de humor (estresse) e a comparação metafórica entre jogos e drogas. Também mapearemos algumas disputas envolvendo os ambientes de jogo, violência e questões suscitadas pelos familiares, cônjuges e demais pessoas afetadas pelo uso dos videogames. Descreveremos em detalhes os próprios games junto aos jogadores, apontando suas diferenças de gêneros, formas de conexão, número de participantes e mecânicas de jogabilidade. Passaremos pela inserção da internet nos games, abarcando os jogos online, assim como os chamados "jogos sem fim". Também adentraremos os mundos dos MMORPG, apontados pelos próprios jogadores e pelos terapeutas como os games com casos mais frequentes de dependência. Por fim, traremos à tona os conhecimentos dos desenvolvedores de jogos sobre mecanismos de recompensa e a teoria do fluxo, terminando com uma reflexão acerca da monetização dos jogos, da "gameficação" e das alternativas propostas pelos jogos independentes.

Palavras-chave: videogames; MMORPG, família; juventude; violência; drogas.

Neste capítulo final, abriremos espaço para diversos comentários e depoimentos dos usuários de videogames e de outros actantes, como pais, mães, esposas e namoradas, em torno de uma discussão da dependência centrada na experiência de jogar videogames. Este é um capítulo de caráter mais descritivo e etnográfico, no qual serão apresentados os principais temas em debate por meio de depoimentos recolhidos no trabalho de campo (em entrevistas e etnografias virtuais) e agrupados em tópicos específicos. Nesse sentido, deixaremos os próprios interlocutores se expressarem e explicarem seus entendimentos, sem a necessidade do pesquisador analisar ou interpretar seus discursos a partir de outro nível epistemológico. Este é um dos motivos por quê este trabalho se 
constitui como um mapeamento de controvérsias (LATOUR, 2007) e não como uma análise de discurso.

Nesta altura do trabalho, evitaremos citar com frequência autores acadêmicos, ou mesmo antropólogos, psicólogos e médicos (excetuando aqueles que foram entrevistados), uma vez que já tiveram um bom espaço nos capítulos anteriores. Dessa forma, ao levar a cabo este empreendimento etnográfico de delinear associações, buscaremos entender o que são, em detalhe, esses jogos; quais forças estão fazendofazer, o que se toma como referência e a que tudo isso, afinal, está levando em termos de transformações.

Para requentar a controvérsia, encontramos nos comentários dos leitores de uma notícia ${ }^{183}$ intitulada "O vício em games e seus efeitos no indivíduo e na sociedade", publicada online no portal Geek, um debate acalorado em torno do assunto. Nesta lista, um jovem identificado como Eduardo colocou-se contra os especialistas, como o Dr. Daniel Spritzer (que é mencionado e entrevistado na reportagem), que alertavam para os perigos do uso de videogames.

Típico. A visão de jogos de videogames como um "mal" que "talvez tenha uma pequena parte boa" é muito difundida por "especialistas". Todos lembram que algumas pessoas sim esperavam toda a semana pelo final de semana e juntavam dinheiro para jogar videogame com amigos (esses viciados, tsc, tsc, tsc). O que ninguém lembra é de pessoas que esperavam toda a semana pelo final de semana e juntavam dinheiro para ir no estádio de futebol, torcer pelo seu time do coração (esses exemplos de brasileiros saudáveis e amantes de esportes). Jogar videogame é uma atividade de entretenimento. Ponto! - Eduardo

Para justificar seu argumento, Eduardo comenta que passar a tarde do domingo jogando videogame é geralmente visto pelas pessoas como algo mau, que gera psicopatas e/ou faz mal a saúde, enquanto que passar a tarde descansando e vendo TV é visto como algo normal, "já que todo mundo precisa relaxar um pouco". Ele acrescenta: "Só eu vejo a hipocrisia nesse pensamento? Pessoas diferentes gostam de coisas diferentes. Pessoas diferentes têm problemas diferentes. Diferentes pessoas que têm problemas sérios se tornam psicóticas", ele afirma. Para ele, gostar de algo como hobby não faz mal, nem gera qualquer tipo de problema.

\footnotetext{
${ }^{183}$ http://www.geek.com.br/posts/15757-o-vicio-em-games-e-seus-efeitos-no-individuo-e-na-sociedade
} 
"Fulano gosta e jogava jogos de videogame logo isso é a causa de fulano ter se tornado psicótico". Alguém realmente leva a sério uma afirmação como essa? É o que parece. Note que qualquer coisa pode trocar de lugar com "videogame" nessa frase. Esse raciocínio é simplesmente falho, para não dizer que é propositalmente falacioso. Mudem de assunto, comecem a estudar o vício em futebol e como gostar de futebol torna pessoas violentas e psicóticas ou algo do gênero. - Eduardo

Na mesma lista de discussão, o usuário Alexo também coloca seu depoimento em defesa dos games, desconfiando dos chamados especialistas e blindando os videogames de acusações.

"Nem todo jogo é ruim"? Que exagero. Eu diria que nenhum jogo é ruim. Videogame é como um esporte virtual, e antes de tudo, uma atividade de entretenimento e, acreditem os "especialistas", de cultura, informação e também desenvolvimento intelectual. Videogames não criam sociopatas; nem influenciam. Seus ideais e práticas assassinas são originárias anteriormente, na convivência com a família, na infância, com os pares na sociedade, etc. Antes de criticarem os videogames, sejam especialistas realmente sobre o assunto (ou procurem fontes críveis para evitar matérias que soam sensacionalismo para a esmagadora maioria de pessoas que joga videogames e, estatisticamente, não assassinaram ninguém). - Alexo

Uma leitora identificada como Paula discorda radicalmente dos argumentos anteriores.

No mesmo endereço eletrônico, ela narra um caso grave, por qual está passando com seu marido:

Meu marido já chegou a ficar 12 horas jogando e isto ocorre direto desde quando namorávamos a 7 anos atrás. Coisa de virar uma madrugada jogando sem parar. Ou seja, se isto não for um vício eu não sei o que é. O curioso é que ele está com todos os sintomas: hiperativo, déficit de atenção, abstinência, mudança de humor e fora o fato dele detestar quando falamos sobre o assunto. Se alguém ligar em casa e perguntar dele, ele pede para eu dizer: "Não diz que eu tô jogando!". Se tem vergonha, então porque continua?! Falta de assumir também é um sintoma.

Eu chego da faculdade todos os dias e dou de cara com ele jogando. A coisa está num ponto que tenho que ficar fiscalizando, quando estou presente, para ele nem sentar na frente do computador senão começa a jogar e não pára mais. Já chegou atrasado no trabalho por várias vezes por conta de que tinha que "fazer a loja" do Priston ${ }^{184}$. Curioso, né, mas conheço tudo porque já tentei de tudo. Desinstalar os jogos e deletar o ".exe", desligar a máquina, deslogar quando ele ia ao banheiro. Até um "char" já criei e o acompanhei em alguns jogos. Mas não aguentei mais de meia hora. Achei um absurdo! Muito tempo perdido! Praticamente só sou casada com um jogador. Até quando não sei!!!

Se você acha isto normal, então você também deve estar dentro desta estatística dos viciados que nunca assumem porque acham que é super normal e preferem

184 Priston Tale é um jogo do gênero MMORPG, desenvolvido na Coreia do Sul pela Yedang Online. 
tampar o sol com a peneira dizendo que tudo no mundo vicia e já que não estão roubando, matando ou se "drogando" nas ruas, ninguém tem que criticar, pois estão fazendo um "bem" a humanidade. Haja ingenuidade! Assim como você, ele também acha ruim eu criticar ou qualquer outra pessoa.

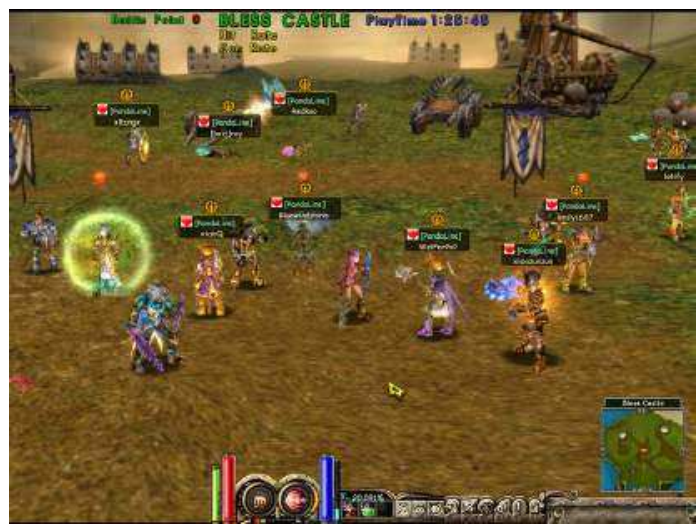

Figura 4.1 - Priston Tale (2005)

Não quero ter que ir ao mercado e deixar nosso filho para ele alimentar, e ao chegar ver que deixou a criança passando fome porque o jogo é mais importante. É muito difícil ver que nós da família somos trocados por uma coisa inanimada que teoricamente não deveria ter poder sobre a mente humana, e no entanto tem. Isto só prova o quanto somos fracos e não prestamos atenção nos detalhes, nas entrelinhas...

Os "benefícios" que os jogos trazem não compensam em relação às destruições que causam aos jogadores e seus familiares. Acontece que quem está de fora é quem consegue ver a gravidade do problema. Pessoas fracas é que se deixam levar por coisas, objetos, enfim... A real importância da vida está no verdadeiro sentido que damos a ela, em nossa família, em nosso lar e amigos. As pessoas que realmente amamos.

Você pode perder todo este tempo com todas estas porcarias e achar que não é nada de mais, mas depois de anos, ao ficar muito velho e se dar conta de que perdeu tempo demais com isto, perceberá que grandes oportunidades na vida foram jogadas fora. Nosso tempo em terra não é como um "level" de um jogo que você perde e em qualquer momento depois pode reconectar para conquistar tudo de novo. O nosso tempo definitivamente não volta. Pergunto-lhe...Você ainda acha que isto é normal?! Se você acha então aconselho a procurar um médico especialista!!! - Paula

Esse embate deflagrado no espaço de comentários dessa notícia retrata uma polêmica viva em torno de um assunto que passa pela Ciência, mas vai muito além desta. Percebemos aqui que há uma variedade de concepções a respeito do que seja vício e dependência. Mapearemos em detalhes essa semântica, bem como alguns dos principais pontos da discussão: além das concepções de vício e dependência, o gerenciamento de humor, os ambientes de jogo, os conflitos entre familiares, a comparação entre os jogos e as drogas, as diferenças entre os tipos de jogos, os MMORPGs, o tema da imersão, da monetização, da gameficação e do desenvolvimento de videogames. 


\section{1 - Concepções de vício}

Nesta seção, examinaremos as descrições dos entrevistados desta pesquisa sobre o que entendem por vício ou dependência. Afinal, esses jogadores se consideram dependentes (ou já se consideraram em alguma época de suas vidas)? Como eles retratam a sua relação com os games? Lembremos, pois, que pelos métodos e teorias apresentadas no capítulo inicial, os jogadores que deram aqui seu depoimento não seriam necessariamente classificados como viciados. De acordo com esses psiquiatras, alguns dos presentes casos poderiam ser "leves" vícios. Sigamos, então, com alguns relatos.

Para o programador Allprot, há nos casos de dependência uma troca da vida pelo jogo: "Na verdade é uma troca. O jogo se transforma na sua vida. E a vida se transforma numa coisa que você tem que tolerar pra ir pro jogo. É muito forte” (ALLPROT, 2013). Nesse apontamento, uma barreira é criada: o jogo não apenas não é vida (ou não faz parte dela), como a esgota; da mesma forma como a vida não é o jogo. Ou seja, ambas, num plano oficial, caminham separadas. Notemos que Allprot não acrescenta o adjetivo "real" à vida, nem emprega a expressão "resto da vida". Em sua fala, ambos, vida e jogo, competem entre si para capturar o jogador.

Naquela época pra mim ligar o jogo era como respirar, eu tinha que jogar. Quando eu desligava não era por vontade, era porque ou não estava aguentando mais, tipo de sono, ou minha mãe estava me obrigando, eu tinha que ir pra escola. Hoje não, eu ligo e desligo porque eu quero assim mesmo: "Ah, eu cansei de jogar", "Ah, quero jogar". Naquela época não, naquela época era uma necessidade. - Allprot

Para o jogador Orochi, uma das características da dependência é a fuga da realidade, o que lembra algumas características enunciadas pela teoria da compensação (já exploramos a questão do escapismo mais detidamente no capítulo anterior).

A dependência do jogo surge porque quando você está jogando, muitas vezes você até esquece que você está ficando muito entretido no jogo, você esquece da sua realidade no momento. Então chega a ser uma certa fuga, assim como pode acontecer com pessoas vendo televisão, ou até as pessoas lendo um livro. A pessoa perde um pouco a identidade dela naquele momento e fica muito ligada no jogo. - Orochi

Para o desenvolvedor marxistpokemon, a questão do controle é central, pois envolve não somente ações, como pensamentos e sentimentos: 
Tem uma questão importante que é a questão de controle. É uma categoria pra pensar, que é assim, quando você tem não controle sobre o seu jogar, mas você consegue sair daquela experiência quando você quer... Eu lembro que eu tive experiência com jogos que fiquei tão absurdamente vidrado na coisa que eu pensava naquilo constantemente, eu não conseguia não pensar naquilo. Eu tinha perdido um pouco do meu controle de o que eu estava pensando, de o quê que eu estava sentindo. - marxistpokemon

Para marxistpokemon, quando encontram uma brecha para atingir um jogador, os games podem afetar profundamente seus pensamentos. E quando esta influência se torna grande demais, haveria uma perda de controle dos pensamentos e sensações por parte da pessoa que está jogando. Ele introduz a questão de idade e da fragilidade das crianças frente a essa captura da subjetividade, fazendo uma distinção entre a vida adulta e como era quando mais novo.

Eu não tinha controle mas eu também não era um adulto, eu também não era um ser muito maduro nessa etapa da minha vida. Esta questão está muito ligada ao pé no chão, à hora que você não consegue mais se realizar como ser humano por conta de alguma coisa. Quando você sente que aquilo está te impedindo de ser feliz. Se aquilo está te ajudando a ser feliz, lindo. Mas se aquilo não te ajudando a ser feliz, porra, tá ruim. - marxistpokemon

A autorrealização e a felicidade (como citado no segundo capítulo, com a pirâmide de Maslow) seriam, então, o critério de marxistpokemon para distinguir as experiências benéficas das doentias.

Hyou também fala sobre o vício e o controle. O seu comentário nos reafirma a possibilidade de pensar numa agência não-humana dos videogames: “A gente ignora que a gente talvez, que o videogame seja uma força aí, que a gente pensa que a gente está livre pra jogar ele, mas a gente está sendo determinado pela nossa vontade de querer jogar".

Sobre esse mesmo aspecto do controle, Paula, da lista supracitada de discussões na internet, comenta:

Concordo que realmente qualquer coisa pode virar um vício, seja ele em jogos de computador, videogames, futebol todos os finais de semana, ou mesmo a clássica TV chata aos domingos. Até o esporte pode viciar, por que não?! Quem é que controla?! É você que controla todas estas coisas ou são elas que controlam você. Ou pior, você achar que pensa controlar alguma delas. Aí sim é muita ingenuidade! O problema é quando o vício deixa mesmo de ser uma diversão e passa a atrapalhar o trabalho, a saúde e os relacionamentos. - Paula 
O psicólogo clínico Lucas Costa atenta para a questão da autonomia na definição de dependência. No entanto, ele também evita o uso desavisado do termo, pois este pode estar carregado de presunções como "liberdade absoluta", "individualismo" e "racionalidade na tomada de decisões"; isto é, conjecturas que desconsideram alguns actantes da rede complexa de faz-fazeres. Costa ressalta, então, uma importância superior dada pela pessoa ao videogame em comparação a outras atividades.

É quando a pessoa perde a autonomia. Mas como fazer isso sem usar a palavra autonomia, que é complexa? É quando a tomada de decisão tem um fator específico e daí na minha opinião ele tem que ser um só, não pode ser uma gama de fatores, um fator específico que induz uma resposta mais provável de "sim". No caso, se eu virar pra um menino e falar, você prefere o quê: sair com todos os seus amigos ou jogar videogame, e daí pra qualquer outra coisa que você colocar nessa balança o "jogar videogame" ganhar, eu acho que a gente já pode começar a pensar nesse nível. - Costa

O terapeuta Janos Geocze coloca que a pessoa pode perder o controle a tal ponto que esta "se torna o jogo". Ele também coloca a importância do fator "sedução", do desconhecido, da surpresa, a partir de seu exemplo com um fliperama do tipo pinball.

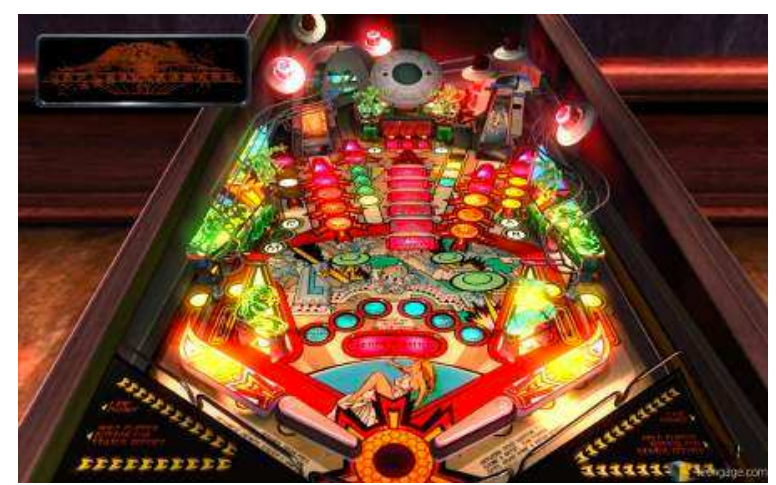

Figura 4.2 - Exemplo de pinball arcade, como Cosmos Factory

O perigo é o quanto você domina aquilo que te dá prazer, o quanto aquilo que te dá prazer domina você. O quanto eu sou o jogo ou o quanto eu sei o jogo. E muita gente se embrulha e vira o jogo. E nem percebe isso. Ele deixa de ser ele e vai virar o jogo. Isso que eu falei do Cosmos Factory. Eu comecei querer a ser aquilo ali. Pra mim aquilo ali tomou uma dimensão que, graças a Deus [...] Quando você descobre tudo do jogo, o jogo deixou de ter graça. Aí tem que ter um novo jogo. - Geocze

Através desses depoimentos, vemos que a ideia de controle age centralmente na ideia de dependência. Essa questão ressoa o problema do humanismo da modernidade, donde se busca a todo tempo controlar o não-humano que quer nos controlar, como no filme Frankenstein, de Mary Shelley (1994). Essa noção de controle pressupõe autonomia, foco no indivíduo e na solidificação da diferença interno versus externo, que 
prevalecem no Humanismo Moderno. Nesse raciocínio, o homem só é homem porque se separa do não-humano.

Na perspectiva que adotamos aqui, não trabalharemos com a ideia de que o usuário do videogame tem pleno controle sobre o objeto "jogo", mas sim com a noção de múltiplas agências humanas e não-humanas que não estão dadas no ser ou ente (como substância). Assim, consideramos, por exemplo, que o fácil acesso e a disponibilidade do videogame também fazem-fazer o jogador jogar. Este não está controlando tudo o que faz, assim como ninguém (ou nenhuma coisa) o faz. Todos "somos superados pelos acontecimentos" (LATOUR, 2002, p. 88).

Os modernos não se mostram a partir de então desprovidos de fetiche, nem desprovidos de culto, como eles se acreditavam - seja para se vangloriarem, seja para se desesperarem. Eles têm um culto, o mais estranho de todos: eles negam as coisas que fabricam a autonomia que conferem às mesmas, ou negam aqueles que as fabricam, a autonomia que estas conferem aos mesmos. Eles pretendem não ser superados pelos acontecimentos. Eles querem manter $\mathrm{o}$ domínio, e encontrar tal fonte no sujeito humano, origem da ação (idem, p. 101).

Afinal, quem age? São indivíduos, pessoas, as máquinas, a estrutura, o jogo? Aqui optamos por uma saída inspirada no conceito de mônadas abertas ${ }^{185}$ de Gabriel Tarde (1910), que nos leva de volta à teoria-ator-rede e à ideia do faz-fazer de Latour: de que as associações, os ou agenciamentos dão o sentido das coisas e pessoas em rede. Assim, a ação é realizada não por um indivíduo autônomo, mas por uma complexa rede de associações que fazem fazer aquele jogador agir de determinado modo e não de outro.

A seguir, Orochi comenta sobre a dinâmica de alguns games mais recentes, como CityVille, que exigem uma atenção constante ao jogo. Com isso, notamos diferenças significativas entre os próprios games. Ou seja, estes aparecem não apenas como intermediários, mas como mediadores e sujeitos dessas relações. Exploraremos tais diferenças mais detidamente ao longo deste capítulo.

Eu percebo isso em pessoas próximas que jogam muito, principalmente esses tipos de jogos que você tem que sempre dar uma olhadinha lá, não adianta você jogar uma hora seguida e depois você pára. Você tem que jogar um minuto agora, daqui a dez minutos você vai e faz de novo, aí dez minutos, você vai e

\footnotetext{
185 “A hipótese das mônadas implica, portanto, a afirmação da diferença como fundamento da existência e, consequentemente, a renúncia ao dualismo cartesiano entre matéria e espírito e àqueles que lhe são correlatos - particularmente o dualismo natureza/sociedade tão caro a Durkheim" (VARGAS, 2004, p. 173).
} 
faz de novo. Isso faz com que seu pensamento fique sempre ligado no jogo. Então você não se concentra no jogo e depois você esquece dele. Você está na sua vida normal mas sempre pensando no jogo. Isso cria uma dependência muito forte. Conheço gente que acorda de madrugada pra fazer isso. Porque se ele passar oito horas sem jogar, que é a hora que ele está dormindo, ele vai produzir muito pouco. Ele acorda, vai lá, faz uma coisinha e aí tenta dormir de novo, e às vezes começa a criar uma certa insônia por causa disso. Essa é uma parte nociva do jogo. E quando os jogos eles não te trazem algo além do entretenimento, eles não te trazem um certo desenvolvimento de percepção, de raciocínio, de coordenação, seja lá o que for, é só esse entretenimento que em que você fica preso, já deixa de ser algo saudável. - Orochi

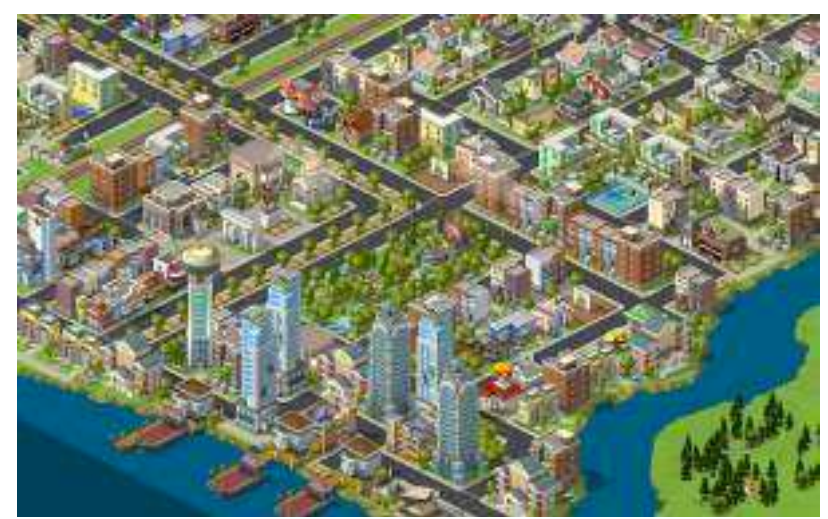

Figura 4.3 - CityVille (2010)

O desenvolvedor independente Johnny William comenta que "não existe pessoa viciada em videogame”. Apesar de ser um argumento questionável (já que logo na sequência ele mesmo afirma ter sido viciado em um jogo), William, neste movimento, manuseia diferentes conotações para a ideia de vício: este também poderia ser saudável.

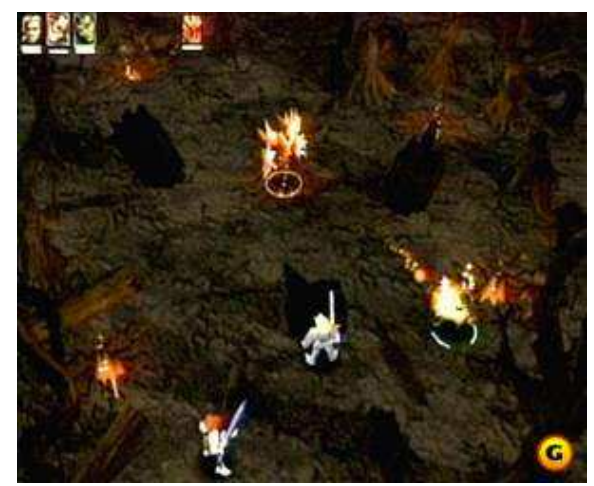

Figura 4.4 - Silver (1999)

Vício em jogos não é que nem vício em chocolate ou vício em bebida. Não existe pessoa viciada em videogame. Existe a pessoa que está maluca, está vidrada naquele jogo específico. É que nem quando você não consegue parar de ler um livro, você adora um filme, você não consegue parar de assistir um seriado. É diferente, é um vício saudável. É aquele vício de arte, é diferente. Eu fui viciado num jogo que chamava Silver. Quando eu terminei o jogo, acabou o vício. Eu não conseguia parar enquanto não terminava, eu estava realmente 
curioso com a história, eu estava envolvido. [...] Mas eu realmente nunca conheci ninguém assim, que é realmente viciado mesmo em jogo. - William

Masamune comenta que não considera casos como esse um vício, pois haveria um esgotamento "natural". Para ele, esse desgaste é uma importante categoria a se pensar:

Imagina que você tem um vício em alguma coisa específica, não vai ser qualquer coisa que vai cortar esse seu vício. Se você tem um vício complicado mesmo, tem que ser uma situação bastante extrema. Se você é "viciado" em alguma coisa, se você gosta muito de alguma coisa, você eventualmente para de gostar dela, pra mim isso não é vício. Aquilo tinha algo que você queria, e aquilo te deu tudo que podia, e acabou. Vício você ainda consegue tirar, você tem a sensação que está tirando alguma coisa de algo que não está te dando nada. Minha percepção de vício. - Masamune

Para Johnny William, o vício seria um alto envolvimento, que, no entanto, acabaria assim que o jogo fosse concluído (logo, se o jogo não possuir um final, há aqui um problema). Em sua fala, ele ressalta aspectos benéficos desse engajamento. Em geral, ao contrário de somente prejudicial, esse envolvimento estaria relacionado com a superação de desafios e a conclusão de histórias.

Geralmente as pessoas que falam que são viciadas pra mim é quando a pessoa está envolvida por um jogo. Minha namorada passou por isso. Ela jogou Dragon Age, ela passou 100 horas quase, tipo, chegou da escola, jogava, jogava, jogava, jogava, ia dormir, ia pra escola, voltava, jogava, ela não fazia mais nada porque ela estava muito envolvida com a história. Aí ela terminou Dragon Age, passou. E isso eu acho bonito. Não tem nada a ver com vício [...] Quando é vício, se você fica sem, você começa a ficar maluco. O problema é que eu nunca fui viciado em nada, eu não sei como é que é. Mas o vício, se a pessoa ficar sem, ela tem aquela crise de abstinência, começa a suar frio e tal. Eu já vi um cara que precisava de cigarro e ele não tinha. Ele começou a passar mal e teve que ir pra um médico porque ele não tinha o cigarro. Eu nunca vi ninguém nesse nível quanto ao videogame, mas geralmente a pessoa fica viajando fora do tempo. Assim, tipo: você está na escola, você chama a pessoa pra conversar, a pessoa está olhando pra cima e não fala nada. "Que foi?", "Tô pensando no jogo", porque ela só pensa nisso dia e noite, mas acho que não chega a ser vício. - William

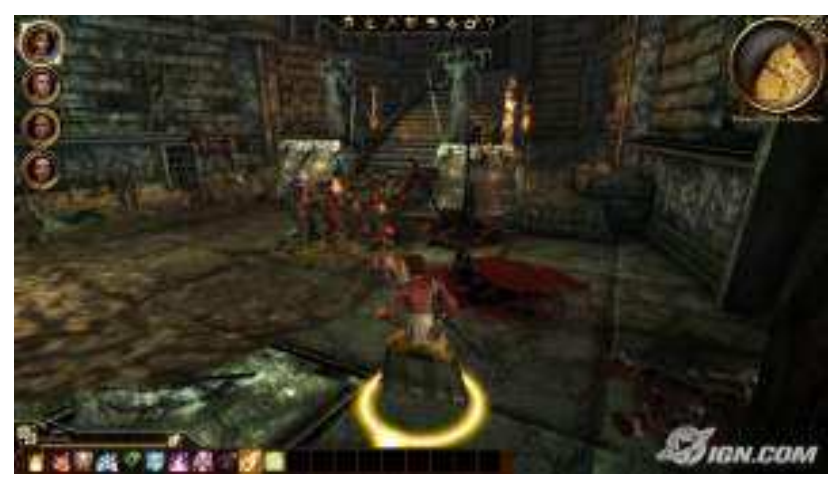

Figura 4.5 - Dragon Age (2009) 
Em consonância com algumas etapas previstas no modelo neuropsicológico abordado no primeiro capítulo, Peter_pano conta a sua experiência com jogos do gênero de tiro em primeira pessoa (First-Person Shooter, ou FPS):

FPS quando você joga geralmente o vício que você tem ali é simplesmente a adrenalina de estar sendo desafiado. É a questão de conseguir fazer alguma coisa que você acha boa e ter aquela dose de endorfina que você fala: "Agora eu sou praticamente invencível!". É normal, você tem isso durante uma partida. Você vai lá, mata cinco, seis caras na sequência, você fala: "Eu sou muito bom nisso". E aí aquilo te dá um prazer enorme. Tanto que são jogos que não tem sentido algum ${ }^{186}$, simplesmente começa, você joga cinco minutos numa fase, enfrentando alguém, é simplesmente um matar o outro e você quer fazer aquilo de novo e de novo e de novo; conseguindo fazer aquilo por quatro horas praticamente. Os incentivos são completamente diferentes, o engajamento é outro. - Peter_pano

Hideko, professora de artes marciais e mãe de Iago, de 7 anos e estudante do Ensino Fundamental (e fã de videogames), comenta a questão da emanação magnética do computador, um assunto até então não lembrado por outros actantes desta pesquisa:

O computador suga a energia das pessoas. Eu observo muito o Iago, e ele come bem, ele dorme bem, tem uma alimentação saudável e a imunidade dele tá muito baixa. E eu acho que é por causa do excesso de horas na frente do monitor. Porque... Não tem por quê... É a única coisa errada. E um pouco de açúcar também [...] Tanto a televisão, quanto o computador, eles têm uma emanação magnética. E eu observo que a Anita [uma de suas filhas], por exemplo, que trabalha muitas horas no computador, ela também tem um nível baixo de imunidade. E além do quê aumenta os cabelos brancos. - Hideko

Este fator dos componentes materiais dos computadores aproxima diferentes usos dessa mesma máquina - tais como jogar videogames, usar internet para entrar no bate-papo ou em redes sociais -, pois o aspecto da emanação magnética reside no seu próprio aparato físico. Assim como William, Hideko também define o vício a partir da crise de abstinência.

É não conseguir ficar sem. Tipo, acabou a luz, a pessoa fica desesperada porque não dá pra jogar. [...] A Anita não pagou a Net e ficou aí mais de uma semana sem internet, não dava pra jogar, não dava pra ver esses vídeos. Então, o que caracteriza o vício é a crise da abstinência. Se não tem a crise da abstinência não é vício, porque se você tem ou se não tem, você fica de boa, então não é um vício. Agora, entrar em crise porque não tem, é vício. - Hideko

\footnotetext{
186 Apesar de Peter_pano afirmar que não há sentido algum neste tipo de jogos, podemos desconfiar também desta colocação. Pode não haver uma história ou um roteiro complexo, mas os sentido (ou significado) existe em qualquer tipo de jogo, vide SALEN; ZIMMERMAN, 2012.
} 
Para ela, apesar da questão da emanação magnética, o problema não estaria de fato no computador ou no videogame, pois segundo ela, não há nada nas "coisas" propriamente. Hideko recupera algumas teorias espiritualistas para apoiar seu argumento. Para ela, o que importa "é a relação da pessoa com a coisa. Isso várias teorias espiritualistas falam isso. Então pra você não se viciar, primeiro você tem que se conscientizar de que você não precisa daquilo".

O que algumas teorias espiritualistas falam é que o vício não é a coisa que vicia, é a pessoa que se vicia. É o jeito da pessoa lidar com as coisas que gera o vício. Então a pessoa usa alguma coisa, um videogame, que seja, ela tem aquela tendência a criar aquele apego com aquilo. Então, é ela que se vicia. Ela acha que ela não consegue viver sem aquilo. Então, é um vício. É um apego, você tem que se desapegar daquilo. Então, não é a coisa que vicia, é a pessoa que se vicia. Seja o que for. Então, quem tem tendência a se viciar, se vicia em qualquer coisa. Num videogame, numa pessoa, em qualquer atitude. - Hideko

Esse pensamento não somente é espiritualista como também humanista, na medida em que entende que a dependência não vem das coisas, mas se origina na própria mente humana. Ou seja, a força de vontade (ou o controle mental) do ser humano é o que importa, e não a força imanente das coisas, já que não haveria nada propriamente nelas fora de suas relações com o homem, seja uma droga, um chocolate ou um videogame. Para Hideko, portanto, a dependência é:

Uma tendência de apego da pessoa, e de fraqueza. Não é a coisa em si. O videogame não vicia. Não tem nenhum componente no videogame que atua no cérebro ou no corpo da pessoa e faz com que ela crie uma dependência daquilo. É a mente da pessoa que se apega àquilo. Falam: "Ai, tá viciado...". Nada! É porque a pessoa não quer ficar sem. Não tem nada no computador. É porque se fosse assim então todo mundo seria viciado, porque você usa uma hora, duas horas, três horas, aí pronto, tá viciado! - Hideko

Para Orochi, a causa da dependência também é a fraqueza da mente. Seja em relação a qualquer objeto, desde as drogas até os games, para ele, é o ser humano que fraqueja em controlar seus impulsos diante das "coisas". Nesse pensamento, o homem deve buscar ser o sujeito dessas relações e dominar os elementos do seu ambiente.

Todas as coisas que a gente tem um prazer, algo que a gente sente necessidade, desde a comida até drogas, jogos e sexo, podem gerar uma certa dependência. E aí poderia se categorizar em tipos diferentes de dependência. Mas a dependência não vem do jogo, da droga, ela vem da nossa mente. Da nossa falta de compreensão de quanto aquilo deve fazer parte da nossa vida ou não, e acaba sendo exacerbado. Porque esses prazeres materiais que a gente tem, na verdade, eles não satisfazem. Então, a gente come uma coisa e depois a gente quer comer de novo, depois a gente quer de novo, e assim vai. - Orochi 
Aprofundando-se um pouco mais na perspectiva da espiritualidade, o psicólogo Lucas

Costa tece um comparativo entre a Ciência, religiosidade e videogames. Não se trata de uma negação da Ciência, tampouco de um anticientificismo; ao invés, sua fala parece uma tentativa de reaproximação simétrica entre ontologias de geometria variável (LATOUR, 1994, p. 87), que reconhece uma dimensão sobrenatural nas práticas científicas.

A Ciência é meio espiritual. É uma atividade meio religiosa, porque você acreditar totalmente no pragmatismo é uma atitude de fé. E fé nada mais é explicado por um movimento praticamente sobrenatural. Então a fé é uma metafísica. Não interessa, se "Ah, eu vou acreditar que $\mathrm{G}=9,8$ ", sabe? Você fincar o pé nessa ideia é, na minha opinião, uma atitude religiosa. É que nem o cara fincar o pé que Deus existiu, que Cristo nasceu, reviveu, morreu, transformou água em vinho e fez o rolê todo. Eu acredito que elas estão no mesmo patamar. Muito dessa discussão eu atribuo ao academicismo. Em algum momento a gente precisou: "Ah, não, aqui a gente vai discutir coisa sérias e verdadeiras, ali eles vão discutir coisas sobre magia e espiritualidade". Mas mesmo assim com o passar do tempo a gente criou Teologia [...] Em todos os momentos pode se tornar uma coisa espiritual. - Costa

Costa concebe, ademais, um espiritualismo latente nos jogos eletrônicos. Essa concepção de espiritualismo, no entanto, não é exatamente a mesma da teorização das mônadas abertas de Gabriel Tarde (1910).

Eu acabo preferindo não traçar uma linha entre o que é e o que não é. Porque no final das contas foi aprendizagem pra mim e na minha opinião isso faz parte da minha fé, eu acredito que o homem tem de aprender e se superar, então, se esse é o meu Deus, pra mim foi uma atitude religiosa. Eu estava tentando me superar. Ver os meus erros e me superar. - Costa

Orochi também apresenta uma visão do vício a partir do desenvolvimento espiritual ${ }^{187}$.

Em sua perspectiva, há uma distinção entre coisas e prazeres mais ou menos "densos".

O nosso prazer material, essa vontade que a gente sente, ela não é algo que nos sacia realmente. Então a gente sempre vai ficar buscando mais. E é uma coisa que às vezes, quando você começa a tentar se desvencilhar um pouco dessas necessidades obsessivas e aumentar a sua percepção das coisas, perceber... Porque, na minha visão, o desenvolvimento espiritual não é uma coisa em que você vai alcançar em outro plano, é simplesmente estar mais presente no plano aqui. Você conseguir perceber o que está acontecendo aqui, perceber as cores

\footnotetext{
${ }^{187}$ Segundo os médicos Hélio Guimarães e Álvaro Avezum (2007), a espiritualidade pode ser definida como uma "propensão humana a buscar significado para a vida por meio de conceitos que transcendem o tangível, à procura de um sentido de conexão com algo maior que si próprio". Para o filósofo ateu André Comte-Spomville (2007), a espiritualidade significaria uma abertura para o ilimitado, um reconhecimento de sermos seres relativos, mas abertos para o absoluto. Seria o reconhecimento da dimensão misteriosa e ilimitada da existência, que não precisaria passar por alguma explicação religiosa; uma experiência que vai além do intelecto.
} 
das coisas à sua volta, os sons... realmente conseguir aproveitar uma coisa que é mais sutil, menos densa, como o prazer por um jogo, ou o prazer por uma droga, ou o prazer por uma comida. Que essas coisas densas que são mais fáceis de se perceber elas fazem com que você fique dependente delas porque elas são necessidades que não vão passar. Eu acredito que a satisfação espiritual de sentir a sua presença real, perceber realmente que você existe, que você está aqui e o que está acontecendo à sua volta, é algo que te dá uma satisfação mais plena. Mas como todas as questões espirituais não é algo que você possa passar falando, é uma experiência pessoal de cada um. A única coisa que dá pra falar é que é como um nível de percepção. Assim é o desenvolvimento espiritual, você vai perceber as mesmas coisas que tão à sua volta que você não percebeu. Mas você consegue perceber a sutileza, como alguns dizem, o milagre que é você estar existindo agora, nesse momento. Que é difícil a gente perceber. - Orochi

Essa dificuldade de autopercepção entra em consonância com o pensamento do antropólogo Marcelo Mercante, que postula (em comunicação pessoal) que o problema das drogas, além de possuir diversas causas, acaba sendo inconsciente para muitas pessoas.

É um problema que tem um monte de causas diferentes. No final das contas, um monte de coisas começa a se movimentar junto. Você está num ambiente que não é legal, você está lidando com pessoas que às vezes não são legais, que estão com uma série de problemas, parecidos com os seus e essas coisas todas começam a se retroalimentar. Você tem problema, você se droga ou joga pra ajudar a tirar os problemas e às vezes os problemas não estão nem conscientes. Âs vezes os problemas estão operando num nível e você usa, seja lá o que for o que você está dependente, como um caminho pra às vezes não chegar nem perto do que você sabe que pode ser um problema. - Mercante

Para evitar que nos baseemos unicamente nas autodeclarações dos jogadores, uma abordagem de redes pode ajudar a entender a situação por diversas perspectivas. A seguir, exploraremos mais essas diferenças de classificações dos médicos e psiquiatras em relação às dos próprios jogadores.

\section{Sobre a autonomia na definição}

O publicitário Chuck coloca que "o engraçado é que quem nomeia que você é um viciado é uma pessoa que não tem noção do que é um viciado”. Ele afirma que a própria pessoa é a única que pode saber se os games estão lhe prejudicando (com a ressalva dos pais, como coloca). Ele acusa o diagnóstico baseado em questionários de ser muito menos trabalhoso para um profissional de saúde do que uma análise em profundidade. Para Chuck, há de se compreender em detalhes a relação entre um jogador e os videogames, tais como "qual jogo ele joga, que horas ele joga o jogo, por quê ele joga o jogo [...] se o moleque quer ficar em negócio de ranking”. Somente com esse tipo de 
informação seria possível entender as conexões dos games com o resto de sua vida. Chuck pondera que nem todos os casos são controversos. Para ele, há sim jogadores viciados, mas há uma diferença entre o vício e "gostar do jogo". Neste ponto, o seu argumento é praticamente o mesmo de alguns terapeutas: "Tem cara fica o dia inteiro, o cara não faz mais nada, o cara come tudo na frente do computador, aí OK, eu entendo". No entanto, para ele, haveria um exagero: "Mas tem gente que acha que quem joga jogo mais de duas horas por dia pode ser classificado como viciado".

Chuck se refere aqui à resolução da American Academy of Pediatics, a qual afirma que uma a duas horas de atividades frente à tela, incluindo, televisão, computador, videogame, celular, tablet etc., seria o máximo tolerável; mais do que isso já seria considerado uso excessivo (KHAN, 2009). Já para marxistpokemon, as respostas dos jogadores quanto às acusações de vício variam muito. Para ele, dependerá da maturidade, da capacidade de autorreflexão e da maleabilidade da pessoa em lidar com esse problema em relação a outras esferas da vida, para que chegue a um bom entendimento (ou não).

Às vezes ela [a pessoa] sabe. Às vezes sabe, às vezes não. Eu já vi gente que sabia e falava, que nem fumar: "Ah, eu escolhi morrer disso". Sabe, o cara fala tipo "Eu sei que está errado mas eu vou fazer mesmo assim", às vezes a pessoa tem essa autoconsciência, e às vezes é uma coisa que você fala e o cara fala "Não, você acha? São só cinco horinhas por dia, cara, não é assim todo dia". Acho que varia muito. Acho que isso vai um pouco da maturidade. De ser capaz de refletir sobre o que você mesmo está fazendo ou passando. marxistpokemon

Hyou afirma a necessidade do pesquisador experimentar a dita "droga" (ou o jogo) para se tornar apto a estudá-la. Para ele, há de se "viver na pele" a experiência para poder analisá-la. Nesse raciocínio, os pesquisadores de games que não jogam não estariam qualificados para entender ou tratar do problema.

Eu continuo com o meu pensamento: há de se experimentar. Se você quiser falar de alguma droga ou de alguma substância você só vai efetivamente saber quando você experimentar. Não que não seja válido o discurso de estar analisando uma coisa que não foi autoexperienciada, mas falta um pouco de espessura na análise, de vivência. - Hyou

Esses jogadores, portanto, reivindicam certa autonomia sobre o saber de seu próprio "vício", ou pelo menos esperam que um especialista na área da dependência entenda, de forma não superficial, algo consistente e empírico sobre os próprios jogos para, então, 
propor soluções. Contudo, como vimos desde o primeiro capítulo, há neurologistas que afirmam a existência de um sistema de recompensa e prazer que colocam em dúvida a preeminência da consciência do jogador.

Para Janos Geocze, trocar atividades importantes como o trabalho e o sono (as chamadas necessidades básicas, por Maslow) seria de fato problemático. Para ilustrar seu ponto, ele comenta sobre uma época em que jogava o jogo River Raid, de Atari.

Eu já tinha filhos e ao invés de dormir à noite eu ficava jogando aquela bosta. E eu sabia que estava fazendo um sacrifício em jogar o jogo em detrimento ao sono, por exemplo. Nunca chegou em detrimento aos meus pacientes ou ao meu trabalho. Porque eu sou muito careta. Eu não deixo pegar aí. Mas pô, comida, sono, não. Aí eu fico preocupado. Quer dizer, quando eu deixo de cuidar de coisas básicas comigo pra ficar na diversão. Eu acho que esse é o meu clique de perceber "eu estou viciando". E aí simplesmente eu largo. Não vou jogar mais.

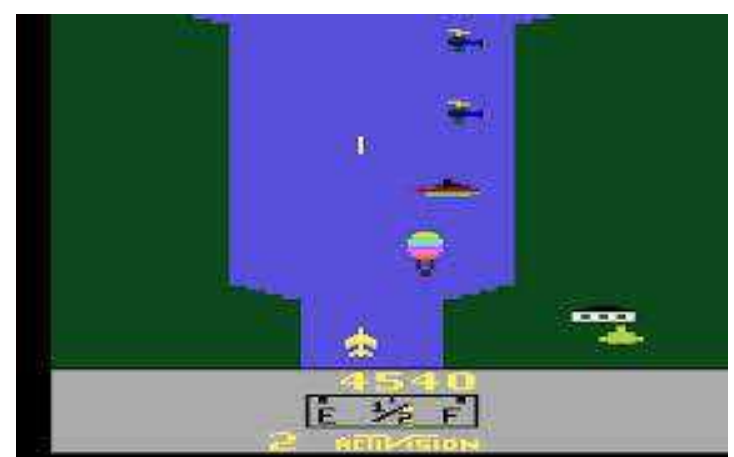

Figura 4.6 - River Raid (1982)

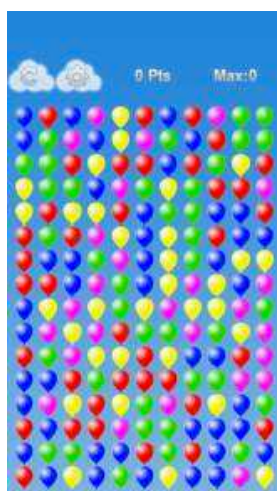

Figura 4.7 - Estoura Balão (2013)

[...] Atualmente, no meu iPhone, tem o Estoura Balão. Então, muitas vezes eu estou assistindo televisão ou fazendo alguma outra coisa e aí estou lá "pleh, pleh, pleh, pleh", estourando os balões e vendo o quê que acontece. São uns balõezinhos que você vai estourando e vai ganhando uns pontos. É um jogo totalmente besta. Mas distrai pra cacete. O problema é: até o momento que eu perceber que ao invés de eu estar interagindo com coisas importantes eu estou fazendo isso, han, han [sinal negativo], aí é vício. - Geocze 
Ele conta que os jogos, especialmente os RPGs, podem se tornar experiências totalizadoras para as pessoas, nas quais nada além do jogo seria necessário para viver:

Eu peguei pacientes para tratar sintoma de dependência de RPG. Esse eu tive que tratar dois casos de rapazes que simplesmente não pensavam em nada mais do que não fosse isso. Inclusive eles falam assim, "se eu tiver dinheiro suficiente pra ficar dentro de um apartamento com meu computador, comida, assim, tal, tal e tal, o jogo pra mim é o suficiente pra eu viver". - Geocze

Com esses depoimentos contemplamos algumas das principais concepções de vício enunciadas pelos jogadores, assim como por alguns terapeutas e outros agentes. Vimos até agora que foram estabelecidas muitas analogias entre videogame e drogas, desde o próprio título desta dissertação até os argumentos dos atores citados, sejam cientistas ou jogadores. Agora passaremos para uma discussão mais estrita sobre esse assunto. Para os jogadores, portanto, qual seria a medida de comparação entre os games e as drogas?

\section{2 - Videogames e drogas: metáfora ou metonímia?}

As metáforas falham no seu intento de produzir compreensão quando elas aniquilam diferenças, reduzindo diferença à similitude; quando bem escolhidas, as metáforas criam novos mundos, funcionando como pontes capazes de ser ao mesmo tempo próximas da experiência do sujeito que tentamos evocar e possíveis de serem imaginadas pela comunidade de possíveis leitores para quem estamos escrevendo (LAGROU, 2007, p. 141).

Como enunciado, o interesse agora é explorar os rendimentos da comparação entre games e drogas (entendidas como componentes farmacológicos ilegais) nesta rede. Seria uma metáfora? Isto é, em alguma medida, games seriam como as drogas? Ou então uma metonímia? Ou seja, os videogames são uma das drogas? Quais são as semelhanças e diferenças entre elas?

Vamos rapidamente esclarecer o que entendemos por estes dois conceitos. Segundo John Fiske, a metonímia opera por associação de significações dentro do mesmo plano sintagmático. "A sua definição clássica é de tomar a parte pelo todo" (1993, p. 130). A metonímia é uma relação de contiguidade. Segundo Coutinho (2006, p. 3), a metonímia é uma "amostra" da realidade. É o tomar um conjunto de ações, situações, cujo tempo e espaço são particulares, como a definição da realidade em si.

Já a metáfora funciona paradigmaticamente, pois opera por "transposições de qualidades de um plano de realidade para outro" (FISKE, 1993). É uma relação de 
similaridade. Segundo Lévi-Strauss, a estes exemplos devemos chamar "a lógica do concreto". Para o antropólogo estruturalista, todas as sociedades necessitam metaforizar as experiências abstratas que lhe são relevantes, de forma a poderem torná-las "instrumentos de pensamento" e com os quais possam "operar" no dia-a-dia (LÉVISTRAUSS apud FISKE, 1993, p. 129). Com essas breves conceituações, seguimos com os relatos de campo.

Para Orochi a aproximação entre drogas e games acontece por ambos serem passíveis de vício para o homem.

O jogo, você não joga um pouquinho, não passa a sua vontade. Você vai querer continuar jogando, assim como uma droga. Você usa um pouco e não vai passar. "Usei uma vez e, putz, foi muito bom e eu não quero mais". Isso não acontece. Você sente vontade de fazer de novo. E assim como muitas outras coisas, então o jogo é sim comparável a uma droga na questão do vício. Mas nesse ponto, na minha visão, a maioria das coisas da vida podem se tornar um vício também. - Orochi

Em sua acepção, tanto os games como as drogas (e outros "objetos") oferecem possibilidades de experimentação de prazeres "densos", "efêmeros" e "materiais".

O cara que é dependente de droga, o cara que é dependente de sexo, o cara que é dependente de chocolate, o cara que é dependente de jogo, dá na mesma. É o cara que não está resolvido quanto àquela questão e está buscando um prazer de forma densa. E até quanto àquela questão se aquilo é real ou não, se o jogo é um plano real ou não... O quê que é real? - Orochi

Mercante, contrapondo-se às perspectivas que se centram nos problemas individuais, comenta que também devemos reconhecer os fatores "sociais" dos mais variados gêneros de dependências. Buscando sair de um individualismo naturalista, ele aponta para uma perspectiva semelhante à do "ser-no-ambiente", de Ingold.

O cara está buscando uma sensação de prazer. Eu acho que não tem esse limite. Você está falando de dependência. A pessoa é dependente. Dependente em quê? Ah, bom, aí vamos determinar pra onde que saiu, pra onde que o problema explodiu. Ah, explodiu com droga, ah, explodiu com jogo ou seja lá o que for. Ou tem gente que é dependente de relacionamento, então está sempre procurando... E às vezes relacionamento problemático, se envolver com pessoas problemáticas... E sai de um e vai pra outro. Então, aparece de $n$ formas. E isso vai voltar lá atrás, na mesma questão de novo: Onde é que está o pepino da história? Está na pessoa ou está no modo como o nosso agrupamento humano, a nossa sociedade funciona? Acho que está no modo como a gente funciona no mundo, como a gente está no mundo. A gente gera isso. Mercante 
Para Hyou, há certamente uma relação entre videogames e as drogas. Apesar de ambas “mexerem profundamente com a gente", em seu entendimento, há diferenças "de processos fisiológicos e químicos do uso de substância”. Ele acrescenta que no caso do videogame "há espaço para criação dentro de uma estrutura apresentada pelo jogo", e a substância, pelo contrário, "já é aquilo".

A nível comparativo são vários os atributos que eles se assemelham, mas é uma coisa muito diferente da outra. Porque esse plano de realidade, você não cria a própria - você pode até criar, você consumindo droga, você criando dentro dela, isso é interessante, mas muitas drogas você consome, você usa... O videogame é uma estrutura já pensada, que você pode criar dentro dela. A substância ela já é aquilo, dependendo da forma que você está, irá experienciar de uma forma ou de outra, como o videogame também. Mas mais como uma metáfora, porque tem muita diferença da droga pro videogame. - Hyou

Para Ricardinson, de 24 anos, programador de softwares, a dependência de games, a princípio, não seria como a de drogas, mas essa comparação depende principalmente do gênero do jogo, como os MMORPGs. Assim como para Johnny William, Ricardinson afirma que estar viciado não é uma condição permanente, já que "uma hora o jogo cansa e perde a graça". Ele comenta que podemos avaliar a questão por meio dos componentes da dependência:

Tem uns indicadores de dependência. Por exemplo, a pessoa fica falando negócio o dia inteiro, ela só sabe falar daquilo. Os jogos podem trazer dependência, mas não é a mesma dependência de droga. Quer dizer, MMO pode até ser. Porque MMO por ser online, por ter sempre update e ter esse negócio da competição, pode até ser mais perigoso. Mas, outros jogos, eu acho muito difícil. Porque o jogo vai cansar. Não dá pro cara jogar 12 horas por dia durante vários dias, que nem o cara consegue usar uma droga, um cara viciado em droga. O cara está viciado. Geralmente a galera de jogo fala "estar viciado", porque não é uma coisa que tem a aparência de ser permanente. Você fica viciado até o ponto que você cansa. Bom, beleza, durante aquela semana tu está pirado no jogo, tu fica o dia inteiro, "caralho, jogo muito louco", que nem quando eu jogava Deus Ex, eu ficava viajando no jogo, "nossa, esse jogo é muito louco...". Fechei o jogo e aí beleza, eu fiquei feliz mais uma semana ou outra pensando na história, mas depois acaba. Agora o MMO é um jogo que não tem fim, então é foda. Mas dá pra cansar também, mas é bem mais difícil. E mesmo assim o cara vai cansar depois de um período muito longo, então, tipo, depois de três anos. Porra, três anos já estragou a vida do cara! Agora os outros jogos, você pode pegar um jogo maior que seja, o cara não vai ficar viciado, viciado mesmo pesado, vai ficar um mês, no máximo, jogando todo dia, mas o cara não vai ficar mais. - Ricardinson

Ricardinson comenta o caso de seu amigo Preto, que perdeu o emprego por jogar exaustivamente um game, a ponto de não ter energia suficiente para trabalhar. 
O Preto largou o emprego, trancou a faculdade porque ele queria ficar jogando DotA, mas eu não acho que se enquadra à situação. Ele estava trabalhando, de tanto ele jogar DotA o bagulho causou um problema na vida dele que ele teve que largar do emprego. Eu já ouvi histórias de um moleque que aconteceu isso, então talvez seja possível sim que ele perdeu o emprego por jogar DotA, porque ele falou que ele passava a madrugada na lan-house jogando DotA e aí ia pro trabalho podre e aí uma hora ele foi demitido. - Ricardinson

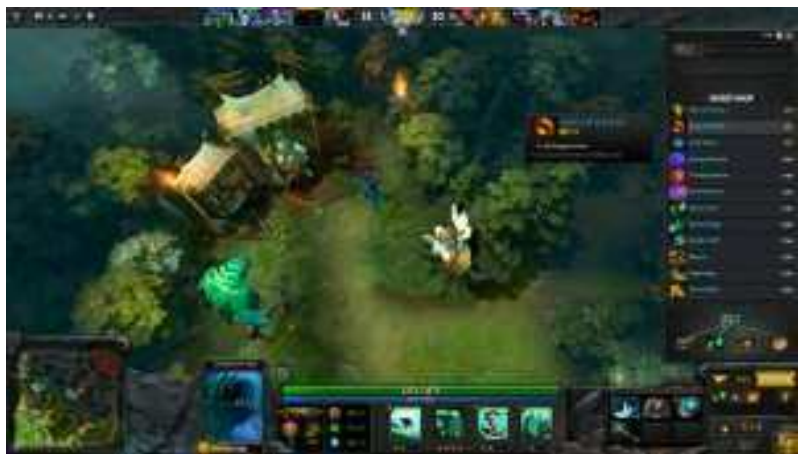

Figura 4.8 - Defense of the Ancients (DotA)

Ricardinson comenta que a dependência tem uma relação tanto com o jogo em si, envolvendo as suas qualidades e mecânicas específicas, como com o resto de sua vida, incluindo suas relações na escola, em casa, no namoro e com os amigos.

O meu vício lá praticamente era, além do jogo ser muito bom, o Ultima Online é um jogo sensacional, é também porque a minha vida não estava boa. Então minha vida não tá boa, minha vida no jogo estava boa, a minha vida no jogo é muito melhor! Mas existe uma certa correlação, porque o jogo consegue influenciar seus sentimentos, assim como as drogas. Um jogo pode te deixar mais feliz, você pode ficar mais emocionado, você pode ter um leque de emoções através dos jogos, assim como você consegue através das drogas. Os dois mexem com o seu psicológico. Pelo fato de um jogo ser uma coisa que é meio repetitiva, ele cansa. Agora, drogas eu acho difícil cansar, não é a mesma coisa. Porque a droga, você fuma e tem a sensação, você usa e tem a sensação depois. Então, usar não está diretamente associado à sensação, então meio que não cansa usar. Enquanto o jogo, você tem a sensação enquanto você joga, então a sensação passa a partir do momento que você cansa do jogo. Sem contar que as drogas ainda causam dependências no teu corpo, porque teu corpo sente substâncias diferentes e tem toda aquela patifaria, nicotina e tal. Enquanto no jogo, não. O teu corpo não pede mais Perfect Dark [jogo de tiro], ele não sabe te dizer, ele não tem como. Ele quer jogar. $O$ teu cérebro sabe que tu quer jogar, mas não tem como ter uma dependência física. - Ricardinson

Para Ricardinson, portanto, o videogame tem a ver com uma dependência psicológica, mas não física (ou química), sugerindo que o primeiro tipo seria mais "leve" que o segundo. Ele opera uma divisão de formas de dependência semelhante àquela proposta por alguns teóricos, como visto no capítulo inicial.

Acho que a psicológica com certeza, normal. Porque tudo pode causar dependência psicológica, mas física, não. Então [os jogos de videogame] tem 
uma relação com as drogas no sentido de causar sensações e tudo mais, mas não no sentido da dependência. Mas jogo tem muitas categorias e talvez a única categoria que se aproxime de jogos que possam causar dependência é o MMO, esses que são multiplayer online de muita gente. - Ricardinson

Interessa aqui explorar com atenção as decorrências desta comparação. Para Peter_pano, a aproximação entre games e drogas se dá pelo sentimento de euforia ou de prazer (adrenalina) presente em ambas as experiências. No entanto, segundo ele, esta rasa comparação ainda não é suficiente para compreender a questão mais ampla da dependência.

Fazendo um parâmetro dá pra você chegar na mesma coisa. Da mesma maneira que tem gente que gosta dos esportes radicais por causa da adrenalina, você pode chegar e viciar num jogo simplesmente porque ele te causa adrenalina $o$ tempo inteiro. Mas acaba sendo uma visão muito minimalista de onde pode realmente estar o problema. Seja se a pessoa passa muito tempo no videogame, ou com alguma droga ou coisa do tipo. O problema não é só esse. - Peter_pano

Peter_pano comenta que os estados de alteração alcançados, tanto na experiência dos games como no uso de drogas, se assemelham. Entretanto, há diferenças notáveis: na droga, haveria um elemento químico; enquanto que no videogame não, pois o próprio cérebro da pessoa seria o causador da reação.

Dá pra comparar, sim. Quando você se droga, a questão do estado de alteração e tudo mais... É possível você chegar num estado de adrenalina absurdo jogando um jogo. Que nem através de uma reação, ou alguma coisa que está acontecendo na vida dela [da pessoa] que te provoca aquela sensação de adrenalina, aquela sensação de descarga; ou mesmo você jogar um jogo de terror e depois ficar com medo de dormir... Dá pra fazer um parâmetro com relação à paranoia de algumas drogas e tudo mais. A gente consegue sim fazer essa comparação na questão do alterar a pessoa. Agora, diferente das drogas, o jogo, se este altera no mesmo nível, é através de um efeito quase que placebo, porque é você causando aquilo, e a droga já passa a ser um elemento químico causando aquilo. Você pode chegar no mesmo efeito, dependendo da droga; é claro, existem drogas e drogas. Mas a questão é: Você pode chegar no mesmo efeito da droga. Só que a diferença da droga é que ela vai causar aquilo através de um processo químico; quando você fala em jogo, não. Tudo vai ser causado por uma reação sua, um sentimento seu, alguma resposta do seu próprio cérebro. - Peter_pano

Ivelise Fortim (2013) fala mais amplamente sobre as diferenças entre a dependência de drogas e as dependências comportamentais, dentre as quais se encontrariam os games. Segundo ela, por não envolverem um componente químico, estas últimas não seriam tão graves quanto as primeiras. 
Todas as escalas e os critérios de dependência comportamental vêm da dependência de drogas. Mesmo de jogo patológico que é super antigo. Então, a primeira tendência é adaptar essas escalas que vêm da dependência comportamental, que vêm das drogas, para o uso de videogames. Eles [os pesquisadores contemporâneos] estão fazendo pesquisas pra ver se tem modificação neurobiológica no cérebro. Porque, qual é a questão de diferença de drogas e dependência comportamental? A dependência de drogas tem um componente químico forte no cérebro. Então, se você deixar um sujeito em abstinência de drogas, ele pode morrer de fato. Então, por exemplo, se você puser o alcoólatra severo em abstinência, sem álcool, durante um tempo, o cara morre. Morre mesmo. Por causa desta neuroquímica. As dependências comportamentais têm a neuroquímica, mas não é a de drogas. É parecido, porque os mecanismos são semelhantes, mas você não produziu nenhuma substância exógena, nenhuma substância externa. Então, se eu deixar um dependente de internet um mês sem acessar a internet, ele vai chilicar, mas não vai morrer. Algumas coisas do comportamento são parecidos, tanto é que os critérios são todos de drogas: tolerância, abstinência... Os critérios são todos de drogas. Mas não tem papel neuroquímico importante. Apesar de não estar a questão da neuroquímica, o modelo de sistema de recompensa que usa no cérebro e o modelo de comportamento é igual ao de drogas, por isso que se faz essa comparação. - Fortim

No entanto, por que também não se poderia pensar em substâncias no caso dos games? Porque nada seria visivelmente ingerido, inalado ou injetado? Percebemos uma assimetria evidente nesses dois entendimentos. Se seguirmos as explicações de Peter_pano e Fortim sobre a dependência de videogames, é a pessoa ela mesma (a partir de seu sistema nervoso) que causa a reação em si própria, ao passo que, no caso das drogas, é esta última que causa a reação no sistema nervoso da pessoa. No caso da ingestão da droga, esta é entendida como o sujeito da relação e como algo externo; o usuário é somente um receptor, intermediário - assim como no caso clássico dos remédios farmacêuticos, em que a pessoa geralmente toma um remédio e espera "passivamente" por sua reação. Isso, no entanto, não explica a diferença das reações entre as pessoas, pois estas não alterariam o resultado; o que importa neste caso é a ação da droga. Como discorre o antropólogo Stelio Marras, esta é uma forma típica do naturalismo de conceber a relação entre fármacos (ou drogas) e usuários (ou pacientes):

Para a terapêutica moderna e sua concepção física e bioquímica, a cura deve resultar, sobretudo e idealmente, da ação das propriedades naturais das substâncias no organismo naturalizado - a ênfase, aí, reside no substrato orgânico de um ser, a todo despeito, insistentemente cultural, isto é, dotado de espírito, fonte de seus desejos, crenças e intenções - cujo controle, repita-se uma última vez, escapa da cognição científica (esta sim) típica. Para um saber que se funda na prática da causação mecânica e experimental, necessariamente descontextualizada, sempre em busca de regularidades e do controle das variáveis, o termo subjetivo deve mesmo ser afastado - porque rebelde ao 
controle (as vicissitudes da sintetização dos medicamentos e o problema do placebo o denotam) (MARRAS, 2002, p. 12).

No entendimento tipicamente moderno, o videogame, diferente da droga, não causa nada - seria o próprio cérebro da pessoa o propulsor da reação. Ou seja, uma vez que o próprio corpo humano seja o causador daquele sentimento, o videogame não teria agência. Somente o humano é considerado sujeito da ação, sendo o videogame relegado a mero intermediário. É, assim, de-substancializado. Nesse sentido, Phillipe Pignarre coloca uma reflexão sobre os medicamentos, os quais (oficialmente) ignorariam todo e qualquer "contexto" (as outras relações, além de suas "propriedades químicas" intrínsecas) para poder funcionar.

Ignora-se a maneira pela qual o mecanismo da cura pela sugestão começa ou não a funcionar. Ignora-se também de que maneira mudanças corporais provocadas pela ação de uma molécula ativa sobre tecidos biológicos são capazes de interagir com esse primeiro efeito. Cada molécula é portadora de um efeito placebo próprio, cujo alcance estamos condenados a ignorar. (...) Entre cura espontânea, cura por efeito placebo e - podemos acrescentar agora - "cura por uma ação biológica, farmacologicamente induzida", nenhum limite preciso pode ser traçado. Há um continuum suscetível de mudar a cada indivíduo, cada molécula e a cada ingestão do medicamento. É dessa incerteza essencial que vai surgir a necessidade de recorrer sempre a um dispositivo estatístico para tratar dados destinados a permanecer empíricos (PIGNARRE, 1999. p. 27).

O nosso esforço aqui, diferente da concepção modernista oficial-purificadoraassimétrica, é recolocar essas descrições em simetria, considerando todos (drogas, games, cérebros e pessoas) agentes e sujeitos da ação. Dessa forma, reconhecemos que alterando, colocando ou retirando qualquer agente da rede de relações, é possível mudar o resultado final e a configuração das relações entre os agentes. Essa é justamente a essência do argumento das Ciências do Complexo (STENGERS; PRIGOGINE, 1984), em oposição às Ciências Modernas. Nessa perspectiva, todos são mediadores, isto é, todos fazem diferença. Portanto, não seria apenas a pessoa (ou seu sistema nervoso), de forma solitária, que causa em si própria a reação de euforia. O videogame também media essa relação; senão, pra quê o jogo?

Ainda buscando explorar essa comparação, Janos Geocze traça um paralelo entre o uso de crack e o de videogames. Ele conta que alguns de seus pacientes trouxeram questões graves envolvendo os videogames em sua clínica:

O grave é quando a pessoa esquece de tudo. É o crackeiro. Quer dizer, o quê que o crackeiro faz? Qualquer coisa pra fumar o crack. Então pra ele não 
importa tomar banho... Ele pode até tomar banho, se você prometer uma pedra de crack depois do banho! Acho que aí você convence ele a tomar banho. Em princípio, se ele tiver aquilo que ele acha na droga, o vício, ele deixa de cumprir com n outras coisas da vida dele. Isso é o máximo. Isso é o vício ao extremo. É onde a pessoa inclusive depois vai morrer. Os jogos fazem isso? Eu tive alguns pacientes que eu vi chegarem nesse nível, de não comer, não dormir, não beber, perder a noção da realidade, do próprio corpo. Isso é perigoso. É que nem crack. E quando você tira, dá síndrome de abstinência violenta também. A pessoa passa mal. Então, como tirar, o que fazer, o que pôr no lugar... - Geocze

Mercante também argumenta que existe um paralelo entre as experiências com as drogas e os games. Para ele, há um forte processo de imaginação em ambos os casos, em que as imagens do jogo permanecem dentro da mente da pessoa mesmo após o uso, ordenando o seu "ser no mundo".

O paralelo é total. Porque na hora que o cara está no barato, no efeito seja lá do que ele está tomando, ele está num universo virtual. Só que é um virtual que tem efeito no real, no lado de cá da história. Então você fica se questionando até que ponto é realmente virtual. Você começa a mexer com emoção, com pensamento, com modo de pensar, modo de sentir... Nem tanto conteúdo, mas a maneira de pensar, de sentir, com caminhos que quando o sujeito está sem efeito de nada, às vezes não funciona daquela maneira que ele acha que é boa. $\mathrm{E}$ a droga proporciona um modo de pensar, de sentir que se adequa a uma determinada necessidade. Por isso que o sujeito não consegue sair dali de dentro. E, às vezes, o jogo faz a mesma coisa. Seja jogo de azar, seja jogo de videogame, você vai cair nesse universo da imaginação do mesmo jeito. Porque, você passa quantas horas na frente de um computador? Dez horas por dia? Você vai sair dali e você vai estar formatado. Você desligou o computador, desligou o game e foi pra outro lugar, mas aquelas imagens estão dentro da tua mente. E aí o único argumento que eu arrumei pra sair disso é: Nós somos as imagens que nós carregamos. Imagens do mundo. E essas imagens estão se movimentando dentro da nossa consciência, e às vezes na inconsciência também. Estão se movimentando dentro da mente da gente. E de certa maneira elas ordenam quem a gente é. E o jogo deve atuar na mesma direção. Tem um modo de pensar que aquele jogo te proporciona, lida com várias imagens e aquelas imagens não abandonam o sujeito. - Mercante

Lucas Costa aproxima o videogame do álcool a partir do transtorno de percepção desencadeado a partir de usos "não-recreativos" de ambos, que ocasionaria um afastamento ou fuga da realidade. Ele comenta que, para explicar isso:

Os médicos usam toda a forma de diagnóstico das drogas. É por isso que eu gosto muito de comparar o videogame ao álcool. Porque ele tem uma capacidade de transtornar a percepção. Por exemplo, uma criança muito fragilizada pode ter um afastamento da realidade, dependendo do tempo que isso acontecer. Só que ao mesmo tempo pode ser um uso só recreativo ${ }^{188}$. Então

\footnotetext{
${ }^{188}$ Desconfiamos de sua definição de uso recreativo (o que seria isso, afinal?) como a única forma considerada inofensiva, deixando fora dessa classificação os usos ritualísticos ou espirituais, considerados mais controlados, de substâncias psicoativas como a ayahuasca.
} 
envolve uma abstração ou até mesmo um mecanismo de fuga. Agora é difícil, porque sempre que você vai falar com os psiquiatras quanto a isso, eles vão acabar tendo que usar os casos mais extremos pra provar o ponto deles. - Costa

Costa comenta que, nas acusações de cisão psicótica ${ }^{189}$ feitas por alguns desses profissionais, há uma tentativa de expiação da causa de certos acontecimentos trágicos ou de casos graves de dependência, em que a "culpa" é direcionada exclusivamente aos games - como se estes, sozinhos, levassem as pessoas a cometer crimes; o que encobre a complexa combinação de agentes, forças e fatores os mais diversos possíveis presentes em cada situação, dentre os quais os games também estão incluídos.

Eles vão usar casos muito extremos de cisão psicótica, como toda aquela polêmica do Tiros em Columbine com os meninos jogando Doom e Wolfenstein $3 D$ e tentarem empurrar isso no Marilyn Manson ${ }^{190}$, tudo isso junto, isso foi uma saída pra quem queria explicar a coisa do viés mais fácil, que eram dois jovens que efetivamente atingiram um nível de desapontamento com a realidade externa a ponto dele conseguir fazer isso. - Costa

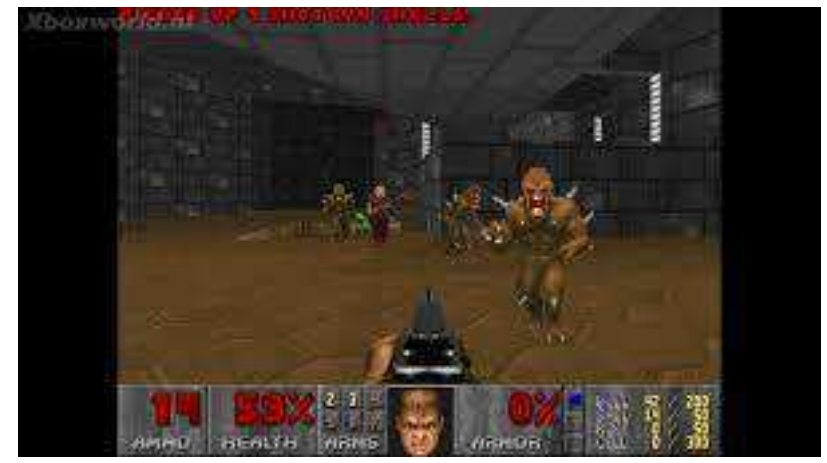

Figura 4.9 - Doom (1993)

Lucas Costa afirma que há uma tendência de medicalização desse tipo de problema, da qual ele próprio discorda. No entanto, o psicólogo argumenta que ainda não se pode abandonar todos os parâmetros para medir a normalidade. "Se você eliminar a régua do

\footnotetext{
${ }^{189}$ Psicose é um quadro psicopatológico clássico, reconhecido pela Psiquiatria, pela Psicologia Clínica e pela Psicanálise como um estado psíquico no qual se verifica certa "perda de contato com a realidade" (FREUD, 1923), sendo esta entendida como séries de saberes, constructos e símbolos compartilhados e validados socialmente. Nos períodos de crises mais intensas podem ocorrer (variando de caso a caso) alucinações ou delírios (KAUFMANN, 1996), desorganização psíquica que inclua pensamento desorganizado e/ou paranoide, acentuada inquietude psicomotora, sensações de opressão e angústia intensa, e insônia severa. Na psicanálise, a psicose corresponde a um funcionamento psíquico que obedece a um princípio de rejeição primordial. Esta consiste na expulsão de ideias ou pensamentos próprios, os quais passam a ser tratados como estranhos ou não acontecidos. Como um efeito dessa rejeição, pode ocorrer a cisão do "eu" em duas partes, uma que é reconhecida e outra que não é reconhecida como própria. Essa cisão caracteriza a esquizofrenia. Quando ocorre de os pensamentos não reconhecidos como próprios serem identificados em outras pessoas, através da projeção, caracteriza-se a psicose como paranoia (FREUD, 1911).
}

${ }^{190}$ Vídeo disponível em: https://www.youtube.com/watch?v=zs_NLL7WW_4 
normal, a gente fica livre demais. A gente não vai conseguir considerar nada merecedor de uma intervenção externa". Para sustentar sua opinião, ele recorre a um argumento embasado pela filosofia hobbesiana: "Assim a gente vai deixar sempre pro livre arbítrio individual. Só que toda proposta de sociedade vai contra isso, você abdica um pouco do livre arbítrio individual pra viver em sociedade".

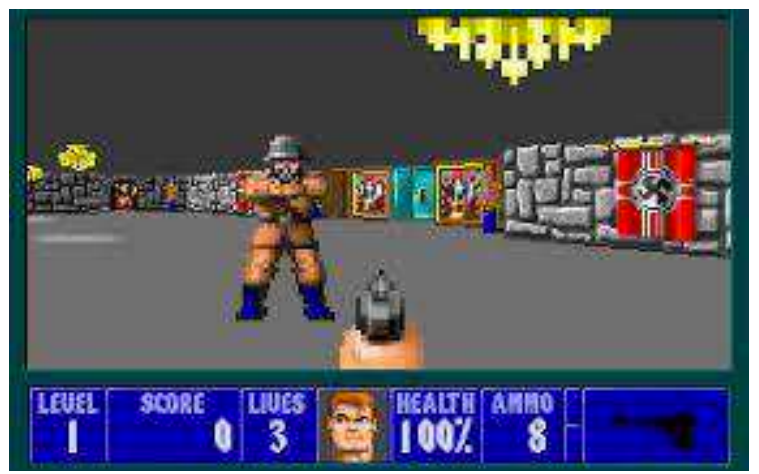

Figura 4.10 - Wolfenstein $3 D(1992)$

Eles [os psiquiatras] vão sempre ter que usar um caso extremo pra provar o ponto. Mas essa é a nossa lógica proibicionista com tudo. Sempre que tem alguma coisa que a gente fica um pouco assustado, a gente estranha um pouco, tenta enquadrar e regulamentar isso rápido. Como se a gente já tivesse tentando criar um remédio pra aquilo. A gente acaba caindo numa lógica extremamente positivista. - Costa

Costa vai além e não apenas cita a questão do proibicionismo das drogas, como também levanta uma discussão acerca dos manicômios, na qual se faz presente esse mesmo tipo de entendimento teórico: a exclusão do diferente, do novo ou daquilo que foge às classificações convencionais.

Isso é muito fruto não só da nossa história proibicionista como de toda nossa discussão manicomial, que é muito recente. O que a gente faz com aquilo que assusta a gente a um certo nível e a gente não sabe como lidar? A Medicina tem uma abordagem prática, então ela classifica em sintomas e tenta subtrair esses sintomas. A Psicologia pensa um pouco diferente. A gente tenta até encontrar os sintomas, ou seja, as especificidades daquela pessoa que estão fazendo dela menos feliz, ou não menos feliz, mas com uma capacidade de se observar de uma maneira mais total. Agora, a intervenção é diferente, porque você não tenta retirar o sintoma e sim buscar a origem. - Costa

Para Janos Geocze, o motivo crucial para o surgimento da dependência é a ausência de significado na vida da pessoa. Segundo ele, na falta de objetivos ou de motivações relevantes, a droga ou o videogame, portanto, passam a ocupar esse lugar vazio.

Por que você acha que a pessoa não quer ficar aí? Porque é uma merda. É chato, não tem significado. A vida besta vai fazer as pessoas entrarem nisso. A não 
significação das coisas. O não desafio. Na guerra não tem depressão! A pessoa não tem tempo de pensar em se matar. Elas não se matam na guerra. Elas lutam pela vida. Como que a pessoa deixa de viver a vida dela pra viver o jogo? Porque a vida dela não tem graça. Olha a palavra: graça. Não tem o significado. O fulano é desgraçado. A droga é para desgraçados. - Geocze

Nesta visão, o videogame seria uma máquina de criação de significado para a vida. Em que medida esta é benéfica ou prejudicial, falsa ou real, depende da avaliação dos próprios actantes.

Neste ponto retornamos para a indagação inicial desta seção: A relação entre videogames e drogas seria metafórica, metonímica ou nenhuma dessas duas opções? Nas descrições vimos que os videogames não são iguais às drogas, mas em certos aspectos são comparados a elas pelos próprios jogadores e terapeutas. Desse modo, como sugere o próprio título deste trabalho, os videogames e as "drogas" podem sim ser aproximados na forma de analogias metafóricas. No entanto, como já adverte o antropólogo José Antônio Kelly: “As analogias ou metáforas são sempre parciais, razão pela qual elas não são apenas mecanismos classificatórios, mas também mecanismos infetuosos, corruptores, ou dissolventes" (2010, p. 155). Metáfora ou não, o ponto mais importante é que essa comparação age e tem produção de efeitos.

Do outro lado, vemos que não é possível tomar essa mesma relação como uma metonímia, pois não podemos substituir um termo pelo outro em qualquer situação ${ }^{191}$. Há quem afirme, como alguns terapeutas da dependência, que a categoria "videogame" deva ser inserida na categoria mais ampla "drogas" (o que faria os videogames serem entendidos como um tipo específico de droga). É exatamente essa relação que parece estar guiando certas formas de classificação, como a dos seis componentes centrais da dependência. Entretanto, essa noção não é válida no sentido inverso (as drogas não são um caso específico dos videogames), tampouco no próprio sentido "original", pois os games somente virariam "drogas" quando a relação entre a pessoa e o jogo se tornasse destrutiva (para a primeira). Se isso não ocorresse, isto é, nos casos "saudáveis", ele não seria “droga". Portanto, essa definição não é de forma alguma ontológica, mas relacional: não há nada no videogame em si, isoladamente, que o aproxime ou que o afaste das chamadas drogas.

\footnotetext{
${ }^{191}$ Isso para não pensar no surgimento de terapias de redução de danos em que as pessoas que sofrem problemas com drogas as substituiriam por videogames, o que exigiria uma totalmente investigação específica, já que não foi encontrada nenhuma referência neste sentido.
} 


\section{3 - Gerenciamento de humor}

Debateremos agora a questão que a que nomeamos "gerenciamento de humor". O que envolve essa discussão? Jogar videogame, em certa medida, pode ser uma forma de descanso, alívio de estresse e/ou controle de emoções negativas? Inicialmente, para Allprot, o videogame também é uma forma de relaxar.

Hoje eu ligo o jogo quando às vezes eu preciso de relaxar, eu estou muito concentrado, eu estou com a cabeça cheia assim de muita responsabilidade, eu estou fazendo uma coisa, eu preciso de relaxar, eu preciso de dar um tempo. Não que o jogo seja a única coisa que eu vá fazer, mas é uma alternativa, uma alternativa que eu gosto, mas tem outras coisas também. - Allprot

Peter_pano afirma que as pessoas precisam extravasar seus sentimentos de alguma maneira; e os games são um meio possível. Ele chega a admitir que em momentos de forte agressividade, os videogames são vias seguras para aliviar estas tensões.

A questão é que apesar de parecer que era uma coisa que me cansava fisicamente e tudo mais, era uma coisa que mentalmente me relaxava. E sem aquela "terapia" pra eu extravasar de alguma maneira, seja através de FPS ou qualquer coisa, eu passava a me sentir pesado em relação às coisas que eu estava sentindo, com relação à preocupação do dia-a-dia. Então aquilo de certa maneira acaba sendo uma via de escape pra sentimentos que estão guardados e simplesmente eu preciso extravasar de alguma maneira. Seja eles de violência ou simplesmente a questão de um afeto ou qualquer coisa do tipo. Acaba sendo desviado também pra isso. É você simplesmente chegar e falar, "Porra, estou bravo, estou nervoso e vou matar gente". Beleza. Você mata no videogame, tá ligado? A coisa sai! - Peter_pano

Para Peter_pano, jogar videogame pode ser comparável a uma psicoterapia. Ele conta que jogar videogame serviu como um remédio para enfrentar um período de estresse em sua vida. A válvula de escape citada por ele, portanto, não seria algo intrinsecamente indesejável ou ruim.

Quando eu fazia terapia, uma das maneiras que eu encontrei pra não precisar tomar um remédio ou qualquer coisa do tipo foi voltar a jogar videogame. Porque eu estava jogando pouco, porque eu estava muito estressado. Eu estava passando por um período muito estressante e a terapeuta pediu pra eu tomar remédio e eu falei: "Não, não quero tomar remédio". O quê que eu fiz? Foi tentar manter a minha rotina de jogar videogame. E isso acabou servindo pra mim como um remédio, uma válvula de escape mesmo. E deu o mesmo efeito praticamente. - Peter_pano 
Já Eskilu sustenta que o game serve como descanso da rotina de trabalho, já que nesse tipo de atividade ocorreria uma descarga emocional. Contudo, ao mesmo tempo ele comenta que jogar exige muita concentração e consome energia. Seria um paradoxo?

Até hoje eu não tenho o descanso que eu tenho quando eu jogo videogame. Tipo, como lazer. Eu pelo menos equilibro ele entre a mesma coisa de sair e tomar uma cerveja... É um descanso pra mim. Hoje, por exemplo, eu jogo quando chego do trabalho. Eu chego do trabalho, como, daí eu jogo duas partidas de LoL [League of Legends] que vão me consumir uma hora e meia. Só que, ao mesmo tempo, é um negócio que consegue fazer com que meu cérebro se foque totalmente em alguma coisa, então é uma atividade que requer muita atenção, ao mesmo tempo que ela desgasta; mas é prazeroso esse desgaste. É como se fosse aquele restante de energia do dia que eu poderia fazer uma academia ou qualquer outra coisa que eu gostasse, mas eu gosto de jogar videogame. Então eu até faço outras coisas, mas a descarga não é a mesma. Existe uma diferença. - Eskilu

Além do descanso e, simultaneamente, do desgaste prazeroso que proporciona, para Eskilu, o videogame também preenche um espaço deixado pela solidão do cotidiano.

[O videogame] aproveita o espaço que é deixado por alguma coisa na vida. Então, eu passava muito tempo sozinho. Então, por passar muito tempo sozinho eu comecei a jogar muito videogame. Eu jogava muito videogame e esse é o lance da energia. Esse negócio acabou se tornando um mecanismo meu. Então, situação de ansiedade, situação de estresse, você conseguia resolver ela através do videogame, como se fosse uma válvula de escape. - Eskilu

Ele afirma que os jogos online são uma forma mais acessível de se encontrar com os amigos num contexto em que as pessoas moram longe umas das outras ou estão "na correria" do dia-a-dia, o videogame funciona como um conector entre elas.

É como se fosse sair pra beber uma cerveja com os amigos. Hoje em dia eu jogo muito League of Legends. Daí a graça toda do negócio é poder jogar com mó galera. Então, chega nove horas da noite, que é a hora que todo mundo mais ou menos já chegou do trampo, já tomou banho... A gente tem tipo uma galera. Você chega, entra no TeamSpeak, tem tipo oito caras já esperando. Uns já jogando, outros esperando pra jogar. Então acaba se tornando uma forma mais cômoda de você se encontrar com pessoas no meio duma correria bizarra. Ou, no meu caso, com pessoas que nem estão na minha cidade. - Eskilu

Fortim admite que o uso do videogame pode ser um modo de gerenciar um estado negativo de humor. No entanto, apesar de concordar com a eficácia desse mecanismo, ela alerta que isso pode ser um sinal de dependência. Para ela, o gerenciamento de estresse, diferente da questão de encarnar em um personagem, é um fator característico da dependência em videogames: 
Você não aguenta ficar estressado, você vai lá e bebe. Você não aguenta ficar estressado, você vai lá e joga MMO. Tem bastante gente que fala assim. "Ah, quando eu tô chateado eu jogo MUD". Muito comum isso. "Porque aí eu estava mal, aí eu entrei no MMO, todos os meus problemas sumiram". Mas isso é um discurso de dependente clássico. "Eu estava péssimo, entrei no bingo, ficou tudo bom". E MMO é muito assim. Tem gente que fala: "Vou jogar meia hora de Counter-Strike pra desestressar". E passa. Então, é um jeito de gerenciar o estado negativo de humor. - Fortim

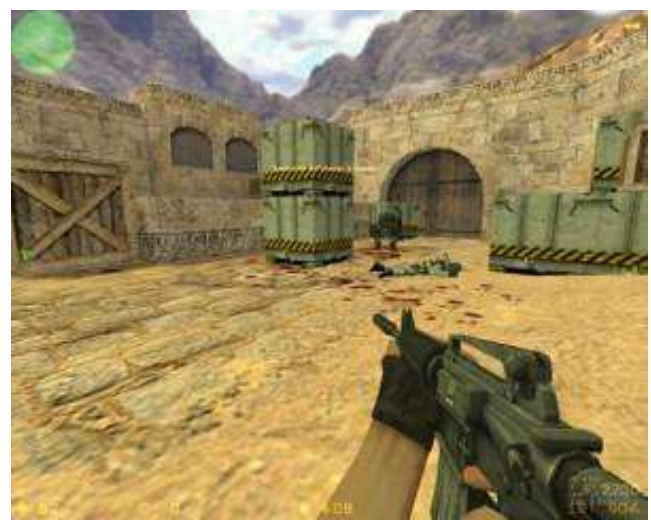

Figura 4.11 - Counter-Strike (2000)

Para Fortim, o problema não é o uso, mas a perda de controle desse mecanismo por parte do dependente, que, nessa lógica, passa a torná-lo um padrão de comportamento: "Então, aí você não consegue mais relaxar com outra coisa, você só consegue relaxar quando você fizer aquilo".

Weistein e Lejoyeux (2010), em sua revisão, mostram que a maioria das pesquisas concorda que o excesso de uso de internet e videogames está ligado a uma forma inadequada de manejo do estresse (p. 55), a qual chamam de coping (enfrentamento). Nessa explicação, o comportamento adictício aos poucos se torna o único modo da psique encontrar homeostase. O comportamento adictício aparece como uma estratégia de escape e evitação, sendo um mecanismo de coping concentrado em torno de um comportamento repetitivo, que descarrega a tensão (SCHOEN, 2009 apud FORTIM, 2013, p. 79).

Segundo Stroppa e Moreira-Almeida (2008), coping pode ser mais bem definido como o conjunto de estratégias utilizadas por uma pessoa para se adaptar a circunstâncias de vida adversas ou estressantes (STROPPA; MOREIRA-ALMEIDA, 2008). A seguir, Fortim descreve sua experiência profissional envolvendo a questão:

Eu trabalhei muito a explicação da dependência na teoria junguiana. E aí você tem $n$ outras explicações. Mas em quase todas as explicações que tem teoria baseada no inconsciente, a ideia é de que a dependência é um mecanismo de 
defesa, que a gente chama de coping. O que é o mecanismo de coping? É um mecanismo de enfrentamento de um problema. Então, você está com outro problema e você tem aquele comportamento pra fugir daquele primeiro. Só que aí você usa tanto esse comportamento que esse comportamento vira um problema em si mesmo. Mas ele é pra esquecer de um primeiro problema que você tem. Então, uma boa parte das explicações que estão baseadas no inconsciente, a teoria principal é essa. É uma estratégia de enfrentar um outro problema; pensando em dependência de verdade.

Em suma, os pesquisadores aqui debatem em torno das distintas formas de uso ${ }^{192}$ para definir quando o videogame pode ser uma via benéfica para o gerenciamento de humor, e quando se torna prejudicial por estimular o vício e a agressividade.

\section{Breve nota sobre a questão da violência}

Aqui não entraremos a fundo nas controvérsias em torno das acusações de violência nos games. Esta não é uma questão menor dentro dos debates em torno dos games, tampouco desprezível. Pelo contrário, é inteiramente relevante e complexa. Em campo, vimos que se há duas grandes controvérsias em torno dos videogames, em resumo, são estas: "Jogos viciam?" e "Jogos violentos geram violência?"

Ainda que estas sejam duas controvérsias marcadamente distintas, isso não significa que estas não compartilhem pontos de contato. Afinal, qual a relação entre jogos violentos e dependência? Certamente não há uma resposta simples, mas a princípio observamos que a imagem negativa dos jogos ditos violentos tem agência nesta presente controvérsia, associando os jogos a coisas aparentemente perigosas, ameaçadoras e passíveis de vício.

Ainda não se chegou ao ponto da criminalização do uso de videogames, mas em alguns países houve a proibição da comercialização de certos jogos considerados violentos, tais como Carmageddon ${ }^{193}$, Counter-Strike ${ }^{194}$ e Grand Theft Auto ${ }^{195}$. Afinal, qual seria

\footnotetext{
192 Apesar de compreender tais diferenças, na perspectiva da teoria-ator-rede, as noções de uso e apropriação, em geral, serão estranhas (RIFIOTIS, 2010). Uma coisa não está "pronta" para alguém usála (supostamente, reificando e solidificando a primeira), pois ambas se modificam nesta relação. Uma máquina, por exemplo, pode usar um humano. Ou seja, nessa linha de pensamento, o jogador tampouco escolherá soberanamente o tipo de uso que deseja praticar, pois este também é usado nessa relação.

193 Segundo notícia publicada no Jornal do Commercio, em 10 de março de 1999, o Ministro da Justiça, Renan Calheiros, determinou ao Departamento de Proteção e Defesa do Consumidor (DPDC) que fosse instaurado um processo administrativo para proibir a distribuição e venda do software Carmageddon II, modelo Carpocalypse Now, um CD-Rom que, segundo as autoridades do Governo, estimulava a violência entre os jovens. Pelas regras do jogo, o condutor do veículo virtual faz mais pontos quando causa "grandes estragos", destruindo maior número de trens, aviões e veículos e atropelando pedestres. O ministro Renan Calheiros, que já havia determinado a suspensão da comercialização da primeira versão do Carmageddon, em novembro de 1997, não gostou de saber que tinha saído a segunda versão do jogo
} 
exatamente o perigo que estes jogos trariam? Transmitir valores "negativos" para as crianças? Estimular comportamentos violentos fora do jogo? Ensinar aos jovens estratégias e técnicas de guerrilha? Fazê-los perder a noção da realidade? Ainda não há como desenvolver todas essas acusações, mas notamos que as questões sobre violência e dependência nos games aparecem em campo frequentemente conectadas.

Lucas Costa ressalta exploração midiática do assunto, que acabaria por causar pavores desnecessários em pais e mães dos jogadores. Há aqui uma concepção de "grupo social" como um conjunto que abarca somente agentes humanos, a qual informa seu discurso:

Tem um nível de comparação que é possível de ser feito. Tem níveis de uso que eu acho perigosos e eu acho engraçado que os que eu considero perigoso nunca são os que são levantados pela mídia, porque eles sempre ficam com medo da violência, e o problema não é tanto a violência e sim o quanto a gente coloca crianças muito pequenas na frente de um celular, de um tablet, de uma coisa eletrônica só pra distrair ela pra gente poder conversar com os nossos amigos em vez de trazer o bebê pra dentro do grupo, trazer a criança pra dentro do grupo social do que o contrário, de querer ver aquilo como uma dependência só pra tentar combater aquilo. A ideia não é combater e sim perceber como é que a gente pode conviver com aquilo e estabelecer o mínimo de regras possível pra que a gente evite coisas muito exageradas. - Costa

Segundo Granic et al. (2014), é provável que o foco nas questões negativas em torno dos videogames não diminua no futuro próximo, em parte por causa da enorme atenção dada pela mídia aos assassinatos em massa (por exemplo, os assassinatos de Columbine

eletrônico. O Carmageddon II foi analisado pelos técnicos do Ministério da Justiça, que consideraram o game uma ameaça para os adolescentes brasileiros. Por sua vez, a diretora administrativa da companhia inglesa SCi, Jane Cavanagh, afirmou que Carmageddon "é um jogo muito divertido de corrida, que integra recursos sofisticados de programação, e que está repleto de humor negro, mas acredito que qualquer jogador poderia vê-lo dentro desse contexto". Disponível em: http://www1.folha.uol.com.br/fsp/1997/12/03/informatica/3.html e http://arena.ig.com.br/2012-1019/artigo-15-anos-depois-proibicao-de-carmageddon-e-apenas-um-fato-risivel.html

${ }^{194}$ Entre 18 de janeiro de 2008 e 18 de junho de 2009, a comercialização de livros, encartes, revistas ou CD-ROM contendo o jogo Counter-Strike foi proibida em território brasileiro, conforme decisão da Justiça do país, devido à sua violência excessiva. O juiz responsável argumentou que Counter-Strike e o jogo EverQuest "trazem imanentes estímulos à subversão da ordem social, atentando contra o estado democrático e de direito e contra a segurança pública, impondo sua proibição e retirada do mercado". Disponível em: $\quad$ http://g1.globo.com/Noticias/Tecnologia/0,,MUL265391-6174,00JUSTICA+PROIBE+GAMES+COUNTERSTRIKE+E+EVERQUEST+NO+BRASIL.html

195 Em 1997, o game Grand Thief Auto foi proibido. Segundo reportagem do Jornal Hoje, "a justiça brasileira considerou o jogo um incentivo ao crime. O Departamento de Proteção ao Consumidor decidiu investigar, mas já suspendeu a propaganda e mandou recolher os CDs. A ordem está no Diário Oficial da União". Segundo a reportagem, empresa que distribui o jogo eletrônico, entrou com um mandato de segurança contra a decisão do ministério da Justiça. O presidente da empresa disse que "o game é divertido e não estimula ninguém a roubar carros”. Disponível em: https://www.youtube.com/watch?v=9DNZr52cz5k 
High School, em 1999), que foram associados a jovens que jogam games violentos ${ }^{196}$ (FERGUSON, 2007). Para compreender mais a fundo essa questão, há um material mais extenso disponível na pesquisa de doutorado de Lynn Alves (2004), a qual se debruçou exclusivamente sobre o assunto. Em torno da controvérsia do gerenciamento de humor, essa pesquisadora coloca que:

Na perspectiva desses jovens, os jogos funcionam como uma válvula de escape, liberadora de questões intrínsecas aos sujeitos e que precisam ser resolvidas. Isso promove um efeito catártico para a agressividade existente em todos nós, ocupando as horas de prazer e lazer como um mero passatempo, portanto, não são encarados como uma compulsão. Embora os "participantes entrevistados" joguem diariamente, no caso específico deste grupo, isso não se constitui em uma compulsão, uma vez que eles desenvolvem outras atividades sociais, nas quais os jogos não entram em cena. Jogam para relaxar, para começar um novo dia, para fluir as emoções (p. 197).

Ivelise Fortim escreve que "é possível que as pessoas já consideradas como mais agressivas procurem entretenimentos mais violentos", mas que não haveria evidências de que os games causem atitudes violentas e agressivas (2013, p. 66). Em consonância com essa afirmação, Lynn Alves conclui que a interação com os jogos eletrônicos não produz comportamentos violentos nos jovens. Segundo Alves, a violência emerge como um sintoma que sinaliza questões afetivas (desestruturação familiar, ausência de limites etc.) e socioeconômicas (como queda do poder aquisitivo e desemprego).

Este trabalho ratificou a tese de que os jogos eletrônicos considerados violentos não geram violência, isto é, a relação não é de causa e efeito. É fundamental analisar o fenômeno da violência mediante os aspectos sociais, econômicos, culturais, afetivos etc. (ALVES, 2004, p. 197).

Certamente, a relação não é de causa e efeito; no entanto, buscaremos aqui não replicar algumas divisões modernas desta explicação. Sabemos, contudo, que não podemos demarcar o problema como puramente "social" ou "afetivo", senão desconsideraríamos a agência desses jogos e outros atores não-humanos. Se, por um lado, os games podem ser benéficos - como postulam os defensores do desenvolvimento da cognição e dos jogos educativos - , eles podem igualmente ser prejudiciais. Se quisermos fazer valer a primeira opinião, temos, simetricamente, de considerar que os games influenciam as pessoas (e vice-versa).

\footnotetext{
196 Nos Estados Unidos, em dezembro de 2012, a revelação de que o atirador da escola de Ensino Fundamental Sandy Hook, jogava jogos de tiro, resultou diretamente num pedido do presidente Obama ao Congresso para destinar 10 milhões de dólares a pesquisas sobre os efeitos de mídias violentas, especialmente os videogames (OBAMA; BIDEN, 2013 apud GRANIC et al., 2014).
} 


\section{4 - Ambientes de jogo}

Nesta seção exploraremos brevemente alguns dos ambientes de jogo, como a casa, o apartamento (em seus detalhes, como a diferença entre o quarto reservado e a sala), a casa de amigos, do sogro, lan-houses, eventos em que se disputam campeonatos etc. Aqui não entram somente os recintos físicos, mas a composição dos coletivos que compõem estes ambientes, incluindo as pessoas, fones de ouvido, ruídos, controles, televisores, monitores etc. Colocaremos algumas questões acerca desse tema: Quê pessoas e coisas circulam nesses ambientes? Trata-se de ambientes públicos ou privados? Seria o ambiente em que ocorre o jogo não-físico? Quais outras materialidades estão envolvidas?

Em alguns de nossos relatos, a sala aparece como um local mais público e aberto para a vigilância dos pais (ou outros responsáveis) em comparação ao quarto privativo, que é mais reservado e mais "propício" para o vício, segundo os especialistas. Outra dinâmica acontece nas lan-houses (Local Area Network). Estas aparecem como locais mais públicos em comparação às residências das pessoas, mas, por outro lado, as pessoas que as frequentam estão ali justamente por objetivos semelhantes, como, por exemplo, utilizar jogos ou navegar na internet, o que não costuma gerar atritos por desafinidade de interesses. Nas lan-houses, em geral, não há uma vigilância em relação ao uso dos videogames; pelo contrário, as pessoas costumam jogar bastante, como, por exemplo, nos corujões, em que os frequentadores passam a madrugada inteira jogando por um preço promocional. Existem, no entanto, determinadas restrições de atividades nos computadores; por exemplo, o acesso à pornografia.

No caso dos games nas lan-houses, por haver diversos computadores conectados em rede (principalmente onde a conexão do sinal de internet não é rápida), as diferentes pessoas podem participar de um mesmo jogo multiplayer local, lembrando a dinâmica presencial dos jogos entre amigos em suas casas. Contudo, diferente desta, nas lanhouses cada um possui seu próprio PC, seu fone de ouvido e, em geral, não podem (ou não devem, no caso de jogos competitivos, embora aconteça) olhar na tela dos outros. Além disso, pode ainda haver a presença de outros jogadores conectados por via online, misturando, assim, as dinâmicas de local area network e online network. 
Neste sentido, Hyou comenta que a experiência de jogo multiplayer presencial, com amigos reunidos numa mesma casa, por exemplo, é diferente de jogar por meio da internet ou solitariamente (num jogo single-player).

O ambiente físico, você tem um espaço que é seu, que você tem liberdade de jogar quando você quer, ou você convida amigos que estimulam também, você começa a se empolgar junto com eles, você joga mais, isso acontece muito, das pessoas se reunirem pra jogar o mesmo jogo, mesmo que seja na internet. $\mathrm{O}$ ambiente relacional fora do jogo é muito influenciado, porque as conversas, as discussões, tanto na internet quanto fora, elas alimentam e você cria um desejo maior de ali estar, de ali criar. - Hyou

Peter_pano descreve o ambiente que ele mesmo prepara para jogar videogame. Ele comenta que ocorria de levar o videogame para a casa de seu sogro, onde, entretanto, não tinha a mesma privacidade de quando jogava em casa, em sua "bolha". Além do ambiente, Peter_pano aponta diferenças entre os equipamentos que se usam no jogo: para ele, jogar o mesmo game num console e num computador é diferente, tanto em relação aos chamados periféricos (como o mouse e teclado no computador versus controles nos consoles), como por aspectos técnicos (velocidade de frames por segundo), qualidade gráfica, forma de conexão, entre outros.

Particularmente eu só jogo no videogame hoje em dia [ele se refere aos consoles, em contraposição ao PC]. Eu não jogo numa TV, eu jogo no monitor, sentado, a $20 \mathrm{~cm}$ dele. Eu particularmente não gosto de jogar em TVs por causa da distância, eu gosto de estar com a imagem inteira ocupando o meu campo de visão. Então, eu prefiro jogar no monitor. A $20,30 \mathrm{~cm}$ de distância do monitor, inclusive pela questão do isolamento que pra mim é mais fácil, eu fico focado. Ponho um fone e simplesmente eu não escuto mais nada. Eu tento montar minha bolha e em casa eu faço isso também. É um ambiente que é separado de toda a casa, separado das pessoas. Então, é um momento privado meu. Pra mim é uma experiência íntima, que eu prefiro passar sozinho. - Peter_pano

Peter_pano explica em detalhes como constrói esse "isolamento" para jogar. Segundo ele, este não é um isolamento total, mas apenas do "ambiente físico".

O isolamento é, digamos assim, físico. Naquele momento, enquanto eu estou jogando videogame, eu estou desligado de tudo que está ao meu redor. Não me importa se eu estou no meu quarto, no quarto na casa de alguém, se tem pessoas do meu lado vendo TV ou alguma coisa do tipo. Se eu estou jogando videogame, eu estou fazendo aquilo e ponto. Tem pessoas que eu vou me comunicar? Claro. Não é um isolamento total. Mas é um isolamento desse ambiente físico. Não é que ele deixa de existir, mas que não tem mais importância naquele momento. $\mathrm{O}$ mais importante naquele momento é o que está se passando na frente da tela. Então é aquela coisa de você esquecer que você está sentado numa cadeira segurando um controle. Você sentir que você faz parte daquilo que você está controlando. - Peter_pano 
Ou seja, a pessoa que está jogando não estaria tentando se desconectar do mundo, mas estaria entrando em comunicação com outros agentes. Em seu relato, pois, há cortes de fluxos. Dessa maneira, há de se diminuir a influência de certos agentes para ressaltar outros. Vimos brevemente que não podemos ignorar a agência desses objetos (que são sujeitos) sociotécnicos que permeiam o modo de jogar e o engajamento dos jogadores nos videogames. Ademais, esses territórios, equipamentos, componentes e materiais, por mais que apareçam como virtuais ou imateriais, mediam as relações e fazem diferença - inclusive para a instauração da chamada "dependência".

\section{5 - Videogames, jogadores e familiares}

Nesta seção exploraremos as opiniões de alguns terapeutas, pais, cônjuges dos jogadores e também dos próprios jogadores enquanto filhos, maridos, namorados acerca das relações (muitas delas familiares) com os jogos. Aqui há uma grande diversidade de relatos, de relacionamentos conflituosos a experiências harmônicas. Para abrir a questão, garoto Tosas, por exemplo, enfrenta problemas dentro de casa. Seu pai, Bino, considera o seu envolvimento com os jogos exagerado. Deparado-se com essa acusação, Tosas opta por uma saída relativista:

Ix! Puta que o pariu! [risos] É assim, o que eles falam é pra dosar. Eu saber dosar. Mas na minha opinião, são parâmetros diferentes. Por exemplo, meu pai acha que eu jogo muito. Mas todos meus amigos que têm pais diferentes não interferem muito, é diferente, mas, eu digo, eles jogam praticamente a mesma coisa que eu. É que são famílias diferentes e visões diferentes. Então não tem muito o que se discutir sobre isso. Aí a visão de cada um de jogar. O que eles acham é que é muito. Mas as outras famílias não ligam muito pra isso. É que é opinião de cada um, realmente. - Tosas

O psicólogo Lucas Costa coloca que não há uma quantidade de tempo estabelecida que torne a atividade prejudicial. Para ele, deve-se analisar se as outras "funções da vida" da pessoa estão operando dentro da "normalidade".

Tem que analisar caso a caso. É lógico que o pai vai achar que, se ele falar que ele joga oito horas por dia, que é muito. Ele vai pensar "pô, eu trabalho oito horas por dia e eu acho muito, então se ele joga oito horas por dia é muito". Por outro lado, a gente tem que saber também o quanto esse pai conhece o filho, e saber qual é o efeito. Então, tipo, "ah, ele joga muito", mas e todas as outras funções da vida dele são normais, ele joga muito mas ele sai pra encontrar com os amigos... Ele joga muito, mas ele consegue parar de jogar, ficar umas duas horas e voltar... - Costa 
Ivelise Fortim aponta para a diferença de parâmetros entre os pais e os filhos para determinar uma boa medida para os jogos, pois ambos construirão noções a partir do seu próprio uso. Ela ressalta que para um terapeuta que se diga especialista em videogames, há de se participar parcialmente da experiência para entendê-la um pouco.

Um dos problemas é que o parâmetro que as pessoas dão de dependência é o próprio uso. Então se você não usa nada e o seu filho joga 2 horas, seu filho é dependente. Se você joga 20 horas e o seu filho joga 8 , então seu filho não é dependente. Se você pegar MMO, MMO tem uma lógica própria. Não dá pra você chegar pra família e falar "vou jogar 15 minutos de MMO", você joga uma partida inteira. Em 15 minutos de MMO você não faz nada. Você precisa de 1 hora, 1 hora e pouco. Então você vai lá e joga uma partida. Mas pra você entender isso... Também não é pra entrar todo dia, não é pra jogar todo dia, que é uma das formas que as pessoas tem de limitar. Então, esse tipo de coisa faz diferença ser jogador ou não, senão você não entende aquilo. - Fortim

Retomando o caso de Tosas, sobre seu filho, Bino afirma: "Se deixar assim, entre viver a família e viver, ficar no computador ele prefere ficar no computador". Bino conta que uma das medidas que tentou tomar foi a limitação de tempo: "que a maioria do pessoal fala, que a gente escuta falar, que é ter um limite”. Para ele, o uso de videogame é:

Como a droga. A pessoa sente necessidade de estar com aquilo lá. [Antes] Não era assim. Eu até ia botar um timer lá pra desligar a internet, mas a mãe "nhanhanhanha", não. Eu tinha botado no Antivírus, pra desligar a internet. A mãe diz que reclamou, mas por mim eu deixava pra limitar o tempo. - Bino

Segundo Bino, seu filho não se desenvolveu como outros jovens da mesma idade por passar muito tempo no videogame. Ele "tem idade, mas é muito criança ainda. Não tem experiência de vida".

Porque desde a minha época muda. Vai mudando também, a faixa etária, o pensamento, tudo... Vai ficando mais velho, tem que criar responsabilidade. É, tem que mudar. Não é eternamente [criança]. Tem uns que demoram pra sair dessa rotina aí. Por isso que tem às vezes as discussões. - Bino

Para o médico psiquiatra Elias Aboujaoude (2011), os games podem ser vistos como uma atividade que proporciona uma regressão à infância. Segundo este autor, o uso excessivo e a dependência de jogos virtuais fariam com que o jogador se sentisse novamente na infância, época em que os erros são mais tolerados. Aboujaoude afirma 
que esta seria uma nostalgia das ações sem grandes consequências, uma vez que nos jogos virtuais seria possível "morrer" e "errar" inúmeras vezes ${ }^{197}$.

Por conta dessas controvérsias, vimos que o próprio pai de Tosas tem problemas de relacionamento com a esposa, a qual prefere que seu filho continue jogando. As discussões às quais ele se refere são os diversos debates que ocorrem dentro de casa: "Eu sou contra, a mulher é a favor". No entanto, ambos, pai e mãe, convergem na questão de preferir que o filho não esteja vulnerável aos perigos das ruas: "Eu prefiro ele em casa do que na rua. Na minha época era diferente. Eu ia pra rua”, diz Bino.

Na família de Hideko há importantes semelhanças e diferenças em relação ao caso anterior. Hideko aponta um conflito instaurado em sua casa em torno dos videogames. Ela lista uma série de fatores para explicar por que entende que esta forma de uso seria prejudicial para o seu filho:

Aqui em casa quem fica mais horas jogando é o Iago, que tem 7 anos. A Anita não joga tanto porque ela trabalha e já tem 20 e tantos anos. Eu acho que é, na verdade é um grande conflito. Porque eu não tenho tempo de ficar controlando, e ele fica muitas horas. Ele só não fica mais horas porque tem a escola. Então, durante a semana ele fica de 2 a 3 horas de manhã... E aí de noite, se não tiver ninguém no computador ele fica mais umas 3 ou quantas horas deixar. E é uma luta, porque tem que ficar brigando pra tirar. E vicia mesmo. E deixa a pessoa super agitada. Não só... Fora a mensagem do jogo, que tem jogo que ensina violência, a maioria dos jogos tem violência, algum tipo de violência... Então, fora a mensagem que vai entrando no subconsciente, tem essa questão do magnetismo do aparelho. Tem essas duas coisas. E a dificuldade de pôr limite. Hideko

Terapeutas e pesquisadores, desde médicos a psicólogos, em geral recomendam uma supervisão dos pais para mitigar o problema da dependência. Perguntemos, então, aos próprios: Afinal, teriam os pais o papel de pôr limites na criança?

Com certeza, obrigação. Fundamental. E eu sou meio falha nessa obrigação, nessa missão. E fora o jogo em si, agora no YouTube ${ }^{198}$ tem os vídeos que as pessoas fazem elas jogando e fazendo comentários. Então, o Iago é viciado também nesses vídeos de YouTube, que o cara fica jogando e comentando. Enquanto ele comenta, ele fala uma porção de coisas que ele não precisava aprender. Fala palavrão... Além do jogo tem todos os paralelos do jogo que vem

\footnotetext{
197 Argumento este que pode ser contestado pelo próprio desenvolvimento de alguns games, como de simulação de situações de guerra para as Forças Armadas, as quais incluem em seu treinamento a prática dos referidos jogos, justamente para melhorar seu desempenho fora deste.

198 Isto a que Hideko se refere são os "YouTubers", um fenômeno relativamente novo no cenário dos jogos, que são populares principalmente entre as crianças. Ver: http://jogos.uol.com.br/ultimasnoticias/2014/10/13/bgs-entre-assedio-e-confusao-youtubers-sao-atracao-a-parte-da-feira.htm
} 
atuar na cabeça da criança. Ele fica às vezes horas assistindo vários vídeos. E só lá posta um vídeo de mais de uma hora, ele jogando com três pessoas jogando, e comentando e falando coisas. - Hideko

Sobre este assunto, o terapeuta Lucas Costa entende que o pai tem responsabilidades, mas que ele, primeiramente, deve procurar entender minimamente o que se passa com seu filho, inclusive em relação aos jogos, para estabelecer boas regras de convívio em casa.

Responsabilidade o pai sempre tem, agora tem que ver se ele está olhando o suficiente... [...] O pai tem que cuidar sim, só que tem que ver se ele está se propondo a realmente cuidar ou se ele só quer estabelecer regras pra ele chegar em casa, olhar e a casa estar do jeito dele. - Costa

Fortim se coloca rigorosamente contra os psicólogos que afirmam, por exemplo, que crianças de dois anos seriam dependentes de iPad: "Desculpa, você que não consegue falar 'não' pro seu filho!". Ainda que sejam preocupações relevantes, a opinião contrária dos pais sobre os videogames não seria também uma decorrência de seu alheamento em relação a eles? Como Hideko mesmo admite, uma possível afinidade dos pais com os games poderia ser uma forma de aproximação com seus filhos. Hideko relata que, para isso, conta com ajuda de suas filhas, irmãs mais velhas de Iago:

$\mathrm{Na}$ verdade, eu passo um pouco dessa missão [de acompanhar o seu filho] pras meninas, porque elas estão mais por dentro do que eu. Então elas dão um toque: "Não, esse jogo não...", mas eu não, porque como eu não gosto, eu não me interesso em ficar lá olhando. Se eu gostasse de jogar até seria um momento de cumplicidade, de brincar com ele, de aproveitar esse momento pra conversar sobre aquilo, mas como eu não gosto e eu não tenho muito tempo, então eu fico meio alheia do que acontece. - Hideko

A partir disso, suspeitamos que haja uma importante questão geracional nesta discussão, a qual, entretanto, não teremos fôlego para explorar aqui em detalhes. Lembremos o argumento de Allprot, de que muitos terapeutas que tratam da dependência de games "não cresceram jogando videogame", o que limitaria seu entendimento sobre o fenômeno. Isso vale não somente para os terapeutas, como também para os pais, mães, avós, entre outros familiares.

Hideko lembra que, com a entrada dos aparelhos eletrônicos dentro das casas, houve uma substituição na forma e nos esforços de educativos das crianças. Para ela, a educação passaria a ser exercida primariamente pela televisão e pelo videogame, em substituição dos pais: "Aliás, é o mal dos últimos tempos é esse. Quem educa o filho não é o pai e a mãe, é a televisão e o videogame", e as crianças hoje "ficam muito mais 
horas conversando com a televisão e com o computador do que com o pai e com a mãe".

Diferente de Bino e sua esposa, pais de Tosas, Hideko não concorda que deixar os filhos jogando videogame dentro de casa seria a melhor solução para o problema da violência nas ruas. Segundo ela: "Essa é a justificativa da sociedade. Então, como na rua tem violência, os pais preferem que o filho fique no computador vivendo a violência de outra forma. Porque na mídia também tem violência. Toda parte tem violência".

Portanto, para ela, não há como se esconder do problema, pois este nos alcança também através dos games. Diante disso, ela se preocupa com o conteúdo violento dos jogos e a qualidade da informação ${ }^{199}$ que podem chegar à criança. A respeito desse ponto, Hideko compara, por meio de uma metáfora sociotécnica, a fragilidade da criança em se "defender" ou "filtrar" estes conteúdos e a capacidade que os adultos têm de fazê-lo:

A mente é que nem um computador. Então você pega um HD limpinho, você vai colocar muito mais coisas do que um HD que já está lotado de coisas. Então, o adulto, a nossa mente, já está cheia de coisas. Agora a criança está num processo de abertura total, numa fase de crescimento. Então, até aquilo que ela não está prestando atenção, ela está recebendo e está ficando na mente dela, lá no inconsciente. A criança, quanto mais nova, mais receptiva ela está pra tudo que passa, todas as informações que ela ouve, que ela vê, que alguém passa falando, vai tudo entrando e vai ficando lá com muito mais facilidade do que o adulto. Fora que o adulto já tem uma capacidade de filtrar. Algumas pessoas filtram informações. E a criança não filtra nada. Entra tudo. - Hideko

Dando sequência à discussão, o jogador Allprot relata um "isolamento" criado entre ele e a sua mãe a partir de sua forte relação com o videogame. Ele relata que nesta situação ambos não partilhavam nem o mesmo interesse, nem a mesma linguagem:

Nessa época que eu fiquei no jogo online, talvez eu não vivi coisas que a maioria das pessoas viveram, da minha idade. Nessa época a galera está começando a sair pra balada, pra essas coisas e eu não tive nada disso, eu fui ter isso bem mais tarde. E mesmo assim a relação com a família, porque era um conflito: eu queria jogar e a minha mãe não queria que eu jogasse, fica um clima meio tenso. Ela sentia falta da minha presença. Embora eu tivesse sempre lá, no computador, eu não conversava com ela, não tinha assunto pra conversar com ela. O quê que eu ia falar com ela? Eu só queria pensar sobre o jogo. Allprot

\footnotetext{
${ }^{199}$ Para atender esse tipo de preocupação, foi criada a chamada Classificação Indicativa de Jogos, a qual pode ser consultada no site do Ministério da Justiça. Nesse sistema há seis faixas: livre; não-recomendado para menores de 10;12; 14; 16 e 18 anos. Em 2013, o Brasil adotou o sistema IARC (International Age Rating Coalition), que considera os sistemas ERSB (Entertainment Software Rating Board), vigente nos EUA, e o sistema PEGI (Pan-European Game Information), que vigora na Europa, retirando os videogames da categoria "filmes" e colocando-os numa categoria própria, junto com os jogos de RPG de mesa.
} 
Portanto, devemos reconhecer que o videogame não somente conecta coisas e pessoas, como também corta redes (STRATHERN, 1996a) e estabelece separações. Reforçando esse entendimento, Ivelise Fortim comenta que sofrimento vivenciado na dependência não seria somente individual, mas expandido - atingindo a família e amigos:

Então, o resto da vida não tem sentido algum. Só que como acontece isso, o resto da família cobra. Família, amigos, todo mundo cobra. Pro sujeito nada mais tem sentido, só o objeto de dependência que tem sentido. E aí é um sofrimento pra todo mundo, porque o dependente tem aquele único interesse, seja ele qual for, a família está vendo que o cara está se afundando. Porque tem um outro problema: todas as dependências geram prazer. E é muito difícil você se livrar de um comportamento que te gera prazer. Muito, muito difícil. Então o sujeito nega. "Não, está tudo bem, os outros é que não me entendem. Eu sou um incompreendido. Eu quero fazer isso e está tudo bem, vocês que tão errados". Com ou sem razão. E aí tem um sofrimento da família, todo mundo vendo o cara se afundar em sabe-se sei lá o quê, e a pessoa nega, e nega ajuda. - Fortim

O usuário Chuck, por sua vez, admite sem quaisquer ressalvas que era viciado na época dos seus estudos no Ensino Médio, quando jogava de madrugada e, segundo ele, sua mãe não ficava sabendo. Ele ressalta um maior potencial "viciante" dos jogos online:

Com certeza no colegial eu era totalmente viciado em Ragnarök. Eu não parava de jogar nunca. Eu acordava de manhã e aí eu não acendia a luz do meu quarto pra minha mãe não encher o saco, aí eu ligava o computador na escuridão e ficava jogando, aí demorava umas duas horas pra ela descobrir que eu já estava acordado, mas eu já estava jogando Ragnarök. O jogo que eu fiquei mais viciado com certeza foi Ragnarök. Era mó divertido. Jogo online geralmente deixa você mais viciado porque ele não tem hora pra jogar e você joga com as pessoas ao mesmo tempo, então, o negócio te segura mais fácil. - Chuck

Chuck conta que, nessa época, embora o seu relacionamento com os pais não chegasse a ser problemático, não era tão próximo como é hoje em dia. Ele relata que nesse período havia uma baixa exigência por parte da escola, que o "liberava" para jogar mais.

O relacionamento com os meus pais nessa época era tranquilo. Era colegial, então, não tinha muita exigência do que você fazia da vida. Então, não me importava muito. Mas com certeza eu via menos eles que hoje em dia, porque eu ficava jogando até a hora da janta, botava o prato na frente do computador e jogava. Só pra não perder o super evento Battle City. - Chuck

Já na família de Hyou, os pais insistiam em controlar a atividade de jogo dos filhos, principalmente em relação ao horário:

Eu nunca me considerei viciado em jogos. Talvez os meus pais controlavam o uso. Mas nunca me trataram como viciado, nem chegaram ao ponto de classificar isso como um vício. De certa parte eles até gostavam, porque a criança está interagindo com uma coisa que, de certa forma, não fogem do 
controle, mas eles apreciam porque ele estão se ocupando de uma forma até positiva. Tive vários amigos que as mães proibiram de jogar, por conta do horário de madrugada que é o horário reservado pra dormir. Pra mãe é isso: não podia jogar de madrugada. E madrugada era o momento mais precioso pra jogar. - Hyou

Peter_pano, por seu turno, conta que não teve problemas com seus pais, mas que, em compensação, teve conflitos com sua namorada ${ }^{200}$ numa determinada época. Acusado de colocar os videogames num patamar de importância superior, Peter_pano se defende argumentando que jogar videogame é uma de suas "necessidades como pessoa", e que sua a namorada teve de assimilar isto ao longo do relacionamento.

Hoje em dia já não tem problema nenhum. Porque como eu trabalho já faz um bom tempo, eu trabalho desde cedo e tal, nunca faltei com as minhas responsabilidades por causa disso. Hoje em dia, pelo menos com os meus pais eu sei que eu não tenho problema. E mesmo quando eu era mais novo eu nunca tive problema porque eu nunca faltei com as responsabilidades dentro de casa, apesar de jogar muito videogame. Com a Carla, a gente chegou já a ter problemas assim de questão dela se sentir, "Pô, você está dando mais atenção, sua prioridade é mais pro videogame e tal". Isso acho que no começo do relacionamento. E foi uma fase que a gente teve mas, ao longo do tempo, ela foi entendendo também a questão das minhas necessidades como pessoa. Isso faz parte de mim. Eu preciso jogar videogame. É uma coisa que pra mim faz parte do meu dia-a-dia, faz parte do meu cotidiano. Se não tiver eu vou sentir falta, como talvez uma mulher se não se arrumar não vai se sentir bem saindo na rua porque faz parte do cotidiano dela, ela precisa daquilo. Ela foi educada daquela maneira. A gente chegou a ter problema com isso, mas foi coisa que durou menos do que um ano. - Peter_pano

Vemos que Peter_pano coloca os games como uma necessidade fundamental, algo que faz parte do seu "jeito de ser", de seu estilo de vida, e que, portanto, deveria ser respeitado pelos outros. A seguir ele detalha os motivos do conflito com sua namorada:

Uma das fases que a gente mais teve problema, mas foi mais fácil a compreensão, foi exatamente nesse período que eu estava mais estressado, que eu acabei usando o videogame como terapia. No começo pra ela foi meio estranho porque antes eu estava jogando uma hora, duas horas a cada três dias, e aí de repente eu estava todo dia jogando três horas. Foi uma coisa que pra ela teve impacto. Mas daí logo na sequência ela entendeu porque aquilo estava acontecendo. - Peter_pano

Caaah_Sion, namorada de Peter_pano, relata que os desentendimentos surgiam quando ele desmarcava programas para ficar jogando ou a deixava sozinha. Outra questão era sua preocupação com as poucas horas de sono do namorado, na época em que este

\footnotetext{
${ }^{200}$ Acerca desse assunto, há pesquisas de caráter convencional divulgadas na grande mídia, que apontam que os videogames seriam responsáveis por 15\% dos divórcios nos EUA e 12\% na Inglaterra. No entanto, informações importantes das mesmas, como a metodologia, são por nós desconhecidas.
} 
jogava Call of Duty de madrugada e pegava o ônibus muito cedo para trabalhar. Ela alertava: "Você está dormindo três ou quatro horas por noite!" No entanto, Caaah_Sion conta que, a partir de conversas e com o passar do tempo, a situação foi resolvida, principalmente porque ela própria aos poucos foi transformando o seu entendimento acerca da relação de seu namorado com videogame.

Eu sou da premissa de que tudo o que é exagerado faz mal. Qualquer coisa que você faça. No começo pra mim era um brinquedo. Do brinquedo passou pro lazer, do lazer fui vendo que era um esporte, como ele mesmo falou, e do esporte eu vi que era terapia. Quando eu cheguei nesse ponto, eu falei, "Opa, isso é bom pra ele, faz parte dele, faz parte da vida dele, assim como eu, eu gosto das minhas coisas particulares, ele gosta de jogar videogame". Eu gosto de ficar horas juntando foto, buscando referência pra minha área, que é a área que eu trabalho, fico lá no computador um tempão. Ele não. Ele gosta de jogar videogame. Então passei a respeitar. Então nunca chegou a me preocupar, tipo: "Meu Deus do céu! O menino precisa ir pra uma clínica de reabilitação". Não, nunca me passou isso pela cabeça. Foram períodos de discussão, mas que passou.-Caaah_Sion

Neste ponto, cabe também lembrarmos que, além da questão etária anteriormente mencionada, há uma importante questão de gênero neste debate. Seriam os videogames uma atividade predominantemente masculina ${ }^{201}$ ?

Eu conheço mais homens do que mulheres que jogam. Mas eu não acho que isso seja uma coisa mais masculina. Na faculdade tem três meninas na minha sala que jogam, às vezes dá intervalo elas estão lá com o [Nintendo] DS, sei que elas têm videogame em casa também. -Caaah_Sion

Peter_pano conta que tentou convencer sua namorada a jogar junto com ele, mas que ela não o acompanhou. Hoje ele somente conta com as companhias masculinas de seus amigos e de seu pai.

A Caaah_Sion é uma negação. Eu já tentei fazer ela jogar mil vezes, dei uns seis jogos pra ela, basicamente dinheiro jogado fora, porque são todos jogos horríveis e que ela não joga. Então não, a única pessoa que eu tenho que joga videogame comigo é o Paulo e a gente sempre joga junto, tenta sempre jogar online e tal, mas dessas pessoas mais próximas nenhuma joga. A única coisa é que meu pai, por exemplo, desde sempre, desde que eu era pequeno ele sempre gostou de me assistir a jogar videogame. Ele nunca gostou de jogar videogame comigo, mas ele adorava ficar assistindo. Então, primeiro eu lembro do jogo que ele passava assistindo era Metal Gear, por exemplo, que ele amava a história. Ele ficava assistindo atrás e torcendo pra ver o que ia acontecer. Peter_pano

\footnotetext{
${ }^{201}$ Certas pesquisas (GRIFFITHS, 1991b, 1993, 1997a, KAPLAN, 1983) apontam que há uma maioria de homens nos jogos, mas que não há nada de natural ou imutável nisso, vide que a participação relativa das mulheres nos games cresceu consideravelmente nos últimos anos.
} 


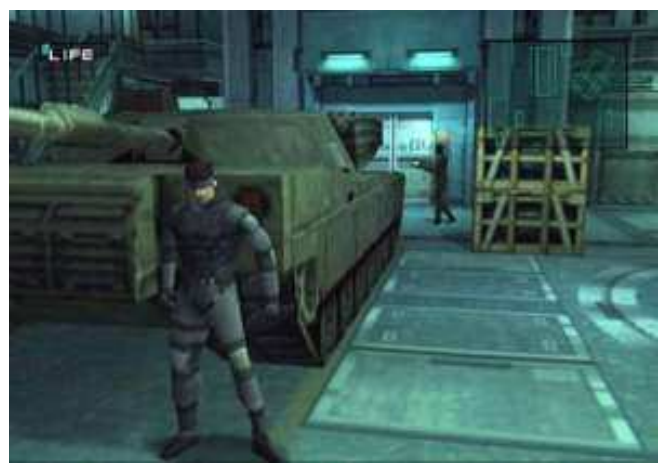

Figura 4.12 - Metal Gear Solid (1998)

No entanto, assim como na questão etária, não teremos condições de nos estender detidamente neste trabalho sobre este denominado "marcador social de diferença". Passaremos, então, a explorar algumas diferenças entre os próprios tipos de jogos, relacionando com o tema da dependência, bem como o da imersão.

\section{6 - Os gêneros de games}

Centenas de jogos foram citados em nossa pesquisa de campo. Observamos que estes variam tanto em gênero, forma de conexão, número de jogadores, mecânicas de jogabilidade, complexidade, potência gráfica, periféricos, entre outros fatores. Como veremos, estas variações têm implicações distintas nas controvérsias de dependência.

Há grandes diferenças nas formas de engajamento entre os distintos gêneros de jogos. Foram mencionados muitos desses gêneros, como: corrida, esportes, futebol, estratégia (em tempo real ou em turnos), plataforma, puzzle, tiro em primeira pessoa (first-personshotter), tiro em terceira pessoa, luta, simulação, construção, RPG, hack n' slash, cartas, trivia, adulto etc. Enquanto há jogos que não se encaixam em classificação alguma, outros podem se encaixar em duas ou mais. Devemos ter em mente, entretanto, que a classificação de dois jogos em um mesmo gênero não significa que um jogo seja necessariamente parecido com o outro. Além dessa variável, existem também as classificações por tema, mas estas são tão variadas que nem tentaremos enumerar.

Granic et al. (2014) propõem agrupar os gêneros de jogos num quadrante, variando pela complexidade no eixo vertical e pela a "sociabilidade" no horizontal. Por este quadro, os jogos de quebra-cabeças e de plataforma seriam classificados como simples e pouco sociais; já os jogos de corrida, de ritmo, de mídias sociais e os party games, seriam simples e sociais. Os jogos de RPG, de tiro (single-player), sandbox (single-player) e hack n' slash (jogos cooperativos de luta, por fases), seriam complexos e pouco sociais. 
Por último, os jogos de esportes, de luta (versus), sandbox (multiplayer), de tiro (multiplayer), MMORPGs e de estratégia, seriam complexos e sociais. Lembramos que aqui o significado de social é aquele moderno (LATOUR, 1991), ou seja, que apenas considera a relação direta entre humanos.

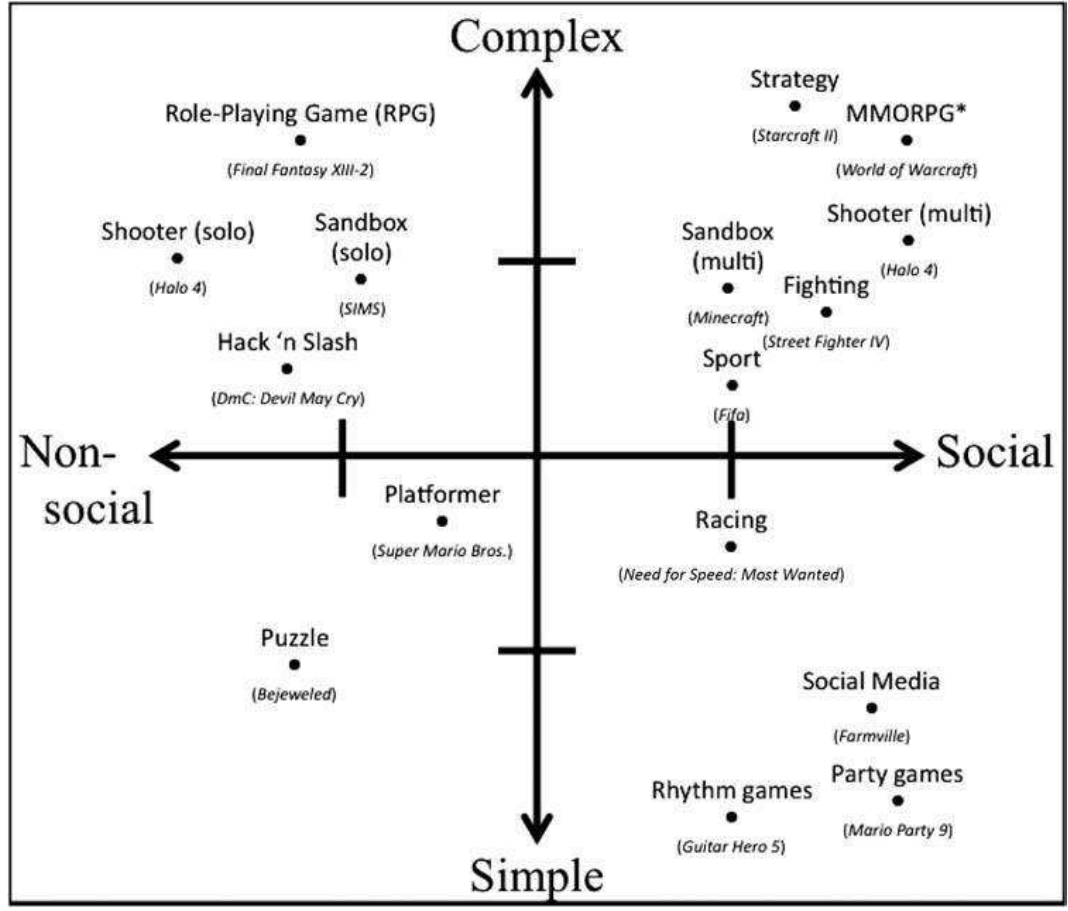

Figura 4.13 - Classificação dos gêneros de games pela complexidade e sociabilidade (GRANIC; LOBEL; ENGELS, 2014).

Ordenando pelo número de jogadores participantes, observamos que há modalidades single-player (como no xadrez contra o computador, paciência, pinball e alguns jogos casuais, como Angry Birds), multiplayer (como os jogos de tabuleiro) e massive multiplayer (nos MMORPGs, como Ragnarök Online). Há, ainda, muitos jogos que possuem modalidades variadas, como GoldenEye 007 e Super Mario World, que têm no mesmo dispositivo um modo single-player e outro multiplayer.

Os jogos também variam na maneira que os jogadores se encontram para jogar. Os três tipos predominantes são: presencial, rede local (LAN) e online. Aqui, novamente, há misturas. Em Counter-Strike, por exemplo, havia originalmente duas possibilidades (LAN e online), mas com a programação dos bots (jogadores comandados por inteligência artificial), criou-se a variante single-player. Isto para não citar a dimensão competitiva (e comparativa) de jogos single-player, exemplificada nos típicos "hall da fama" ou "recordes", que os fariam entrar numa lógica de múltiplos jogadores. Hyou explica algumas dessas particularidades: 
É claro que tem diferenças nesses jogos. E níveis de aproximação com os outros. Tem jogos que você joga no mesmo console, um do lado do outro, que é uma relação bem mais íntima que você tem com a pessoa enquanto joga, você vai desafiando ela, você vai sentindo as emoções, vai compartilhando. Via internet é uma questão mais de uma invenção de uma máscara, de um personagem. Até o seu "eu", que está jogando por trás daquele boneco, é uma invenção também. Tem um processo de mediação por conta do avatar, do personagem, mas também tem o discurso que a gente faz sobre nós mesmos, que jogando num console entre amigos num jogo de videogame é mais complicado. Tem diferença substancial isso, faz você jogar mais um jogo do que eu, e cultivar a sociabilidade nos jogos, independente de qual for. Mas existem grandes diferenças entre jogos, interativos, singulares, que você joga, tipo Mario, e MMORPG, que você joga com uma rede de pessoas anônimas. Hyou

Orochi descreve algumas diferenças entre os tipos de jogos, as formas de jogar, os graus de esforço requeridos por parte do jogador e a relação desses tipos de jogos com a dependência. Ele escolhe dois exemplos ilustrativos: Civilization, um jogo de estratégia, e Ragnarök Online, um MMORPG.

Eu percebo que tem algumas formas diferentes no jogo aparecer pra você. Tem jogos que você joga sozinho, ou seja, você joga no seu tempo, pode parar e continuar depois, que não são jogos online. No meu caso, eu vou pegar um exemplo de cada um, seria nesse caso, por exemplo, o Civilization. Eu jogo sozinho, posso jogar dez minutinhos agora, se eu quiser daqui a pouco eu jogo mais um pouco, se tem um dia que eu quero passar o dia inteiro jogando você fica jogando, está totalmente ao seu tempo. Aí um jogo online como Ragnarök, que é um jogo que você precisa estar bem mais envolvido com aquele jogo porque senão você acaba ficando pra trás, você vai ter clã, você vai estar ligado com outros jogadores e a galera está produzindo e você não está. Aí é como se você estivesse todo mundo estudando e você não está, você não consegue acompanhar a produção do jogo. - Hyou

Uma categoria bastante ressaltada são os jogos "sem fim". Em boa parte dos jogos antigos, "zerar" ou "fechar" o jogo implica abandonar o jogo subsequentemente, "cortar o vício". Como comenta Johnny William: "Games quando é vício é por alguma coisa específica. O problema é jogos que nem LOL [League of Legends], porque é um jogo infinito. E o cara não consegue parar de jogar”. Isso, no entanto, nem sempre acontece. Chuck comenta que a questão da infinitude não concerne somente a jogos de MMORPG, mas que jogos normais, como os de esportes, podem ter um alto fator de replay (um atributo que, aliás, é muito considerado pelas revistas especializadas na avaliação da qualidade dos games).

Eu terminei o Skate 3. Só que eu continuo jogando ele, como dá pra você andar de skate pela cidade aberta, à vontade, eu continuo jogando. Então, eu não me importo muito com isso. Jogo online também é a mesma coisa. Você não tem 
um fim. O fim não existe. Você chegou no level máximo, o que a galera faz: começa um cara novo do zero pra ter mais um cara level 99, tem gente que quer ter todos os personagens do jogo level 99. Tinha aquele jogo, LOL [League of Legends], que quando você chegava no level 99 você reiniciava o jogo e você ia vendo quanto bom você era por quantas vezes você conseguiu chegar no 99. Tipo, "reiniciei 23 vezes", "reiniciei 20 vezes". Esse jogo é mais louco ainda. Porque, quantas vezes eu joguei até o level máximo do jogo e voltei? Pra mostrar como eu sou um viciado? Isso aí é foda. Esse jogo bateu o recorde em viciamento. - Chuck

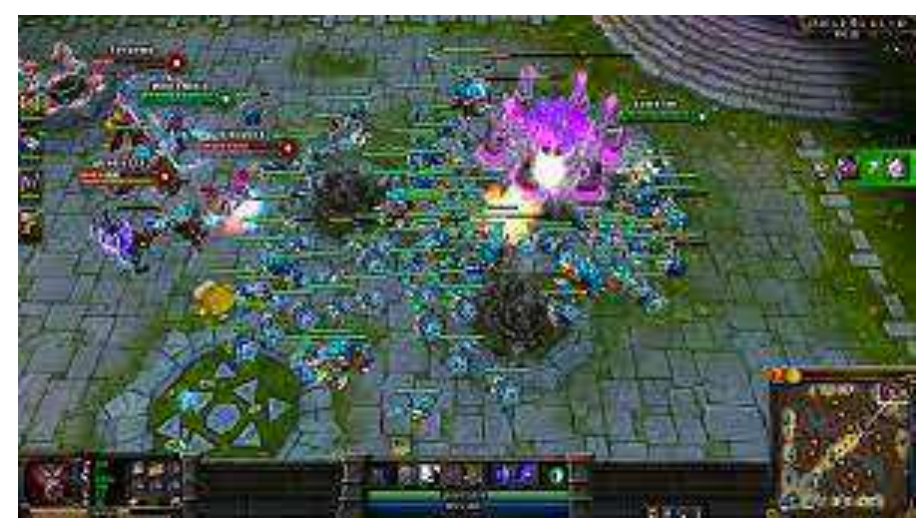

Figura 4.14 - League of Legends (2009)

Há casos que a pessoa gosta de voltar para o mesmo jogo repetidamente, assim como existem pessoas que assistem mais de uma vez ao mesmo filme ou leem o mesmo livro. OlavoFelipe comenta uma experiência com o jogo Sonic 2, que começou na infância e se repetiu ao longo de sua vida.

Sonic 2 foi o jogo que eu mais joguei, não numa época só, mas eu sempre jogo, porque é o jogo da minha vida, então eu sempre jogo ele de novo, de novo e de novo. Tipo, eu fecho, passa um tempo eu jogo ele de novo, fecho ele de novo e tal. Porque ele é muito nostálgico pra mim. E ele já é um jogo bom. Não é aquele nostálgico hiper travado e tal. Ele é muito legal, as músicas, o gameplay dele, a narrativa dele, que não tem história quase nenhuma, ele é bem simples, ele é bem fluido. As fases... tem fases naturais, tem fases industriais, eu gosto muito desses dois tipos. Então, eu gosto muito dele. É o jogo que eu mais joguei, se bobear, em tempo de jogo na minha vida. Passei a minha vida inteira fechando ele. - OlavoFelipe

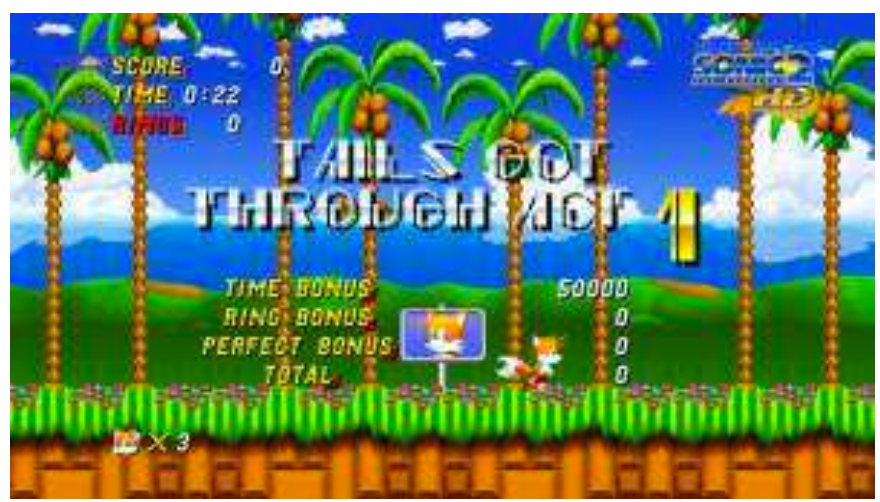

Figura 4.15 - Sonic - The Hedgehog 2 (1992) 
Na contramão dos jogos "clássicos", em que o jogador "fecha" ou "zera" o jogo e subsequentemente o abandona, muitos dos jogos do século XXI se aproveitam de mecânicas de monetização para estender o máximo possível os seus finais. O fim, por exemplo, pode ser prorrogado com o lançamento de atualizações, expansões e outros conteúdos adicionais. Masamune conta que "o Candy Crush pode ser considerado também um jogo sem fim, porque para uma pessoa chegar no level 300 tem que ter muita, muita sorte". Ele completa: "E aí o cara chega no 300, vem uma atualização com mais 50 fases, e aí a pessoa fica naquilo". Podemos pensar que o fim, enfim, é relativo.

Outro modo de jogo bastante citado são aqueles com a opção de conexão online ${ }^{202}$. Para entender isso, temos de retroceder um pouco no tempo e captar a mudança drástica que a chegada da internet engendrou no universo dos games. Segundo alguns entrevistados, na época em que havia somente jogos de console e de PC jogados offline, nas décadas de 80 e 90, a duração dos games era, em geral, mais curta, assim como eram menores as possibilidades de mecânicas de jogo e de sociabilidade.

Além de revolucionar a forma como os games passaram a ser jogados, a internet também possibilitou um aumento em seu acesso e circulação. Assim, se antes eles eram somente transportados e vendidos via disquetes, CDs e DVDs, agora podem ser baixados da Web, seja gratuitamente ou mediante pagamento. A internet, enfim, aparece como importante mediadora e criadora de laços. Sua agência é tão decisiva, a ponto de Fortim afirmar que não há como falar em vício em videogames antes de sua chegada:

Antes, vamos pensar década de 80 , década de 90 , se a gente for pensar em console, os consoles não estão espalhados pelo mundo todo, os jogos não duram 80 horas, os jogos são jogos tipo Mario, que dura oito horas no máximo. Isso [o vício] não é uma questão que existe pro console. Ele é uma questão que começa a ter por causa dos jogos online na internet. Começa lá na pré-história, com a questão dos MUDs. O MUD, mundo virtual em texto, não acaba nunca. É um ambiente permanente onde eu posso entrar e sair $n$ vezes. Nos consoles da época, na hora que você acabou aquele jogo, ele não existe mais. Dependência

\footnotetext{
202 A chegada da conexão em banda larga, principalmente no caso brasileiro, foi um aspecto técnico importante na expansão deste tipo de jogo (online games). Em geral, a conexão discada (por telefone) era por demais devagar para acompanhar o ritmo de muitos dos jogos em rede, em especial aqueles com gráficos mais exigentes e com a possibilidade de conectar múltiplos jogadores. Nesta transição em direção à conexão banda larga, as lan-houses predominaram no cenário nacional - por conta de sua conexão (LAN) ser muito mais rápida e pelo aproveitamento econômico na aquisição de melhores máquinas, cuja potência era condição para os jogos da época - em detrimento dos computadores pessoais, em geral, lentos e sem tanta capacidade de processamento de dados e sem conexão online de alta velocidade. Com a expansão da conexão banda larga no país, esse cenário foi se invertendo, porém, ainda persiste em pequenas cidades e em regiões com menores índices econômicos.
} 
de videogame, pensando em console, não era uma questão entre as décadas 80 e 90. E é por isso que os jogos online estão inseridos nos estudos de dependência de internet. Porque os primeiros que vão gerar mais dependência são os MMOs. Ainda hoje, o que se considera que mais gera dependência é o MMO. Então, começa nos estudos de internet. Depois, conforme vai evoluindo os videogames, que começa a ter consoles com jogos muito grandes, que você pode ficar muito tempo, aí começa a ser uma questão pro console e pra internet.

Fortim comenta que um dos motivos para a criação da relação de dependência é a duração dos jogos. No entanto, vemos que não há um tempo fixo em jogos online, como MMORPG: como não há um fim, não há como "fechá-los". Essa característica, no entanto, não se aplica a jogos de futebol, como FIFA, ou àqueles focados em experiências multiplayer, como Counter-Strike; diferente dos jogos de passar fases, ou de cumprir missões para "fechar" o jogo, como Assassin's Creed (em geral, jogos single-player) em que essa lógica até poderia ser válida. Mesmo nesses casos, entretanto, pode também acontecer de pessoa abandonar o jogo antes, caso empaque em alguma parte específica ou perca a motivação para jogar, independentemente do jogo ter "tantas horas" ou "tal tamanho" em sua totalidade.

Fortim também relaciona os games com o tema do jogo patológico e os compara com os jogos de apostas. Ela comenta que há fatores da dependência exclusivos ao videogame, como a permanência do espaço, a representação de personagens e as comunidades virtuais, enquanto outros são também comuns ao jogo patológico, como a sensação de risco e a possibilidade de vencer ou perder.

Tem muita gente que fala de Candy Crush Saga. Não é um mundo permanente. Mas ele tem um sistema que é parecido com o sistema - que em literatura é diferente gambling de gaming, apesar de em português está tudo traduzido como jogo. Então, o Candy Crush tem uma dinâmica parecida com gambling. Que é uma dinâmica que antes os consoles não exploravam. Você tinha lá um jogo de carta, que nem a indústria de cassino, que nem a indústria de jogo mesmo, de jogar dinheiro. Que é uma outra coisa que o pessoal fala assim: "Gera dependência, mas gera dependência igual caça-níquel, igual bingo", então essa história que os jogos geram dependência é antigo. Você tem viciado em cavalo, você tem viciado em bingo, você tem um vício de jogo que é muito antigo. Comprovadamente, alguns tipos de jogos viciam. O que acontece é que hoje tem alguns jogos que tem essa dinâmica, que lembra dependência de jogo, dependência por jogo a dinheiro; e tem outros que a dependência é movida por outras questões: permanência do espaço (o mundo ser persistente enquanto você não está lá), representação de personagem, comunidades virtuais; são questão que são exclusivas de videogame. Não tem a ver com jogo patológico. - Fortim

Em todo caso, vemos que a entrada da internet muda drasticamente a relação com os jogos. Allprot cita, por exemplo, que teve de se abster dos jogos online por conta da alta 
demanda de tempo em sua competitividade.

O jogo normal, a hora que você sai dele, acabou aquilo. Por mais que você tenha vontade de jogar, você consegue dar continuidade na sua vida. Agora o jogo online não, a parada está rolando enquanto você está tomando banho. Você não pode perder tempo [...] Eu não tinha dinheiro pra comprar cash. Eu tinha que usar o meu tempo pra alcançar os caras que compravam cash. Os GMs faziam vários eventos pra estimular as pessoas que não tinham cash a continuar jogando, é todo um ciclo vicioso. Ou você joga ou você não joga. Tanto é que eu não jogo jogos online por causa disso. - Allprot

Lucas Costa concorda com Ivelise Fortim na questão da mudança radical trazida pela internet. Para ele, "o que a intervenção que realmente permitiu que chegasse nesse nível é a internet". Ele acrescenta que "ainda tem os smartphones, esses negócios, essas coisas estão mais gritantes do que nunca".

A entrada dos smartphones, na segunda década do século XXI, transforma o conceito de dependência. Com a internet "na palma da mão", as fronteiras entre o online o offline ficam ainda mais borradas, uma vez que é possível estar conectado o tempo todo. Nos últimos cinco anos, os smartphones se espraiaram rapidamente, multiplicando a quantidade de games no mercado (em plataformas como Google Play e Apple Store) e inovando a forma de jogar, com a predominância dos controles touch-screen:

A entrada da internet no smartphone, como um dos dispositivos móveis, vai mudar esse conceito de dependência de internet. Porque você tem internet das coisas. Então, vai mudar um pouco o conceito. Que é diferente dessa imagem tradicional do dependente de MMO na frente do PC. - Fortim

Em uma revisão bibliográfica, Sublete e Mullan (2012), psicólogas da Universidade de Sydney (Austrália), resumiram alguns efeitos de se jogar online, mostrando tanto os positivos, como os negativos. Aqui retomamos os argumentos do "escape da vida real" e da substituição das relações face-a-face pelas relações online, já largamente debatidos no capítulo anterior:

O impacto dos videogames online nas vidas sociais dos jogadores parece ser ambivalente: ao mesmo tempo em que aumentam a socialização online, a offline fica reduzida, pois os jogadores preferem se comunicar online do que face a face. Outros estudos apontam que apenas em casos de dependência existem alterações na vida social dos jogadores. As autoras apontam que existem pesquisas que mostram que alguns jogadores usam o videogame para outras finalidades além do entretenimento, tais como escapar da vida real (SUBLETTE; MULLAN, 2012 apud FORTIM, 2013). 
Vimos que, além dos MMORPGs, jogos casuais como CityVille, FarmVille e Clash of Clans partilham dessa característica chamada permanência no tempo. Nestes jogos há uma contagem de tempo - baseada numa relação entre o tempo do jogo e o tempo cronológico -, a qual o jogador deve aguardar antes de partir para novas ações. Esse aspecto também está intimamente ligado à forma de monetização do jogo, a qual detalharemos numa seção posterior, ainda neste capítulo.

Tem esses jogos que ultimamente são bem mais comuns em iPad, como aplicativos, são jogos que você começa a jogar e, por exemplo, quando você quer construir alguma coisa, ele tem um tempo de construção. Então, você faz aquela ação no jogo, aí você tem que esperar uma hora pra aquilo se concluir. Isso faz com que você esteja sempre olhando um pouquinho no jogo. Você não está $100 \%$ do tempo jogando, mas você sai e volta, sai e volta, sai e volta, e acaba ficando praticamente o dia inteiro no jogo. Inclusive esses jogos eles dependem até de uma parte financeira. Não adianta você comprar o jogo e jogar. Você tem que ficar gastando durante o jogo pra construir coisas, senão você acaba ficando também pra trás, porque tem gente que vai comprar, que vai gastar, que vai fazer essa construção de uma hora, você pode gastar um pouquinho que aí ela fica em dez minutos. Ou então quem gasta está muito à frente, então acaba me parecendo um jogo que você fica muito mais preso. Se você não está todo dia mexendo, você fica pra trás. E se você não começa a gastar no jogo, você também fica pra trás. Então, cria um vício e uma dependência muito maior esse tipo de jogo. São jogos que, quando eu era mais novo, na época que eu jogava mais, não tinha muito. Hoje em dia são bem mais comuns [...] Eu não conheço muito dos jogos atuais, mas eu vejo muito isso em outras pessoas. Essa dependência de estar sempre um pouquinho; faz uma coisa, daqui a pouco volta, faz uma ação no jogo, aí vai fazer as suas atividades, daqui a pouco volta, faz uma açãozinha. E acaba que a mente está ali o tempo inteiro ligada no jogo. - Orochi

Além desses jogos casuais com ações baseadas em contagem de tempo, outros casos de permanência no tempo são os jogos que funcionam em tempo integral e em "mundos" que existem e se desenvolvem em servidores (computadores dedicados a hospedar estes jogos), independente da presença (online) de qualquer jogador, como os já citados MMORPGs. Ao longo deste trabalho, nos referimos a estes últimos diversas vezes, como um dos gêneros dentre os jogos eletrônicos que mais geraria dependência. Na sequência, eles serão descritos de modo mais particular.

\section{7 - MMORPGs}

Os jogos conhecidos como MMORPGs (Massive Multiplayer Online Role Playing Games) são apontados por muitos teóricos (por exemplo: FORTIM, 2013; RUFFO, 
2011b; BLINKA; SMAHEL, 2011) e jogadores como uma atividade de potencial adictício muito elevado. Apresentando esse tipo de jogo, Ivelise Fortim escreve:

Um MMORPG geralmente apresenta um lugar bem semelhante ao mundo real, mas com componentes mágicos e fantásticos. Os jogadores podem se envolver em uma variedade de interações com outros jogadores através de batalhas, comércio, vendas de itens valiosos, namoros e sexo virtual, aventuras feitas pelos programadores. O objetivo principal no início é melhorar o personagem, adquirindo armas e equipamentos. Com a interação social, os jogadores adquirem outros objetivos como participar de clãs, guildas, campeonatos, coleções de itens, aventuras em grandes grupos, missões etc. (FORTIM, 2004a apud FORTIM, 2013, p. 65).

Alguns pesquisadores (SNODGRASS; LACY; DENGAH II et al., 2011) entendem que esses jogos têm como características principais a imersão em uma realidade virtual primorosamente simulada, o contato social intenso com outros jogadores e sua permanência - isto é, independente da presença do jogador, o mundo virtual continua existindo. Fortim acrescenta, em comunicação pessoal, que os MMORPG têm a característica da reunião de jogadores em tribos urbanas ${ }^{203}$ online.

É que MMO tem, além da parte addiction do jogo, outras coisas: você tem permanência do mundo, você tem representação de personagem, você tem se expressar de uma forma que você não se expressou, você tem novos amigos, você tem uma tribo urbana que você não tem em outro lugar... A sua tribo urbana só se reúne online. - Fortim

Ao que ela se refere como a "parte addiction" seria a dinâmica de progressão do personagem, ou seja, de acúmulo de experiência, pontos de atributo, itens e habilidades especiais. Fortim tenta resumir as motivações gerais que explicariam o maior grau de dependência neste tipo de jogo:

Nos jogos de MMORPGs, os motivadores principais da dependência parecem ser sociabilidade, escapismo, vivência de uma vida paralela, expressão de aspectos da personalidade que não encontram expressão em outro lugar, vivências de aventura e os aspectos específicos relacionados a ludicidade do jogo (FORTIM, 2004 apud FORTIM, 2013, pp. 116-117).

Sublete e Mullan (2012) apontam que, não obstante o sensacionalismo da mídia, há evidências inconclusivas de que o uso regular de MMOGs (multiplayer online games)

\footnotetext{
${ }^{203}$ Em contraposição ao conceito de tribos urbanas de Maffesoli (1988), Magnani (1992) coloca que este termo seria uma metáfora inadequada para tentar descrever este tipo de fenômeno e não uma categoria propriamente analítica, a qual encontra respaldo na realidade empírica das grandes cidades.
} 
causa efeitos negativos na vida psicossocial dos jogadores. Também não existiriam evidências concretas de que há efeitos negativos na vida acadêmica ou no trabalho dos jogadores comuns, sendo estes problemas exclusivos dos chamados "dependentes". Segundo as autoras, apenas sujeitos classificados como dependentes ou patológicos sofreriam de consequências negativas como perda de sono, conflito, tolerância, abstinência, ânsia e recaída (SUBLETTE; MULLAN, 2012) - o que parece ser uma referência circular, já que são esses os próprios critérios que formam a classificação e os conceitos que definem dependência.

Snodgrass ${ }^{204}$ et al. (2011) entendem que a experiência que o usuário tem no jogo World of Warcraft seria similar a um "transe xamânico", uma experiência de cura conhecida em muitas culturas. Esse transe, ou "voo mágico", seria uma forma de lidar com o estresse e sentimentos negativos, além de ter efeitos benéficos em muitos sujeitos. Entretanto, outra parcela abusaria desse mecanismo, tornando-se, assim, dependente desta experiência, que passaria de positiva para prejudicial.

Passando a discutir esse gênero de jogos junto com os usuários, Hyou comenta que nos MMORPGs há um processo infindo de criação e customização de seu personagem, que é potencializado pela conexão online.

Nos jogos de MMORPG você tem todo um processo de criação do personagem, que é um processo infinito, se você continua no jogo, você não tem barreiras pra acabar. O jogo está aberto pra você renovar e criar outros personagens pra continuar jogando. E a possibilidade de jogar na internet também é um meio de interação, de sociabilidade dentro do jogo. - Hyou

Eskilu comenta que os MMOs, além das variadas possibilidades de customização e de progressão in-game, este tipo de jogo trás a possibilidade do jogador "transmutar sua pessoa" o tempo todo, propiciando experiências de caráter muito singular.

É que eu tenho um passado com MMO. Tipo, ex-usuário de crack. Começa a jogar de novo, você fica muito a fim de jogar e fica mega bolado. E daí as possibilidades de customização sempre são diferenciais, na minha opinião. Você não ter uma skilltree fechada, de vez em quando isso é até melhor que uma recompensa em si. Só de você poder ficar upando loucamente, vários bagulhos aleatórios... Tipo, no Ultima Online, "agora eu vou upar tayloring". Que é o fator que trás o vício também. A liberdade incomum que você acha no jogo que é diferente da vida real, da sua possibilidade de transmutar sua pessoa o tempo todo. Daí você começa a se ver num outro local, e aí é um perigo entre

${ }^{204}$ Jeffrey Snodgrass é antropólogo ligado à Colorado State University (CSU), Canadá. 
você saber que aquilo é só um jogo e o momento que você começa realmente experienciar aquela vida de uma forma diferente - Eskilu

Eskilu comenta que, em dada altura, trocou os MMORPGs, que exigiam muito tempo de dedicação, por jogos como Counter-Strike, que em tese seriam mais esporádicos. No entanto, ele admite que isso não adiantou muito, uma vez que seu envolvimento era ainda muito grande. Somente após um tempo, com o despertar de novos interesses na adolescência, ele conta que foi possível diminuir o ritmo de jogo.

O que eu mais joguei foi Ultima Online, foram uns três anos. Sexta, sétima e oitava série. Aí então eu tinha uns 12, 13 e 14 anos. Aí era imersão realmente. Pelo menos umas seis a oito horas diárias. Eu não tinha o que fazer, não saía de fim de semanas... No fim de semana devia passar de dez horas diárias. Foi uma época bem tensa. Até que depois eu parei pra perceber que consumia muito tempo e eu parei de jogar. Daí eu comecei a jogar CS [Counter-Strike] porque era uma coisa mais esporádica, mas na real eu percebi que no fundo eu gostava muito de videogame, porque acabava fazendo corujão da Monkey [lan-house], então passava 12 horas jogando $C S$ de vez em quando. Depois eu joguei Ragnarök também por algum tempo, mas não foi tão intenso quanto o Ultima Online. A gente já estava numa fase mais adolescente, já saía mais, daí já diminuía um pouco a coisa. Mas via que era um substituto. - Eskilu

Nesse discurso, vemos que Eskilu passa a colocar menos ênfase nas propriedades dos gêneros dos jogos em si e do que nas fases de sua vida. Já Ricardinson descreve que houve diferença entre a sua relação com jogos de gêneros diferentes, no caso um MMORPG e um MOBA (Multiplayer Online Battle Arena).

$\mathrm{Eu}$ sempre joguei videogame. Só que Ultima Online foi um jogo especificamente que eu fiquei viciado. É coisa de dependente mesmo. Mas outros jogos, o DotA e tal, não é que eu sou viciado, eu gosto muito de jogar. Se eu tiver tempo pra jogar, eu vou jogar, qualquer oportunidade que tiver eu vou jogar. Mas não é algo que eu penso em jogar DotA o dia inteiro. Se eu não puder jogar, não é um bagulho que me afeta. - Ricardinson

Ricardinson crê que a competitividade germinada nos MMORPGs é muito intensa e, se levada a sério, é infinda - o que explicaria, em parte, a sua maior propensão na constituição de um comportamento de dependência.

MMO é muito mais viciante. Eu não tenho a menor dúvida disso. Você pode ver a galera que joga Tíbia, joga esses jogos aí que a galera fica mal. Eu acho que é por causa da competitividade que forma no jogo. Tipo, eu trabalho. Mas tem um cara que não trabalha. Eu vou jogar o jogo por três meses e vou alcançar o mesmo resultado que um moleque consegue alcançar em uma semana. E o moleque sabe disso. Então, ele joga uma semana inteira pra passar quem joga três meses, só que depois que ele joga uma semana inteira construtiva, ele não vai parar depois. "Ah, cheguei nesse estágio aqui, agora eu 
preciso treinar mais pra ninguém me passar". Aí o cara fica indo nessas e nessas e nessas e não sai nunca. - Ricardinson

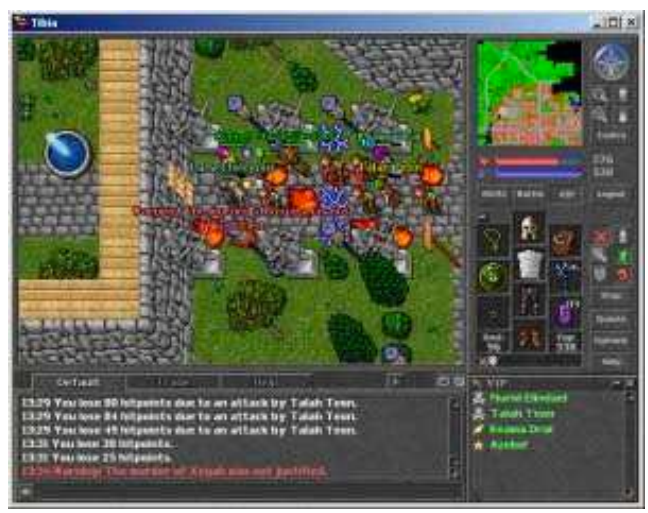

Figura 4.16 - Tibia (1997)

A psicóloga Luciana Ruffo (2011b), do Núcleo de Pesquisas da Psicologia em Informática (NPPI), numa postagem intitulada "Games fundem vida real e virtual", na coluna "Cyberpsicologia" do blog Vya Estelar/UOL, apresenta, por fim, uma descrição densa deste tipo de jogo. Este relato, obviamente, é informado por sua formação acadêmica na área de Psicologia:

Antes de tudo, esqueça a realidade como você a conhece. Imagine que você imerge em um filme, onde você é o personagem principal. Imagine um sonho, tudo em cores e detalhes riquíssimos, com possibilidades diferentes e que tornam o participante um personagem único dentro daquele ambiente. Para começar você escolhe a imagem 'física' que vai ter. Pode então compensar aqueles seus atributos físicos que não lhe agradam e/ou ressaltar o que tem de melhor; ou, se você quiser o respeito dos demais, pode intimidá-los, assumindo por exemplo, a identidade de um "bad boy"... (Acredito que esses avatares muitas vezes são o canal de manifestação de nossa sombra). Em seguida você escolhe o tipo de 'poder' que deseja ter. Se você é alguém mais rústico, escolhe um personagem onde a força se torna o principal atributo. Se você é mais intelectual, pode por exemplo, escolher 'classes' onde impera a magia. Depois você batiza o seu personagem e dali pra frente você vai ser chamado tantas vezes por esse nome que vai responder se alguém lhe chamar assim na rua. É como se você desse vida a um "mini eu". E esse mini eu tudo pode! Ele existe quando você quer, como quer e realiza apenas o que quer. Não tem obrigações, apenas faz o que julga ser bom para si e seus amigos. - Ruffo

Na visão de Ruffo, há implícita uma imagem de absoluta liberdade, no sentido de uma libertação de amarras da "identidade" ou do que ela entende por "eu verdadeiro" (que está presente não declaradamente quando usa o termo "mini eu" para se referir ao avatar) - um ponto já questionado no capítulo anterior. Nem mesmo a chamada "sombra", isto é, o entendimento do avatar como um duplo inverso do suposto "verdadeiro eu", não é inquestionável em campo, pois os jogadores também enaltecem algumas de suas características psicofísicas quando da criação do personagem. Além 
disso, como vimos no segundo capítulo, os jogadores podem ter sérias obrigações no jogo em relação aos seus clãs, guildas, campeonatos, às suas promessas, anseios etc.

Nesse universo novo que se abre à sua frente, você vai fazer tudo o que faz na vida real para manter o seu personagem vivo. E ainda vai viver segundo ideais de nobreza e cavalheirismo, tão distantes, mas tão almejados ainda nos dias de hoje. As pessoas se ajudam, se agrupam, se ensinam e também se admiram perante o conhecimento dos demais. E logo você descobre que é realmente preciso ser inteligente para poder participar desse tipo de jogo! Qualquer atributo que se mude, altera todas as características do seu personagem. Lembrando que cada personagem tem ao menos sete atributos diferentes, isso faz com que cada um seja realmente único e especial no mundo virtual. Além de necessário, pois as pessoas se complementam no jogo, procurando atingir objetivos comuns. Você também pode descarregar ali suas raivas e frustrações, por exemplo, "matando monstros". E se a raiva for grande contra sua própria espécie, poderá entrar em 'modo PVP' ("player versus player") e matar outro jogador. A vivência pessoal do tempo, no virtual, funciona de forma diferente ainda que as horas sejam contadas normalmente em minutos. Acontece que você tem que viver uma vida inteira e "envelhecer" seu personagem rapidamente. Isso gera uma noção completamente diferente do tempo real. É fácil o jogador se sentar para jogar por 5 minutos e ao olhar para o relógio ter passado 5 horas, pois fica completamente absorvido, com a atenção e a imaginação toda funcionando a serviço do jogo. É uma imersão total em um filme de ação, fantasia, romance ou o seu gênero preferido. Nada mais invade seu pensamento, o foco é único. Qualquer coisa externa atrapalha. - Ruffo

Nesse relato, Ruffo novamente opera os grandes divisores "real" e "virtual", os quais já debatemos largamente. Ela demarca o seu entendimento de "real" como presencial, no entanto, considera o "virtual" como menos real que o primeiro. A autora ainda manipula uma visão nostálgica de comunidade e retoma a questão da "descarga emocional" para explicar a mecânica de jogo, em que os personagens devem matar monstros ou outros personagens. Não há nenhuma indicação empírica de que isto deva ser visto como um "ato que pode ser entendido como matar em nós aquilo que não damos conta", como Ruffo postula; mas que, por exemplo, a pessoa possa estar simplesmente jogando para se divertir e cumprir os objetivos do jogo, não importando, neste sentido, se o referido ato desempenhado pelo personagem é "matar um monstro", "estourar um balão" ou "pegar uma estrelinha".

Aliás, a vida real aqui começa a se fundir com a virtual. Quando se joga de forma saudável, você conhece pessoas que têm o mesmo interesse que o seu, que gostam do mesmo universo que você: das músicas, que para muitos é diferente, do estilo de ser e de pensar que faz de você um completo estranho no meio de pessoas que cultuam o corpo e não o intelecto. E a maioria de nossa sociedade atual é assim. Sua capacidade de planejamento faz com que você consiga coisas que o tornem poderoso. Depende basicamente do seu 
conhecimento, e não de todos os outros fatores envolvidos na vida presencial (real) para conquistar algo. Você pode experimentar ser quem você quer ser, quem não quer, quem pensa que é, popular ou não. Ali só existe espaço para uma realidade: a que você cria para si mesmo. E se você cansar ou não gostar, é só deletar e se desligar. As sensações físicas são tão intensas quanto as que acontecem com alguns fatos da vida presencial. A ansiedade vai a mil. A euforia, a tristeza, a raiva também. Os objetivos são tangíveis. As regras, claras. Não existem entrelinhas, comportamentos dúbios. É assim que se cresce no virtual. Simples assim (RUFFO, 2011b).

Ruffo ainda tece um elogio à cultura do intelecto em detrimento à cultura do corpo, sem qualquer menção a fontes. Contra o argumento da autora, muitos jogadores atestam que o desempenho no jogo não depende somente de seu conhecimento ou habilidade dentro do jogo: as diferenças de tempo e de dinheiro disponíveis entre eles consistem em um grande elemento de vantagem ou desvantagem. E apesar de constatar a presença de emoções verdadeiras, a autora ainda trabalha com uma concepção estritamente individual de imaginação, quando coloca que nesses jogos haveria espaço para somente "uma realidade: a que você cria para si mesmo", desconsiderando os coletivos presentes na rede de agências que atuam nesta suposta "realidade".

\section{8 - A imersão nos games}

Agora exploraremos brevemente alguns dos mediadores que atuam na construção do engajamento dos jogadores nos games. Aqui logo entra em cena uma figura fundamental: o game designer. Diferente do que pode parecer para os desacostumados com a linguagem do desenvolvimento de games, este não é o artista gráfico ou digital $^{205}$, mas o idealizador dos jogos, isto é, o criador de suas mecânicas, jogabilidade, roteiro, história, balanceamento, enfim, da sua concepção mais abrangente. Apresentando essa experiência de desenvolvimento, Masamune explica um pouco sobre a lógica de programação por trás de Candy Crush Saga, a qual retoma a discussão sobre os mecanismos de recompensa, iniciada no primeiro capítulo junto aos neuropsicólogos:

O Candy Crush tem o negócio do vício que é forte. Atualmente eu estou desenvolvendo um clone, porque você vai entendendo mais ou menos isso à medida que desenvolve. O design dele é todo voltado pra fazer a pessoa achar que é um bom jogador, mas no fundo não é; tudo o que está acontecendo com ela é pura sorte, é como quando você joga Black Jack ou quando você joga roleta, quando você está ganhando, você pensa que você é um jogador bom, mas não, é tudo acaso. O game design do jogo está pronto pra o acaso fazer você se sentir um bom jogador, mas como você não percebe, você fica naquela: "vou

205 Exceto em casos bastante incomuns, como de equipes muito reduzidas, em que a mesma pessoa responsável pela arte pode também acumular a função de game design. 
jogar mais uma, de repente eu melhoro". Aí você tem aquela noção de que "nem sempre eu vou ganhar", todo mundo tem essa noção. "Vou tentar ganhar essa agora", "vou tentar de novo", e vai e vai. O jogo estimula esse comportamento viciante porque o design dele está calcado no acaso e em fazer você pensar que é um jogador bom, quando no fundo você só está ganhando por pura sorte. E o Candy Crush tem muito isso, porque ele é muito aleatório. Você vai jogando várias fases, e tem um monte que é fácil. Essas fases fáceis estão lá pra você pensar que você é um jogador bom, aí vem uma fase fudida pra fazer você perder todas as vidas que você tem. Quando você perde todas as vidas, você fica meia hora sem poder jogar. Mas você tem a opção de comprar mais vidas. Ou, por exemplo, tem muita fase do Candy Crush que você tem um conjunto X de movimentos, aí você só tem cinco, aí você: "Putz, não vou ganhar", aí tem um botãozinho lá embaixo "comprar mais"; aí você compra. Por quê? Porque você vê que algumas fases são muito longas, então você quer aquela satisfação instantânea de ganhar, às vezes você cede a esse desejo de querer ganhar e compra o negócio só pra ganhar, pra passar daquela fase filha da puta, pra não perder a vida e ficar meia hora sem jogar. É um ciclo vicioso, é um jogo que eu sinto que realmente se aproveita das fraquezas das pessoas. - Masamune

\section{O psicólogo Janos Geocze compara essa forma de engajamento proposta por Candy}

Crush Saga a um mecanismo de punição, à moda do behaviorismo, que é aplicado inclusive para gerar receitas adicionais para as empresas produtoras de jogos.

Isso é punição. Eu retiro a punição desde que você me dê algo. É exatamente isso que se faz para que um urso ande em si mesmo numa bola e fique jogando petequinha pra você dentro do circo. Ou você faz o que eu quero ou eu vou te punir. Agora, se você fizer o que eu quero além de não te punir, ainda te dou um agrado. Você domina o mundo com isso. Você pega uma coisa que é incrível, eu vi no Candy Crush! Quer dizer, tem um que você perde a vida. Se você compra, você ganha mais vida, se você espera 30 minutos, também ganha. As pessoas não aguentam os 30 minutos! - Geocze

Masamune conta que, com o tempo, houve uma mudança de lógica no desenvolvimento de jogos. Para ele: "o game design não é mais tão focado em fazer o cara perder muito. O game design hoje está mais focado no lance da experiência”. A duração do jogo, portanto, não parece importar tanto: "Pode ser um negócio curto, mas enquanto ele está ali ele está tendo uma experiência impressionante... Hoje esse é o foco”. Masamune, não obstante, retoma a questão da duração do jogo. Ele conta que houve uma transformação nas tecnologias de game design ao longo dos anos que permitiu a produção de jogos mais longos.

Uma das razões pelas quais eu não me viciei tanto é porque esses elementos de game design não eram tão presentes. O que tinha antigamente no game design dos jogos era fazer o cara perder muito, pra ele ter um maior aproveitamento do jogo. O foco do game design naquela época na minha percepção era o jogo ser difícil pra que cara demorasse mais pra zerar. Então isso acabava não permitindo que o cara viciasse tão bem, porque ele ficava naquela onda de 
querer zerar e tal, mas no momento que aquilo acabava, cortava. [...] E aí nessa época o game design tinha muito isso, de fazer o jogo ser difícil pra que aí você tentasse tirar o máximo que você pudesse de pouca coisa, porque naquela época, por exemplo, o jogo Super Mario, tinha 32 fases. Pelos padrões de hoje, 32 fases é pouca coisa, principalmente porque você tinha o limite de 300 segundos pra zerar. Isso no mundo real dá 5 minutos. Então, se você multiplicar isso, se você levar ao pé da letra, você vai ter um aproveitamento de umas três a quatro horas do jogo, do Super Mario Bros. Se você for muito bom, você zera nesse tempo. Hoje em dia as experiências de jogo são dez horas, 18 horas, 20 horas; às vezes oito, depende do jogo. - Masamune

Na contra corrente dos game designers convencionais, marxistpokemon coloca que não tem a preocupação de criar jogos precisamente imersivos:

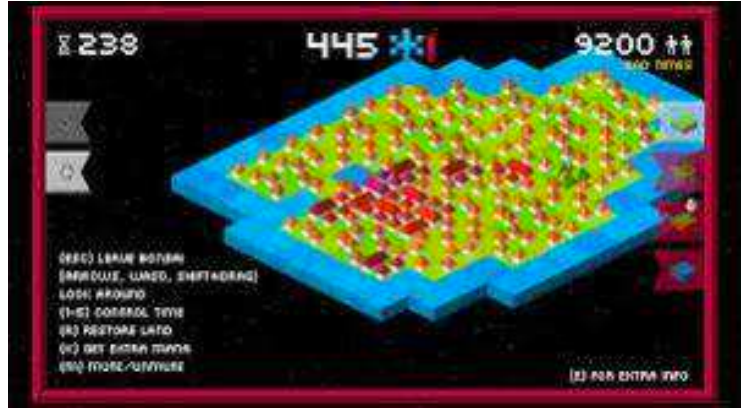

Figura 4.17 - Bonsai Worlds (2013)

Eu não tenho a preocupação de imersão. Pra mim isso é um modelo bem furado. Não é um negócio que eu aspiro a como fazedor de jogo. Eu quero que a pessoa se sinta não excitada, mas, que cutuque. Que cutuque a curiosidade, cutuque a vontade de imaginar uma coisa a mais, ou então aquela vontade de competir em alto nível. Por exemplo, aquele jogo de navinha lá que eu fiz. Aquilo lá é um jogo que eu não estou preocupado se o cara vai se imergir naquilo, mas se aquilo serve de plataforma pro cara ter sensações legais de estar jogando com outra pessoa. Eu não quero que o cara se feche. Eu fiz um jogo [Bonsai Worlds] que é construir mundos. Pode soar como a coisa mais escapista do universo, mas eu acho que pra mim tem uma coisa muito importante nesse jogo que é que nem o momento que você está cuidando de um jardim. Você está fazendo jardinagem. Você está cuidando de um bonsai mesmo. - marxistpokemon

Em seu exemplo, marxistpokemon dá mostras de formas de envolvimento com

videogames numa medida que entende como saudável e não tomadora de tempo.

Que é uma coisa que é um pequeno momento na sua rotina no qual você faz uma atividade, que te faz imaginar alguma coisa, te faz parar e tomar algumas ações. Não é se imergir naquilo, isso é parte da sua rotina. Isso é parte da sua vida como um todo. Pra mim o ideal é que o jogo fosse um porta retrato digital daqueles que vende no camelô, que você vai lá, interage dois minutos, "Ah, ficou mais bonitinho assim, beleza", continua fazendo outra coisa. marxistpokemon

Marxistpokemon considera que há um limite para o game designer influenciar ou guiar a experiência do jogador. Ele nem sempre consegue fazer o que quer: 
[O game designer] Ele tenta. Só que o jogo tem uma carga de liberdade muito grande. Então, ele pode sugerir caminhos. Mas quem faz o caminho é o jogador. A experiência do jogar é uma. A experiência de inventar o jogo é outra, na minha cabeça. A hora que você está inventando o jogo, você está construindo um labirinto. Você constrói um labirinto e nele podem ter muitas coisas. Só que nem você que constrói o labirinto sabe todas as coisas que tem nele. Ele é uma máquina de gerar histórias. Porque daí quando você conversa com uma pessoa que jogou o seu jogo, você ouve as histórias delas. O jogar do jogo só existe no jogar das pessoas. O jogo existe como objeto. O videogame, pelo menos, o jogo de tabuleiro. Mas a experiência completa dele só existe na cabeça da pessoa ou na experiência coletiva daquelas pessoas. - marxistpokemon

Allprot comenta que a lógica de persuasão dos games pode ser aproveitada para outros fins, considerados por ele como mais "úteis" ou "produtivos". Para argumentar, ele recorre ao conceito de jogos persuasivos ${ }^{206}$ de Ian Bogost (2007).

O Ian Bogost fala do jogo persuasivo, que é persuadir o jogador a alguma coisa. Por exemplo, num jogo educacional, você está passando um conhecimento que não é a diversão. Hoje em dia os jogos são muito persuasivos, só que eles persuadem as pessoas a continuarem jogando, que é o sistema de recompensa. O sistema de recompensa é o mecanismo pra fazer você continuar jogando. Mas quem disse que essa é a única maneira? Você pode fazer um sistema de recompensa pra pessoa recolher o lixo na rua, ter um melhor relacionamento com as pessoas; é tudo questão de mecânica. - Allprot

Reconhecendo, como Bogost (2007), o poder de expressão e de comunicação dos videogames, Allprot comenta que os desenvolvedores podem pensar em outras abordagens que escapam a essa lógica de mercado ou do entretenimento.

Além dos mecanismos de recompensa, Chuck coloca a afinidade com o tema do jogo como um ponto importante nesta discussão da dependência. Aqui ele dá mostra de passagens entre o "real" e o "virtual".

Se o jogo for de um tema que você gosta, você fica viciado mais fácil. Tipo, eu gosto de skate, então jogo de skate me deixa viciado muito mais fácil. Jogo online deixa você viciado mais fácil ainda, porque tem a questão da competitividade contra outras pessoas; não é contra um computador que você está jogando, então você quer ser melhor que os outros caras. Também tem a parte social, que você quer falar com seus brothers, é a mesma coisa que você tiver saindo com teus amigos e ao mesmo tempo você está jogando. Então você está saindo com a galera, você tem uma competitividade absurda com outros caras, a qualquer hora do dia você pode entrar lá que vai ter gente. Não é tipo videogame que você vai chegar, ligar e você vai jogar sozinho sempre. É tipo um multiplayer eterno que você pode jogar a qualquer momento. Com certeza isso deixa muito mais viciante. - Chuck

206 Ian Bogost (2007, p. 46) dá o nome “jogos persuasivos” aos videogames que montam retóricas procedurais de forma efetiva (cujos argumentos não são feitos por meio de construção de palavras ou de imagens, mas através da criação de regras de comportamento e da construção de modelos dinâmicos. 
O desenvolvedor marxistpokemon comenta sobre o seu envolvimento com o jogo TIE

Fighter, o qual lhe propiciava uma imersão no universo de Guerra nas Estrelas (Star

Wars). Ele retoma aqui as temáticas do tempo livre e da infância:

TIE Fighter era um jogo que você é um caça do império no Star Wars. Esse jogo é uma leseira. É um jogo que as missões duravam tipo uma hora e meia, voando numa nave, um jogo complexo, tinha mil teclas pra você decorar, e as missões eram super demoradas; você estava numa situação super frágil, você tomava um tiro, já era. Só que tinha uma conexão tão forte com o universo temático do Guerra nas Estrelas que eu achava legal, e a sensação de que você podia fazer a coisa do seu jeito, tipo, eu te falava o objetivo, mas como que você ia fazer, se vira. E eu tinha 11, 12 anos. Então, na época que você tem um monte de tempo livre, pelo menos eu tive o privilégio de ter tempo livre quando eu estava com essa idade, e de ter acesso ao computador e tudo. E com isso, aquilo animava a minha imaginação num nível louco, eu achava aquilo muito pirado; espaço... Eu sempre gostei muito de Astronomia, então toda aquela ideia do espaço, mitologia, uma coisa que eu adorava também, então isso era muito forte. Tinha um escapismo muito grande. Mas como isso era parte da minha imaginação infantil, de certa forma... Criança é muito carente. Então, o jogo tem um pouco isso. - marxistpokemon

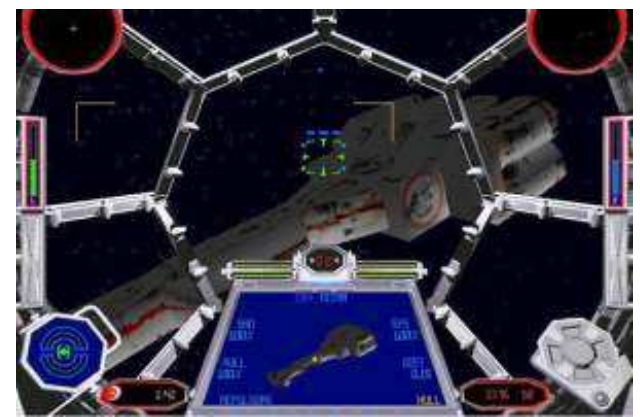

Figura 4.18 - Star Wars: TIE Fighter (1994)

O desenvolvedor marxistpokemon coloca-se contra a pretensão do designer de jogos de querer controlar a experiência do jogador.

Existe uma preocupação, e eu vejo isso como uma linguagem dominante, uma tendência dominante, na qual essa coisa da recompensa, do cara ter que estar engajado, parece que o designer quer que o jogo seja o cordão umbilical do jogador; seja aquilo que dá tudo o que o jogador precisa enquanto ele está naquela experiência. Eu acho que isso é muito totalizante. Eu acho um pensamento muito fascista, na real. - marxistpokemon

Eskilu afirma que o tipo de envolvimento está estreitamente relacionado com a forma pessoal de jogar do jogador.

Esse é o caso do MMO. Se é MMO, você vai ter muita recompensa, só que o jogo no fundo é cansativo. É tipo Skyrim, quando você fecha, fica gerando quests randômicas. Aí vai ter uma hora que você vai ter que só jogar porque você quer upar loucamente, ele não vai ter fim normalmente, tipo Tibia. Que 
faz o cara ficar upando até o level 690. Aí eu prefiro, por exemplo, um mecanismo de recompensa tipo achievement, da Steam.

Mas é um negócio que vicia. Por exemplo, com o PES [Pro Evolution Soccer], eu de vez em quando estou jogando só pra pegar os troféus. Mas é um comportamento que não é de todo gamer. Dos meus amigos, tem um pessoal que faz isso realmente e fica intrigado e quer catar os achievements, e aí tem uma galera que não, que só quer jogar se tiver alguém pra jogar. - Eskilu

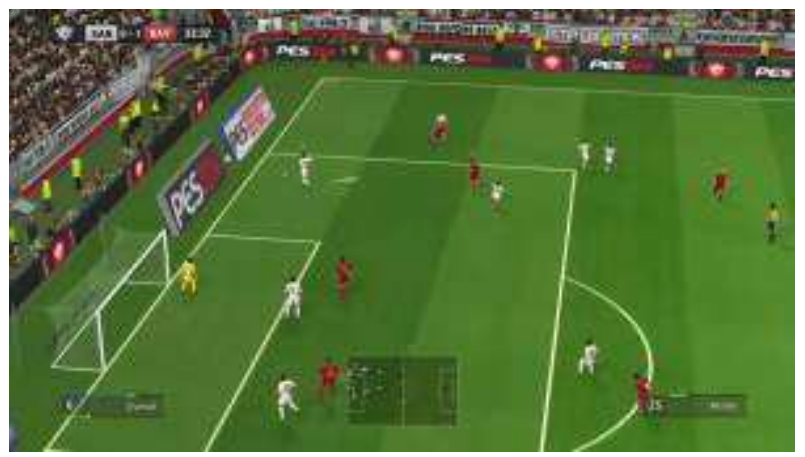

Figura 4.19 - Pro Evolution Soccer 2014 (2013)

\subsection{1 - A Teoria do Fluxo}

Neste momento, retomamos a teoria do fluxo, enunciada no capítulo inicial. A teoria do fluxo foi proposta pelo psicólogo húngaro Mihaly Csikszentmihalyi, a partir de suas pesquisas iniciais sobre os estados de felicidade e de criatividade. Sua ideia, publicada no livro Flow: The Psychology of Optimal Experience (1990), parte do princípio de que a felicidade acontece quando indivíduos experimentam estados mentais ótimos, denominados por ele de flow (fluxo) e entendidos como estados de consciência caracterizados pela imersão e concentração totais, além da presença da motivação intrínseca e de um sentimento de total envolvimento e sucesso no processo da atividade, tão perseguidos por psicólogos e gestores quando na busca do engajamento das pessoas em atividades de criação, educação e trabalho.

De acordo com o autor, os componentes de uma experiência de fluxo podem ser especificamente enumerados. Apesar de todos os componentes acima caracterizarem o estado de fluxo, segundo o Csikszentmihalyi, não é necessária a presença de todas estas sensações para experienciá-lo.

1. Objetivos claros (expectativas e regras são discerníveis);

2. Concentração e foco (um alto grau de concentração em um limitado campo de atenção); 
3. Perda do sentimento de autoconsciência (sentimento de êxtase, de estar fora da realidade do dia-a-dia);

4. Sensação de tempo distorcida (uma ideia de estar além da dimensão temporal, totalmente focado no momento presente. As horas parecem passar como se fossem minutos);

5. Feedback direto e imediato (acertos e falhas no decurso da atividade são aparentes, podendo ser corrigidos se preciso);

6. Equilíbrio entre o nível de habilidade e de desafio (a atividade nunca é demasiadamente simples ou complicada);

7. A sensação de controle pessoal sobre a situação ou a atividade (um sentimento de serenidade, sem preocupações, e um sentimento de estar crescendo além dos limites do ego);

8. Motivação intrínseca (a atividade é em si recompensadora);

9. Quando se encontram em estado de fluxo, as pessoas praticamente "se tornam parte da atividade" que estão praticando, e a consciência é focada totalmente na atividade em si.

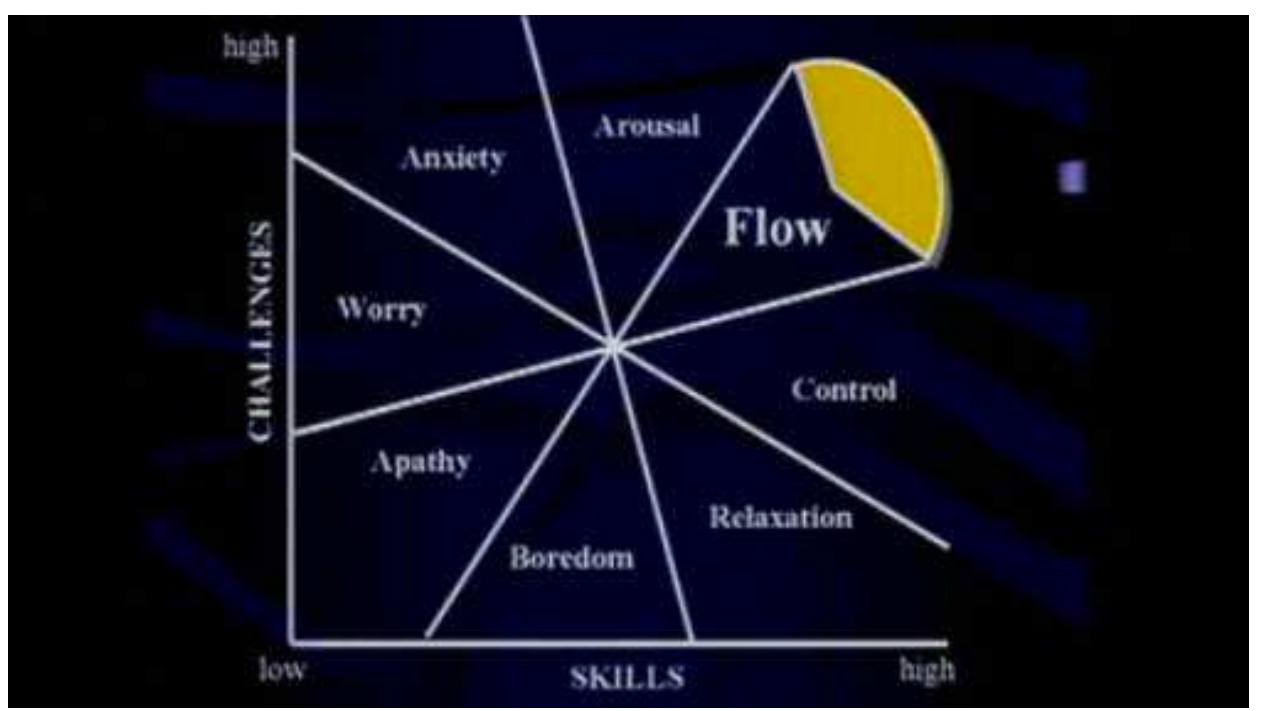

Figura 4.20 - Teoria do fluxo

Gráfico: O eixo horizontal representa o nível de habilidades e o eixo vertical representa os desafios. Quanto maior o desafio e o grau de competência, maior a tendência em encontrar flow.

O conceito de flow tem sido utilizado em uma grande variedade de campos. Em sua primeira obra, Csikzentmihailyi não se refere especificamente aos videogames como possíveis geradores de estados de fluxo, mas algumas pesquisas (CHEN, 2006; HOLT, 2000) desenvolvidas a partir da experiência de uso dos jogadores evidenciaram a presença desses estados mentais em jogadores, fossem eles contumazes ou ocasionais. Esses autores, portanto, entendem o flow como uma das principais motivações por quê 
as pessoas jogam videogames, já que o objetivo principal desses jogos seria criar entretenimento através de uma motivação intrínseca, que está relacionada ao fluxo.

\begin{tabular}{|c|c|c|}
\hline Estado de humor & Desafio da atividade & Habilidade exigida \\
\hline Apatia (apathy) & baixo & pouca \\
\hline Ansiedade (anxiety) & alto & pouca \\
\hline Relaxamento (relaxation) & baixo & muita \\
\hline Fluxo (flow) & alto & alto \\
\hline Preocupação (worry) & médio & média \\
\hline Excitação (arousal) & alto & média \\
\hline Tédio (boredom) & baixo & muita \\
\hline Controle (control) & médio & paca \\
\hline
\end{tabular}

Tabela 3 - Nível de dificuldade versus habilidade para execução

Segundo esses autores, através do equilíbrio entre a habilidade exigida e o nível do desafio, o cérebro do jogador seria despertado e passaria a operar em alta intensidade. Para os mesmos (CHEN, 2006; HOLT, 2000), no estado de fluxo, em geral a experiência de jogo é fluida e psicologicamente gratificante por si só, independentemente da pontuação ou do sucesso no jogo. Assim, o uso dos princípios da teoria do fluxo nos games parece ajudar a promover uma experiência agradável, o que, por sua vez, aumenta a motivação e engaja os jogadores para que continuem jogando.

Alguns game designers se esforçam para integrar os princípios de fluxo em seus projetos. Jenova Chen (2006), por exemplo, tentou traduzir essas ideias para o jogo flow. Para Chen, o fluxo é o estado em que todo designer de jogos deseja colocar o seu público, pois é nele que o verdadeiro prazer e êxtase acontecem.

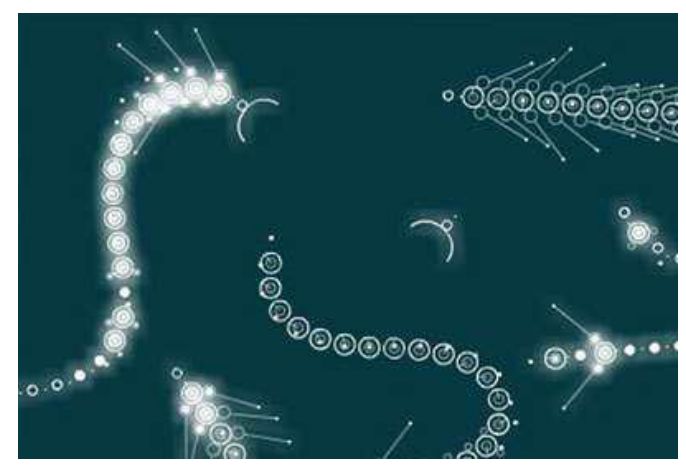

Figura 4.21 - flOw (2006)

O ponto é que, o mesmo conhecimento que explica a imersão e o engajamento no jogo do ponto de vista dos desenvolvedores, se invertermos as perspectivas, isto é, se 
olharmos pelo ponto de vista dos neuropsicólogos, seria justamente o nível de envolvimento gerado pelo chamado estado de fluxo que agiria nos casos de dependência. Em ambos os casos, o que está em jogo é conceituar o envolvimento do jogador com o jogo e as suas experiências de sensações de prazer.

\subsection{2 - Gameficação}

A questão dos mecanismos de recompensa evoca o tema, hoje em voga, da gameficação $^{207}$ (gamification), também conhecida como "ludificação", que basicamente consiste em uma tentativa de transportar a lógica dos games para a chamada "vida real", isto é, para além dos videogames. Ou seja, a partir de instrumentos de game design, tenta-se implementar certas técnicas de engajamento e motivação em empresas, aplicativos e outros objetos diferentes dos convencionais jogos de videogame.

Algumas dessas técnicas (SUTTER, 2010) incluem o uso de emblemas de conquistas e níveis de conquistas; classificação de usuários; dinheiro virtual; sistemas para premiar, recuperar, trocar ou presentear pontos; desafios entre usuários, incorporação de pequenos jogos casuais em outras atividades (TAKAHASHI, 2010) e a utilização de barras de progresso ou outras métricas visuais que indicam o quão perto as pessoas estão de completar certas tarefas -, por exemplo, completar um perfil numa rede social ou ganhar um prêmio por lealdade de frequência a lojas (O'BRIEN, 2010).

Coisa básica de gameficação que você vai ver em todo aplicativo por aí: um ranking com pontos e premiozinhos, tipo badges [troféus ou medalhas] que nem tem no FourSquare Badges também que você tem no Waze. Tipo, "Você chegou no lugar mais longe", ou no Instagram, "Você deu check-in em um outro continente!", aí você ganha. Isso tem em tudo, se você parar pra ver, todo aplicativo hoje em dia tem a mesma coisa: um ranking e premiozinhos pra cada pessoa, pra elas ficarem acompanhando. "Ó, eu tenho esse!", "Como que você conseguiu?", "Ah, tem que fazer isso...", “Ah, eu tô em quarto!”; “Ah, eu tô em primeiro". Aí o cara vai lá pra poder tentar chegar em primeiro, mesmo que o cara tenha que roubar pra fazer isso. Ficar dando check-in em lugar que ele não vai. Um monte de gente faz isso. - Chuck

Chuck explica melhor sobre o que hoje se entende por "gameficação do mundo", algo praticado, por exemplo, por muitas empresas e em aplicativos de celulares. Segundo ele, a princípio qualquer coisa poderia entrar na lógica dos games. Surge aqui nova questão:

\footnotetext{
${ }^{207}$ Gameficação é o uso de técnicas de design de jogos que utilizam mecânicas de jogos e pensamentos orientados a games para enriquecer contextos diversos normalmente não relacionados a jogos. Tipicamente aplica-se gameficação a processos e aplicações com o objetivo de incentivar as pessoas a adotá-lo ou influenciar a maneira como são usados (POPKIN, 2010).
} 
não poderia a dinâmica do vício também ser entendida de maneira simétrica à de "motivação", assunto tão caro aos departamentos de RH das empresas?

Hoje em dia, quando a galera vai fazer depuração de propaganda, ou quando uma empresa vai fazer um aplicativo pra ela, ou qualquer aplicativo que você vai ver aí: Waze, que é o GPS, ou aquele aplicativo que é um Task Manager, que você vê as tarefas que você vai fazer no dia; o cara coloca elementos de jogo pra pessoa viciar no aplicativo. Ele coloca um ranking, ele coloca que você passa level, se você chamar amigo você ganha mais. No Waze, quanto mais você usar o Waze pelo mapa, mais ponto você ganha, que você vai passando por cima das balinhas, quanto mais você reportar coisa no mapa, mais ponto você ganha e tem um ranking com os seus amigos.

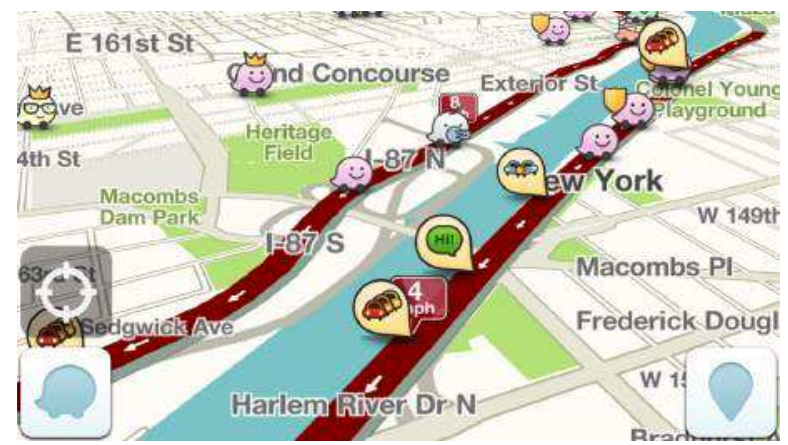

Figura 4.22 - Waze (2013)

Todo mundo está transformando tudo em jogo. Por quê? Porque é muito mais fácil você viciar as pessoas assim. Você vai querer competir. Não tem como, todo mundo é competitivo. Se você vai colocar um ranking, a pessoa vai querer competir. Tudo é competitivo hoje em dia. Reality show não passa de um jogo. "Mestre da cozinha", o cara vai fazer bolo. Quem é o melhor bolo? Todo mundo vai jogando fora até achar o melhor bolo. É outra competição, é tudo jogo. O pessoal fica achando aquele negócio: "Ai, jogos eletrônicos...", mas tudo é um jogo. Se você coloca jogo as pessoas gostam mais, não tem como. Qualquer coisa o pessoal hoje em dia fala, "Ah, coloque elementos de gameficação que o negócio vai ficar muito mais legal". Fica. Por quê? Porque todo mundo fica viciado e vai jogar. Pô, FourSquare, que todo mundo fica dando check-in, é um jogo aquele negócio! Você dá check-in pra poder virar o prefeito do lugar. Quanto mais check-in você dá, você é o dono do lugar e você pode ganhar uma badge que você mostra pro seu amigo que ele não tem, e o cara vai ficar louco pra conseguir a mesma coisa. Então todo mundo está transformando tudo em elementos de jogo pra colocar nas coisas, pra deixar as coisas mais viciantes. Não tem como falar que isso não vicia. Vicia. Mas também tem que ver o jeito que você fica viciado. - Chuck

De acordo com Chuck, portanto, o uso dessas técnicas de gamificação seria justamente uma tentativa dos desenvolvedores ou das empresas de "viciar" as pessoas (ou seus clientes), seja em videogames ou quaisquer outras coisas. Assim como no caso da teoria do fluxo, a ideia de "viciar", aparece com um significado semelhante ao de "engajar" ou "motivar", mas com o sinal invertido. 


\subsection{3 - Monetização}

Neste trecho exploraremos algumas questões envolvendo a forma de monetização dos games e a sua relação com a questão da dependência. Basicamente, a ideia de monetização é o aproveitamento de algo como fonte de receita. Este termo é derivado do verbo "monetizar", que designa o ato de transformar algo em dinheiro. A princípio qualquer coisa (objeto, informação, título, dívida etc.) pode ser usada para monetização, por exemplo, videogames, aplicativos, blogs e vídeos no YouTube. Neste caso específico, entendemos por monetização, pois, a forma com que o jogo gerará receitas para a empresa ou para o desenvolvedor, bem como a sua forma de financiamento.

Segundo Mariana Boucault, game designer, as modalidades principais em monetização de videogames são: preço fechado, assinatura, demonstração, propagandas, ad-value e de graça para o jogador (free-to-play). Todas têm suas vantagens e desvantagens. Julio Vieitez, diretor da Level Up Games, explica resumidamente a diferença entre algumas formas de monetização mais conhecidas:

A gente tem basicamente duas possibilidades: ou você vende um jogo completo pra alguém ou você vende partes desse jogo. Quando a gente pensa no modelo de vender completo, você pode vender por download, por mídia física; e quando a gente pensa do outro lado, em vender partes do jogo, você pode vender itens, você pode vender o acesso - porque quando você está pagando pra jogar World of Warcraft, você está, na verdade, todo mês pagando pra ter aquele acesso. Você pode vender pra ter parte do conteúdo, então você tem alguns jogos que você joga uma parte dele de graça, e pra desbloquear um nível ou desbloquear uma outra parte, você passa a pagar alguma coisa. Todos esses modos a gente acaba juntando em microtransação. - Vieitez

Vieitez comenta que, na perspectiva do desenvolvedor e da empresa publicadora de jogos, o primeiro grande desafio é decidir se irá vender o conteúdo como um todo ou se irá vender micropagamentos. Esta foi uma controvérsia na própria indústria:

Essa era uma discussão que a cinco anos atrás era a mais acalorada da indústria. Pra resumir bem, o lado ocidental achava que você tinha que vender o conteúdo e o lado oriental, China, Coreia, Japão, vendia partes do conteúdo. Ao longo do tempo, está se massificando que você está cada vez vendendo partes do conteúdo, e as empresas, principalmente online, vendem menos esse acesso total. A gente vê até as $D L C \mathrm{~s}^{208}$, você vende coisas até pros jogos completos Vieitez

${ }^{208}$ DLC (Download Content) são os conteúdos extras possíveis de serem baixados via internet, geralmente mediante pagamento adicional. 
De acordo com a perspectiva da empresa, há de se fazer um cálculo entre a quantidade que a empresa pode cobrar por um benefício e o grau satisfação do consumidor:

E essa parte da monetização, do micropagamento, isso é um desafio. Porque você não consegue saber qual é o máximo que você pode extrair de receita daquele jogo por usuário sem você tornar a experiência dele negativa. Então, esse balanceamento é que é muito importante. Você tem que instigar a pessoa a pagar, mas você tem que fazer com que, quando ela faça um pagamento, quando ela está jogando, que ela sinta que aquilo valeu a pena. - Vieitez

Julio Vieitez dá um exemplo de quando esse cálculo falha, pregando, assim, uma perspectiva "voltada ao usuário". Para ele, "as mecânicas são uma forma de você conseguir que o cara pague por algo que satisfaça ele". Dessa forma, as mecânicas de monetização, assim como o game design, devem estar atreladas à sua experiência:

Tem um cara que trabalha comigo que jogava um jogo, era um tema romano, com gladiadores e tal. E ele comprou uma espada XYZ pra passar de um nível lá que ele não conseguia passar, comprou a espada e não conseguiu passar. E o jogo mais ou menos indicava: "ó, compra isso aqui que você vai conseguir". O cara abandonou na mesma hora. Então, [...] o máximo que você pode cobrar tem que estar atrelado à satisfação que você vai entregar. - Vieitez

André Faure, executivo da empresa americana GameHouse, comenta sobre a existência de um suposto "algoritmo da felicidade" que a produtora King aplicaria em seu jogo:

Na Casual Conect, em San Francisco [EUA], a King deu uma palestra muito interessante sobre por quê o Candy Crush é um sucesso. O primeiro, eles falaram sem falar, de uma coisa que todo mundo sabe que existe, mas eles não confirmam, que é um algoritmo de felicidade que o Candy Crush tem. Então, quem joga Candy Crush sabe que o jogo começa muito fácil, e ele gera uma curva de satisfação e no topo dessas curvas de satisfação ele te sacaneia. Ele te sacaneia e te apresenta um item "Aqui ó, ou, bacana ó... Você não tá pilhado? Ó, então, compra esse item aqui ó, baratinho". Baratinho não, né, custa um dólar o desgraçado... "Você compra esse item aqui que eu vou manter a sua serotonina", literalmente, "Eu vou manter a sua serotonina alta e você vai continuar vencendo". Você compra o item, o algoritmo te joga um pouco mais de satisfação, lá pelas tantas ele te quebra de novo, e aí ele vai diminuindo esse tempo... Qual um outro exemplo do que faz isso? Cocaína! Então, Candy Crush nada mais é do que cocaína digital. - Faure

Vemos que a aproximação entre games e drogas retorna novamente, agora pela perspectiva de um empresário da indústria. Segundo André Faure, "o Candy Crush é um grande exemplo de como você consegue gerenciar tesão, de como você consegue gerenciar satisfação de jogador". Já Felipe Barreto, da produtora Mobits, comenta que o sucesso comercial de um jogo não depende somente do conhecimento da suposta "fórmula mágica", pois há uma série de outros fatores que estão agindo. 
O cara do Candy Crush é o Breaking Bad ${ }^{209}$ dos jogos, ele descobriu uma fórmula e começou a fabricar cocaína, meta-anfetamina na garagem dele. Ele não sabia que aquele jogo ia bater lá em cima e ficar. Então, a minha provocação é: Será que a gente analisa muito pelo top? E o top também não é muito sorte? Ou seja, não tem uma fórmula mágica. O cara sabe a fórmula mágica, mas ele não botou outros jogos lá em cima... - Barreto

Masamune explica um pouco sobre o funcionamento dos jogos (a princípio) gratuitos e outras formas de monetização mais comuns nos games atuais. O que ele chama de retail (ou preço fechado) é o modo tradicional de venda de jogos, em que o jogador compra na loja o jogo completo. Free-to-play são jogos que, para começar a jogar, não é exigido pagamento, mas em geral há de se desembolsar para liberar conteúdos adicionais, além de vantagens, itens especiais etc. Ele associa esses modelos de negócios com a questão da dependência e dos sistemas de recompensa.

O modelo viciante costuma ser, na minha visão, free-to-play. Porque o free-toplay ganha dinheiro em cima do engajamento da pessoa. Porque, por exemplo, num jogo retail, que não tem DLC, ele se importa no momento que você paga, no momento que você compra. O que você fizer com o jogo não interessa mais, desde que você não venda pra outra pessoa, porque aí ele perde dinheiro de fato. No momento que você compra, é aquele momento só em que o cara ganhou. É só ali que ele ganha. O free-to-play prevê que ele possa ter um lucro cíclico bastando que as pessoas se engajem, então há uma preocupação maior em viciar as pessoas. Em jogos retail, o engajamento costuma vir antes, as pessoas se engajam com o trailer, se engajam com vídeo de gameplay, se engajam com demos, e aí quando sai o jogo, às vezes é bom, às vezes é ruim, mas não interessa, pra empresa a venda já ocorreu, ela já conseguiu fazer a pessoa comprar. Em free-to-play, pra ela não basta gameplay, vídeo de gameplay, essas coisas. A empresa tem que criar uma mecânica que permita que a pessoa queira jogar sempre. Isso não quer dizer necessariamente que o jogo é melhor ou pior, tem um game design melhor ou pior. Quer dizer que ele estimula muito mais as recompensas imediatas, o imediatismo.

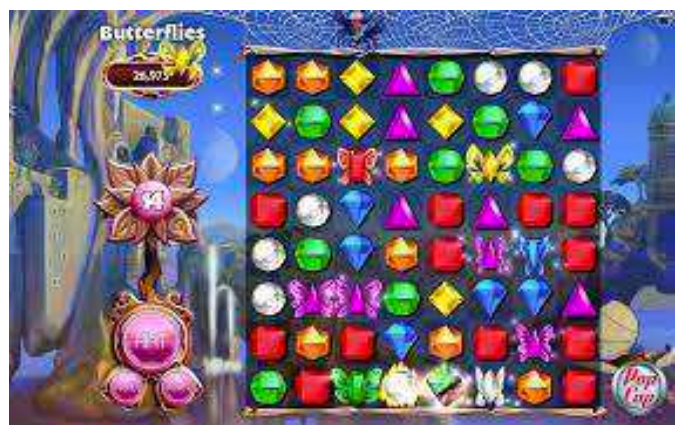

Figura 4.23 - Bejeweled (2001)

\footnotetext{
${ }^{209}$ Breaking Bad: A Química do Mal é uma série de televisão estadunidense. Sua história gira em torno do professor de química Walter White, que quando é diagnosticado com cancro do pulmão, sofre um colapso e abraça uma vida de crimes, produzindo e vendendo metanfetaminas com o seu ex-aluno Jesse Pinkman, com o objetivo de assegurar o futuro financeiro de sua família no caso da sua morte.
} 
Não é porque você fez um movimento certo, você automaticamente ganha ponto. Então, a relação dele entre esforço e recompensa é assim. Se você não consegue fazer um movimento válido, o movimento volta e continua na mesma. Mas não tem problema, porque é um jogo de high score, você não tem perda ou ganho. Ou você faz melhor do que antes ou pior. É um jogo de treino. Então, pode nunca acabar. Um jogo que você pode ficar treinando pra sempre. E aí quando a recompensa fica sendo tão imediata, você fazer uma coisa, você já ganhar uma coisa logo, é muito complicado, fica difícil pra pessoa se desengajar, porque qualquer coisa que ela fizer ela ganha uma coisa interessante. Pelo menos interessante no contexto do jogo. Aí cabe a quem faz tornar aquela recompensa interessante. Se ela conseguir deixar interessante o suficiente, aí, cara, engajar não fica tão difícil assim. Difícil é você engajar uma pessoa sem você ter que recorrer a esse tipo de coisa. - Masamune

Masamune toca num ponto importante: os interesses materiais das empresas de jogos e seus investidores. Como essas empresas têm, em geral, fins lucrativos, elas buscam gerar receitas das mais variadas formas. E algumas dessas formas podem eventualmente se tornar perversas, pois, por meio de mecanismos complexos de comportamento elaborados no game design de seus jogos, elas buscam se aproveitar de fraquezas das pessoas para auferir maiores ganhos.

Eu trabalho numa empresa que desenvolve jogos parecidos com esse, com o mesmo esquema do Candy Crush. Eles são voltados pra pessoa, chega um dado momento que ela não consegue mais jogar, está precisando de comprar formas de continuar jogando. Então, ela se aproveita, ela engaja o cara pra estimular o cara gastar dinheiro. Se isso é moralmente certo ou não, isso não entra em questão. Isso não é crime. Blackjack, bicho... Não é crime. Ok, bicho é crime, mas tudo bem. Porque esses jogos em que a mecânica depende de dinheiro, geralmente o modelo de negócio da empresa está atrelado ao game design. É típico do capitalismo de querer explorar o máximo que pode da pessoa. Então, é natural também que a empresa queira lucro. Se ela tem uma forma de explorar aquilo pra obter dinheiro, ela naturalmente vai integrar, vai criar uma mecânica que permita que ela ganhe o máximo de dinheiro possível. Seja por vida extra, seja por, por exemplo, no Colheita Feliz, você comprava umas moedas verdes, podia comprar batatas, podia comprar coisas pra sua colheita. Isso permitia que você tivesse uma colheita melhor. Ele se aproveitava do fato de que a pessoa muitas vezes não conseguia, na própria vida pessoal, fazer um negócio interessante, que no jogo ela tinha uma coisa legal. - Masamune

Masamune comenta que, para ter sucesso, uma empresa deve buscar um alinhamento fino entre o game design, a forma de monetização do jogo e o seu modelo de negócio para que todas convirjam para o mesmo objetivo. Ele comenta o caso do jogo Turma do Chico Bento, em que a empresa responsável (Level Up Games) não obteve um bom retorno financeiro apesar de o jogo ter sido bem sucedido - tanto tecnicamente (em termos de qualidade), como em termos de público - por conta da escolha equivocada da forma de monetização. 


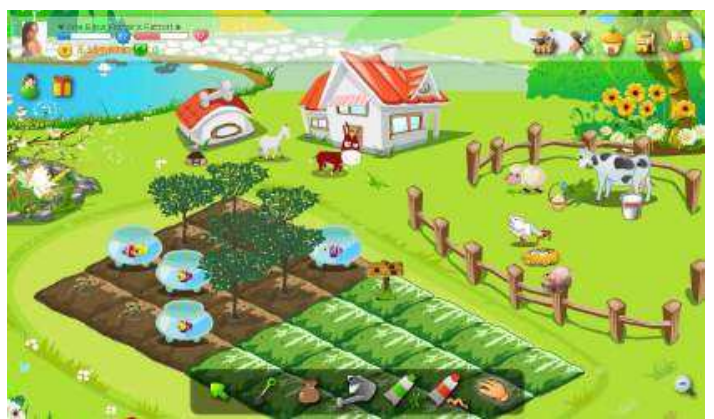

Figura 4.24 - Colheita Feliz (2009)

Se você faz free-to-play, o game design e a forma de ganhar dinheiro, o modelo de negócio, eles são assim [faz gesto juntando os dois dedos indicadores], se o jogo é bom, eles costumam ser assim, ou pau-a-pau. Quando não é, geralmente o jogo não faz sucesso, ou se faz, não dá dinheiro. Por exemplo, da Turma do Chico Bento. Pô, o cara jogou e tal, se engajou, mas aquele modelo de negócio não ficou tão bem atrelado à mecânica, e a galera não gastou dinheiro. Aí complica. Aí o jogo agora infelizmente vai morrer. - Masamune

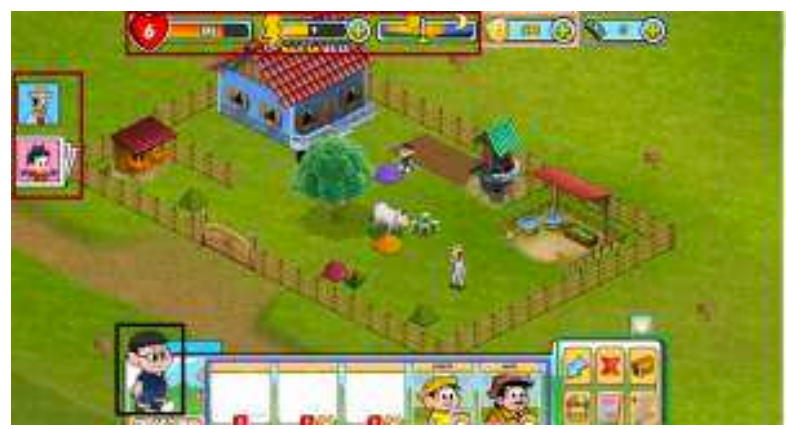

Figura 4.25 - Turma do Chico Bento (2012)

O próprio executivo responsável por este jogo deu um depoimento sobre este numa mesa redonda que tratou especificamente do tema "monetização em games", no evento SBGames 2013 (SP), negando o erro na decisão de monetização, e sim admitindo um atraso da empresa em aproveitar a onda dos jogos casuais nas redes sociais.

Eu vou contar um erro que a gente fez. O Chico Bento chegou a 900 mil jogadores por mês com pouco investimento de marketing. A gente tinha bala na agulha pra investir muito mais. Só que a monetização dele não funcionou, então ele não pagava os custos operacionais. Qual que era a nossa estratégia inicial? Ó, vamos pegar um modelo já conhecido, modelo Fazendinha, botar algo a mais, botar uma marca e fazer uma boa publicação. A gente sabia quanto as outras empresas estavam faturando na época, que era muito dinheiro, a gente falou "beleza, acreditamos que vai funcionar". A gente não almejava o topo, mas a gente achava que a gente ia ficar no break even, ia pagar o que a gente gastou. Quê que aconteceu? A gente conseguiu ter muita gente, a gente conseguiu que esse pessoal continuasse jogando, que é uma tarefa muito difícil, a retenção do usuário é muito difícil, só que a gente não conseguia fazer esse cara gastar. Aí a gente conseguiu investir mais tempo nisso, a conversão melhorou, mas não chegava ainda nem a pagar os custos. A gente contratou uma empresa especializada em dados de jogos de Facebook mobile pra dizer pra gente mais ou menos como a gente estava. E a má notícia foi: vocês estão 
fazendo em média o mesmo faturamento por usuário que as outras empresas estão fazendo. Depois disso, fechou o Sims Online, começaram a fechar alguns jogos da Zynga e por aí vai. Por quê que eu estou contando essa história? Aonde a gente errou? A gente não errou no jogo, não errou na marca, não errou na monetização, não errou em nada disso, a gente errou no timing. A gente entrou dois anos atrasado. Então, realmente tinha uma janela de mercado. - Vieitez.

Orochi também comenta que houve uma mudança no mercado de games ao longo dos anos. Os jogos, que antes apareciam como unidades completas e fechadas (portanto, negociadas e/ou comercializadas de uma única vez), hoje, com o advento das comercializações in-game, as atualizações (updates) constantes e a criação de conteúdos novos, há um favorecimento aos jogadores que gastam dinheiro para comprar "itens" ou "expansões". Dessa forma, torna-se necessário ter um gasto contínuo para sustentar a atividade de jogo, criando, segundo ele, uma maior relação de dependência.

Com esse surgimento desse tipo de jogo, foi mudando. Antigamente eu podia comprar um jogo, eu gastava lá um trocado, comprava um jogo e podia jogar o jogo completo, com todas as ferramentas que o jogo tinha e podia me divertir à vontade quando tempo eu quisesse. Hoje, eles são uma manutenção, você tem que gastar frequentemente. Se você para de gastar, você para de jogar. Então, isso também me desanimou um pouco dos jogos. Isso é uma ferramenta de marketing muito forte. Você vê o jogo, ele é de graça. Aí você fala, "ah, vou só ver como que é", aí você começa, acha o jogo legal. Você fala, "ah, é legal, mas eu não vou gastar, vou jogar só a parte que é de graça". Aí daqui a pouco você chega num limite de coisas que você conseguiu fazer, você progrediu muito no jogo, mas você não tem como progredir mais enquanto você não gastar. Se você chegou até esse ponto, pode ter gerado uma certa dependência já no jogo. $\mathrm{O}$ jogo é legal, você está se divertindo, você quer continuar. Pra continuar você vai ter que começar a gastar. Cria uma maior dependência, talvez, ou imagino que essa seja a estratégia de marketing dos games hoje em dia. - Orochi

O vício, portanto, parece estar alinhado com a preocupação financeira das empresas de games, as quais se interessam em "capturar o cliente" e mantê-lo consumindo pelo maior tempo possível os seus jogos e demais produtos. Ademais, como foi desde o início arquitetado para suprir tais interesses, o jogo pode se tornar não-saudável, criando, por fim, relações problemáticas.

Acredito que o jogo pode ser algo muito saudável, pode ser uma ferramenta muito grande de educação, inclusive. Mas eu percebo que na maioria das empresas de games essa não é a preocupação da empresa. A preocupação dela é que você crie essa dependência. - Orochi

Assim como a teoria do fluxo e a gameficação, a monetização também mostra outros aspectos de como os conhecimentos de game design e de estudos sobre a imersão dos jogadores podem estar intimamente ligados à questão da dependência. Pois, como já 
adiantamos, ambos tratam de coisas semelhantes - discussões em torno das formas e motivações que produzem o engajamento do jogador no jogo -, mas um com o significado invertido do outro. Por fim, passaremos brevemente pelo tema dos jogos indies (independentes), que, em tese, apresentariam uma alternativa em relação a essa lógica de mercado das grandes empresas de games.

\section{9 - Indie games, serious games, videogames e capitalismo}

Diante do cenário predominante, seriam os jogos independentes uma alternativa a ao tipo de envolvimento dos jogadores característico dos games produzidos pelas grandes empresas? Poderíamos suspeitar, em hipótese, que, como os desenvolvedores indies não estariam tão preocupados com o sucesso comercial de seus jogos como o estão as grande empresas, não haveria a necessidade de implementar mecânicas para induzir induzissem o jogador a gastar mais ou jogar compulsivamente. Trata-se de uma questão complexa, que exigiria um estudo detalhado. Aqui, entrentanto, vamos nos deter a descrever rapidamente alguns pontos sobre os tais jogos independentes e discutir, afinal, o que os definem.

Os games conhecidos como indies são jogos, em geral, com baixo custo de produção e desenvolvidos por uma equipe reduzida, muitas vezes de forma "caseira" ou “artesanal”, e em alguns casos sem fins lucrativos. Há jogos que são desenvolvidos por uma, duas ou três pessoas, o que contrasta com as equipes de centenas de funcionários das grandes empresas. Muitos jogos independentes como Braid, Fez e Super Meat Boy alcançaram um grande sucesso (inclusive comercial) na segunda década deste século, o que foi bem retratado no documentário Indie Game: The Movie (2012).

Nesse período, tais jogos se alastraram significativamente e atingiram não somente os computadores, como também, mais recentemente, os consoles, os quais tinham históricas barreiras de entrada no mercado, tais como os altos custos dos kits de desenvolvimento e os rígidos controles de qualidade das empresas responsáveis pela publicação, comercialização e distribuição dos grandes jogos. Com o advento das chamadas game engines, como Unity 3D, Unreal Engine, XNA Game Studio, Game Maker e RPG Maker, a produção desses jogos se tornou mais acessível aos pequenos desenvolvedores pois permitiram simplificar e aumentar o desempenho dos processos de produção de um videogame. 
Essa expansão foi tão intensa também por conta da expansão dos smartphones e da agência das plataformas de distribuição como Steam, Desura, Apple Store, Google Play, PSN e Xbox Live e de sites como Kongregate e Newgrounds (especialistas em jogos de Flash), que tornaram possível a esses games alcançar uma quantidade enorme de pessoas em diferentes lugares do planeta. Em suma, o advento e a expansão dos jogos indies abriram possibilidades de trabalho para muitos aventureiros e pequenos empresários da área, que passaram a criar jogos, fosse por hobby ou a trabalho.

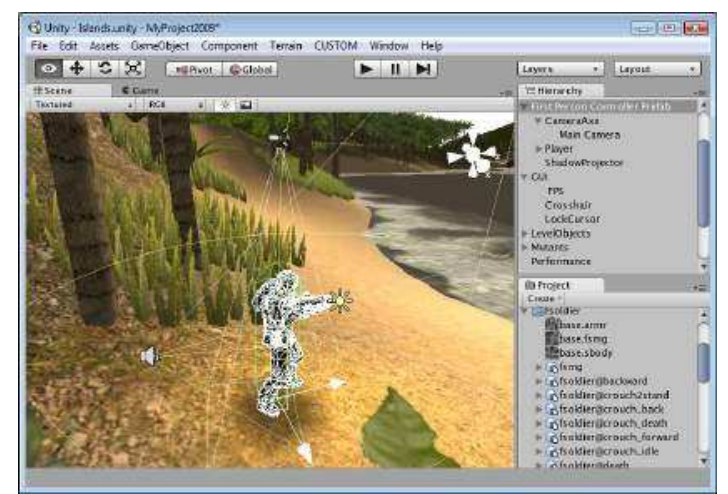

Figura 4.26 - Unity 3D (Game Engine)

Além dos jogos independentes, existem também os chamados serious games (ABT, 1970), ou jogos sérios, os quais não têm o puro entretenimento como objetivo principal. Para tanto, o game design desses jogos é orientado nesse sentido (ROCKWELL; KEE, 2011; ALVARES et al., 2007). O adjetivo "sério" é geralmente usado para se referir a produtos ligados a campos da educação, defesa civil, saúde, religião, política, planejamento urbano, engenharia e políticas públicas. Gonzalo Frasca ${ }^{210}$, em Videogames of the Opressed (2001), afirma que o objetivo em alguns desses jogos não é simplesmente ganhar, mas apreender conteúdos e alcançar objetivos criados pelos usuários. Alguns exemplos bem-sucedidos desses jogos são Darfur is Dying, September $12^{\text {th }}$, Play Madrid, Peacemaker, Global Conflicts, Democracy e Half the Sky. É nesta mesma onda que vêm os movimentos das redes Games for Change, Games for Health, Jogos para Educação, entre outros.

Não obstante essas novas iniciativas, há sérias dúvidas sobre o que definiria precisamente, afinal, um jogo independente. Afinal, eles seriam independentes de quê? De publishers e distribuidoras? Dos “interesses do capital”? Das estruturas hierárquicas das grandes empresas de jogos (onde são poucos que têm a possibilidade de participar

${ }^{210}$ Gonzalo Frasca (Montevideo, 1972) é um game designer e pesquisador acadêmico com foco em serious games de conteúdo político. 
das atividades de game design)? Da necessidade de alcançar um determinado número de vendas? Em muitos casos a resposta é positiva, mas nem sempre. Observamos que sob a mesma alcunha (indie games) encontra-se uma grande diversidade de jogos, desde aqueles como Limbo, da Playdead, que gerou US\$ 7,5 milhões de dólares em vendas na Xbox Live, até jogos caseiros, sem fonte de financiamento e distribuídos gratuitamente, como Cubisland, do solitário desenvolvedor Johnny William.

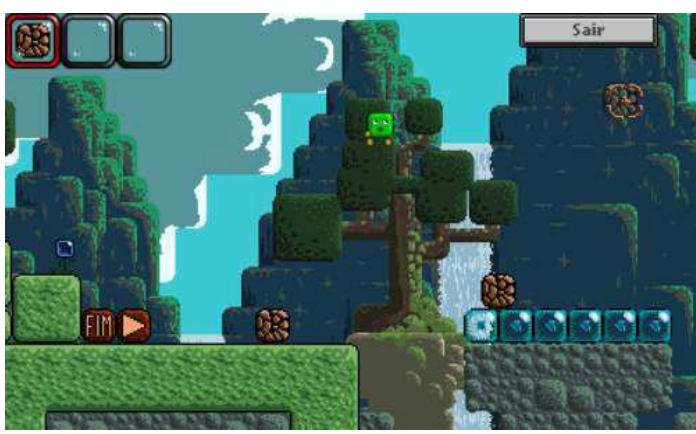

Figura 4.27 - Cubisland (2013)

Demonstrando uma reflexão que passa pela crítica marxista, indo de encontro à realidade atual da indústria dos games, marxistpokemon rejeita categoricamente esse rótulo. Com estes pertinentes questionamentos, poderíamos começar a pensar, afinal, quais são as relações possíveis entre videogames, capitalismo e dependência?

Eu não gosto dessa palavra de jogo independente. Isso é uma etiquetona pra valorizar e vender, que pra mim é tipo "foda-se". Eu realmente não faço questão de ter essa marca. Mas é foda que ao mesmo tempo as pessoas que estão ao meu redor se organizam em torno desse nome, e aí fica difícil pra mim querer participar dos encontros das pessoas ignorando completamente o nome. Isso é muito complicado. É uma coisa que eu gostaria muito de conseguir resolver, mas que eu ainda não consegui encontrar a síntese. Em suma, o que eu acho é que a gente vive numa sociedade que é totalizante, uma sociedade que impõe. Não é que ela impõe negativamente, ela produz um pensamento muito único em relação às coisas, que é a relação de consumo e mercado. As pessoas veem o trabalho como consumo e mercado, vê a relação de experiência estética dela como uma relação de consumo e mercado. Parece que você não está participando de uma experiência que você e o jogo constroem. Você está consumindo um serviço que o jogo te proveu. Como se o jogo fosse um escravo seu. O que é uma coisa bizarra. Na real, qualquer jogo que é feito com a perspectiva de lucrar, lucrar num nível de produzir capital - não é o cara que vendeu o jogo pra pagar a comida que ele precisa pra viver. Comércio é uma coisa, lucro e mais-valia é outra... 


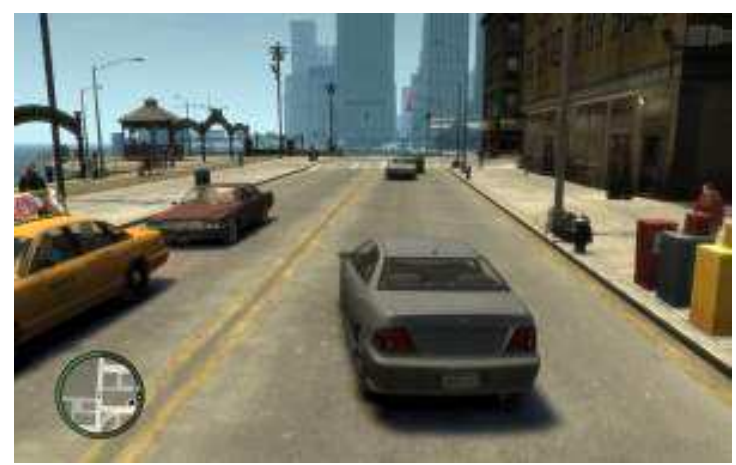

Figura 4.28 - Grand Theft Auto IV (2008)

Os jogos com J maiúsculo, os Games, o GTA, o triple A, o mainstream, todos esses nomes... Esse jogo, no geral, é um jogo que está lá pra realmente vender. Mercadoria. E que te totaliza, te engaja, tipo Hollywood. Quer que você seja o milionésimo espectador. Dentro do sistema capitalista é muito difícil você fazer uma coisa que esteja fora disso, muito difícil, muito, muito. Eu não consigo fazer uma coisa que esteja fora disso, talvez tem até quem diga que é impossível. A questão é: Onde que a gente acha as fronteiras disso? Onde que a gente empurra a coisa? Isso é não o dever, mas era uma pergunta que pelo menos tem que se fazer alguma vez na vida: Você quer reproduzir o status quo ou você quer questionar ele, você quer que ele exploda? Eu adoraria que ele explodisse, mas é difícil pacas. - marxistpokemon

As reflexões de marxistpokemon carregam consigo uma questão que não podemos omitir: Estaria a questão da dependência de alguma forma relacionada a um processo mais amplo, ligado, por exemplo, às dinâmicas de funcionamento das economias capitalistas? Antes de tudo, devemos ter em mente que essa questão é por demais ampla para tentar respondê-la em breves linhas e que esta exigiria uma investigação profunda e detalhada.

Apesar disso, podemos indicar que no caso dos videogames há possíveis ligações: 1) as formas de concepção, produção, financiamento, publicação e distribuição dos grandes jogos; 2) o modo como o trabalho é organizado nas grandes companhias de games; 3) a maneira desses jogos se relacionarem com o cotidiano das pessoas que os jogam (e das que não jogam); 4) as possibilidades de engajamento relacionadas às compras adicionais, cujo consumo excessivo é incitado pelas empresas; e 5) as diversas formas como a questão da dependência é entendida e tratada nas ciências e terapêuticas modernas. A hipótese de que a dependência está relacionada a processos das economias capitalistas, portanto, não é infundada, como já vêm mostrando os trabalhos de Bruce 
Alexander $^{211}$ (2001 e 2008), de Ole Bjerg ${ }^{212}$ (2008 e 2009), de Gerda Reith ${ }^{213}$ (2004), dentre outros. Como esta última autora mesmo coloca:

A noção de "adicção" tem particular valência nas sociedades liberais avançadas, nas quais uma ênfase sem precedentes nos valores de liberdade, autonomia e escolha, não só incentivam as condições para a sua proliferação em áreas cada vez mais amplas da vida social, como também revelam tensões profundas dentro da própria ideologia do consumismo (REITH, 2004, p. 283, tradução nossa).

No entanto, temos aqui diferenças significativas em relação a esses autores, que, eventualmente recorrem a teorias macroexplicativas para dar conta dessa dimensão ampla e coletiva da dependência. O desafio, portanto, é não partir de uma entidade transcendental pré-explicativa como o "capitalismo" ou o "consumismo", mas chegar a estas respostas por meio da abordagem das redes. Temos, pois, de explorar essas questões partindo da mesma orientação teórico-metológica (mais especificamente, a teoria-ator-rede) que guia esta pesquisa. Neste sentido, uma indicação para pesquisas futuras seria abrir suas caixas-pretas e reconstruir estas noções em campo junto com os actantes, a partir de suas próprias ações. ${ }^{211}$ Bruce K. Alexander é um psicólogo e professor em Vancouver, Canadá. Alexander e seus colegas da
SFU conduziram uma série de experimentos em dependência de drogas, conhecidas como "as
experiências de Rat Park". Escreveu o artigo The Roots of Addiction in Free Market Society e o livro The
Globatization of Addicion: A Study in Poverty of the Spirit (2008). Abaixo, selecionamos dois trechos do
primeiro trabalho, que indicam sua hipótese de pesquisa:

"De um mero incômodo no mundo antigo, a adicção transformou-se numa ameaça crescente no mundo moderno, da mesma forma como a sociedade se moveu para a economia de livre mercado e para a Revolução Industrial. Analisar a ameaça ainda crescente da adiç̧ão implica examinar os tóxicos efeitos colaterais dos "mercados livres" e da "nova economia". Naturalmente, esse exame é desconfortável num momento em que todas as nações do mundo parecem tender para a adoção do livre comércio para provar as guloseimas e desfrutar da euforia da alta tecnologia. Ignorar o problema, porém, é aceitar efeitos colaterais que são claramente visíveis" (ALEXANDER, 2001, p. 3, tradução nossa).

"Porque a sociedade ocidental está baseada em princípios de livre mercado que produzem deslocamento em massa [o autor chama de deslocamento a ligação entre a nova economia e a adicção], e porque o deslocamento é o precursor da adiç̧ão, a adicção em uma ampla variedade de atividades não é o estado patológico de poucos, mas, em maior ou menor grau, a condição geral da sociedade ocidental. Porque a sociedade ocidental de mercado livre fornece o modelo para a globalização, a adicção em massa está sendo globalizada, junto com a língua inglesa, a internet e o Mickey Mouse" (idem, p. 5, tradução nossa).

212 Ole Bjerg é professor associado ao Departamento de Administração, Política e Filosofia da Copenhagen Business School. Acerca desse tema, ele escreveu o artigo Drug Addiction and Capitalism (2008) e o livro Too close to capitalism: Ludomania, narcomania and shopoholism (2009).

${ }^{213}$ Gerda Reith é professora de Sociologia na Universidade de Glasgow (Escócia) e Senior Lecturer e diretora de pesquisa do "Gambling Research Group", na mesma instituição. Escreveu o artigo Consumption and its discontents: addictions, identity and the problems of freedom (2004). 


\subsection{0 - Fim de jogo}

Neste capítulo passamos por uma série de questões. Por mais que de modo demasiado ligeiro ou sem a profundidade de reflexão que gostaríamos, buscamos adentrar estes "mundos dos games" para trazer novas perspectivas sobre as controvérsias em torno da dependência de jogos eletrônicos. Desse modo, com as descrições dos atores, entendemos que este capítulo complementa as descrições médicas e psiquiátricas expostas nos capítulos anteriores.

De início, exploraramos as diferentes concepções de vício entre os jogadores, trazendo à tona debates acerca de sua própria existência, do autocontrole, do magnetismo dos computadores, dos seus conteúdos simbólicos e seus efeitos, da síndrome de abstinência e de uma visão espiritualista dos vícios. Em seguida, testamos o rendimento da comparação entre games e drogas, seja esta metafórica ou metonímica, que evidenciou formas de aproximação e diferenciação. Alguns jogadores narraram experiências de uso dos videogames como formas de gerenciamento de humor (ou de alívio de estresse), que vão da terapia à beira da violência - assunto este pouco explorado aqui.

Na sequência, descrevemos controvérsias e experiências em relação aos ambientes de jogo (quarto, sala, lan-house), incluindo os equipamentos, controles, consoles e demais periféricos, atentando aos múltiplos quase-sujeitos/quase-objetos que compõem suas redes, os quais têm implicações na forma de jogar e numa suposta relação de dependência. Neste ponto, adentramos nas relações familiares e conjugais em torno dos videogames, evidenciando conflitos que emergem da relação entre pessoas que jogam e que não jogam (mas partilham do mesmo ambiente). Foram mencionadas questões referentes a diferenças de idade, geração e gênero - todas brevemente exploradas -, à responsabilidade dos pais, à questão da segurança/violência nas ruas (e em casa) e a um certo cuidado para com a infância e juventude em relação aos conteúdos dos jogos.

Exploramos a grande variedade dos games, seja em termos de gênero, tema, forma de conexão, número de jogadores, duração, plataforma e mecânicas de jogo. Além disso, vimos que os jogos online e o chamados jogos "sem fim" (ou com alto nível de "replay") apresentam dinâmicas particulares, que agiriam mais fortemente na produção de uma relação de "dependência". A internet entra como um ator importante nessa rede, bem como outras inovações, como a dos smartphones e tablets, que, junto com os jogos 
de realidade aumentada, transformaram as formas de comprar, jogar e distribuir jogos, quebrando barreiras entre a "cibercultura" e o dito "mundo ordinário", bem como as dicotomias online/offline, in-game/off-game e jogo/não-jogo.

Os MMORPGs, considerados por muitos jogadores e terapeutas como os jogos mais "viciantes", também apresentam lógicas específicas, como a permanência do mundo e um sistema "infinito" de progressão, que se aliam a dinâmicas de personalização, seja ela visual (do avatar), matemática (em relação aos atributos do personagem) ou de outras formas lúdicas, que também agiriam no sentido de estimular a criação de uma relação de dependência. Concluímos que a imagem do jogador como antissocial não tem sustentação empírica, pois os próprios gamers estão o tempo todo buscando conectar-se a seres não-humanos e humanos, especialmente nos MMORPGs, em que este fator "social" seria visivelmente exacerbado.

Na seção posterior, buscamos compreender mais a fundo a questão do engajamento nos videogames. Para isso, recuperamos a fala de diversos jogadores acerca dos mecanismos de recompensa, além da própria Teoria do Fluxo, que propõe uma relação entre o nível de dificuldade do desafio e a habilidade requerida para executá-lo, formando uma curva que tem no seu ponto ótimo o chamado "flow". O tema da gameficação, em voga nos últimos anos, também aparece na rede, apontando uma expansão da lógica dos games para além deles próprios. Mapeamos, na sequência, algumas formas de monetização dos jogos, isto é, formas das empresas gerarem receita, abarcando na rede outros importantes actantes, como os empresários e a indústria de jogos, e os conectamos ao tema da dependência. Por esses assuntos, observamos que, em certa medida, diferentes discursos - alguns positivados como engajamento, motivação, enquanto que outros negativados como dependência ou vício - partiriam de alguns mesmos princípios.

Por fim, passamos por alguns apontamentos acerca do desenvolvimento de games, com o depoimento de profissionais da área e a apresentação de lógicas de motivação, que indicam a proposta (também controversa) dos jogos independentes. Os jogos sérios (serious games) aparecem como outra opção possível para escapar dessa lógica de mercado das grandes empresas de games. Por fim, refletimos de forma inicial e ensaística sobre uma possível relação entre videogames, dependência e capitalismo. Com estas reflexões, encaminharemos, a seguir, as considerações finais deste estudo. 


\section{Considerações finais}

\section{1 - Fechamentos provisórios}

Retomando o argumento inicial, percebemos que há uma noção naturalista de dependência que traz uma série de pressupostos do que é o real e o humano em oposição ao que é concebido por virtual e maquínico. A perspectiva do ciborgue de Donna Haraway nos permite trabalhar com a hipótese de que o vício seria um fenômeno que compreende relações não-controladas, não-domesticadas, em que está em jogo a captura da subjetividade humana e, portanto, certa imagem de humanismo (LATOUR, 1991; HARAWAY, 2009). Nesse campo de estudos, há uma polarização em torno de duas formas mais comuns de abordar as relações humanas com os videogames. $\mathrm{Na}$ primeira, o objeto videogame causaria um vício incontrolável ao homem, que perderia sua racionalidade e capacidade de falar por si mesmo, ou seja, seu estatuto enquanto sujeito. Já a segunda partiria dos benefícios que o homem - sujeito por excelência, em pleno controle da relação - colheria a partir do uso dos jogos eletrônicos. Afinal, quem engloba quem? Quem está no controle? O homem ou o videogame? Essas duas abordagens do problema parecem paralisar a discussão, uma vez que não colocam o foco nas relações.

Como anunciado desde a introdução, o diferencial desta investigação, em um tema tão pesquisado mundialmente, reside em seu modo específico de abordar a questão, à maneira como a Antropologia da Ciência e da Tecnologia (área que tem afinidade com os sciences studies) nos instrui: colocando o foco na relação entre homens e coisas (e não os termos em si), o que nos leva a problematizar muitos dos conceitos geralmente tomados como dados (ou caixas-pretas, na terminologia de Bruno Latour) em outros estudos deste tema, marcadamente dominado por trabalhos das áreas da saúde - em geral, Psiquiatria e Psicologia.

Em campo, observamos que as ciências não parecem ocupar uma posição central em todos os casos. Em termos de intervenção clínica, as iniciativas ainda são incipientes. Em países como China, Coreia do Sul, Japão, Estados Unidos, Alemanha, Holanda e Finlândia, há centro de tratamentos, e mesmo no Brasil, já existe no Hospital das Clínicas (SP) um trabalho experimental nesse sentido. Esta, entretanto, não é nem de 
longe a forma predominante de tratar o assunto. Muitas vezes as discórdias em torno dos videogames são tratadas em âmbito doméstico; por exemplo, com os pais proibindo o filho de usar o aparelho. As pessoas de gerações mais antigas, em geral, desconhecem os videogames ou não têm a mesma familiaridade que seus filhos com o assunto, gerando desentendimentos, uma vez que a maioria dos pais não têm outras referências para orientar o seu comportamento. É nessa brecha que entra um dos papéis da Ciência.

Apesar de sustentadas por actantes como o DSM (uma rede de médicos, instituições aliadas e financiamentos da indústria farmacêutica), muitas das resoluções oficiais como a da American Academy of Pediatrics ${ }^{214}$, que determina duas horas por dia como o tempo máximo para atividades frente à tela - vão contra as formas atuais de estudo e de trabalho em vigentes em grande parte do mundo. Classificar a maior parte da população como dependente não parece ser a melhor solução. Aliás, a heterogeneidade nas classificações de dependência marca as discussões no campo, pois, mesmo no campo científico, não há formas de diagnóstico e tratamentos que sejam consenso.

Alguém poderia se apressar em resumir este assunto recuperando as máximas: "Nada faz mal, desde que em moderação" ou "Tudo em excesso faz mal" - que, por mais que possam ser verdadeiras em muitos casos, sua simples reafirmação não exigiria sequer o início deste estudo aprofundado acerca das controvérsias, que são atuantes em diversas dimensões e produtoras de uma série de ideias e conceitos acerca da dependência de videogames. Ademais, vimos que os actantes variam muito. Não é possível, por exemplo, homogeneizar a área da Medicina (da Psiquiatria) ou da Psicologia; tampouco generalizar quais são, o que afirmam ou o que fazem seus actantes. Por isso, o exame “caso a caso" apresenta-se como mais fiel à realidade das práticas.

Em termos teóricos, há um esquema geral oriundo do estudo das drogas químicas se propõe a explicar o chamado comportamento adicto, dividindo-o em seis fases: saliência (a atividade se torna a mais importante da vida da pessoa), mudança de humor, tolerância, sintomas de abstinência, conflito, recaída e reinstalação. Esse esquema é aplicado para quase todas as dependências e foi levemente adaptado (sem nenhuma

\footnotetext{
${ }^{214}$ Houve uma discussão séria em torno da inclusão das dependências de jogos online no novo documento da associação, o DSM-V (Manual Diagnóstico e Estatístico de Transtornos Mentais), que, se fosse aprovada, deveria aumentar a medicalização na forma de intervenção sobre os usuários.
} 
modificação estrutural, entretanto) para os casos da internet e dos videogames, por pesquisadores como Mark Griffiths.

No entanto, em tese, tal forma de entender essas intensas conexões poderia ser aplicada a quase todo tipo de relação, desde relacionamentos amorosos, passando pelo trabalho, até leitura ou assistir televisão. Contudo, estas, em geral, não são motivo de escândalo, perigo ou apreensão como os videogames, que aparecem como um alvo privilegiado para críticas. Vimos que este modelo conforma uma gramática estruturante adaptável para explicar todo tipo de dependência. Entretanto, se adentrarmos seus pormenores, veremos que esta não é neutra, nem autoevidente, mas recheada de valores e símbolos.

Afinal, o que o videogame e o crack teriam em comum - passando pelos vícios associados, como os jogos de azar, pornografia, internet - que justificaria a utilização dos mesmos métodos de diagnóstico e de tratamento? Vimos que, em alguns casos, os videogames são aproximados dos jogos de azar por partilharem as mesmas características lúdicas, por seu caráter específico de jogo. Em outros (YOUNG, 2011, por exemplo), são encarados como um subcaso do vício em internet, enfatizando, desta vez, o caráter virtual desta forma de relação. Isso não é óbvio. A investigação de como se conforma essa ligação é o caminho por qual esta pesquisa percorreu.

$\mathrm{O}$ vício em videogame e em internet são diferentes em grande medida. Segundo a teoria do fluxo (CSIKSZENTMIHALYI, 1990), os videogames possuem, por exemplo, lógicas específicas que envolvem sistemas de recompensas dos jogos, incluindo um balanceamento preciso entre o nível de desafio e a curva de aprendizagem do jogador, de modo que atenção do jogador seja retida por um período prolongado. Por outro lado, a própria internet também é muito diversa. Além das tecnologias, portanto, deve ser investigado o que exatamente a pessoa pratica com cada uma delas (no computador, por exemplo). Estas são, antes de tudo, mediadores. Os excessos, enfim, se mostram como resultado das relações e não da tecnologia em si.

Para determinar a suposta dependência, existem alguns modelos mais comuns, sobretudo entre psicólogos e psiquiatras. Um deles é o modelo cognitivocomportamental, que trabalha com a ideia de Uso Problemático de Internet (UPI). Neste modelo, o critério principal para o diagnóstico da dependência seria a instauração de "consequências negativas" para o indivíduo, tais como problemas físicos (fadiga, dor 
física, redução do tempo de sono, perda de refeições), problemas na vida pessoal (conflitos com a família e/ou amigos, baixa interação social) e problemas acadêmicos e profissionais (falta às aulas ou ao trabalho, desempenho ruim), além do sentimentos de isolamento, depressão e baixa autoestima.

Já o modelo neuropsicológico baseia-se na ideia de impulso primitivo associado à dependência para examinar o que seria o comportamento cerebral, criando uma associação direta com seu aspecto físio-químico. Nessa perspectiva, a ativação farmacológica dos sistemas de recompensa do cérebro seria o grande responsável pela produção das potentes propriedades adictícias das drogas. Outro dos modelos mais conhecidos é a teoria da compensação, que trabalha com a ideia do uso de videogames como um meio de compensar ou lidar com déficits de autoestima, identidade e relacionamentos. Nessa teoria, argumenta-se que foram encontrados níveis mais elevados de solidão entre os considerados usuários patológicos. Ainda que se tratem dos modelos mais comuns, em todas as teorias supracitadas há diversos pontos controversos, os quais foram explorados com cuidado ao longo deste trabalho.

Insistimos em tocar em subcontrovérsias que sustentam a ideia do vício, tais como: a comunicação face-a-face como mais "humana" que a comunicação digital; o mundo dos jogos como mundo falso, em oposição ao mundo verdadeiro das relações sociais, o que gera uma visão "escapista" da realidade; o videogame e a internet como local da anonimidade e da não-seriedade; o estudo e o trabalho como únicos usos legítimos do computador, em oposição aos usos lúdicos, tomados como improdutivos e "perdedores de tempo". Contudo, não estamos afirmando que, por exisitirem usos benéficos, que não existam usos nocivos para a saúde e o bem-estar das pessoas. Uma perspectiva não anula a outra. Os videogames não são ontologicamente bons nem maus. Mais uma vez, o foco está na relação, não na tecnologia em si.

Nosso esforço, enfim, foi tentar desarmar a armadilha do título do trabalho - o videogame é droga? -, porque este é um dilema raso e que não nos ajuda a caminhar na produção de um conhecimento diferente daquele majoritariamente disponível na literatura especializada. Não estamos aqui, portanto, questionando se um tratamento terapêutico pode (ou não) ajudar uma pessoa em relação a seus eventuais problemas com os videogames, mas sim a validade de seu discurso oficial, o qual solifica uma 
noção de vida real oposta a certas concepções de virtual e lúdico. Desse modo, estamos colocando em questão não as práticas científicas em si (as quais são híbridas e variadas), mas, sobretudo, o seu discurso oficial purificado.

\section{Algumas limitações deste estudo}

Uma das limitações desta pesquisa se deve aos materiais utilizados. Como os dados foram construídos majoritariamente por meio de entrevistas, artigos científicos, manuais de tratamento e notícias jornalísticas, não temos a pretensão de determina-la como de cunho etnográfico, no sentido restrito de uma observação participante nos moldes clássicos - em que se acompanha de perto a vida de determinadas pessoas num local fixo, incluindo a relação entre o que elas afirmam, o que praticam de fato e o que as outras pessoas afirmam sobre elas - como poderia ser feito, por exemplo, acompanhando experiências de tratamento e atendimento médico-psicológico ${ }^{215}$. Concebemos esta pesquisa simplesmente como um esforço para construir, junto com os actantes, uma triangulação entre as diferentes perspectivas e discursos ${ }^{216}$ em torno dos pontos controversos mapeados em campo.

Além disso, outra limitação foi não ter sido possível adentrar a fundo os temas da violência, juventude (das diferenças geracionais), gênero e das "novas tecnologias", bem como a história pessoal dos jogadores - assuntos estes que apareceram em abundância em nosso trabalho de campo, mas que exigiriam um tratamento para além das condições práticas e dos objetivos acadêmicos desta dissertação. Também existem outras teorias da dependência, bem como uma grande quantidade de questionários e métodos de diagnóstico, os quais não foram aqui explorados. Outra limitação pode ser uma suposta minoria de casos acusados como "graves" ou "gravíssimos" na pesquisa de campo, em relação à presença dominante de casos "leves" ou "moderados".

Por fim, vimos que, se as controvérsias, por um lado, atingem uma escala global, por outro, que é possível pesquisá-las localmente, já que a questão permeia este mesmo plano de ações dos actantes. Nesse mapeamento não houve uma determinação rígida

\footnotetext{
${ }^{215}$ Não foi possível acompanhar etnograficamente grupos de tratamento ou o atendimento médico a dependentes, principalmente por conta de uma norma ética da profissão, que impede que alguém "de fora" intermedeie a relação entre terapeuta e paciente.

${ }^{216}$ Nesse sentido, tampouco devemos separar estes dois elementos (prática e discurso), uma vez que o discurso é também uma prática, pois tem efeitos práticos: fazem-fazer.
} 
tempo nem de espaço. As controvérsias em torno da dependência de videogames, portanto, são demasiadamente amplas e difusas, de modo que, se não determinássemos cortes de rede, não seria possível esgotar o assunto de forma alguma.

\section{2 - Nova luz sobre a questão da dependência}

Como antecipamos na apresentação da controvérsia, os casos extremos são mais fáceis de descrever, pois, em geral, há consenso. É quando estamos no meio que as coisas se tornam mais complicadas, e por isso mesmo mais interessantes. Por conta das discussões que surgem neste meio que nos interessamos pelas controvérsias. Nesse sentido, o antropólogo Maurício Fiore, a partir de uma reflexão sobre o uso de substâncias psicoativas, coloca:

O meio, ou seja, aquilo que é ambíguo, escapa à classificação exata que a medicina está acostumada a lidar no caso de outras doenças crônicas. A linha traçada entre um indivíduo que não usa substância psicoativa alguma, e aquele que, concretamente não parece mais estabelecer outra relação com sua vida que não seja através de alguma(s) substância(s), é repleta de curvas e lacunas. A prática da clínica, o planejamento de saúde pública e a construção de legislações tentam contorná-las, estabelecendo limites mais ou menos rígidos, alicerçados nos pontos que parecem estar mais claros nesta linha: seus extremos, assumindo, assim, uma série de riscos e contradições (FIORE, 2008, p. 14).

Uma das maneiras de a prática clínica tentar contornar esses riscos é a partir de técnicas estatísticas conhecidas como normalização. Neste método, opera-se uma quantificação de uma diversidade de casos qualitativamente distintos, para assim separar o doente do normal. Dentro dessa lógica, o doente nada mais é do que um ponto fora da curva normal, e o sadio, um ponto dentro desse intervalo criado pelo pesquisador - de modo que, antes da prática científica, não há nada pronto ou autoevidente.

O estabelecimento de uma patologia, como o uso abusivo ou nocivo e a dependência de "drogas", vem acompanhado da necessidade de classificações nosológicas claras. A complexidade de se operar estas classificações no caso do uso de "drogas" é explicada pela a ausência de fatores sintomáticos claros (FIORE, 2008, p. 10).

Para o antropólogo João Biehl (2008), as $\operatorname{drogas}^{217}$ acabam funcionando como tecnologias morais que se ligam a padrões de normalidade, as quais não são apenas fruto de um construtivismo relativista.

\footnotetext{
${ }^{217}$ Para Biehl "os psicotrópicos mediam o abandono, tanto pelo valor de verdade científica que conferem ao que está acontecendo, como também pelas alterações químicas que ocasionam” (2008, pp. 440).
} 
Não quero dizer que as desordens mentais são basicamente uma construção social, mas sim que elas ganham forma naquele nexo mais pessoal que liga $\mathrm{o}$ sujeito à sua biologia e à recodificação técnica e intersubjetiva do que vem a se constituir enquanto normalidade no mundo local. É nesse sentido que os representantes do senso comum e da razão estão imbricados nas desordens mentais, sendo sua responsabilidade dar conta desta imbricação no desdobramento das desordens (BIEHL, 2008, p. 440).

Carole Cain (1991) também questiona os padrões de normalidade em sua pesquisa sobre os Alcóolatras Anônimos. Para ele, o dependente é definido em função da forma como seu comportamento é "rotulado" pelos outros.

\begin{abstract}
Alcoólatras são rotulados como alcoólatras por outras pessoas no momento em que seu comportamento se torna problemático segundo os padrões de normalidade, e não pelo volume de álcool bebido ou a frequência com que se fica bêbado. O 'alcoolismo' descreve a tendência de um comportamento inapropriado, desviante. $\mathrm{O}$ desvio não é uma qualidade dos atos ou comportamentos assim rotulados. É uma consequência da quebra de regras e sanções criadas por um grupo que está em posição de poder e que acha o comportamento do outro 'problemático"” (CAIN, 1991, p. 211, grifo nosso).
\end{abstract}

Apesar de concordarmos em parte com o argumento deste autor, não nos apressaremos, no entanto, em explicar esses eventos por uma estrutura de poder. Primeiro, porque não entendemos o poder como algo pronto ou localizável em uma posição estrutural. Mesmo se levássemos a cabo este argumento, como poderíamos mensurar o suposto poder dos tratamentos clínicos e das tentativas de intervenção farmacológica frente à indústria bilionária dos videogames? Há diversos poderes e fazeres nesta controvérsia. Não buscaremos soluções, assim, em macro-explicações. A descrição se dá constantemente no nível das associações. Interessa, pois, entender como se dão estes processos de conexão entre mônadas abertas (TARDE, 1910).

O antropólogo Eduardo Vargas (2008) escreve que há um duplo processo medicalização e criminalização - que funda a própria questão das drogas entre os modernos. Vargas coloca que esses dois processos (que se interligam) não são apenas fundamentais para compreender a criação do fenômeno das drogas no Ocidente, como também suas duas principais vias de repressão. Não estaríamos tomando um caminho semelhante no caso dos videogames?

Mais do que se apropriar da experiência do consumo de drogas, o que as sociedades contemporâneas parecem ter feito foi criar literalmente o próprio fenômeno das drogas: mais remotamente, com a loucura das especiarias e, mais recentemente, com o duplo processo da invasão farmacêutica e da criminalização das drogas" (p. 55) [...] O problema de repressão e de incitação, 
a "droga", tal como é hoje o sexo, não existiu desde sempre, sendo invenção social recente e muito bem datada. De fato, mais do que apropriar-se da experiência do uso de drogas, o que as sociedades modernas parecem ter feito foi criar literalmente o próprio fenômeno das drogas; e o criaram por duas vias principais: a da medicalização e da criminalização da experiência do consumo de substâncias que produzem efeitos sobres os corpos e que, até sua prescrição e penalização, não eram considerada como "drogas" (VARGAS, 2008, p. 124).

Para Stelio Marras (em comunicação pessoal), esta forma de apreensão e regulamentação das drogas e dos videogames está relacionada a uma captura estatal que tende a unificar e nivelar diferenças. O psicólogo Lucas Costa coloca que nesse pensamento de normatização e de repressão está presente uma ideologia do medo.

O ser humano mais racional tenta sempre buscar explicação pra tudo, e esse é o medo original. "De onde viemos?", "Quem somos?", "Para onde vamos?" É o básico do Existencialismo. No final das contas, acaba caindo muito na coisa do medo, então por isso também do pragmatismo na hora de tentar consertar. "Ah, não, mas isso é muito perigoso! Ah, não pode, cuidado. Proíbe, proíbe, tira daqui!". É uma atitude de alguém que está assustado. É um bater ou correr. Ou ele entra no mecanismo de fuga e esquiva, ele olha e fala: "Hum, ataco? Não, saio fora". - Costa

Por fim, este trabalho permite avançar importantes conclusões sobre a noção de dependência. Primeiro, que se trata de uma categoria de acusação. Segundo, que esta aparece quando se ferem valores como trabalho, estudo, geração de renda etc. Quando não fere tais valores, ela tende a não se afirmar. Pondo deste modo, deslocamos o problema da dependência, a qual não mais seria assentada na diferença improdutiva entre real e virtual, que é uma função generalista e, por isso, pouco realista quando se quer fielmente captar cada caso real.

O problema exige, portanto, a análise do "a cada vez" e não a do "de uma vez por todas". É claro que nessa e naquela vez podemos flagrar morbidade na relação do jogador com o jogo. Aqui estamos adentrando o âmago da prática médica entre os modernos. Isto é, como tratar a dependência sem generalizá-la? Qual seria, por exemplo, uma política pública de saúde que realmente atenta para as diferenças que não cessam de subverter cânones e teorias? Sublinhamos a exigência de se pensar o problema da dependência a partir de gradientes selvagens (mais difícil, porém mais fiel ao real), do que a partir de polos ou dicotomias intransitivas.

É “a cada vez" que podemos (como na clínica médica) desdobrar associações que fazem-fazer uma rede de múltipla causalidade que um sujeito concreto experimenta. 
Assim, buscamos mostrar duas coisas correlatas: primeiro, os pressupostos invisíveis nas acusações e nas categorias; segundo, a exigência de se desvelar associações para se compreender concretamente cada caso e, só assim, pensar terapêuticas caso a caso. Tentamos mostrar, assim, a falência da compreensão e das terapêuticas de signo generalista.

\section{3 - Breve reflexão sobre o culto moderno da Ciência Moderna}

Ao tratar o humano como sujeito e videogame como objeto (ou, do mesmo modo, como uma substância), a maioria das teorias da dependência aqui apresentadas acaba por operar, num plano oficial, teórico e discursivo, uma separação em dois mundos: a sociedade dos humanos (na perspectiva dos humanos, é claro) e o da tecnologia, no qual se incluem os videogames (também na perspectiva desses humanos). Ao mesmo tempo, num plano oficioso, se invertermos as perspectivas, os objetos aparecem como participantes da sociedade, e os humanos, como construtores e produtos da tecnologia.

No plano oficial, estas sofisticadas teorias erigem uma barreira (pensada como) intransponível entre esses mundos, apesar de oficiosamente reconhecerem passagens do videogame positivo (benefícios) para o negativo (prejuízos, como a dependência), nas quais os actantes circulam de um plano para o outro, causando efeitos uns sobre os outros, fazendo-fazer de forma generalizada. Latour faz uma ponderação semelhante em Reflexão sobre o culto moderno dos deuses fe(i)tiches, que tomaremos aqui como aliada para discutir estas questões, que parecem convergir no mesmo sentido.

Para Latour, os modernos estão muito ligados a uma diferença essencial entre fatos e fetiches. A crença não tem por objetivo nem explicar o estado mental dos fetichistas, nem a ingenuidade dos antifetichistas. Ela está ligada a algo inteiramente diverso: a distinção do saber e da ilusão, ou, antes, a uma forma de vida prática que não faz essa distinção e uma forma de vida teórica que a mantém (LATOUR, 2002, p. 31). Os pensadores críticos ou os antifetichistas lutam bravamente para separar, nos termos de Latour, os objetos-encantados (fetiches), dos objetos-causa (feitiches).

A palavra "fato" parece remeter à realidade exterior, a palavra "fetiche" às crenças absurdas do sujeito. Todas as duas dissimulam, na profundeza, de suas raízes latinas, o trabalho intenso de construção que permite a verdade dos fatos como a dos espíritos. É essa verdade que precisamos distinguir, sem acreditar, nem nas elucubrações de um sujeito psicológico saturado de devaneios, nem na 
existência exterior de objetos frios e a-históricos que cairiam nos laboratórios como do céu. Sem acreditar, tampouco, na crença ingênua. Ao juntar as duas fontes etimológicas, chamaremos fe(i)tiches a firme certeza que permite a prática passar a ação, sem jamais acreditar na diferença entre construção e compilação, imanência e transcendência (idem, pp. 45-46).

O que Latour toma aqui como baixo mundo seria o plano oficioso onde circulam, se modulam e se constituem as diversas entidades separadas pela taxonomia moderna, que divide o mundo entre natureza e sociedade, objeto e sujeito, real e fabricado, fato e fetiche. O alto mundo, situado no plano oficial, por sua vez, seria este da Ciência, autorizada a produzir verdades sobre ambos os polos, natureza e sociedade, com as suas Ciências Naturais e Sociais, bem separadas em seus respectivos domínios.

De fato, não podendo mais situar as inumeráveis entidades com as quais misturamos nossas vidas (já que a imagem tradicional da ciência nos descrevera este baixo mundo repleto de causalidades eficazes), e não podendo tampouco nos resignarmos em alojá-las no âmago do nosso eu, transformando-as em fantasias, complexos ou jogos de significantes, só tínhamos como recurso inventar um outro mundo [...] Não existe outro mundo senão o baixo mundo. Não se tem tampouco que sucumbir às fantasias do eu (idem, p. 88).

Com essas duas esferas apartadas, é produzido um conhecimento específico para cada uma delas. Os homens, no reino da sociedade, seriam os únicos sujeitos - seriam indivíduos, dotados de um "eu", que almeja ter controle de si e também da natureza. Psicologiza-se, assim, o humano. As coisas, situadas no reino da natureza, seriam então os objetos cujas verdades, únicas e prontas desde sempre, apenas “descobertas” pelos cientistas. Naturaliza-se, da mesma forma, todos os não-humanos.

Se o antigo sujeito da psicologia podia acumular sobre si mesmo, no seio de sua interioridade, a totalidade de seu ser, aquele que aqui aparece, quase-sujeito misturado aos quase-objetos, assemelha-se antes com algo disposto em camadas, como uma massa folhada, atravessado por diferentes veículos onde cada um o define em parte, mas, sem jamais ali se deter completamente. Como se pode perceber, ao menos eu espero, abandonar as diferenças entre as interioridades da psicologia e as exterioridades da epistemologia não torna a misturar tudo. Ao se perder a distinção entre as representações e os fatos, não se mergulha de forma alguma no indiferenciado. Seguir os diversos veículos permite, ao contrário, retraçar outras distinções além das duas únicas impostas pela cenografia moderna, e nos convida a registrar outros contrastes (idem, p. 94).

O que fazer, então, quando coisas e humanos aparecem tão intrinsecamente conectados, como os jogadores e seus videogames? Como descobrir o efeito "puro" do videogame sobre uma pessoa, sem saber de qual jogo específico estamos tratando, qual pessoa 
específica, e tudo o mais a que ambos estão relacionados? Como dar conta de uma explicação sem misturas e a produção de inúmeros híbridos? Como, enfim, negar o ciborgue (HARAWAY, 2009)? Curiosamente, alguns psiquiatras procedem operando de modo a contornar essas questões.

O teórico da etnopsiquiatria nos interessa pois, menos que o prático. O que este faz? Ele trata o doente, por meio de gestos, no interior de um dispositivo experimental artificial, que revela um tipo particular de energia cuja existência havíamos esquecido, de tanto epistemologizar nossos objetos e de psicologizar nossos sujeitos. Ele é um grande "charlatão", e eu não teria compreendido o que ele faz antes de ter restituído um sentido positivo a esta palavra que serve comumente para estigmatizar o mal médico ${ }^{218}$ (LATOUR, 2002, p. 92).

Somente trabalhando a partir destas oposições fundadoras - sociedade e natureza; sujeito e objeto - é que podemos postular a existência destes dois mundos ontologicamente distintos: os chamados "real" e "virtual". Oficialmente, o mundo real seria somente composto por certos humanos e certos objetos; humanos que viveriam somente na sociedade, e objetos que pertenceriam exclusivamente ao mundo das coisas. Para os modernos, coisas e pessoas (oficialmente) fazem ou são feitas. Nesta perspectiva, ou o jogador joga o jogo (com uma suposta "autonomia"), ou o jogo joga o jogador (por exemplo, causando dependência). Trava-se assim uma guerra de agências. Em meio a essas alternativas infernais, tenta-se eleger uma causa primordial para observar seu efeito a partir de uma perspectiva solitária. Para os não-modernos, entretanto, coisas e pessoas (oficiosamente) fazem $e$ são feitas simultaneamente. De forma que o jogador pode jogar o videogame, ao mesmo tempo que o videogame pode jogar o jogador. Aqui, pois, eliminamos a relação causa-efeito univetorial, abrindo a possibilidade de se pensar agências de múltiplos sentidos e direções, que é, afinal, o que se observa na prática.

Sob pretexto de que ajudamos a fabricar os seres nos quais acreditamos, tal pensamento esvaziava todos os objetos-encantados, expulsando-os do mundo real, para transformá-los, uns após os outros, em fantasias, em imagens, em ideias. [...] Sob o pretexto de que os objetos-feitos, uma vez elaborados no laboratório, parecem existir sem a nossa presença, ele alinhava os fatos em batalhões compactos, compondo um "mundo real", contínuo, sem lacuna, sem vazio, sem humano (idem, p. 75).

\footnotetext{
${ }^{218}$ Ao aplicar aos humanos um modelo epistemológico que nenhum cientista jamais aplicara aos objetos, os psiquiatras não teriam conseguido compreender, por imitação de um modelo inexistente da Ciência, a originalidade própria da cura. Paradoxalmente, é preciso tratar os humanos como Pasteur trata o fermento de seu ácido lático, a fim de começar a "fazê-los falar" de maneira interessante. Sobre toda esta confusão dos modelos de dominação, ver Isabelle Stengers (2003).
} 
Desse modo, doente seria o homem que não vive mais em sociedade, isto é, entre relações humanas; mas que passa para o outro lado, que vive no mundo "irreal" dos objetos. Nesse pensamento, o jogador que perde o controle da relação com o videogame seria capturado pelas máquinas, sendo destituído da suposta essência de sua humanidade. Por isso, essa pessoa precisaria de ajuda terapêutica para "voltar" ao mundo dos humanos e reestabelecer suas relações "verdadeiras". Latour comenta que "são feitos esforços, por intermédio da cura, para dotar os doentes de uma identidade, para congregá-los novamente, para reinseri-los em um território" (LATOUR, 2002, p. 90). Cria-se, assim, uma identidade doentia a partir de concepções de "real" e "virtual" que distingue radicalmente o que é o humano e o não-humano.

Vemos, no entanto, que as relações de captura simultânea entre coletivos de videogames e jogadores ultrapassam as acepções modernas de natureza e sociedade. Expandindo essas fronteiras, numa tentativa de composição de um mundo comum, não poderíamos caminhar de volta para o terreno do sobrenatural? Segundo Isabelle Stengers e Phillipe Pignarre (2005, p. 39), o que é entendido como "sobrenatural" é tudo aquilo que escapa às explicações do que julgamos "natural", aqueles que fazem um apelo aos processos e mecanismos que devem supostamente surgir da "natureza" ou da "sociedade".

Em todo caso, "nós" modernos é que batizamos com o mesmo nome uma multiplicidade de práticas e que as unificamos sob o mesmo gênero, para depois distingui-las entre espécies diferentes, como nas taxonomias biológicas. E, se "nós" conseguimos fazer isso de forma completamente legítima, talvez seja porque "nós" - incluindo os etnólogos que visitaram os "outros" - nos mantemos, com toda tranquilidade, firmes na diferenciação entre o que é natural e as crenças no sobrenatural, a partir do qual estaríamos alegremente livres (STENGERS, PIGNARRE, 2005, p. 40, tradução nossa).

Como indicamos na conclusão do primeiro capítulo, poderíamos pensar a questão da dependência de videogames em termos de entrecapturas (STENGERS; PIGNARRE, 2005). De acordo com Stengers (2003), quando se produz um duplo processo de constituição de identidade, isto é, quando "sobre um modo ou outro, e usualmente sobre modos completamente diferentes, as identidades que se coinventam integram cada uma por sua própria conta uma referência à outra", há um processo de entrecaptura, assim como um processo de "coprodução de identidades" (p. 43).

Ou seja, a ideia de transformação mútua entre entidades - sejam elas objetos, técnicas, sujeitos e/ou paisagens - é o elemento central do conceito, que é incorporado na noção de entrecaptura. Para Stengers (2003, p. 48), opera-se 
assim um deslocamento da atenção e das questões, abandonando-se "as problemáticas filosóficas clássicas, tais como sujeito e objeto, que comunicam sempre com questões de direito, de legitimidade, e portanto também com o poder de desqualificar", para, a partir da noção de entrecaptura, se colocar o foco sobre o evento, sobre um "como funciona". Dessa forma, não se envia a uma instância mais geral a qual as transformações constituiriam uma tradução local, mas ao aqui e agora que elas fabricam e que as torna possíveis (STENGERS, 2003 apud FLEURY, 2013, p. 13).

Não seriam, afinal, as influências entre games e jogadores tornadas visíveis por um modelo de feitiçaria (STENGERS; PRIGOGINE, 2005)? Ademais, o conceito de entrecapturas pode ser entendido paralelamente à ideia de "possessão recíproca" de todos por cada um, de Gabriel Tarde (1910). Victor Cândido (2013, p. 16) comenta que, de fato, em Tarde a relevância da mônada encontra sua justificação enquanto perspectiva, mais do que propriamente em sua substância ou essência. As mônadas têm a seu favor o fato de serem capazes da "redução a uma só destas duas entidades, a material e o espírito, confundidas na segunda, e ao mesmo tempo a multiplicação prodigiosa dos agentes espirituais do mundo" (TARDE, 1910, p. 53).

O ponto de chegada para o método monadológico de Tarde é, "de um lado, a redução do ser, até então cindido na dicotomia entre corpo e alma, a esta última, ou seja, ao espírito", e, "de outro e consequentemente, a profusão dos agentes dotados de alma no mundo". Eduardo Vargas (2004, p. 174) aponta que, nesse passo, a Ciência "termina necessariamente espiritualizando sua poeira” (apud TARDE, 2010, p. 45) e unificando a dualidade cartesiana entre matéria e espírito num "psicomorfismo universal" (p. 32). Foi a partir desse espiritualismo espraiado, que reconhece na prática as contaminações recíprocas entre os actantes, que buscamos contribuir para uma compreensão mais complexa das controvérsias em torno da dependência de jogos eletrônicos.

\section{GAME OVER}




\section{Referências}

ABREU, Cristiano Nabuco de et al. "Dependência de Internet e de jogos eletrônicos: uma revisão". Revista Brasileira de Psiquiatria, no. 30(2), São Paulo, 2008, pp. 156-67.

ABREU, Cristiano Nabuco de. (2013) "O uso da internet como fuga da realidade". Disponível em: http://cristianonabuco.blogosfera.uol.com.br/2013/08/02/o-uso-dainternet-como-fuga-da-realidade/

ABT, Clark. Serious Games. Nova York: Viking Press, 1970.

ALEXANDER, Bruce. The globalization of addiction: a study in poverty of the spirit. Oxford: Oxford University Press; 2008.

ALEXANDER, Bruce. "The Roots of Addiction in Free Market Society", Canadian Centre for Policy Alternatives, 2001.

ALVARES, Julian et al. Serious Game: just a question of posture? Artificial \& Ambient Intelligence, AISB'07, Newcastle, UK, pp. 420-423, 2007.

ALVES, Lynn. Game Over: jogos eletrônicos e violência. Salvador, 2004.

AMERICAN PSYCHIATRIC ASSOCIATION. Diagnostic and Statistical Manual of Mental Disorders ( $5^{\text {th }}$ ed.). Arlington, VA: American Psychiatric Publishing, 2013.

ANDERSON, C. A. et al. "Violent video game effects on aggression, empathy, and prosocial behavior in Eastern and Western countries: A meta-analytic review". Psychological Bulletin, n. 136, pp. 151-173, 2010.

ANTUNES, Ricardo. Adeus ao trabalho? Ensaio sobre as metamorfoses e a centralidade do mundo do trabalho, São Paulo: Cortez, 1995.

AMARAL, Adriana; NATAL, Geórgia; VIANA, Lucina. "Netnografia como aporte metodológico na pesquisa em comunicação digital". In: Comunicação Cibernética. Porto Alegre: Famecos/PUC-RS, n. 20, 2008, pp. 34-40.

ARTAUD, Antonin. O teatro e seu duplo. São Paulo: Martins Fontes, 1993.

AVEDON, Elliott; SUTTON-SMITH, Brian. The Study of Games. Nova York: John Wiley \& Sons, 1971, p. 405.

BABOR, T. F. "Controvérsias sociais, científicas e médicas na definição de dependência do álcool e das drogas". In: EDWARDS, G; LADER, M (ed.) A natureza da dependência de drogas. Porto Alegre: Artes Médicas; 1994, pp. 35-60

BANTICK, Chris. "Why Computer Games should Worry Parents", The Age, Disponível em: (http://www.theage.com/au/articles/2004/01/14/1073877896185.html) Acesso em: $15 / 05 / 2011$.

BARLOW, John Perry. (1996). A Declaration of the Independence of Cyberspace. Acesso em: Julho de 2014. Disponível em: http://homes.eff.org/ barlow/DeclarationFinal.html 
BARTLE, Richard. (2003). Designing Virtual Worlds. Indianapolis: New Riders.

BATESON, Gregory. Steps to an Ecology of Mind: Collected Essays in Anthropology, Psychiatry, Evolution and Epistemology. University of Chicago Press, 1972.

BAUDRILLARD, Jean. Televisão/revolução: o caso Romênia. In: PARENTE, André. Imagem-máquina: a era das tecnologias digitais, Rio de Janeiro: Ed. 34, 1996.

BEAVIS, C. "Computer Games: Youth Culture, Resistant Readers and Consuming Passions." Research in Education: Does it Count-Australian Association for Research in Education Annual Conference, Novembro/Dezembro, 1998.

BERLIN, Isaiah. (1958) "Dois conceitos de liberdade". In: Estudos sobre a Humanidade - Uma antologia de ensaios. São Paulo: Companhia das Letras, 2002.

BERRIDGE, V. "Dependência: história dos conceitos e teorias". In: EDWARDS, Griffiths; LADER, Malcolm (ed.) A natureza da dependência de drogas. Porto Alegre: Artes Médicas, 1994. pp. 13-34.

BIEHL, João. "Antropologia do devir: psicofármacos - abandono social - desejo". Revista de Antropologia, São Paulo, v. 51, n² 2, pp. 413-449, jul./dez. 2008

BINAISA, Mazzi. "All Clicked Out". Game On: The History and Culture of Videogames, ed. L. King. Estados Unidos: Universe Publishing, 2002, pp. 44-45.

BJERG, Ole. "Drug Addiction and Capitalism: Too close to the body". Body \& Society, n. 14, pp. 1-22, 2008.

BJERG, Ole. Too close to capitalism. Ludomania, narcomania and shopoholism. Københavns Universitet: Museum Tusculanums, Forlag, 2009.

BLINKA, Lukas; SMAHEL, David. Dependência virtual de role-playing games. Capítulo 5, In: YOUNG, K. et al. Dependência de Internet: Manual e Guia de Avaliação e Tratamento, Porto Alegre: Artmed, 2011.

BLIZZARD, E. Número de Jogadores do World of Warcraft., 2012. Disponível em: < http://us.blizzard.com/pt-br/company/events/wow-brazil.html >. Acesso em: $12 / 03 / 2015$.

BOGOST, Ian. Persuasive Games: The Expressive Power of Videogames. Cambridge/Massachusetts: MIT Press, 2007.

BRABANT, Georges Philippe. Chaves da psicanálise. Rio de Janeiro: Editora Zahar, 1973.

CAILLOIS, Roger. (1957) Os jogos e os homens. Lisboa: Portugal, 1990.

CAIN, Carole. "Personal stories: identity acquisition and self-understanding in Alcoholics Anonymous". Ethos, n. 19(2), pp. 210-253, 1991.

CÂNDIDO, Victor Porto. "Fragmento de direito futuro". Trabalho de Conclusão de Curso (Bacharelado em Direito), Universidade Federal de Santa Catarina, 2013. 
CAMARGO, Luiz Octávio de L. A pesquisa em lazer na década de 70 In: IV Seminário, 2003, Belo Horizonte. Coletânea IV Seminário. Belo Horizonte: UFMG/DEF/CELAR, vol. 1, pp. 33-45, 2003.

CAPLAN, S. E. "Problematic Internet use and psychosocial well-being: Development of a theory-based cognitive-behavioral measurement instrument". Computers in Human Behavior. n. 18, 2002, pp. 553-575.

CAPLAN, Scott. E; HIGH, Andrew. C. "Beyond excessive use: The interaction between cognitive and behavioral symptoms of problematic Internet use". Communication Research Reports, n. 23, pp. 265-271, 2007.

CERRETANI, Jessica. "Extra Sensory Perceptions”, Harvard Medicine, 2010.

CASTELLS, Manuel. (2001) "A Galáxia da Internet: reflexões sobre a internet, os negócios e a sociedade”. Rio de Janeiro: Jorge Zahar, 2003.

CASTRONOVA, Edward. "The Right To Play". New York Law School Law Review, 49, pp. 185-210, 2004.

CHEN, Jenova. "Flow in games". Dissertação de Mestrado, University of Southern California, Los Angeles, USA, 2006.

CHIQUETTO, Rodrigo. "Futebol é lazer? Reflexões sobre a aplicação das categorias de tempo livre, tempo ocupado, lazer e trabalho para o estudo da prática futebolística." Artigo apresentado na $28^{a}$ Reunião Brasileira de Antropologia, São Paulo, 2012.

CHIQUETTO, Rodrigo. "Reflexões sobre a aplicação da categoria Lazer para a análise da prática futebolística. Artigo apresentado no Seminário XIV O Lazer em Debate, Campinas, 2013.

CHINA YOUTH ASSOCIATION FOR NETWORK DEVELOPMENT (CYAND). Report of China teenagers' Internet addiction information. Beijing: China, 2005.

CHOMSKY, Noan. "The Case Against B. F. Skinner," New York Review of Books, 30: pp. 18-24, 1971.

CLAVREUL, Jean. Poder e Impotência no Discurso Médico. São Paulo: Ed. Brasiliense, 1983.

CLIFFORD, James. "Sobre a autoridade etnográfica". In: A experiência etnográfica: antropologia e literatura no século XX. Rio de Janeiro: Editora UFRJ, 1998.

COMTE-SPONVILLE, André. O espírito do ateísmo: introdução a uma espiritualidade sem Deus. São Paulo: WMF Martins Fontes, 2007

COPIER, Marinka. "Connecting Worlds. Fantasy Role-Playing Games, Ritual Acts and the Magic Circle". Proceedings of DiGRA, 2005.

COSTIKYAN, Greg. "I Have No Words and I Must Design". Interactive Fantasy, no. 2, 1994. 
COUTINHO, João Pedro. Metáfora e metonímia. Faculdade de Belas Artes da Universidade de Lisboa (FBAUL), 2006.

COUTINHO, Tiago. "Xamanismo da floresta na cidade: Um estudo de caso". Tese de doutorado. Universidade Federal do Rio de Janeiro. Instituto de Filosofia e Ciências Sociais. Programa de Pós-Graduação em Sociologia e Antropologia. Rio de Janeiro, 2011.

COVER, Rob. "Gaming (Ad)diction: Discourse, Identity, Time and Play in the Production of the Gamer Addiction Myth". Game Studies, Volume 6, no. 1, 2006.

COYNE, Sarah. "Game On Girls: Associations Between Co-playing Video Games and Adolescent Behavioral and Family Outcomes". Journal of Adolescent Health, 2011.

CRAIA, Eladio. "O virtual: destino da ontologia de Gilles Deleuze". Rev. Filosofia, Aurora, Curitiba, v. 21, n. 28, pp. 107-123, 2009.

CROWE, Marie. Constructing normality: a discourse analysis of the DSM-IV. Journal of Psychiatric and Mental Health Nursing, n. 7, pp. 66-77, 2000.

CSIKSZENTMIHALY, Mihaly. The psychology of optimal experience. Harper Collins, 1990.

CSIKSZENTMIHALY, Mihaly. Beyond Boredom and anxiety. San Francisco, CA, 1975.

CSIKSZENTMIHALY, Mihaly. "Towards a Psychology of optimal experience". In: Review of Personality and Social Psychology Beverly Hills, 1982.

DAVIS, D. D. “(Non Fiction('s) Addiction(s): A NarcoAnalysis of Virtual Worlds”, in: High Wired: On the Design, Use, and Theory of Educational MOOs, ed. HAYNES, C.; HOLMEVIK, J.R. Ann Arbor: University of Michigan Press, pp. 267-285, 2001.

DAVIS, R. A. “A cognitive behavioral model of pathological Internet use”. Computers in Human Behavior, n. 17, 2001, pp. 187-195.

DELEUZE, Gilles; GUATTARI, Félix. Mil Platôs: capitalismo e esquizofrenia. Editora 34, 1995.

DELEUZE, Gilles. Diferença e repetição. Tradução br. de Luiz Orlandi e Roberto Machado. Rio de Janeiro: Graal, 1998.

DELL'OSSO, B. et al. "Ecitalopram in the treatment of impulsive-compulsive Internet usage disorder: An open-label trial followed by a double-blind discontinuation phase". Journal of Clinical Psychiatry, n. 69(3), pp. 452-456, 2008.

DERRIDA, Jacques. "The Rhetoric of Drugs," trans. Michael Israel. Points... Interviews, 1974-1994. ed. Elisabeth Weber, trans. Peggy Kamuf et al. Stanford, CA.: Stanford University Press, pp. 228-254, 1995.

DI CHIARA, G. "Role of dopamine in the behavioral actions of nicotine related to addiction”, European Journal of Pharmacology, n. 393(1-2), pp. 295-314, 2000. 
DSM-IV. Manual diagnóstico e estatístico de transtornos mentais. Porto Alegre: Artes Médicas, 1995.

DUMAZEDIER, Joffre. Lazer e cultura popular. Col. Debates, São Paulo: Perspectiva, 1976.

DUMONT, Louis. $O$ individualismo. Uma perspectiva antropológica da ideologia moderna. Rocco, Rio de Janeiro, 1985.

DURHAM, Eunice. "Uma Nova Visão da Antropologia". In: Malinowski. Coleção Grandes Cientistas Sociais. (Org.) DURHAM, E., n. 55. São Paulo, Ática, 1986.

ELIAS, Norbert; DUNNING, Eric. A busca da excitação. Lisboa: Difel, 1992.

EVANS-PRITCHARD, E. E. Os Nuer. Sao Paulo, Perspectiva, 1978.

FERGUSON, C. J. "Violent video games and the Supreme Court". American Psychologist, n. 68, pp. 57-74, 2013.

FERREIRA, Acácio. Lazer Operário: Um Estudo da Organização Social das Cidades. Salvador: Livraria Progresso, 1959.

FIORE, Maurício. "Prazer e Risco: uma discussão a respeito dos saberes médicos sobre o uso de "drogas"”. In: LABATE, Beatriz et al. Drogas e Cultura. Salvador: EDUFBA, 2008.

FISKE, John. (1990) Introdução Ao Estudo da Comunicação. Porto: Asa, 1993.

FLEURY, Lorena. "Disputas cosmopolíticas e conflito ambiental na Amazônia brasileira a partir da construção da Usina Hidrelétrica de Belo Monte", Artigo apresentado na $4^{a}$ Reunião Brasileira de Antropologia da Ciência e da Tecnologia, Campinas, 2013.

FONSECA, Rodrigo. "Realidade Virtual X Realidade Virtual: O Controle do Simulacro e a Ética da Criatividade". Razón y Palabra, no. 53, 2006.

FORTIM, Ivelise. Aspectos psicológicos do uso patológico de internet. Tese de Doutorado em Psicologia Clínica - Pontifícia Universidade Católica de São Paulo. São Paulo, 2013.

FORTIM, Ivelise. Alice no país do espelho: o MUD - jogo e realidade virtual baseado em texto. (Dissertação de Mestrado). Programa de Estudos de Pós-Graduação em Ciências Sociais, Antropologia, PUC-SP, São Paulo, 2004.

FOUCAULT, Michel. (1978-79) O Nascimento da Biopolítica. $2^{\mathrm{a}}$ Ed. São Paulo: Martins Fontes, 2008.

FOUCAULT, Michel. "L'éthique du souci de soi comme pratique de liberté". Concordia Revista Internacional de Filosofia. (Internationale Zeitschriff für Philosophie), s/1, pp. 99-116, 1984.

FOUCAULT, M. "Verdade e Poder". In: FOUCAULT, M. Microfísica do Poder. Rio de Janeiro: Graal, pp. 1-14, 1988. 
FOUCAULT, Michel. (1995) Vigiar e punir: nascimento da prisão. 36 a ed. Petrópolis, Ed. Vozes, 2009.

FRANCO, Sergio de Gouvêia. Hermenêutica e psicanálise na obra de Paul Ricoeur. Edições Loyola. São Paulo, 1995.

FRASCA, Gonzalo. Videogames of the Opressed: Videogames as means for critical thinking and debate. (Dissertação de Mestrado). Georgia Institute of Technology, 2001.

GAILLOT, Michel. Multiple Meaning: Techno: An Artistic and Political Laboratory of the Present, Entrevistas com Jean-Luc Nancy e Michel Maffesoli, 1998.

GEERTZ, Clifford. (1973) "Um jogo absorvente: notas sobre a briga de galos balinesa". Capítulo 9. In: A interpretação das culturas. Rio de Janeiro: LTC, 2008.

GEERTZ, Clifford. Negara: o Estado-Teatro do Século XIX. Rio de Janeiro: Bertrand, 1991.

GOFFMAN, Erving. The Presentation of self in everyday life. New York: Doubleday, 1959.

GOFFMAN, Erving. (1959) A representação do eu na vida cotidiana. Trad. Maria Célia Santos Raposo. 8.ed. Petropolis, RJ: Vozes, 1999.

GOMES, Cristina Marques. Dumazedier e os estudos do lazer no Brasil: breve trajetória histórica. Rio de Janeiro, SESC, 2004.

GRANIC, Isabela; LOBEL, Adam; ENGELS, Rutger. "The Benefits of Playing Video Games". American Psychologist, American Psychological Association, vol. 69, n. 1, pp. 66-78, 2014.

GRIFFITHS, Mark; DAVIES, Mark. "Does Video Game Addiction Exist?" In: Handbook of Computer Game Studies. Eds. GOLDSTEIN, Jeffrey; RAESSENS, Joost. Cambridge: MIT Press, pp. 359-368, 2005.

GRIFFITHS, Mark. "Video game addiction: Fact or fiction?" In: WILLOUGHBY, T; E. WOOD, E. (Eds.), Children's learning in a digital world. Oxford: Blackwell Publishing, 2008, pp. 85-103.

GRIFFITHS, Mark. "Internet Addiction: Does it Really Exist?" In: Psychology and the Internet: Intrapersonal, Interpersonal, and Transpersonal Implications. Ed. Jayne, 1998.

GRIFFITHS, Mark. "Online video gaming: what should educational psychologists know?". Educational Psychology in Practice, n. 26(1), pp. 35-40. 2010.

GREENFIELD, D. N. "Sexuality and the Internet”. Counselor, n. 2, 2001, pp. 62-63.

GROHOL, J. M. "Review: Caught in the Net”. Addiction, 95(1), pp. 139-140, 2000.

GROSZ, Elizabeth. Architecture from the Outside: Essays on Virtual and Real Space. Cambridge, Massachussets: MIT Press, 2001.

GUATARRI, Félix. Caosmose: um novo paradigma estético. São Paulo: Editora 34, 1992. 
GUIMARÃES, Hélio Penna; AVEZUM; Álvaro. "O impacto da espiritualidade na saúde física”. Revista de Psiquiatria Clínica, n. 34, supl. 1, pp. 88-94, 2007.

HALL, A. S; PARSONS, J. "Internet addiction: College students case study using best practices in behavior therapy". Journal of Mental Health Counseling, n. 23, 2001, pp. 312-322.

HARAWAY, Donna; KUNZRU, Hari; TADEU, Tomaz. Antropologia do Ciborgue: as vertigens do pós-humano. $2^{\mathrm{a}}$ Ed. Belo Horizonte: Autêntica Editora, 2009.

HARAWAY, Donna; GANE, Nicholas (2006). "Se nós nunca fomos humanos, o que fazer?" Trad. Ana Letícia de Fiori. Ponto Urbe, n. 6, São Paulo, 2010.

HARAWAY, Donna. "A partilha do sofrimento: relações instrumentais entre animais de laboratório e sua gente". Horizontes Antropológicos, Porto Alegre, ano 17, n. 35, pp. 27-64, 2011.

HARDIN, G. “The Tragedy of the Commons”. Science, n. 162, 1968, pp. 1243-1248.

HEATH, D. B. Anthropology and alcohol studies: current issues. Annual Review of Anthropology, n. 16, 1987, pp. 99-120.

HINE, Christine. Virtual Ethnography. Thousand Oaks, CA: Sage Publications Inc., 2000.

HOLOHAN, C. Employee sues IBM over Internet addiction, 2007. Disponível em: http://www.businessweek.com/print/technology/content/dec2006/tc20061214_422859.h tm. Último acesso em: 10/12/2014.

HOLLIDAY, Heather. "Hooked on the 'Net". Psychology Today, 33(4):10, 2000.

HOLT, Robertson. "Examining Video Game Immersion as a Flow State", B.A. Thesis, Department of Psychology, Brock University, 2000.

HUIZINGA, Johann. (1938) Homo Ludens: o jogo como elemento da cultura. $6^{\text {a }}$ Ed. São Paulo: Perspectiva, 2010.

HUMPHREYS, Sal. "Online multi-user games" In: Australian Journal of Communication. no. 30(1), 2003, pp. 79-91.

INGOLD, Tim. The Perception of the Environment. Essays on livelihood, dwelling and skill. London \& New York: Routledge, 2000.

INGOLD, Tim. "Materials against materiality". Archaeological Dialogues, v. 14 (1), pp. 1-18, 2007.

JOHNSON, Nicola. The Multiplicities of Internet Addiction: The Misrecognition of Leisure and Learning, Ashgate, 2009.

KELLY, José Antonio. "Perspectivismo multinatural como transformação estrutural". Ilha, vol. 12, n. 1, pp. 135-160, 2010. 
KHAN, Mohamed. "Emotional and Behavioral Effects, Including Addictive Potential, of Video Games". Report of the Council on Science and Public Health. CSAPH Report, 12-A-07, 2009.

KING, B.; BORLAND, J. Dungeons and Dreamers: The Rise of Computer Game Culture. USA: McGraw-Hill/Osborne, 2003.

KIRK, Stuart A. "Are we all going mad, or the experts crazy?" Los Angeles Times, 14 de Agosto, 2005.

KNORR-CETINA, Karin. "The Couch, the Cathedral and the Laboratory: on the relationship between experiment and laboratory in science". In: PICKERING, A. (ed.) Science as Practice and Culture. University of Chicago Press: Chicago, 1992.

KRANT, R. et al. "Internet paradox: A social technology that reduces social involvement and psychological well-being?" American Psychologist, n. 52, 1997, pp. 1017-1031.

LANGLOIS, Mike. Reset: Video Games \& Psychotherapy. FeedBrewer, $2^{\text {a }}$ ed., 2011.

LART, Rachel. "Medical Power/Knowledge: The Treatment and Control of Drugs and Drug Users," In: The Control of Drugs and Drug Users: Reason and Reaction, ed. Ross Coomber. Amsterdam: Harwood, pp. 49-68.

LATOUR, Bruno. "Technology is society made durable". In: LAW, J., (Eds.). A sociology of monsters: essays on power, technology and domination, Routledge, 1991.

LATOUR, Bruno. (1991) Jamais fomos modernos. São Paulo, Editora 34, 1994.

LATOUR, Bruno. Ciência em ação: como seguir cientistas e engenheiros sociedade afora. São Paulo: Editora UNESP, 2000.

LATOUR, Bruno. "Gabriel Tarde and the end of the social", in: JOYCE, Patrick (org.), The social and its problems, Londres, Routledge, 2001.

LATOUR, Bruno. Reflexão sobre o culto moderno dos deuses fe(i)tiches. EDUSC, 2002.

LATOUR, Bruno. Reassembling the Social: An Introduction to Actor-Network-Theory. Oxford University Press, 2005.

LATOUR, Bruno. (1999) Políticas da natureza: como fazer ciência na democracia. Bauru, SP: EDUSC, 2004.

LATOUR, Bruno. "Como terminar uma tese de sociologia: pequeno diálogo entre um aluno e seu professor (um tanto socrático). In: Cadernos de Campo, n. 14/15, São Paulo, 2006.

LATOUR, Bruno. (2005) "Como prosseguir a tarefa de delinear associações?" Configurações, v. 2, pp. 11-27, 2006.

LATOUR, Bruno. "La cartographie des controverses". In: Technology Review, n. 0, 2007, pp. 82-83, 2007. 
LATOUR, Bruno. "Why Has Critique Run out of Steam? From Matters of Fact to Matters of Concern". Critical Inquiry, University of Chicago, no. 30, 2004.

LATOWSKA, Greg. "The Rules of Play”, AoIR 8, 17 de Outubro, 2007. Acesso em: 25 /07/2014, em: http://terranova.blogs.com/RulesofPlay.pdf

LE BRETON, David. L'adieu au corps. Paris: Éditions Métailié, 1999.

LEHDONVIRTA, Vili. "Virtual Worlds Don't Exist: Questioning the Dichotomous Approach in MMO Studies". Game Studies, vol. 10(1), 2010.

LEMOLA, S. et al. "Habitual computer game playing at night is related to depressive symptoms". Personality and Individual Differences, n. 51, pp. 117-122, 2011.

LEMOS, André. A comunicação das coisas: teoria ator-rede e cibercultura. São Paulo: Annablume, 2013.

LEMOS, Igor Lins; SANTANA, Suely de Melo. "Dependência de Jogos Eletrônicos: o surgimento de um novo diagnóstico psiquiátrico". Revista de Psiquiatria Clínica, 2012; 39(1), pp. 28-33.

LÉVY, Pierre. O que é o virtual? São Paulo: Editora 34, 1996.

LIN, Holin; SUN, Chuen-Tsai. "Cash Trade Within the Magic Circle: Free-to-Play Game Challenges and Massively Multiplayer Online Game Player Responses". Proceedings of DiGRA, pp. 335-343, 2007.

LISTER, M.; DOVEY, J.; GIDDINGS, S.; GRANT, I. \& KELLY, K. New Media: A Critical Introduction. London \& New York: Routledge, 2003.

MAFFESOLI, Michel (1998). O Tempo das Tribos: o declínio do individualismo nas sociedades de massa. 4a ed. Forense Universitária, 2006.

MAGNANI, José Guilherme. "Tribos urbanas: metáfora ou categoria? Cadernos de Campo, v. 2, n. 2, 1992.

MAGNANI, José Guilherme. "De perto e de dentro: notas para uma etnografia urbana." Revista Brasileira de Ciências Sociais, ANPOCS, vol. 17, n. 49, 2002.

MALABY, Thomas. "Beyond Play A New Approach to Games". Games and Culture, vol. 2, no. 2, pp. 95-113, 2007.

MALINOWSKI, Bronislaw. "A Teoria funcional”. In: Malinowski. Coleção Grandes Cientistas Sociais, organizada por E. R. Durhan, No. 55, São Paulo, Ática, 1986.

MALINOWSKI, Bronislaw. Argonauts of the Western pacific. Londres, George Routledge \& Sons, 1922.

MARCELLINO, Nelson Carvalho. Lazer e educação, Campinas: Papirus, 1990.

MARCUS, George. "Ethnography in/of the world system: the emergence of multi-sited ethnography". Annual Review of Anthropology, Palo Alto, California, v. 24, pp. 95-117, 1995. 
MARCUS, George. "Ethnography in/of the world system: the emergence of multi-sited ethnography". In: MARCUS, George. Ethnography through Thick/Thin. Princeton: Princeton University Press, 1998.

MARRAS, Stelio. "Ratos e homens - e o efeito placebo: um reencontro da cultura no caminho da natureza. Revista Campos, n. 2, PPGAS/UFPR: Paraná, pp. 117-133, 2002.

MAUSS, Marcel. “As técnicas do corpo” (1934[1935]). In: Sociologia e antropologia. São Paulo: Cosac Naify, 2003, pp. 399-422.

MAUSS, Marcel. (1926) Manuel d'ethnographie. Paris: Éditions sociales, 1967.

MAUSS, Marcel. "Technologie" (1928). In: Schlanger, Nathan (ed.) Marcel Mauss. Techniques, technologie et civilisation. Paris, PUF, 2012, pp. 295-326.

MAX-NEEF, Manfred; ELIZALDE, Antonio; HOPENHAYN, Martin. Human Scale Development: conception, application and further reflections. New York: Apex, 1989.

MÁXIMO, Maria Elisa. "Das metropoles às redes sociotécnicas: a caminho de uma antropologia no ciberespaço", in: RIFIOTIS, T. et al. Antropologia no cibeserpaço, Florianópolis, Ed. USFC, 2010.

MCGONIGAL, Jane. A realidade em jogo: por quê os games nos tornaram pessoas melhores e como eles podem mudar o mundo. Rio de Janeiro: Ed. Best Seller, 2012.

MENESES, Guilherme. O conceito de identidade em estudos organizacionais: uma revisão bibliográfica sobre os usos e origens do conceito. Relatório de Iniciação Científica, Fundação Getulio Vargas, EAESP, 2009.

MERCANTE, Marcelo. "Dependência, recuperação e o tratamento através da ayahuasca: definições e indefinições. Saúde e Transformação Social. Florianópolis, v. 4, n. 2, pp. 126-138, 2013.

MEYROWITZ, J. "The separation of social space from physical place", The Media Studies Reader, ed. O'SULLIVAN, T.; JEWKES, Y. London: Edward Arnold, pp. 4552, 1997.

MOL, Annemarie. "Política ontológica: algumas ideias e várias perguntas". In: NUNES, João Arriscado; ROQUE, Ricardo (org.) Objectos impuros: Experiências em estudos sociais da ciência. Porto: Edições Afrontamento, 2007.

MORAES, Márcia Oliveira. "O conceito de rede na filosofia mestiça". Revista Informare, v. 6, n. 1 Rio de Janeiro, pp. 12-20, 2000.

MORAES, Márcia Oliveira. "Por uma Estética da Cognição: A Propósito da Cognição em Latour e Stengers", Revista Informare, Rio de Janeiro, v. 4 (1), 49-56, 1998.

NEWMAN, James. "The Myth of the Ergodic Videogame: Some thoughts on playercharacter relationships in videogames". Game Studies, vol. 2, n. 1, 2002.

O'BRIEN, Chris. "Get ready for the decade of gamification", San Jose Mercury News, 24 de Outubro, 2010. 
OLSON, Cherry. "Violent Video Games Help Kids Manage Stress". Journal of Adolescent Health, 2011.

OLSON, Mancur. The Logic of Collective Action: public goods and the theory of groups. Cambridge, Massachusetts: Harvard Univesity Press, 1965.

ORTNER, Sherry. "Poder e projetos: reflexões sobre a agência". In: Conferências e diálogos; saberes e práticas antropológicas (25 RBA, Goiânia, 2006). Blumenau, ABA/Nova Letra, pp. 45-80, 2007.

ORZACK, Maressa Hecht. "Computer addiction: Is it real or is it virtual?". Harvard Mental Health Letter, n.15 (7), p. 8, 1999.

PEELE, Stanton. "The concept of addiction". In: PEELE, S. The meaning of addiction: Compulsive experience and its interpretation. Lanhan: MD, Lexingtion Books, 1985.

PETRY, Nancy et al. "An international consensus for assessing internet gaming disorder using the new DSM-5 approach". Addiction for debate. Society for the Study of Addiction, pp. 1-8, 2014.

PIGNARRE, Philippe. O que é o medicamento? Um objeto estranho entre ciência, mercado e sociedade. São Paulo: Ed. 34, 1999.

POPKIN, Helen. "FarmVille invades the real world", MSNBC, 01/06, 2010.

PORNOGRAPHY AND SEXUAL VIOLENCE. Evidence of the Links: The Complete Transcript of Public Hearings on Ordinances to Add Pornography as Discrimination Against Women: Minneapolis City Council, Government Operations Committee. Londres: Everywoman, 1983.

REID, Elizabeth. Electropolis: communication and community on internet relay chat. Honours Thesis, Departamento de História, Universidade de Melbourne, 1991.

REQUIXA, Renato. Sugestões de diretrizes para uma política nacional de lazer, São Paulo, 1980.

RHEINGOLD, Howard. A comunidade virtual. Lisboa: Gradiva, 1996.

RHEIT, Gerda. "Consumption and its discontents: addictions, identity and the problems of freedom”. The British Journal of Sociology, v. 55, n. 2, pp. 283-300, 2004.

RIFIOTIS, Theophilos. (2010) "Comunidades virtuais, duas ou três coisas sobre elas". In: RIFIOTIS et al. Antropologia no ciberespaço. Editora USFC, 2010.

RIFIOTIS, Theophilos. "Desafios contemporâneos para a antropologia no ciberespaço: o lugar da técnica". Civitas. Porto Alegre, v. 12, n. 3, p. 566-578, 2012.

ROBINSON, Bryan E. Chained to the Desk: A Guidebook for Workaholics, Their Partners and Children, and the Clinicians Who Treat Them. Nova Iorque: New York University Press, p. 62, 2001.

ROCKWELL; Geoffrey, KEE, Kelvin. "The Leisure of Serious Games: A Dialogue”. Game Studies, vol. 11, n. 2, 2011. 
RODRIGUEZ, Hector. "The Playful and the Serious". Game Studies, vol. 6, no. 1. 2006.

ROOM, Robin. "Dependence and society". British Journal of Addiction; no. 80, pp. 133-139, 1985.

ROSSINI, Vinícius. “Os manjadores entenderão: os conteúdos virais e a sociabilização no ciberespaço". Ponto Urbe, n. 14, 2014.

RUFFO, Luciana. "Porque alguém se vicia?". Núcleo de Pesquisas da Psicologia em Informática. Setembro de 2011, 2011a.

RUFFO, Luciana. "Games online fundem vida real e virtual". Cyberpsicologia. Vya Estelar. Universo Online (UOL). 29 de Agosto de 2011, 2011b. Disponível em: http://www2.uol.com.br/vyaestelar/cyberpsicologia_games.htm

SALEN, Katie; ZIMMERMANN, Eric. As Regras do Jogo: Fundamentos do Design de Jogos. São Paulo: Blucher, 2012.

SCARPATO, Artur. Videogames e dependência: quando o jogar se torna perigoso. Disponível em: <www.psicoterapia.psc.br/scarpato/t_games.html> Acesso em: 20/06/2011, 2004.

SCHAPIN, Steve; SCHAFFER, Simon. Leviathan and the Air-Pump: Hobbes, Boyle and the Experimental Life. Princeton University Press, New Jersey: Princeton, 1985.

SCHECHNER, Richard. "Pontos de contato entre o pensamento antropológico e teatral”. Cadernos de campo, São Paulo, no. 20, pp. 213-236, 2011.

SCIRÉ, Claudia. "Uma etnografia multissituada das práticas populares de consumo". Plural - Revista do Programa de Pós-Graduação em Sociologia da USP, São Paulo, v. 16, n. 1, pp. 93-109, 2009.

SEGATA, Jean. "Entre sujeitos: O Ciberespaço e a ANT", II Simpósio Nacional da ABCiber, 2008a.

SEGATA, Jean. "Para além da pele e da tela: demarcando as fronteiras entre o humano e a máquina no ciberespaço". Trabalho apresentado na $26^{a}$ Reunião Brasileira de Antropologia, Porto Seguro: Brasil, 2008 b.

SENNETT, Richard. A corrosão do caráter: consequências pessoais do trabalho no novo capitalismo. Trad. Marcos Santarrita. Rio de Janeiro: Record, 1999.

SIMMEL, Georg. (2005). As grandes cidades e a vida do espírito (1903). In: Mana, Rio de Janeiro, vol.11, n. 2, p. 577-591, out. 2005.

SILVA, Adelina M. Ciberantropologia, o estudo das comunidades virtuais. Portugal: Universidade Aberta, 2007.

SKINNER, B. F. Science and Human Behavior, New York: Macmillan, 1953.

SOPER, W. B., \& MILLER, M. J. "Junk time junkies: An emerging addiction among students”. School Counsellor, n. 31, pp. 40-43, 1983. 
SMAHEL, David. "Adolescents and young players of MMORPG games: Virtual communities as a form of social group". XIth EARA conference, 2008.

SMAHEL, David. et al. "Playing MMORPGs: Connections between addiction and identifying with a character". CyberPsychology \& Behavior, n. 11, pp. 480-490, 2008.

SMAHEL, David; BLINKA, Lukas, LEDABYL, O. "MMORPG playing of youths and adolescents: Addiction and its factors" Artigo apresentado na Association of Internet Researchers, Vancouver: Internet research 8.0: let's play, 2007.

SNODGRASS, J. G.; LACY, M. G.; DENGAH II, H. J. F. et al. "Magical Flight and Monstrous Stress: Technologies of Absorption and Mental Wellness in Azeroth". Culture, Medicine \& Psychiatry, v. 35, n. 1, pp. 26-62, 2011.

STEBBINS, Robert A. "Serious leisure: A conceptual statement". Pacific Sociological Review, 25, pp. 251-272, 1982.

STENGERS, Isabelle. Cosmopolitiques I. Paris: La Découverte, 2003.

STENGERS, Isabelle. "La proposition cosmopolitique". In: Lolive, Jacques \& Soubeyran, Olivier (eds.). L'émergence des cosmopolitiques. Paris: La Découverte, pp. 45-68, 2007.

STENGERS, Isabelle; PIGNARRE, Phillipe. (2005) Capitalist Sorcery: Breaking the Spell. Palgrave Macmillan, 2011.

STENGERS, Isabelle; PRIGOGINE, Ilya. (1984) A nova aliança: metamorfose da ciência. Brasília: Editora da UnB, 1991.

STRATHERN, Marilyn. The gender of the gift. Berkeley \& Los Angeles: University of California Press, 1988.

STRATHERN, Marilyn. "Cutting the Network". Journal of the Royal Anthropological Institute. (N.S.) 2, pp. 517-35, 1996a.

STRATHERN, Marilyn. "The concept of society is theoretically obsolete". In: INGOLD, T. (ed.). Key debates in anthropology. London: Routledge, $1996 \mathrm{~b}$.

STRAUSS, Anselm. "A Social World Perspective". In: DENZIN, N. (Ed.), Studies in Symbolic Interaction 1. Greenwich, CT: JAI Press, pp. 119-128, 1978.

STROPPA, André; MOREIRA-ALMEIDA, Alexander. "Religiosidade e Saúde". In: SALGADO; FREIRE (orgs.) Saúde e Espiritualidade: uma nova visão da medicina. Belo Horizonte: Inede, pp. 427-443, 2008.

SUBLETTE, Victoria Anne; MULLAN, Barbara. "Consequences of Play: A Systematic Review of the Effects of Online Gaming". International Journal of Mental Health and Addiction, v. 10, n. 1, pp. 3-23, 2012.

SUITS, Bernard. Grasshoper: Games, Life, and Utopia. Boston: David R. Rodinge, 1990. 
SUTTER, John D. "Browse the Web, earn points and prizes", CNN, 30 de Setembro, 2010.

SZTUTMAN, Renato; MARRAS, Stelio, Ementa do curso "Cosmopolíticas em comparação: diálogos entre a Antropologia da Ciência e da Modernidade e a Etnologia Indígena”, Universidade de São Paulo, 2013.

TAO, R; YING, L, YUE, X. D; HAO, X. "Internet addiction: Exploration and intervention”. Shangai People’s Press. Shangai: China, n.12, 2007.

TARDE, Gabriel. (1910) Monadologia e Sociologia - e outros ensaios. São Paulo: Cosac Naify, 2007.

TAYLOR, T. L. Play Between Worlds: Exploring Online Game Culture. Cambridge, MA: MIT Press, 2006.

TELLES, Edward. "O significado da Raça na Sociedade Brasileira". Tradução por: Ana Arruda Callado. Race in Another America: The Significance os Skin Color in Brazil. Princeton e Oxford: Princeton University Press, 2004.

THOMPSON, C. "Violence and the Political Life of Videogames", in: Game On: The History and Culture of Videogames, ed. L. King. USA: Universe Publishing, pp. 22-31, 2002.

TURKLE, Sherry. "Fronteiras do real e o do virtual". Revista FAMECOS, Porto Alegre, no. $11,1999$.

TURKLE, Sherry. A Vida no Ecrã: a identidade na era da Internet, Lisboa: Relógio D’Água, p. 28, 1997.

TURKLE, Sherry. $O$ segundo $E U$ - os computadores e o espírito humano. Lisboa: Presença, 1989.

VAILLANT, George E. The natural history of alcoholism revisited. Cambridge, MA: Harvard University Press, 1995.

VALENTIM, Daniel Costa. Unidos pelo Controle: uma etnografia das práticas de sociabilidades dos cyberatletas de Fortaleza. Dissertação de Mestrado, Universidade Federal do Ceará, 2012.

VANDENBERGHE, Frédéric. "Jamais fomos humanos". Liinc em Revista, v. 6, n. 2, Rio de Janeiro, pp. 214-234, 2010.

VARGAS, Eduardo Viana. "Multiplicando os agentes do mundo: Gabriel Tarde e a sociologia infinitesimal”. Revista Brasileira de Ciências Sociais. vol. 19, no. 55, São Paulo, 2004.

VARGAS, Eduardo Viana. "Uso de Drogas: a alter-ação como evento." Revista de Antropologia, São Paulo, USP, v. 49, n. 2, 2006.

VARGAS, Eduardo Viana. "Fármacos e outros objetos sócio-técnicos: notas para uma genealogia das drogas". In: LABATE, Beatriz et al. Drogas e cultura: novas perspectivas. Salvador: Ed. UFBA, pp. 41-64, 2008. 
VENTURINI, Tomasso. "Diving in Magma: How to Explore Controversies with Actor Network Theory”. Public Understanding of Science, 2009.

VENTURINI, Tomasso. "Building On Faults: How to Represent Controversies with Digital Methods". Public Understanding of Science, 2010.

VIRILIO, Paul. “The Third Interval”, in: Rethinking Technologies, ed. CONLEY, V. Minneapolis: University of Minnesota Press, 1993.

VIVEIROS DE CASTRO, Eduardo. "O nativo relativo". Mana, vol. 8, no. 1, Rio de Janeiro, 2002.

VIVEIROS DE CASTRO, Eduardo. "Perspectival anthropology and the method of controlled equivocation". In: Tipiti, n. 2, v. 1, 2004.

WAGNER, Roy. (1981) A invenção da cultura. São Paulo, Cosac Naify, 2010.

WAGNER, Roy. "Are there social groups in the New Guinea Highlands?". In: LEAF, M. J. (ed.). Frontiers of anthropology: an introduction to anthropological thinking. New York: D. Van Nostrand Company, 1974.

WATSON, John. "Psychology as a Behaviorist Views It," Psychological Review, n. 20, pp. 158-177, 1913.

WILlIAMS, Ray. "The Hidden Costs of Workaholism”. Fast Company. Publicado em: 09/07/2009, 2009.

WILLIAMS, Ray. "Workaholism and the myth of hard work", Psychology Today, Publicado em: 15/03/2012, 2012.

WORLD HEALTH ORGANIZATION. Neuroscience of psychoactive substance use and dependence. Genebra: World Health Organization; 2004.

WORLD HEALTH ORGANIZATION. The ICD-10 classification of mental and behavioural disorders: clinical descriptions and diagnostic guidelines. Genebra: World Health Organization; 1992.

YEE, N. "The demographics, motivations and derived experiences of users of massively-multiuser online graphical environments". Presence: Teleoperators and Virtual Environments, no. 15, pp. 309-329, 2006.

YOUNG, K; DONG, X; YING, L. "Estimativas de prevalência e modelos etiológicos da dependência de internet". Capítulo 1, In: YOUNG, K; ABREU, C. N. (orgs). Dependência de Internet: Manual e Guia de Avaliação e Tratamento, Porto Alegre: Artmed, 2011.

YOUNG, Kimberly. “Avaliação clínica de clientes dependentes de internet”. Capítulo 2, In: YOUNG, K; ABREU, C. N. (orgs). Dependência de Internet: Manual e Guia de Avaliação e Tratamento, Porto Alegre: Artmed, 2011.

YOUNG, Kimberly. Caught in the Net: How to Recognize the Signs of Internet Addiction - and a Winning Strategy for Recovery. New York: John Wiley \& Sons, 1998. 
YOUNG, K. "Cognitive-behavioral therapy with Internet addicts: Treatment outcomes and implications". Cyber Psychology \& Behavior, n. 10 (5), pp. 671-679, 2007.

YOUNG, K; ROGERS, R. "The relationship between depression and Internet addiction". CyberPsychology \& Behavior. no. 1 (1), pp. 25-28, 1997.

\section{Entrevistas}

ALLPROT. Entrevista I. [23/06/2013]. Entrevistador: Guilherme Pinho Meneses. São Paulo, 2013. 1 arquivo .m4a (19 min.)

HYOU. Entrevista II. [24/06/2013]. Entrevistador: Guilherme Pinho Meneses. São Paulo, 2013. 1 arquivo .m4a (35 min.)

RICARDINSON. Entrevista III [26/06/2013]. Entrevistador: Guilherme Pinho Meneses. São Paulo, 2013. 1 arquivo .m4a (20 min.)

JOHNNY WILLIAM. Entrevista IV [04/09/2013]. Entrevistador: Guilherme Pinho Meneses. São Paulo, 2013. 1 arquivo .m4a (09 min.)

SEPIO. Entrevista V [30/09/2013]. Entrevistador: Guilherme Pinho Meneses. São Paulo, 2013. 1 arquivo .m4a (26 min.)

MASAMUNE. Entrevista VI. [02/10/2013]. Entrevistador: Guilherme Pinho Meneses. São Paulo, 2013. 1 arquivo .m4a (26 min.)

CHUCK. Entrevista VII [09/10/2013]. Entrevistador: Guilherme Pinho Meneses. Santos, 2013. 1 arquivo .mp3 (20 min.)

MARXISTPOKEMON. Entrevista VIII [06/11/2013]. Entrevistador: Guilherme Pinho Meneses. São Paulo, 2013. 1 arquivo .m4a (27 min.)

FORTIM, Ivelise. Entrevista IX [12/11/2013]. Entrevistador: Guilherme Pinho Meneses. São Paulo, 2013. 1 arquivo .m4a (1h 13 min.)

TOSAS. Entrevista X [25/12/2013]. Entrevistador: Guilherme Pinho Meneses. Santos, 2013. 1 arquivo .m4a (22 min.)

BINO. Entrevista XI [25/12/2013]. Entrevistador: Guilherme Pinho Meneses. Santos, 2013. 1 arquivo .m4a (17 $\mathrm{min}$.)

OROCHI. Entrevista XII [03/03/2014]. Entrevistador: Guilherme Pinho Meneses. Santos, 2013. 1 arquivo .m4a (50 min.)

COSTA, Lucas Cruz. Entrevista XIII [04/03/2014]. Entrevistador: Guilherme Pinho Meneses. Santos, 2013. 1 arquivo .m4a (47 min.)

BRÁS, Iago Haibara. Entrevista XIV [05/03/2014]. Entrevistador: Guilherme Pinho Meneses. São Paulo, 2013. 1 arquivo .m4a (08 min.)

HIDEKO. Entrevista XV [05/03/2014]. Entrevistador: Guilherme Pinho Meneses. São Paulo, 2013. 1 arquivo .m4a (24 min.) 
MERCANTE, Marcelo Simão. Entrevista XVI [09/03/2014]. Entrevistador: Guilherme Pinho Meneses. São Paulo, 2013. 1 arquivo .m4a (44 min.)

PETER_PANO; SION, Carla Neves. Entrevista XVII [18/03/2014]. Entrevistador: Guilherme Pinho Meneses. Santos, 2013. 1 arquivo .m4a (36 min.)

SILVA, Olavo Felipe Souza. Entrevista XVIII [03/04/2014]. Entrevistador: Guilherme Pinho Meneses. São Paulo, 2013. 1 arquivo .mp3 (43 min.)

GEOCZE, Janos Andreas. Entrevista XIX [08/04/2014]. Entrevistador: Guilherme Pinho Meneses. São Paulo, 2013. 1 arquivo .m4a (57 min.)

VALADARES, Jeferson; FAURE, André; VIEITEZ, Júlio. "Monetização: Novos desafios para empresas as de jogos", XII Simpósio Brasileiro de Jogos e Entretenimento Digital (SBGames 2013), 2013.

\section{Lista de games}

Assasin's Creed III (2012), Ubisoft

Bejeweled (2001), PopCat Games

Bonsai Worlds (2003), Enric Llagostera

Braid (2008), Number None

Call of Duty: Ghosts (2013), Infinity Ward

Candy Crush Saga (2012), King

Castle Crashers (2010), The Behemoth

CastleVille (2011), Zynga

CityVille (2010), Zynga

Civilization II (1996), MicroProse

Counter-Strike (2000), Valve

Cubisland (2013), Dome Game Studios

Defense of the Ancients (2009), Icefrog

Devil May Cry (2013), Capcom

Deus Ex (2000), Ion Storm

Doom (1993), id Software

Dragon Age (2009), BioWare

Elder Scrolls V: Skyrim (2011), Bethesda Game Studios

Estoura Balão (2013), Quadrimind 
FarmVille (2009), Zynga

Kane (2013), Paranaue Ninja Games

Kinect (2010), Microsoft

FIFA 14 (2013), EA Sports

Grand Theft Auto IV (2008), Rockstar North

Huni Kuin (2016), Bobware

League of Legends (2009), Riot Games

Metal Gear Solid (1998), Konami Computer Entertainment Japan

MSN Messenger (1999), Microsoft

Perfect Dark (2000), Rare

Priston Tale (2005), Yedang Online

Pro Evolution Soccer 2014 (2013), Konami

Pokémon (1996), Nintendo

Ragnarök Online (2002), Gravity

River Raid (1982), Activision

Skype (2003), Skype Technologies

Silver (1999), Infogrames

Sonic: The Hedgehog 2 (1992), Sega

Star Wars: TIE Fighter (1994), Totally Games/Lucas Arts

Super Mario Bros. (1985), Nintendo

The Last of Us (2013), Naughty Dog

Tibia (1999), CipSoft

Turma do Chico Bento (2012), Level Up Games

Ultima Online (1997), Origin Systems

Unity3D (Game Engine) (2005), Unity Technologies

With Your Destiny (2003), JoyCompact Co.

Wolfenstein 3D (1992), id software

World of Warcraft (2004), Blizzard Entertainment 


\section{Referências Online}

Mapeamento digital da pesquisa

http://gamedependencia.wordpress.com

Referências online sobre o mapeamento de controvérsias

http://medialab.sciences-po.fr/controversies/

http://www.demoscience.org/

http://www.mappingcontroversies.net/ 